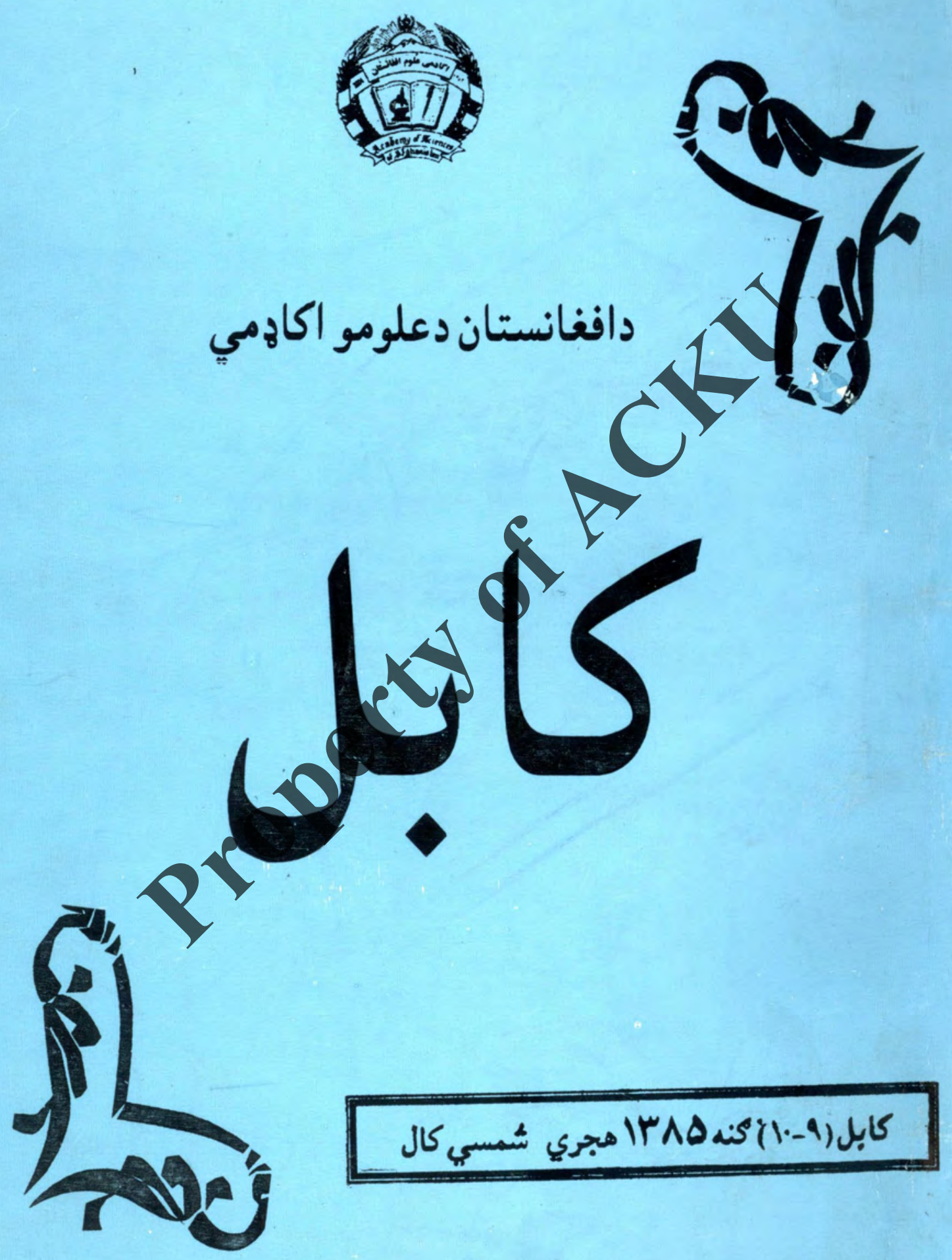




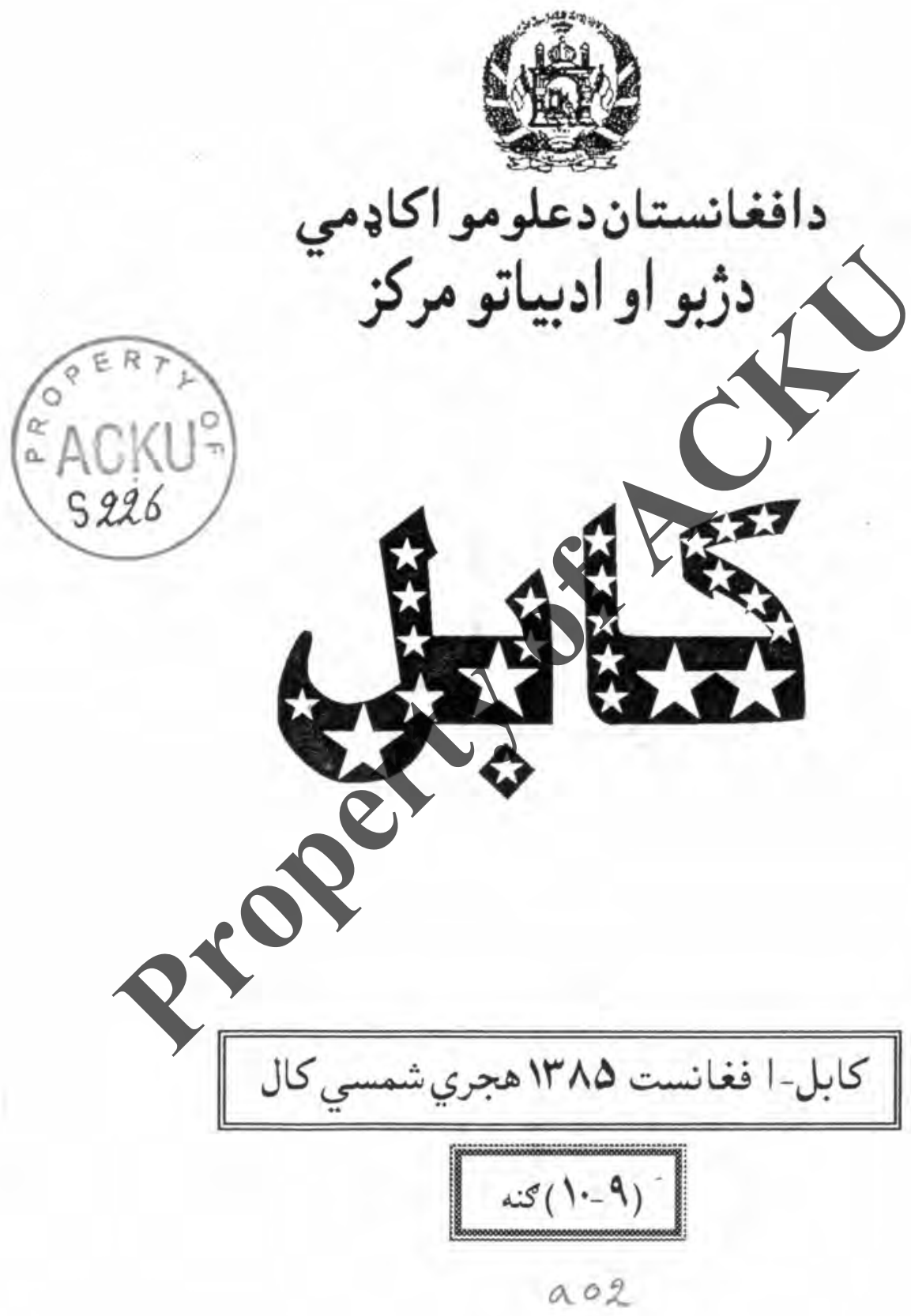




\section{6 의}

ثبنى او ادبي مياشتنى خِيرونه

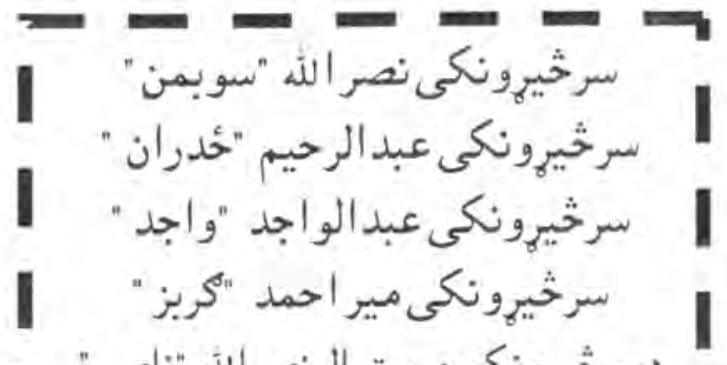

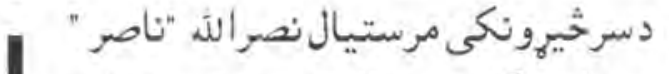

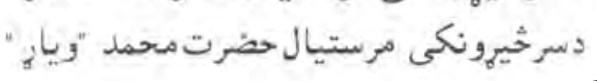

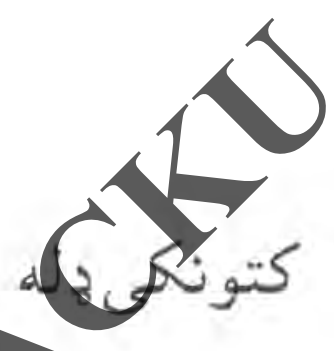

0

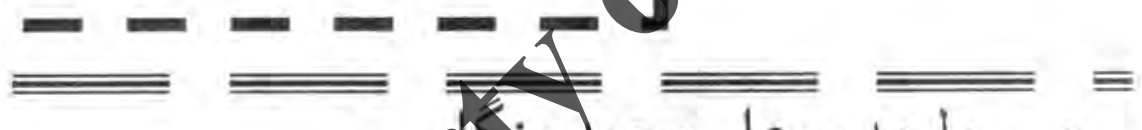
مسوول مدير: على محمد منهن

\section{.}

مجلملنى كله ون:

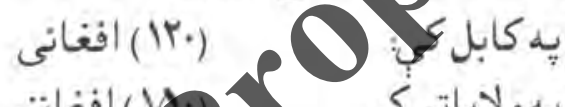

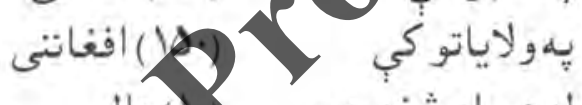

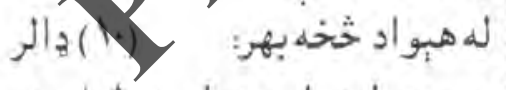
د محصلينو او متعلمينو لياره نيمه بيه

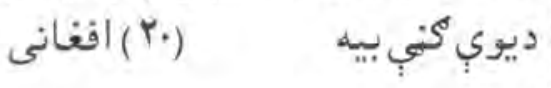

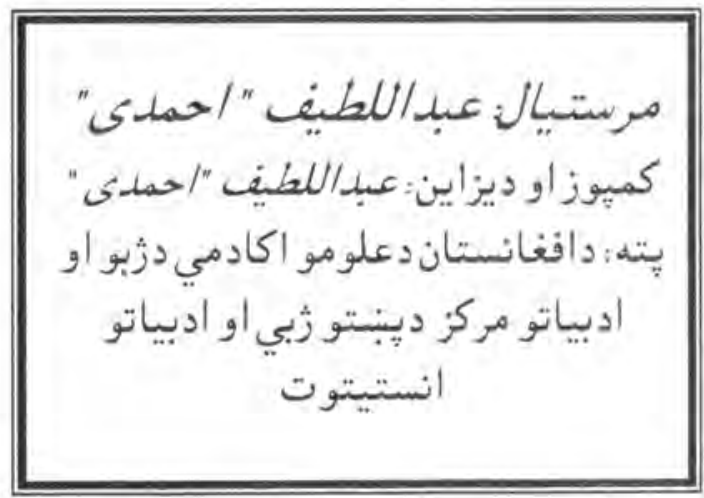

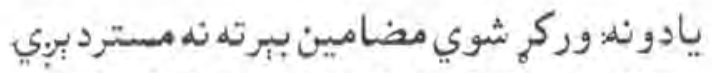

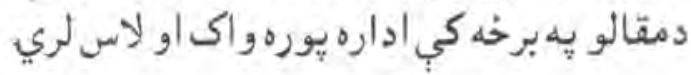
a. 03 


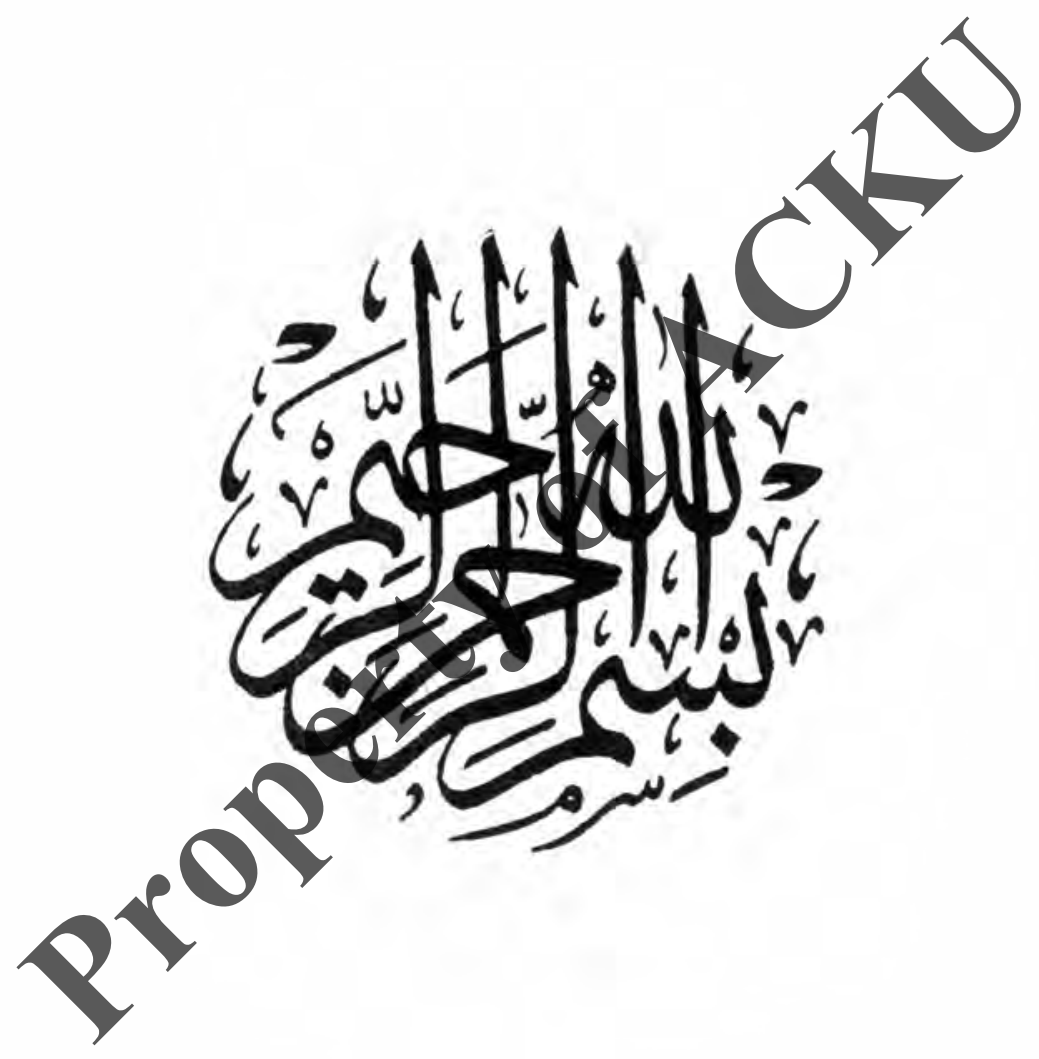

004 


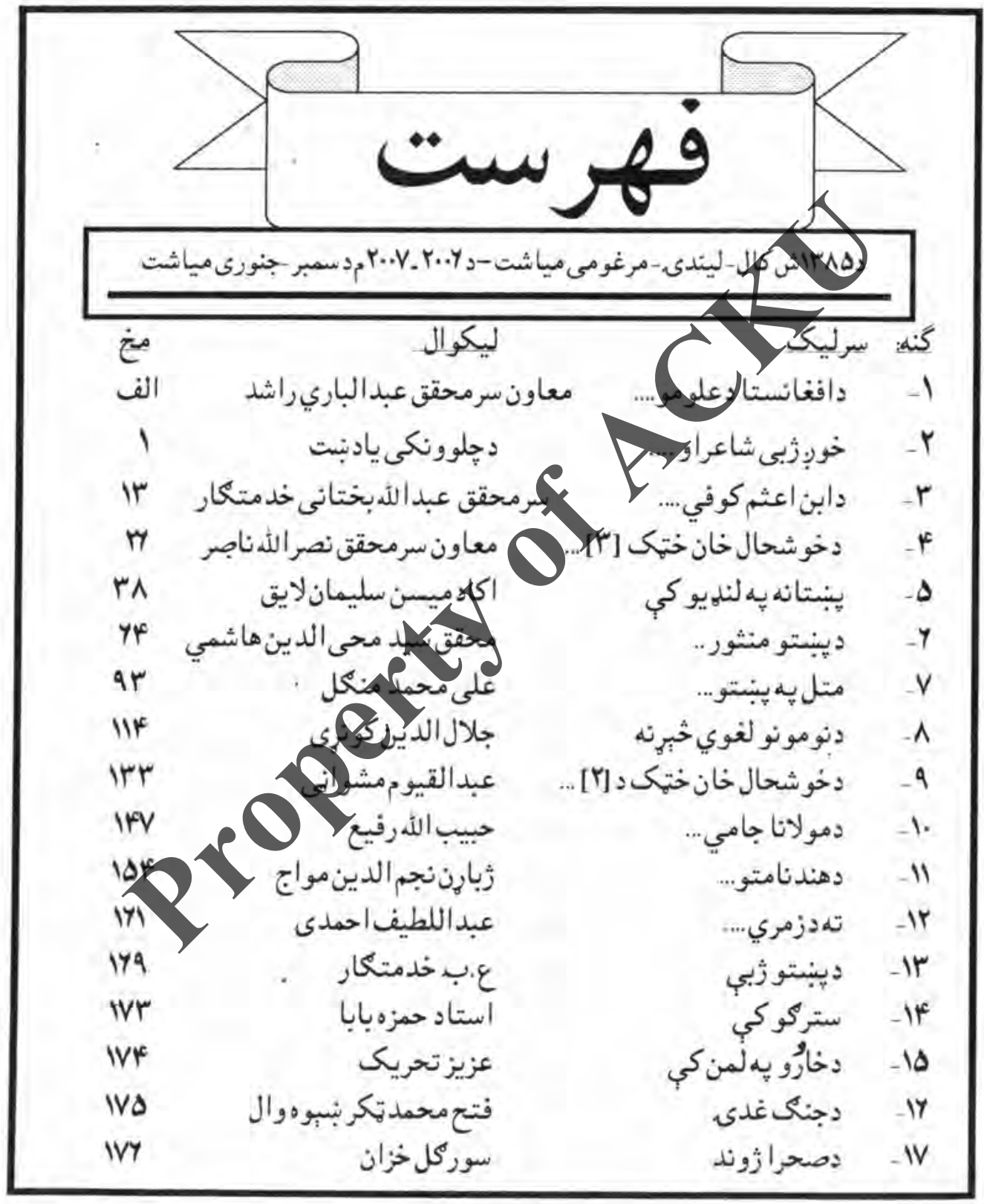




\section{بسم اللذ الرحمن الرحيم.}

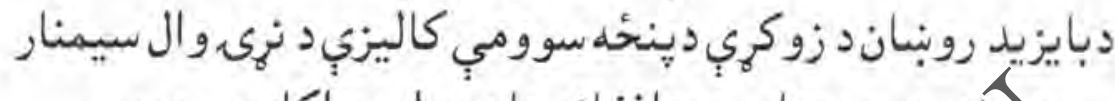

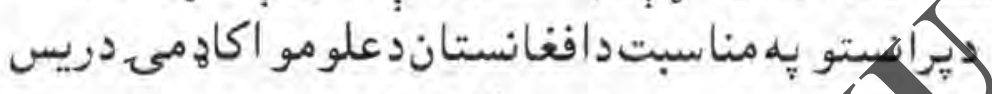

$$
\text { د ير انستونكي وإِينا متن }
$$

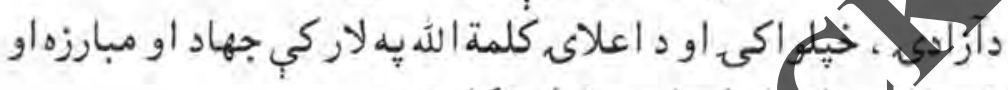

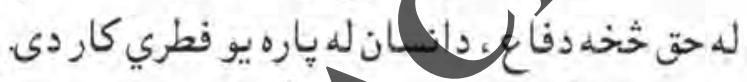

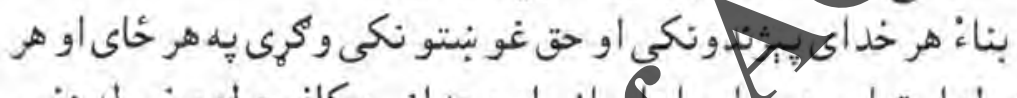

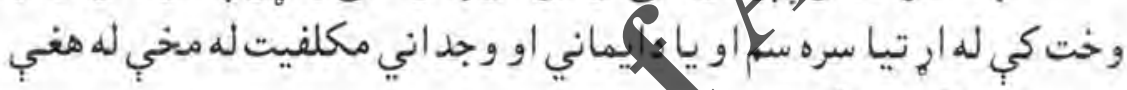

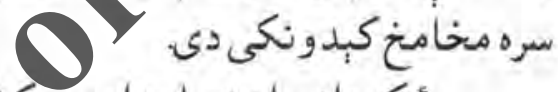

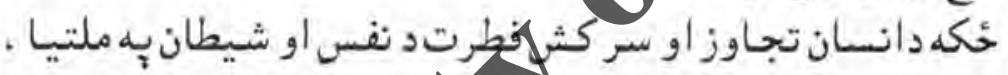

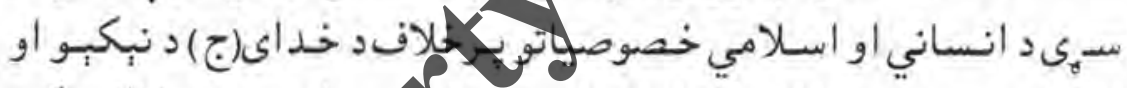

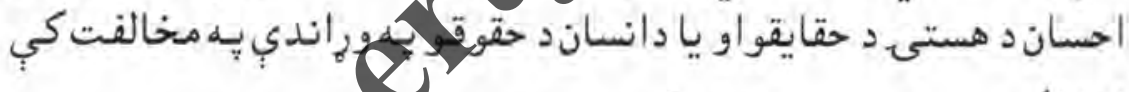
دروي.

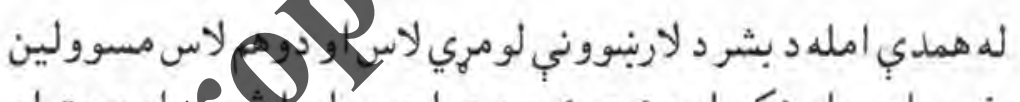

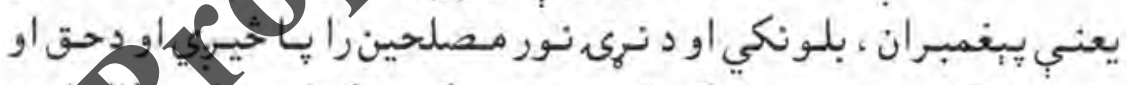

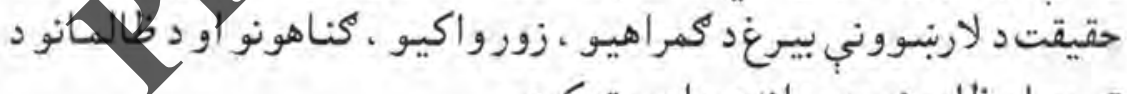

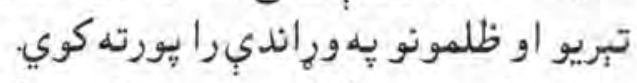

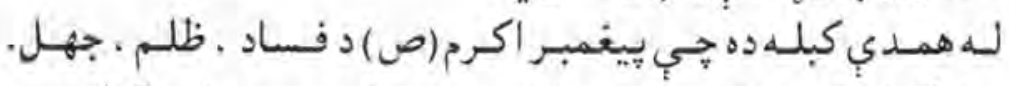

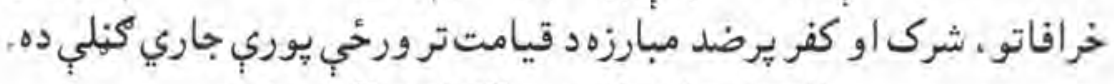
الجهاد ماض الى يو القيامة ( الحديث)

$$
\underbrace{1}_{a 06}
$$


زياره: جهاذ به دقيامت تر ورخي يوربي روانوي:

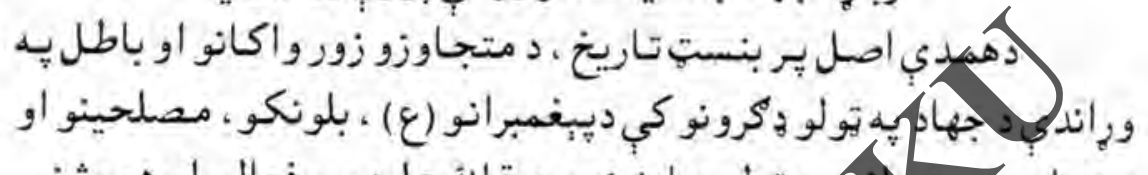

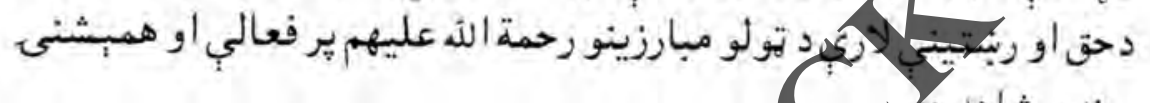

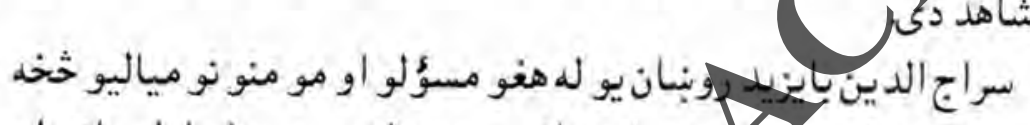

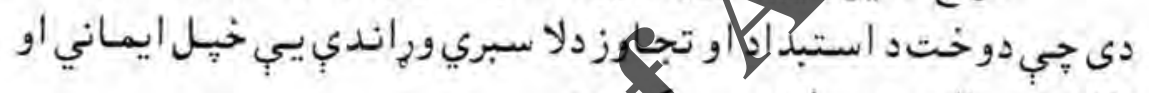

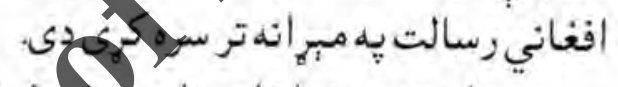

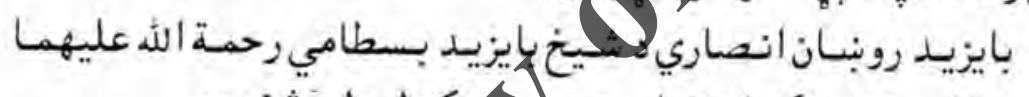

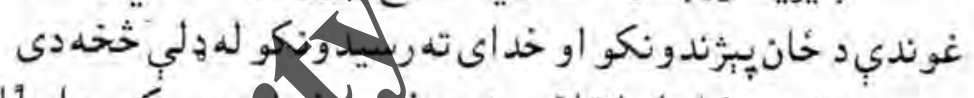

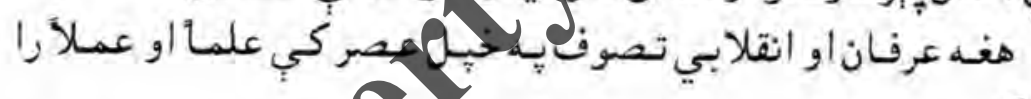

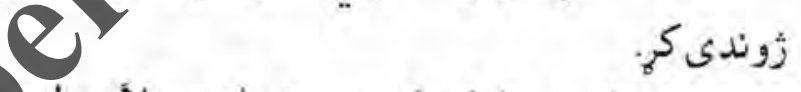

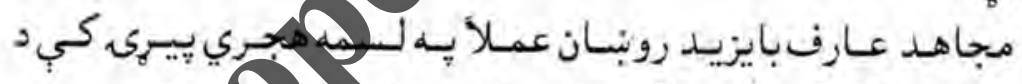

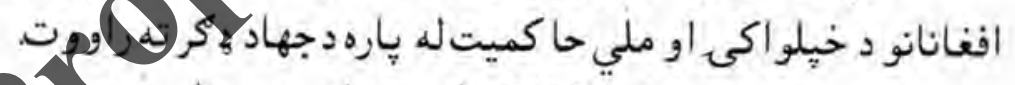

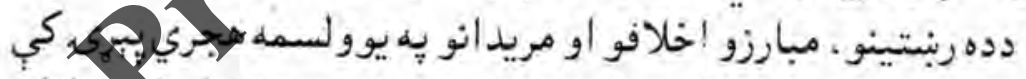

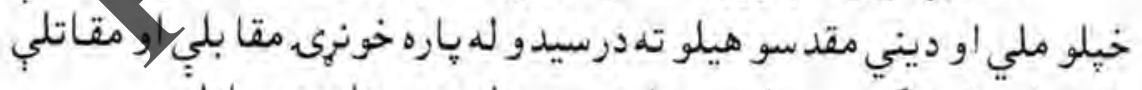

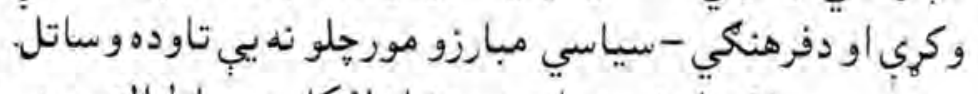

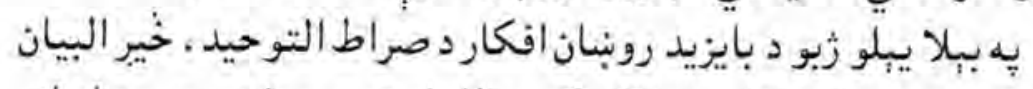

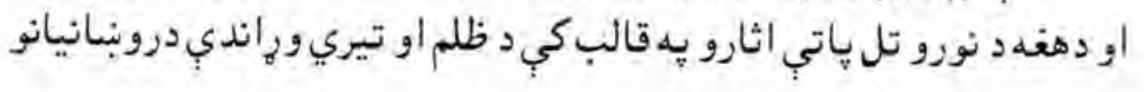

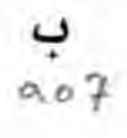


دمليكامي بنبونكي نهضت ديو محرك خو اك يه تو كه، دروبناني نهضت روحتشيليوية

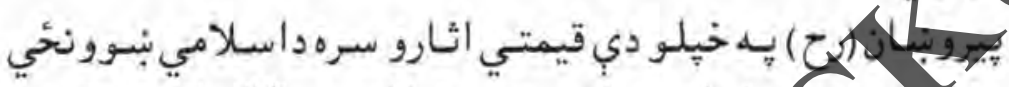

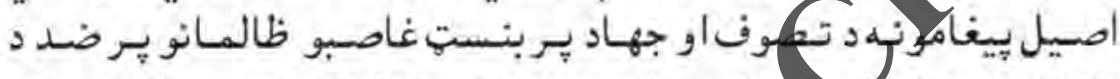

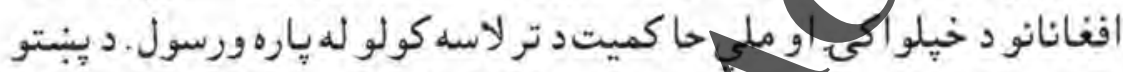

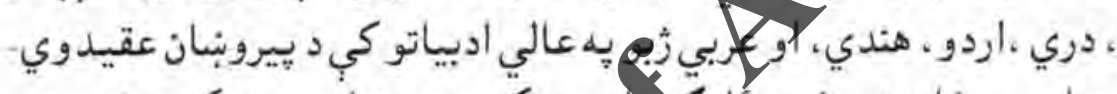

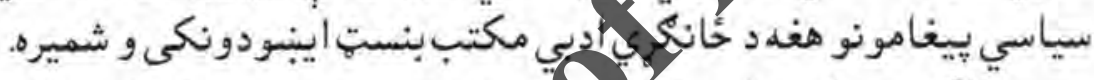

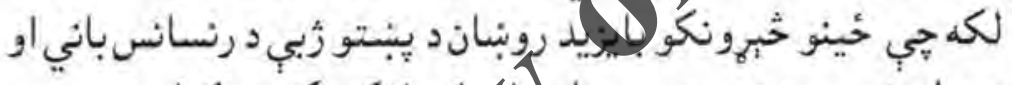

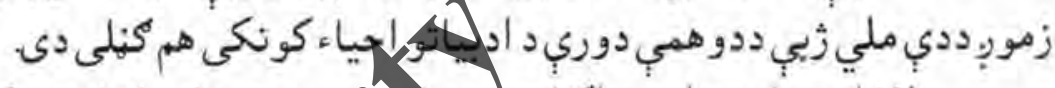

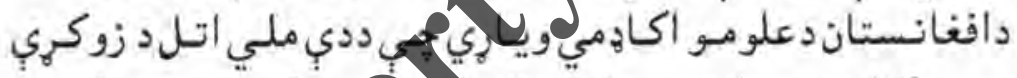

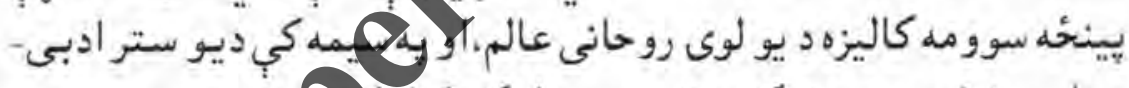

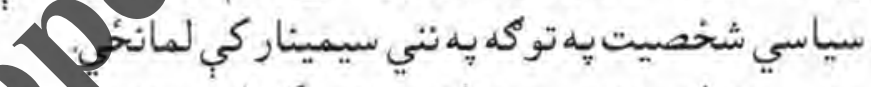

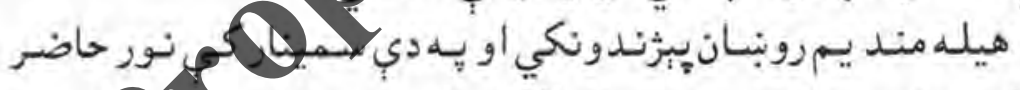

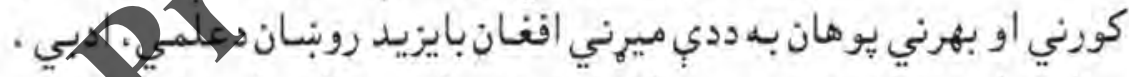

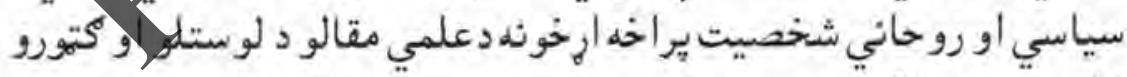

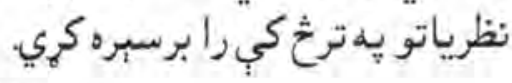
يهمدرناوي

معان سرمحقق عبد الباري (راشدي ) 
دلوى او مهربان خداى(ج) يه نامه

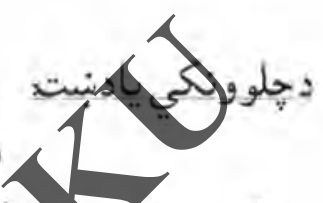

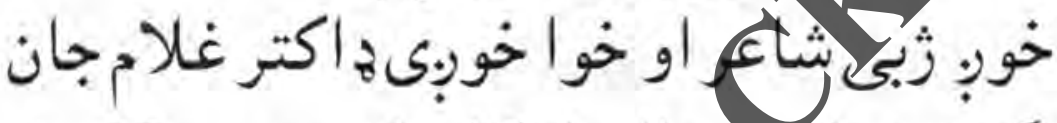

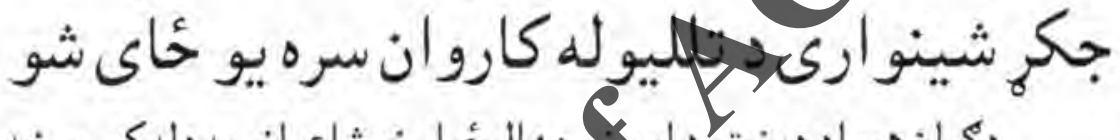

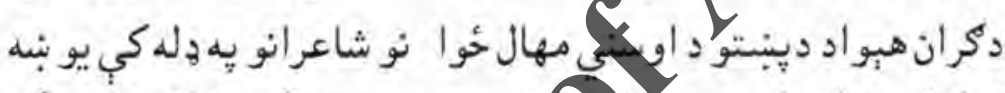

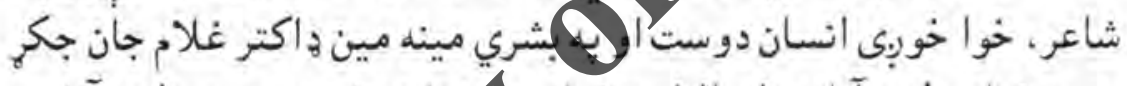

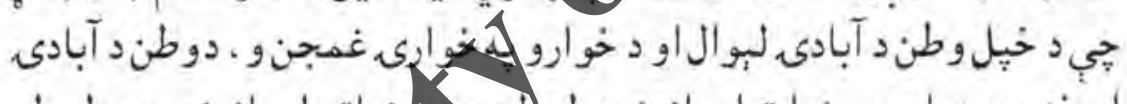

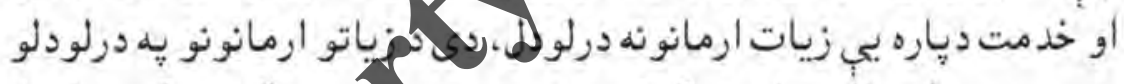

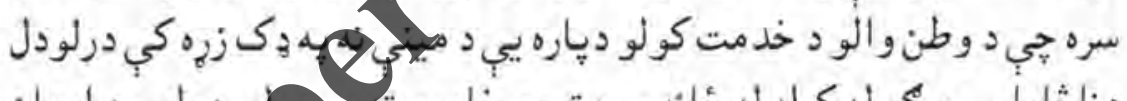

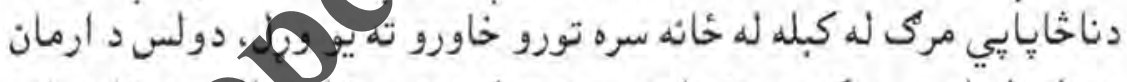

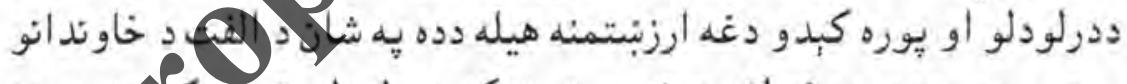

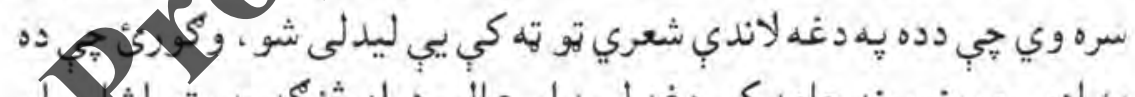

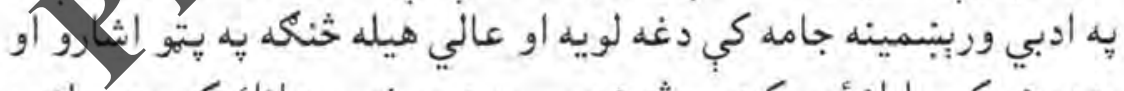

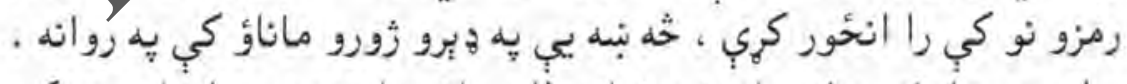

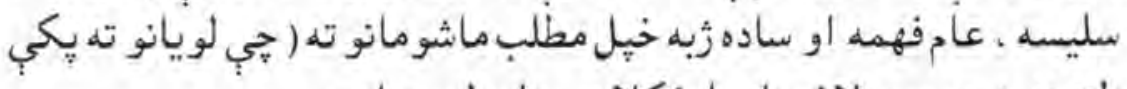

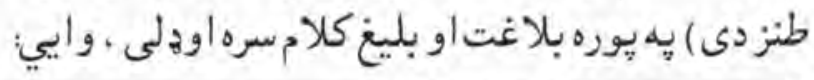

J $1 \times 1 \times \Delta$

1

$\cdot 1.9$ 


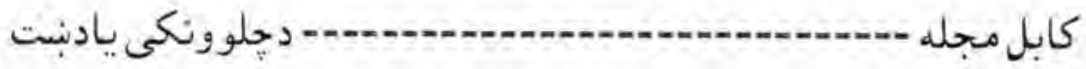

$$
\text { بل نهل لرمارمان }
$$

مينه يُ تلو راتلو زياتببري

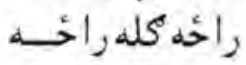

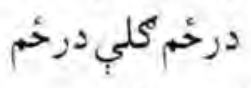

مر مي لف تا كلهصبر بربي

منم كرانه منم

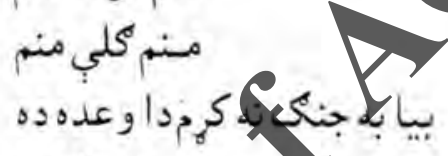

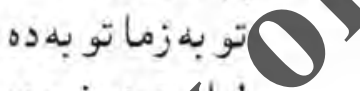

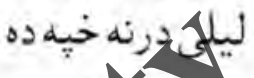

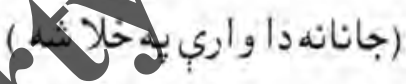

زمه زونه

دا تا كلة يربوبده

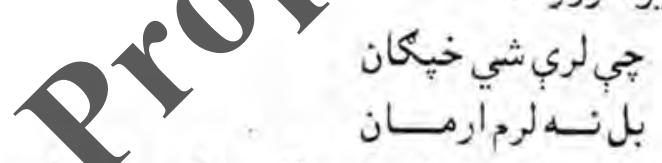

$$
\text { زما دا يوهاروز دهد }
$$

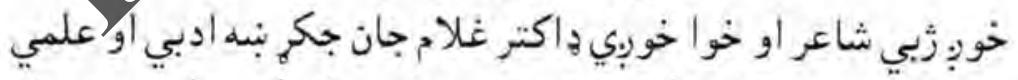

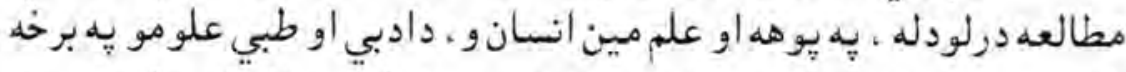

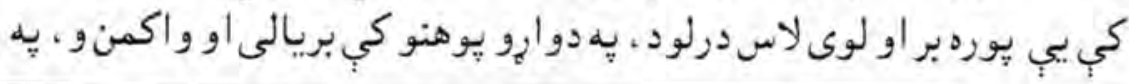

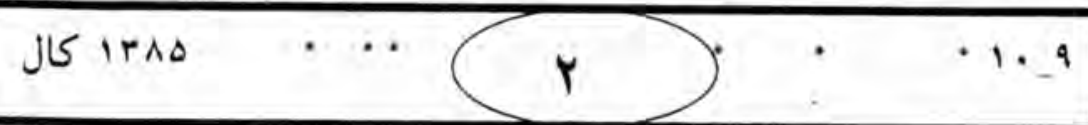




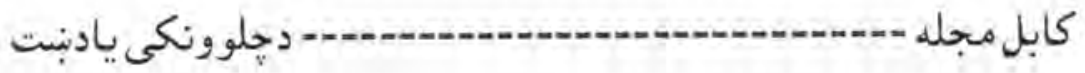

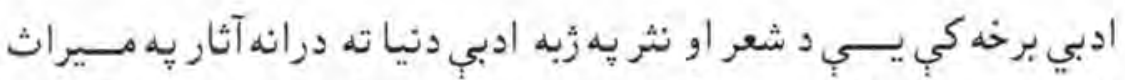

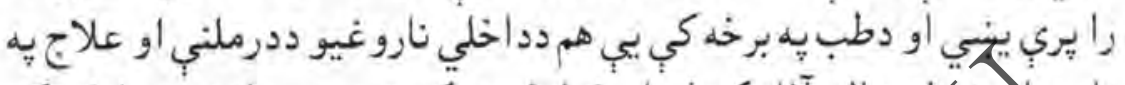

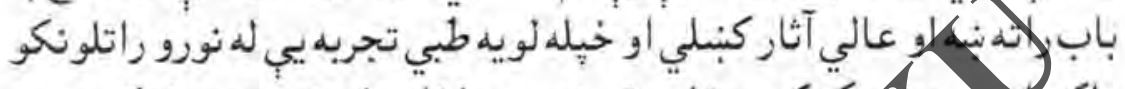

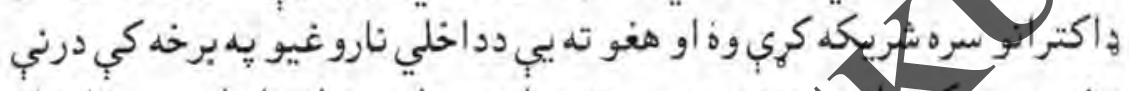

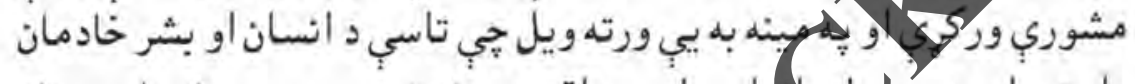

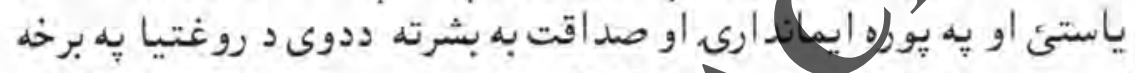

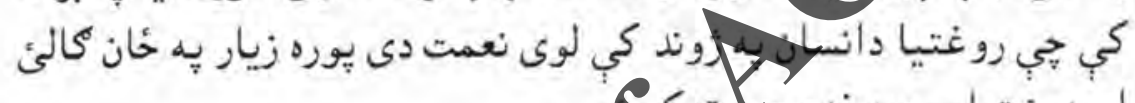

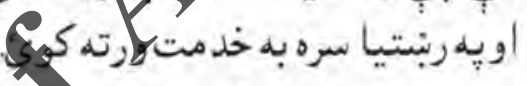

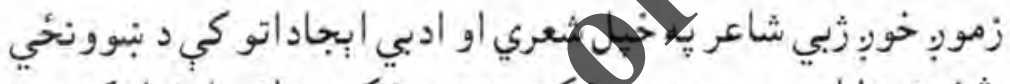

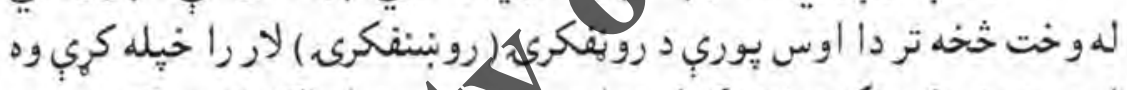

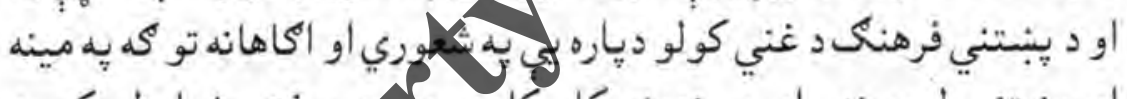

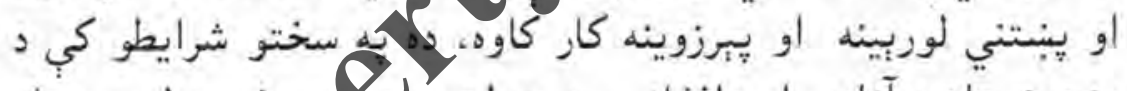

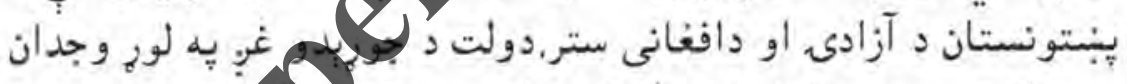

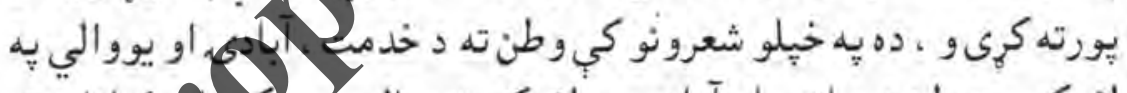

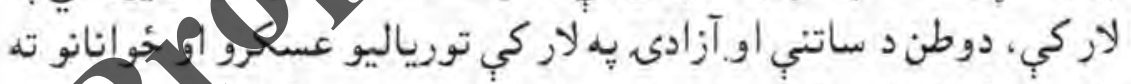

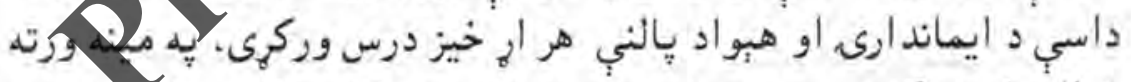

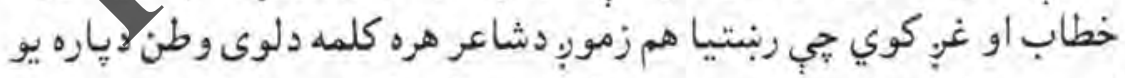

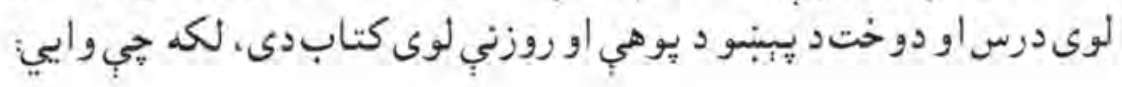

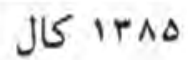
$r$
- 1. 9 


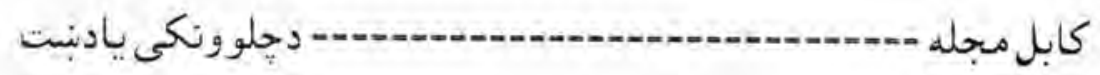

\section{عسكر ته}

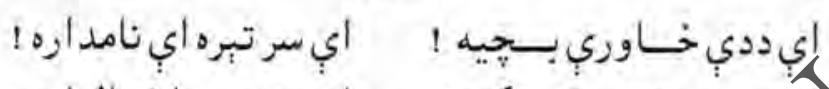

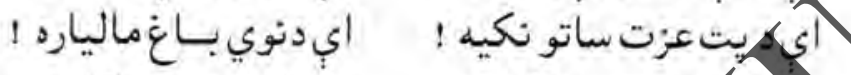

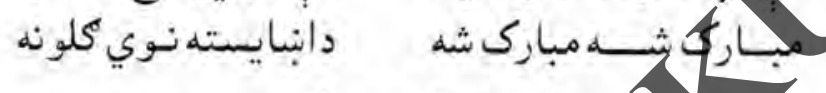

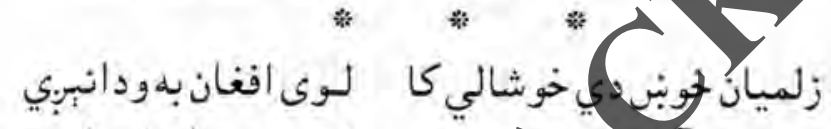

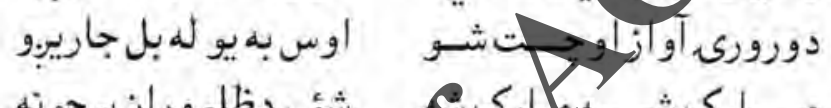

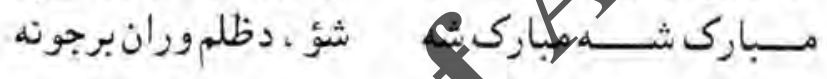

*ै

مهدي خاوره سيرلي تير شول

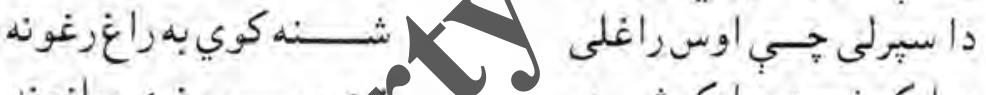

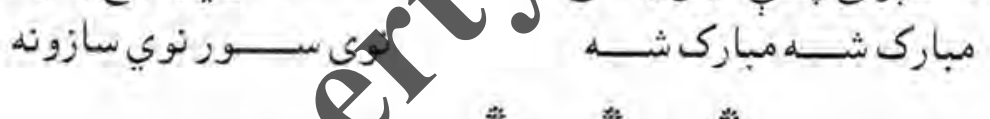

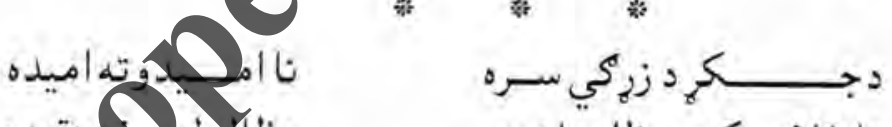
تا خلاص كري مظلوماندي

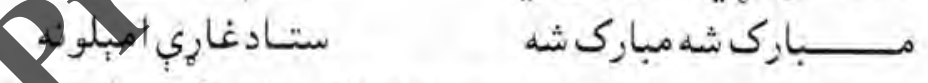

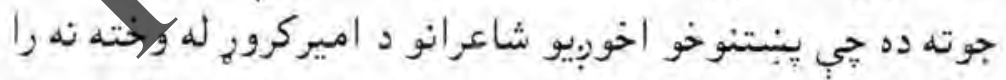

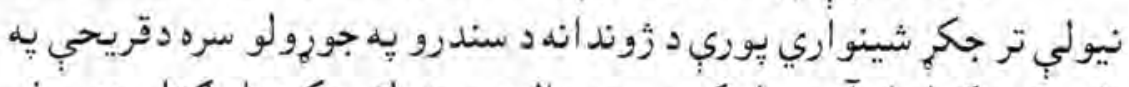

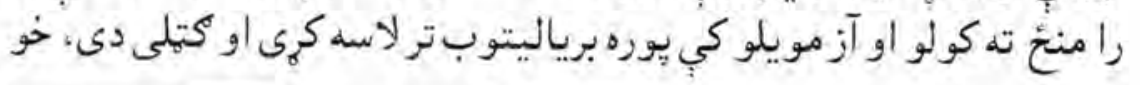
Jirno $\cdots \leqslant$ 


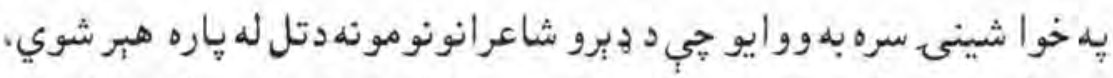

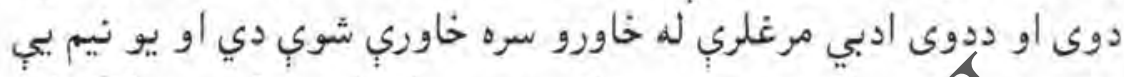

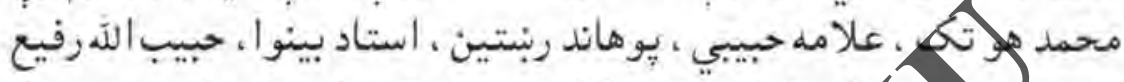

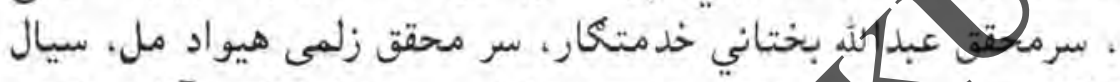

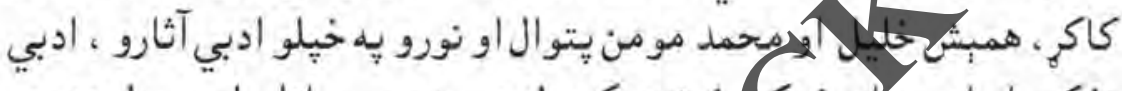

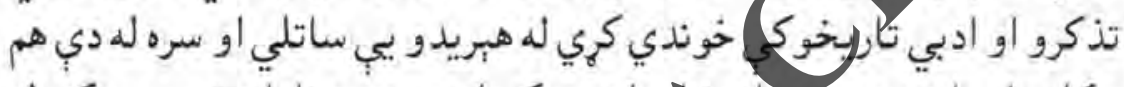

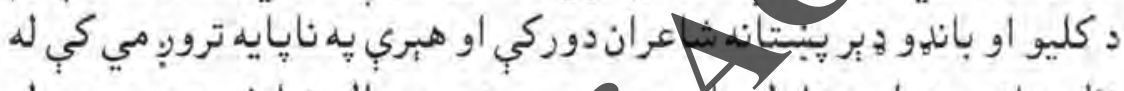

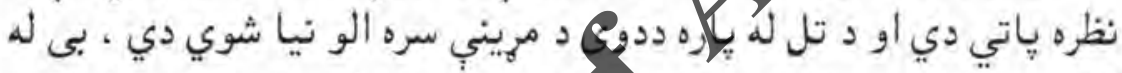

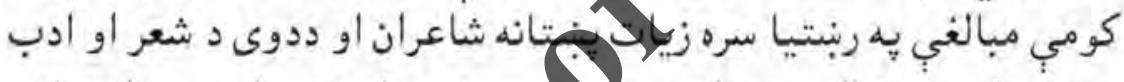

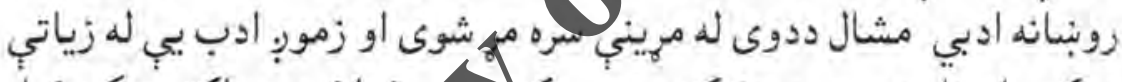

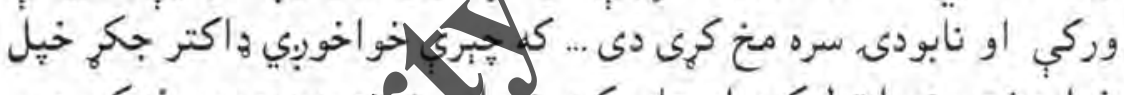

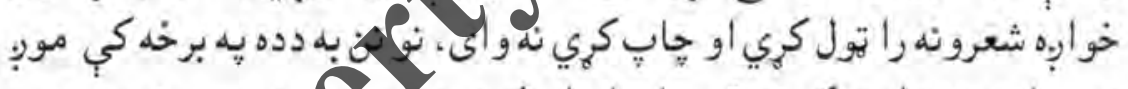

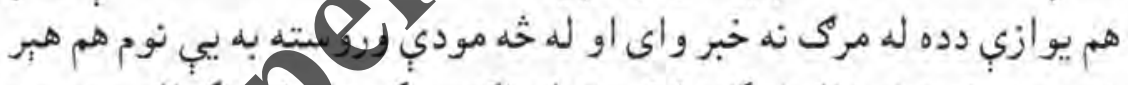

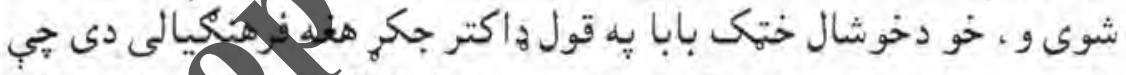

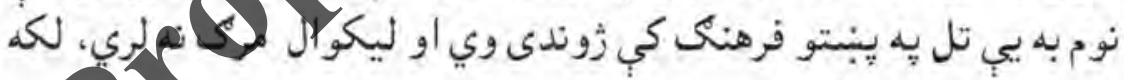

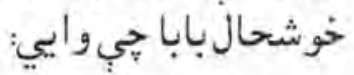

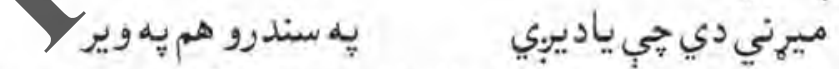

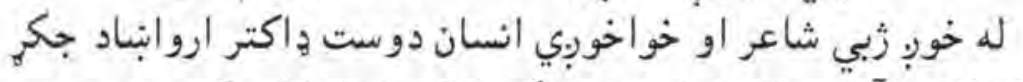

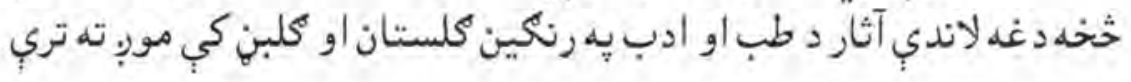
S1ro
0
- 1. 9 


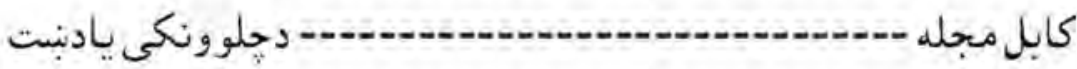

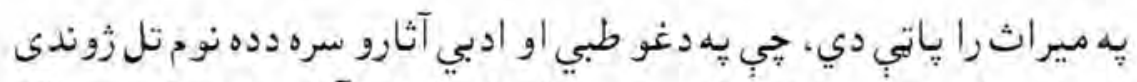

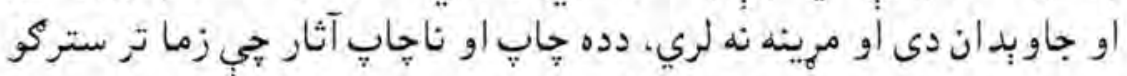

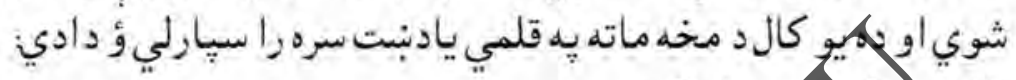

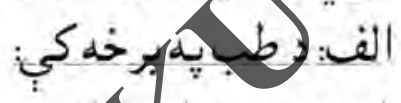

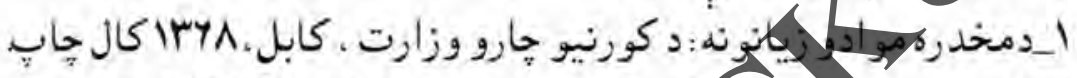

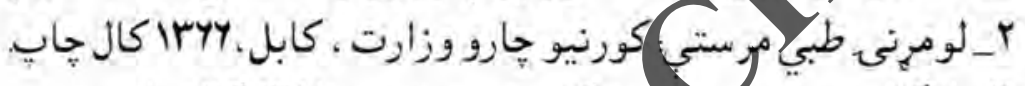

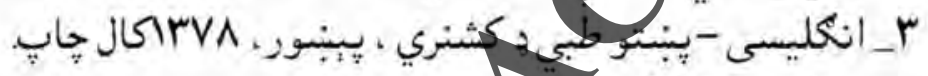

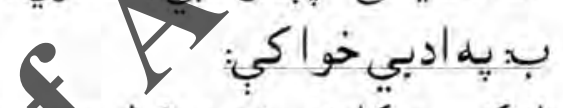

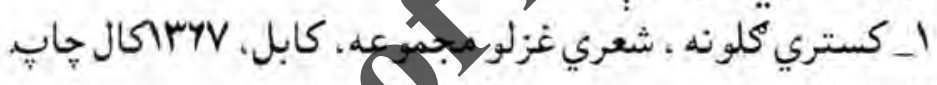

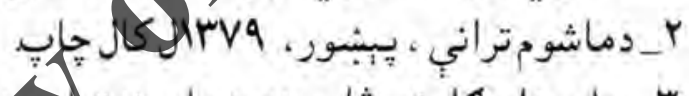

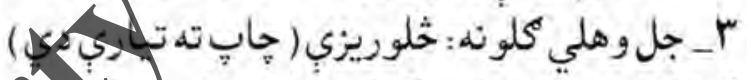

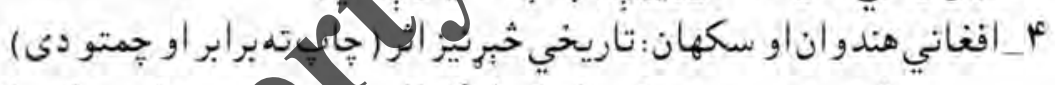

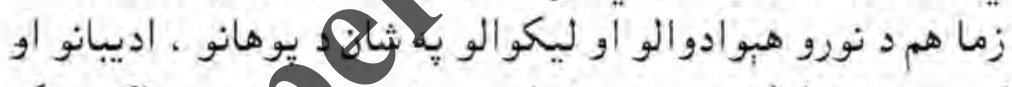

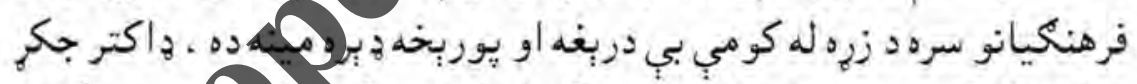

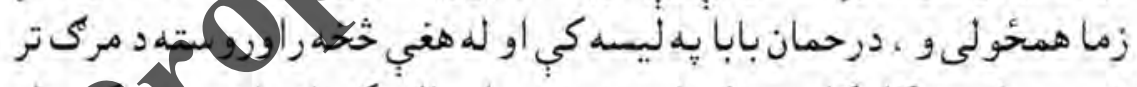

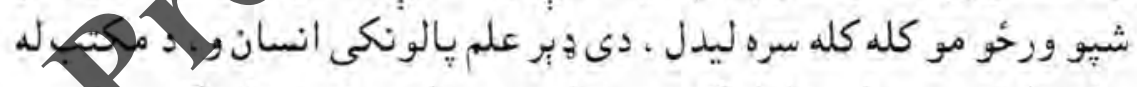

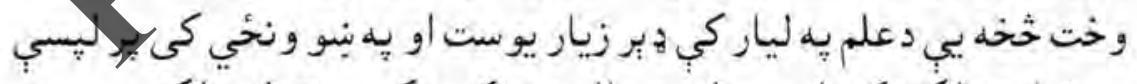

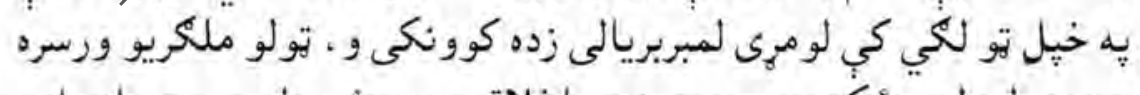

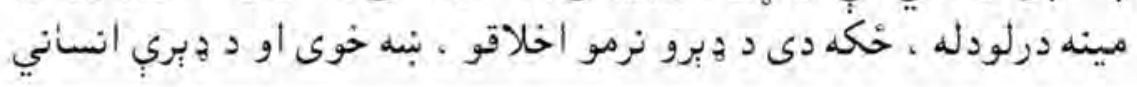

J ITA 


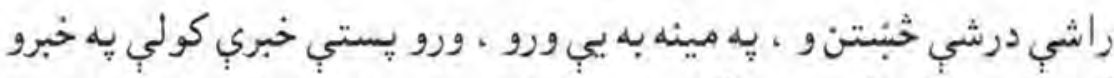

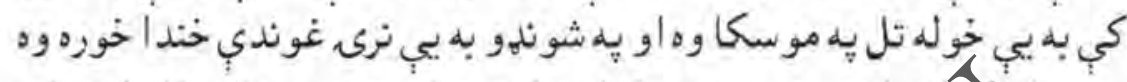

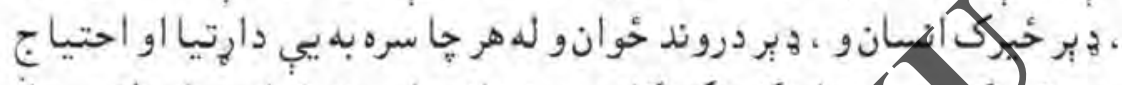

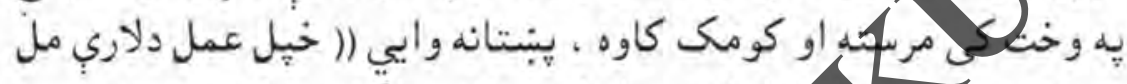

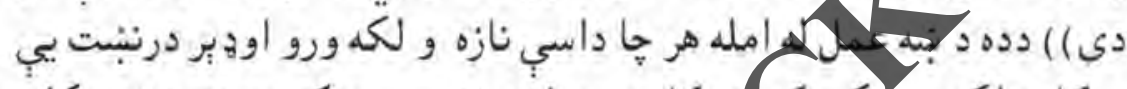

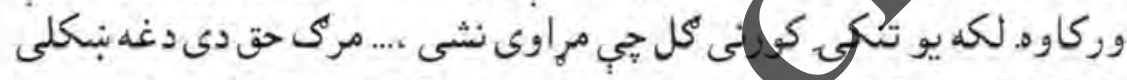

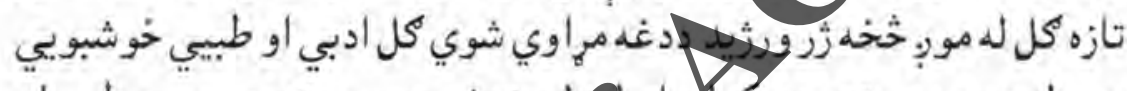

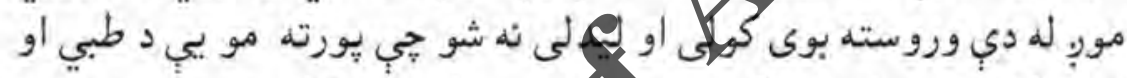

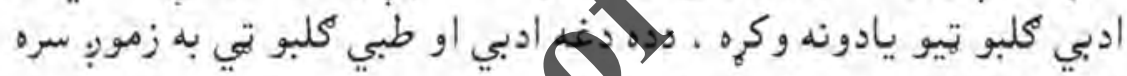

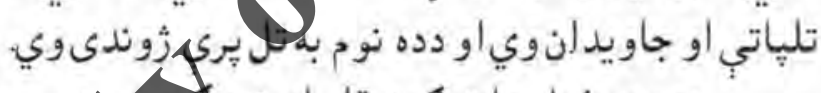

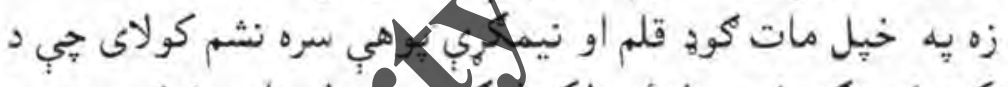

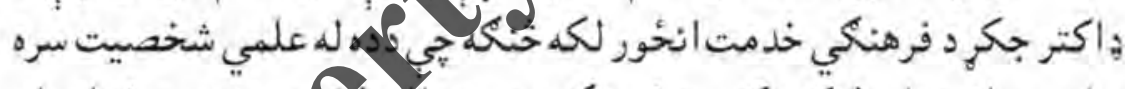

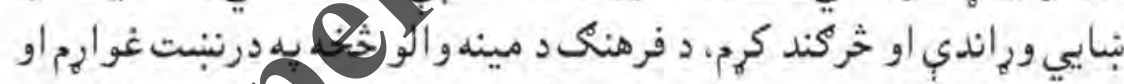

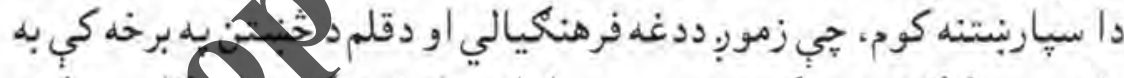

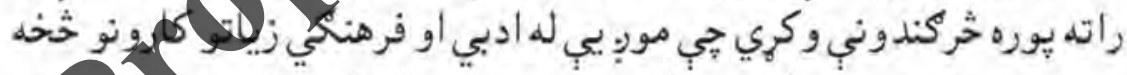

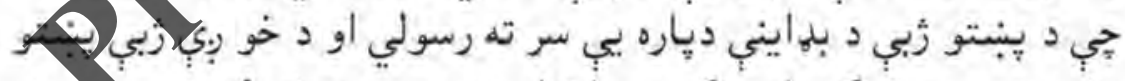

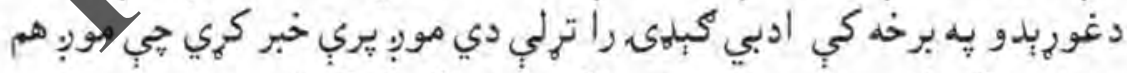

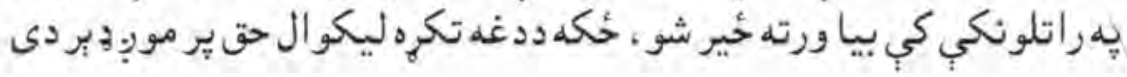
SARA
V
1. 8 


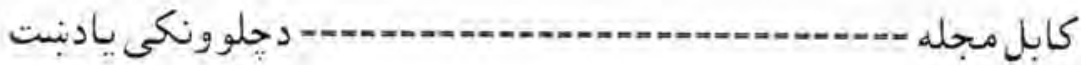

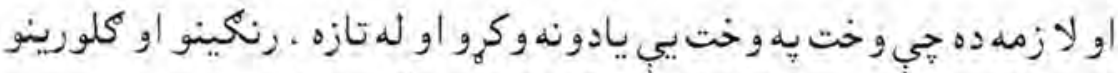

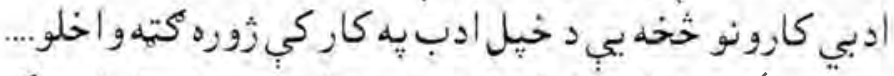

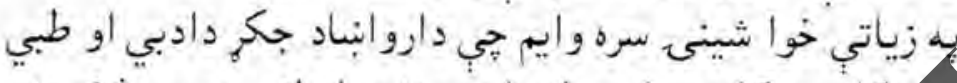

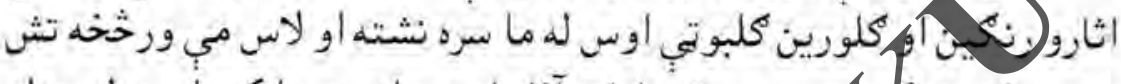

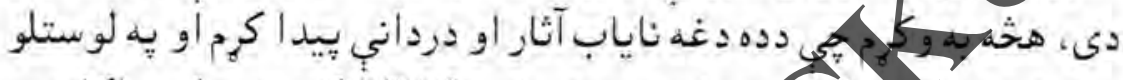

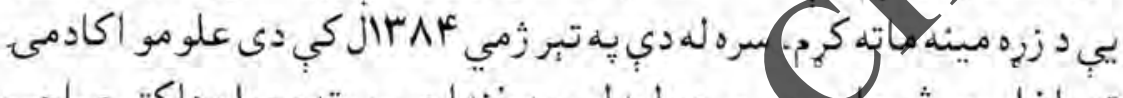

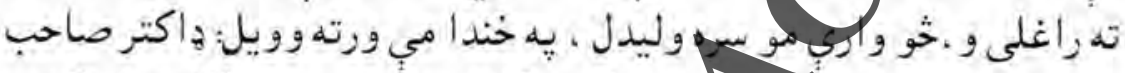

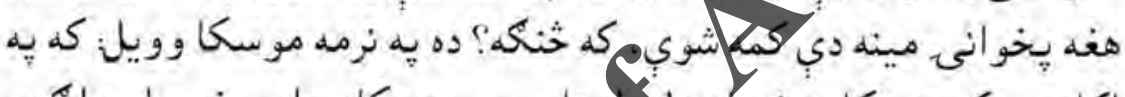

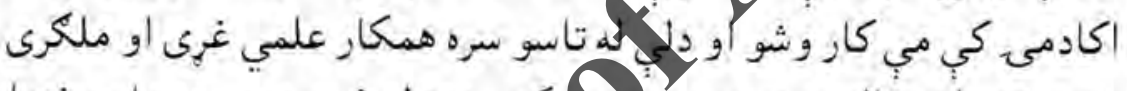

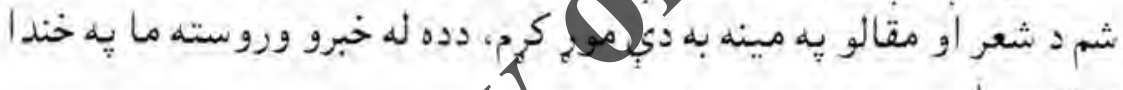
ورتهوويلن

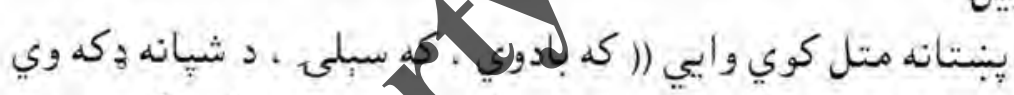

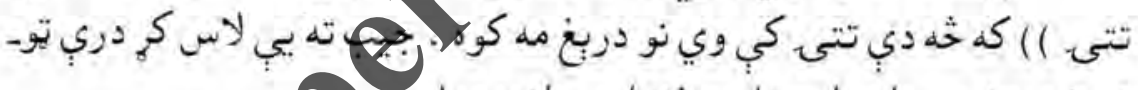

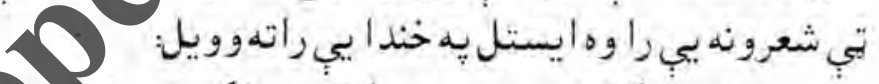

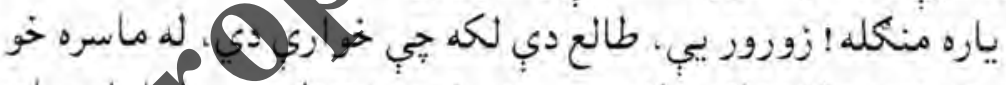

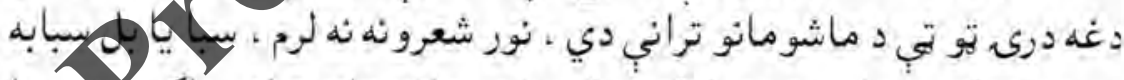

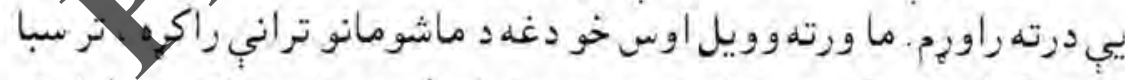

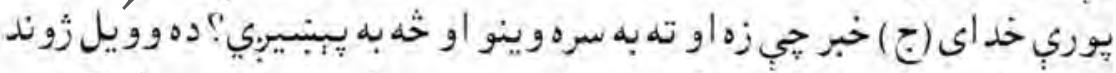

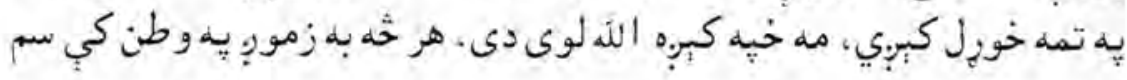

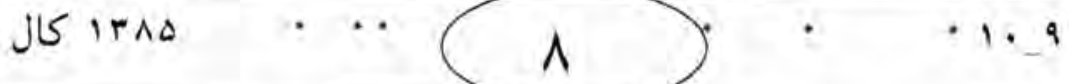




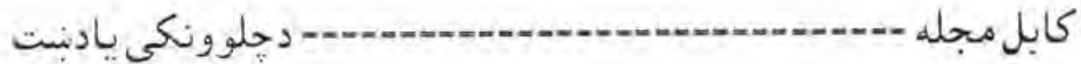

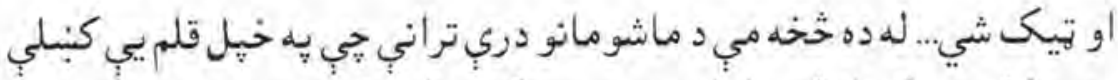

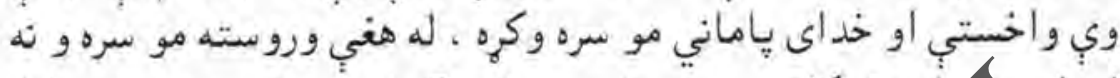

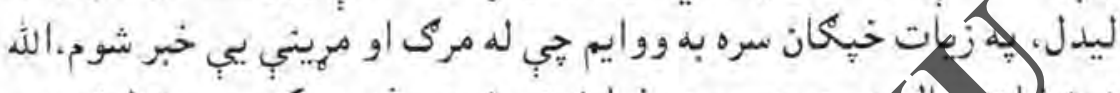

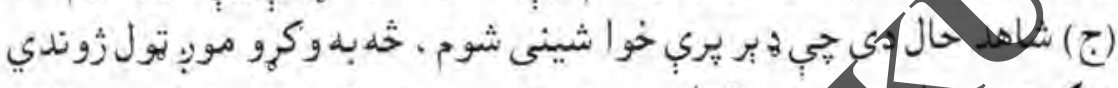

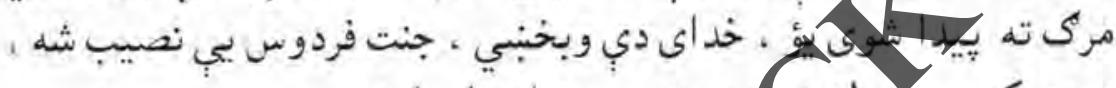

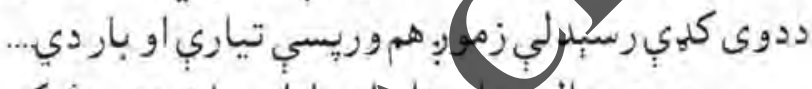

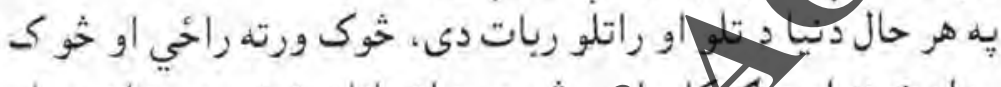

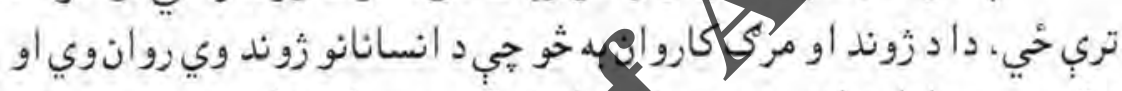

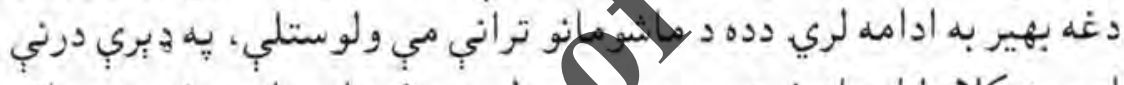

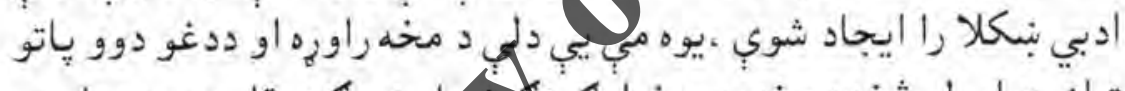

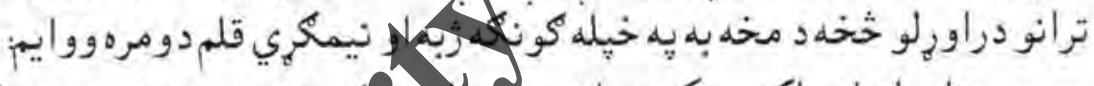

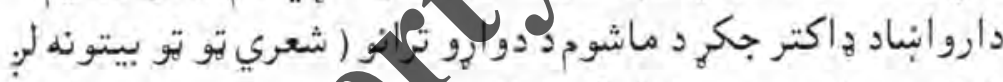

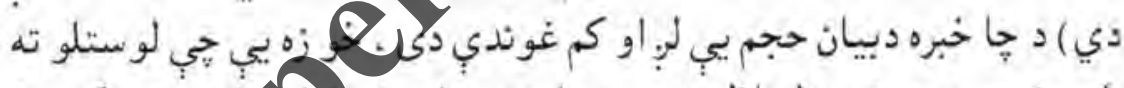

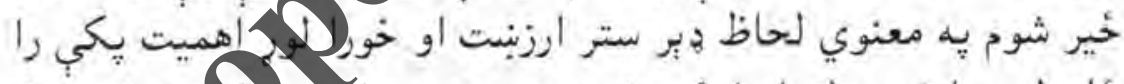

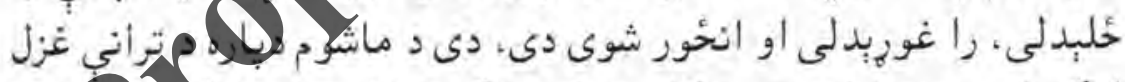

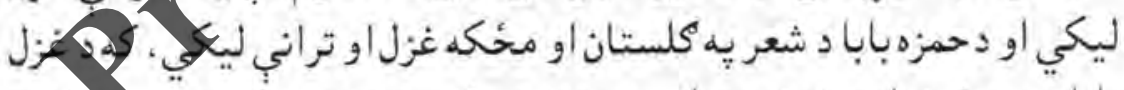

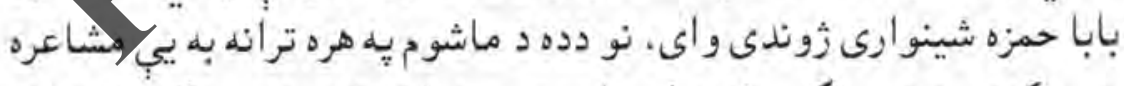

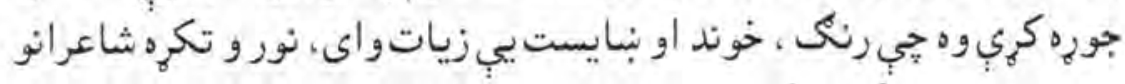

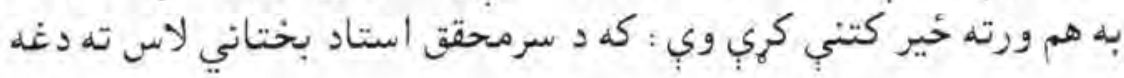

J S IrA

9

$-1.9$ 


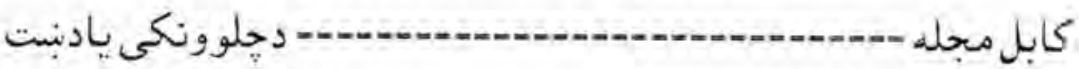

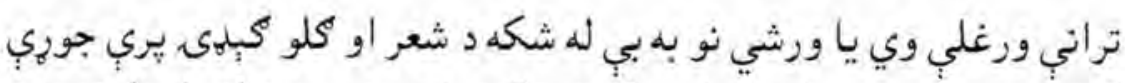

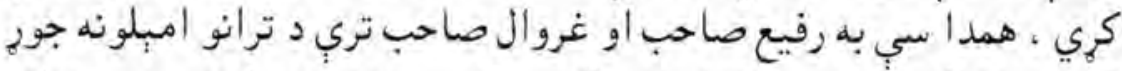

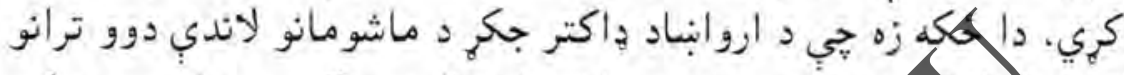

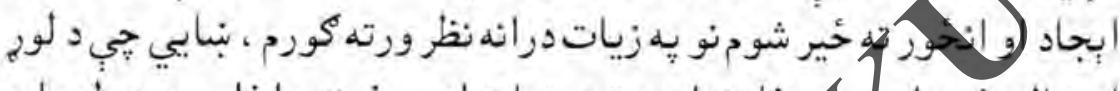

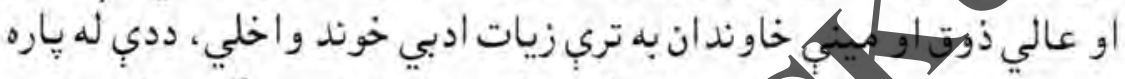

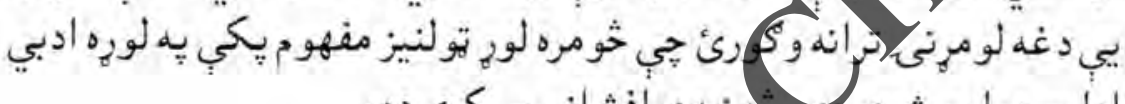

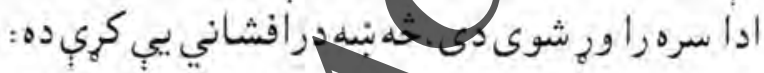

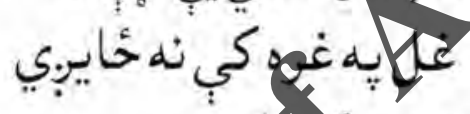

منزل ته نهرسيكونيجيا

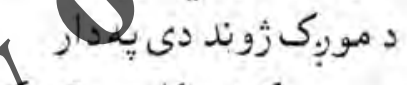

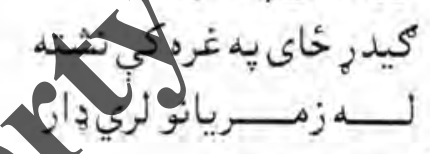
2
يسهندوركو دي يوهيدلي
كف نايوه دي كة هونبيار

غل يه غره كي نهخايبيار

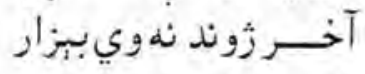

$$
\begin{aligned}
& \text { خيـلـل لاسه كله لاسه }
\end{aligned}
$$

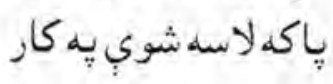

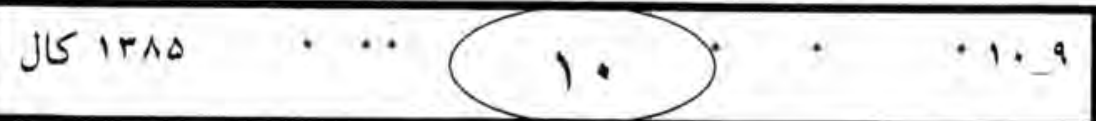


دجلوونكى يادنبت

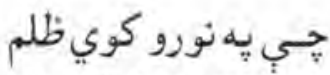

$$
\begin{aligned}
& \text { شي يه خيله خو ارو زار } \\
& \text { يه تيولنه كي خأى نشته } \\
& \text { د تنبـلـل او دبي كـــار }
\end{aligned}
$$

كابل مجله

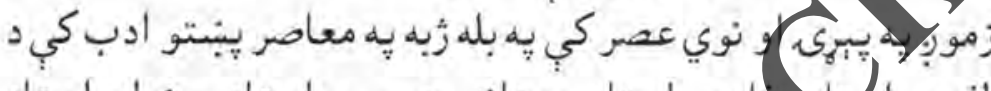

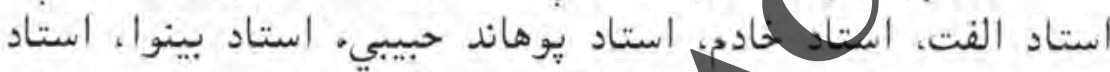

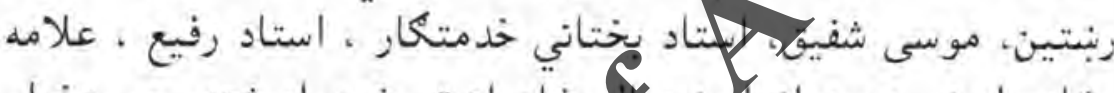

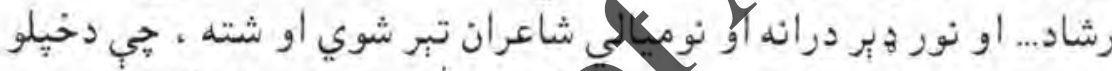

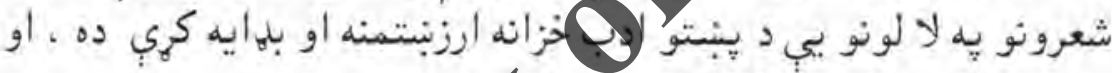

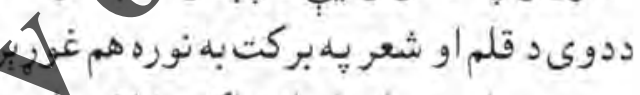

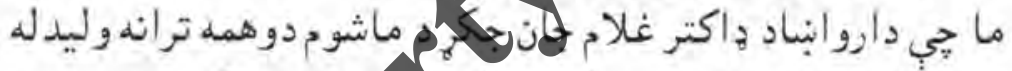

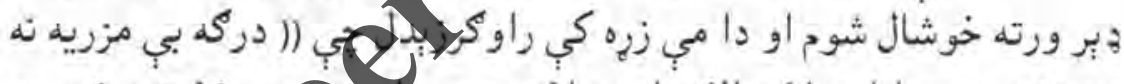

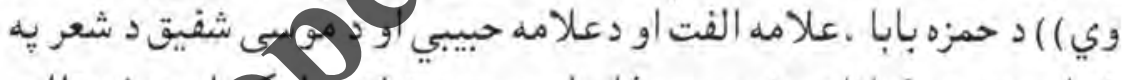

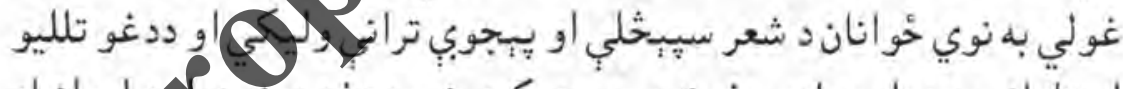

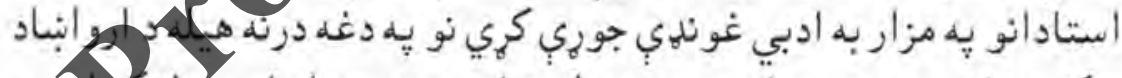

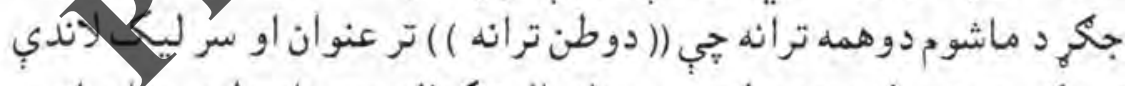

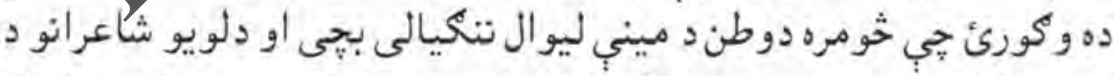

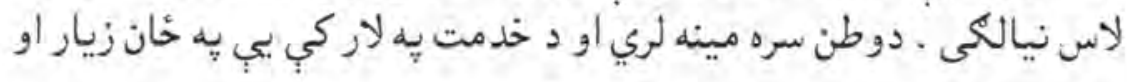
J IrAs
1)
- 1. 9 


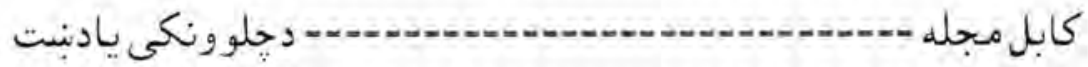

زحمت فرضكني، د مشرانو او لويانو درناوى كوي او د ملي يو والى كلك انك دوطن ترانه

بنبايسته مو دا كلشندى

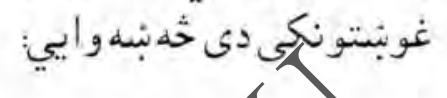

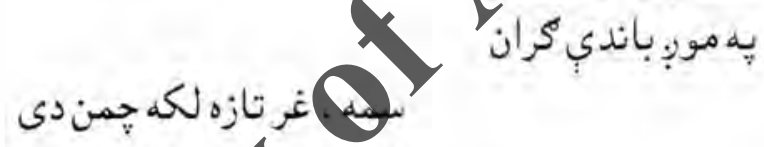

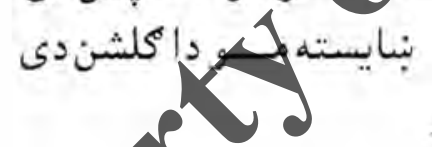

$$
\begin{aligned}
& \text { خدمت خيل وطن كرو برو }
\end{aligned}
$$

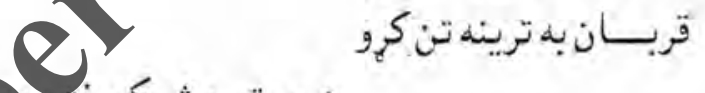

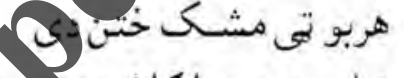

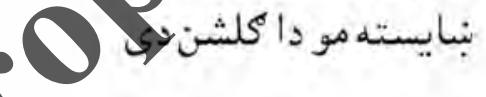

$$
\begin{aligned}
& \text { بجِيان ددي هبو اد يؤ } \\
& \text { هي ورونهـ يؤئ آباد يؤي }
\end{aligned}
$$

$$
\begin{aligned}
& \text { ديو والي زُوند يُّمن دى } \\
& \text { بنايسته مو دا كلشندي دونى } \\
& \text { ية درنبنبت }
\end{aligned}
$$




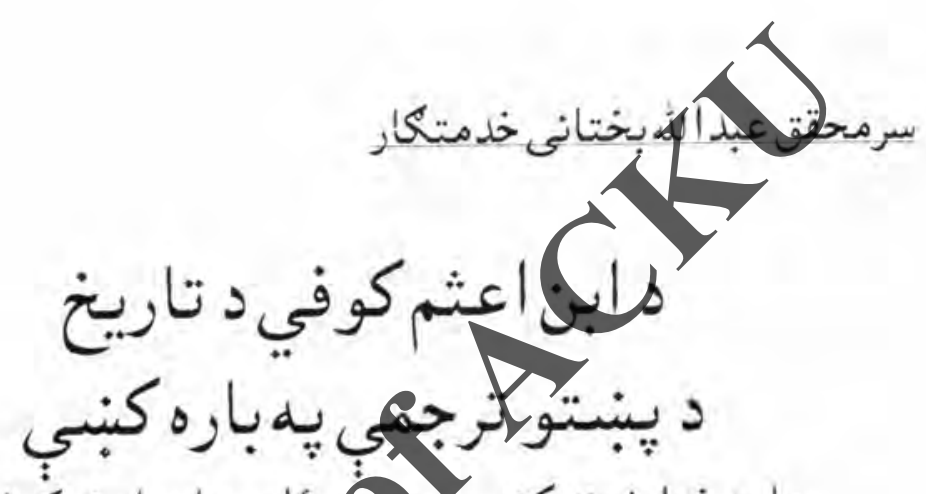

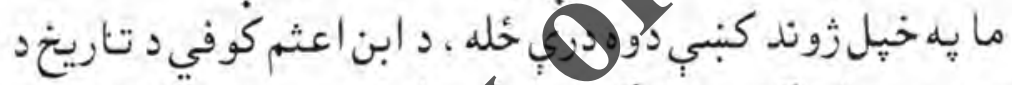

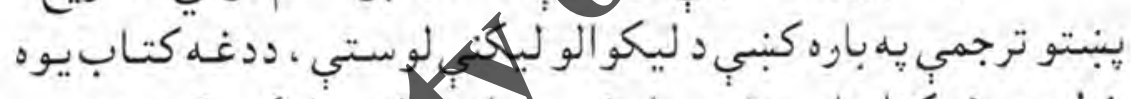

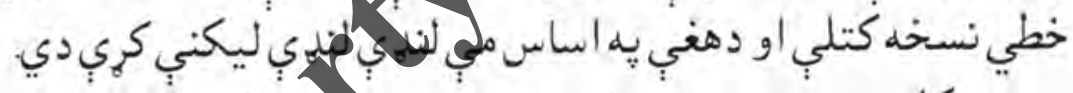

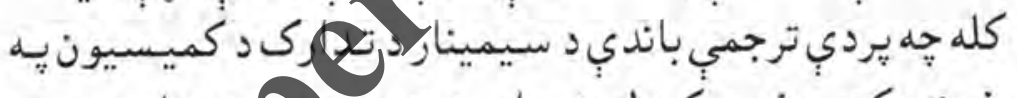

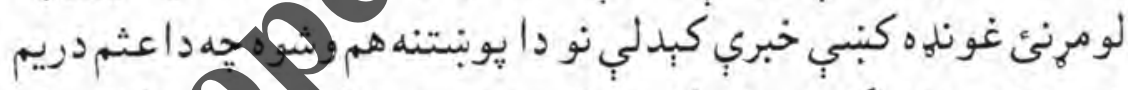

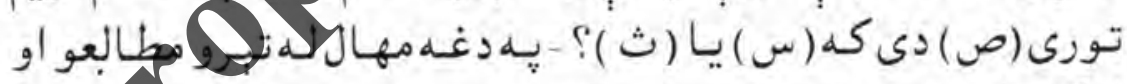

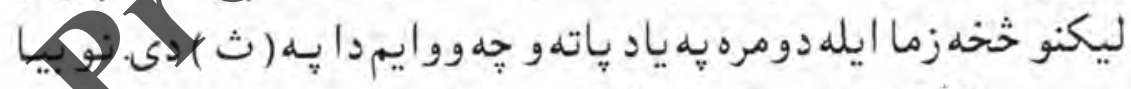

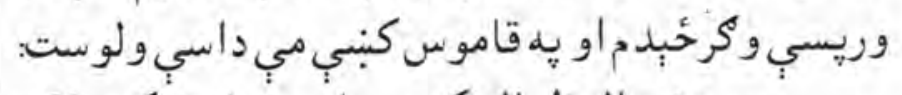

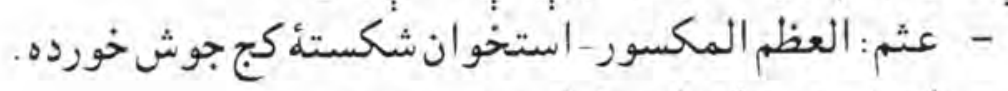

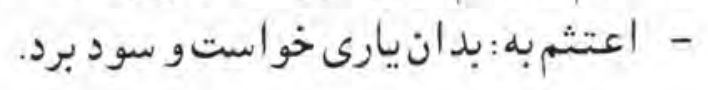

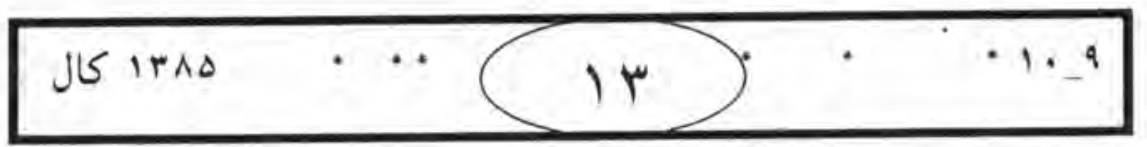




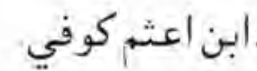
كابل

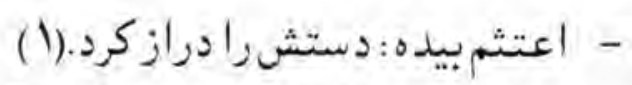

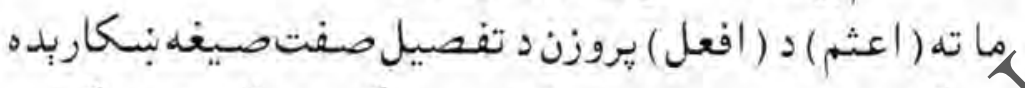

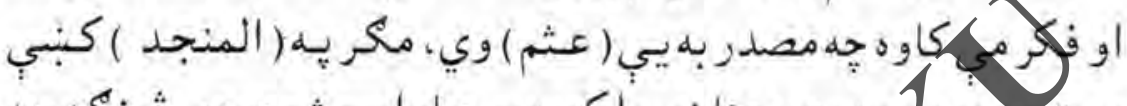

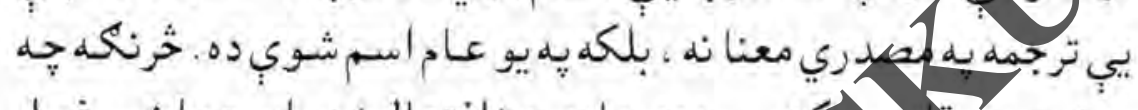

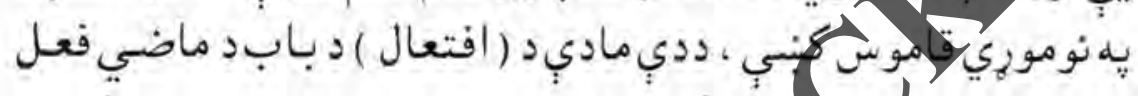

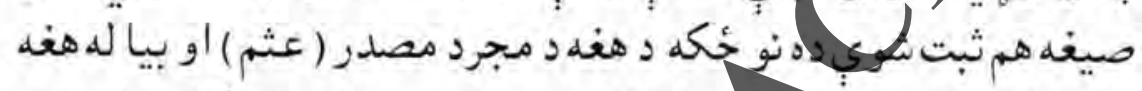

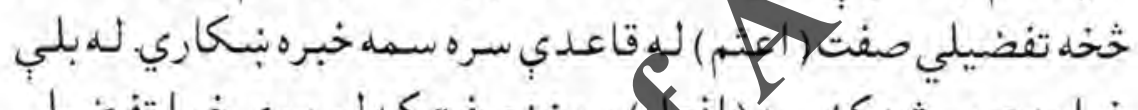

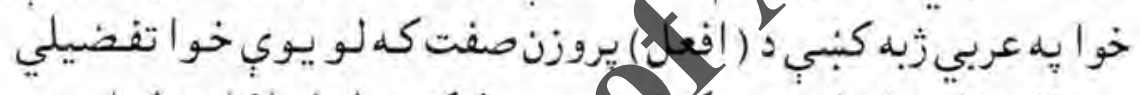

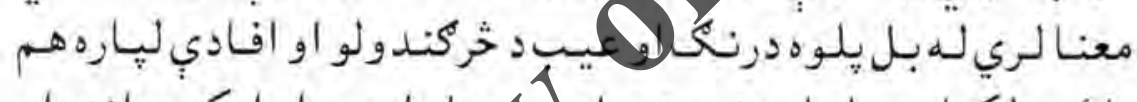

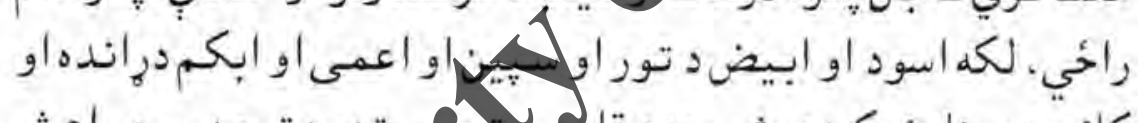

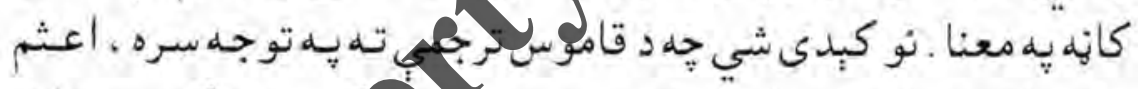

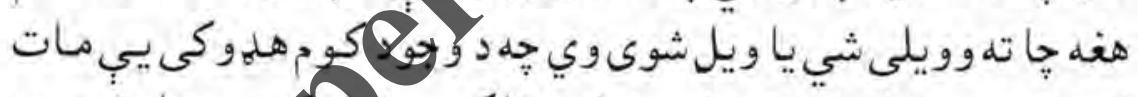

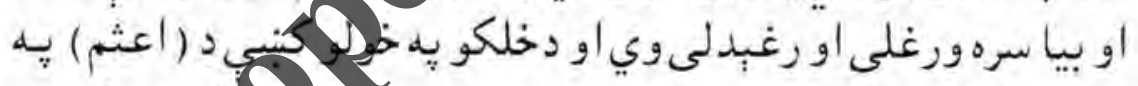

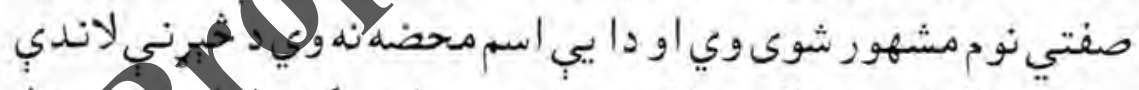

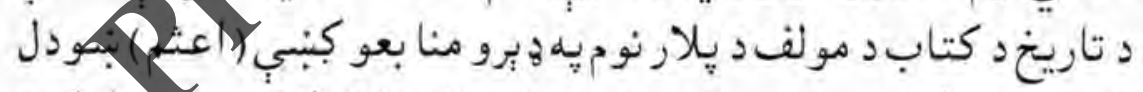

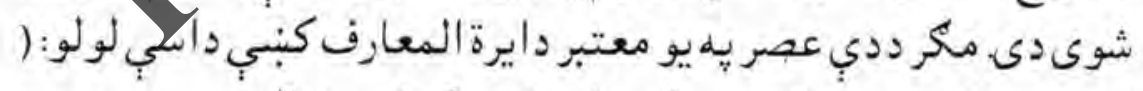

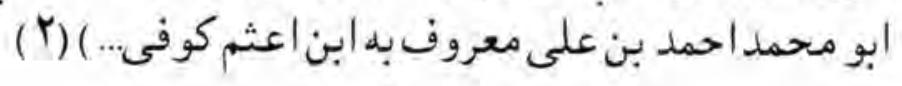
IrAo 


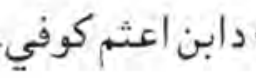

كابل مجله -

نو دي سند سره زمونبِ تو جبه قوتمومي جه دغه شخص (علي)

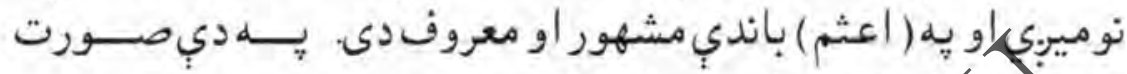

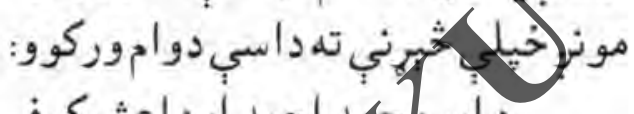

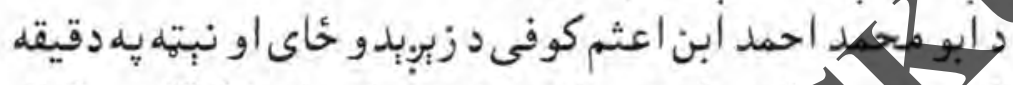

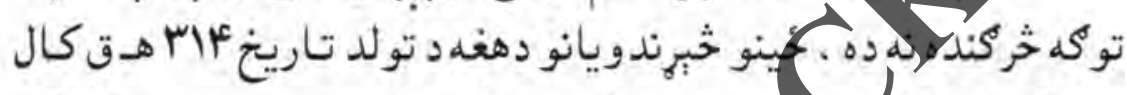

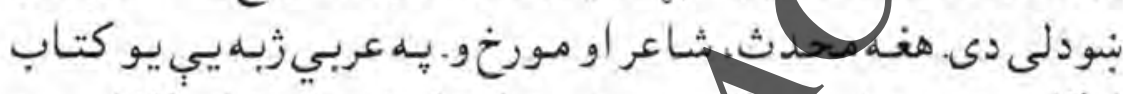

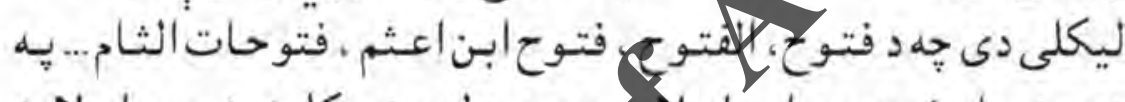

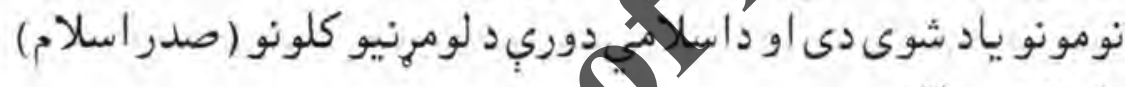
تاريخ دى. (r) (r)

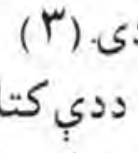

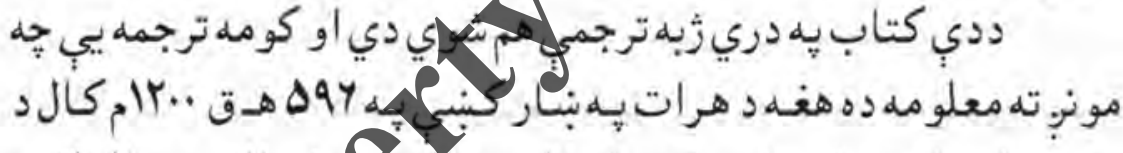

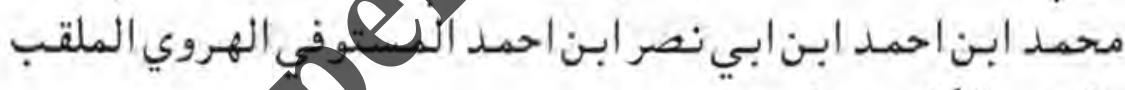

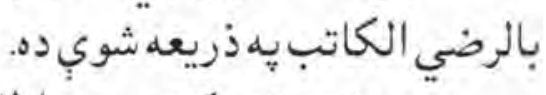

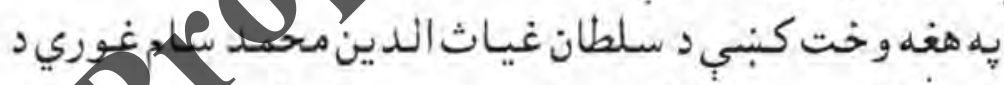

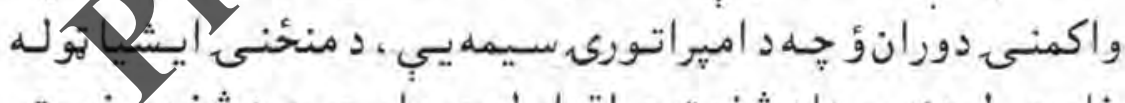

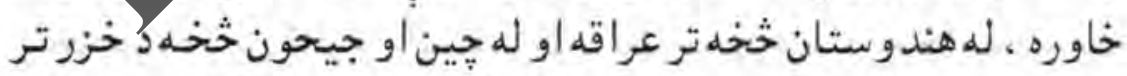

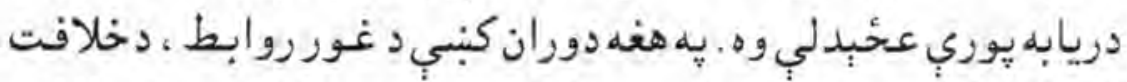

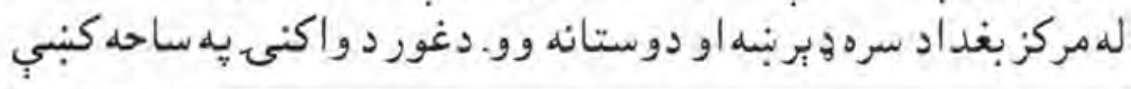
Jirno $\cdots 10$ 


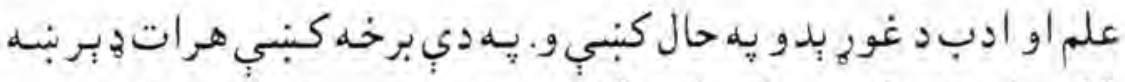

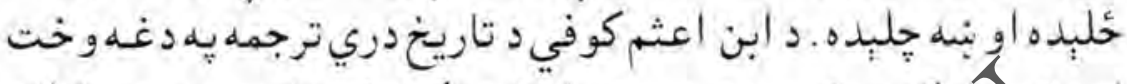

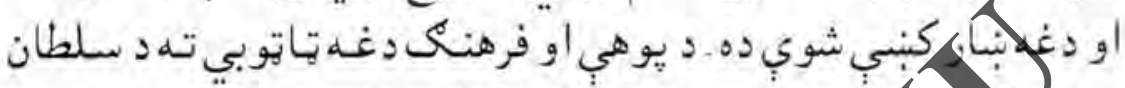

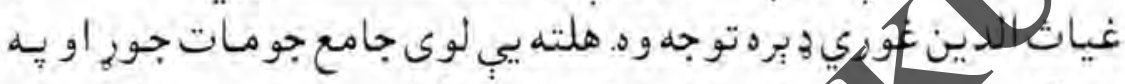

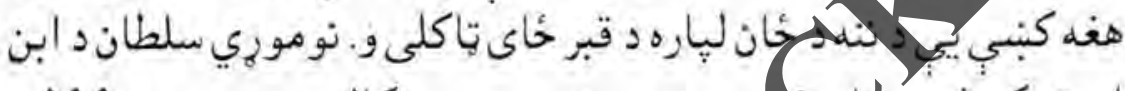

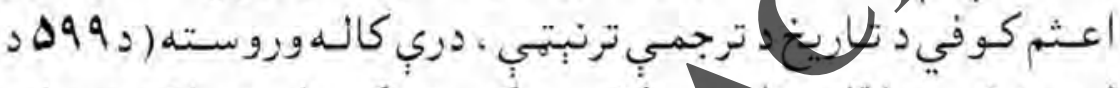

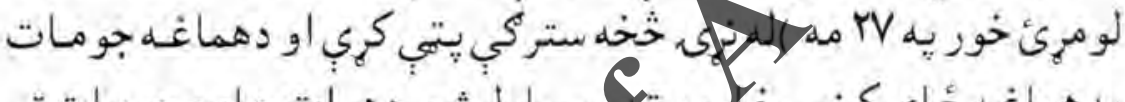

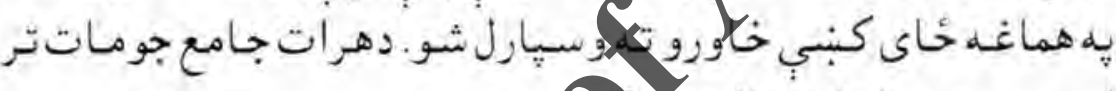

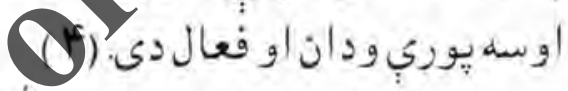

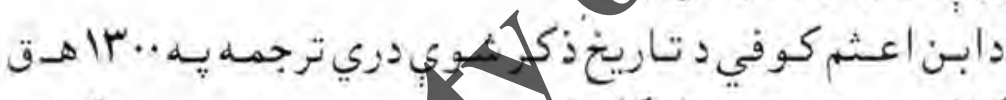
جا MAY

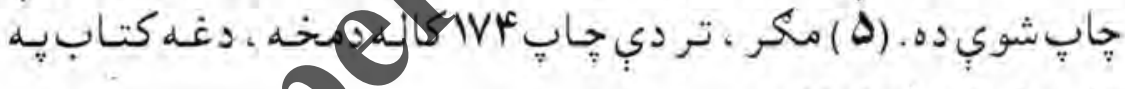

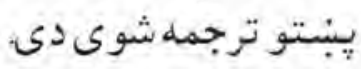

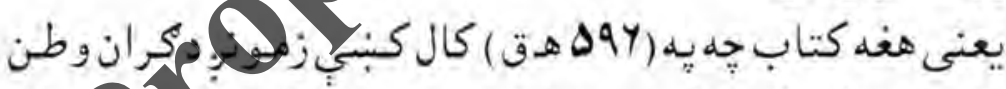

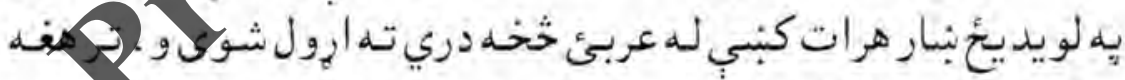

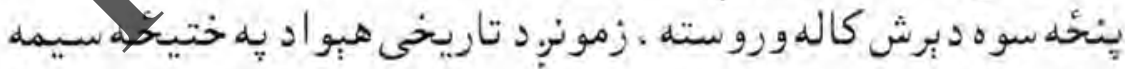

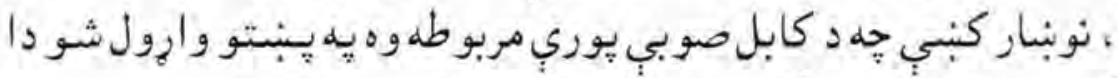

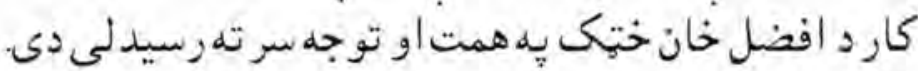


دابن اعشم كوفي - مابي كابل مجله

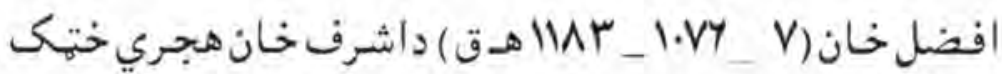

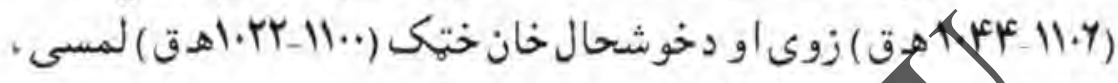

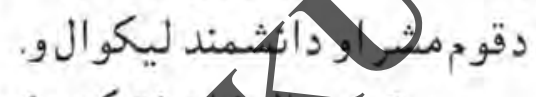

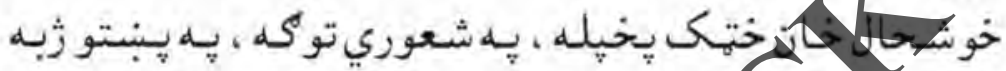

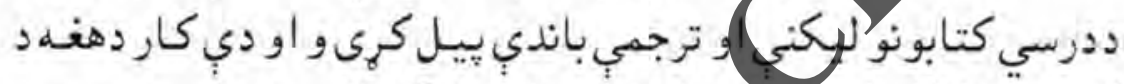

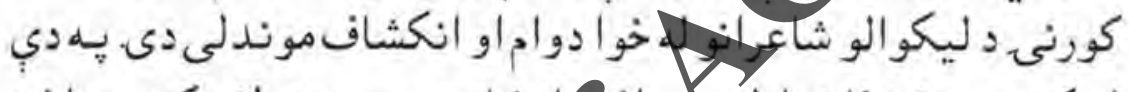

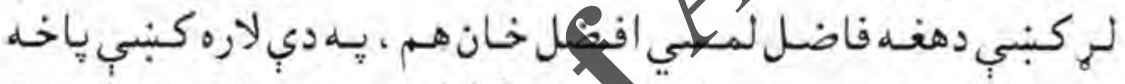

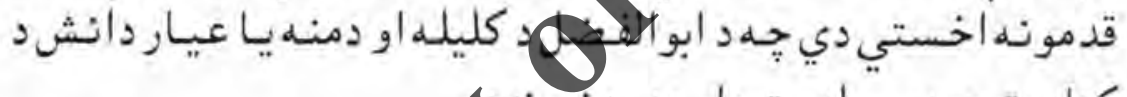

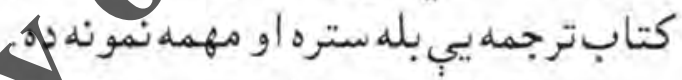

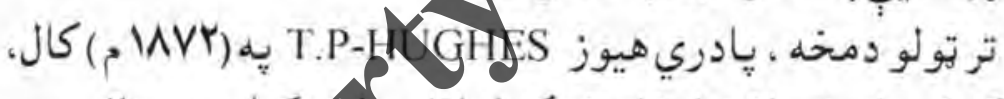

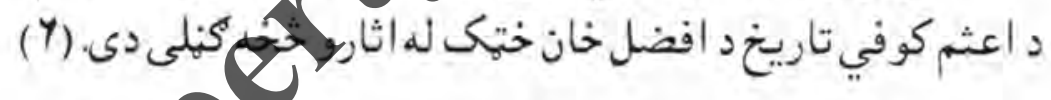

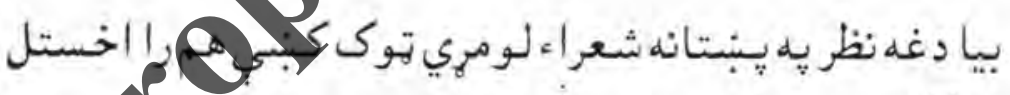

$$
\text { (V) شوى (V) }
$$

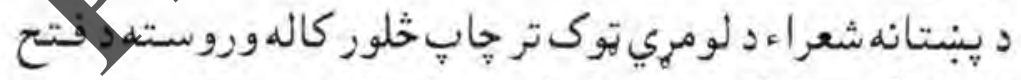

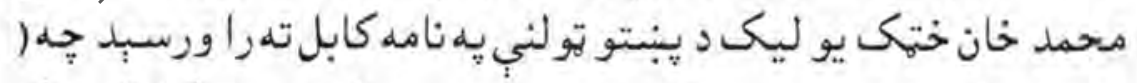

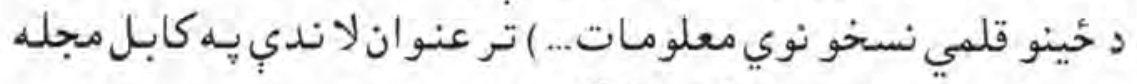

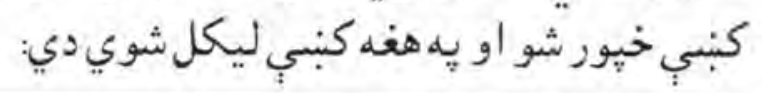

J IrAs 


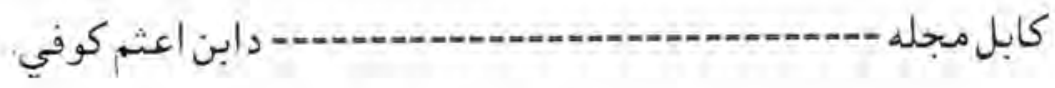

((... زه د خوشحال خان ختيك نوسى يم او ماسرد خه يخو اني

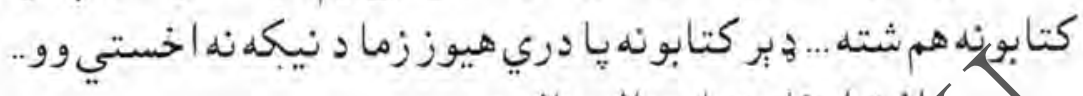

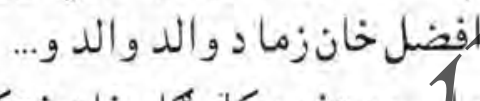

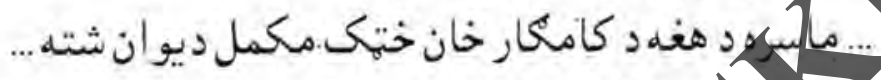

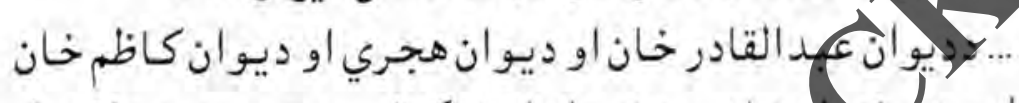

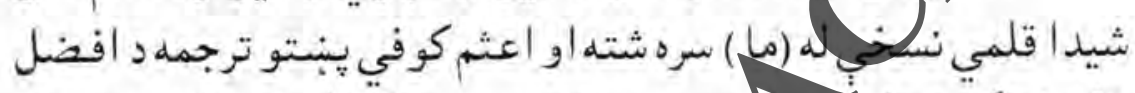

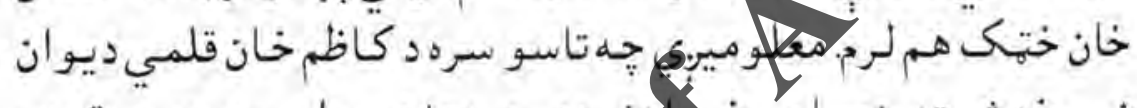

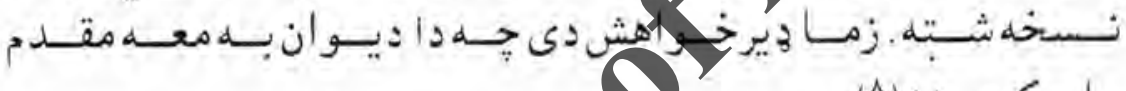

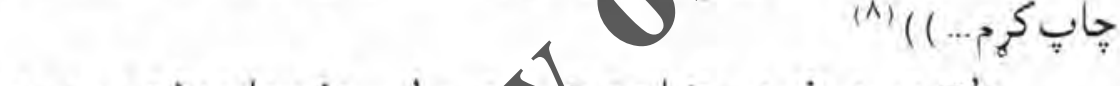

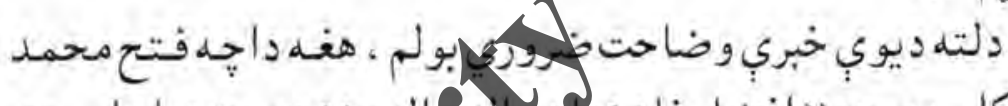

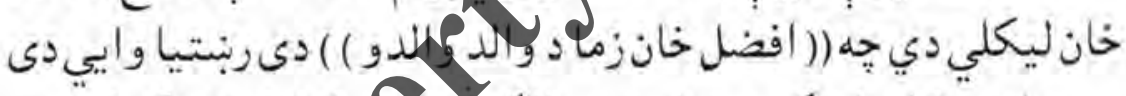

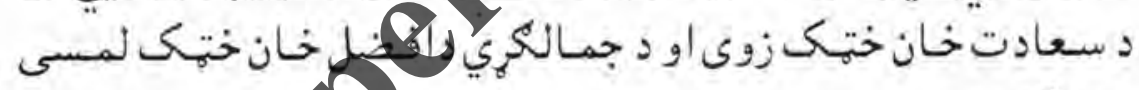

(9)

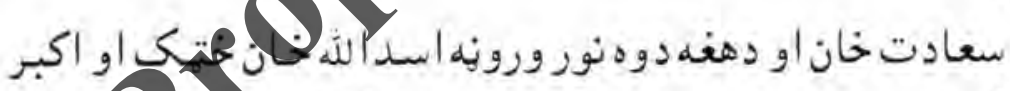

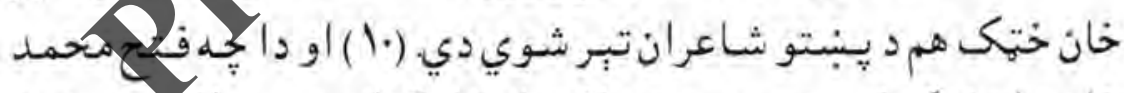

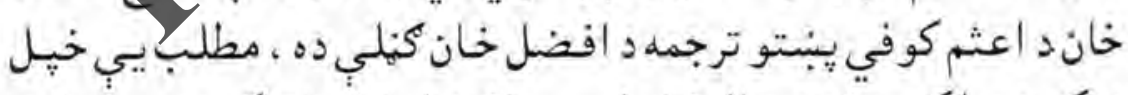

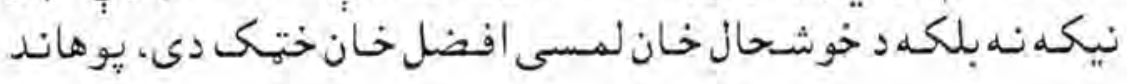

Irıo

11

1. 9 
دابن اعثم كوفي - مابي

صديق الله ربنـتين د فتح محمد خان د خطي نسخي تر كتلو وروسته

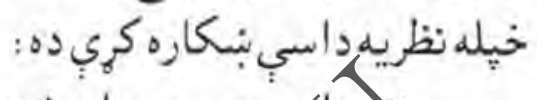

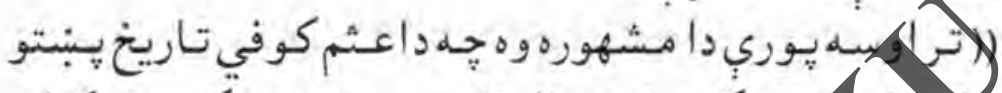

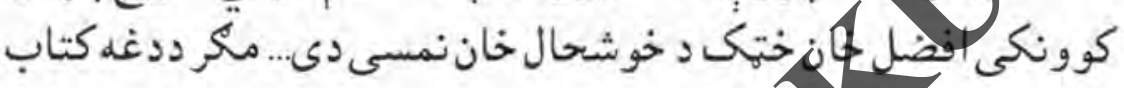

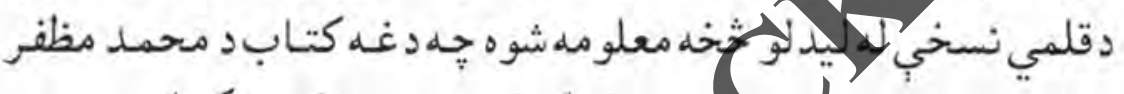

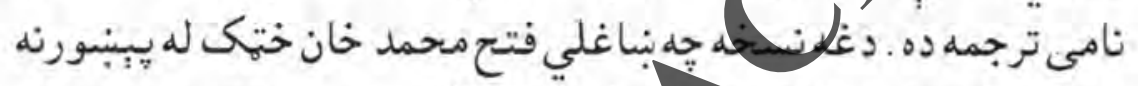

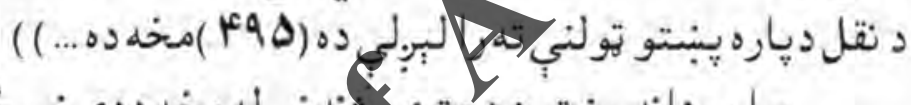

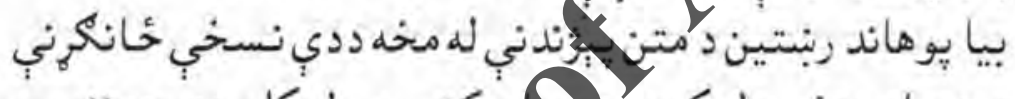

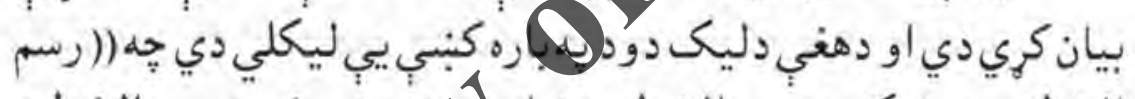

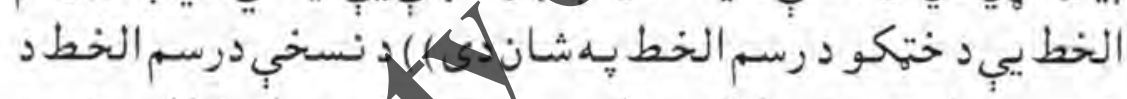

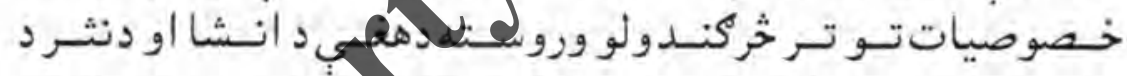

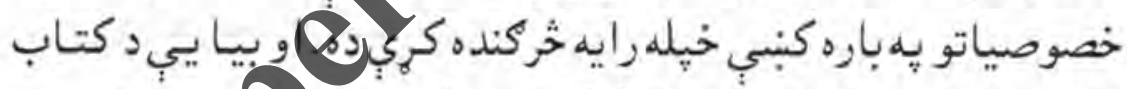

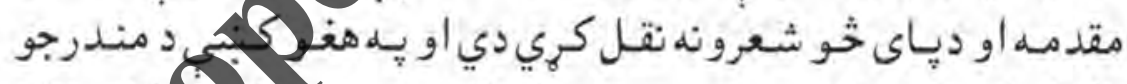

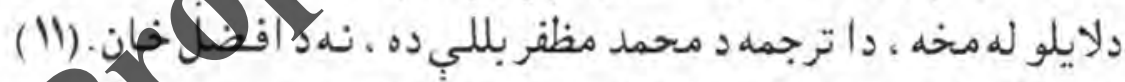

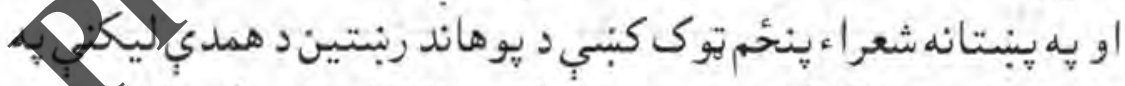

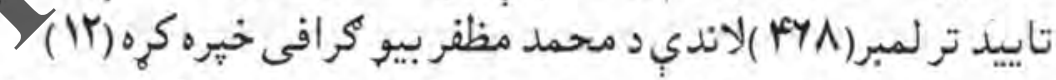

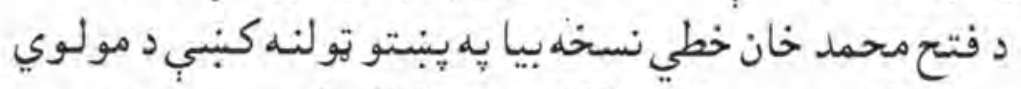

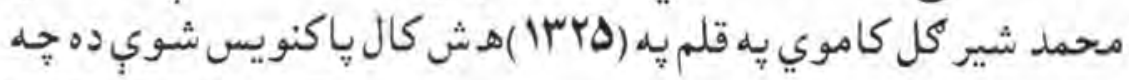
Jirso $\cdots(19$ 


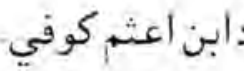
كابل مجله

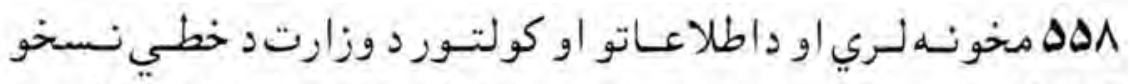

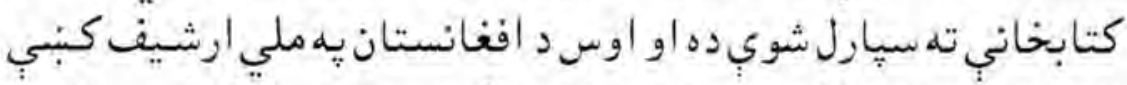

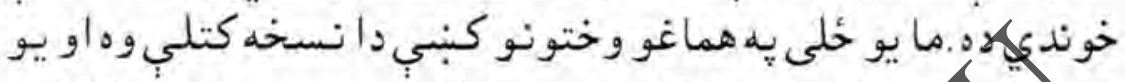

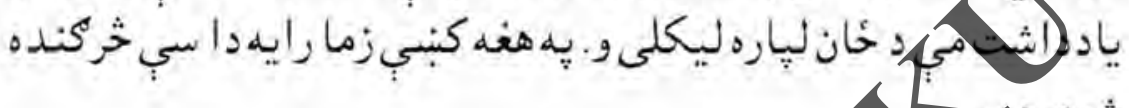

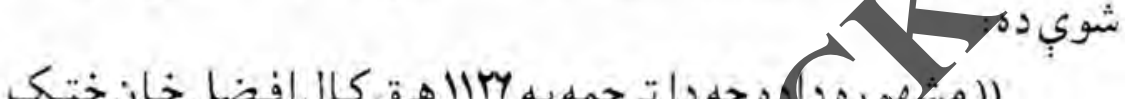

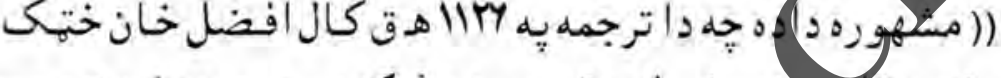

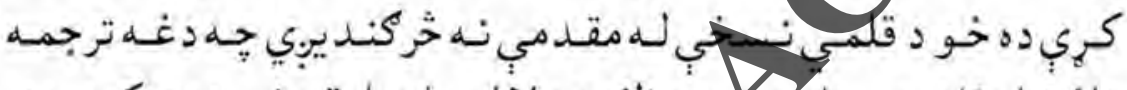

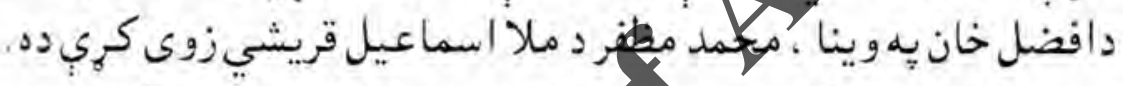

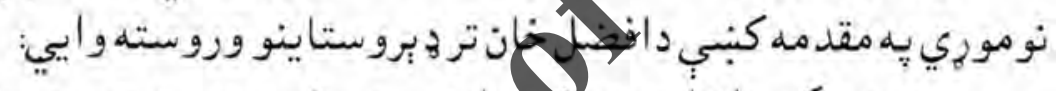

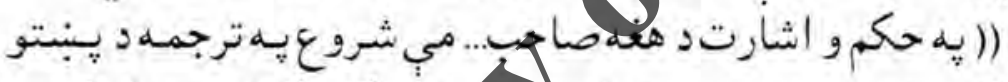

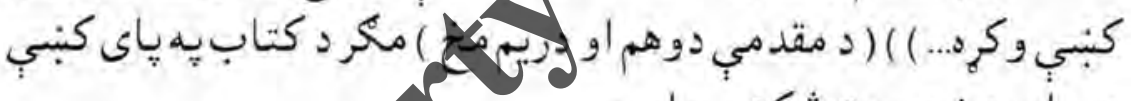

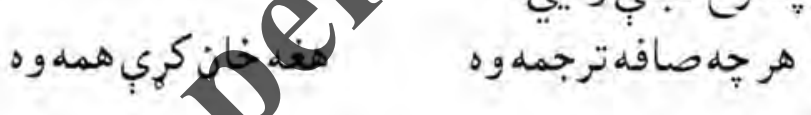

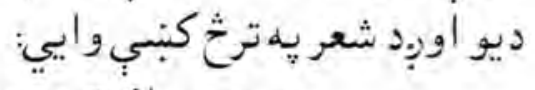
بيا وايبي:

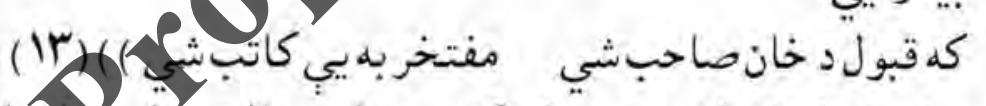

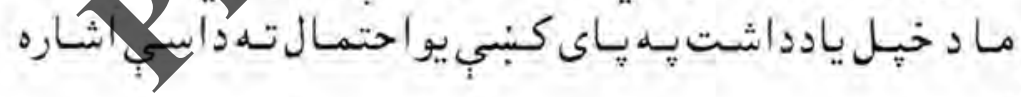
كري

J Irss $r$ 
مابن اعثم كوفي

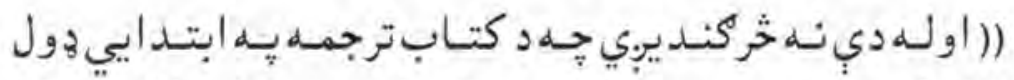

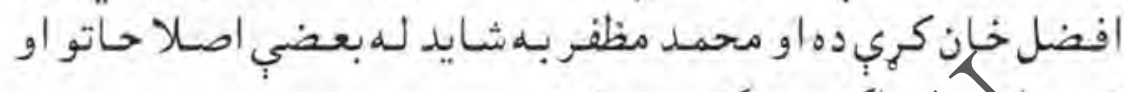

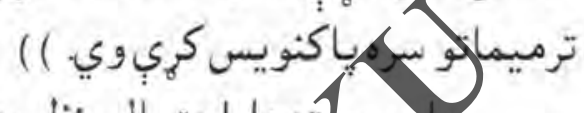

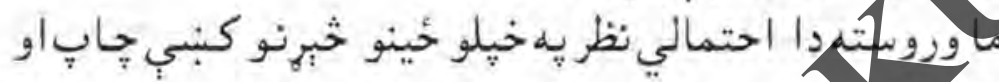

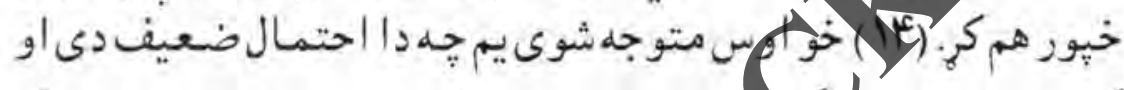

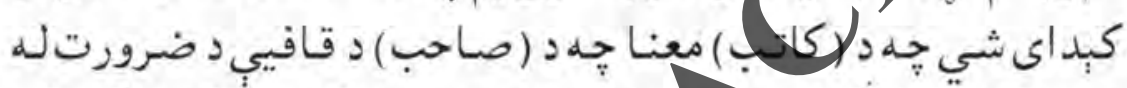

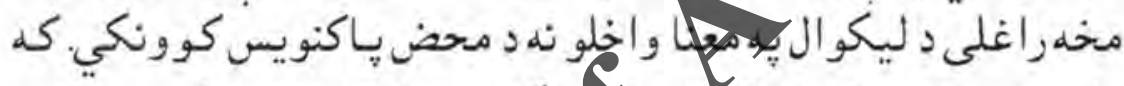

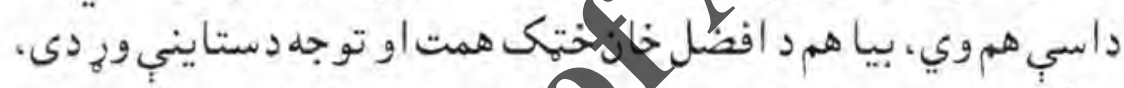

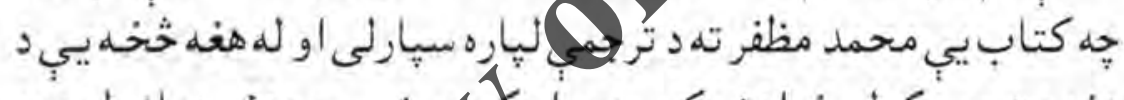

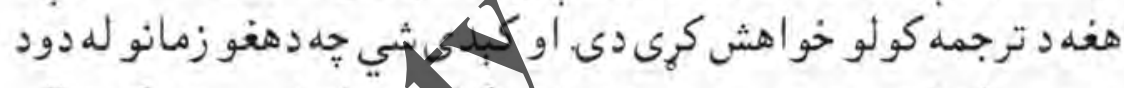

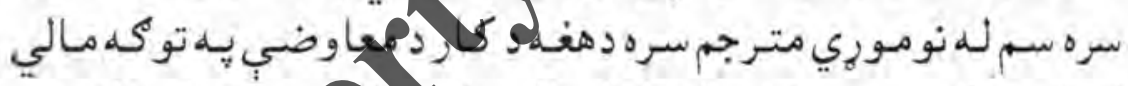

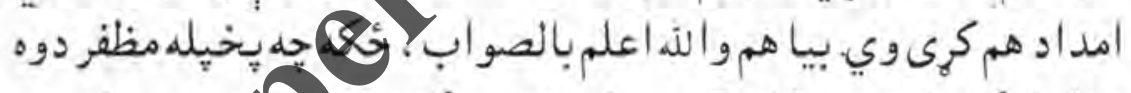

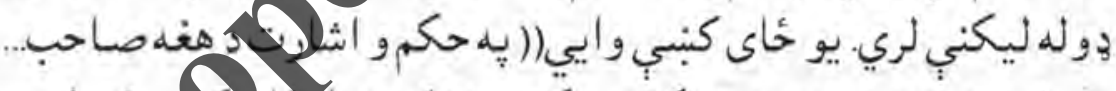

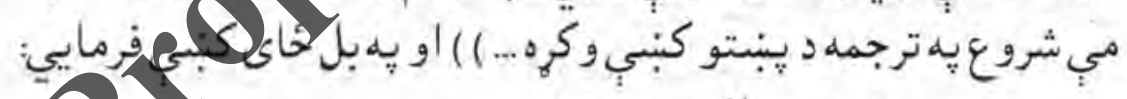

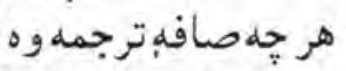

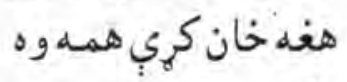

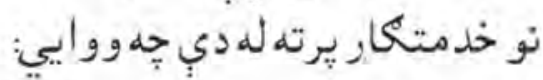

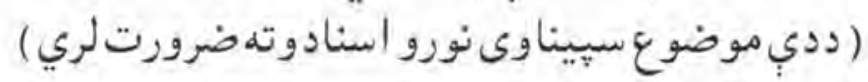




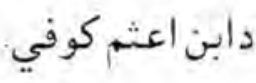

\section{ز غرده قضاوتنه شي كولي}

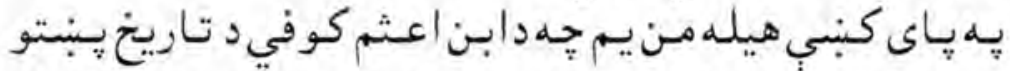

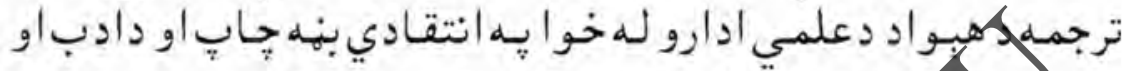

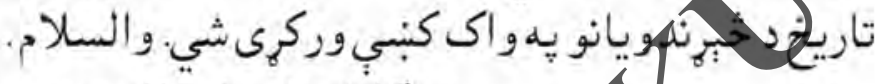

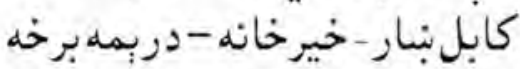

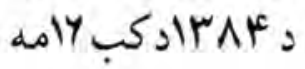

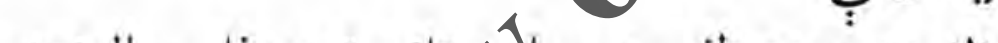
بادووني:

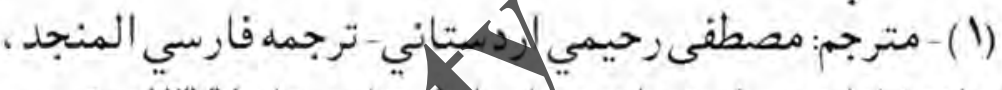

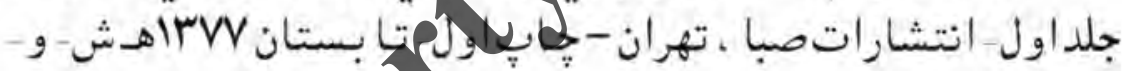
فروشخادكتاب الازهر - يشاور.

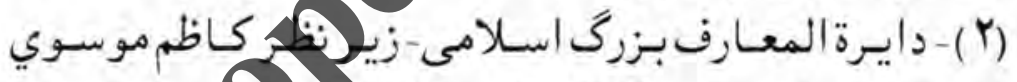

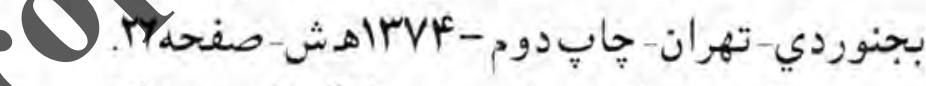

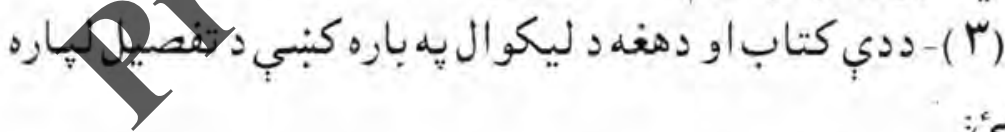
الف: تبـ ماخد.
J 1 irso
rr
$\cdot 1 \cdot 9$ 


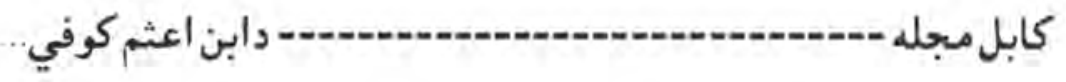

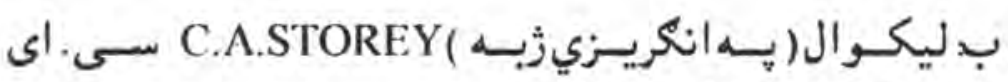

ستورى PERSIAN LITERATURE

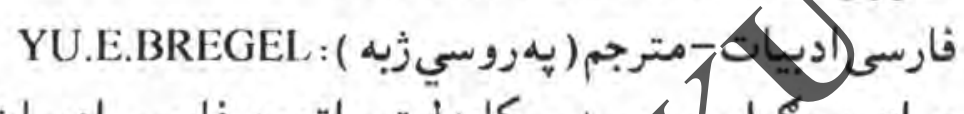

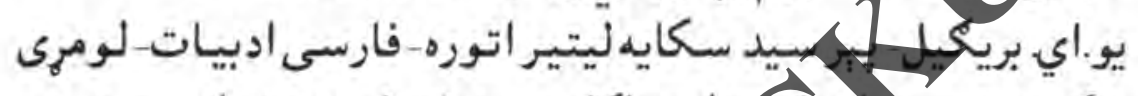

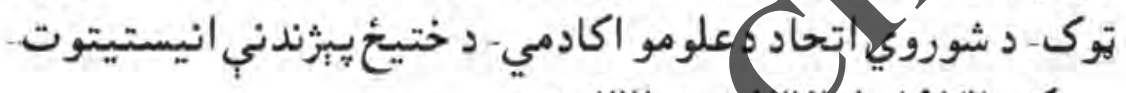

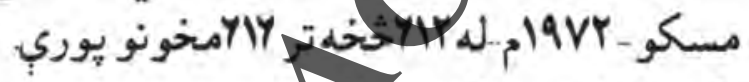

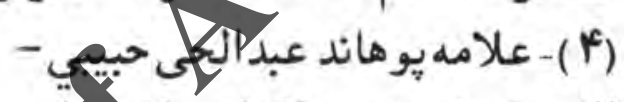

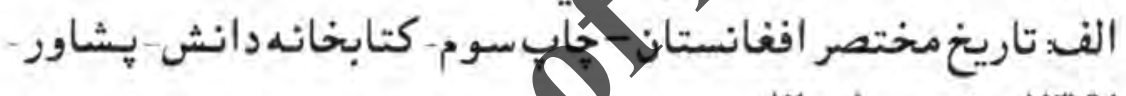

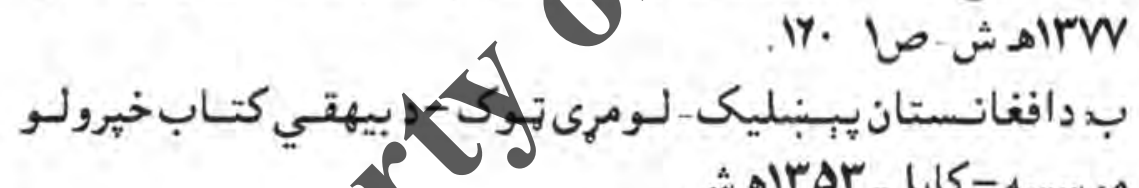

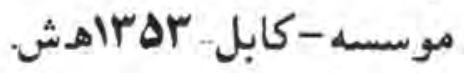

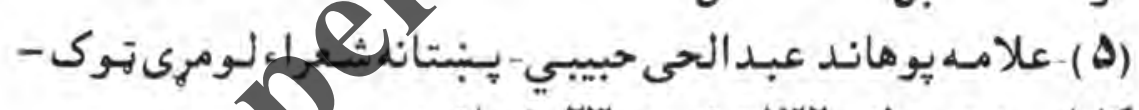

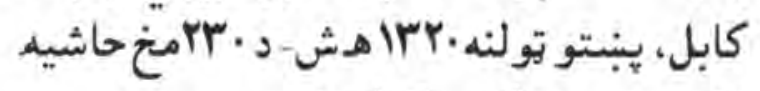

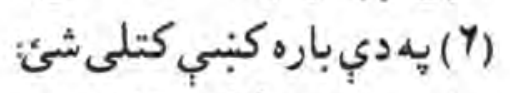

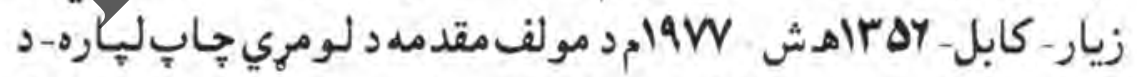

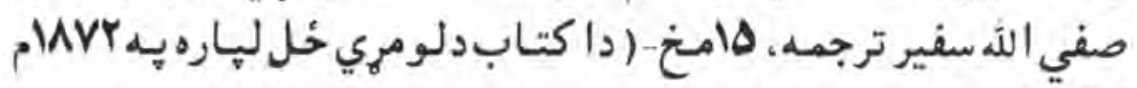

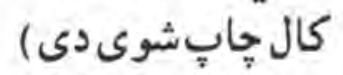




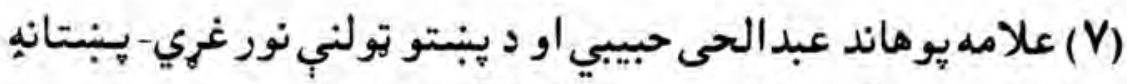

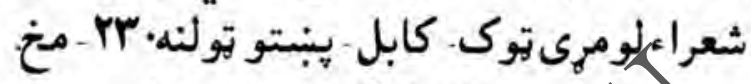

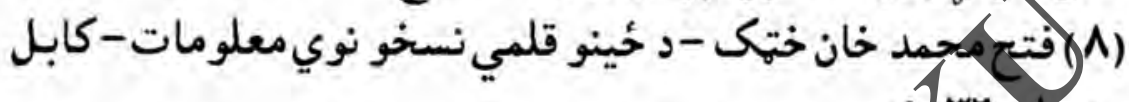

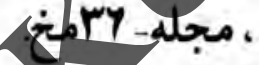

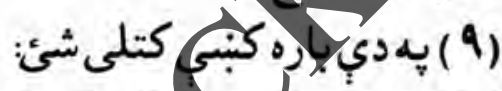

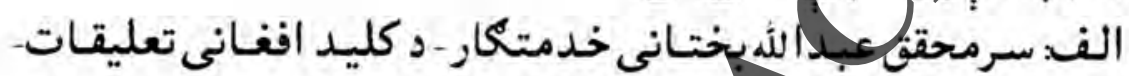

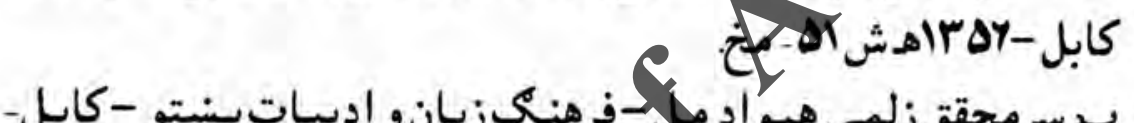

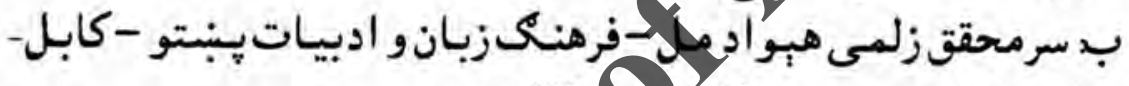

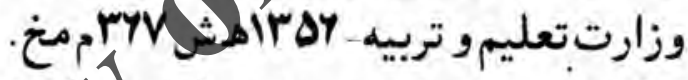

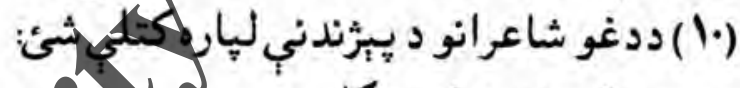

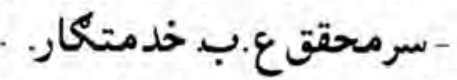

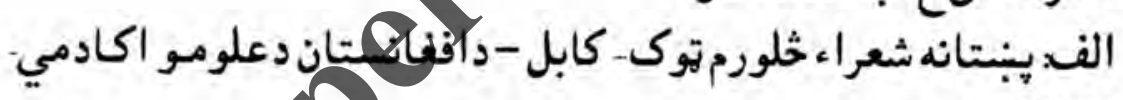
هـ Ir v V

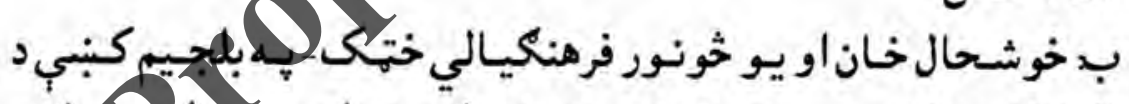

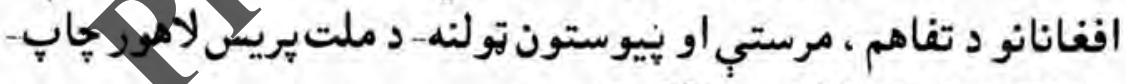

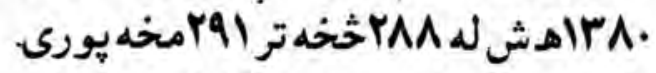
(II) (1)
J IrAs
Y乏
- 1. 9 


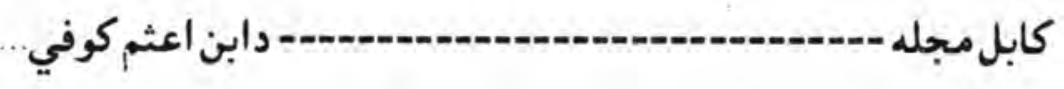

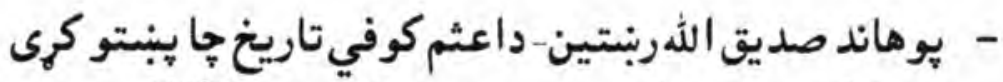

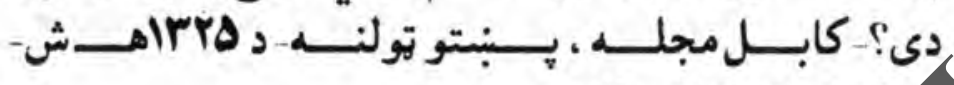

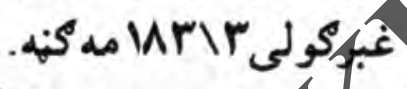

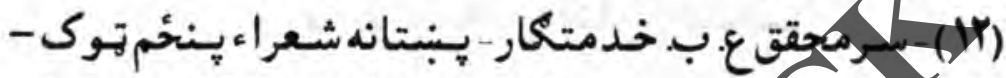

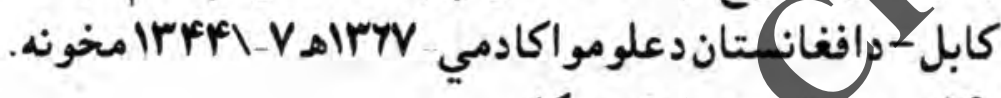

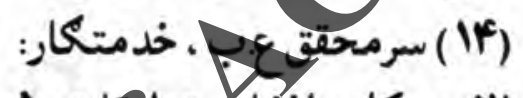

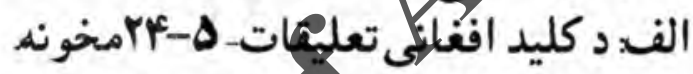

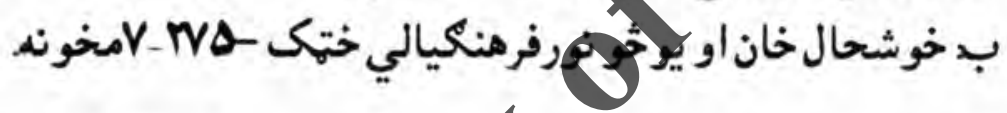

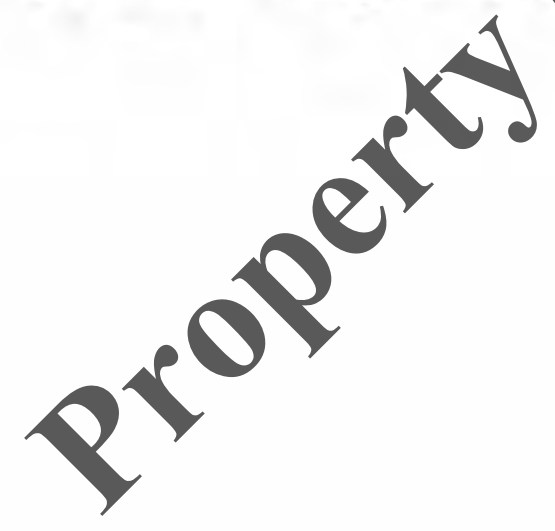

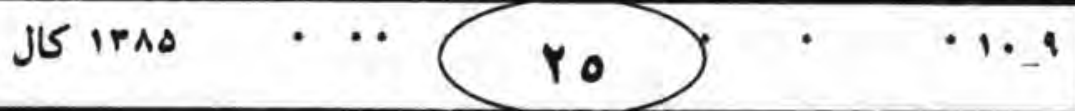




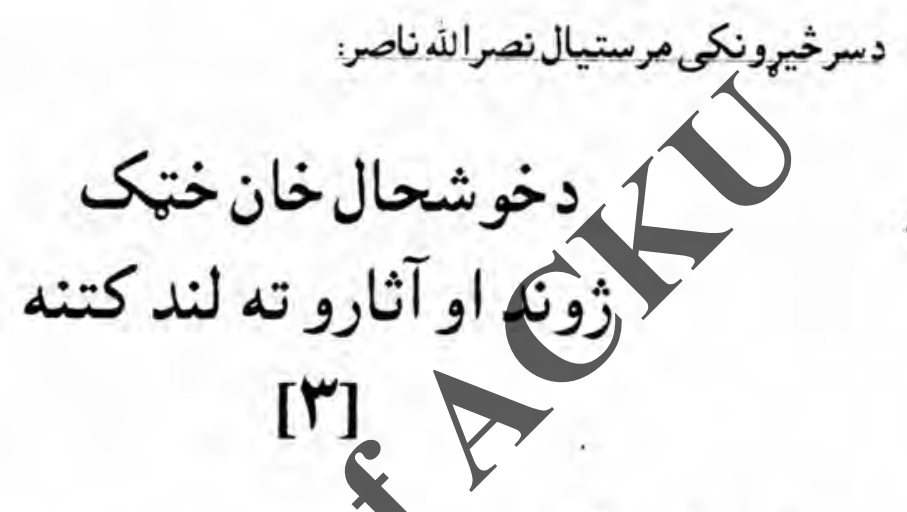

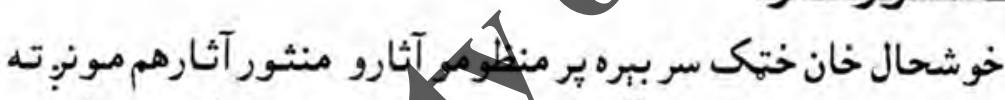
دو همه منثور آثار:

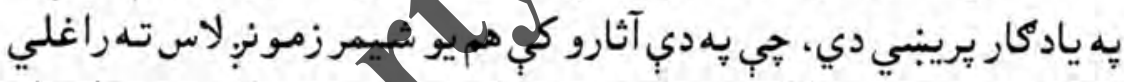

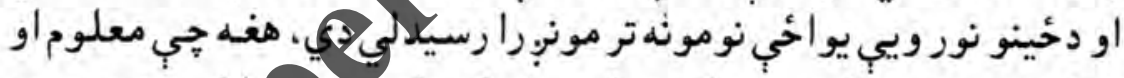

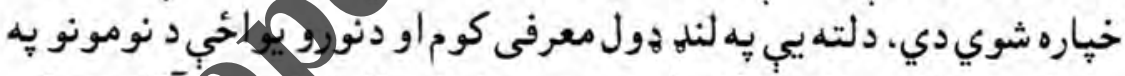

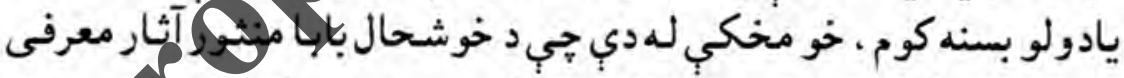

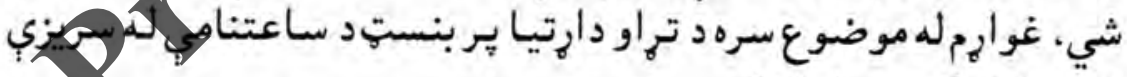

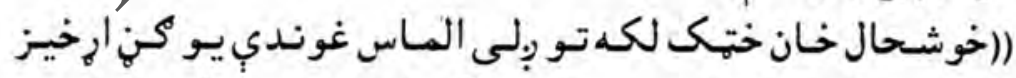

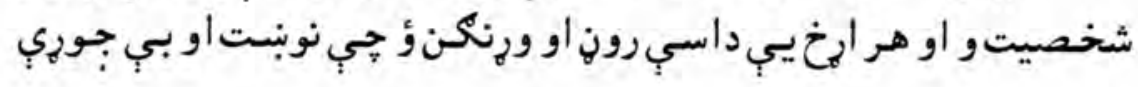
סגו Sו
r 7
- 1. 9 
دخوشحال خان ختكى

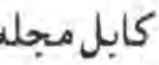

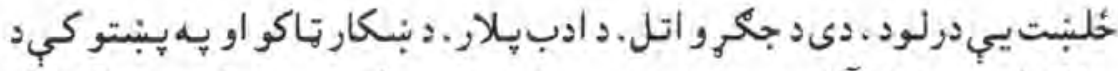

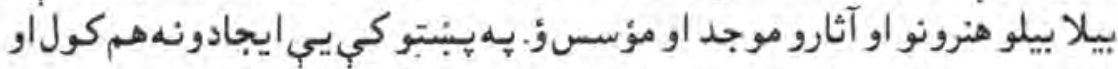

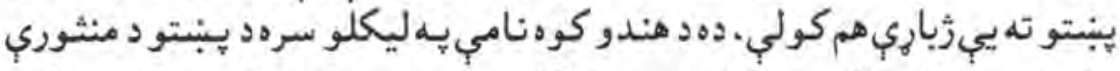

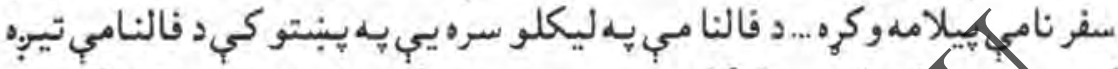

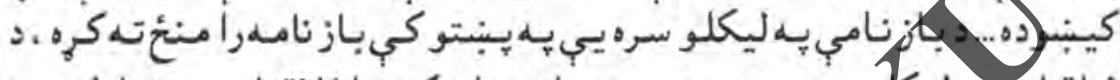

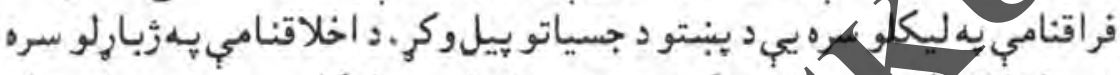

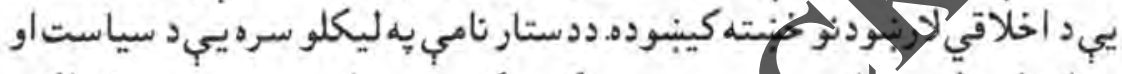

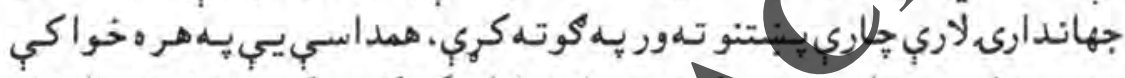

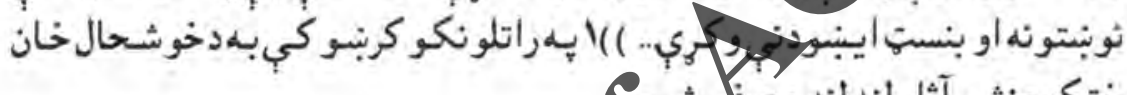
ختخى منثور آثار لندلنه معرنفي شيني

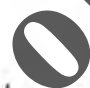
أ_بياض:

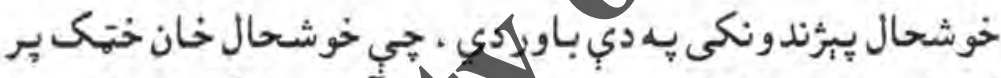

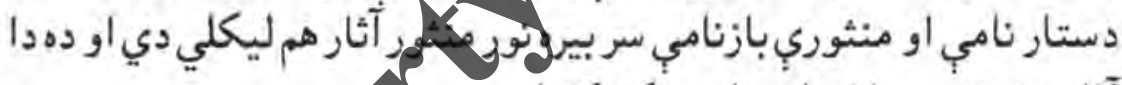

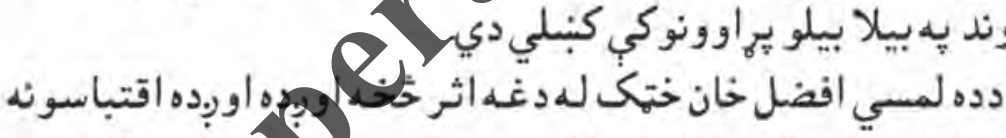

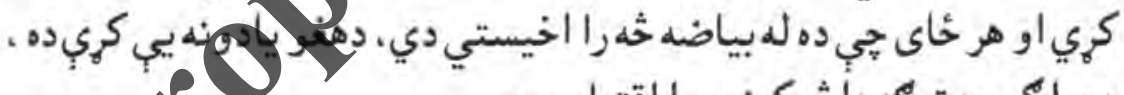
$\checkmark$

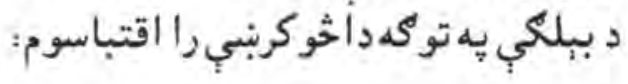

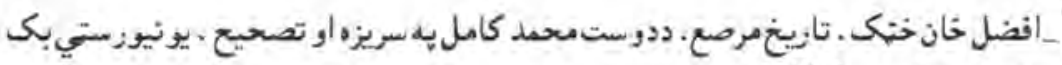

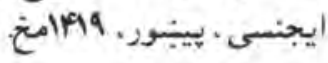

JITAO

YV

1. 9 


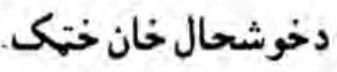
كابلمجل

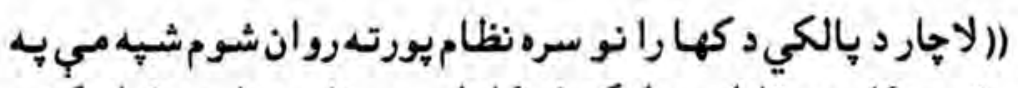

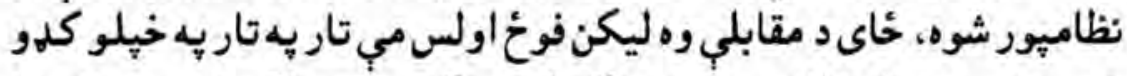

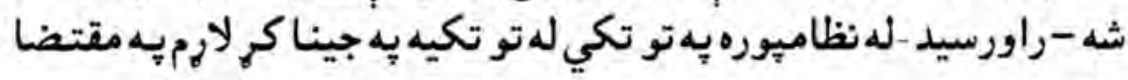

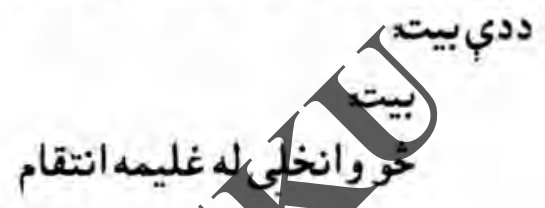

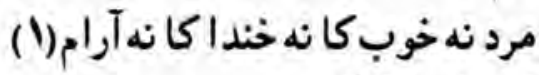

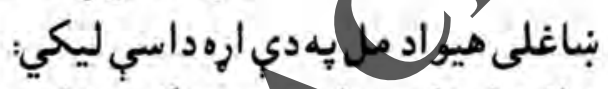

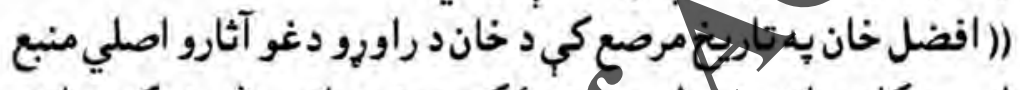

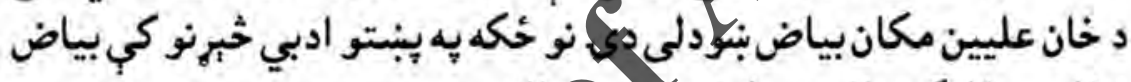

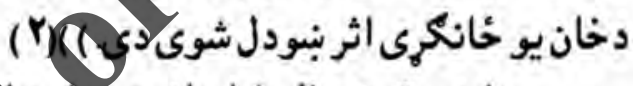

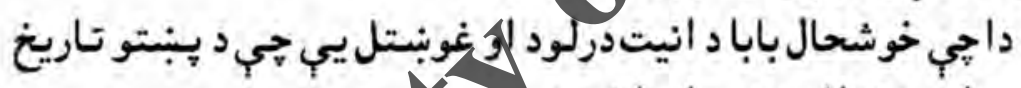

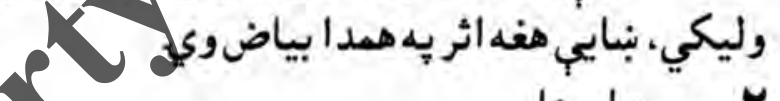

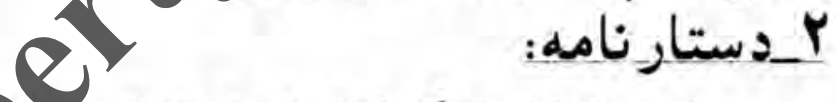

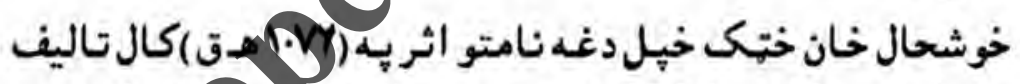

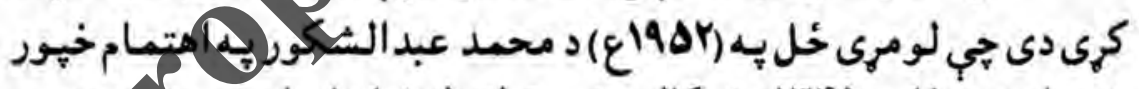

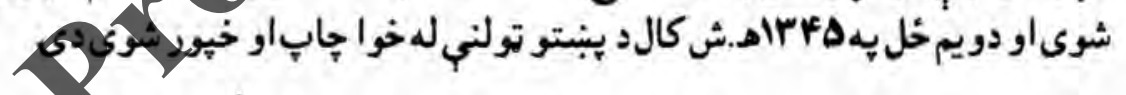

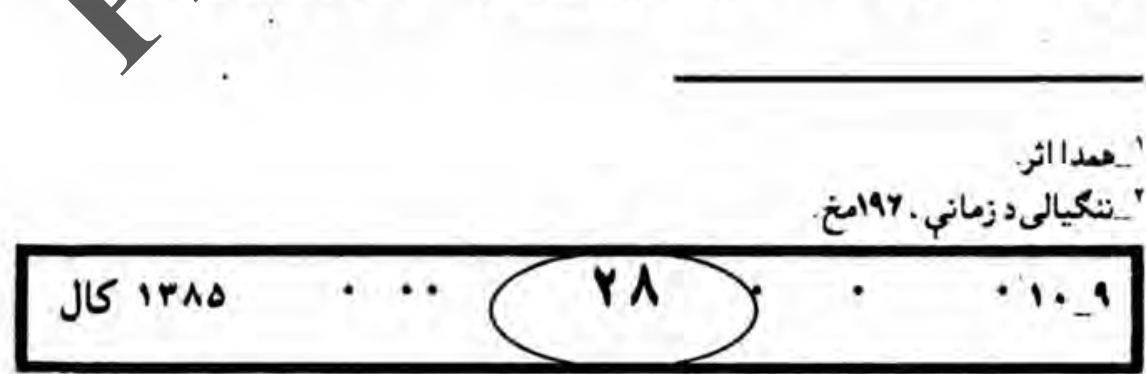




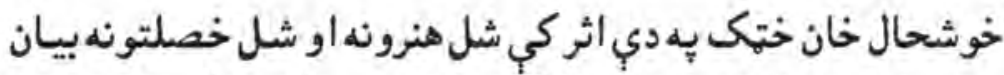

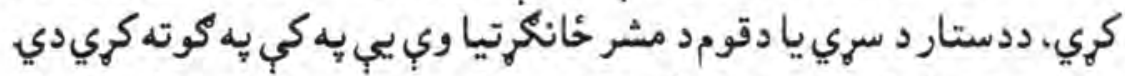

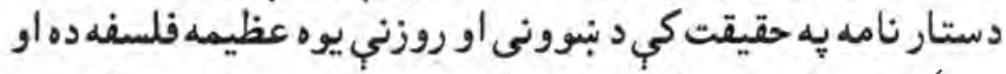

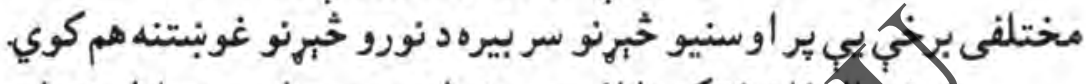

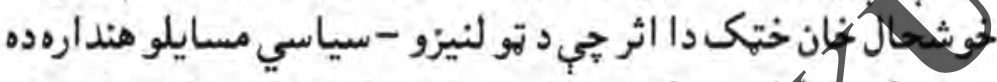

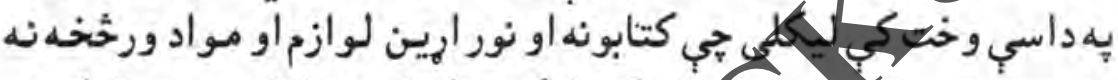

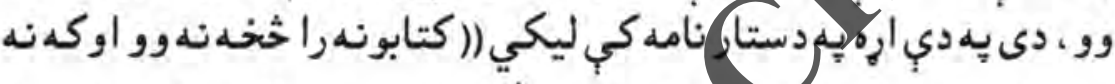

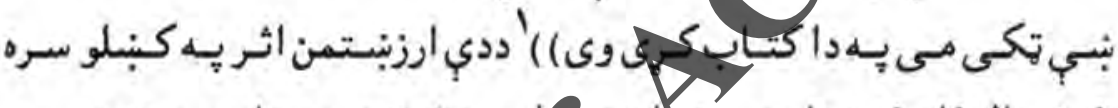

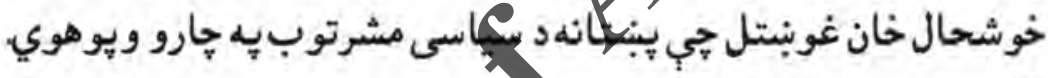

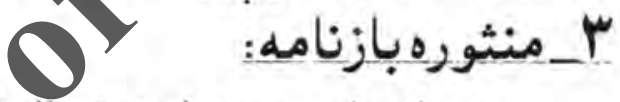

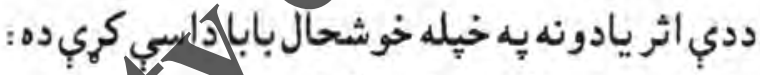

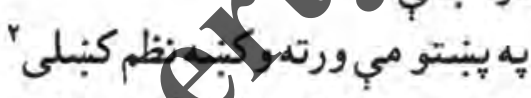

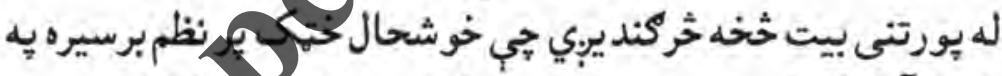

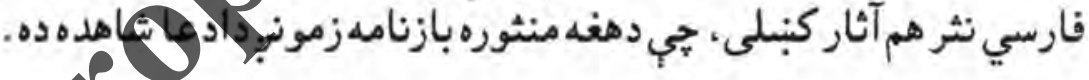

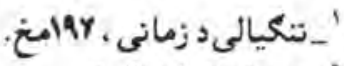

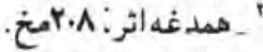
Jirno $\cdots(1.9$ 


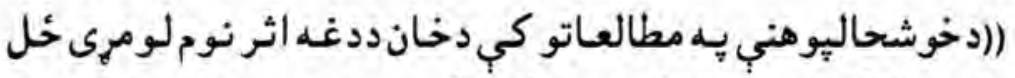

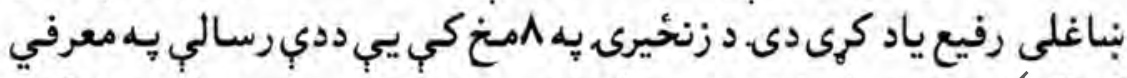

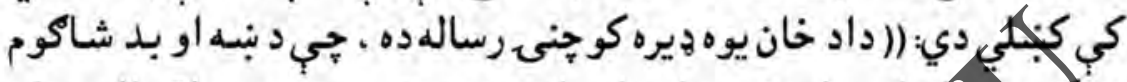

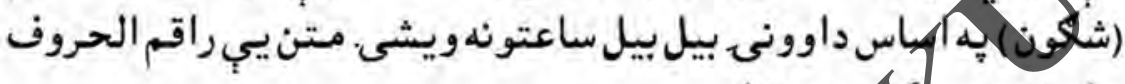

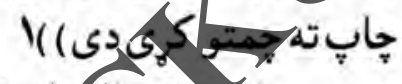

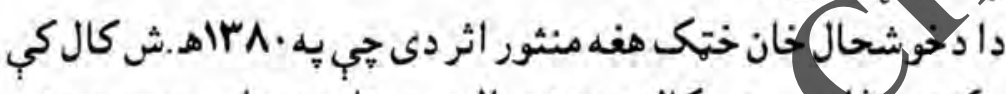

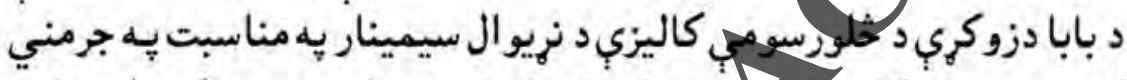

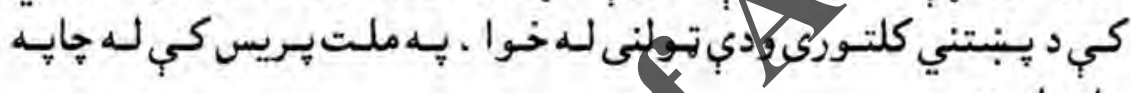
راوتلى

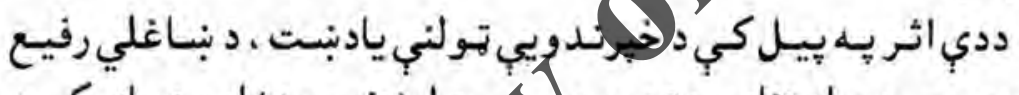

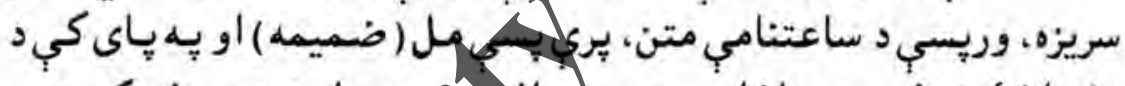

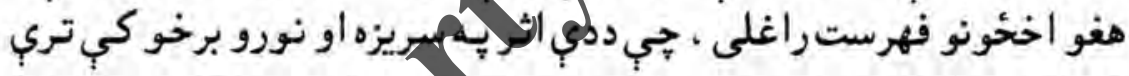

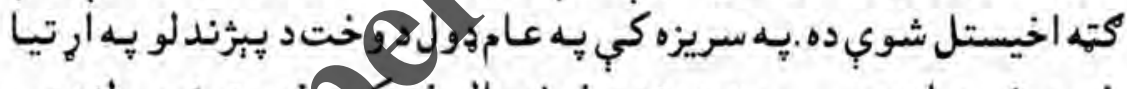

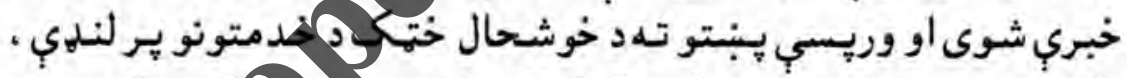

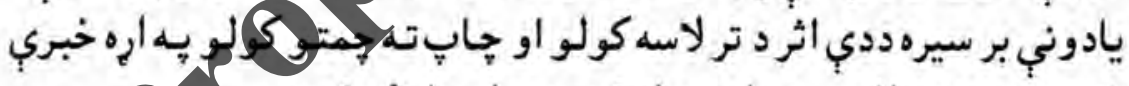

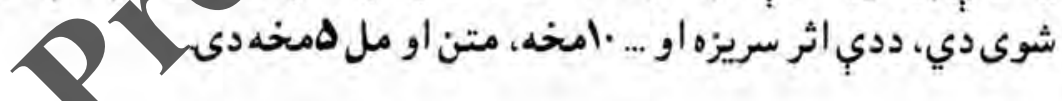

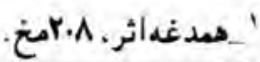

J




\section{هـوصيتنامه:}

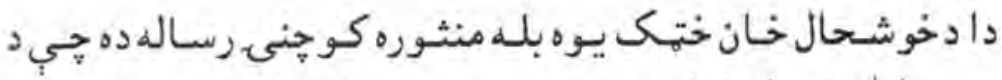

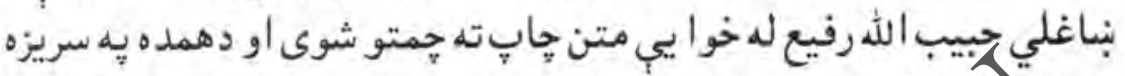

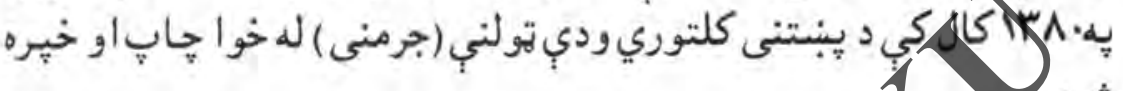

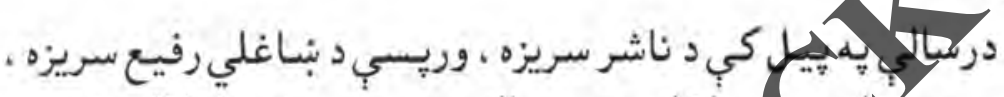

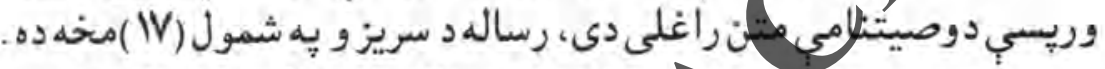

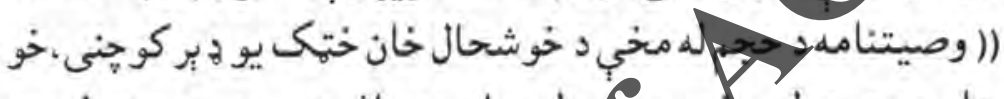

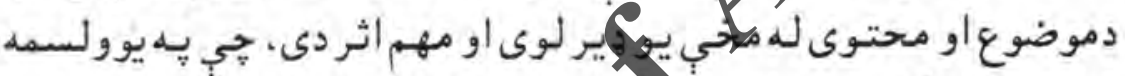

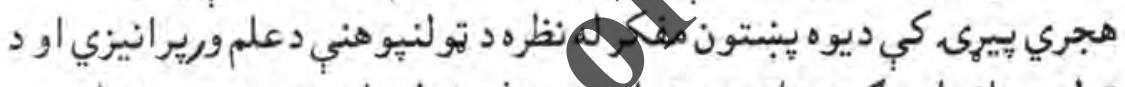

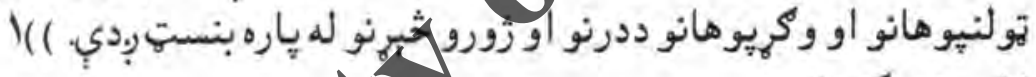
Y ختجك:امه

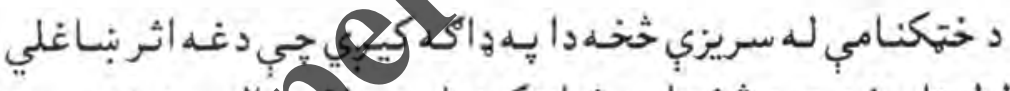

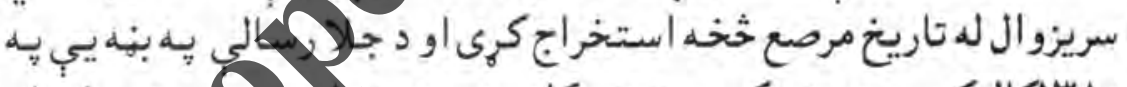

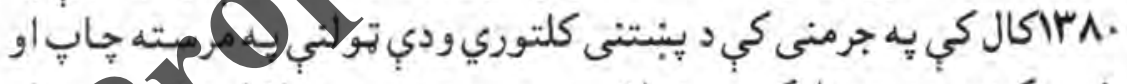

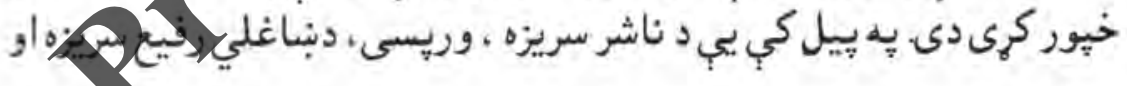

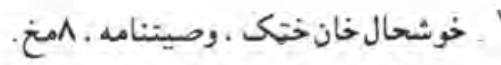
J
()
1. 9 


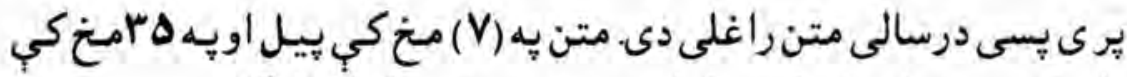

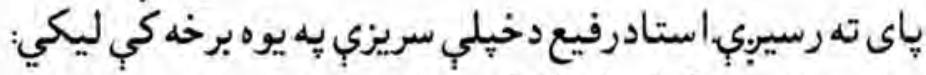

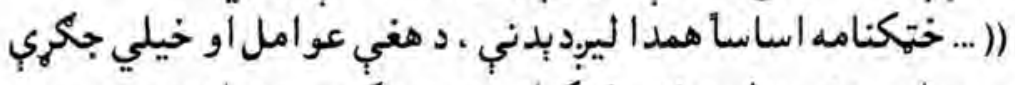

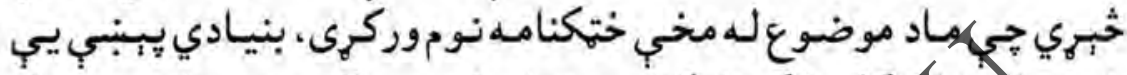

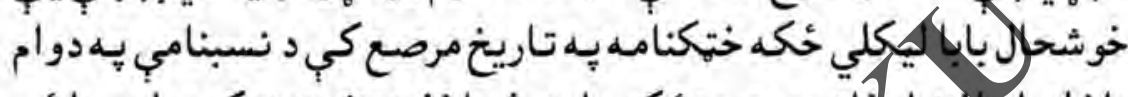

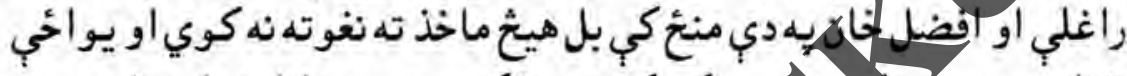

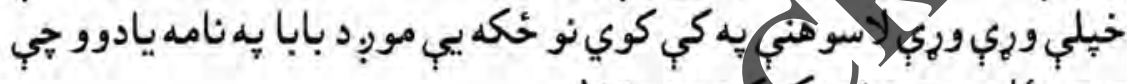

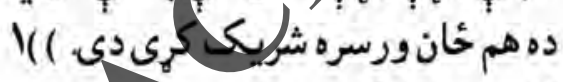

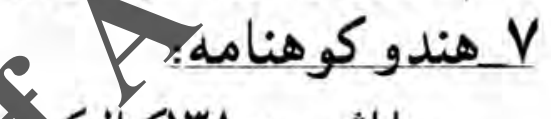

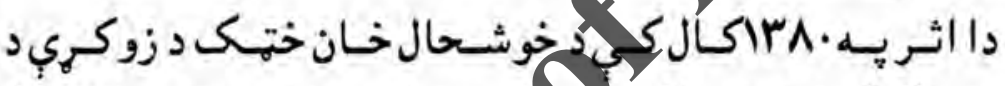

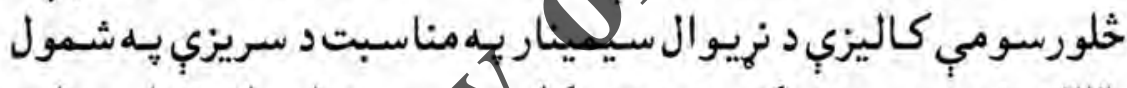

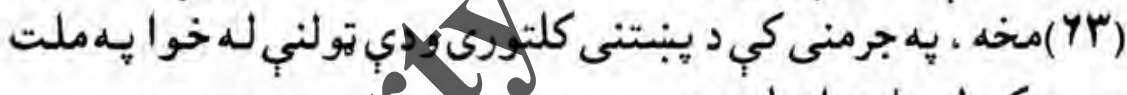

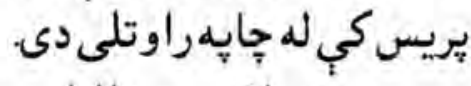

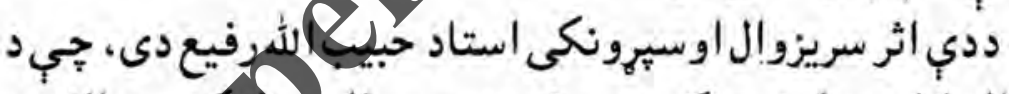

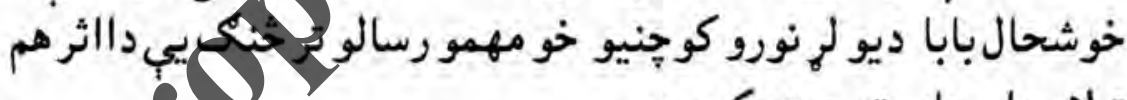

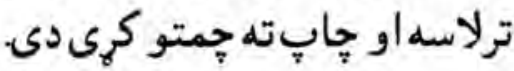

'خوشحال خانختك ، ختكنامه ، سريزه ،هضخ.

Jirso

ry

- 1. 9 


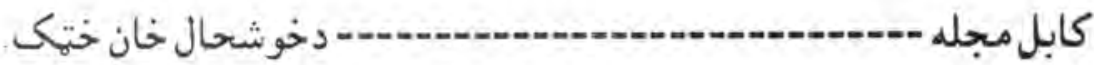

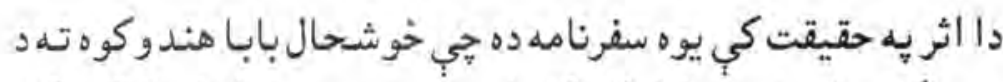

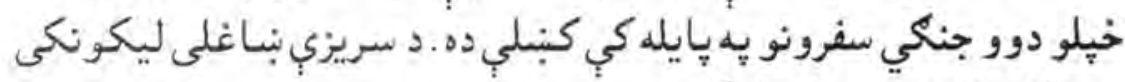

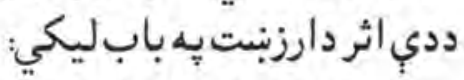

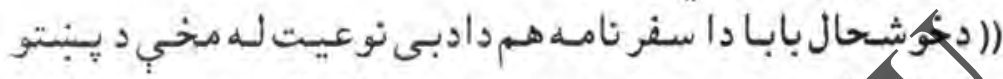

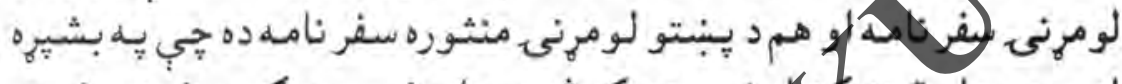

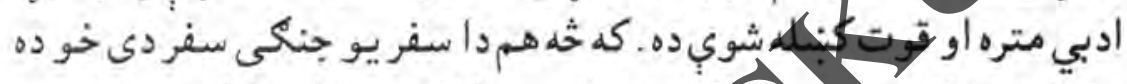

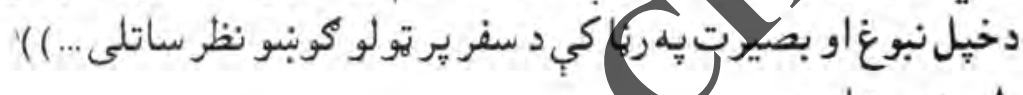

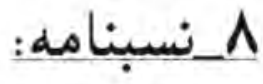

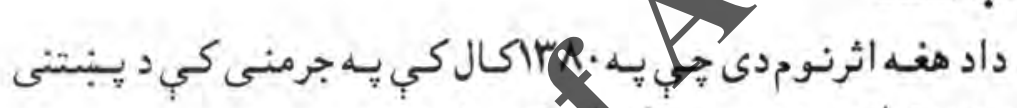

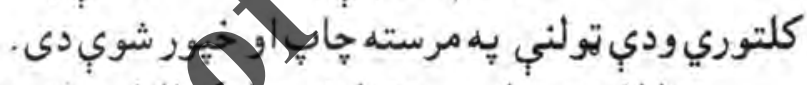

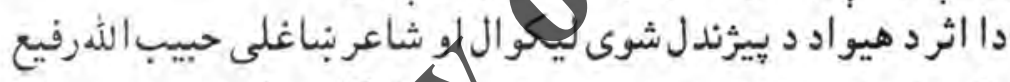

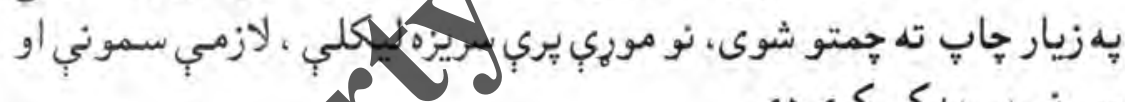

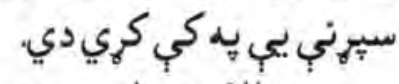

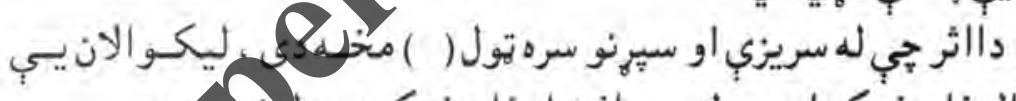

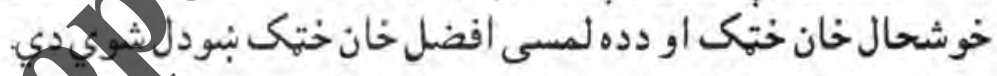

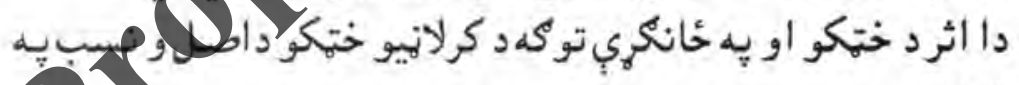
باب كبنل شوى

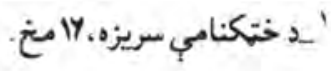

J 1 irso

$\mu$

1. 9 


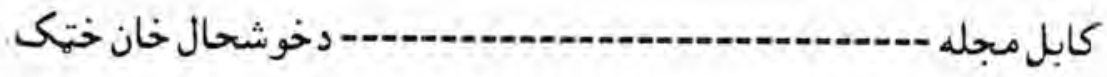

\section{9- زنحيرى ياخطنامه:}

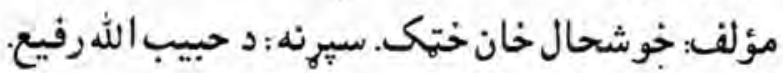
خيروونكى: دافغانستان دعلومو اكادمي ، د زبو او اديع ادبياتو مركز ، كابلجنهن

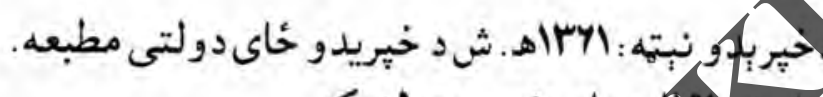

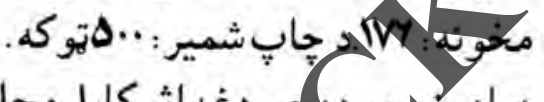

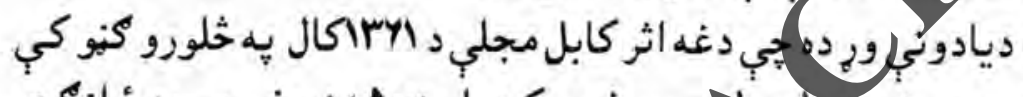

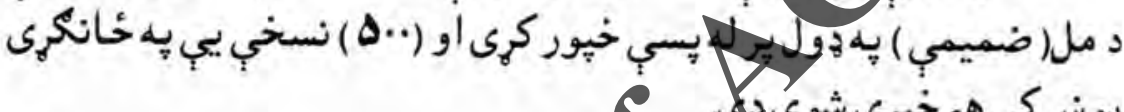

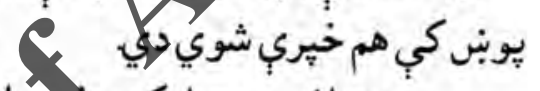

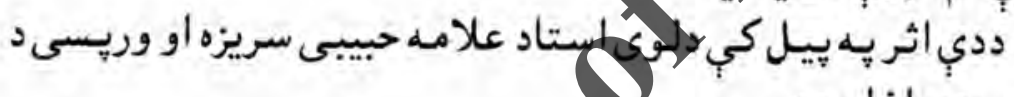

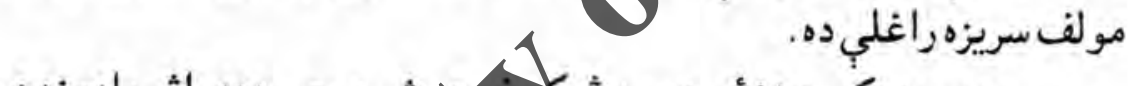

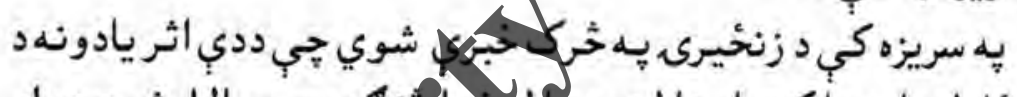

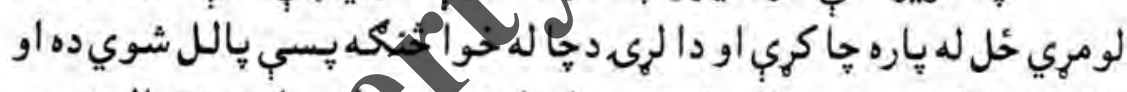

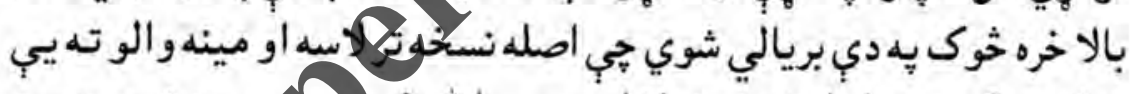

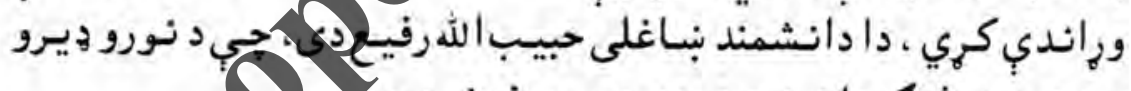

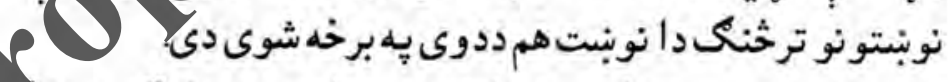

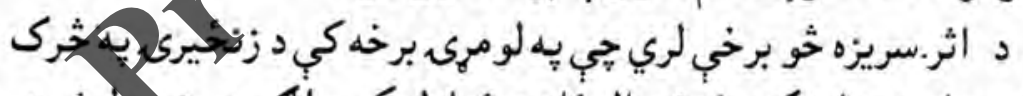

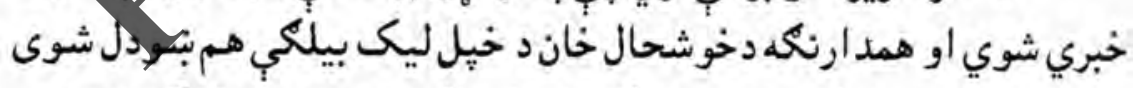

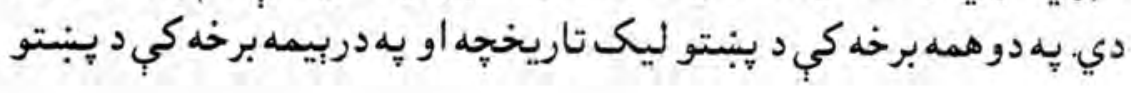

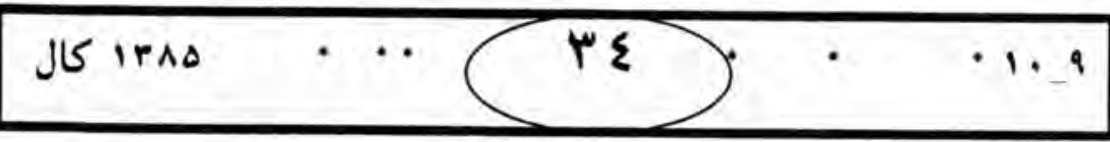


دخوشحال خان خترى كابل مجله

غبونو توري بنسودل شوي اود ليكونو بيلكى هم راورل شويدي. وريسيد زنتخيرى متن يَيل كيبري.

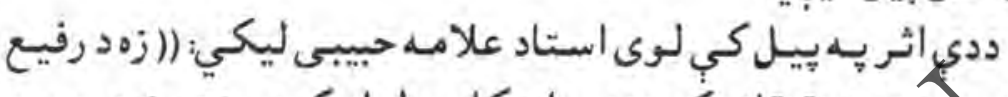

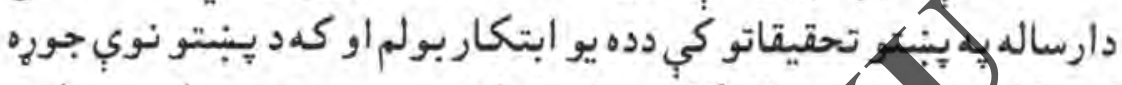

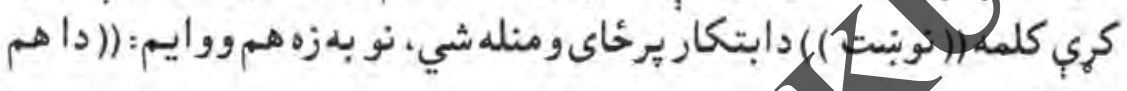

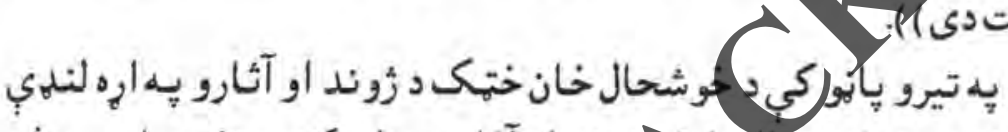

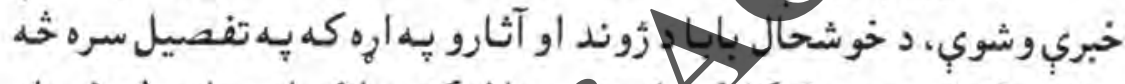

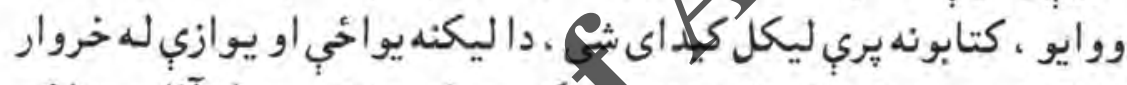

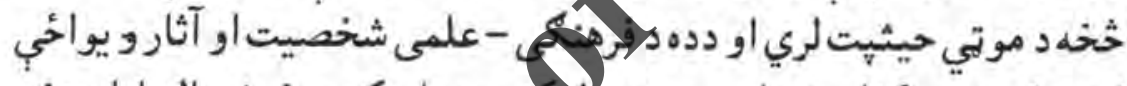

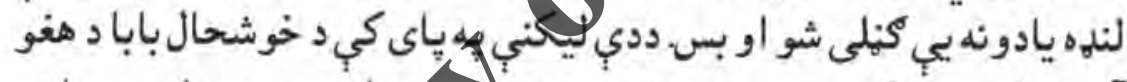

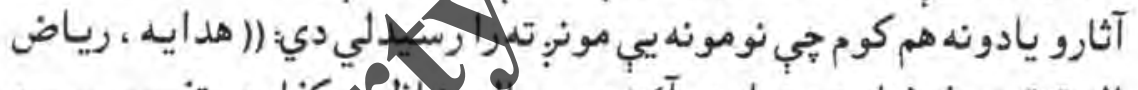

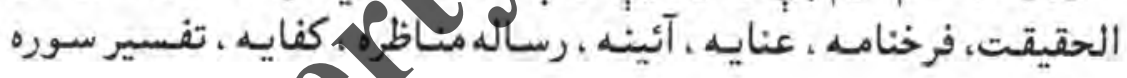
$Q$

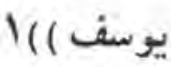
اخخونيه:

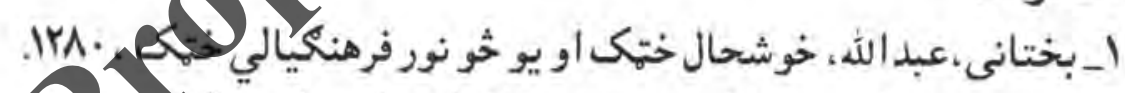

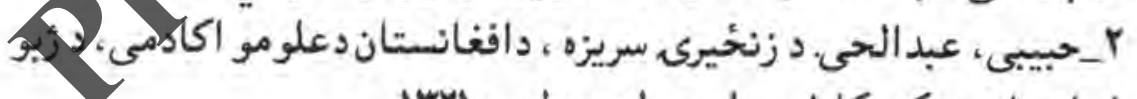

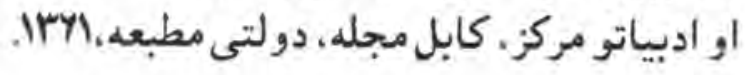

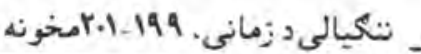

J




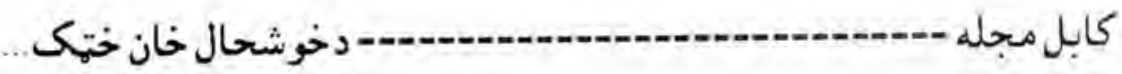

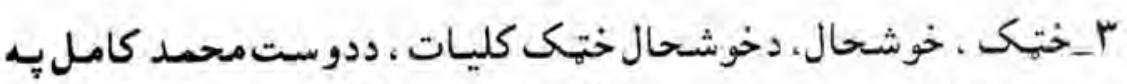

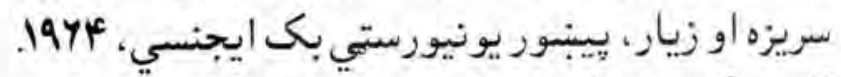

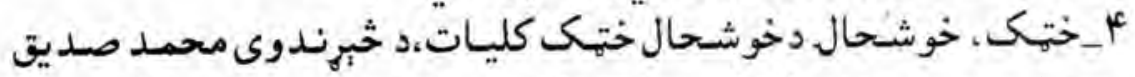

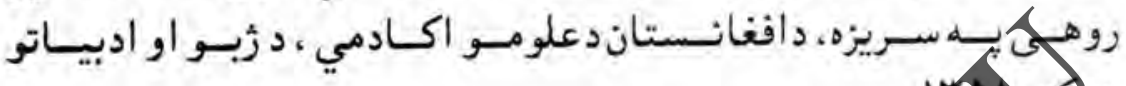
مرك- مون

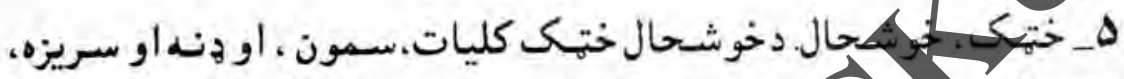

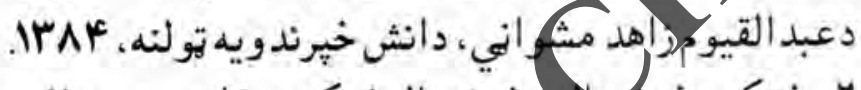

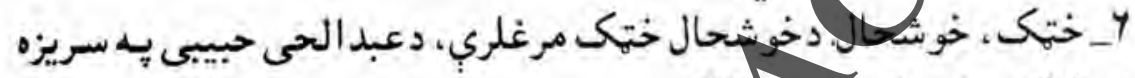

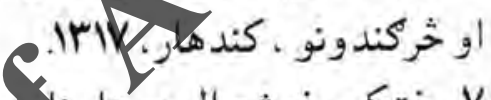

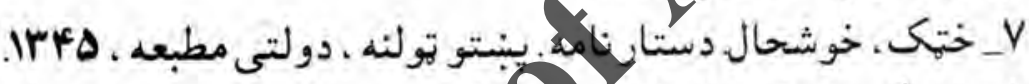

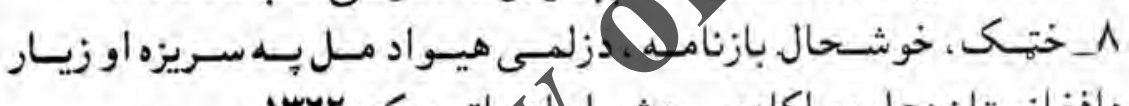

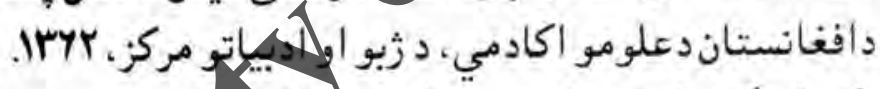

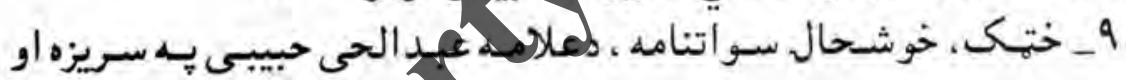

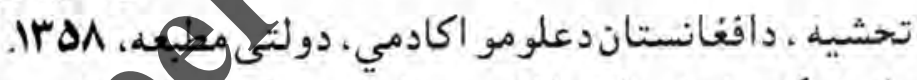

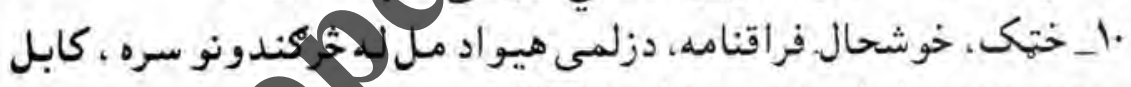

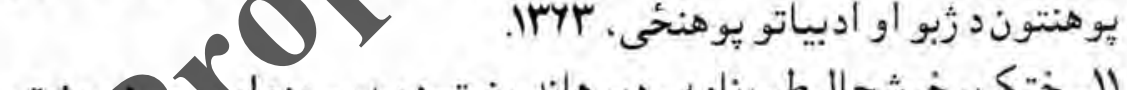

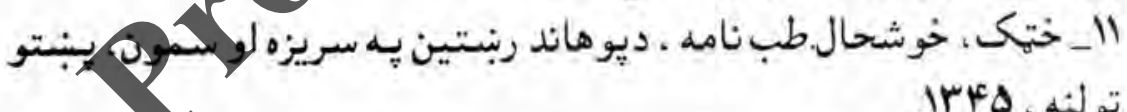
تولنه . IFH

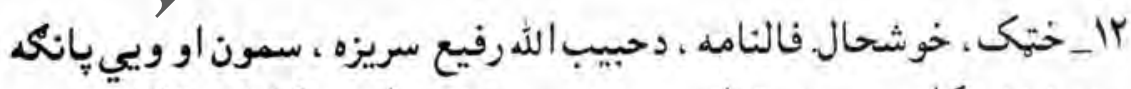

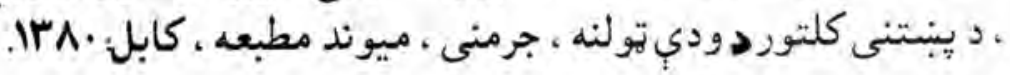

J IrAs $\cdots$ ry




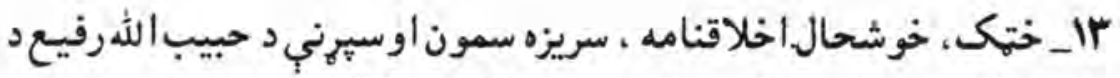

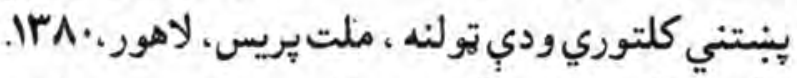

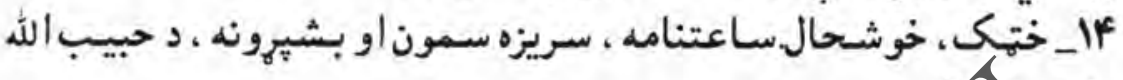

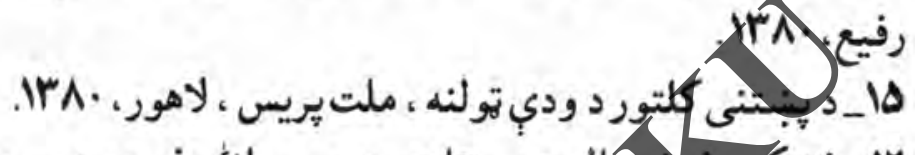

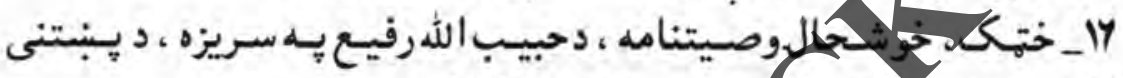

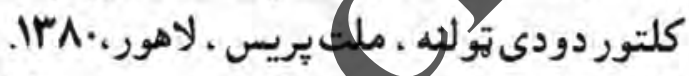

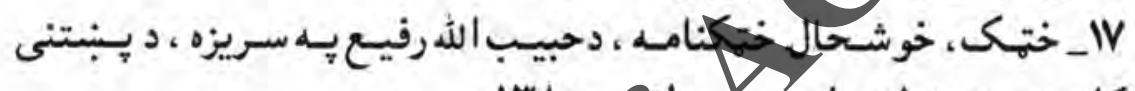

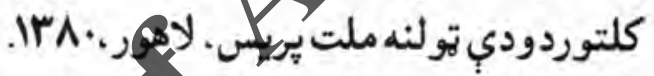

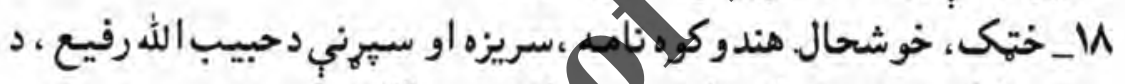

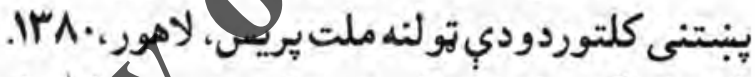

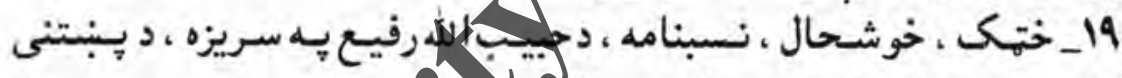

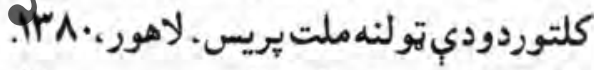

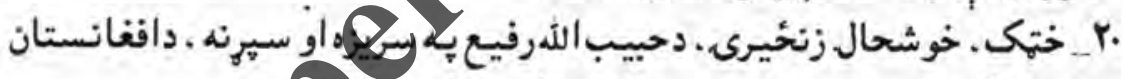

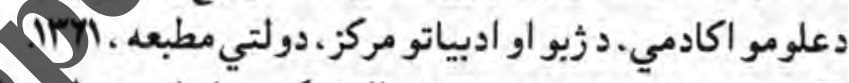

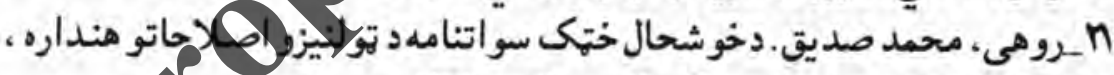

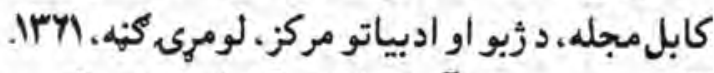

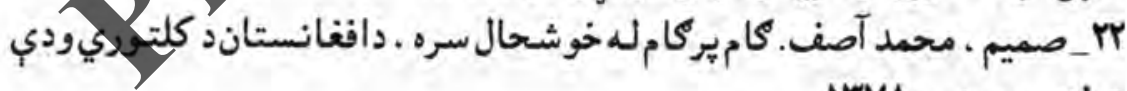
تولنه ، جرمنى. IrVA

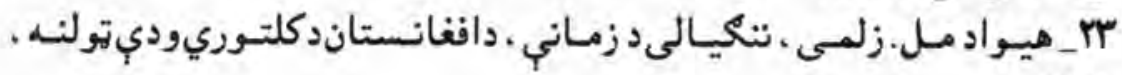
IrA.

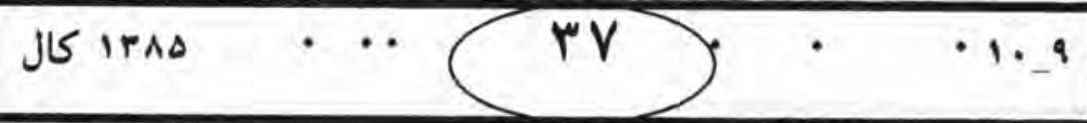




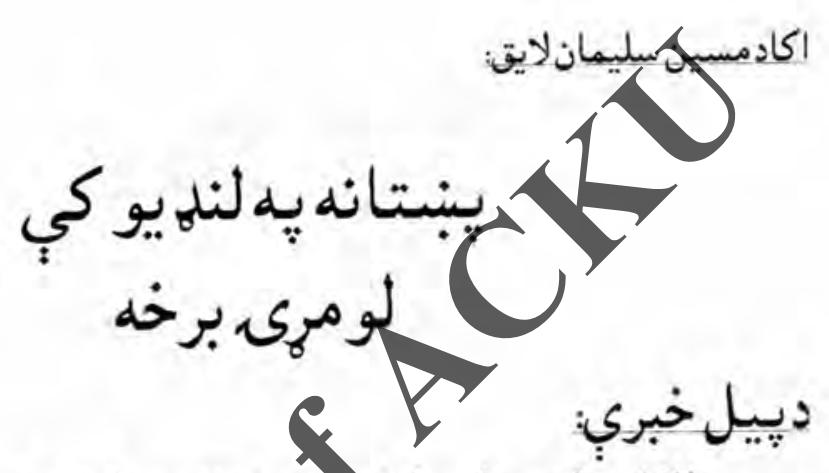

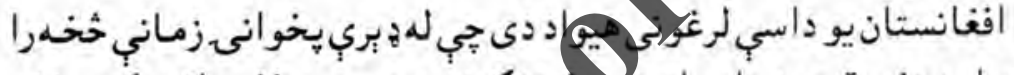

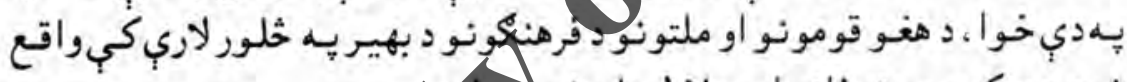

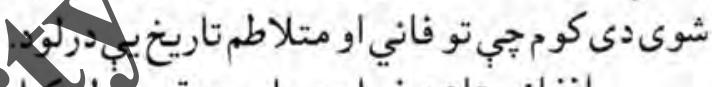

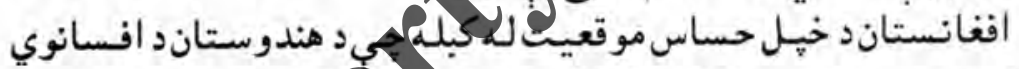

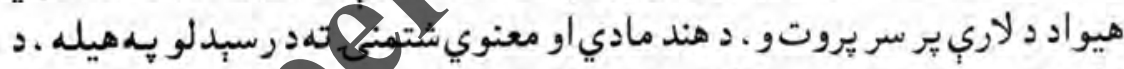

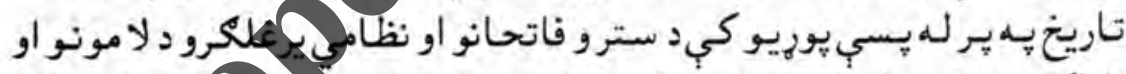

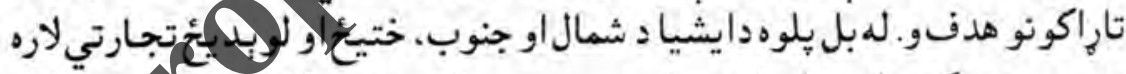

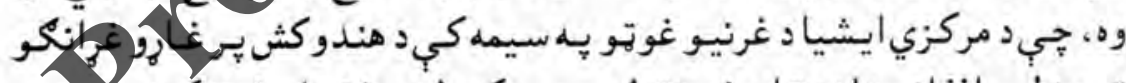

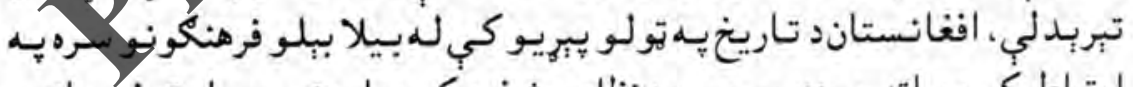

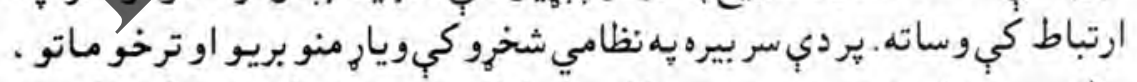

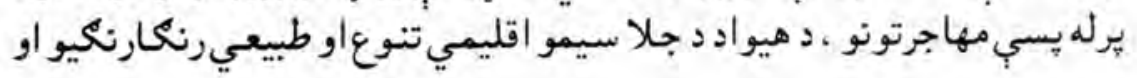
J IrAs
$r \wedge$
1. 9 


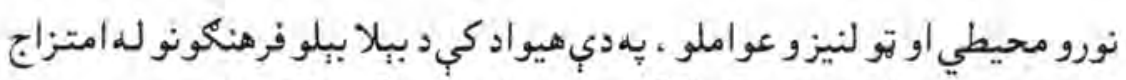

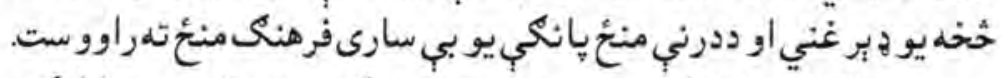

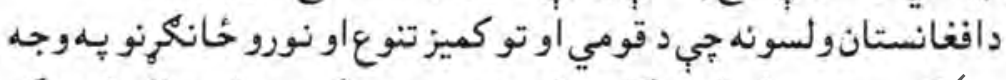

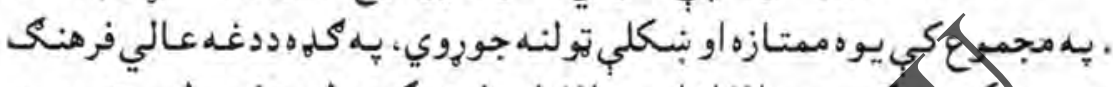

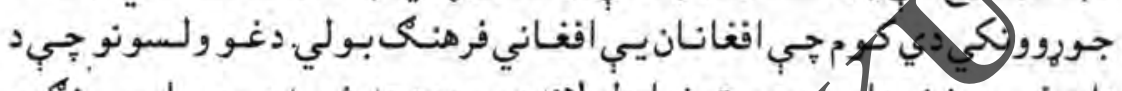

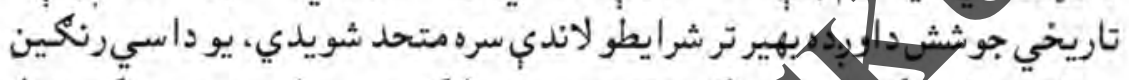

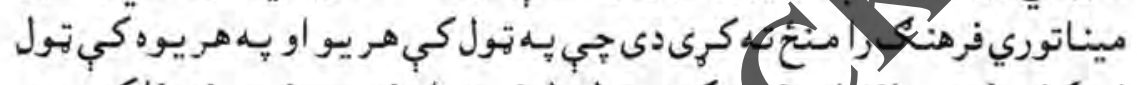

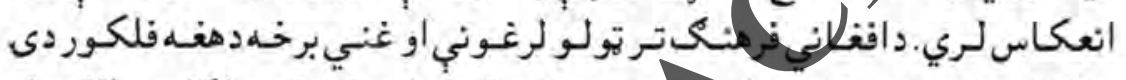

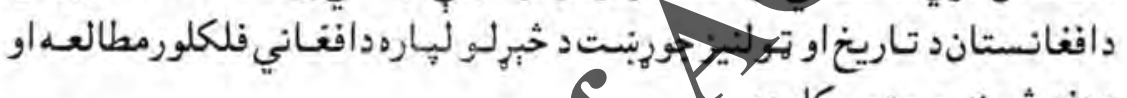

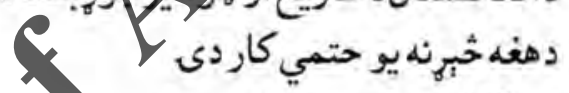

\section{فلكلورخه تهو اييك:}

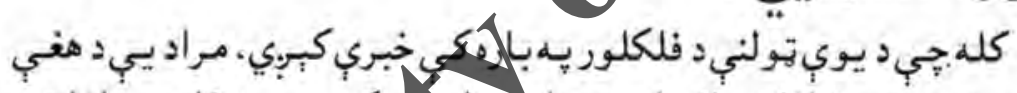

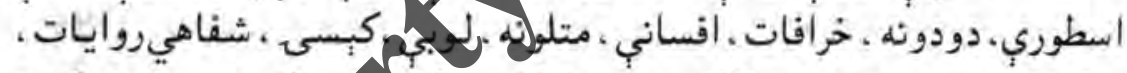

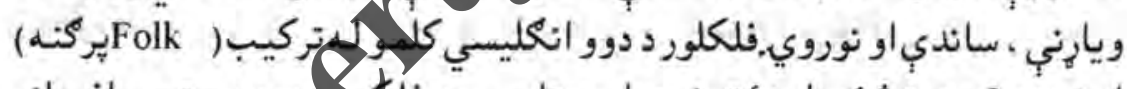

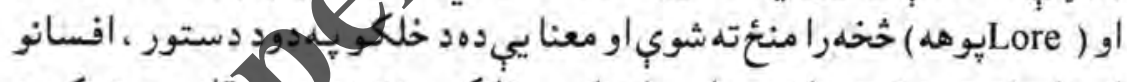

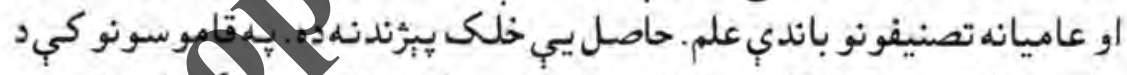

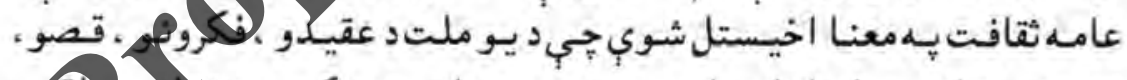

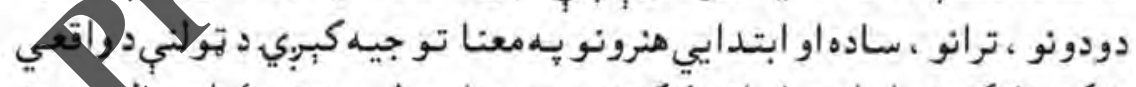

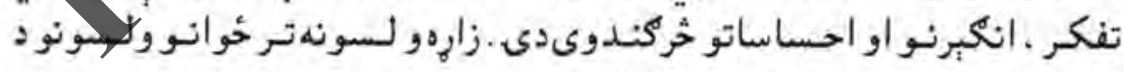

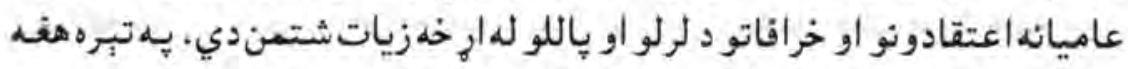

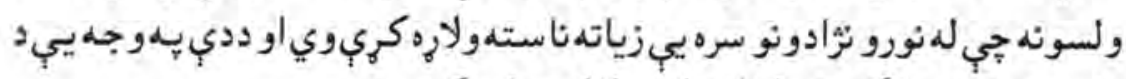

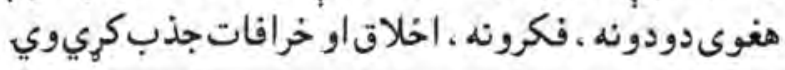
Irıo
rq
- 1. 9 


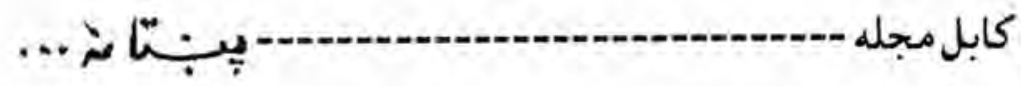

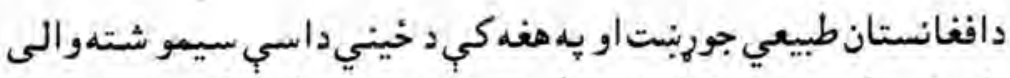

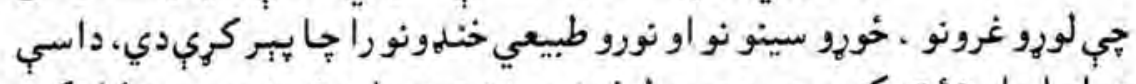

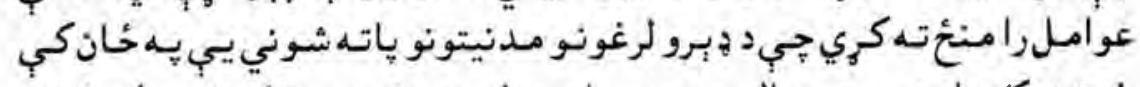

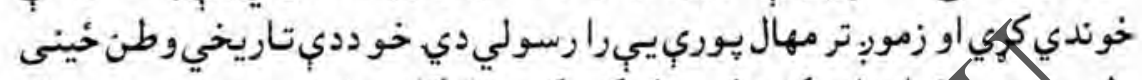

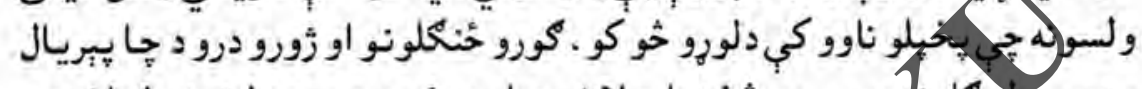

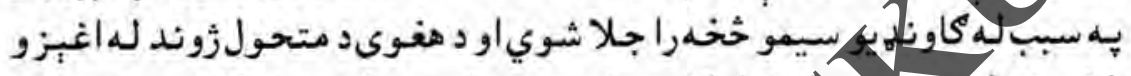

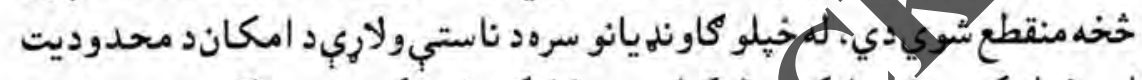

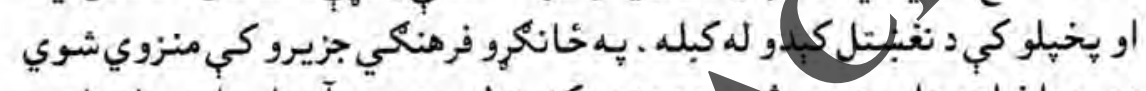

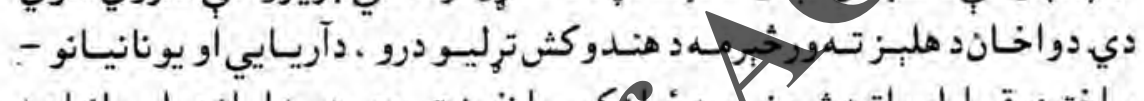

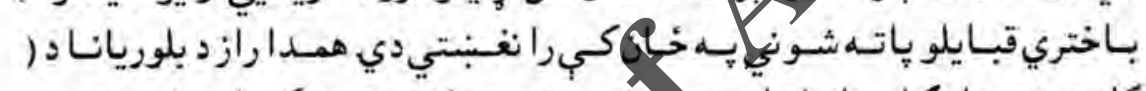

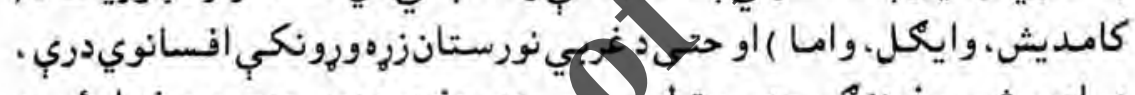

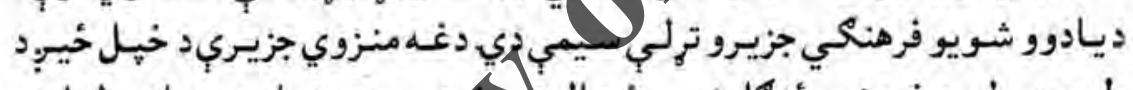

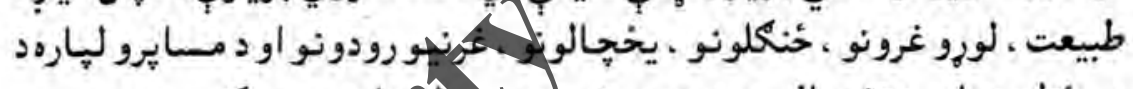

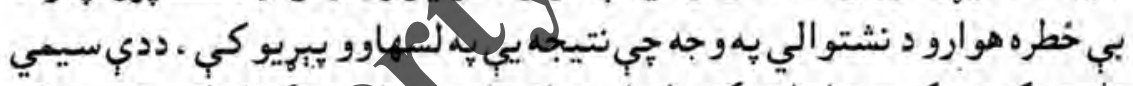

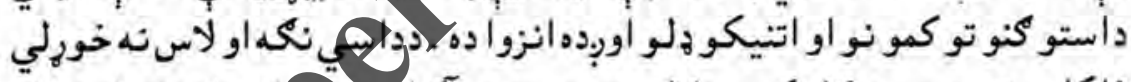

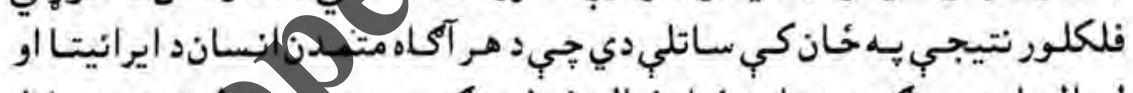

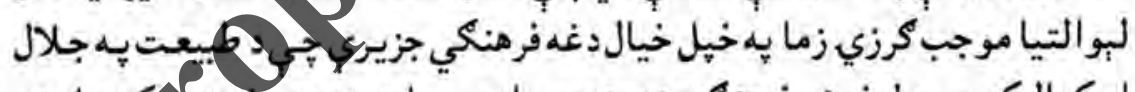

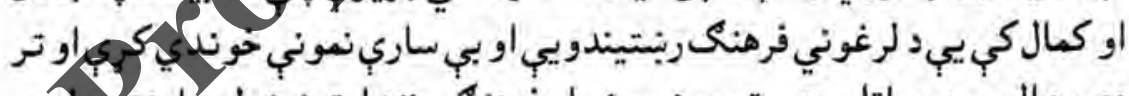

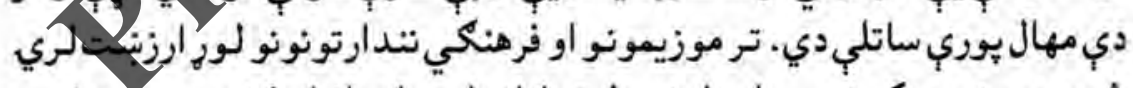

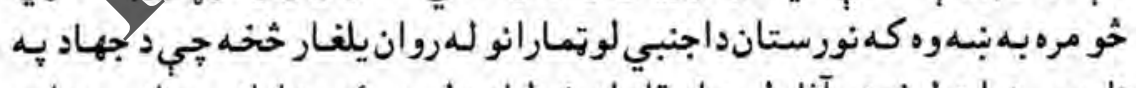

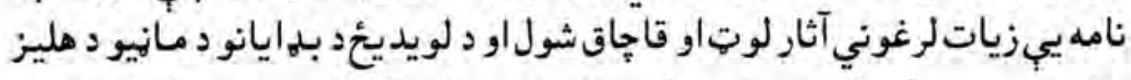

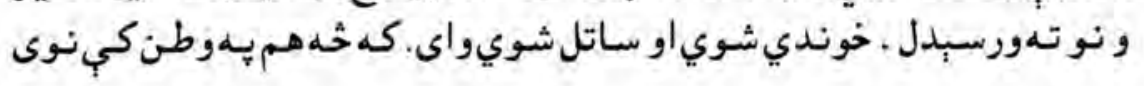

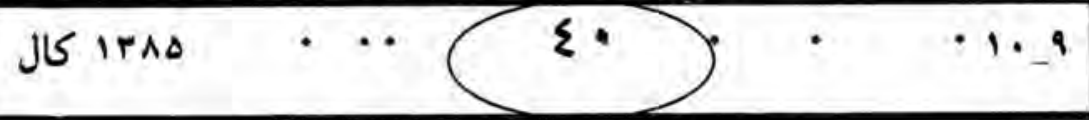




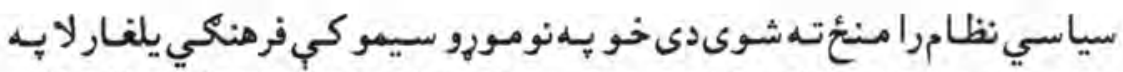

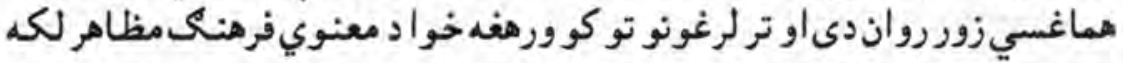

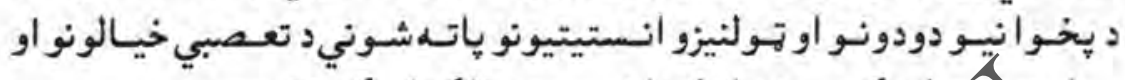

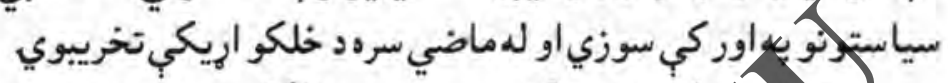

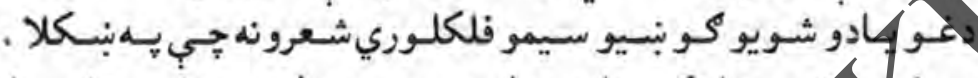

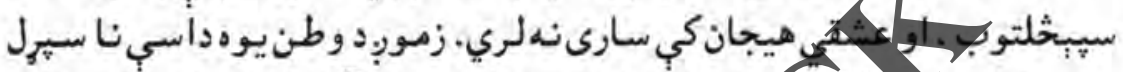

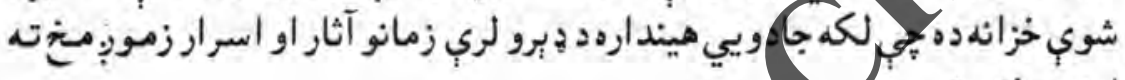
ابتبوو لالىشي.

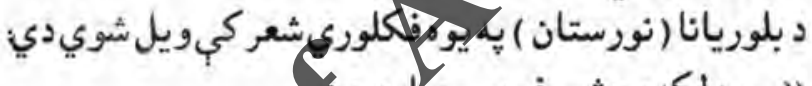

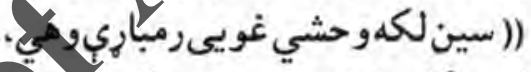

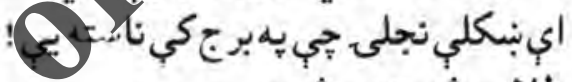

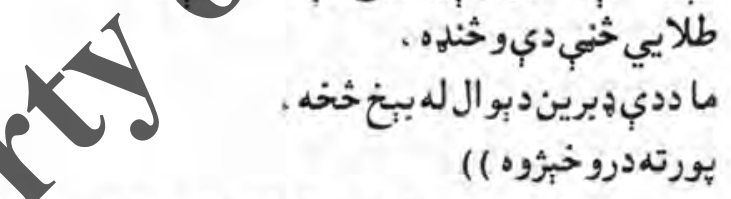

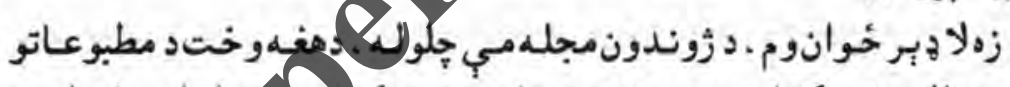

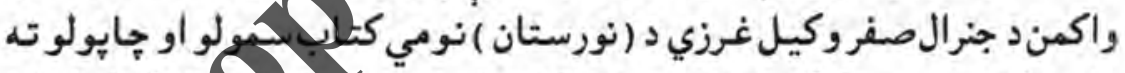

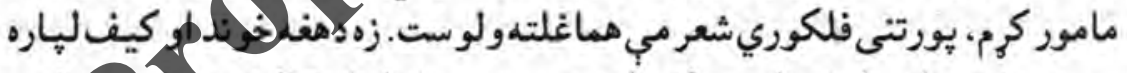

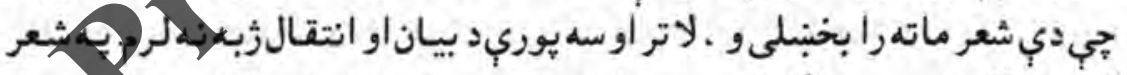

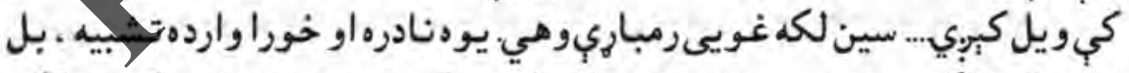

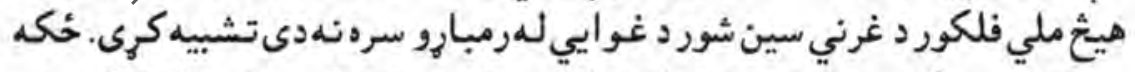

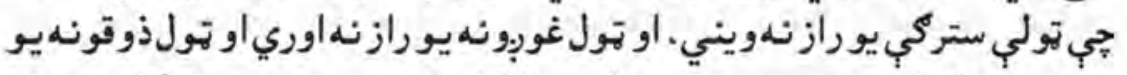

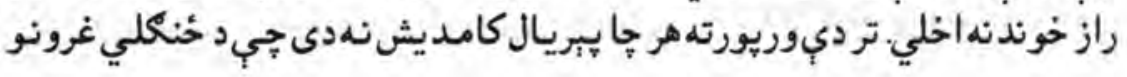
J ITAS
₹
1. 9 


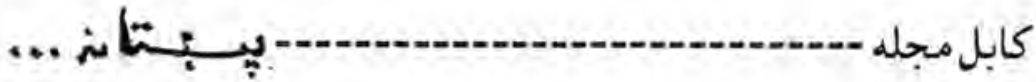

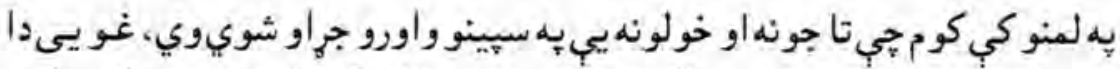

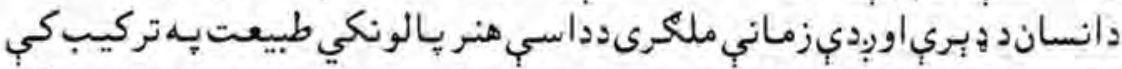

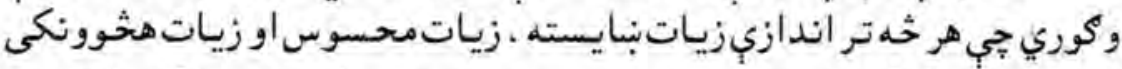

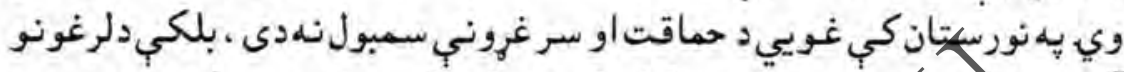

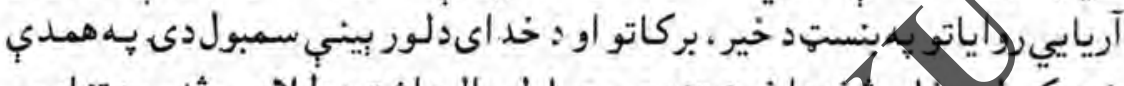

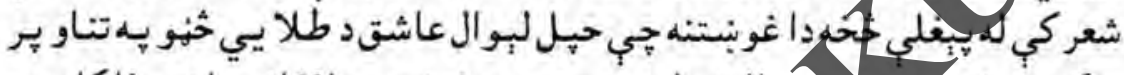

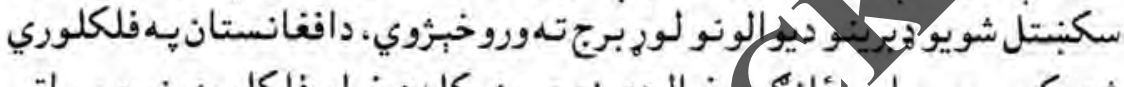

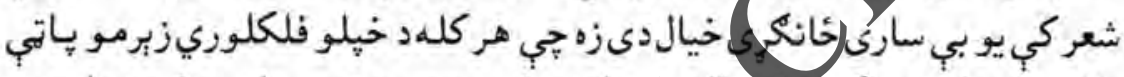

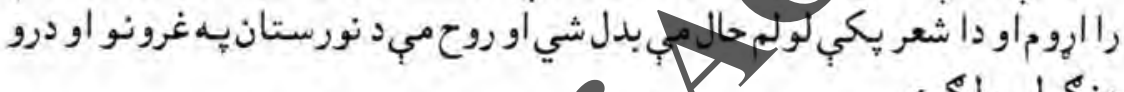

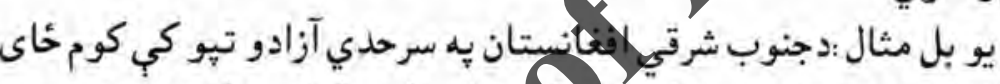

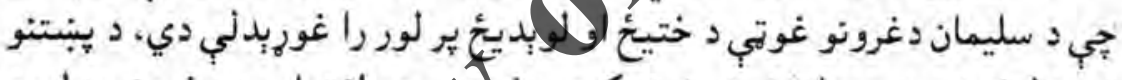

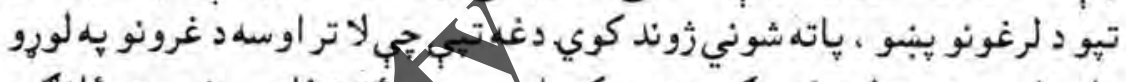

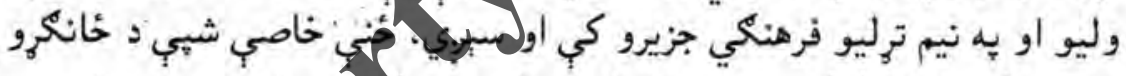

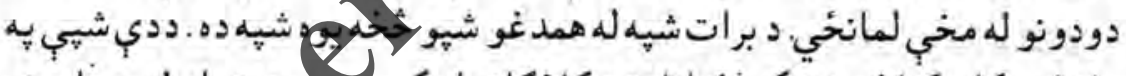

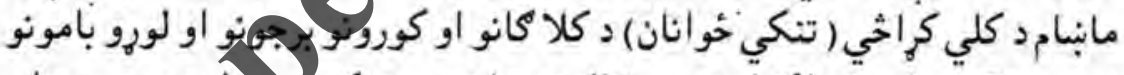

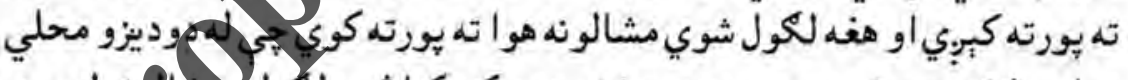

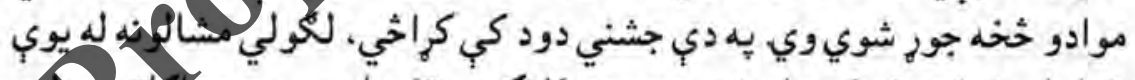

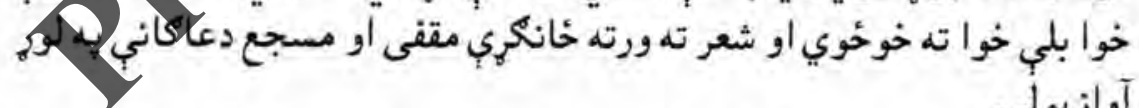

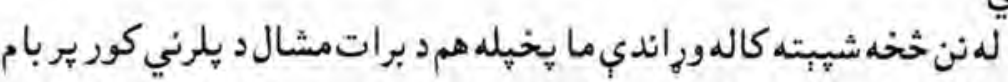
آواز بولي ئي

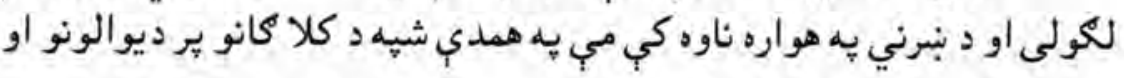

J IrAd

$\sum Y$ 1. 9 


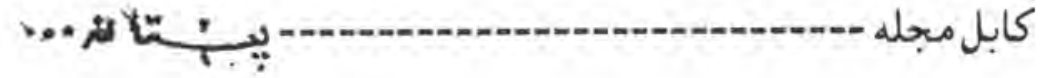

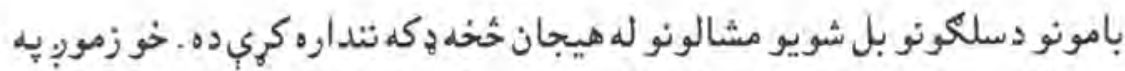

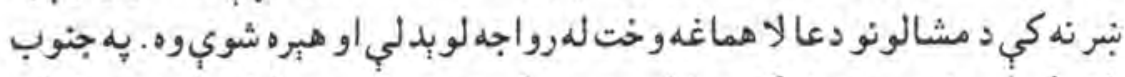

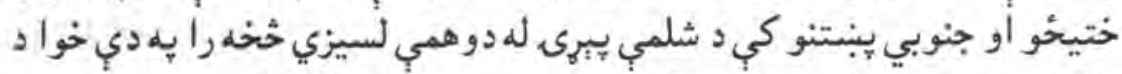

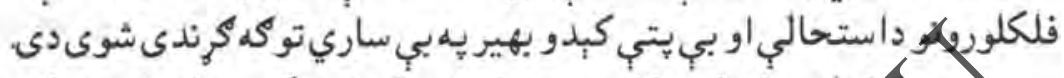

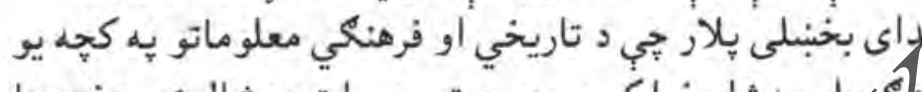

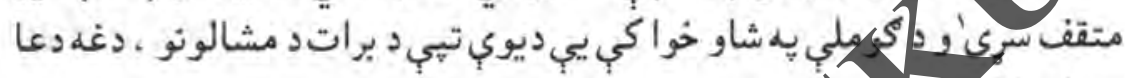

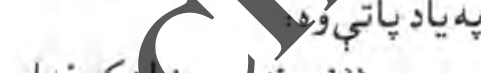

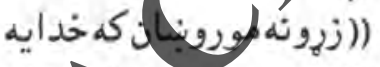

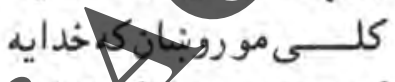

$$
\begin{aligned}
& \text { كوروندمو روبنانكله خدابهان }
\end{aligned}
$$

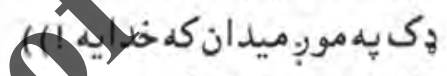

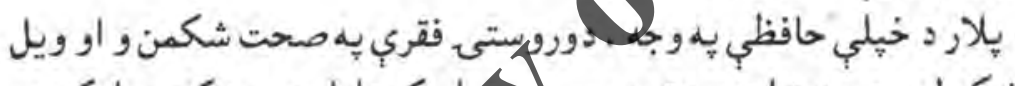

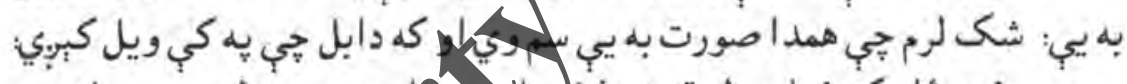

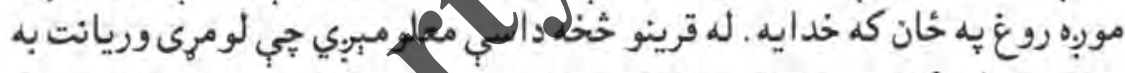

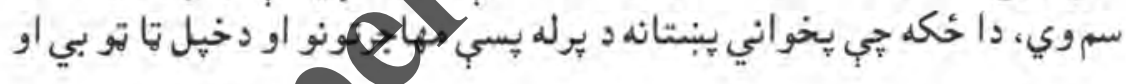

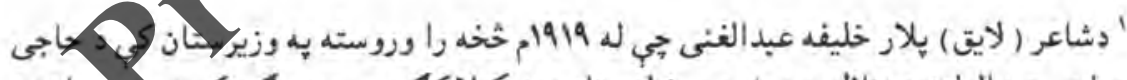

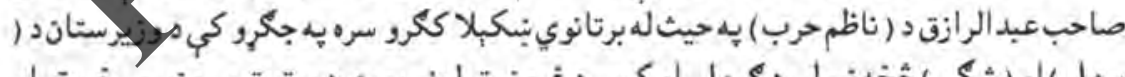

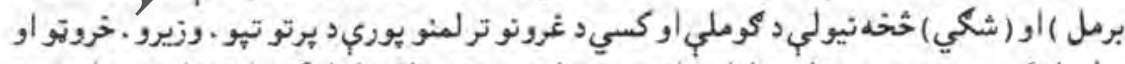

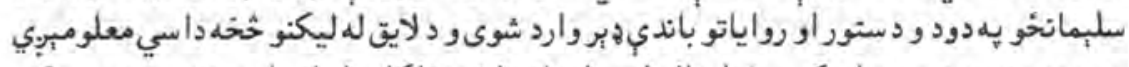

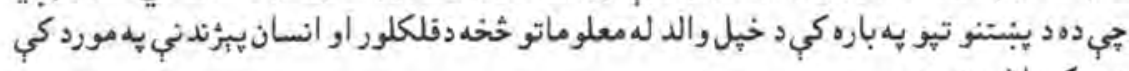
هيبروكته اخيستيده.

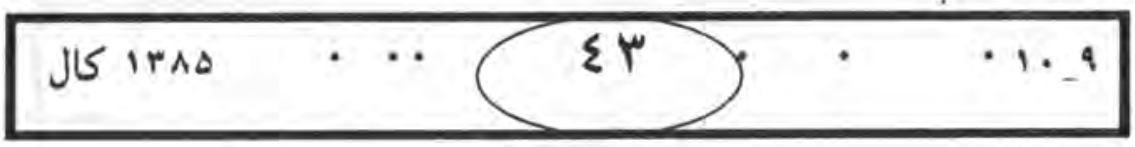




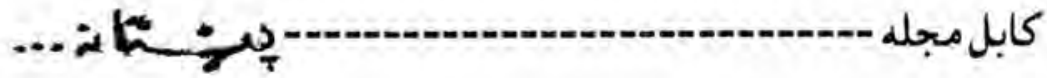

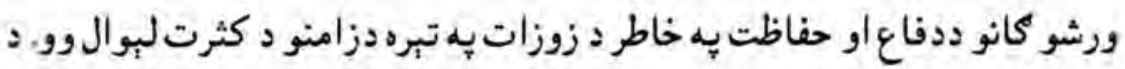

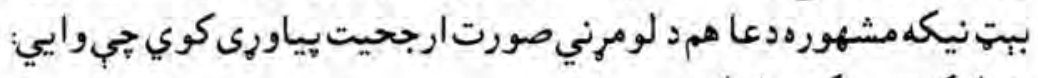

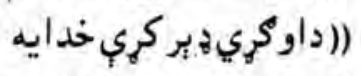

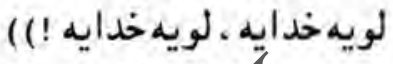

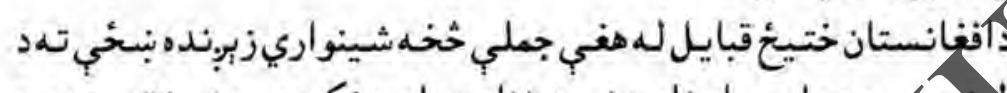

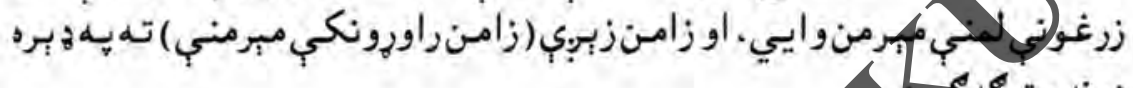

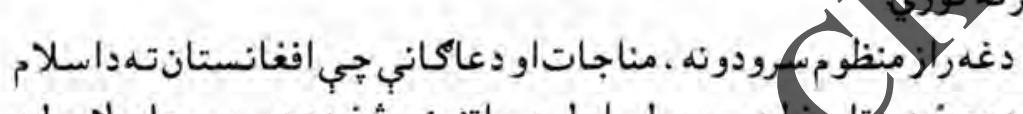

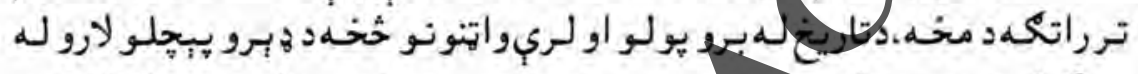

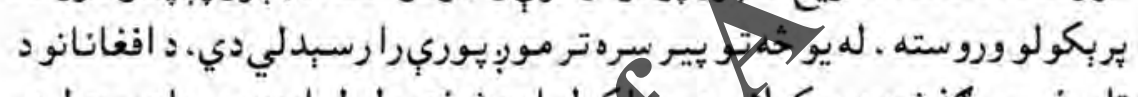

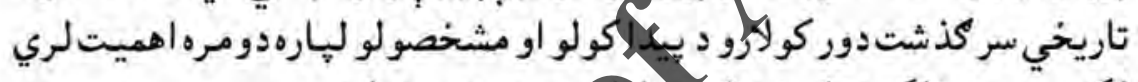

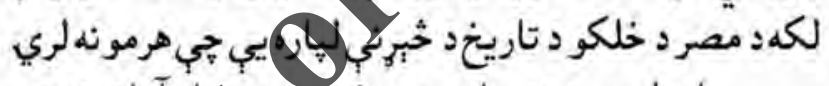

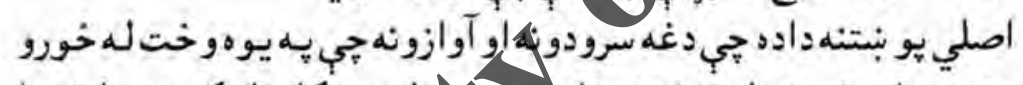

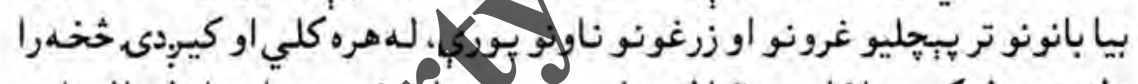

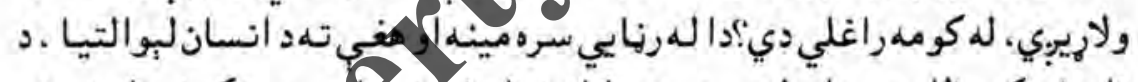

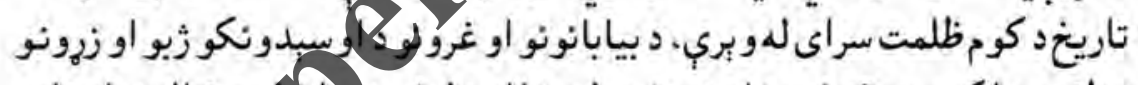

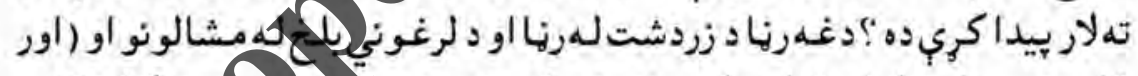

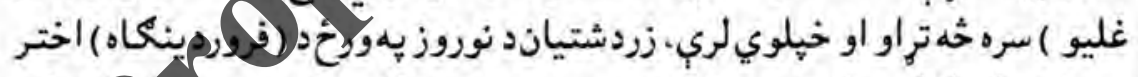

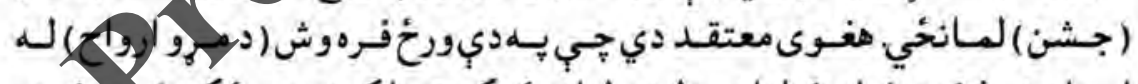

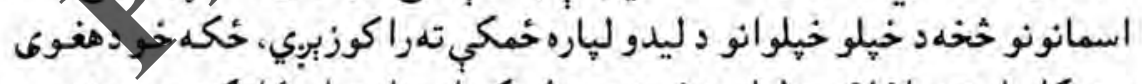

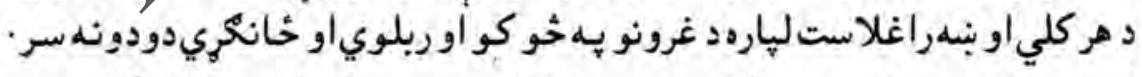

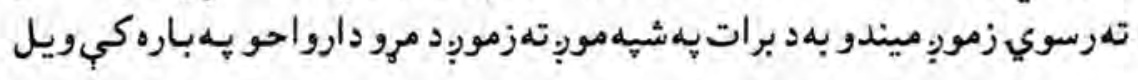

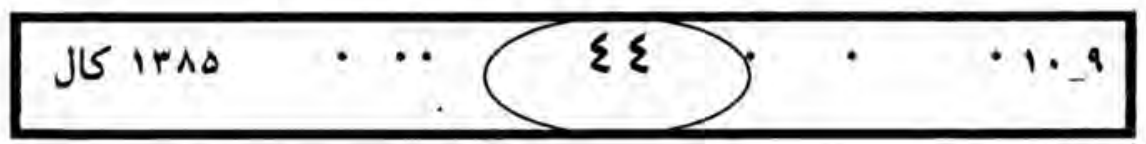




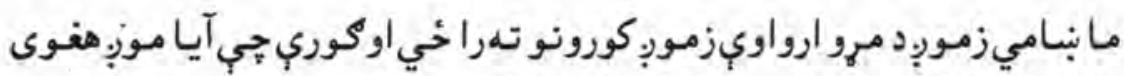

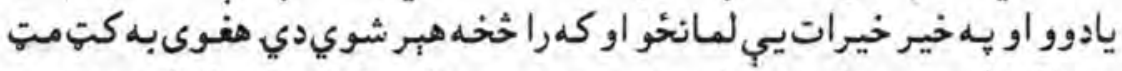

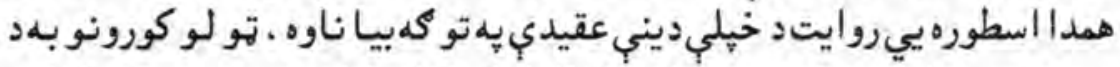

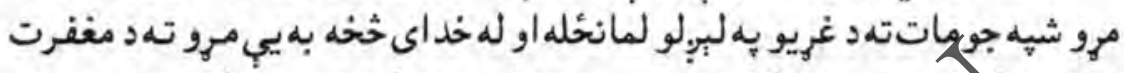

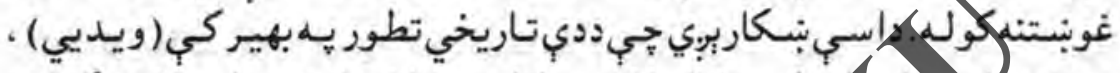

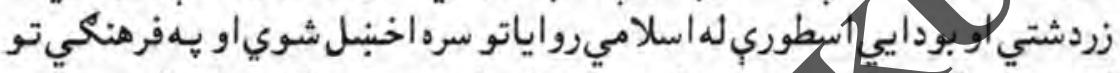

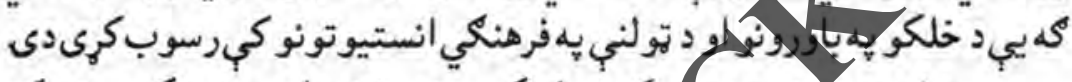

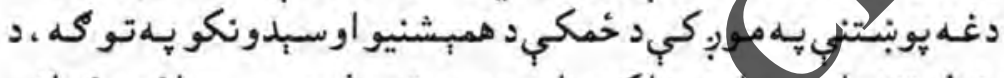

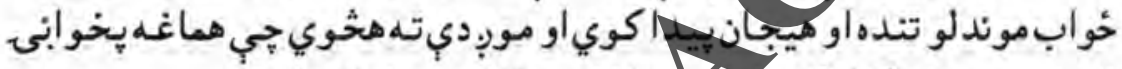

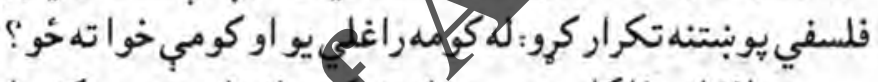

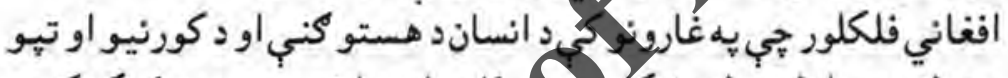

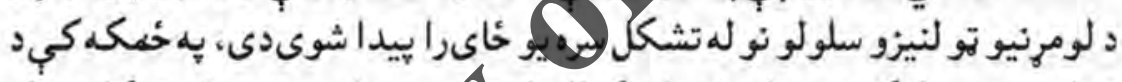

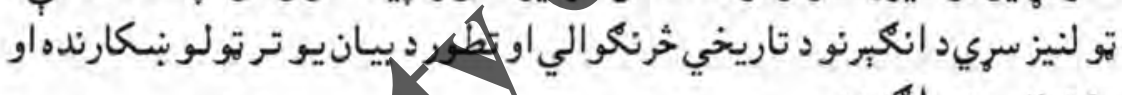

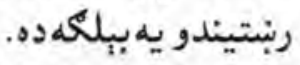

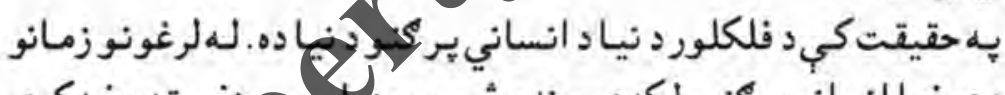

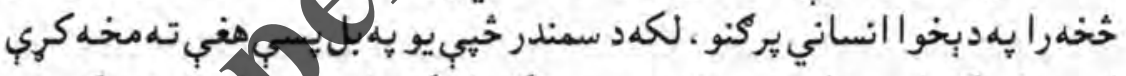

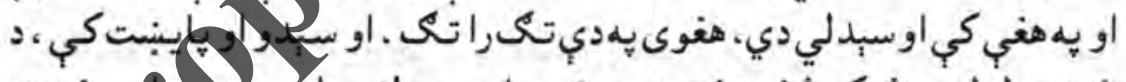

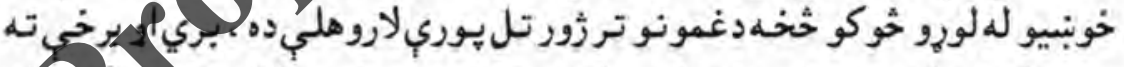

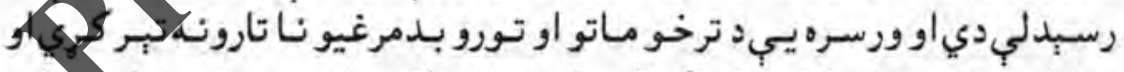

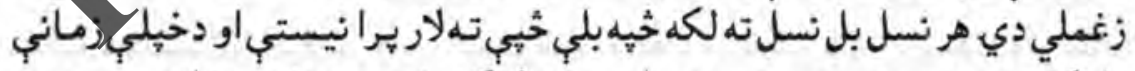

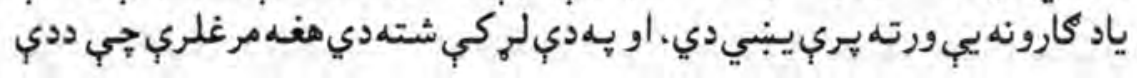

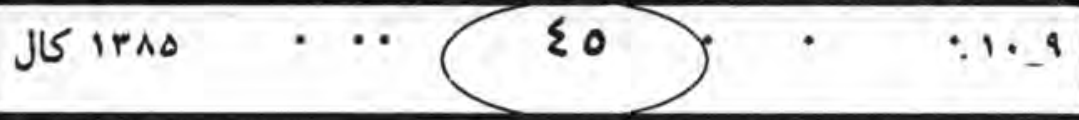




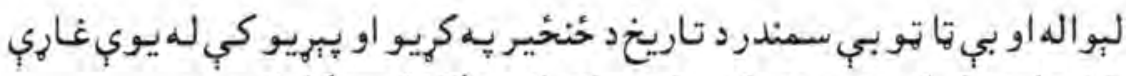

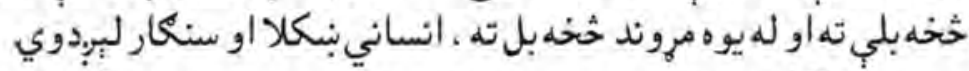

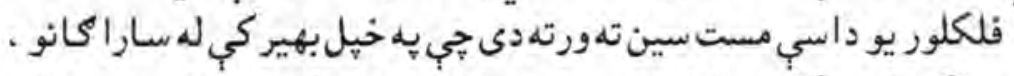

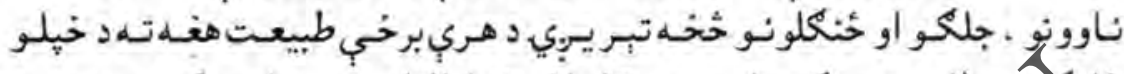

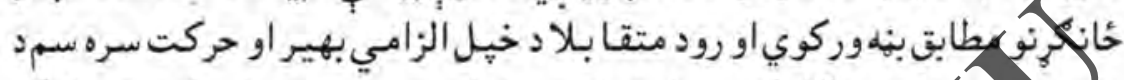

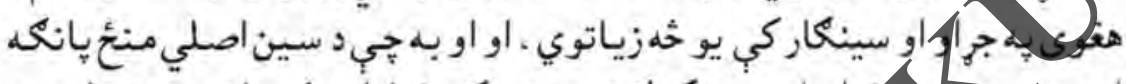

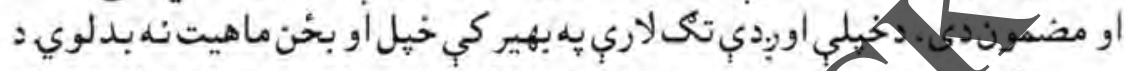

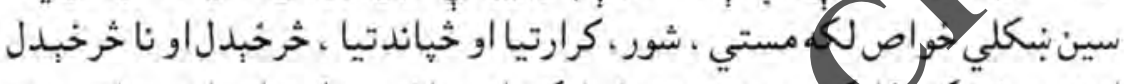

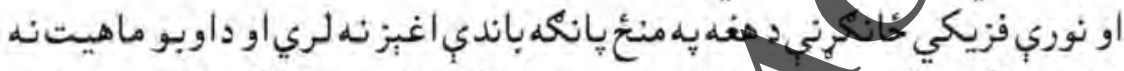

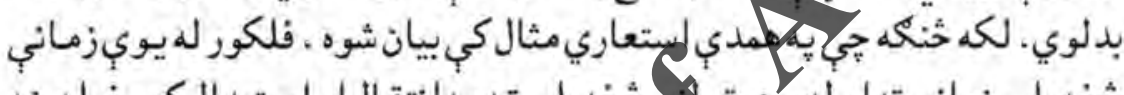

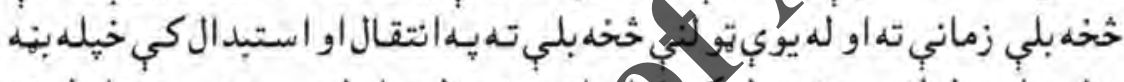

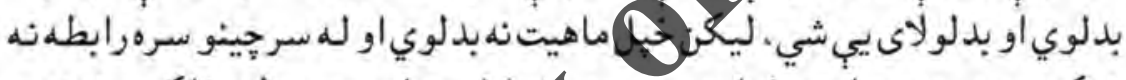

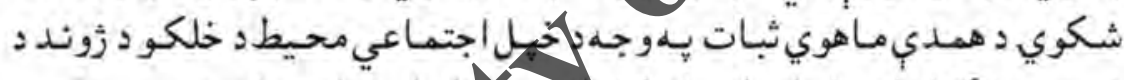

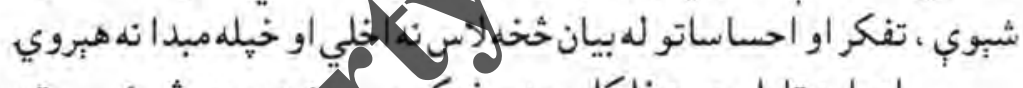

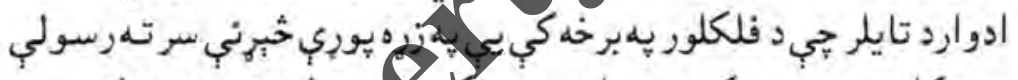

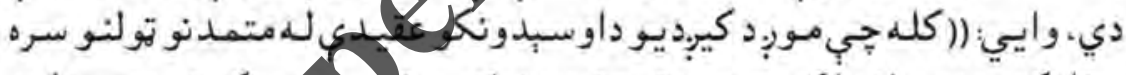

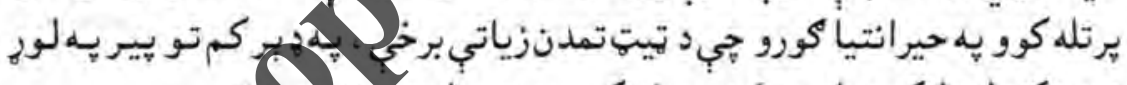

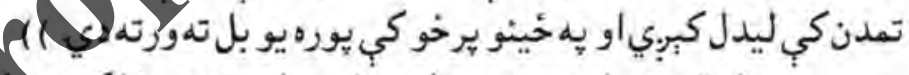

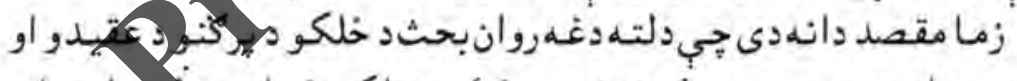

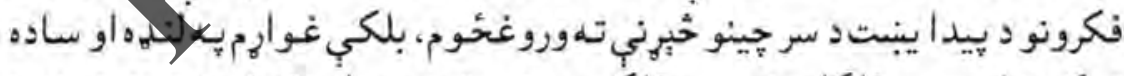

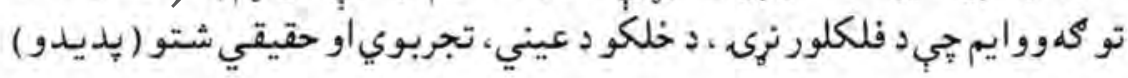
توى

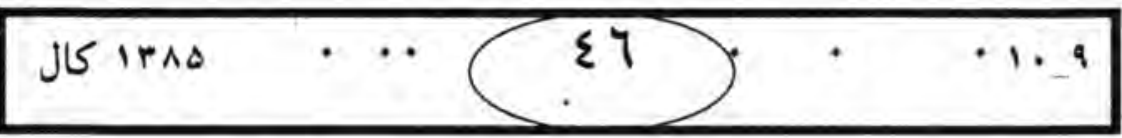




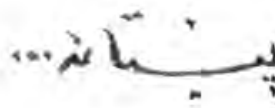

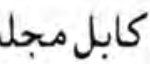

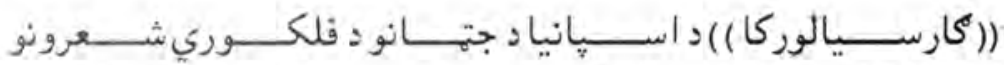

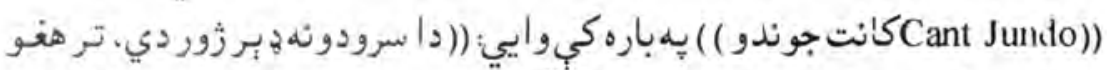

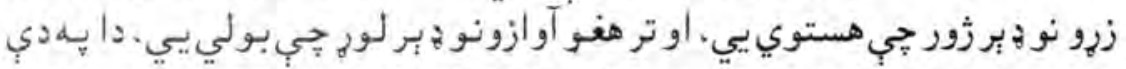

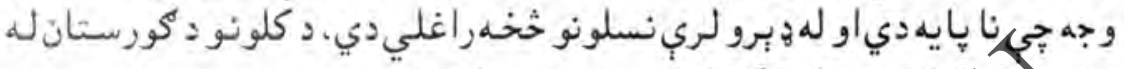

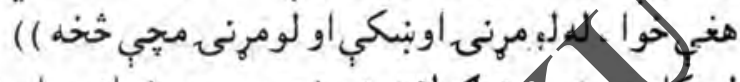

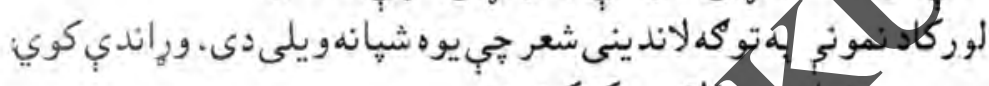
زال)

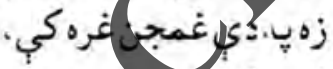

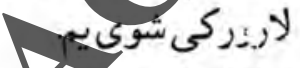

خداى ليارهيربيتك.

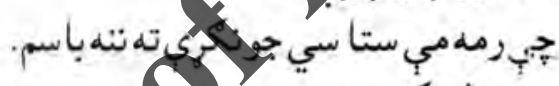

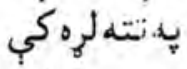

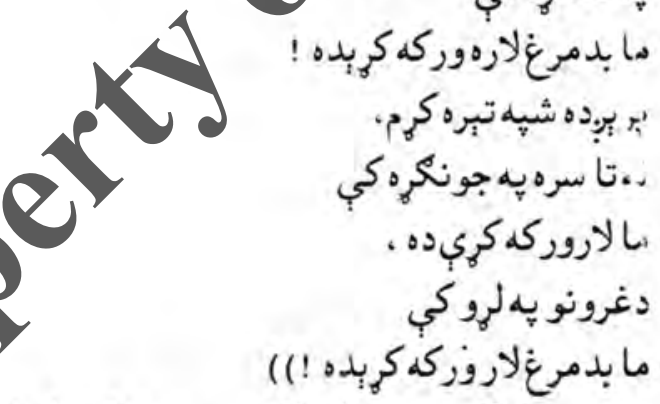

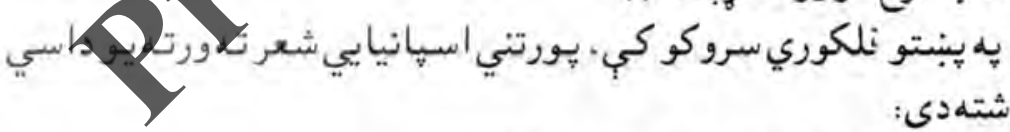

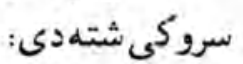

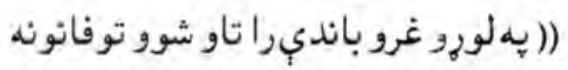

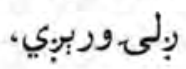




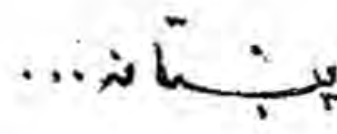

كابل مجله

$$
\begin{aligned}
& \text { مه حمه ، } \\
& \text { دلتهشيه وكرهه } \\
& \text { ياتيشه } \\
& \text { باراندى!) }
\end{aligned}
$$

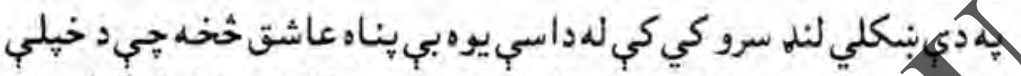

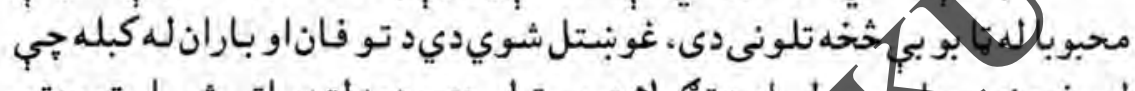

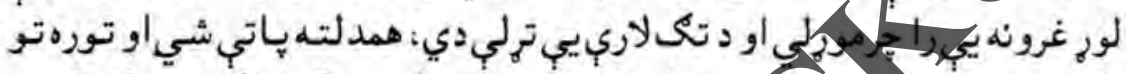

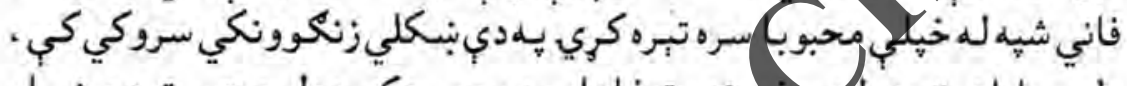

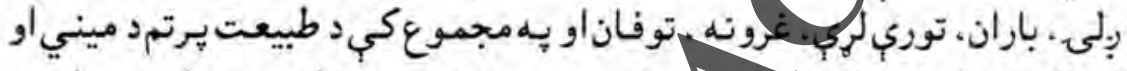

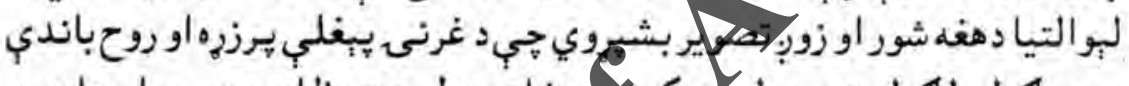

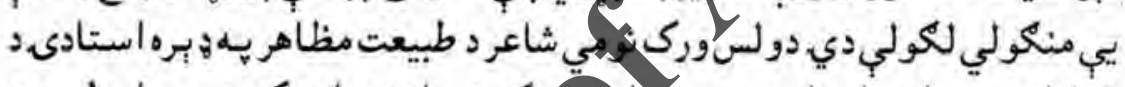

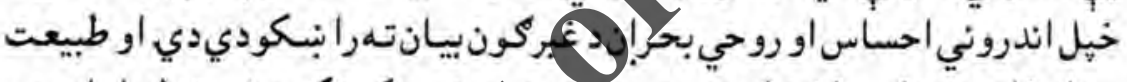

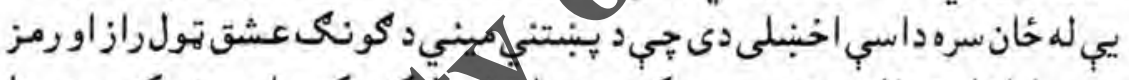

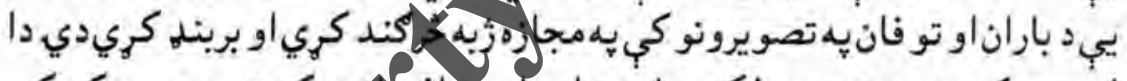

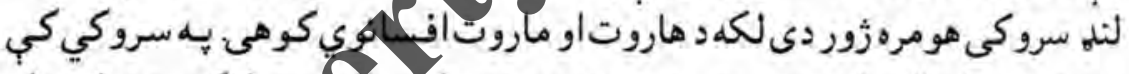

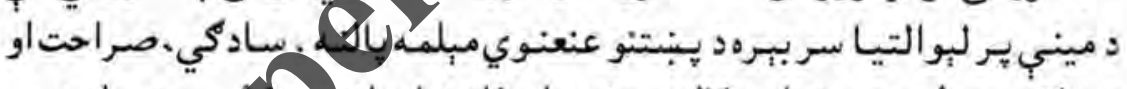

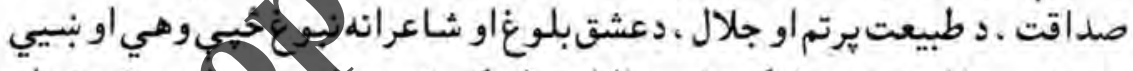

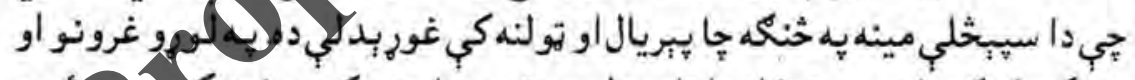

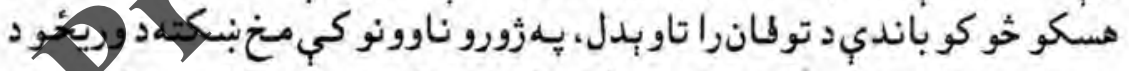

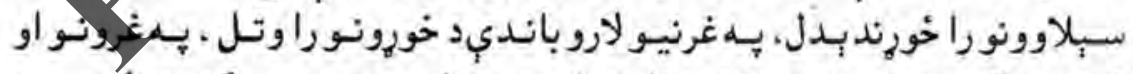

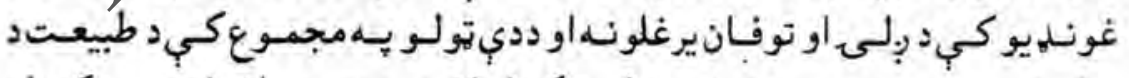

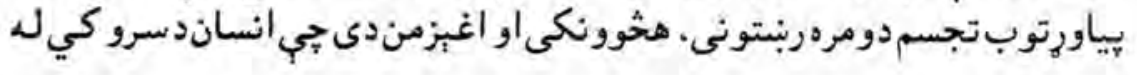

$$
\text { J }
$$




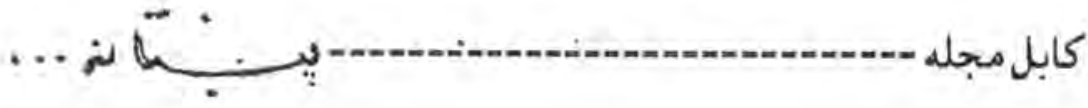

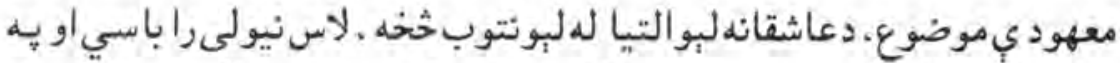

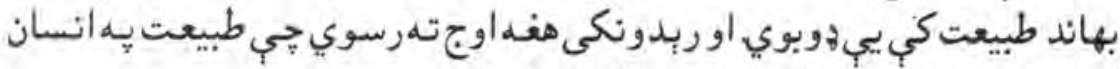

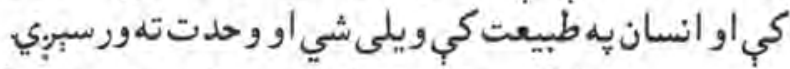

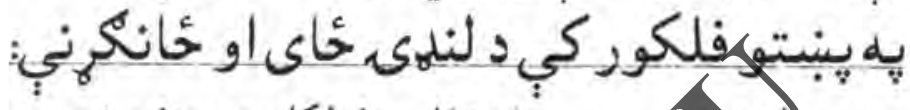

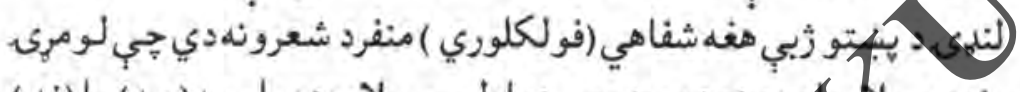

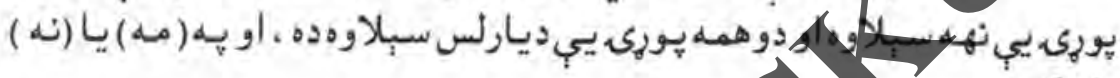

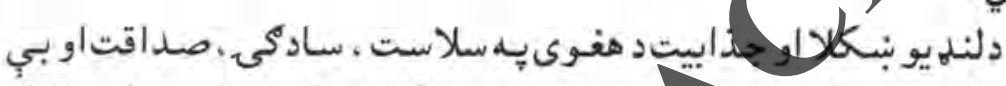

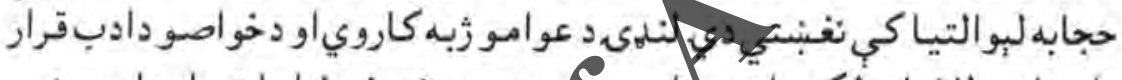

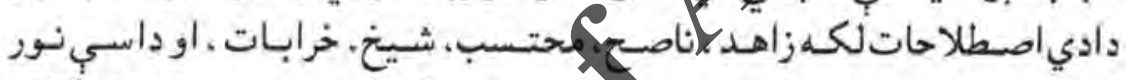

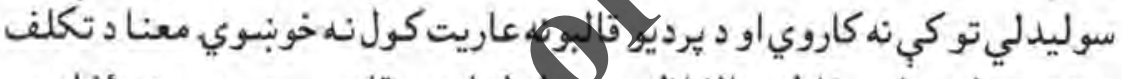

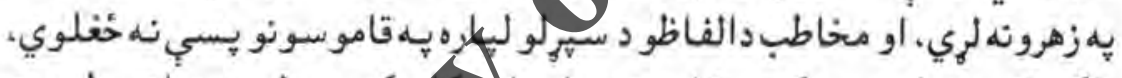

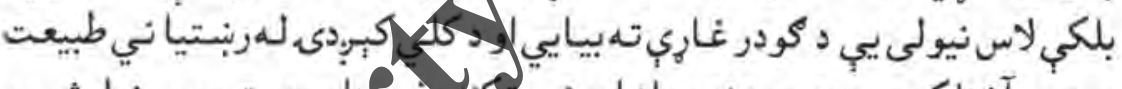

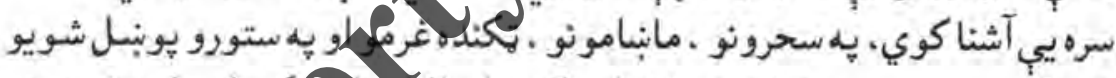

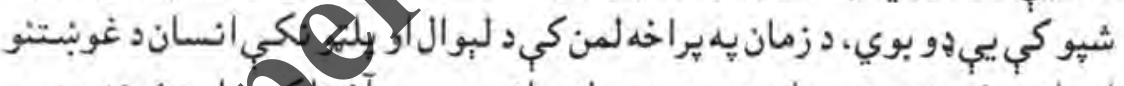

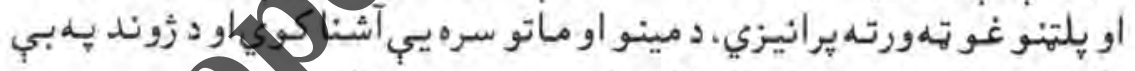

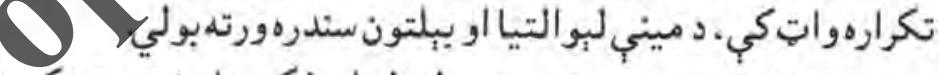

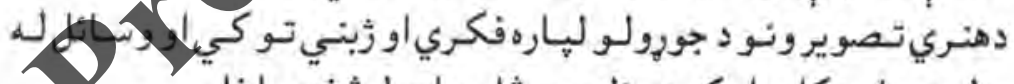

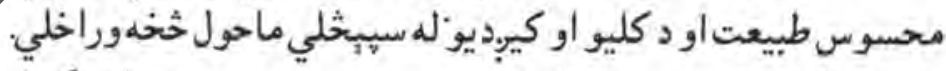

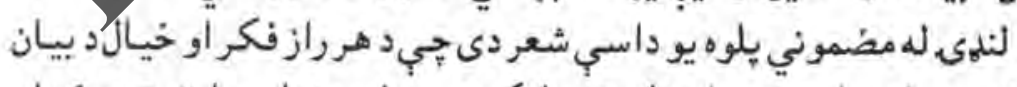

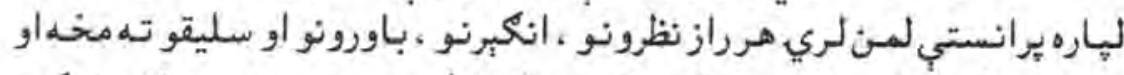

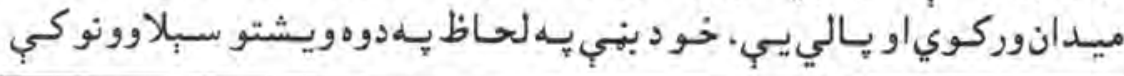

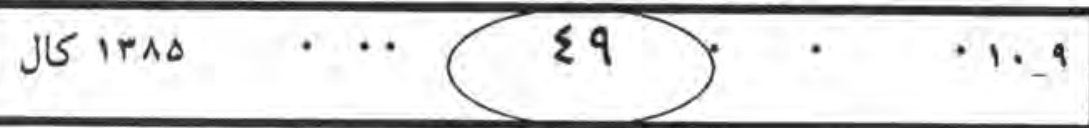




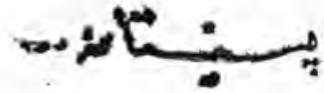

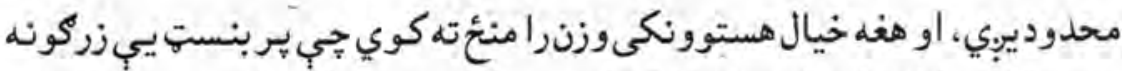

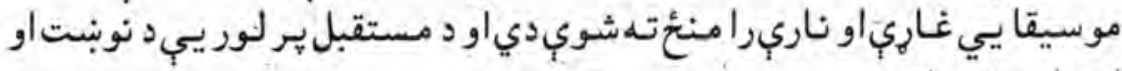

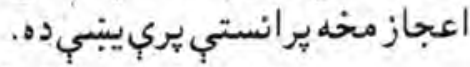

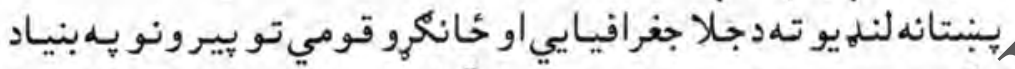

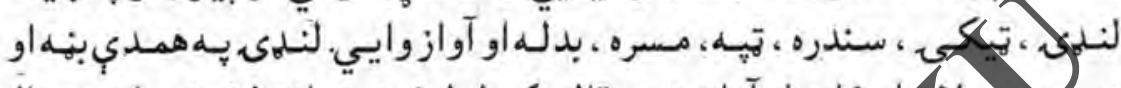

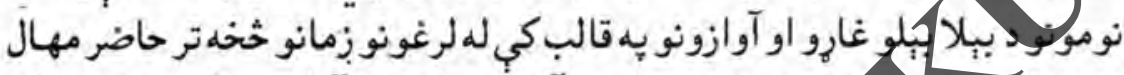

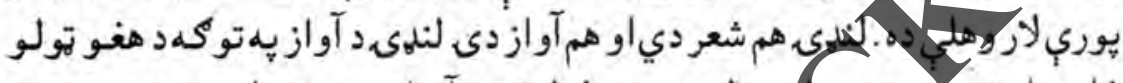

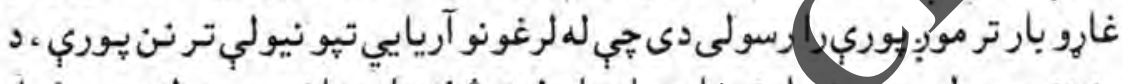

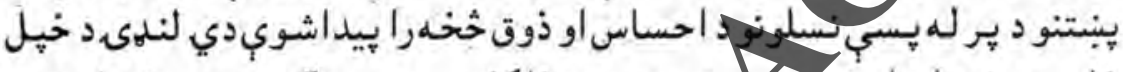

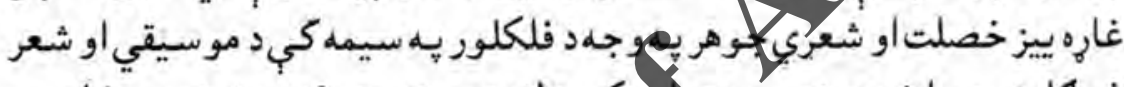

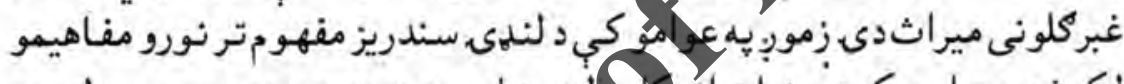

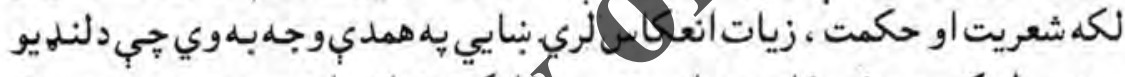

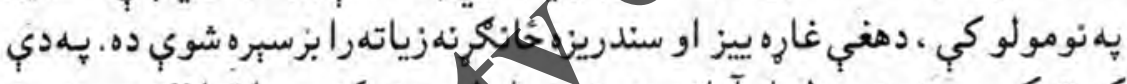

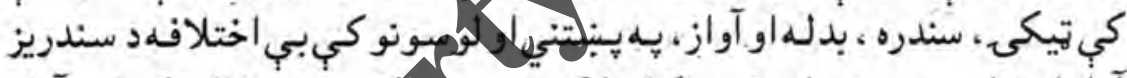

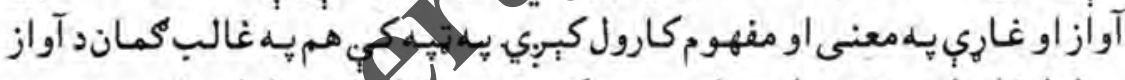

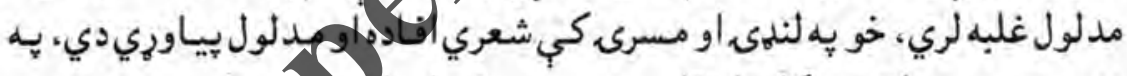

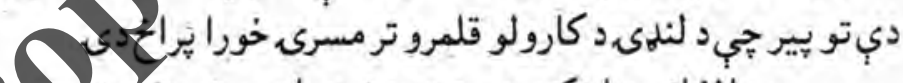

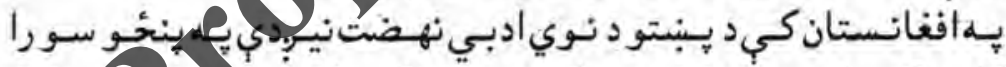

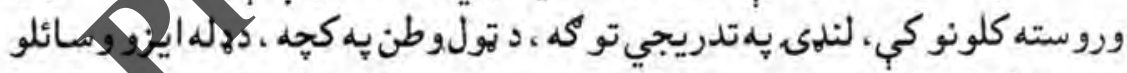

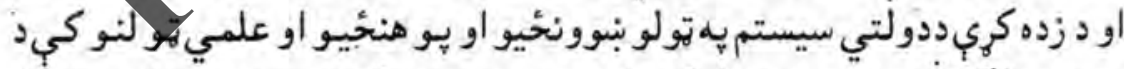

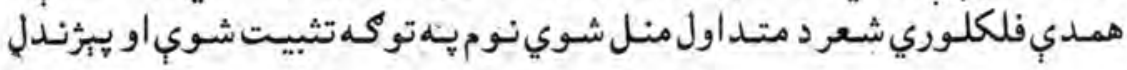
شوي مده.
Irno
0 .
$\cdot 1 \cdot 9$ 


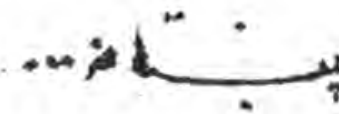

كابل مجله

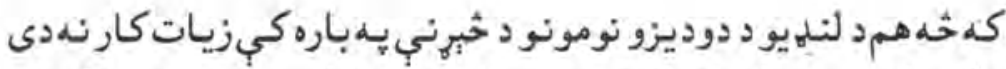

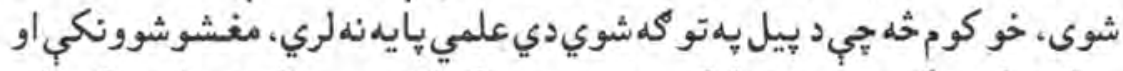

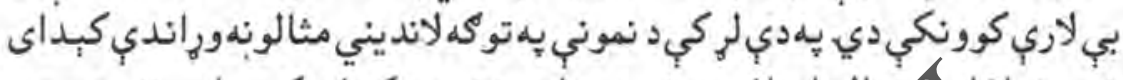

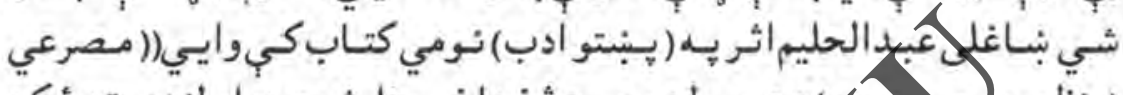

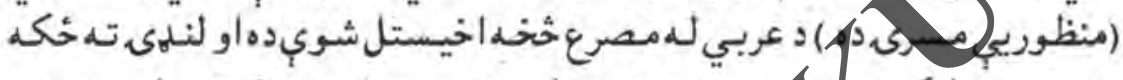

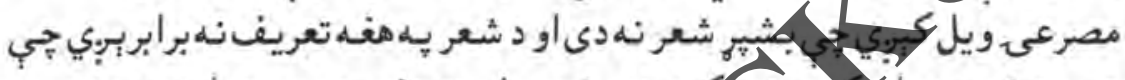

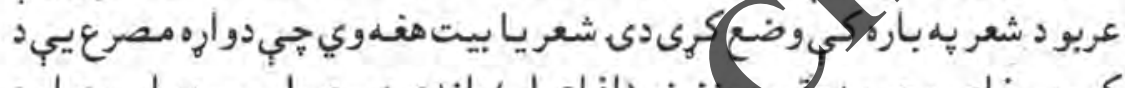

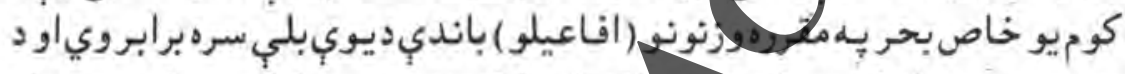

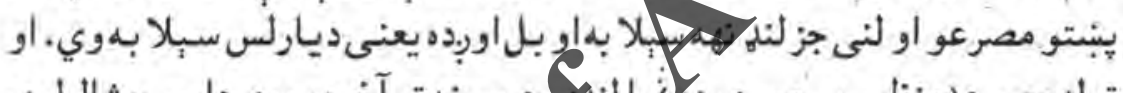

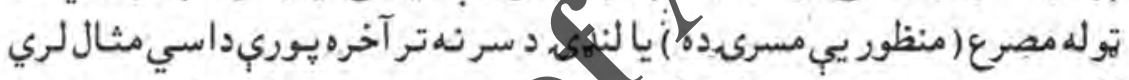

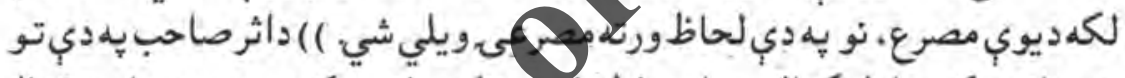

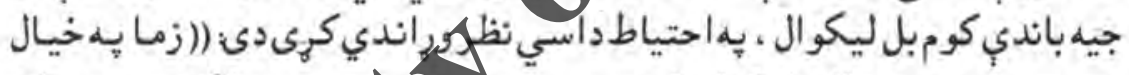

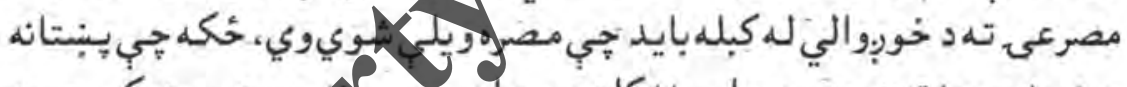

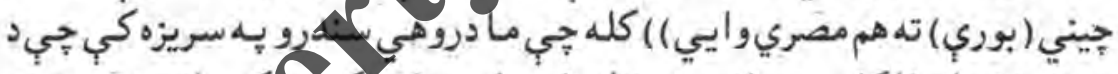

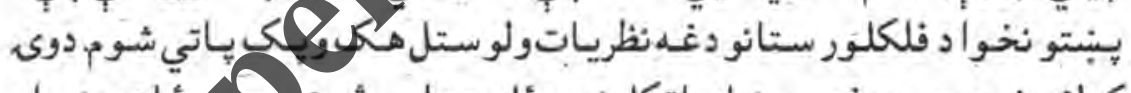

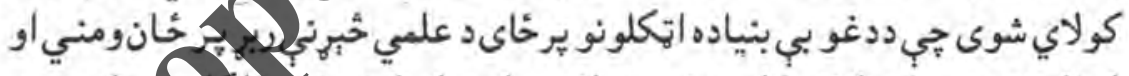

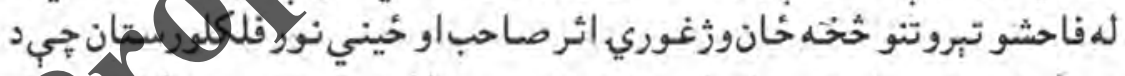

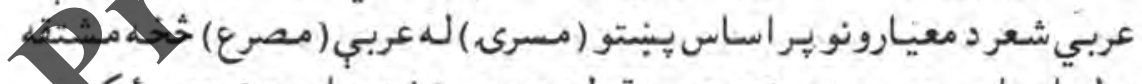

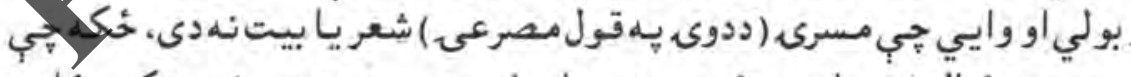

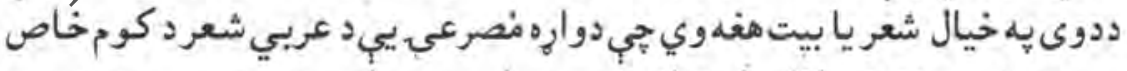

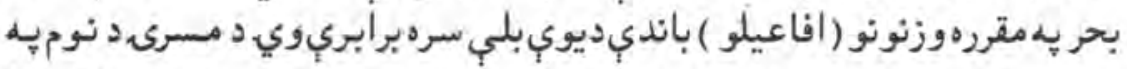

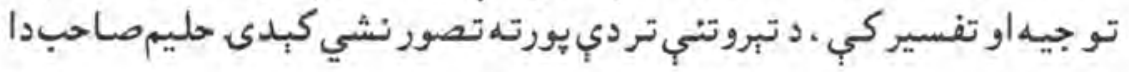
DAr
01
- 1.9 
هبروي جي مسرى (لنلهى) عربي شعرنهدى جب عربي نوموركرى شي او يا دعربي

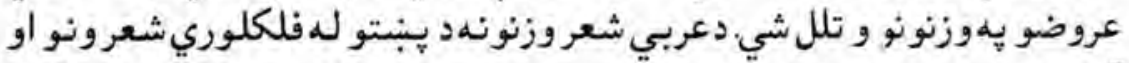

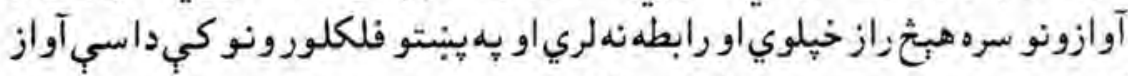

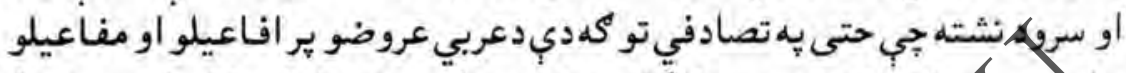

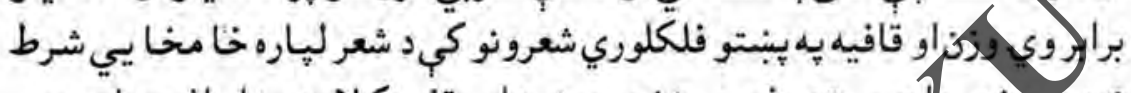

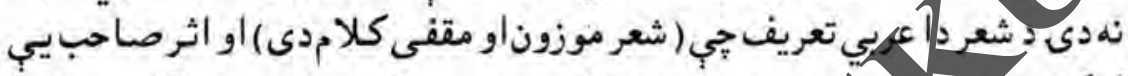

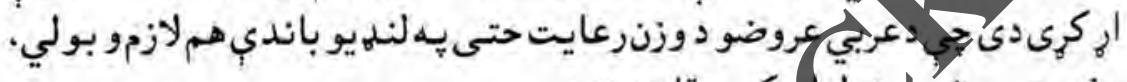

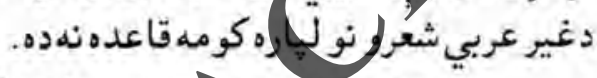

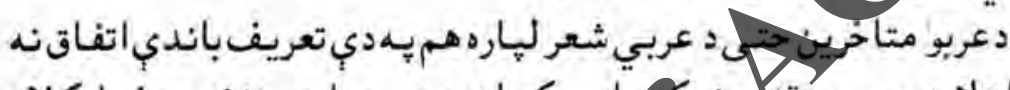

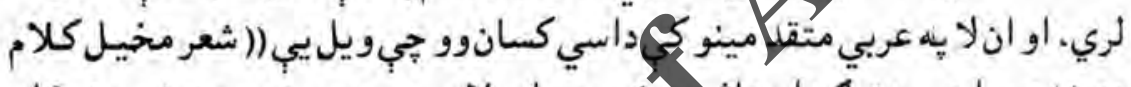

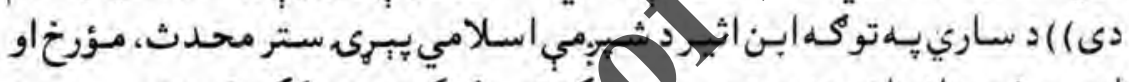

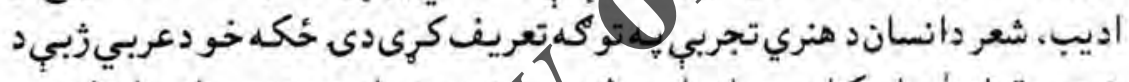

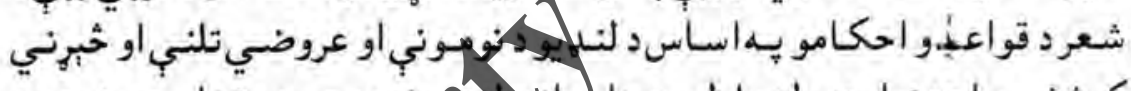

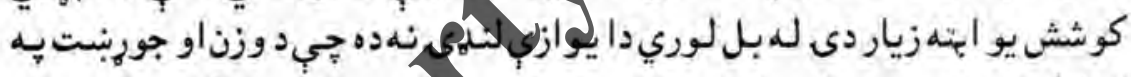

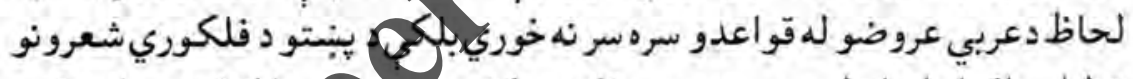

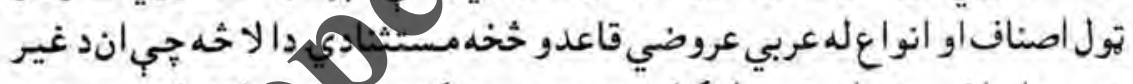

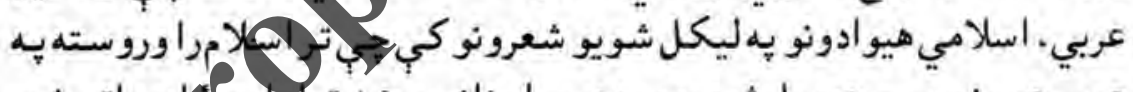

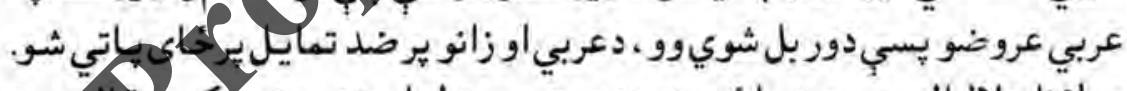

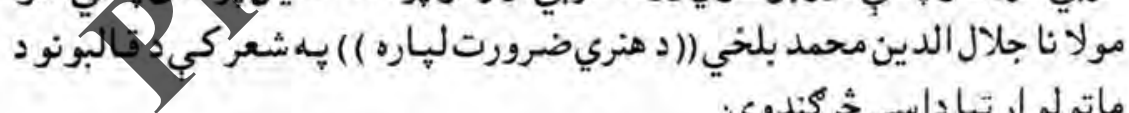

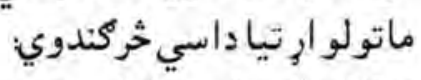

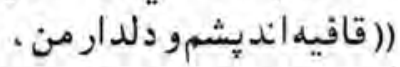
كويد منديش جز ويدارمن

J Irیs

$0 Y$

1. 9 


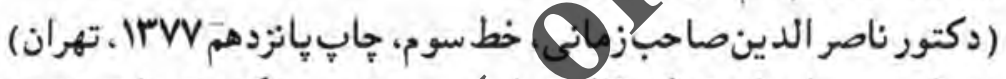

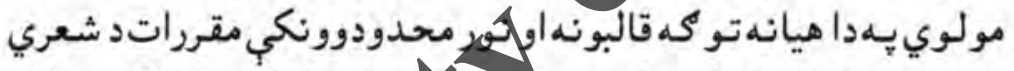

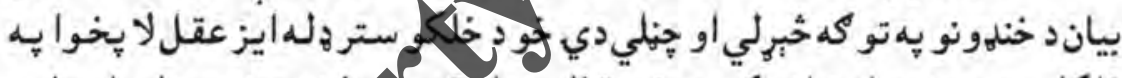

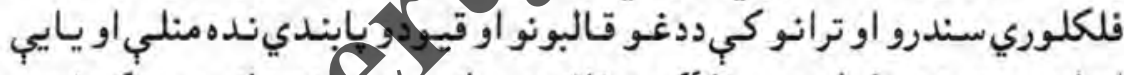

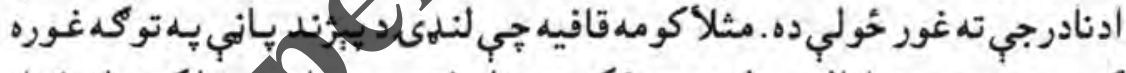

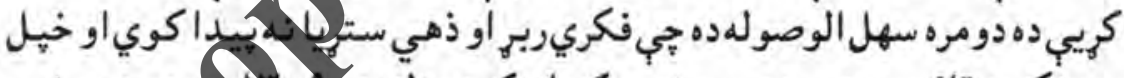

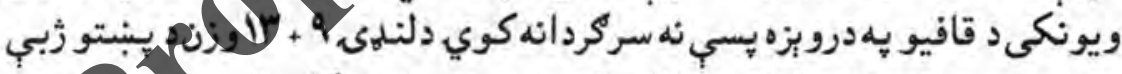

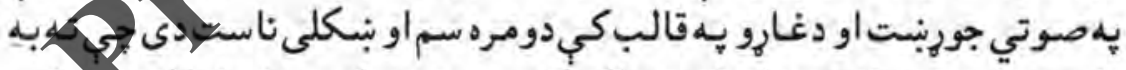

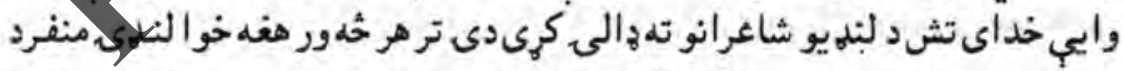

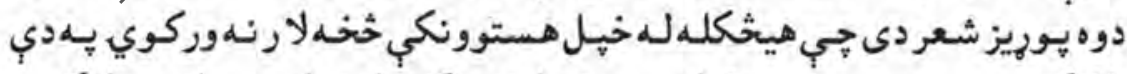

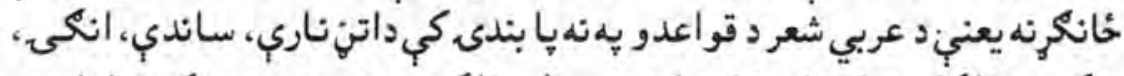

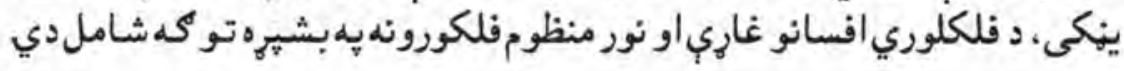

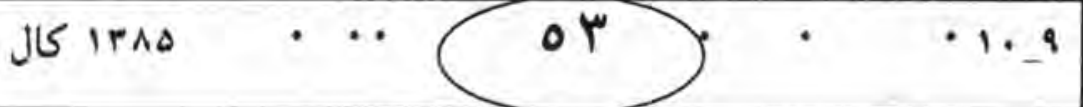




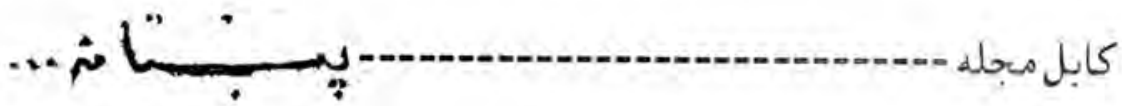

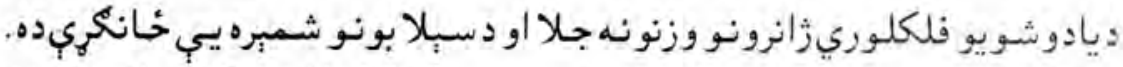

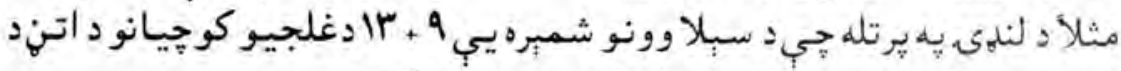

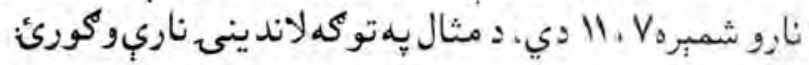

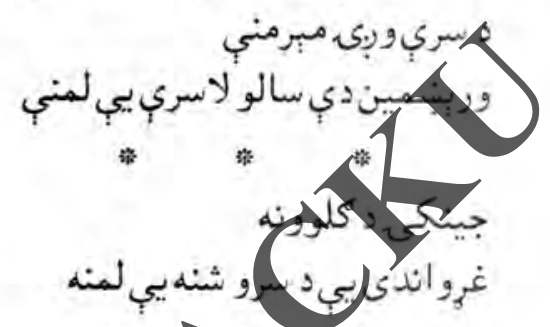

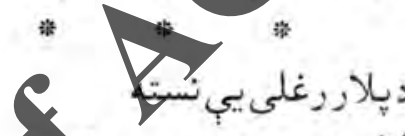
لالى توريوهي برى يبينسينة

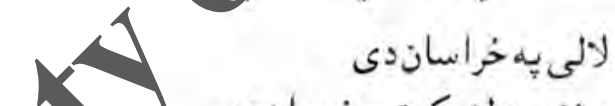

$$
\text { لالى يمه خراساندى }
$$

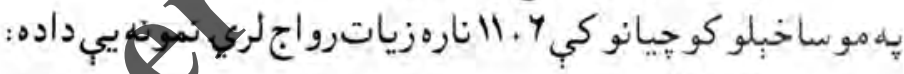

$$
\begin{aligned}
& \text { جتبي نجلى جتي }
\end{aligned}
$$

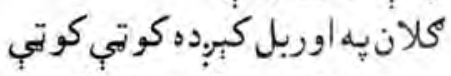

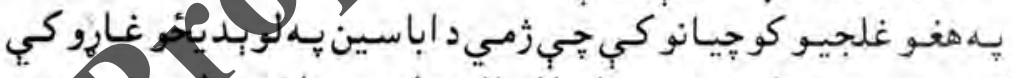

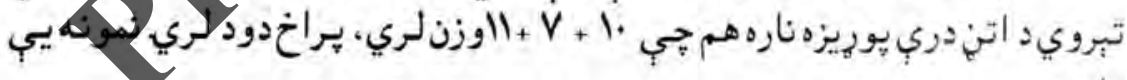

$$
\text { كيودي يه دامان توري كيبرديه }
$$

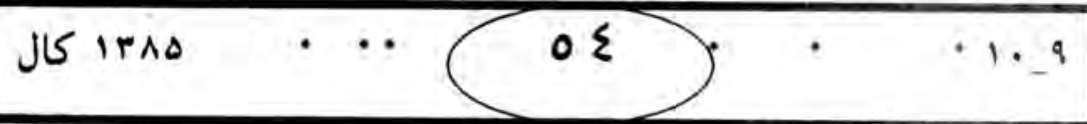




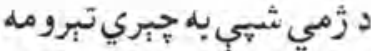

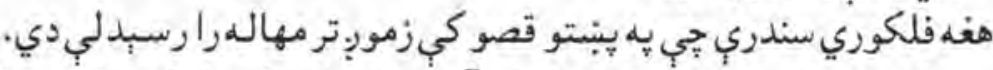

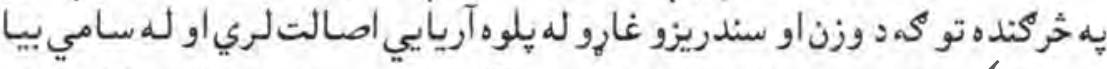

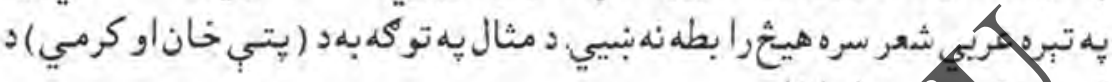

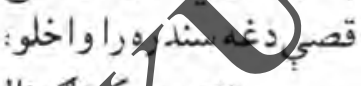

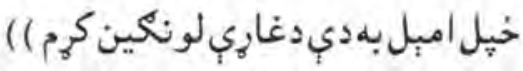

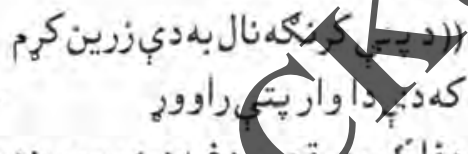

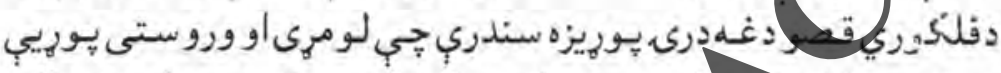

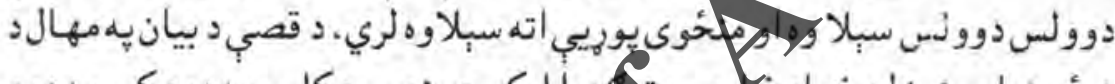

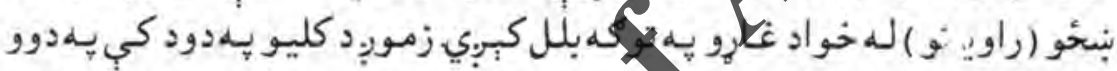

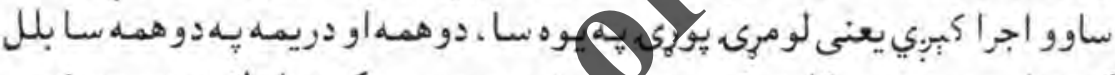

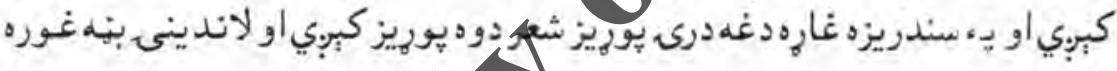
P.

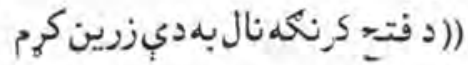

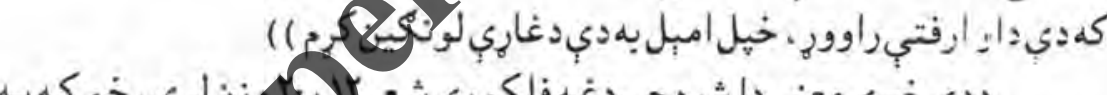

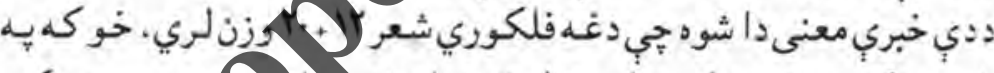

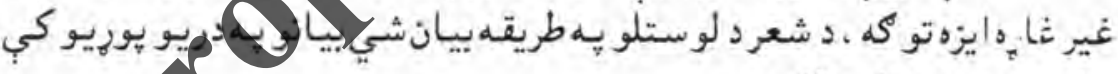

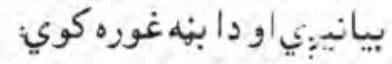

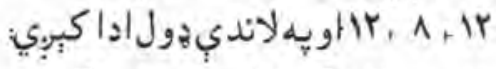

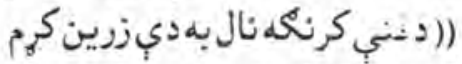

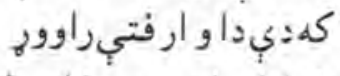

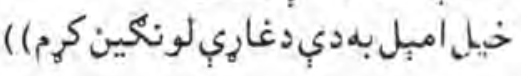




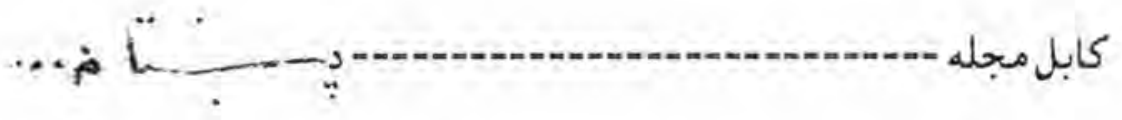

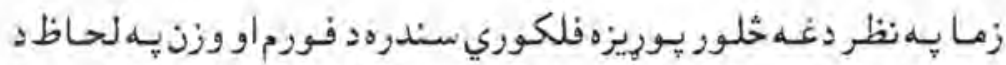

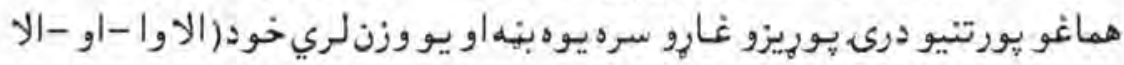

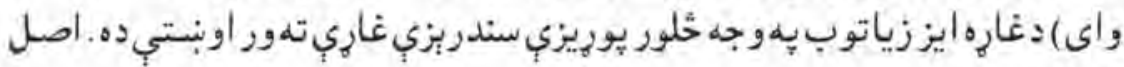

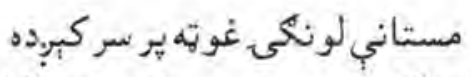

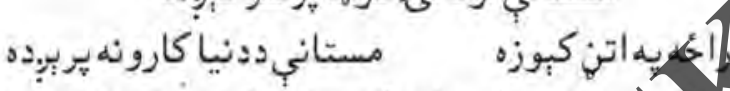

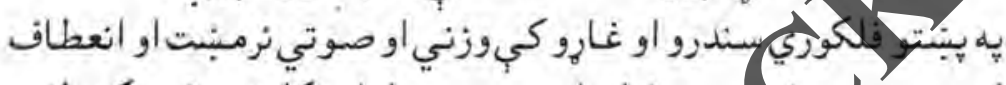

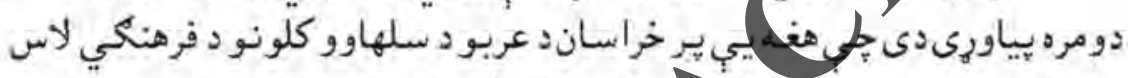

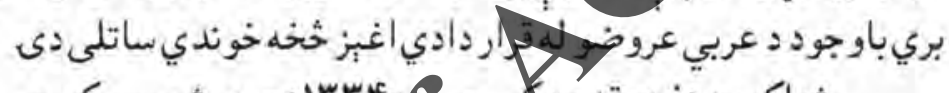

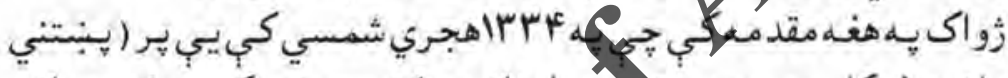

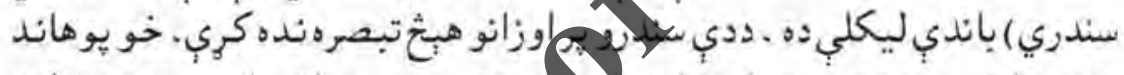

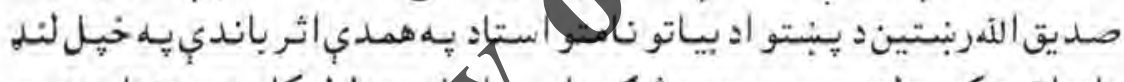

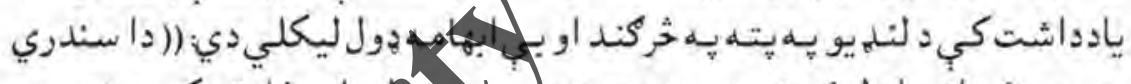

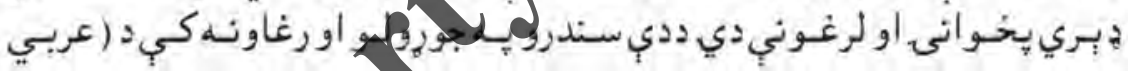

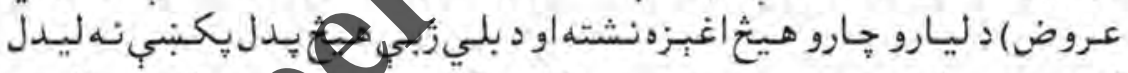

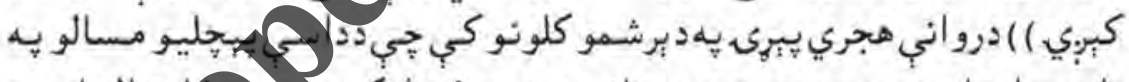

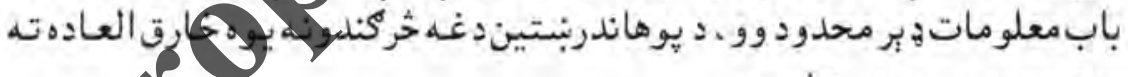

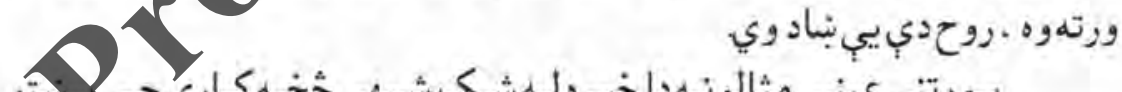

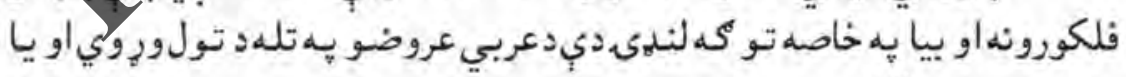

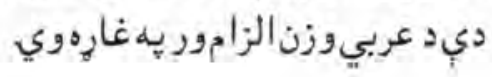




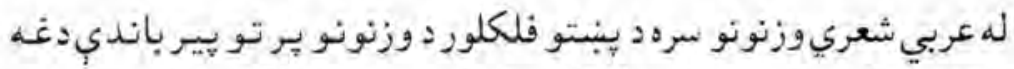

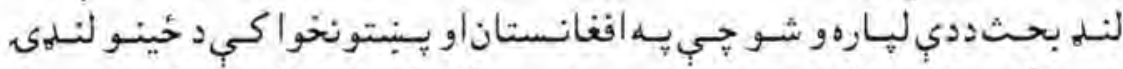

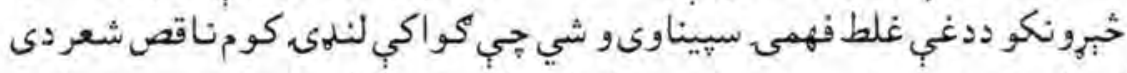

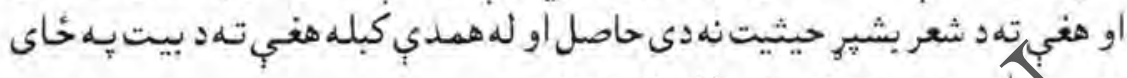

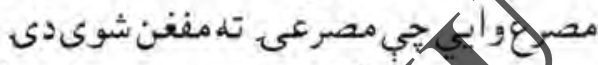

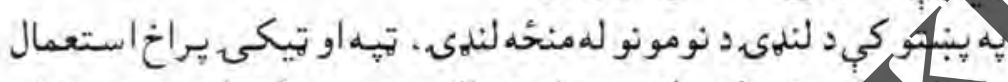

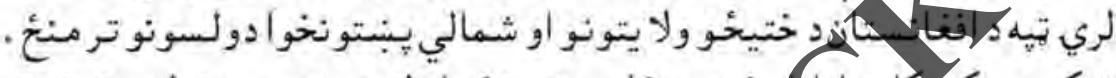

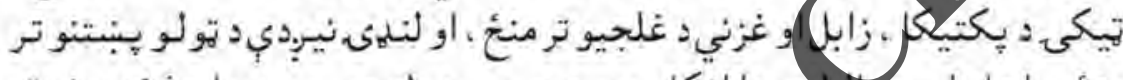

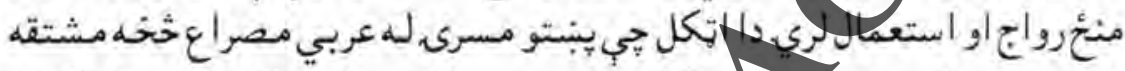

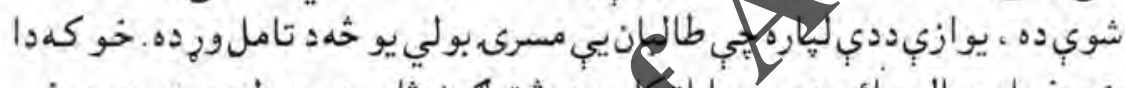

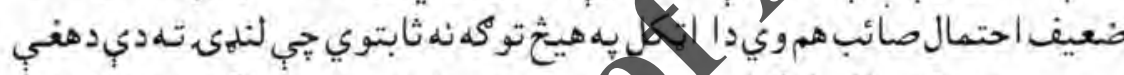

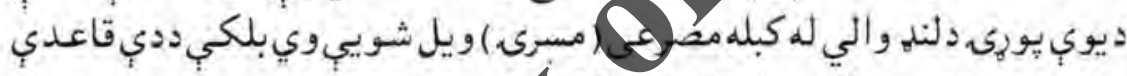

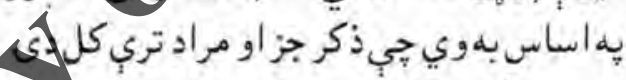

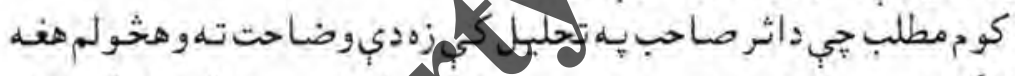

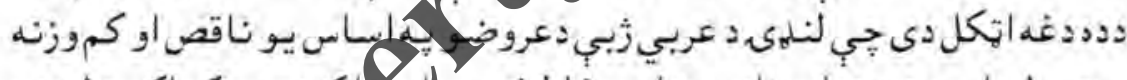

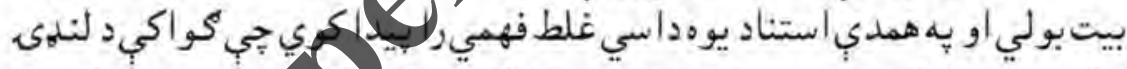

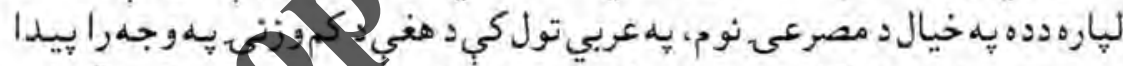

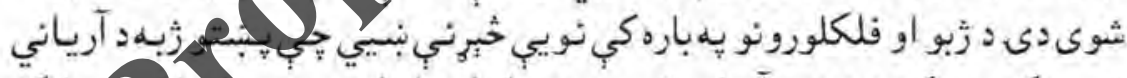

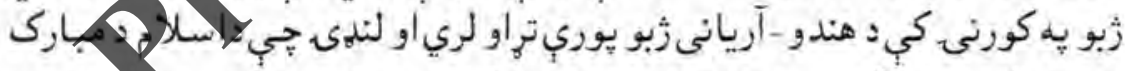

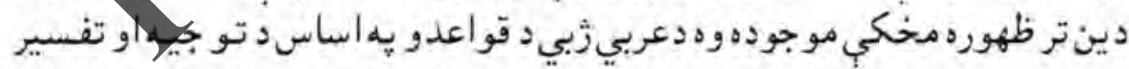

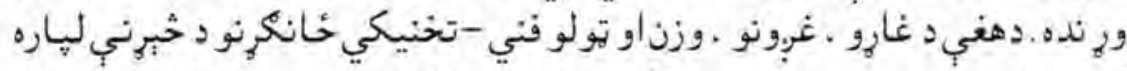

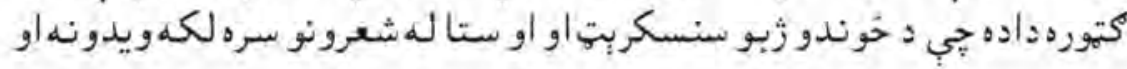




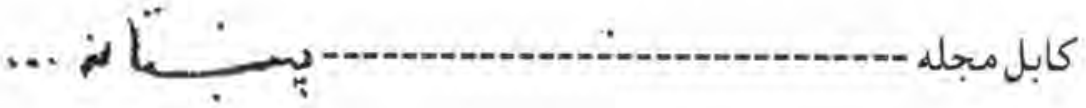

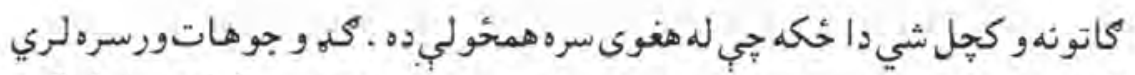

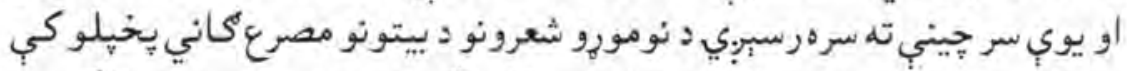

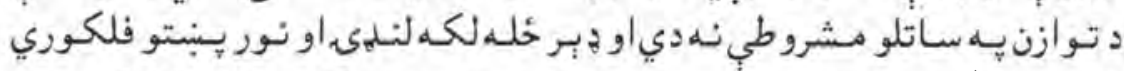

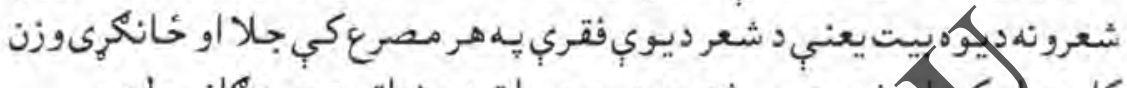

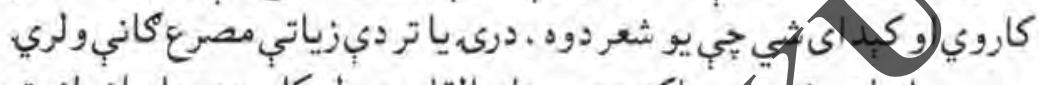

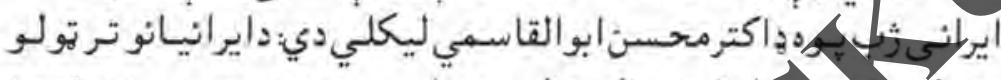

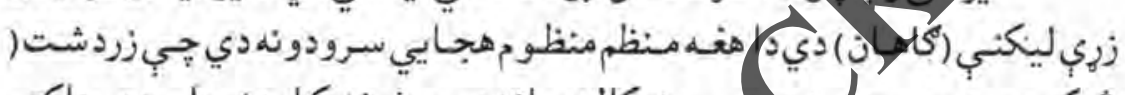

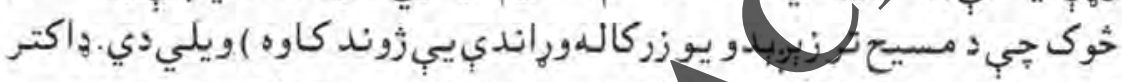

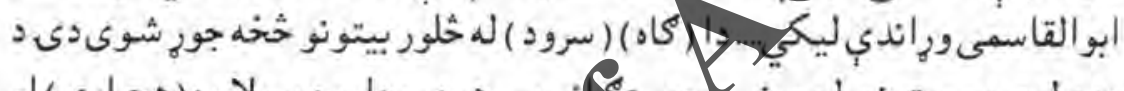

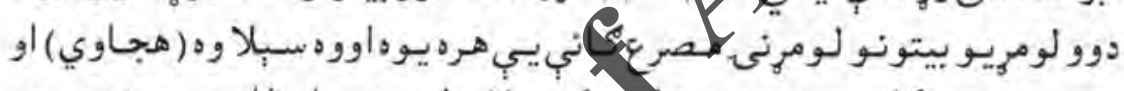

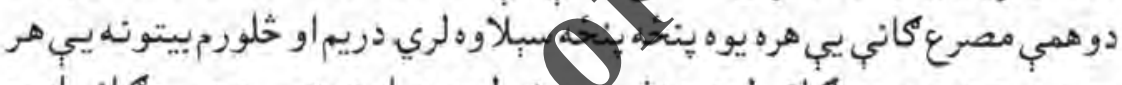

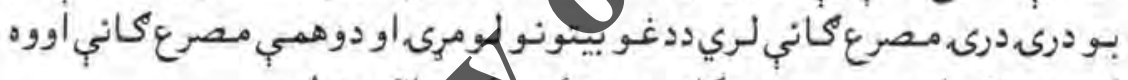

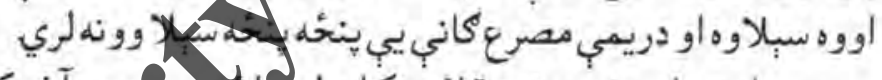

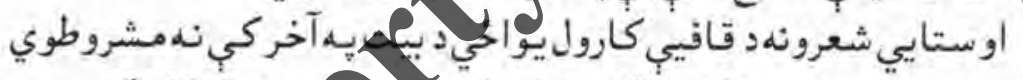

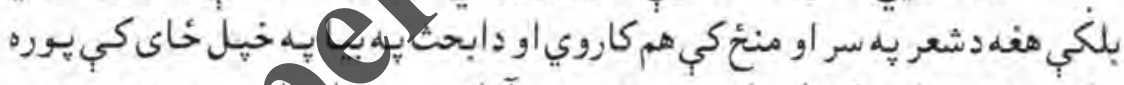

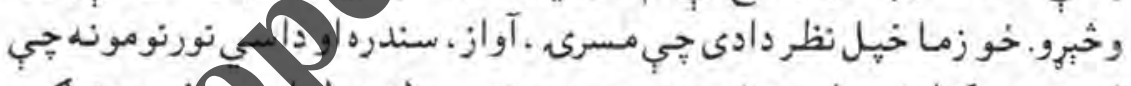

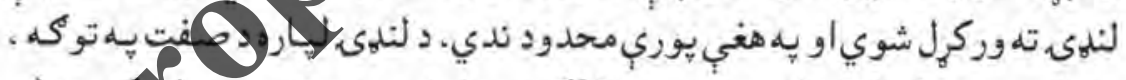

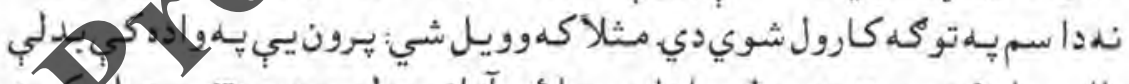

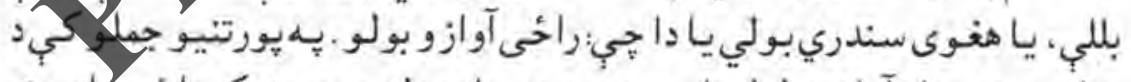

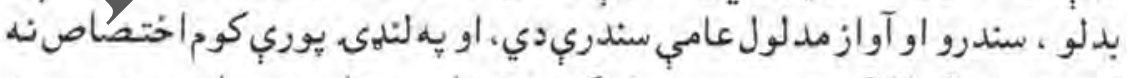

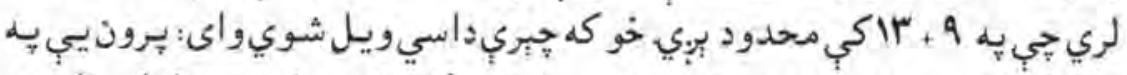

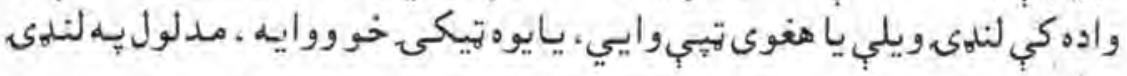

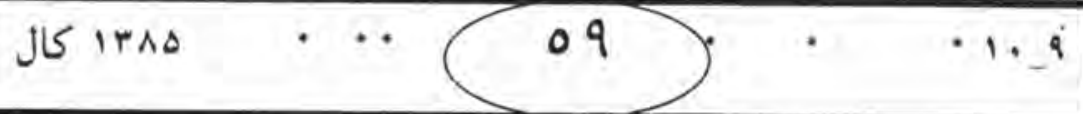


$\cdots ; \dot{\sim}$

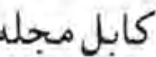

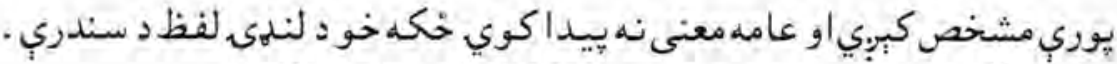

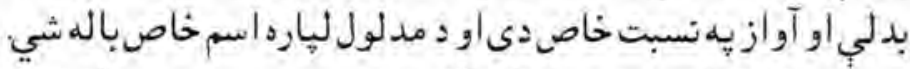

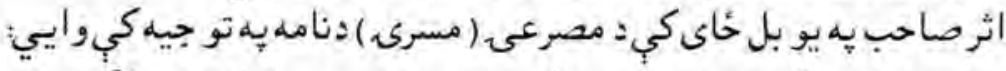

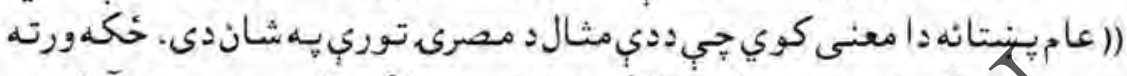

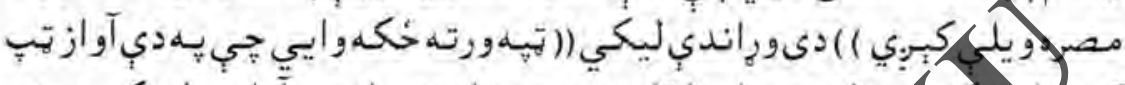

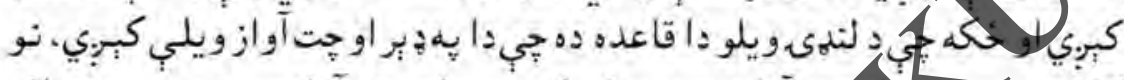

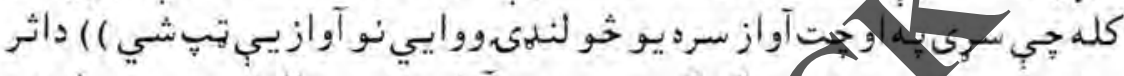

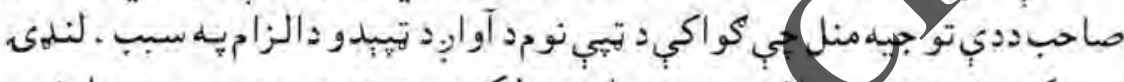

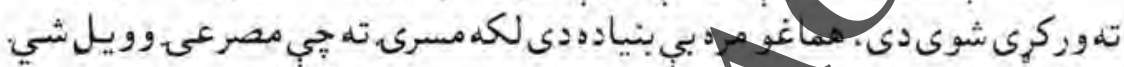

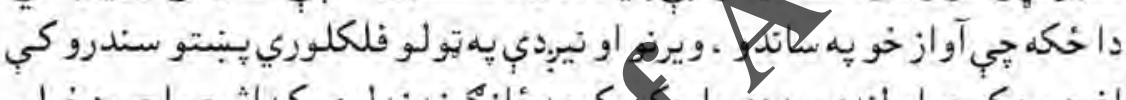

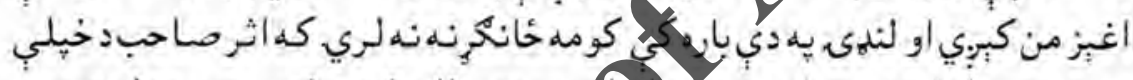

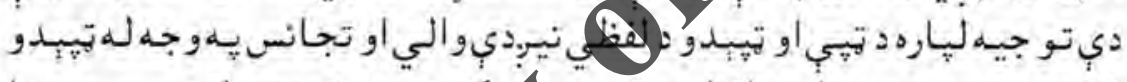

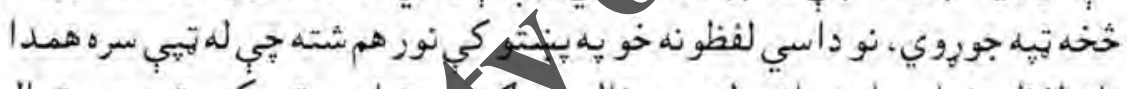

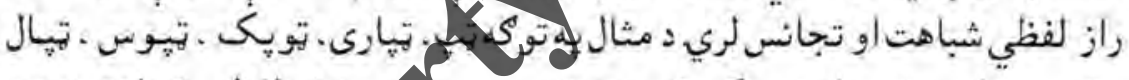

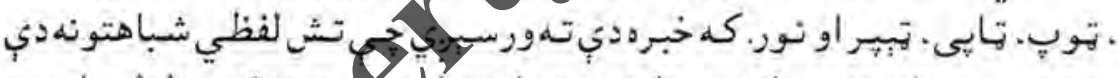

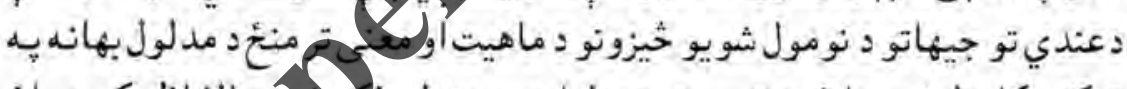

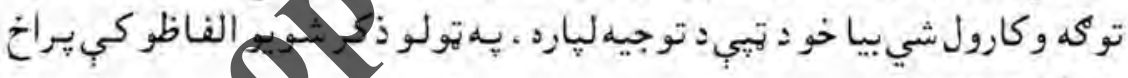

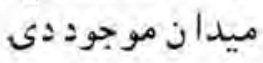

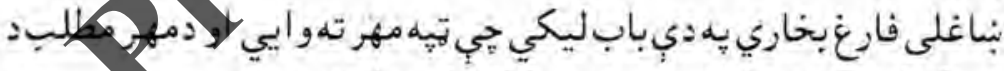

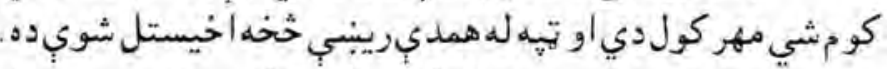

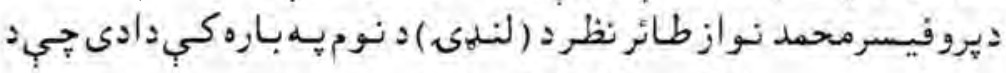

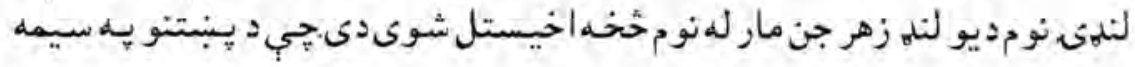

$$
\begin{aligned}
& \text { J IrAd } \\
& 7 . \\
& \text { - } 1.9
\end{aligned}
$$




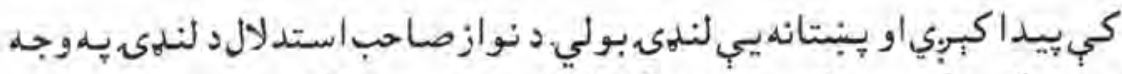

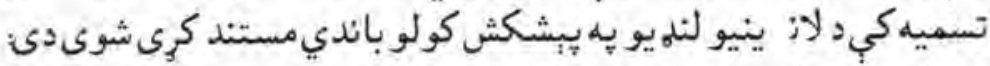

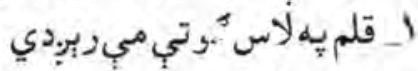

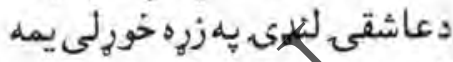

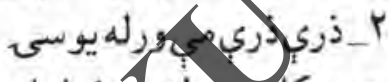
جي كابسيري لنديل خورار ا يخه شينه

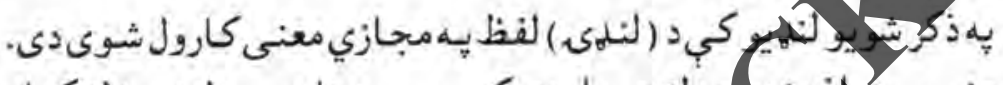

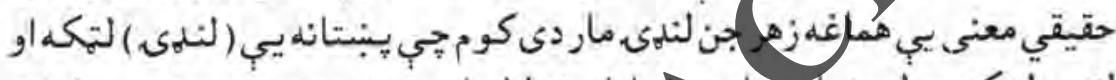

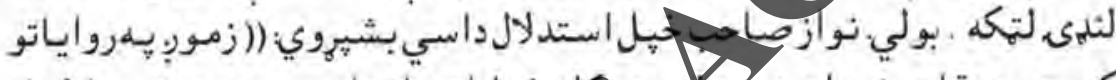

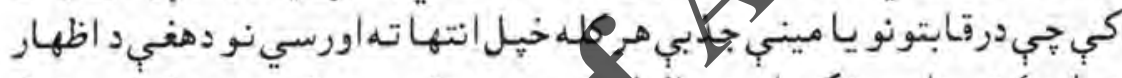

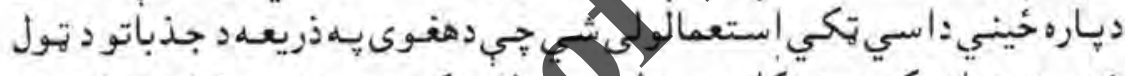

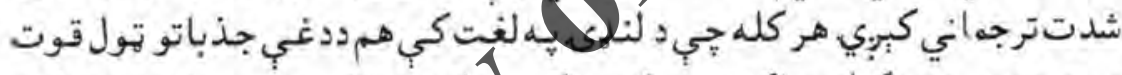

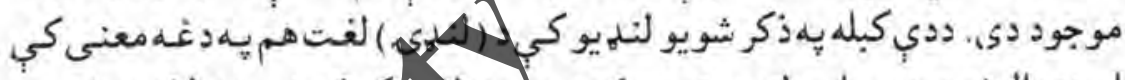

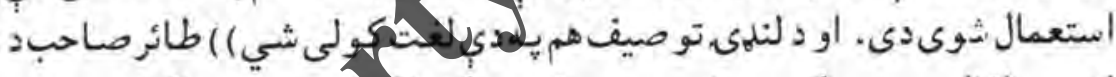

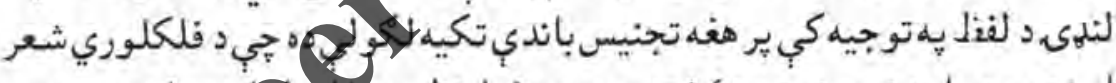

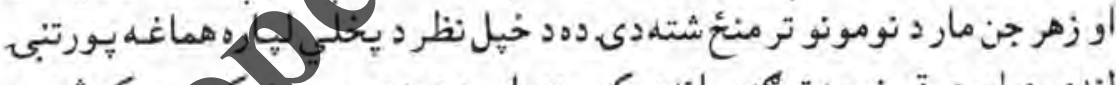

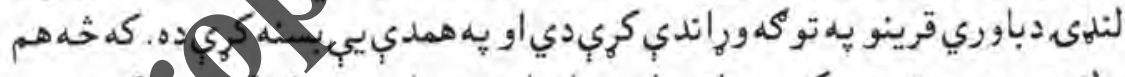

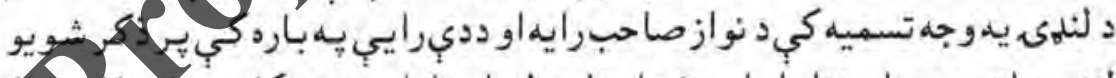

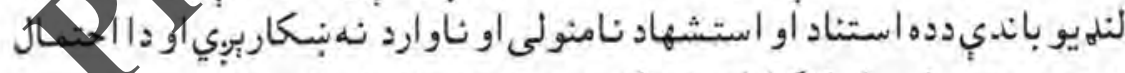

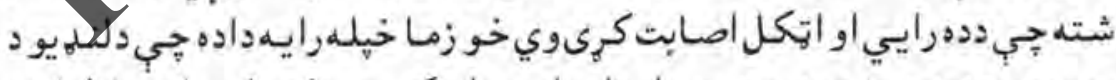

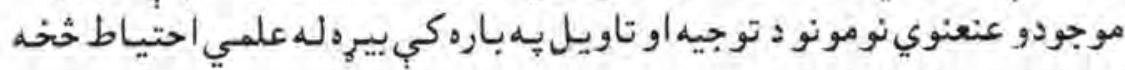

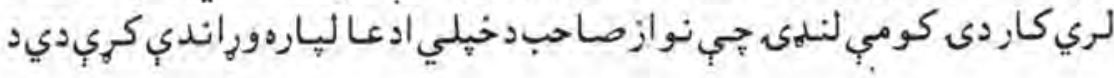

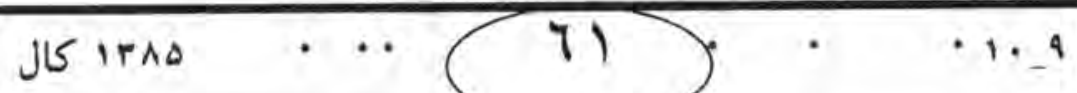

\section{$7)$}




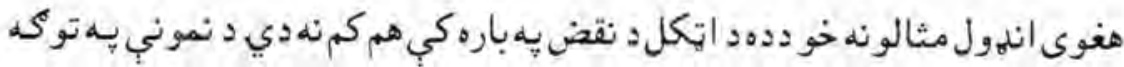

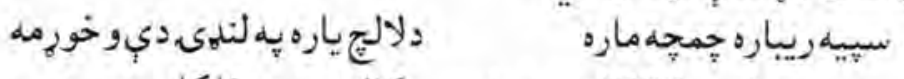

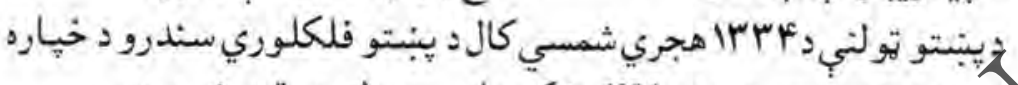

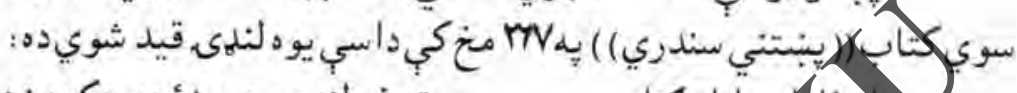

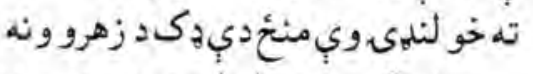

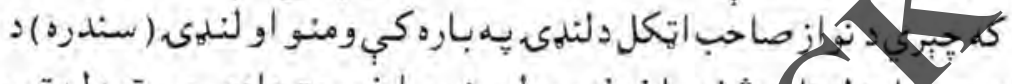

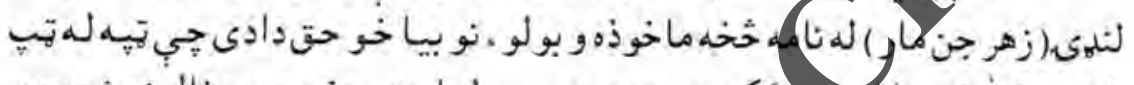

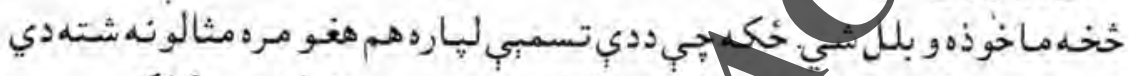

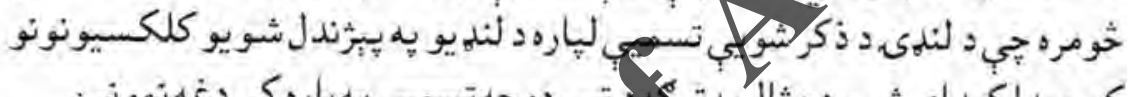

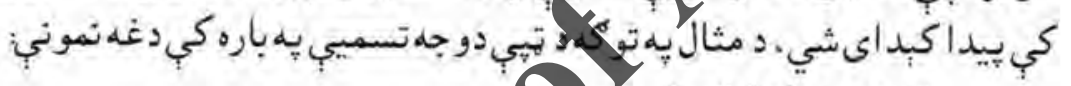

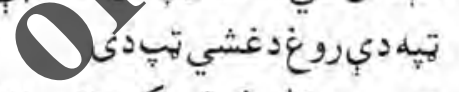

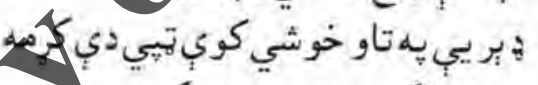

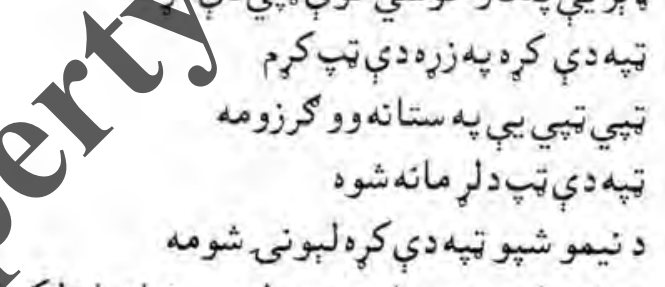

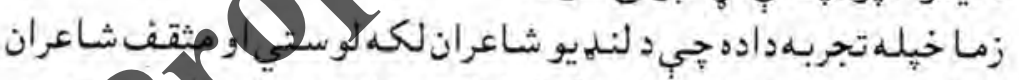

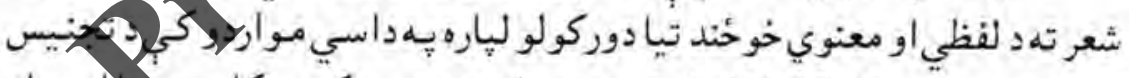

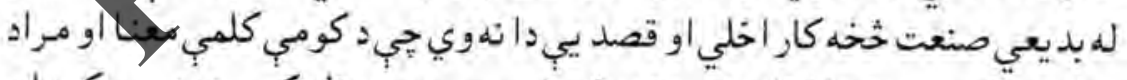

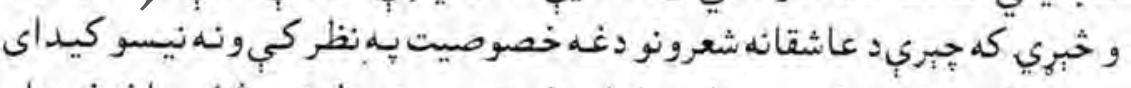

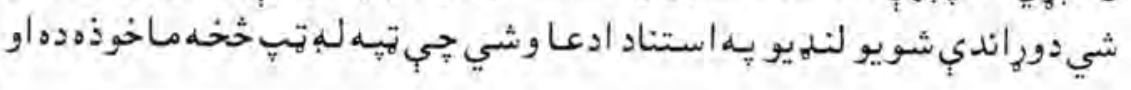

IrAo

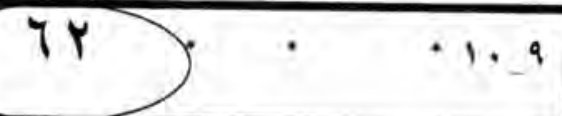




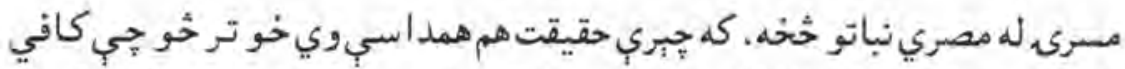

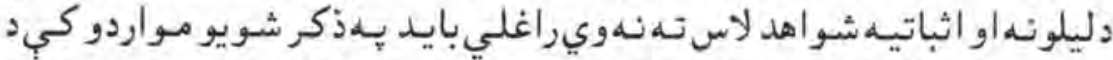

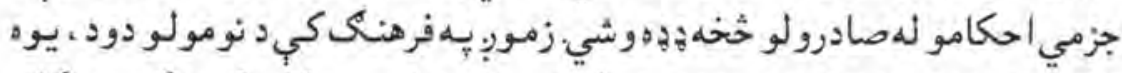

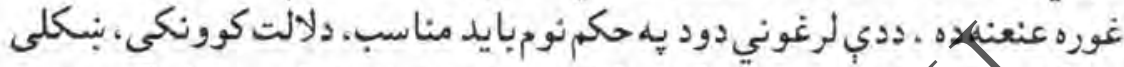

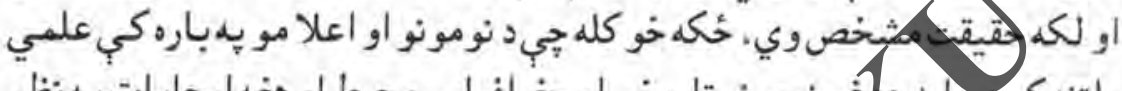

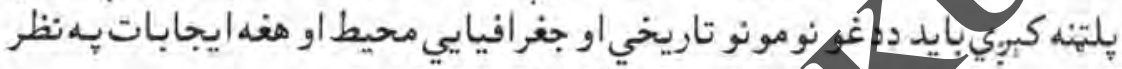

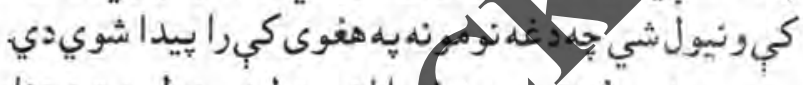

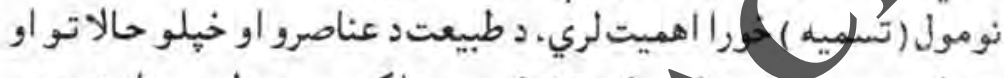

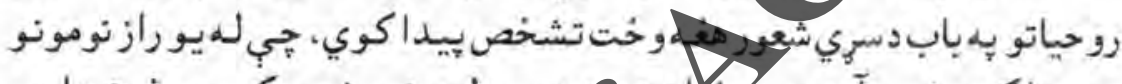

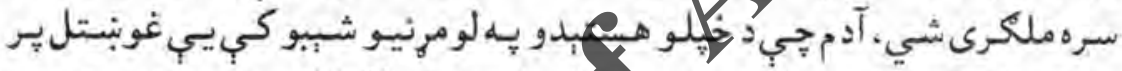

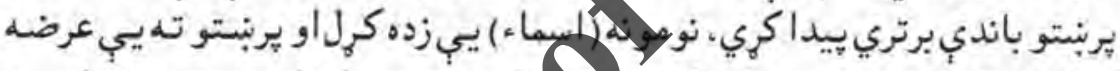

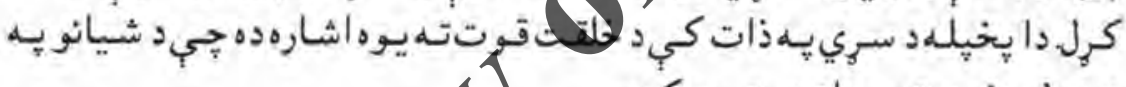

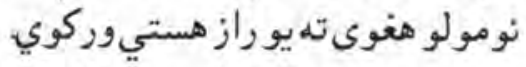

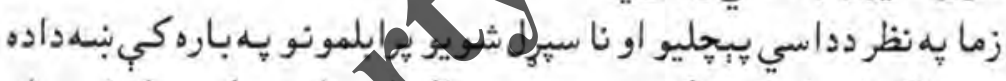

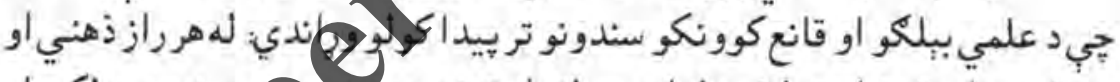

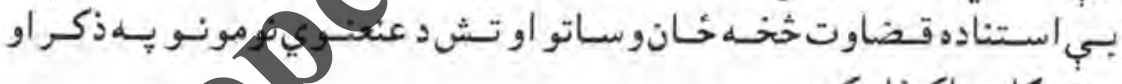
(

8

(نوربيا) بيثرندكلوى اكتفاوكرو.
Jl 1 irso
Tr
$\cdot 1 \cdot 9$ 


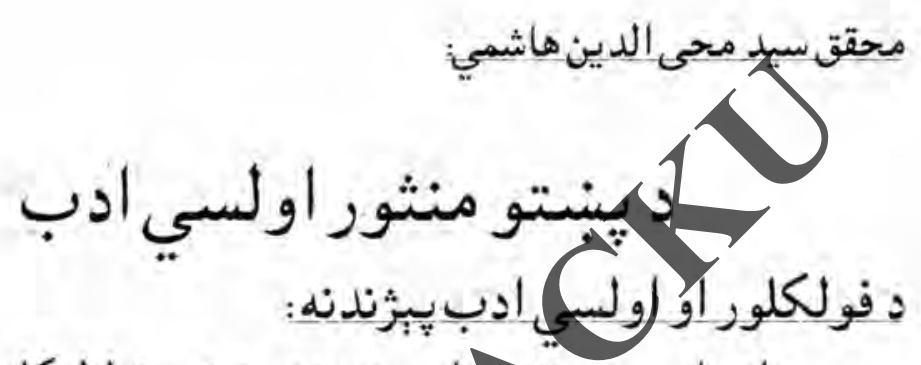

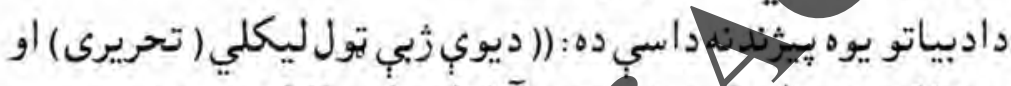

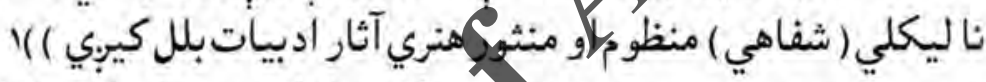

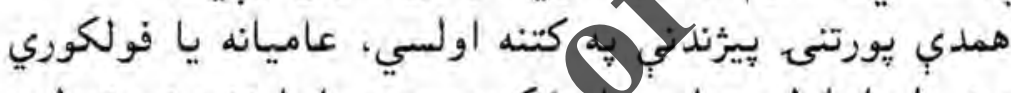

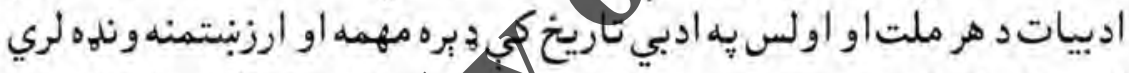

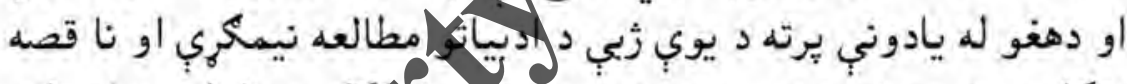

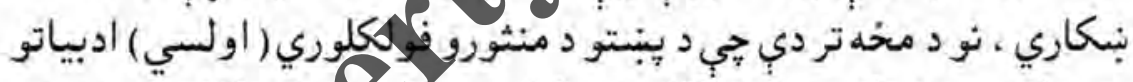

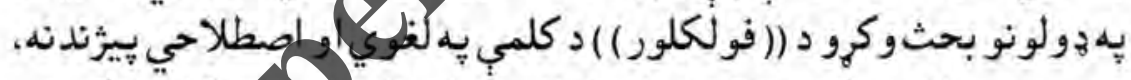

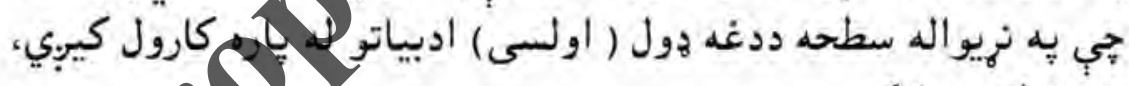

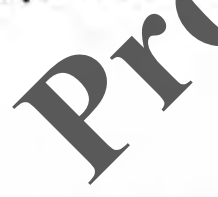

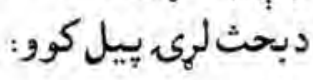

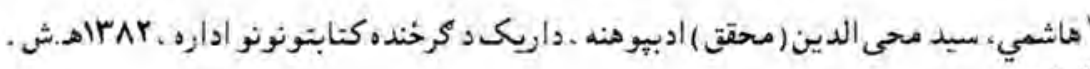
"أمئ. J SIrAd . . . $7 \varepsilon$ -1. 9 


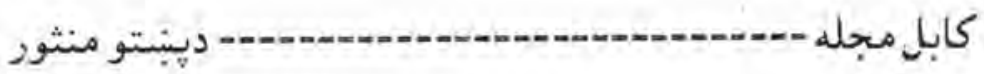

د فولكلور لغوي او اصطلا حي يبزندنه:

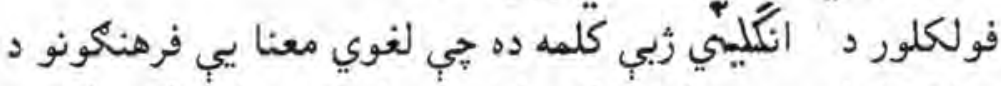

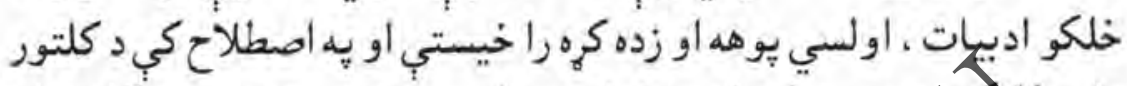

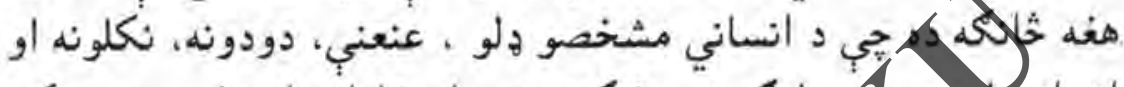

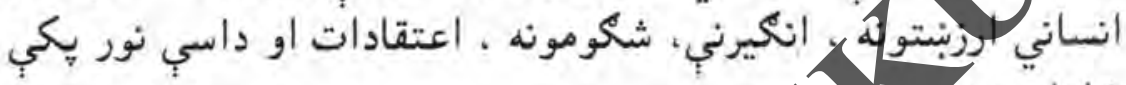

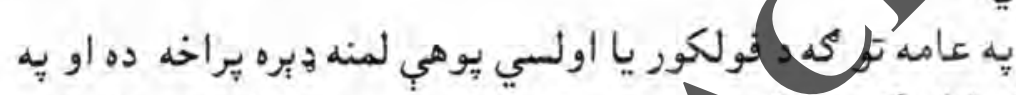

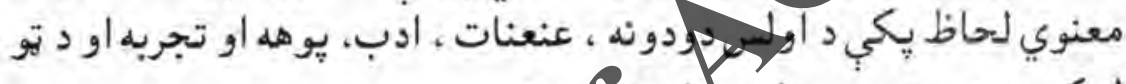

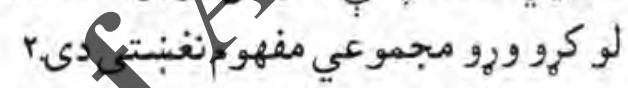

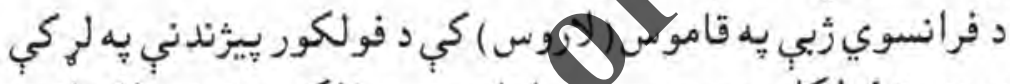

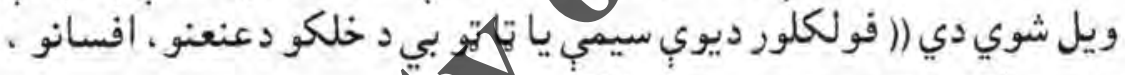

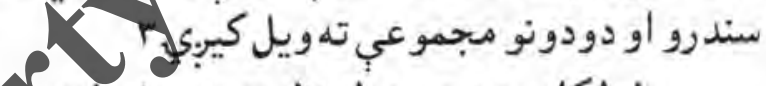

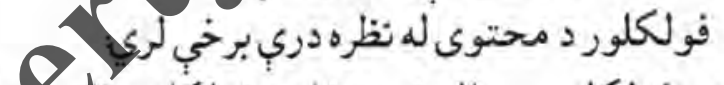

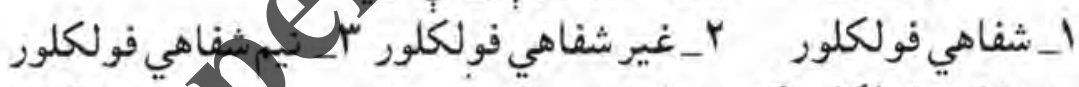

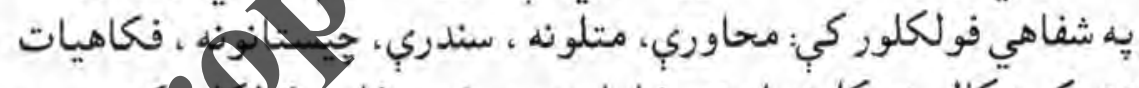

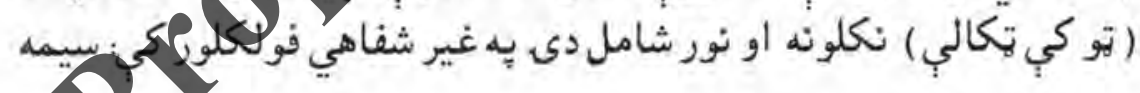

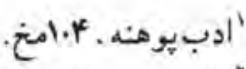

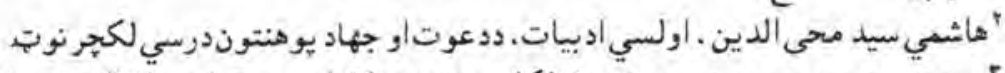

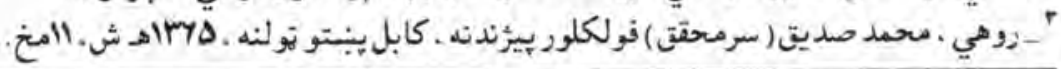

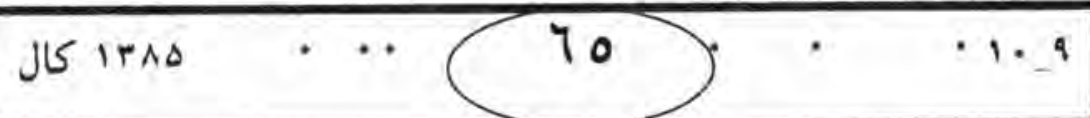




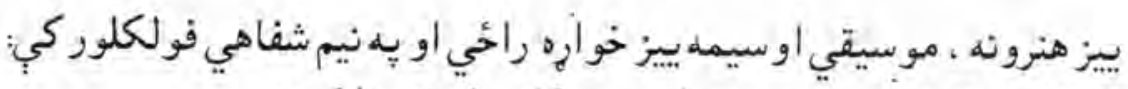

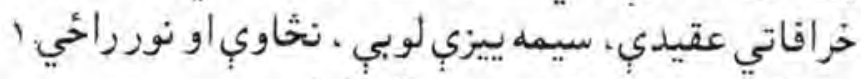

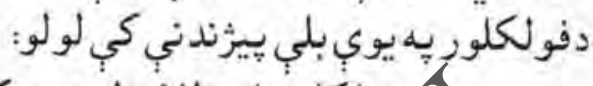

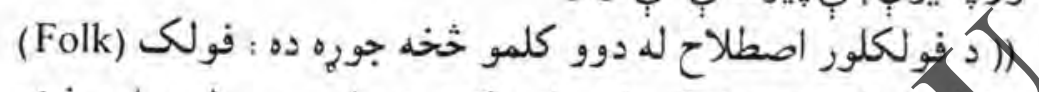

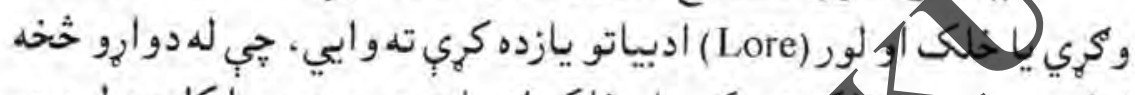

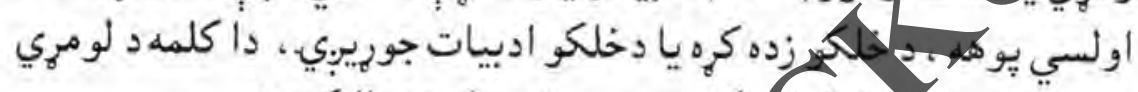

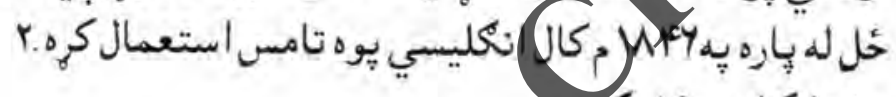

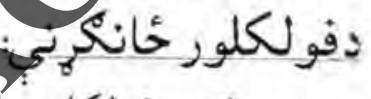

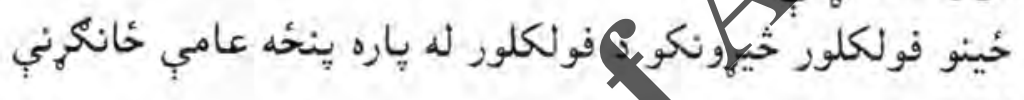

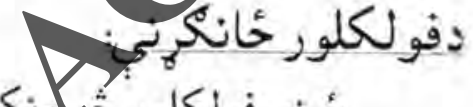

نبودلي دئي

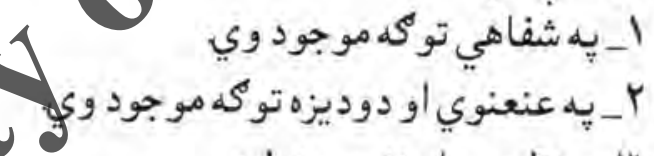

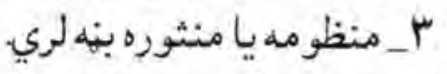

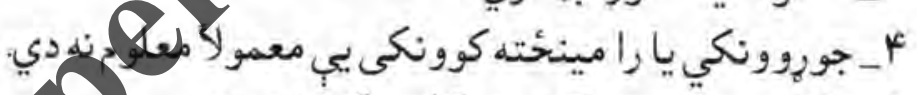

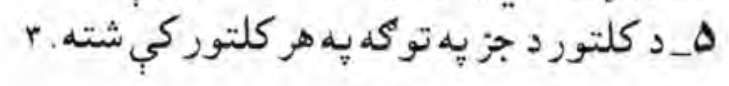

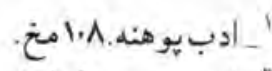

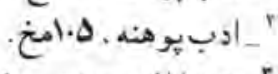

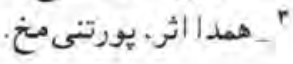

J STAD

77

+ $1 \cdot 9$ 


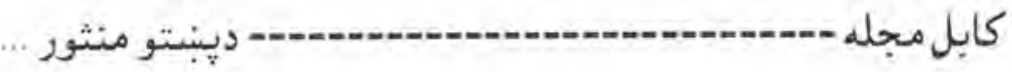

اوس جي مو فولكلور ٍِ لغوي او اصطلاحي لحاظ دروييرًاند د بحث

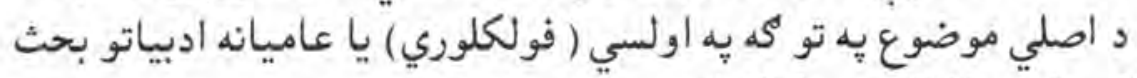

$$
\begin{aligned}
& \text { كوو او ترئانكي سي سر ليك لاندي بي دريبرنو: } \\
& \text { اولسي يا فو لكلوري ادبيات }
\end{aligned}
$$

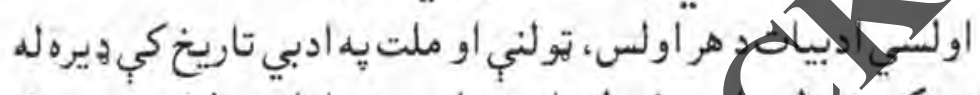

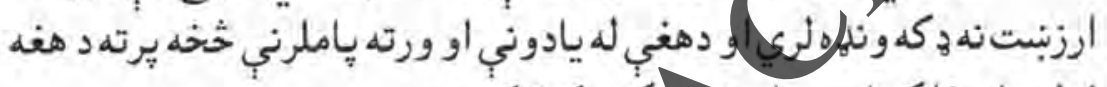

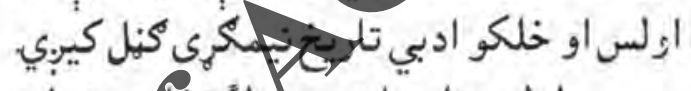

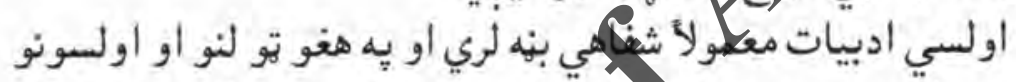

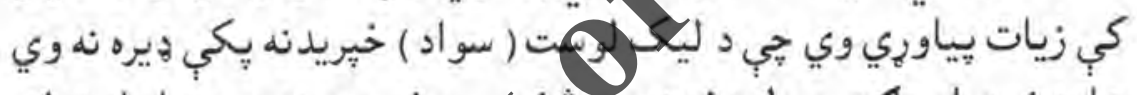

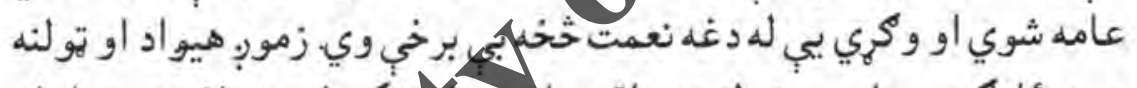

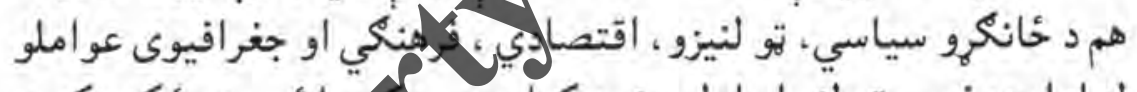

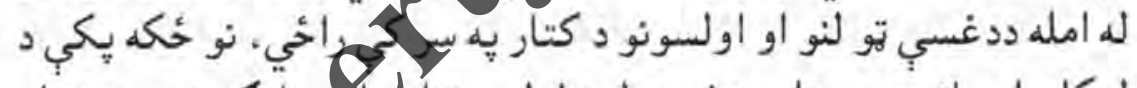

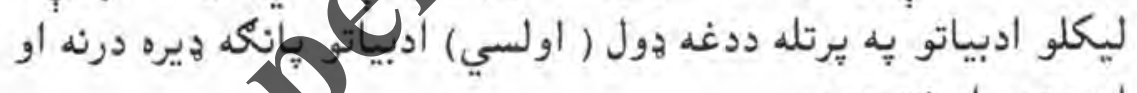

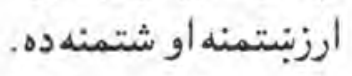

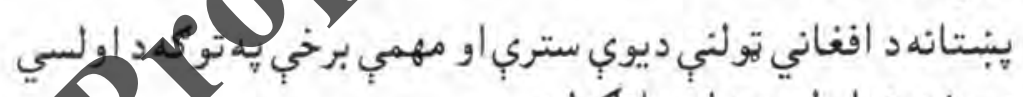

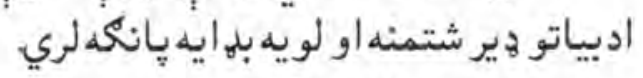

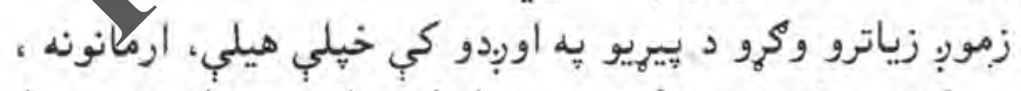

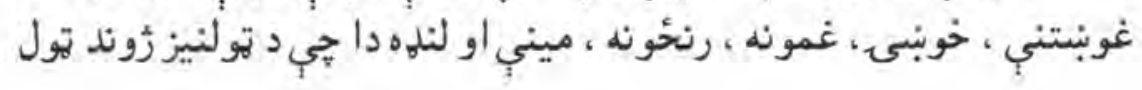
Jiris
$7 \mathrm{~V}$
$+1.9$ 


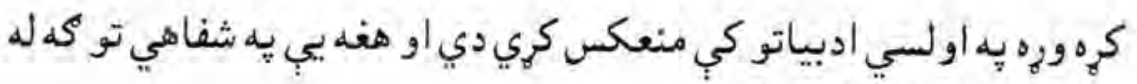

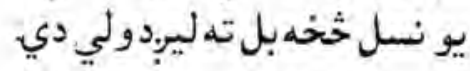

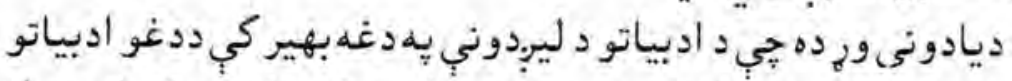

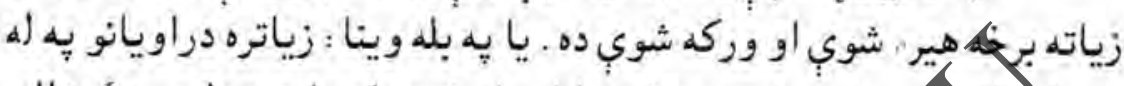

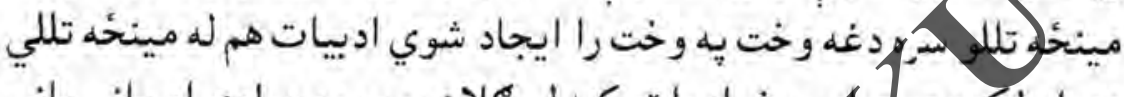

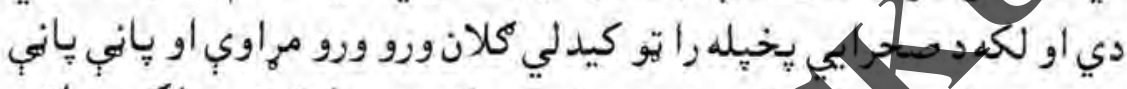

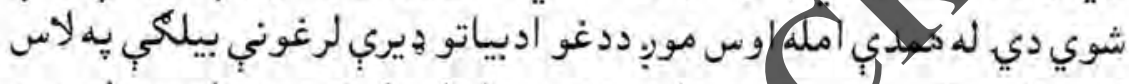

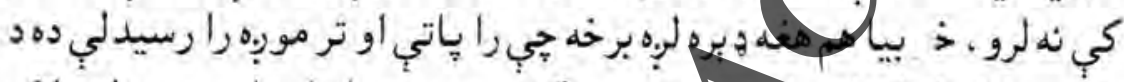

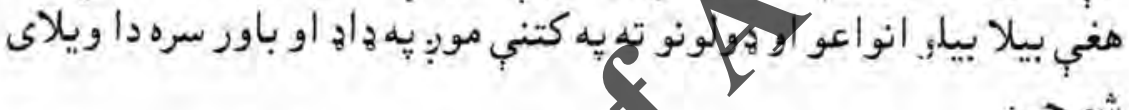
زمور, عامو اولسي وكئوكهيك لوست نشو كولى او د سو اد له

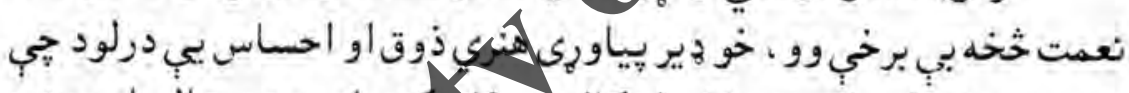

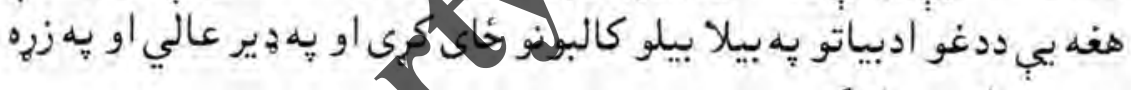

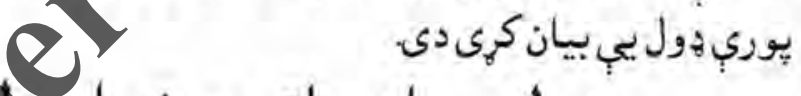
دولسي ادبياتو و بش او هيميلمي

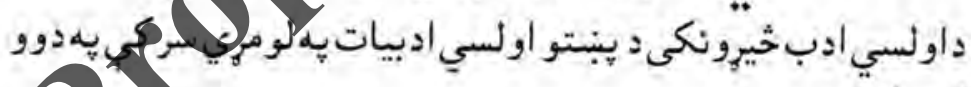

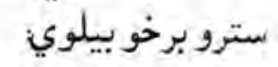

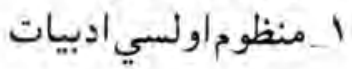

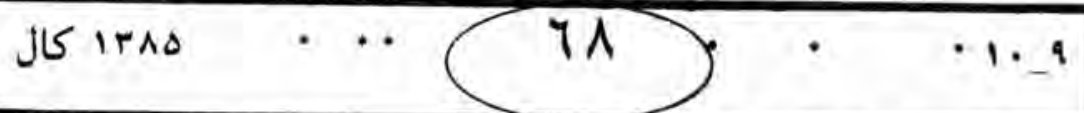




$$
\text { r_منثور اولسي_ادبياتِا }
$$

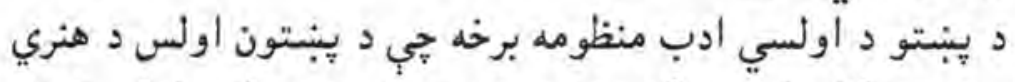

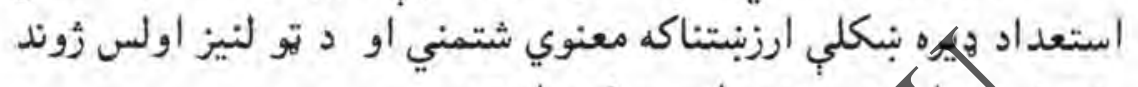

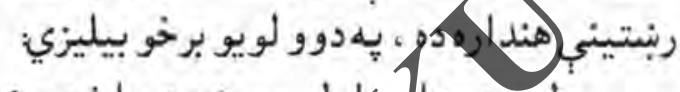

$$
\begin{aligned}
& \text { لو لومي عالمجل لو لسي سندري يا شعرونه }
\end{aligned}
$$

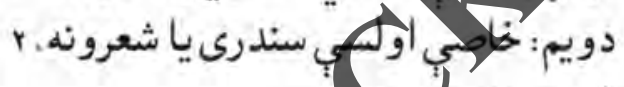

$$
\begin{aligned}
& \text { عام اولسي شعركنه. }
\end{aligned}
$$

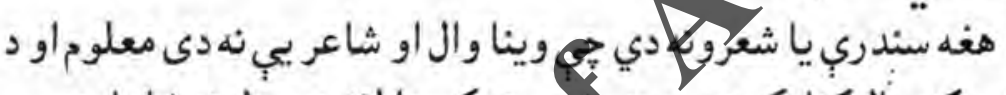

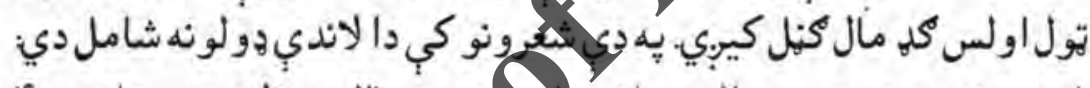

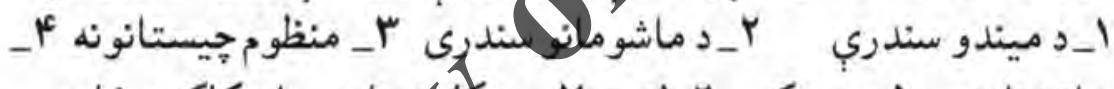

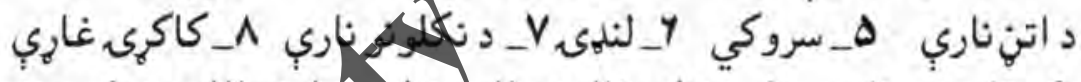

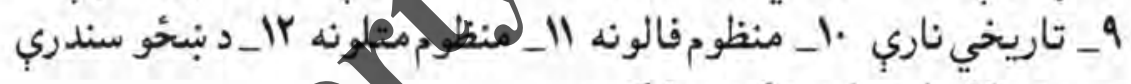

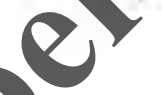

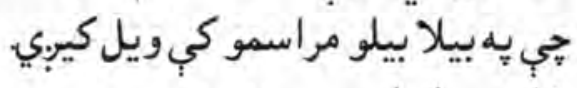
خاصبي اولسي سندرين

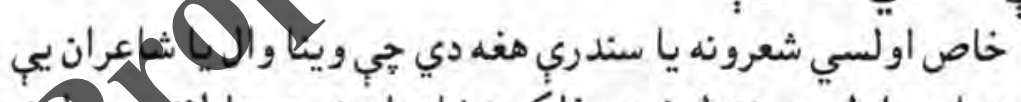

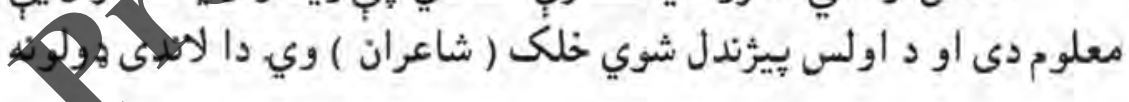

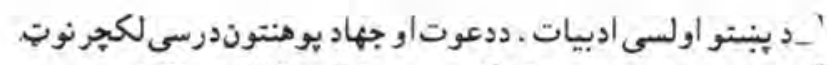

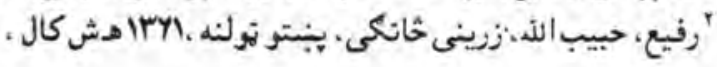
IrAo
79
1. 9 
ديبنتو منثور

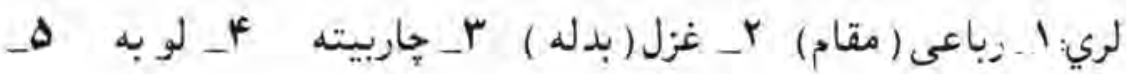

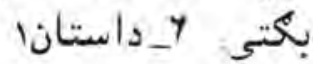

\section{: ينبـتو منثور اولسي (فولكلوري) انبيات}

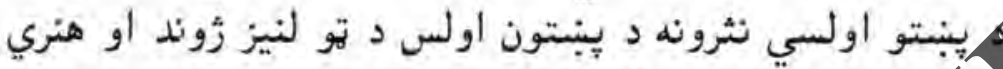

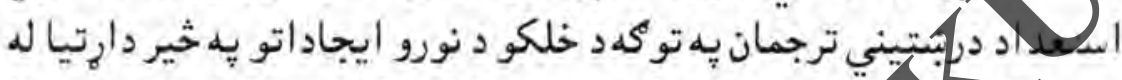

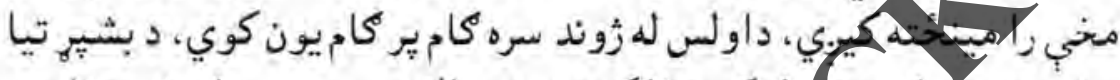

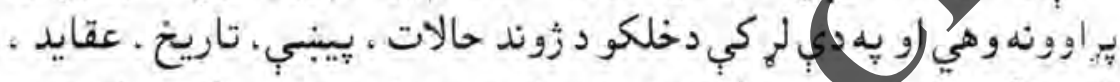

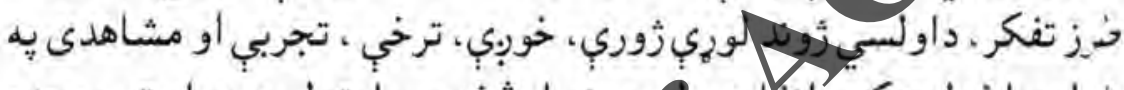

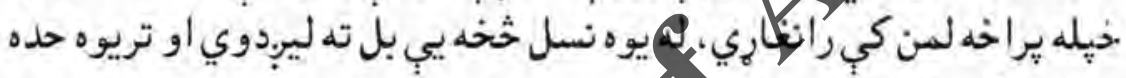

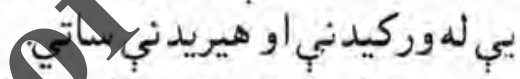

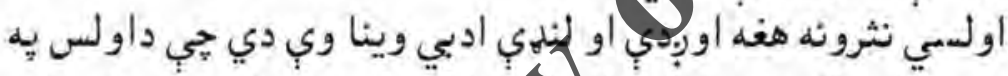

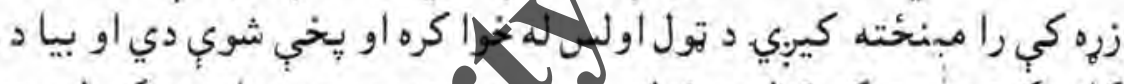

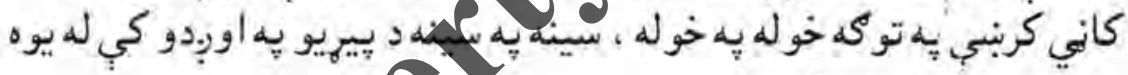

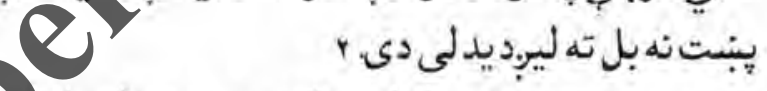

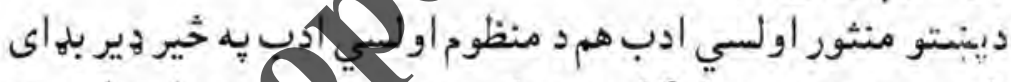

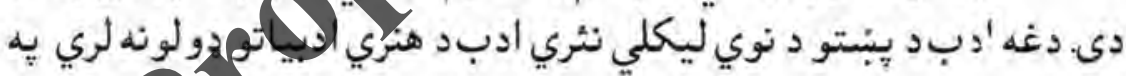

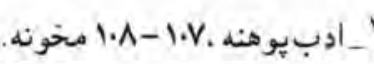

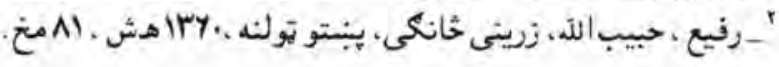

J STAD

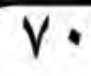

- 1, 9 


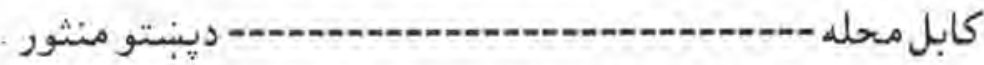

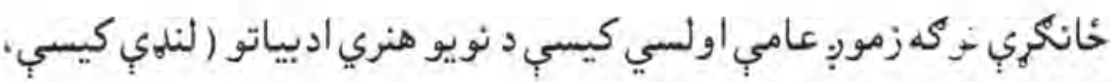
ناول، نير مي او نورو ) تهورتهبني لرئي

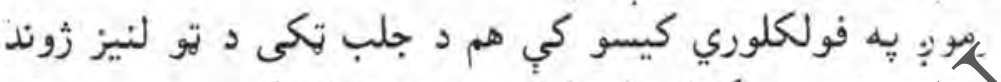

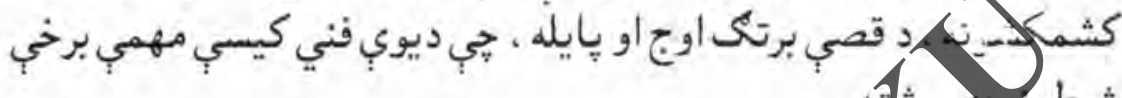

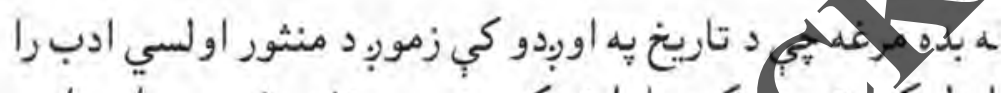

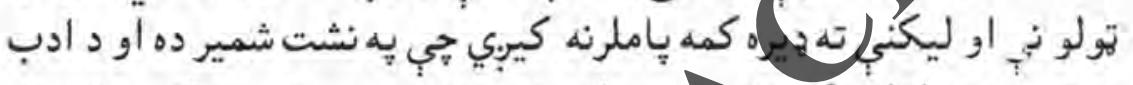

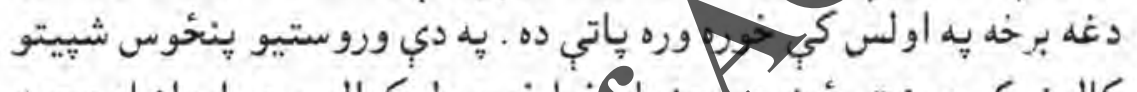

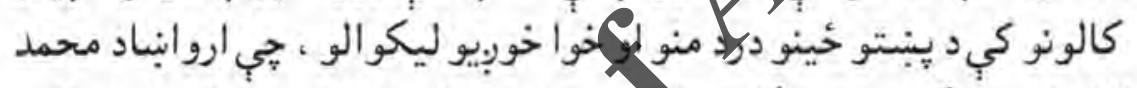

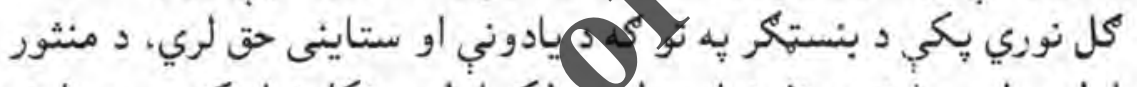

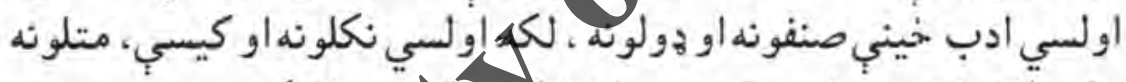

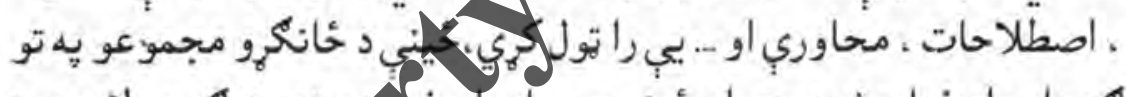

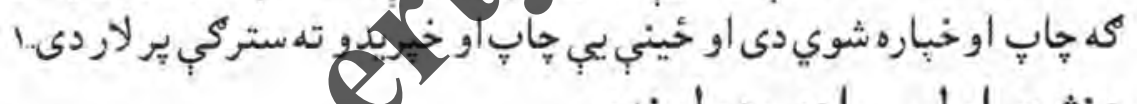

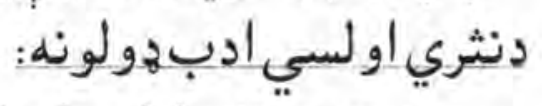

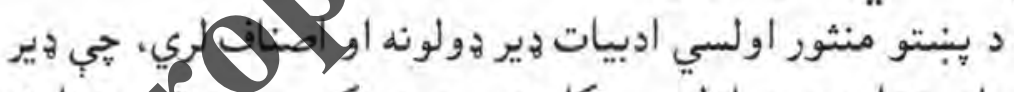

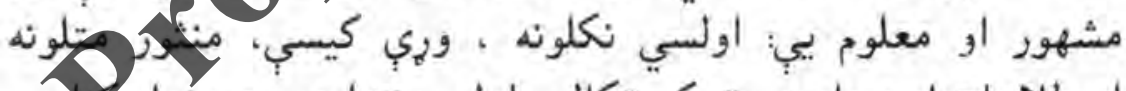

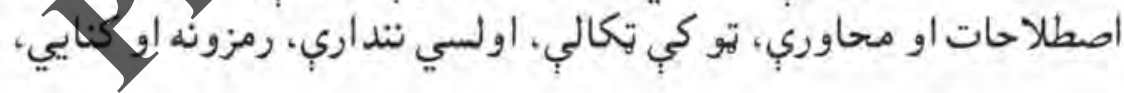

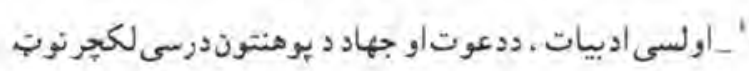

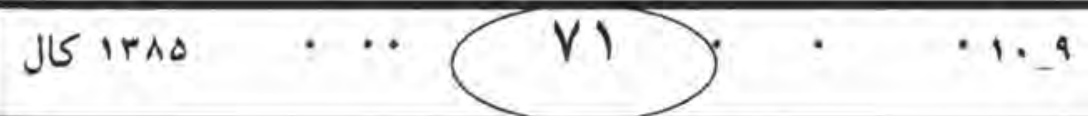




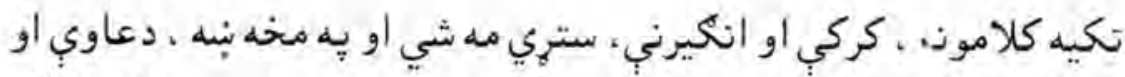

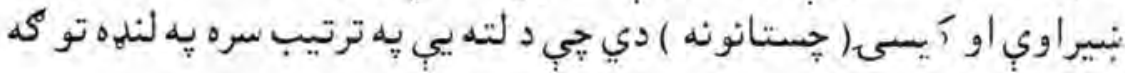

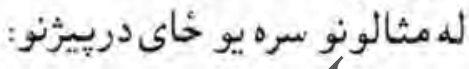

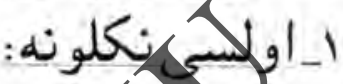

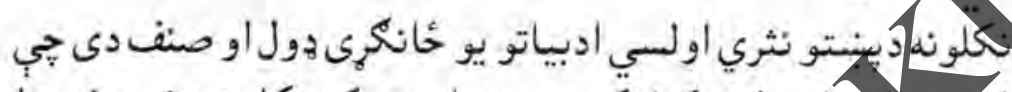

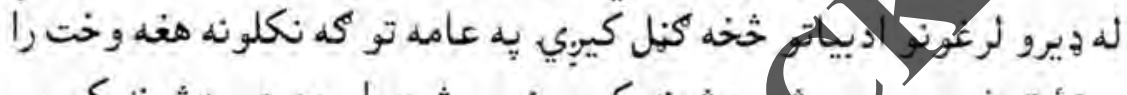

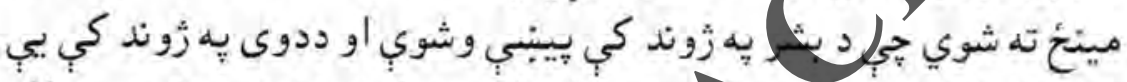

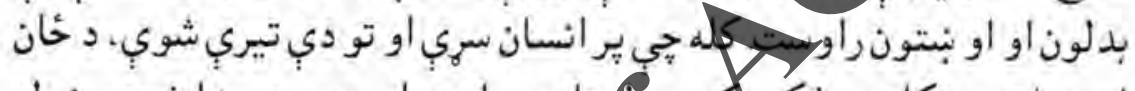

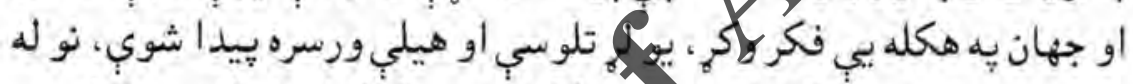

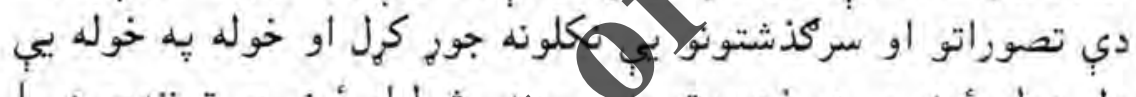

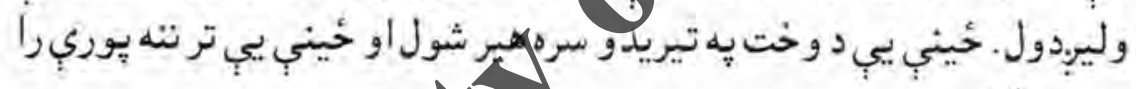
ورسيدل

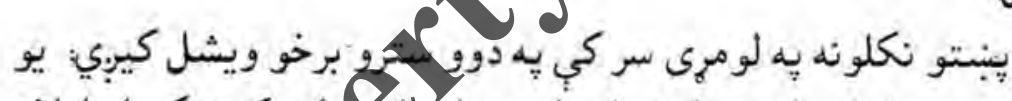

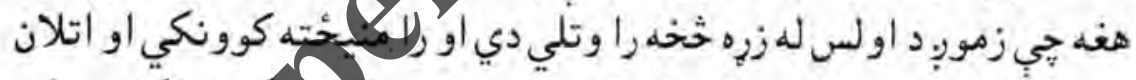

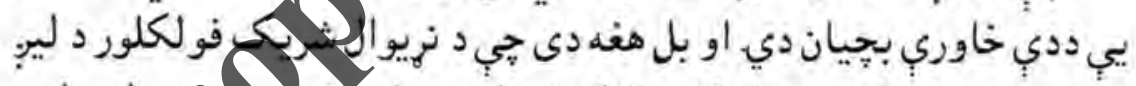

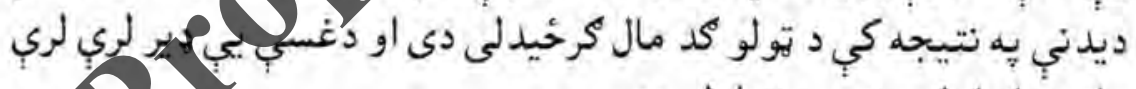

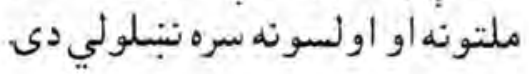

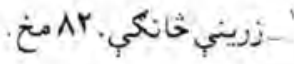

JL irso

VY

- 1. 4 


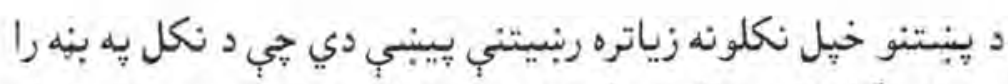

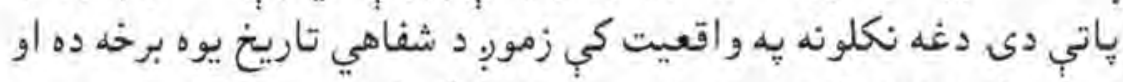

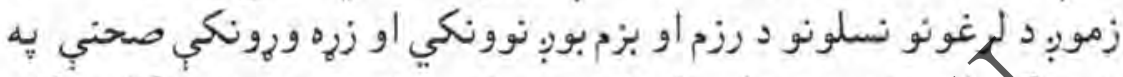

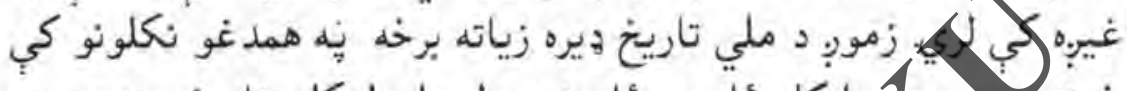

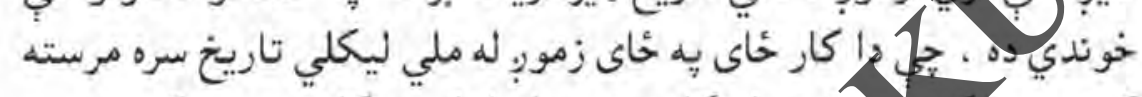

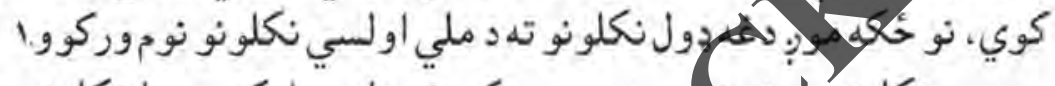

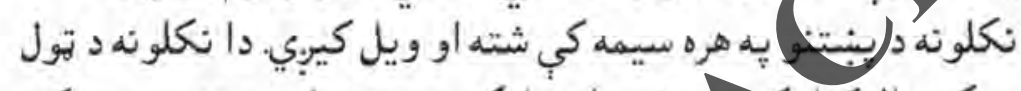

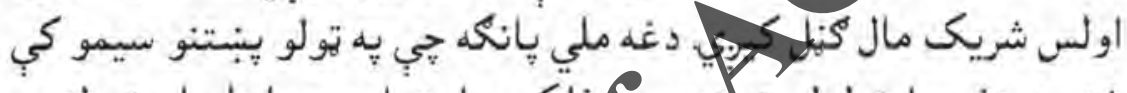

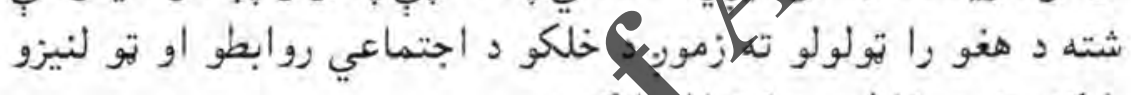

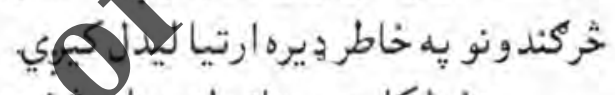

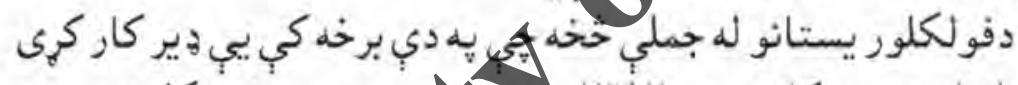

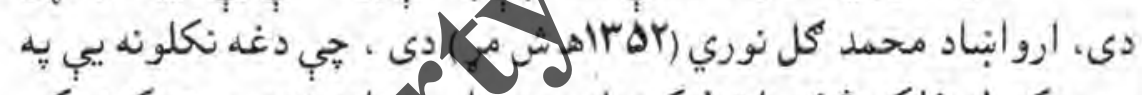

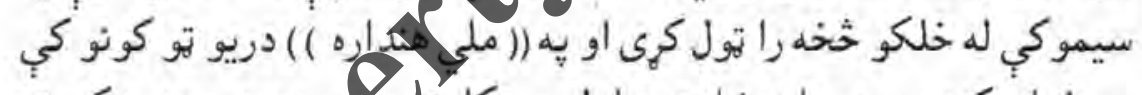

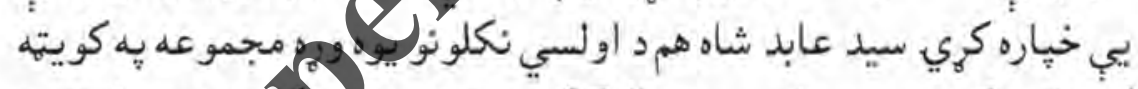

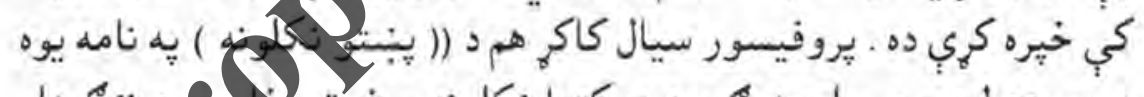

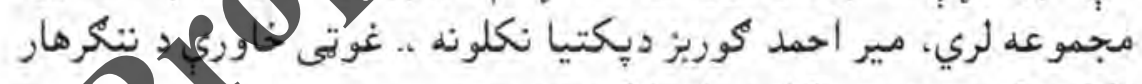

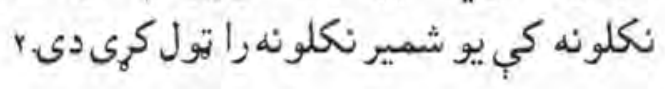

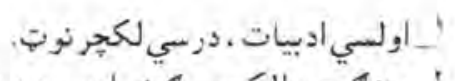

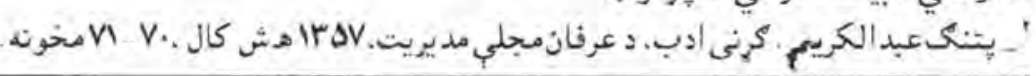

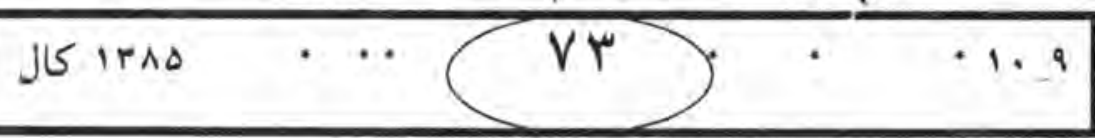




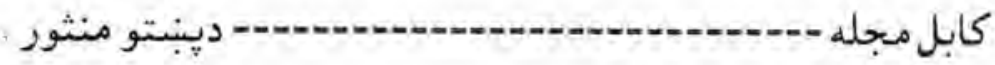

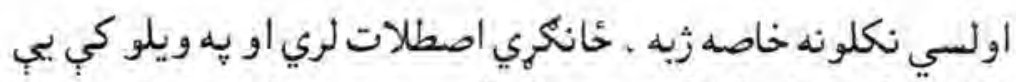

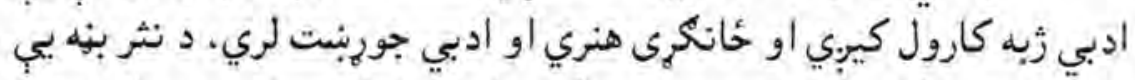

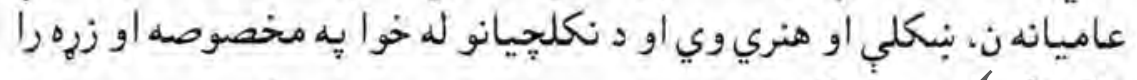

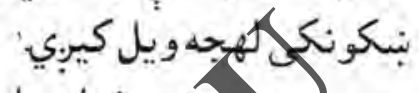

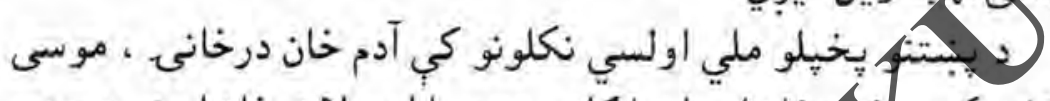

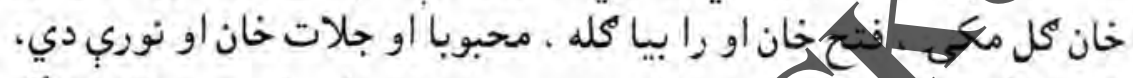

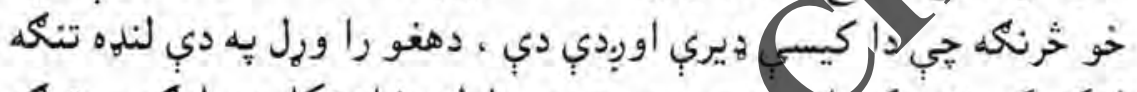

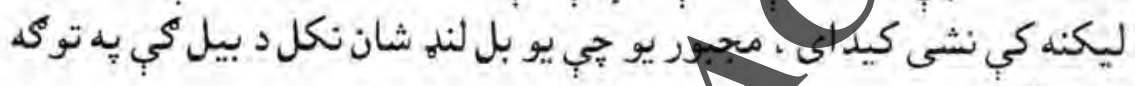

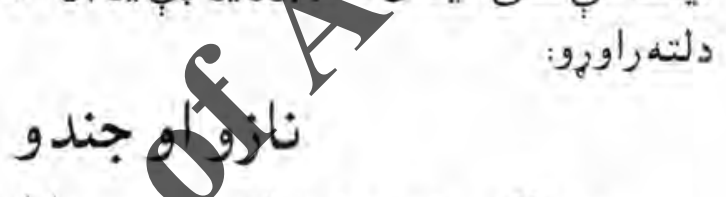

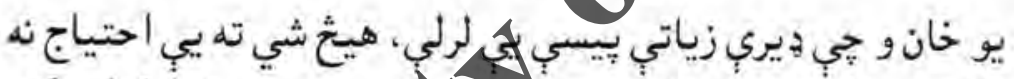

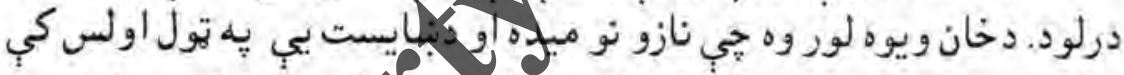

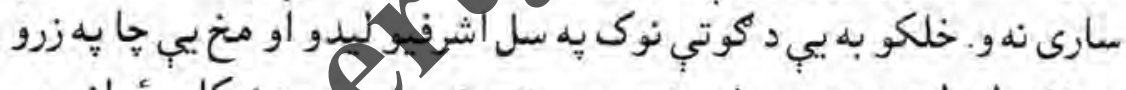

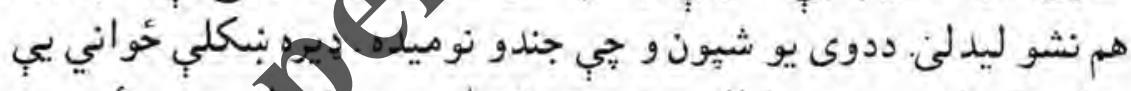

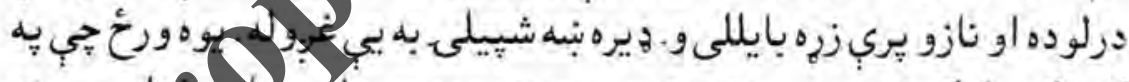

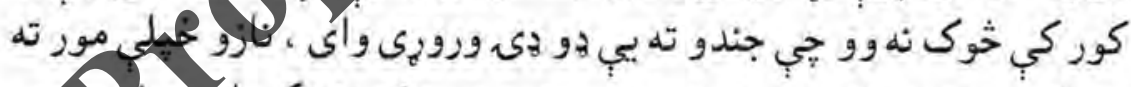

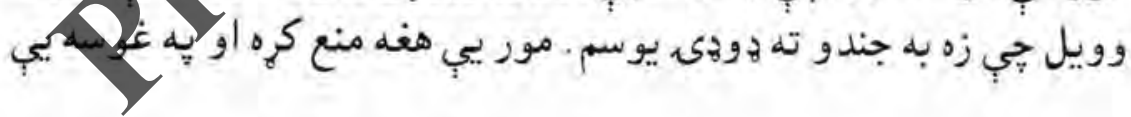

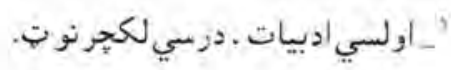

J I I r s

$V \varepsilon$

. 1. 9 


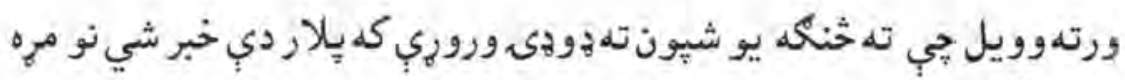
بdدي كري

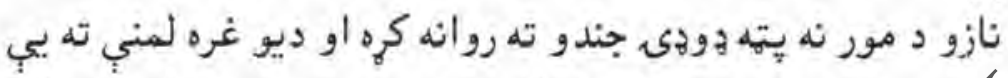

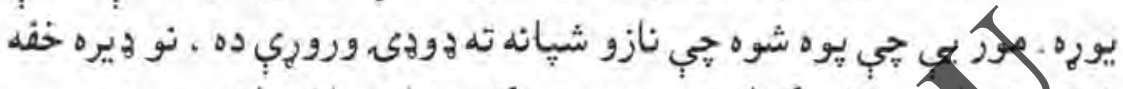

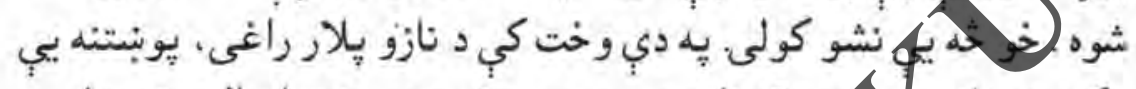

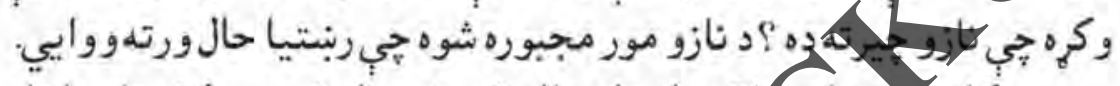

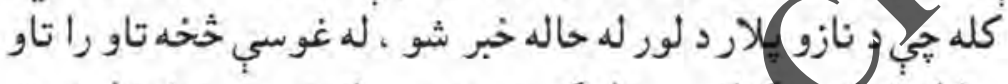

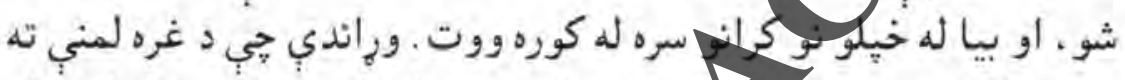

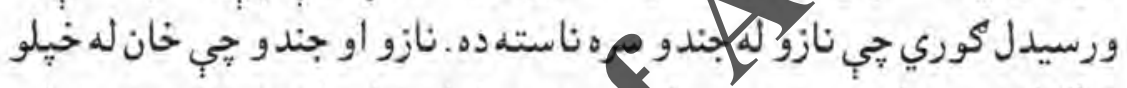

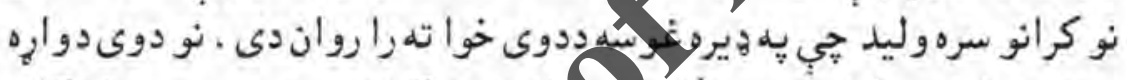

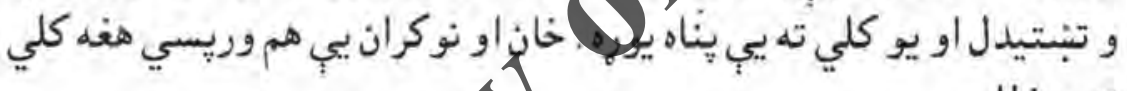
ته ورغلل. ت تئل

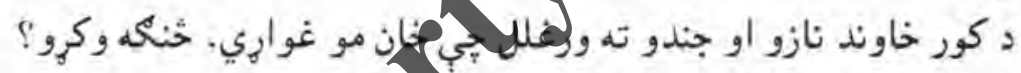

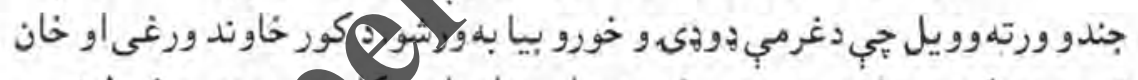

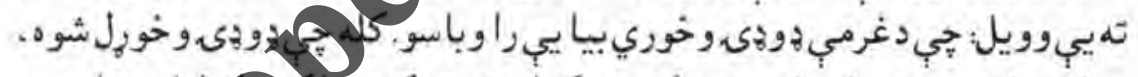

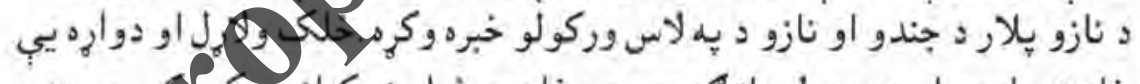

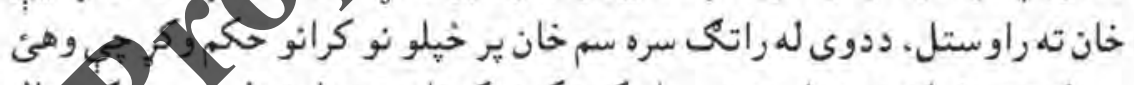

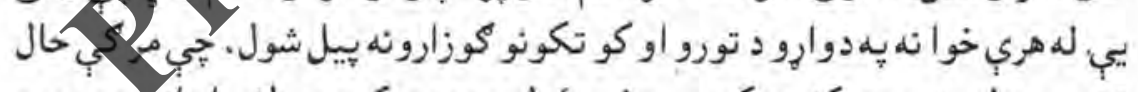

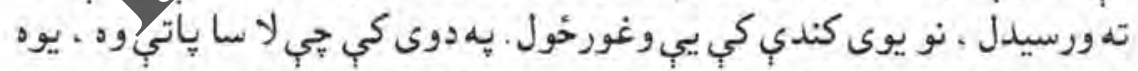

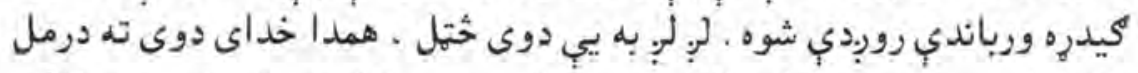

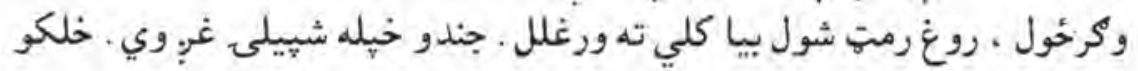

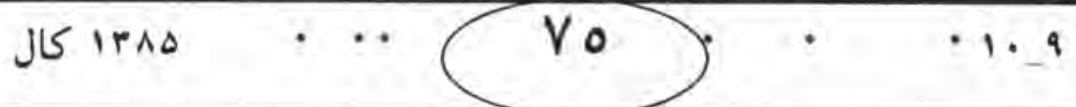




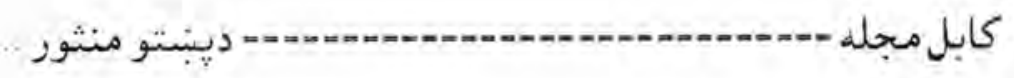

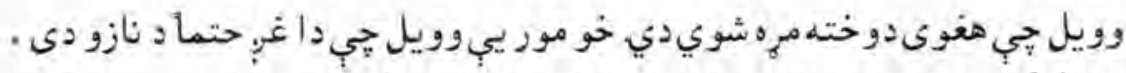

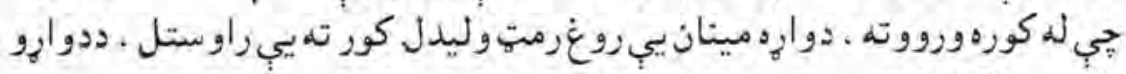

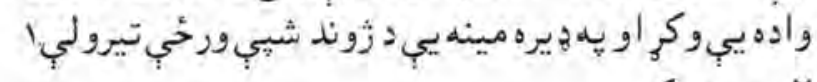

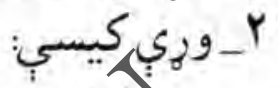

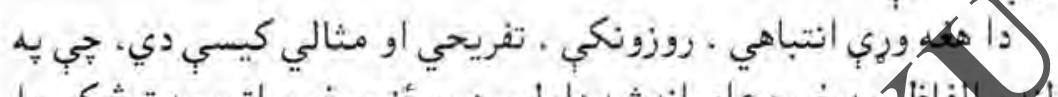

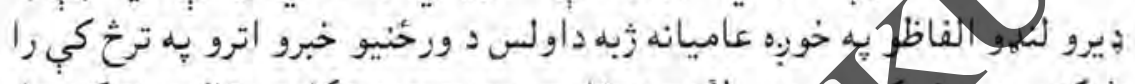

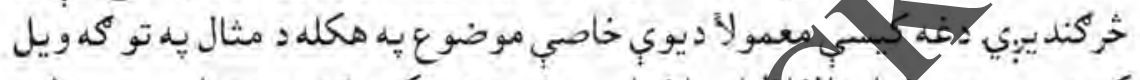

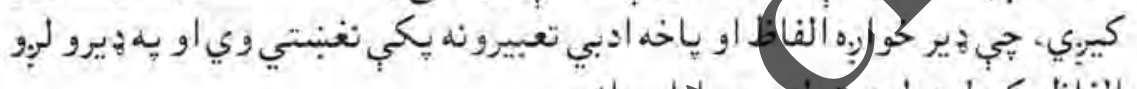

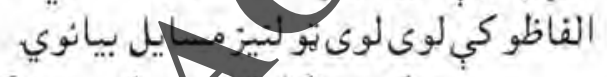

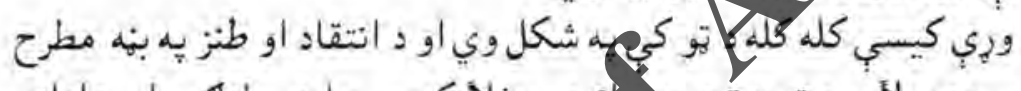

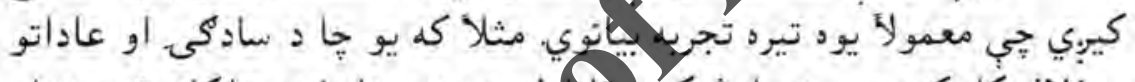

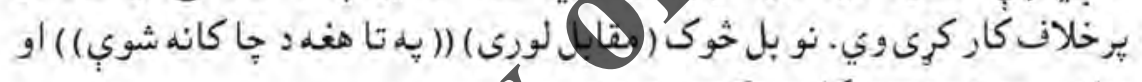

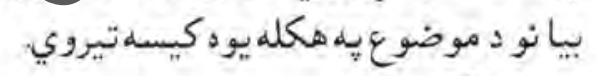

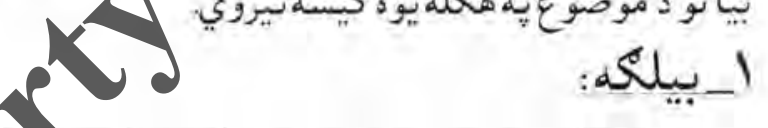

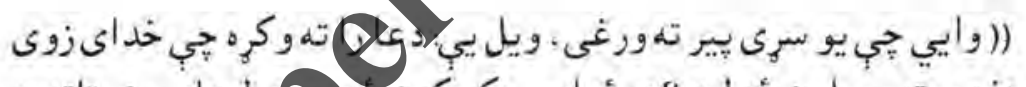

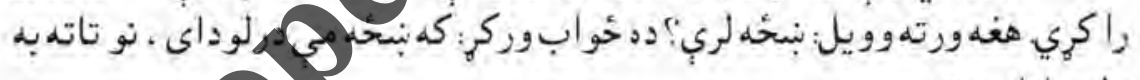

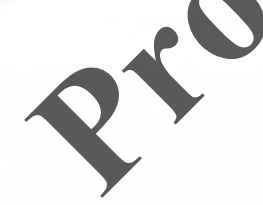

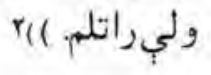

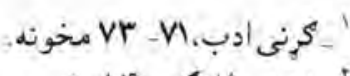

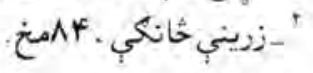

Irid

VY

- 1. 9 


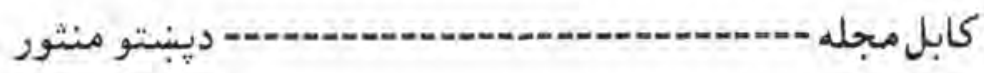

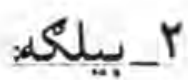

كه يوخوك يه ورخني زوند كي له لتى او تنبلى نه كار اخلي، نو نو ورته

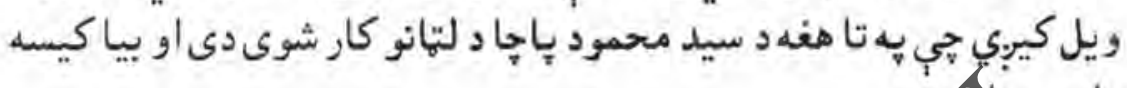

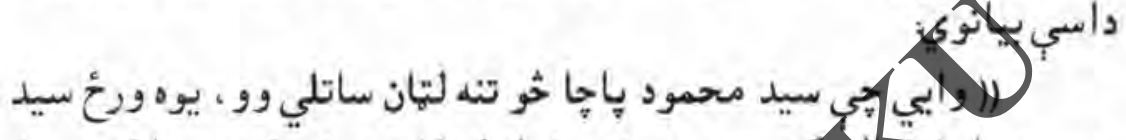

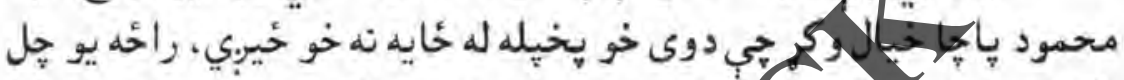

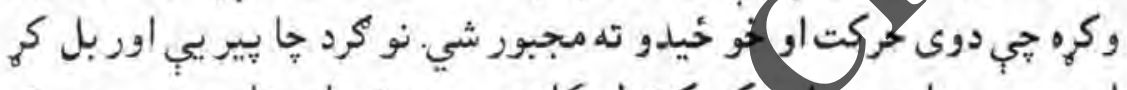

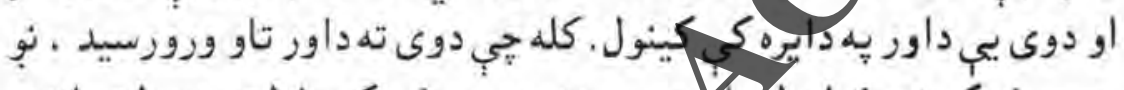

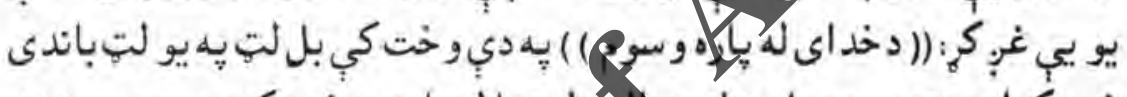

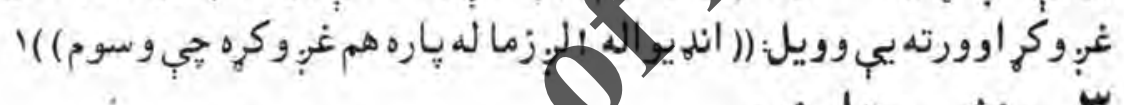

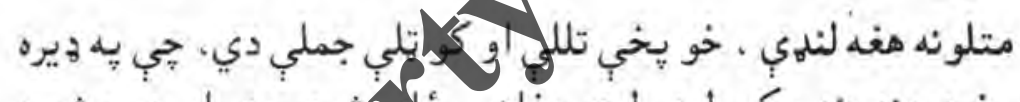

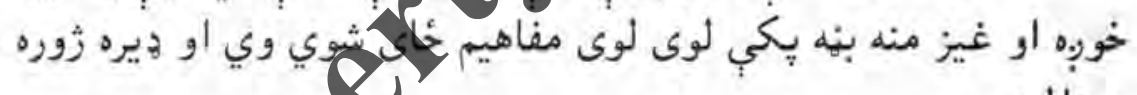
معنالري

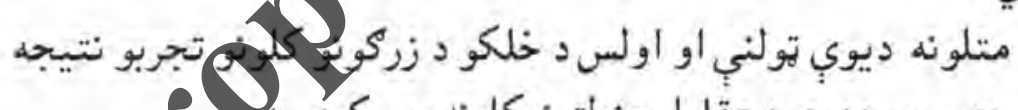

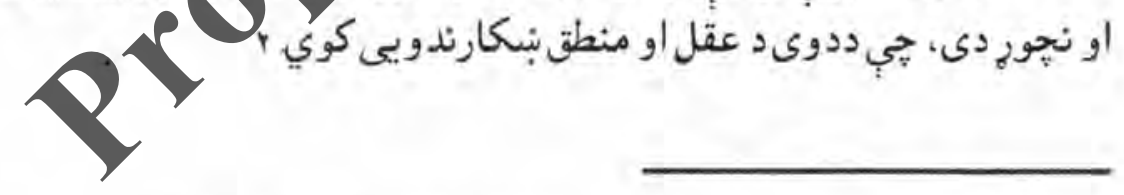

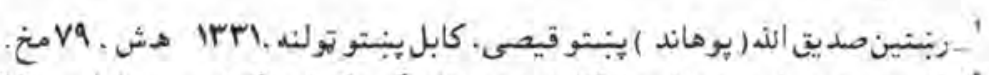

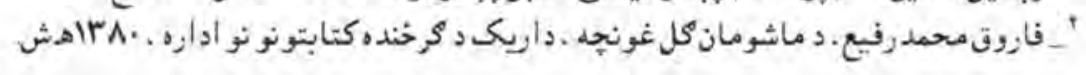
Irso
VV
- 1. 9 
د متل د كلمب د لغوي تحليل يه هكله خينب ادبيوهان يه دي عقيده

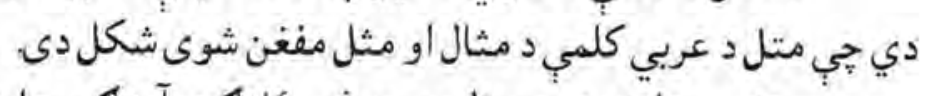

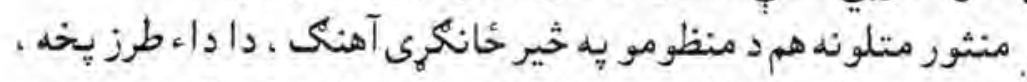

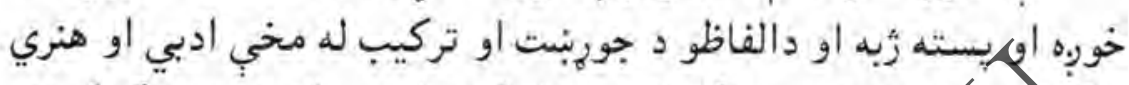

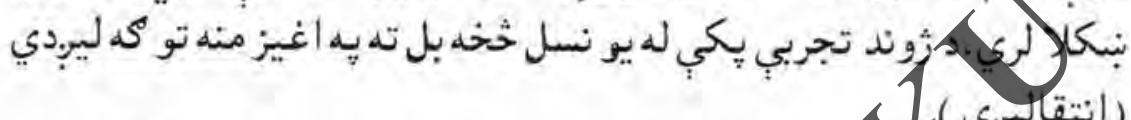

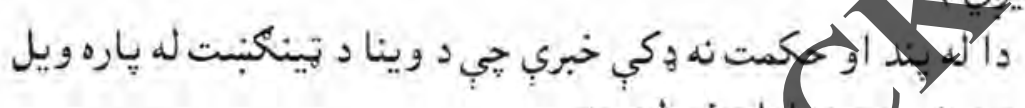

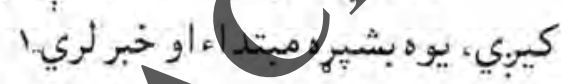

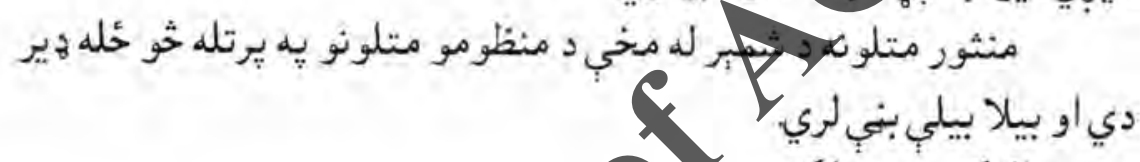

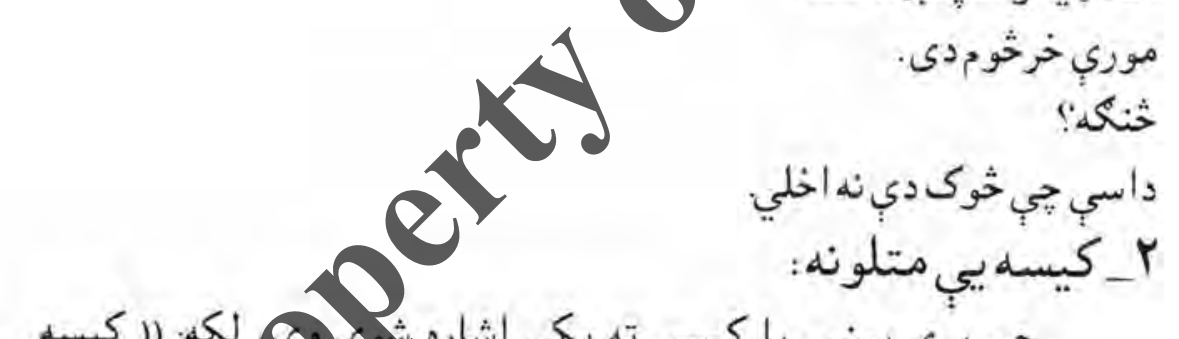

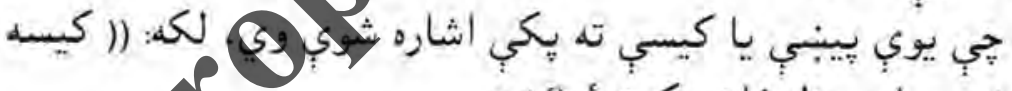

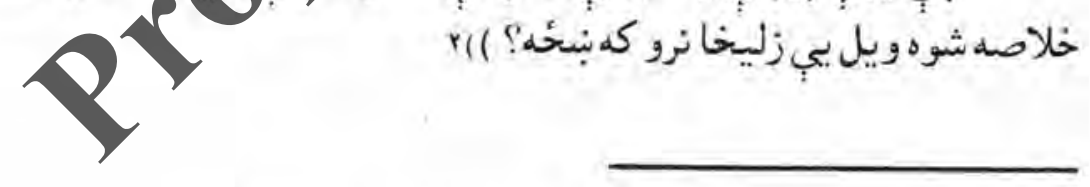

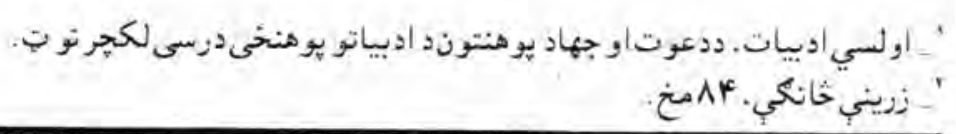

$$
\text { J }
$$




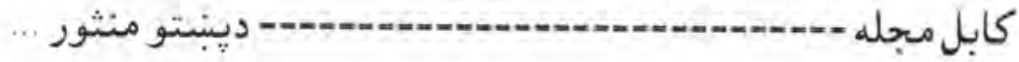

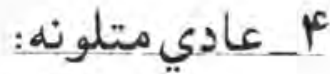

جِي عام اولسي فلسفي افكار او زور مطالب ِّكب بيان شوي وي.

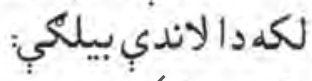

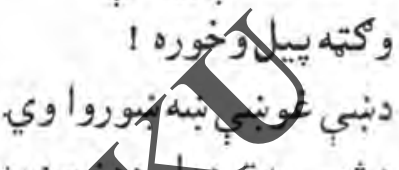

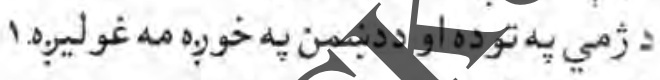

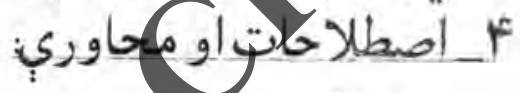

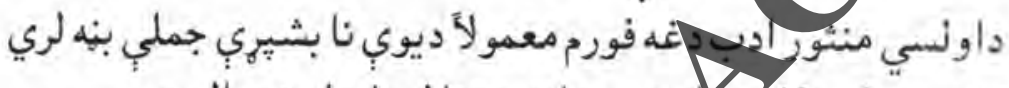

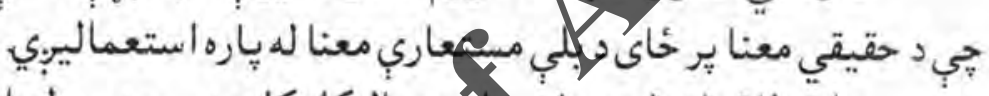

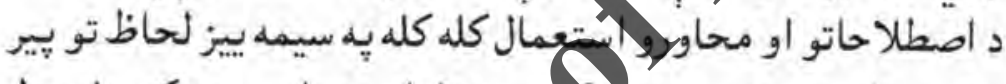

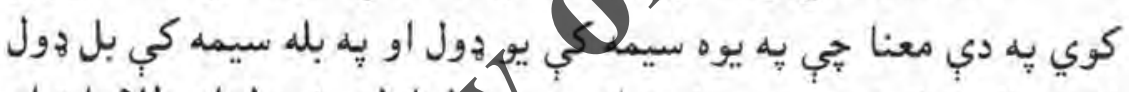

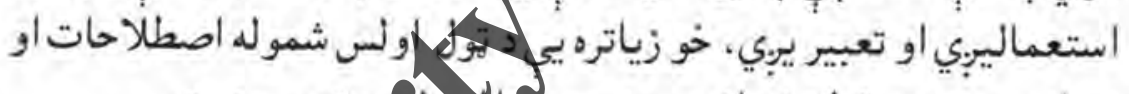

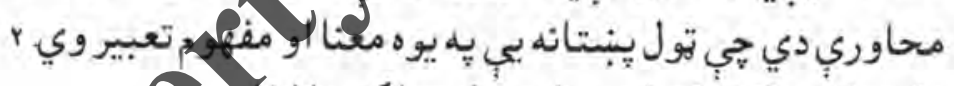

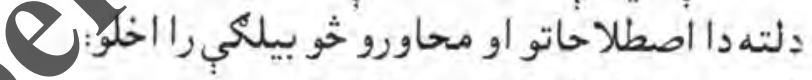

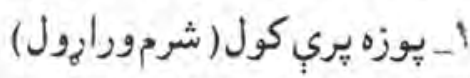

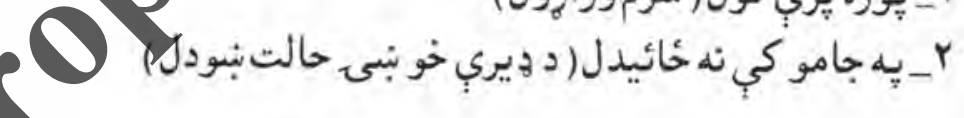
se

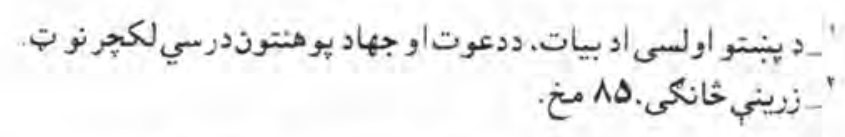

$$
\begin{aligned}
& \text { J STA } \\
& 19 \cdot 1 \cdot 9
\end{aligned}
$$




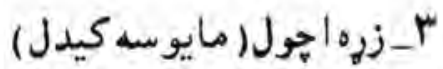

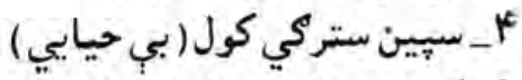

$$
\begin{aligned}
& \text { ه_كوته يه غابنَنيول ( حير انتياكول ) }
\end{aligned}
$$

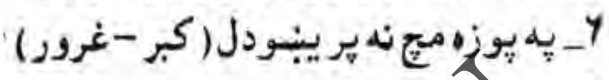

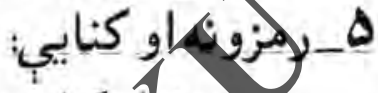

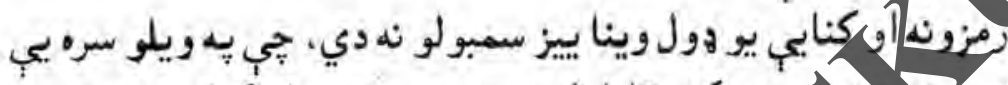

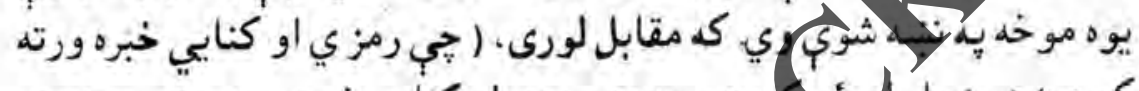

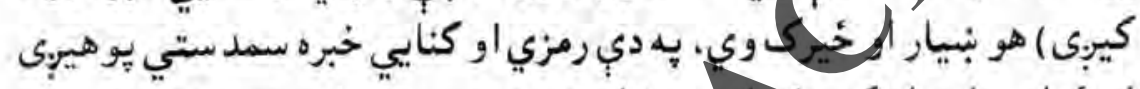

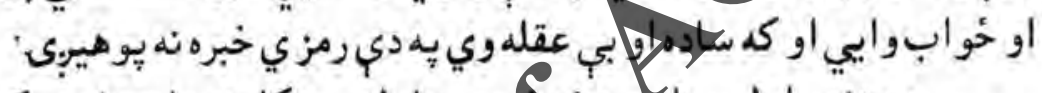

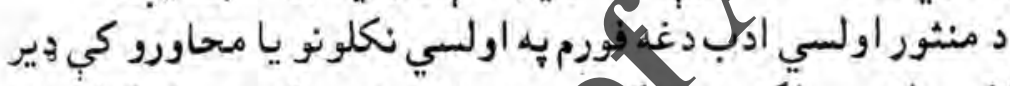

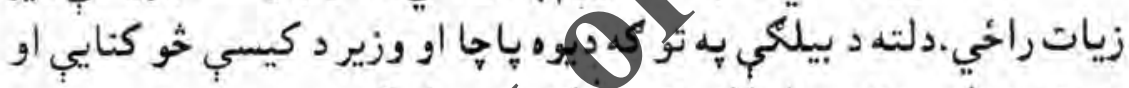

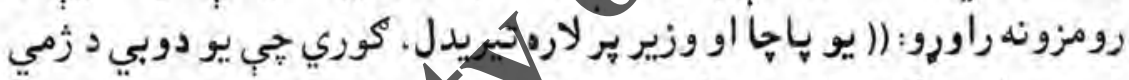

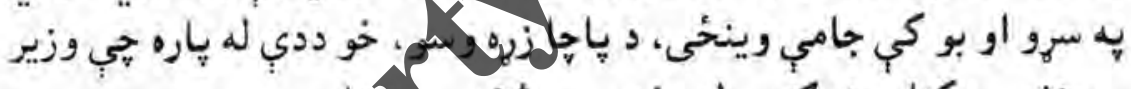

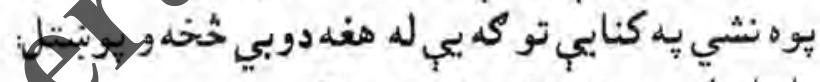

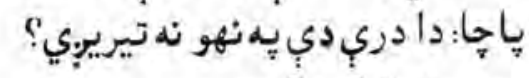

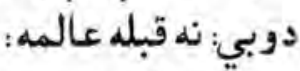

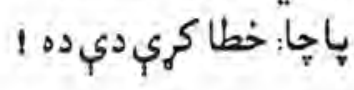

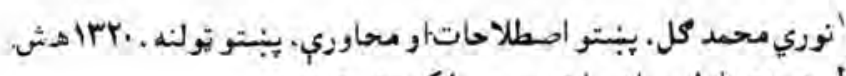

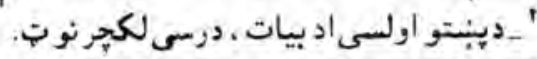




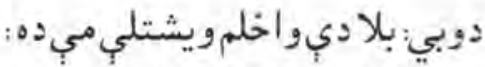

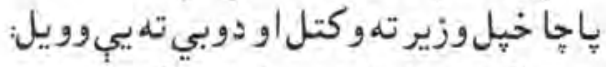

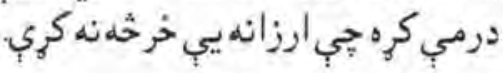

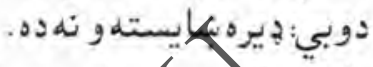

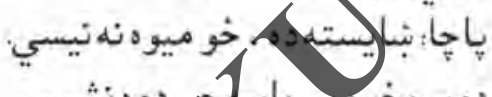

$$
\begin{aligned}
& \text { دوبي خووبي باسلجاجي دوهن نشي. }
\end{aligned}
$$

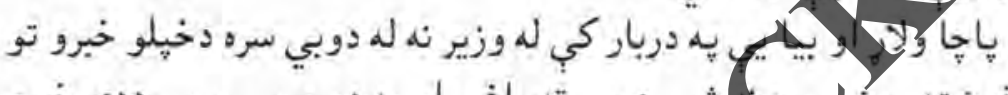

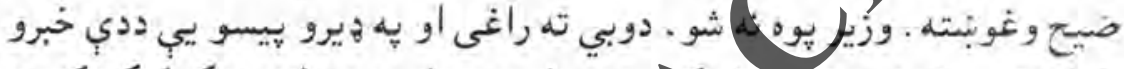

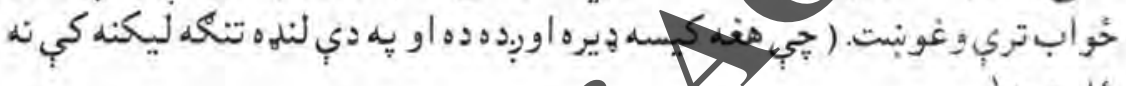
غايبري)'

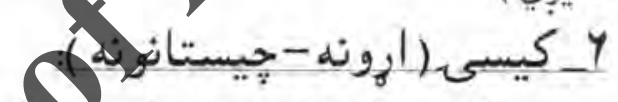

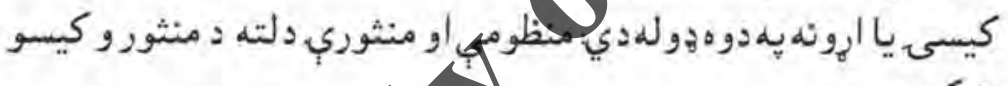

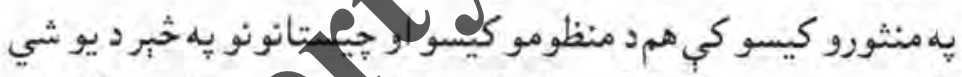
ينه الره بحث كوو.

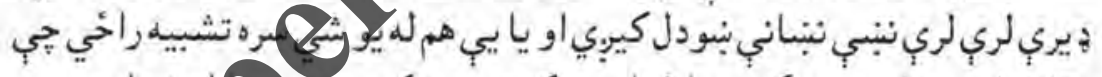

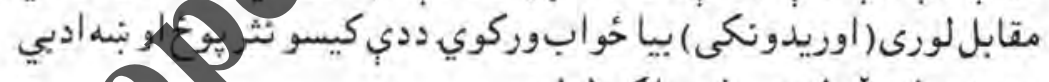

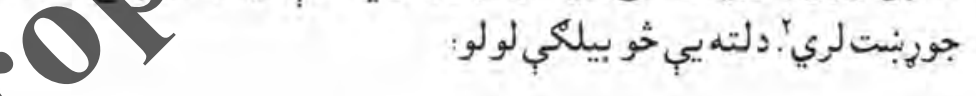

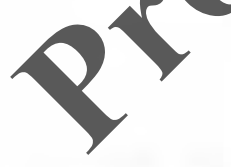

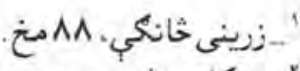

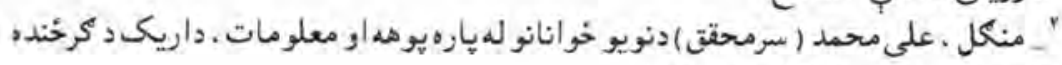

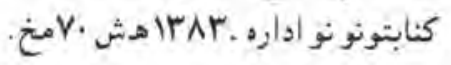

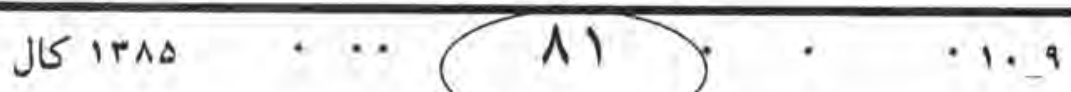




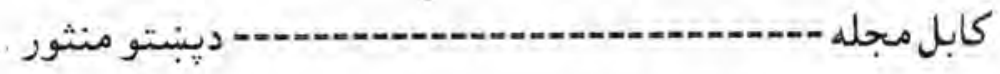

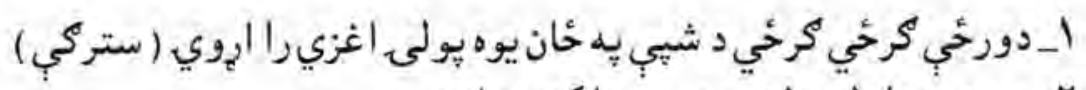

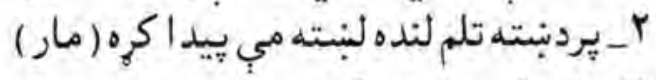

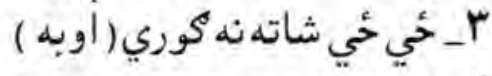

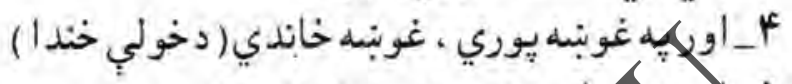

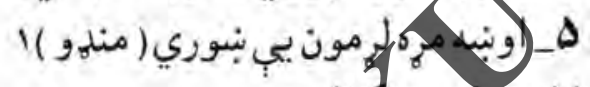
لون

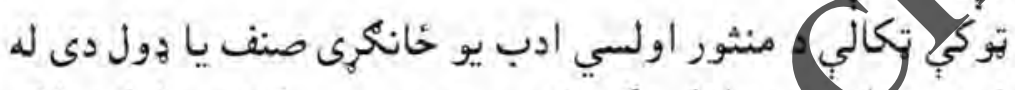

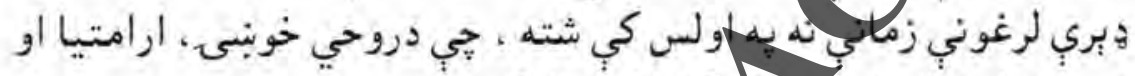

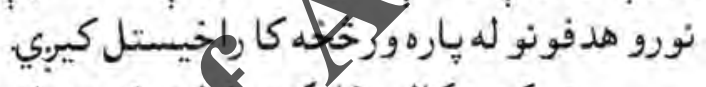

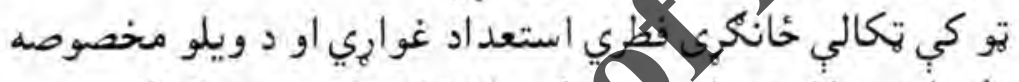

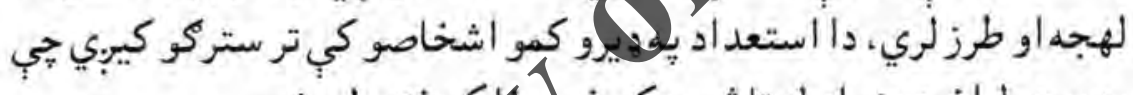

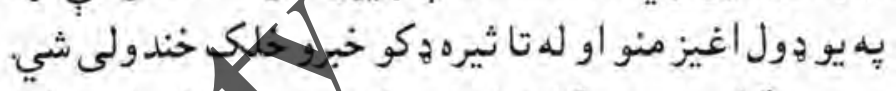

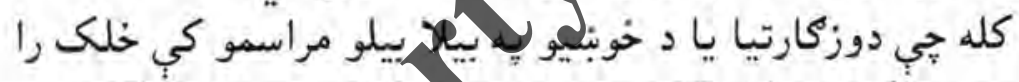

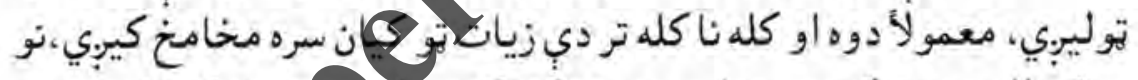

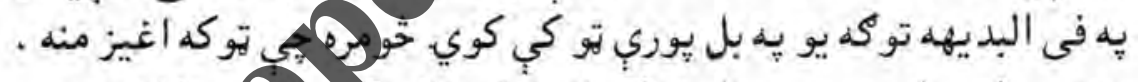

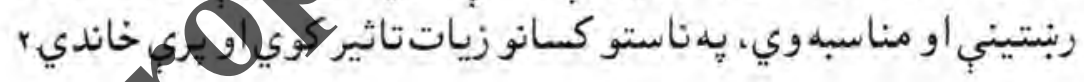

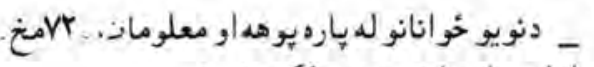

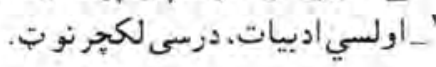

J ITAD

Ar

- 1. 9 
يه توكو كي كله كله ثرور سياسي او انتقادى مطالب هم نغبنتي وي.

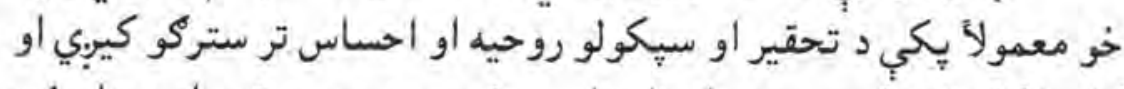

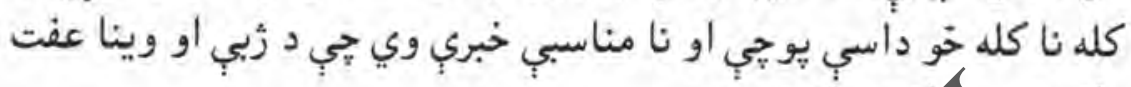

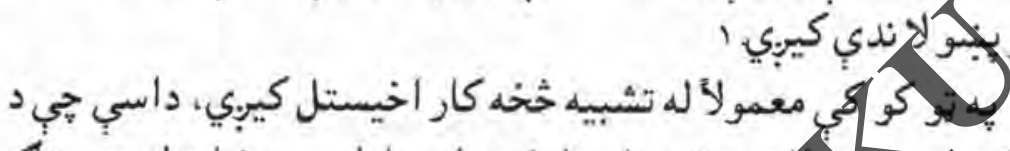

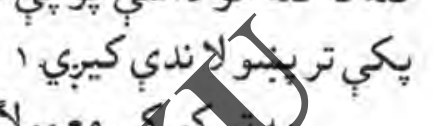

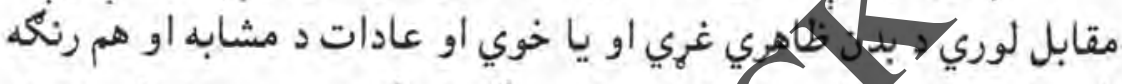

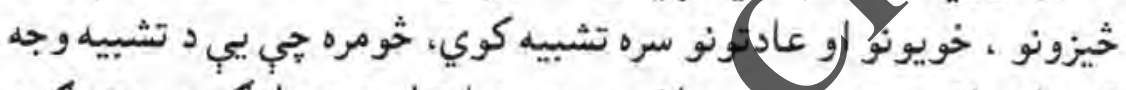

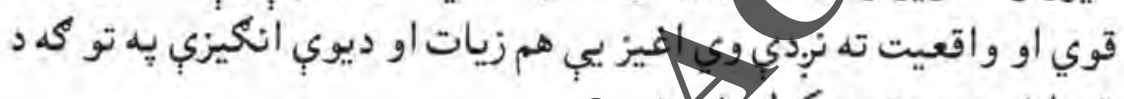

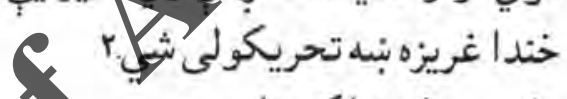

$$
\begin{aligned}
& \text { دلته يب خو بيلكي راورو: } \\
& \text { ا_مخدي لكه يتيره }
\end{aligned}
$$

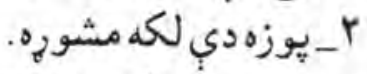

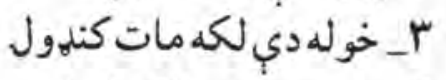

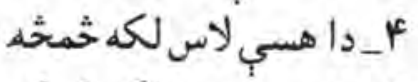

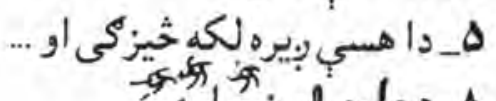

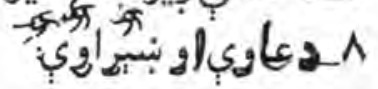

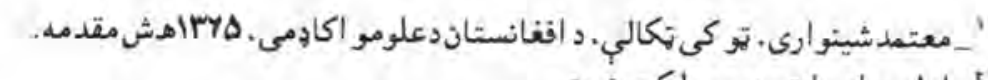

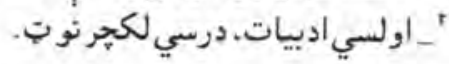

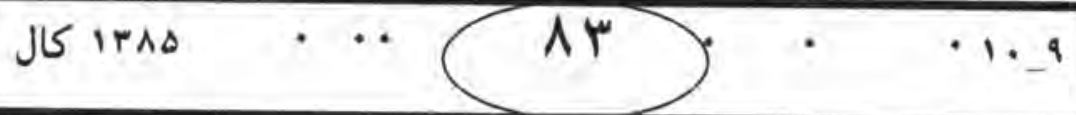




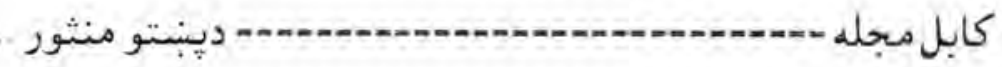

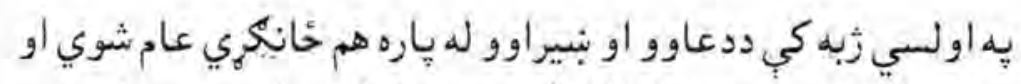

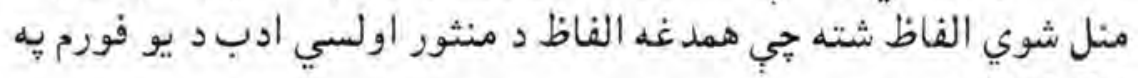
توكمكئل كيبري.

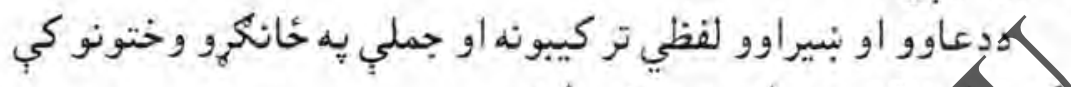

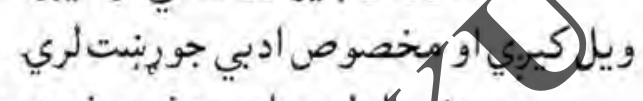

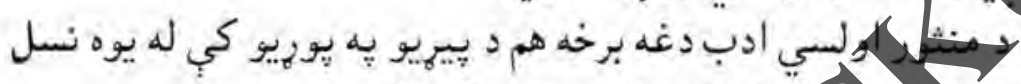

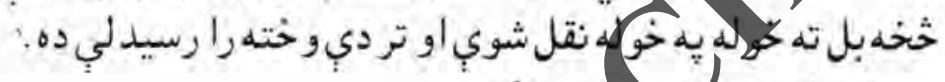

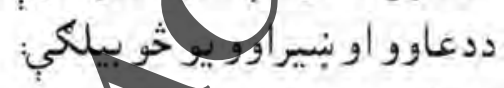
إخداوي:

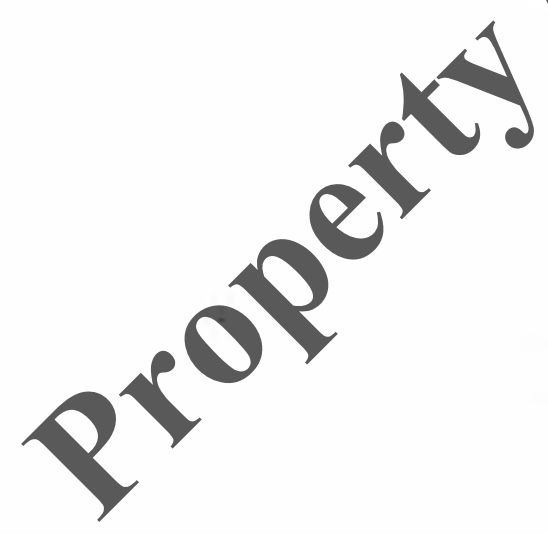

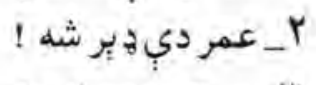

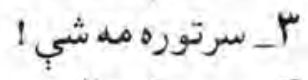

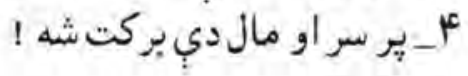

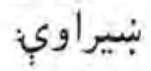

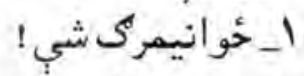

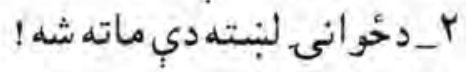

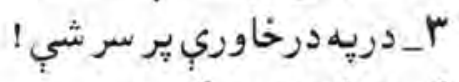

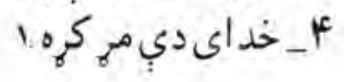

' ـاولسي ادبيات . دوعوتاو جهاد يوهنتوندرسي لكجر نوتي.

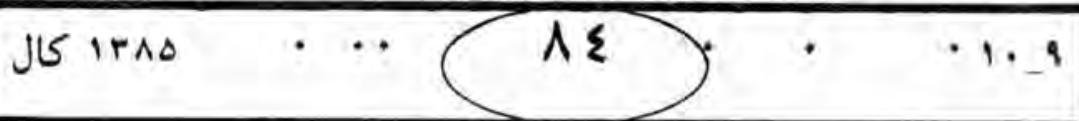




\section{9- تكيه كلامو نه:}

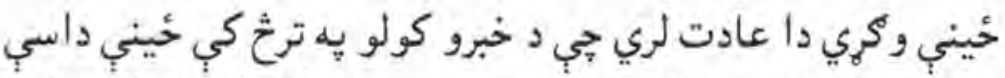

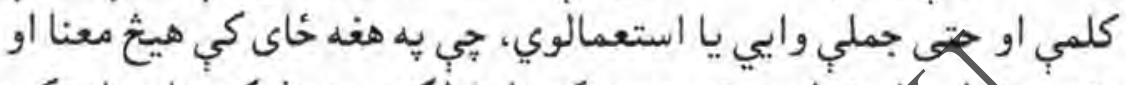

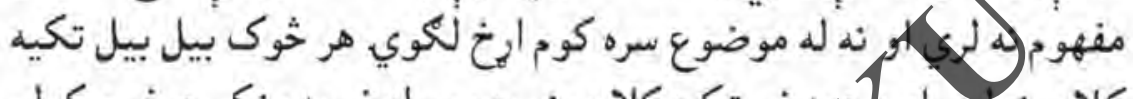

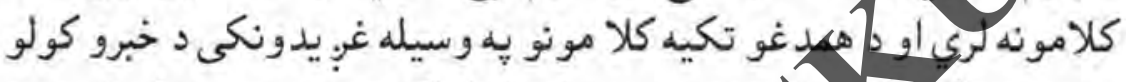

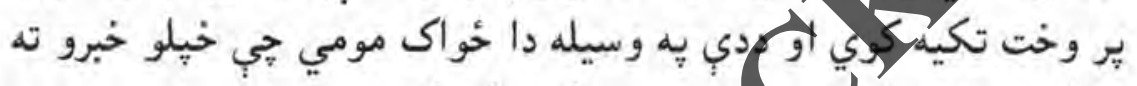

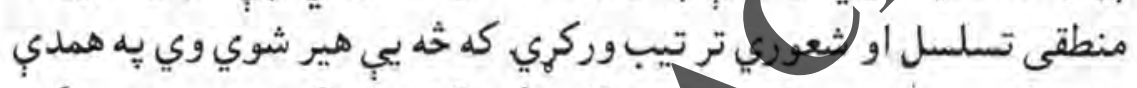

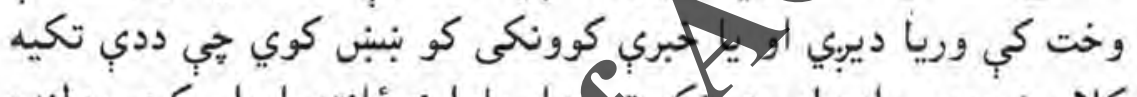

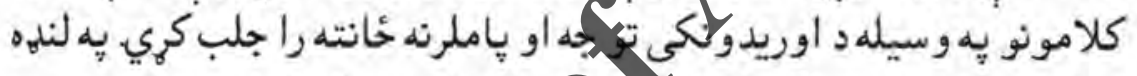

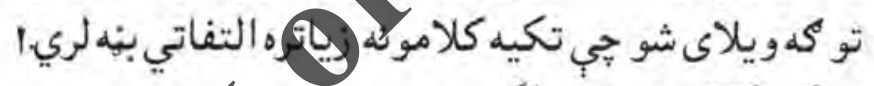

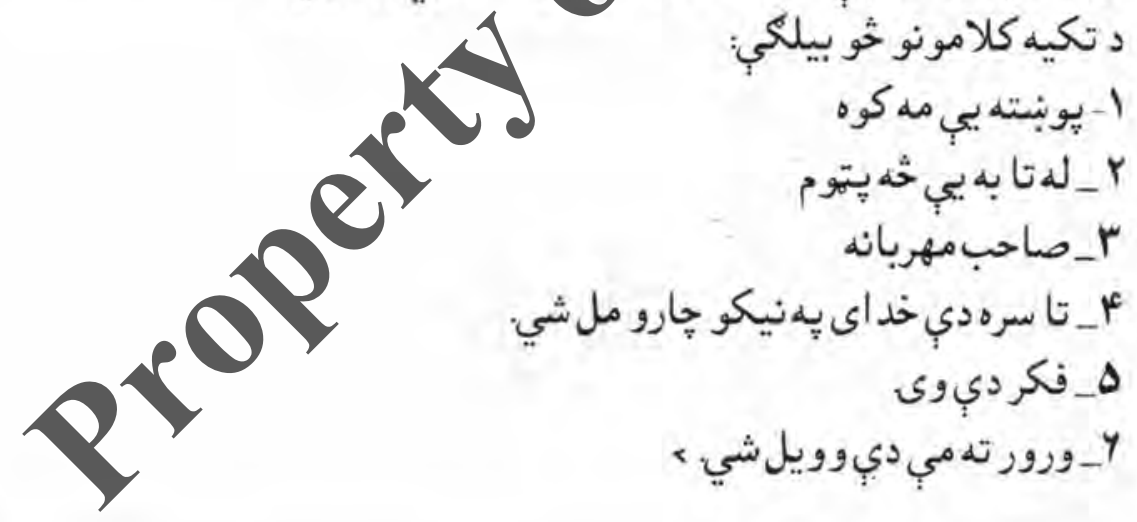

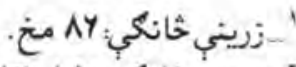

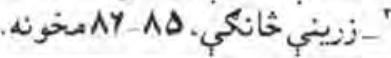

J 1 irno $\cdots(10.9$




$$
\begin{aligned}
& \text { V_كويا جي دى او نور. }
\end{aligned}
$$

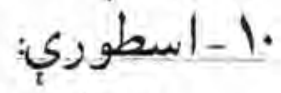

له اولسي خلكو سرهد طبيعي مو جود اتو قه باب خاصبي عقيدي شته.

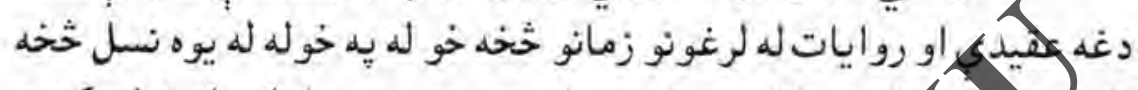

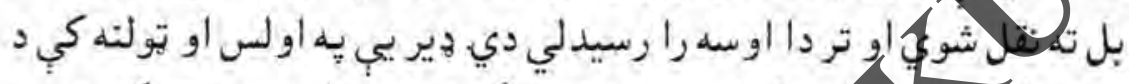

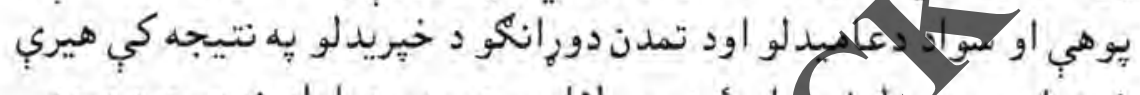

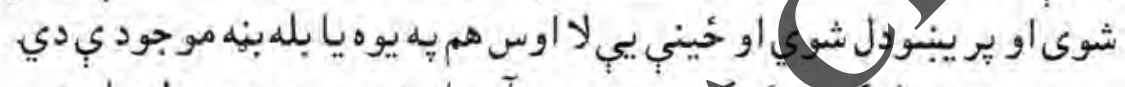

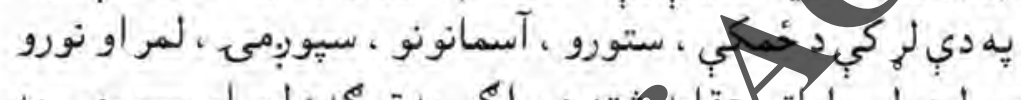

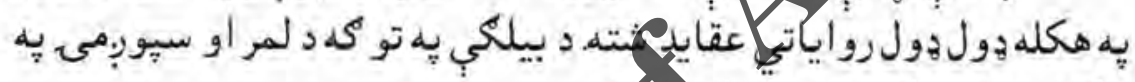
هكله ية اولس كي داسي روابياتهمته:

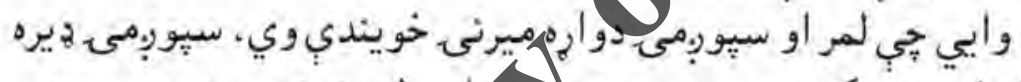

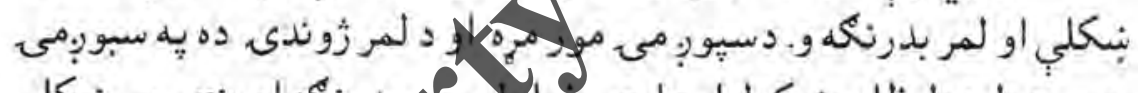

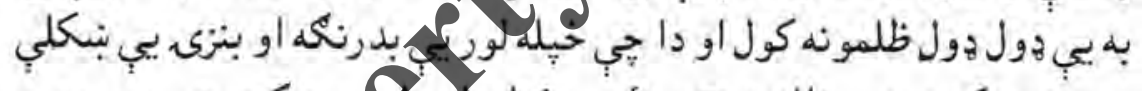

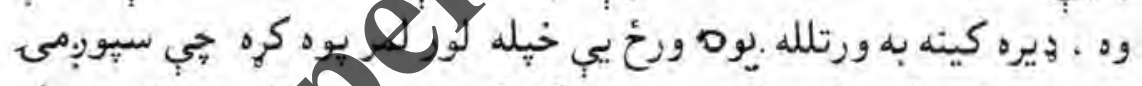

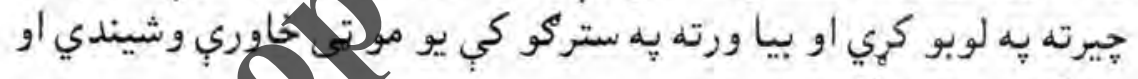
ستركي يب ريندي كري.

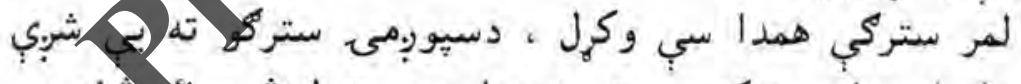

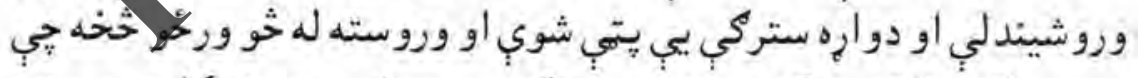

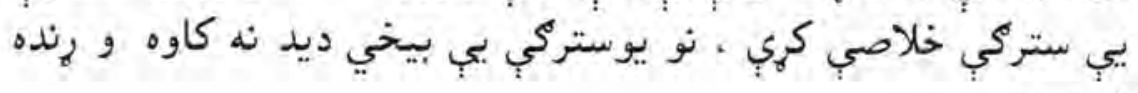
شويوه.
J IrAD
17
- 1. 9 


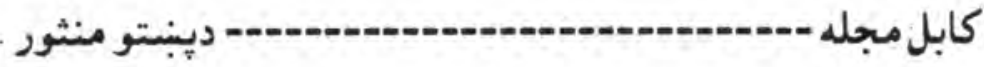

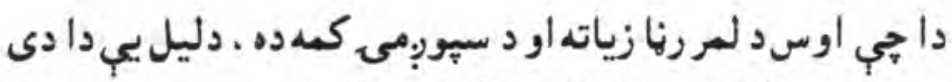

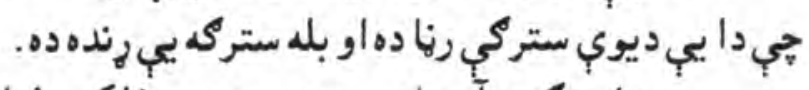

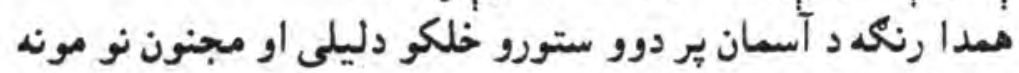

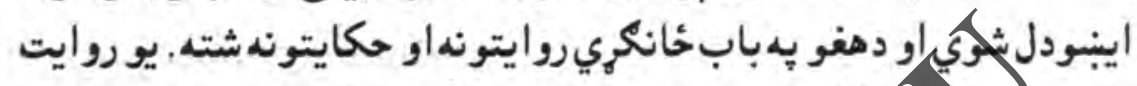

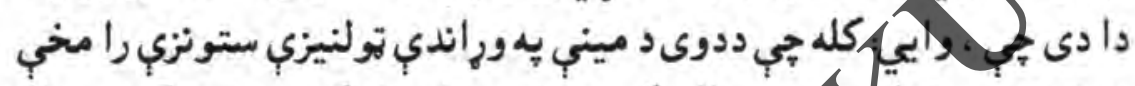

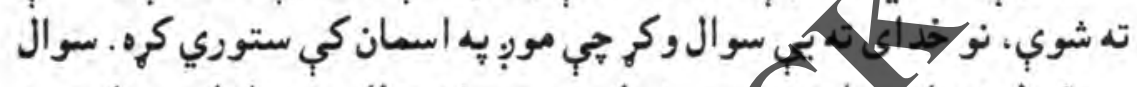

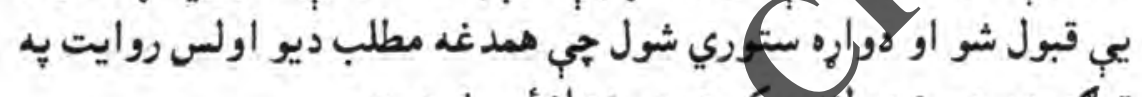

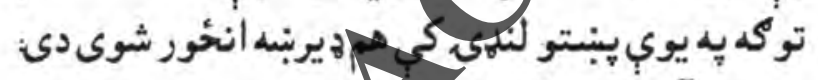

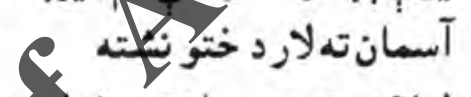
ليلا مجنون يه عاشقى ختليديدي

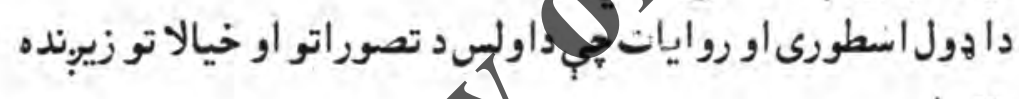
دي، نديردي' 11

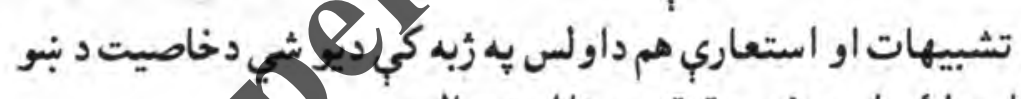

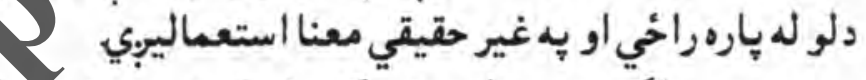

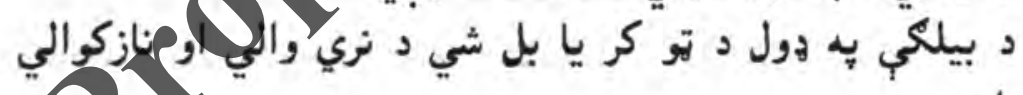

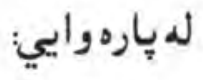
' - اولسي ادبيات ـ دوعوتاو جهاد د يوهنتوند ادبياتو درسي لكجرنوت. J Ir^s AV -1. 9 


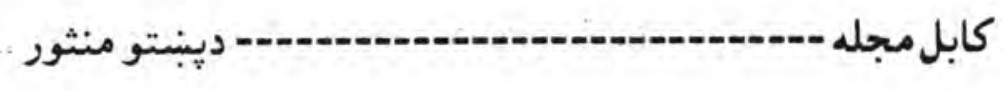

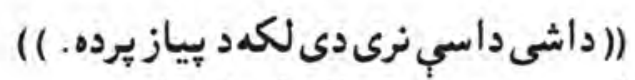

$$
\begin{aligned}
& \text { او يو شي ددروند والي لهياره وابي: }
\end{aligned}
$$

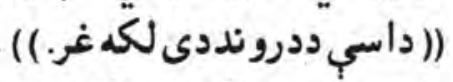

$$
\begin{aligned}
& \text { يا (( داسيخ سيك دوى لكدبنكه. ) ) }
\end{aligned}
$$

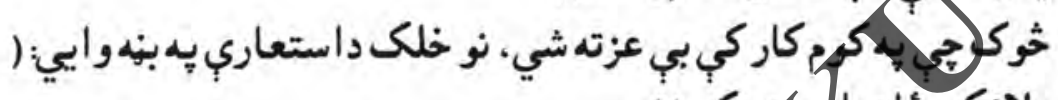

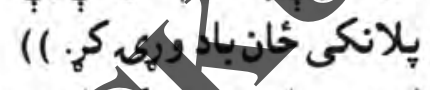

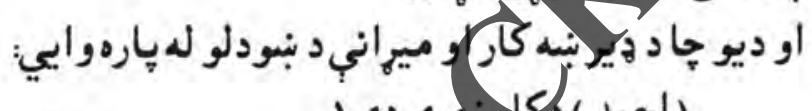
(احمد ) دكلازمري.

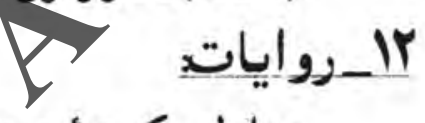

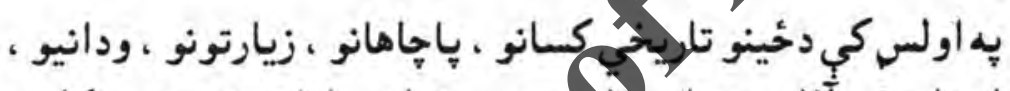

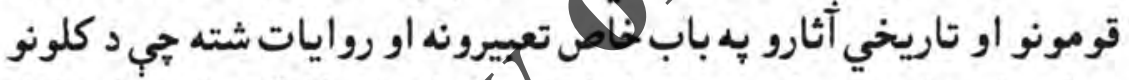

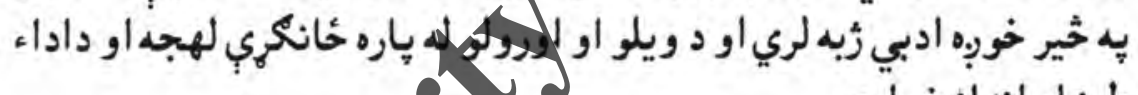
طرز او اندازغواري.

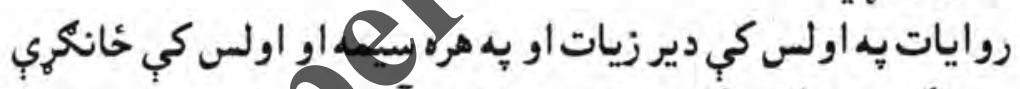

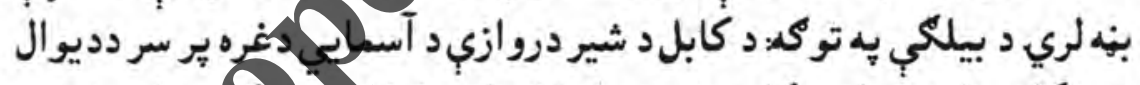

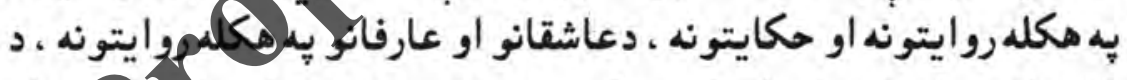

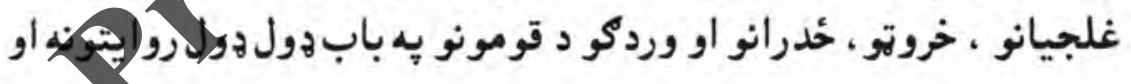

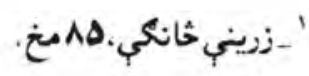

$$
\text { JIrAD } \cdots(11.9
$$


همدارنكه د بيلا بيلو كسبونو ، لكه جلا كري، آهنكري تركانى او نورو بـ بابروايتونه. ولته د بيلكي په تو كه د آسمابي غر خه سر دديوال او د شاه

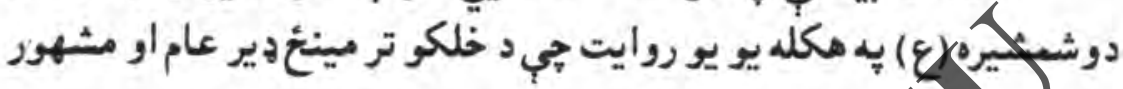

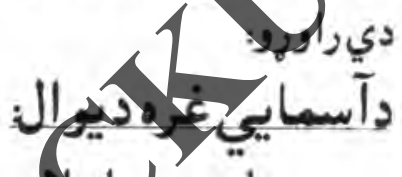

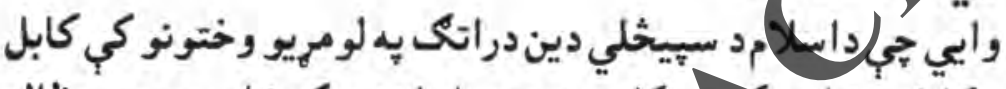

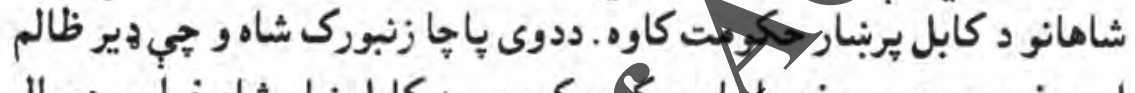

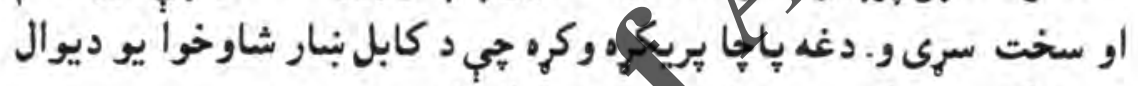

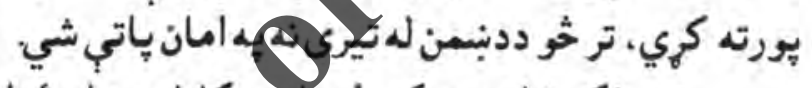

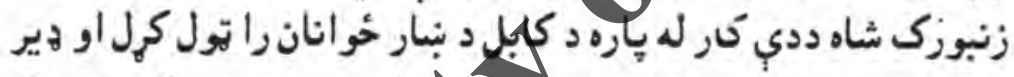

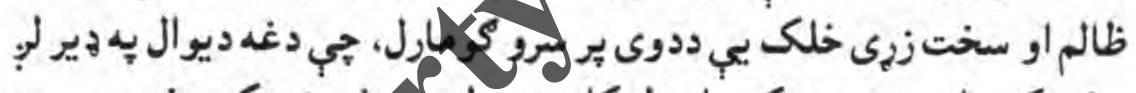

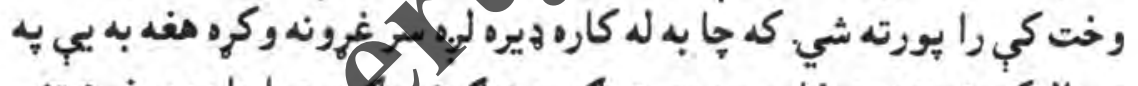

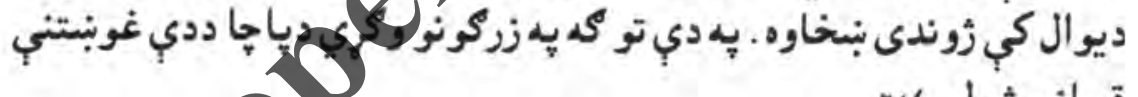

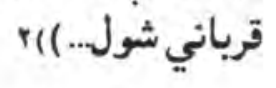

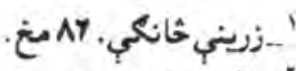

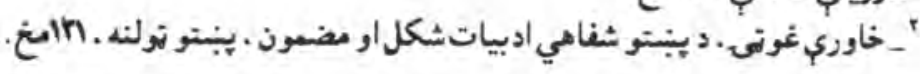

J 1 irAd $\cdot 19$




\section{شاهدو شمشيره(ع): (ع)}

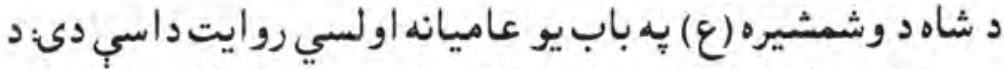

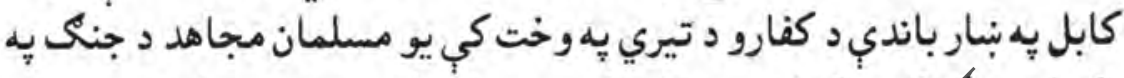

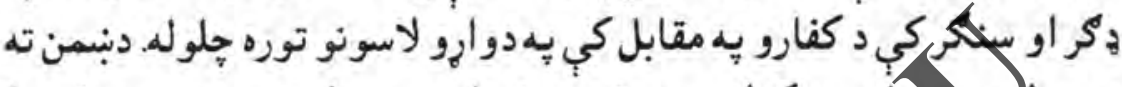

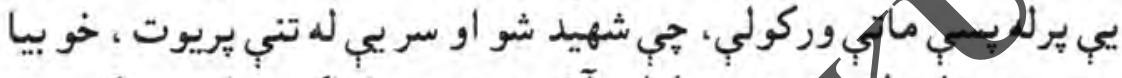

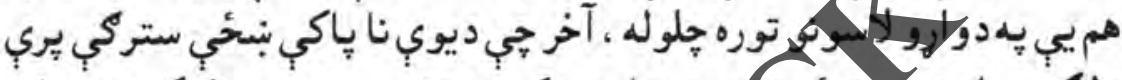

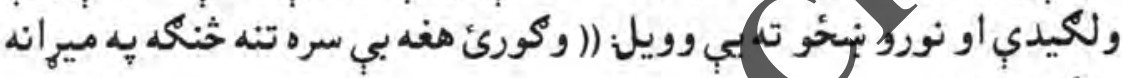
جنكيبيجي. ) )

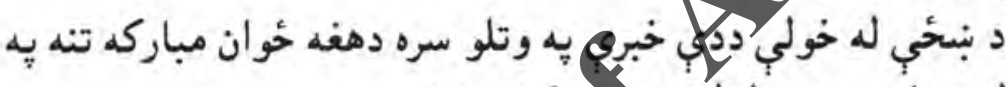

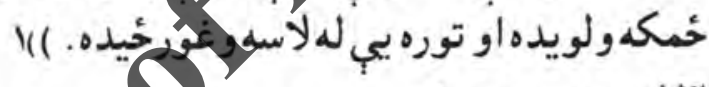

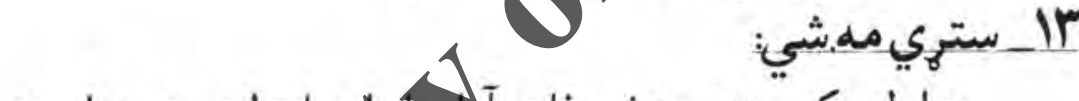

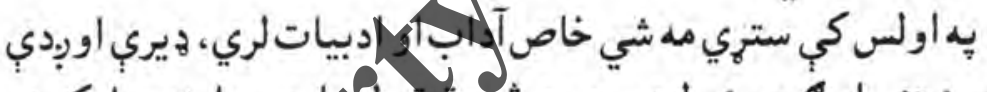

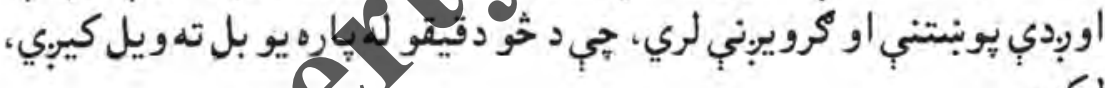

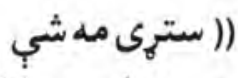
جور !تازه !سلامت !يه خير پِ خير !... ) )

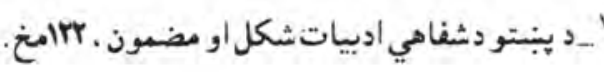




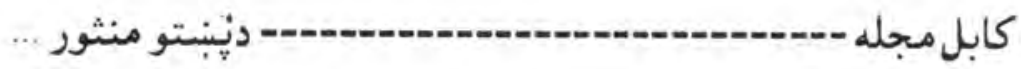

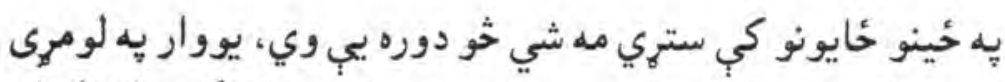

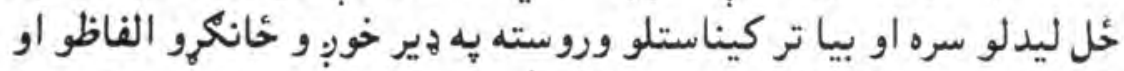

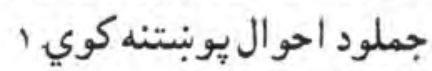

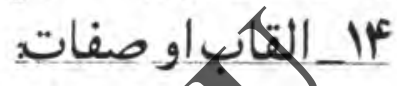

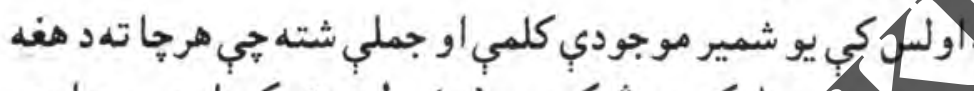

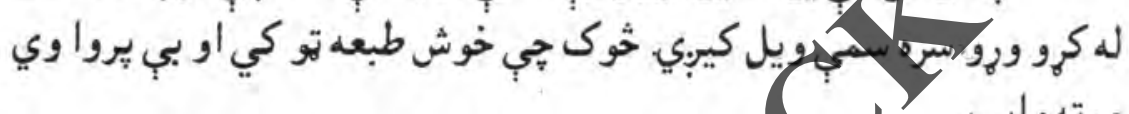

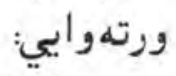

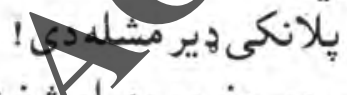

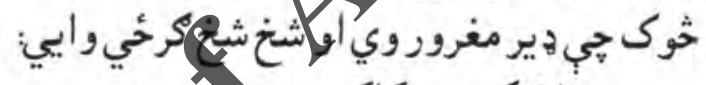

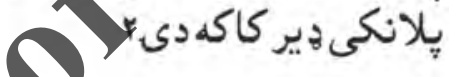

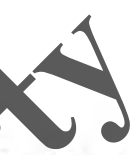

$$
\text { الها_نو ماسي_نورن }
$$

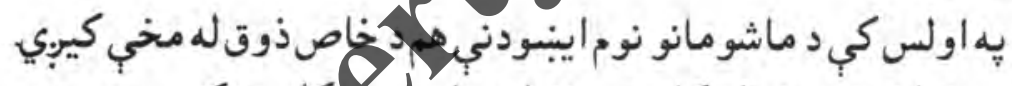

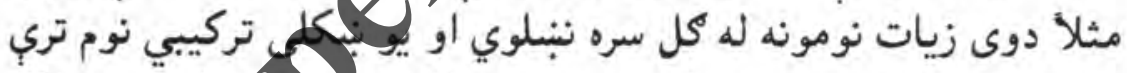

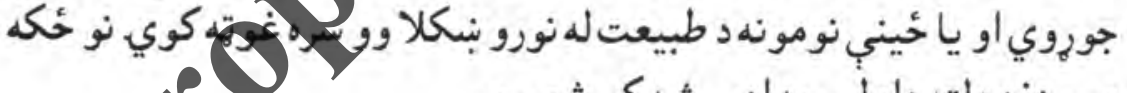

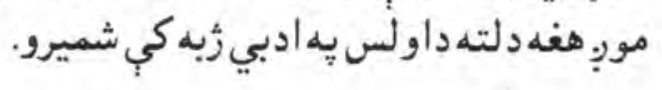

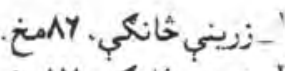

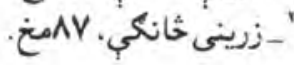

$$
\text { Jirnd } \cdots 99
$$




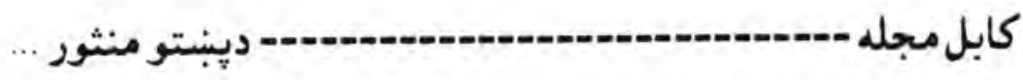
كيلكي يبي دادي:

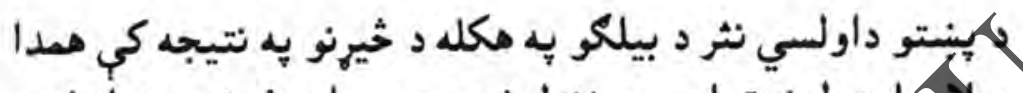

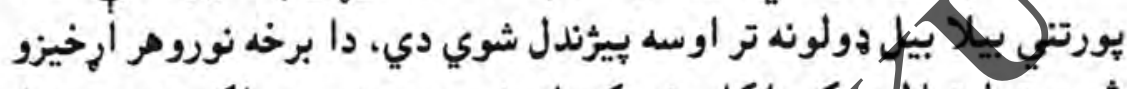

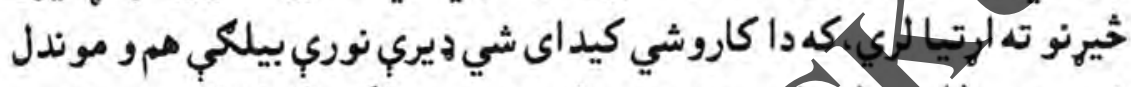

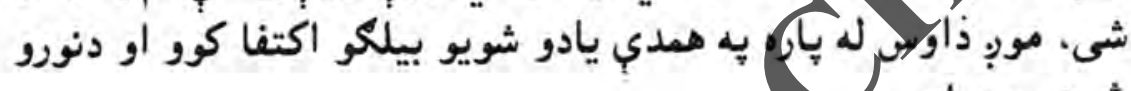
خيرنو يه هيله يو.

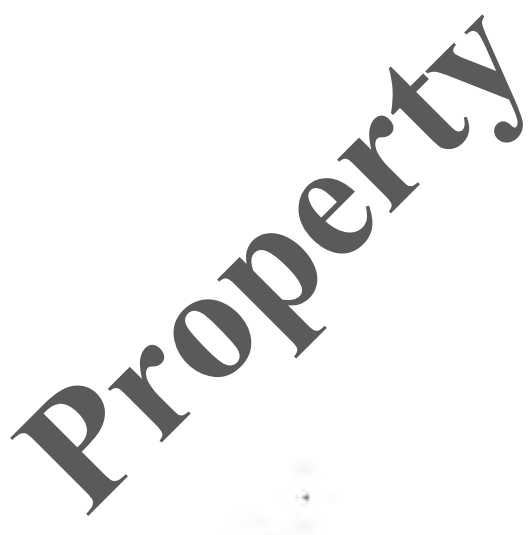

- - بورتنى اثر - يورتنىمغ.

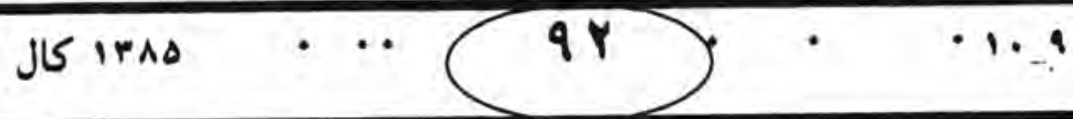




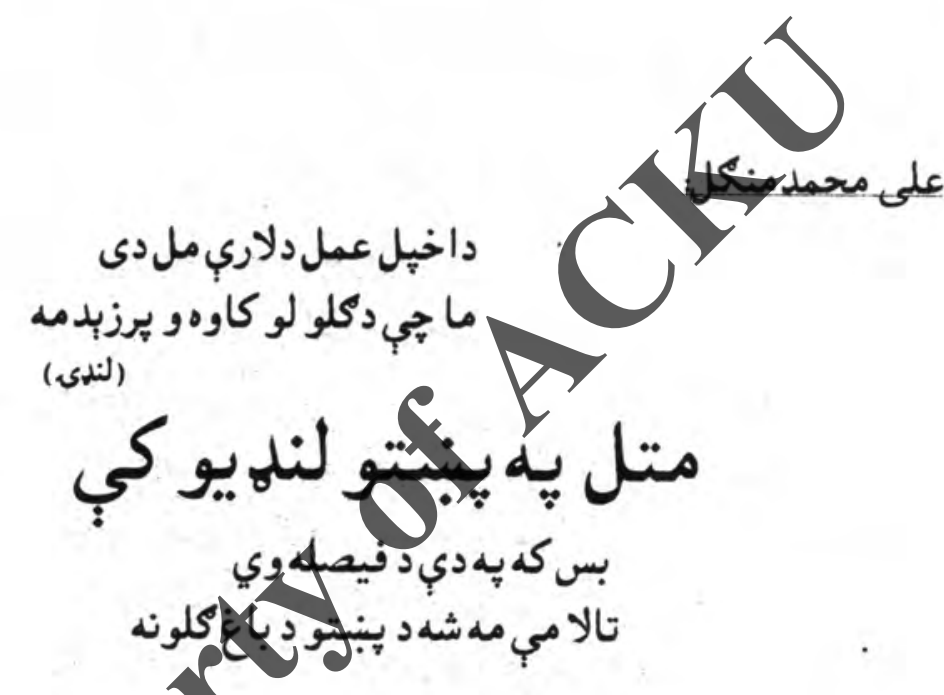

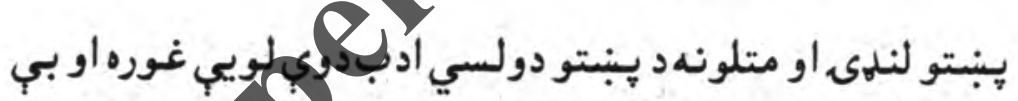

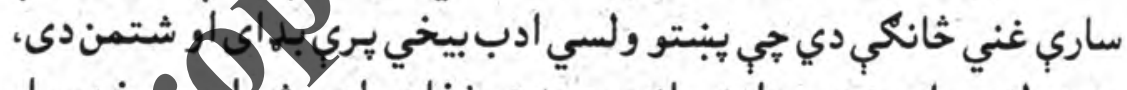

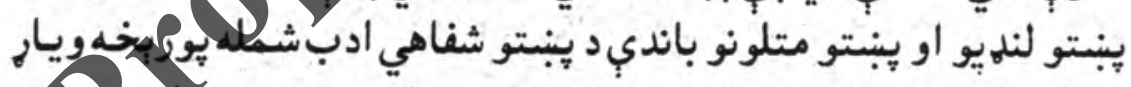

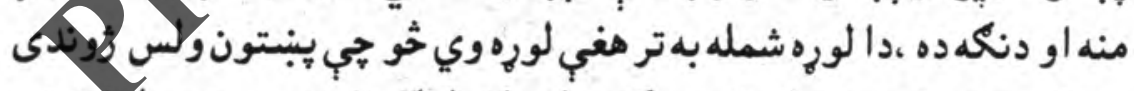

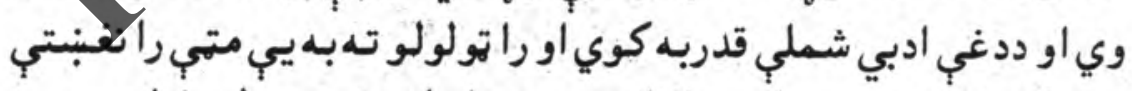

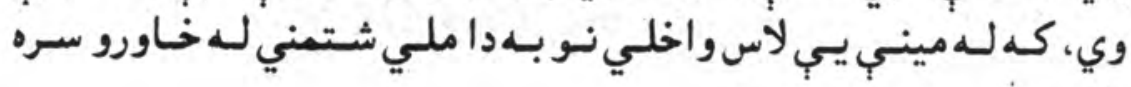

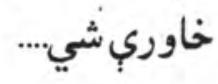

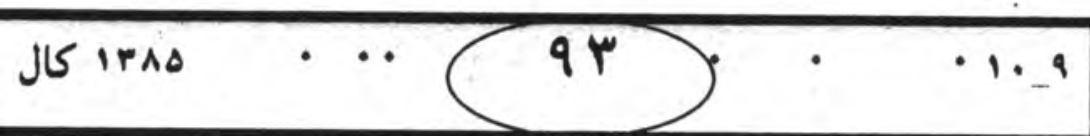




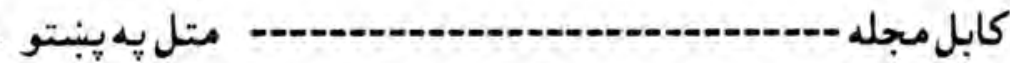

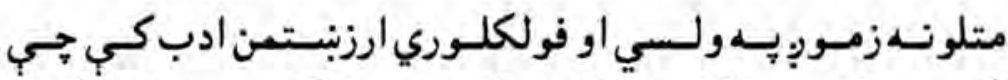

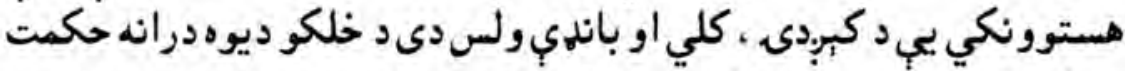

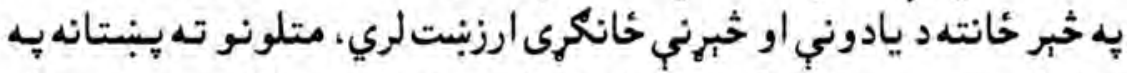

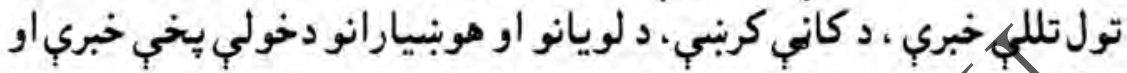

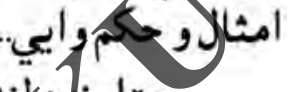

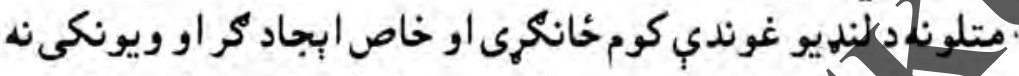

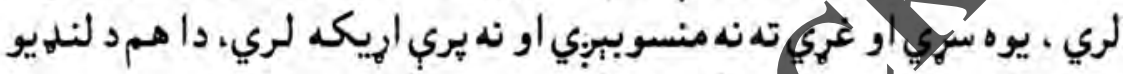

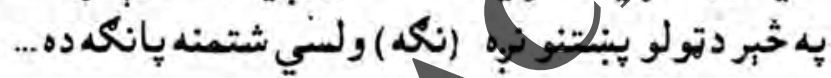

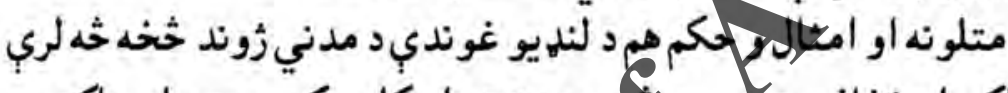

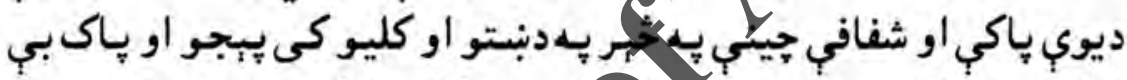

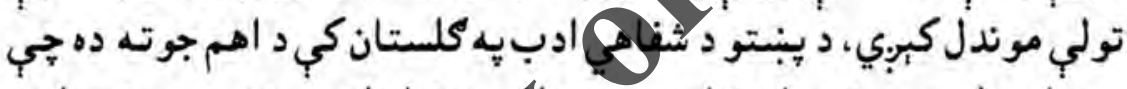

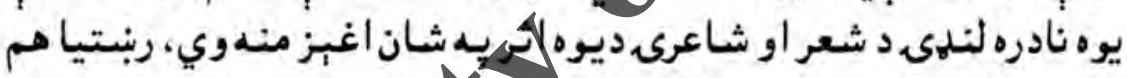

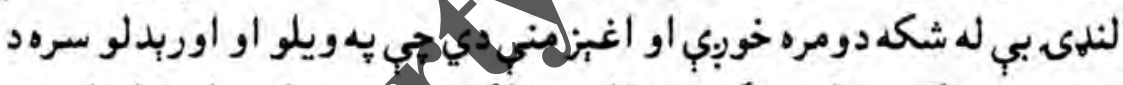

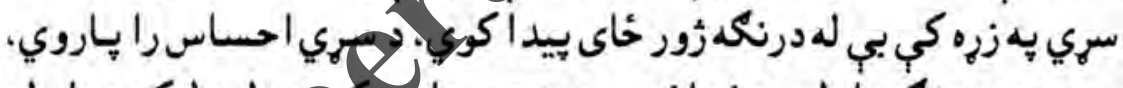

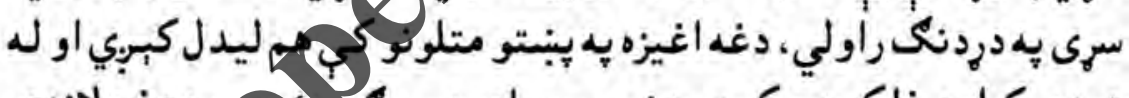

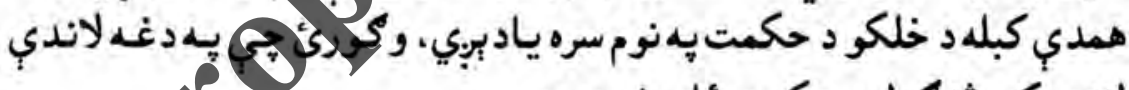

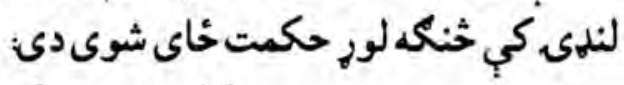

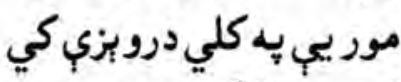

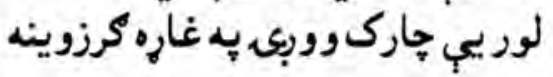
J IrAs
$9 \varepsilon$
-1..9 


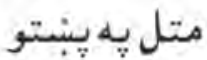

كابل مجله

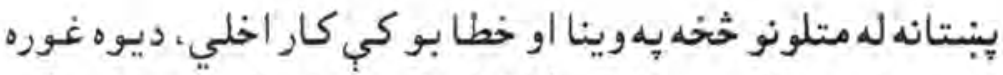

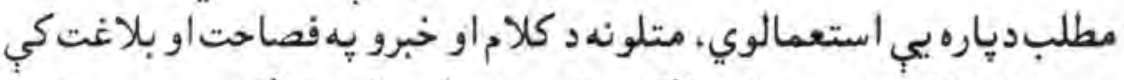

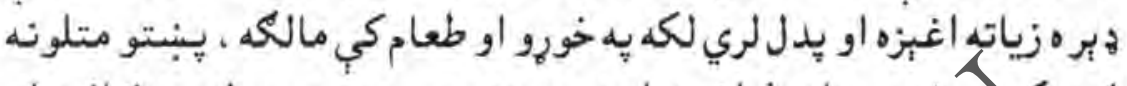

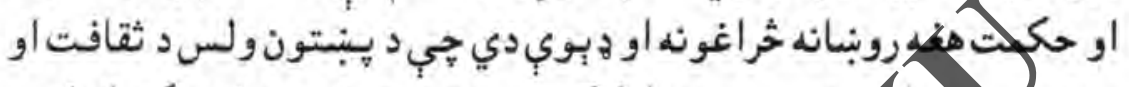

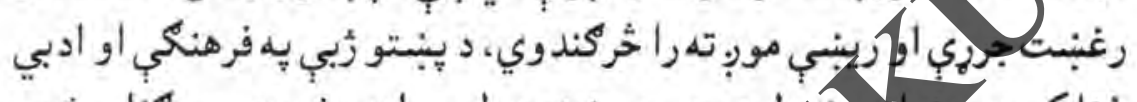

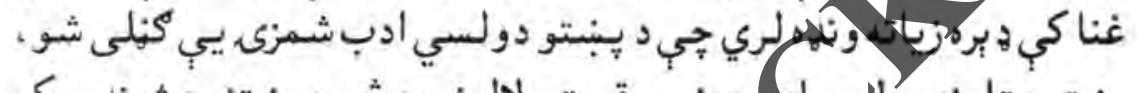

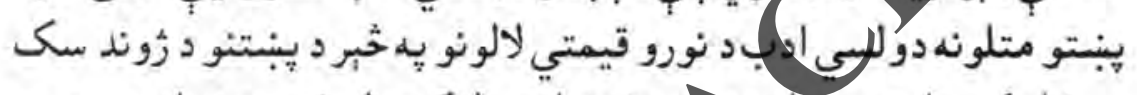

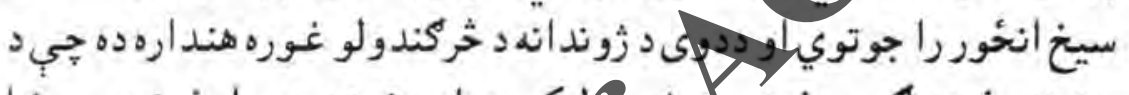

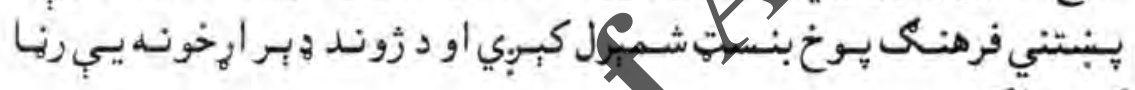
كوي، لُكه: نه به تل ناصر خان وى، ثلدب سبري غر انكي اوبنان وي

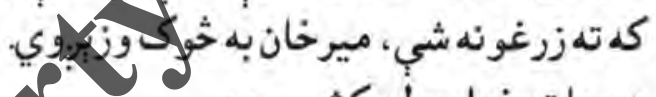
$Q$ هر جا ته خيل وطن كشمير دي، ميرخان به

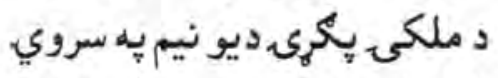

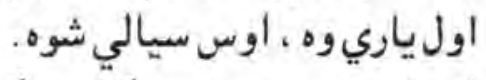

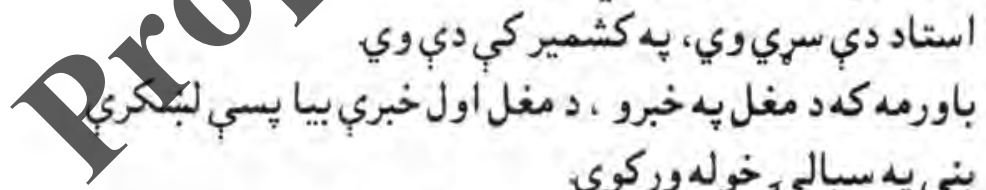
بني يه سيالى خوله وركوي.

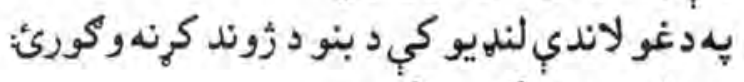
يه جلمدوي سكروتي كبربده 


$$
\begin{aligned}
& \text { لكهدوب بنب يه سيالى خوله وركوينه } \\
& \text { دا لنهى داسي هم ويل شوي ده : } \\
& \text { يه جِلم سري سكروتي كبِوبده } \\
& \text { لكه دوي بني يه سيالى خوله ورئه }
\end{aligned}
$$

• .

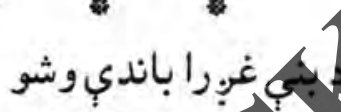

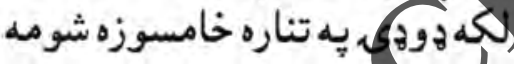

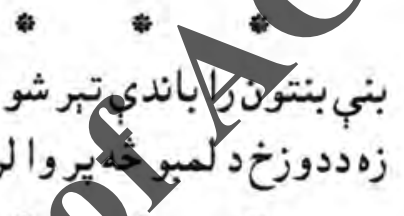

-

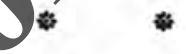

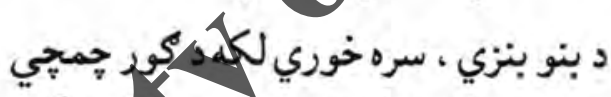

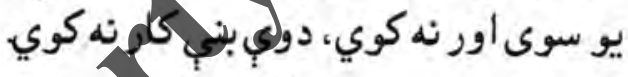

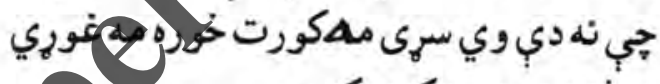

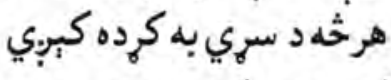

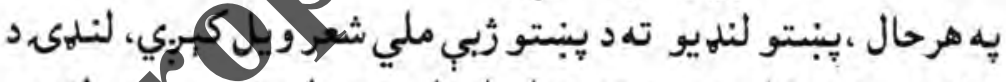

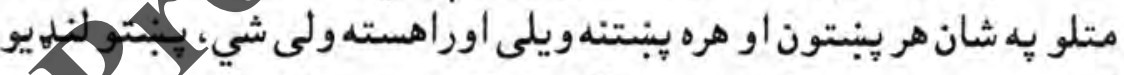

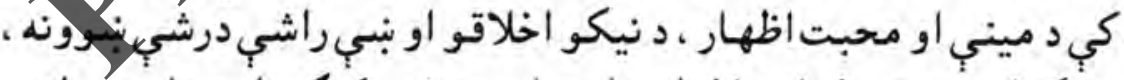

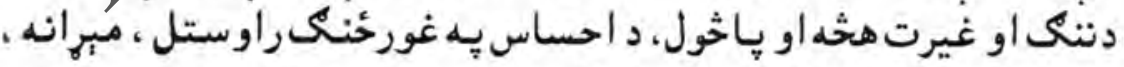

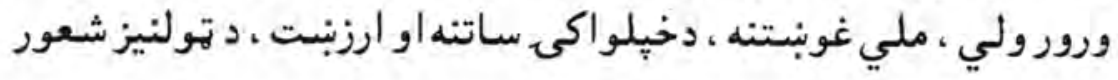

$$
\text { Jirna } \cdots 97
$$




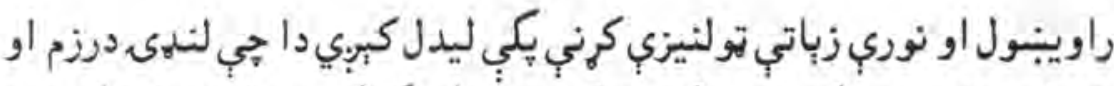

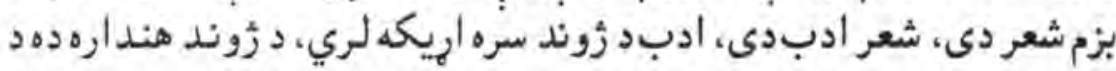

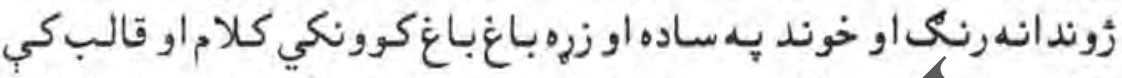

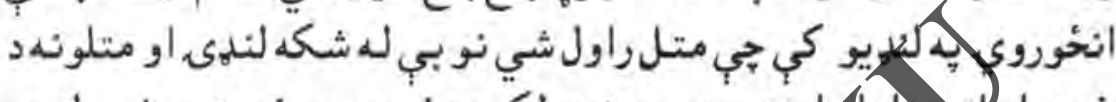

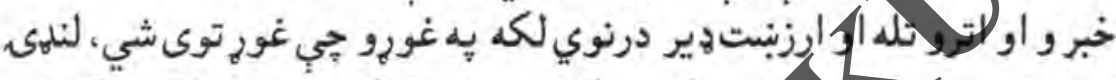

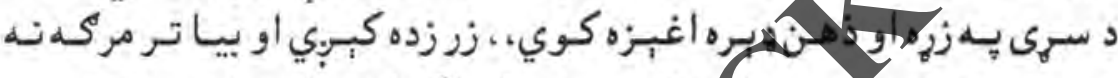

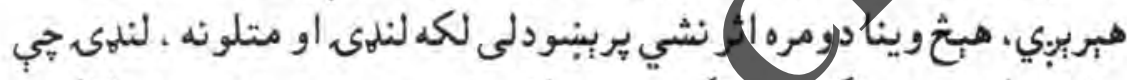

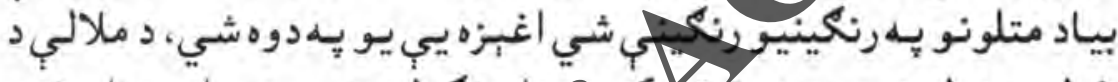

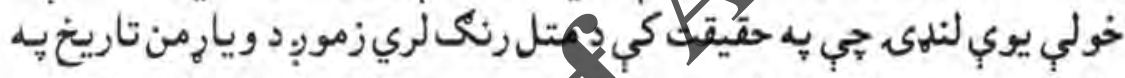

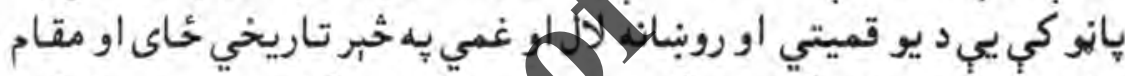

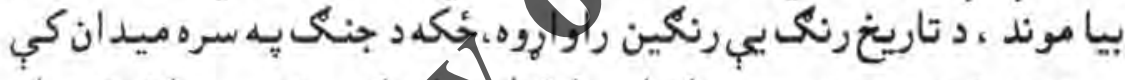

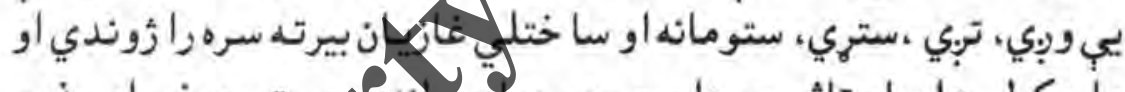

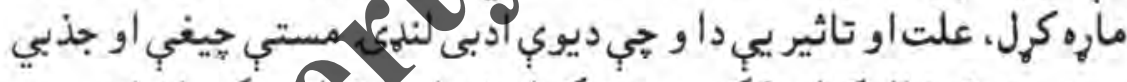

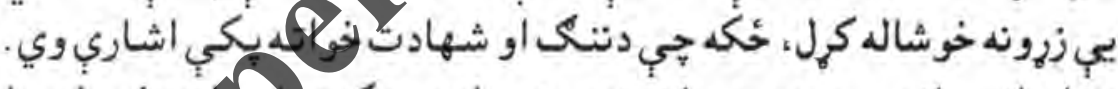

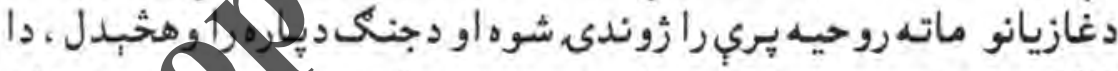

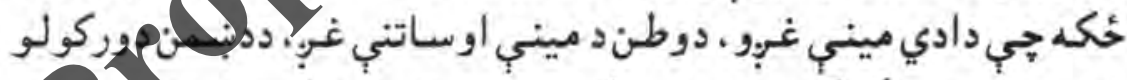

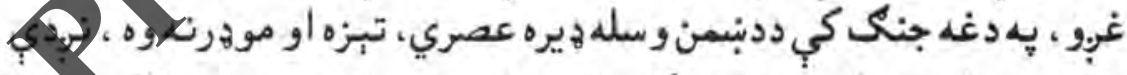

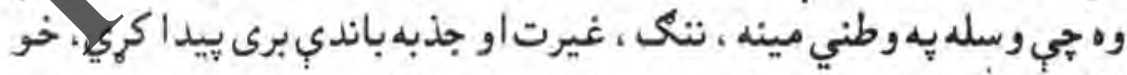

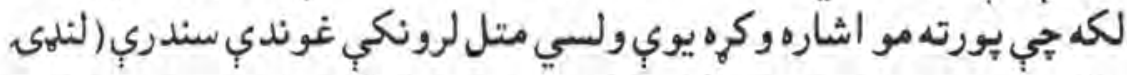

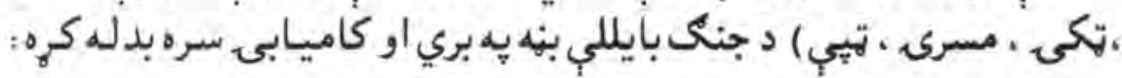

irso 


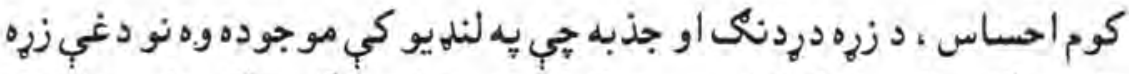

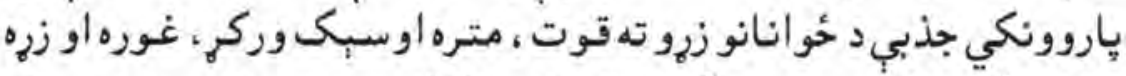

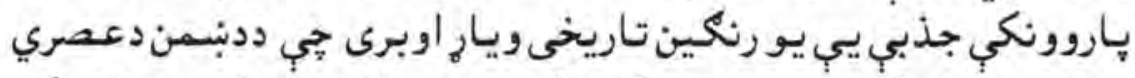

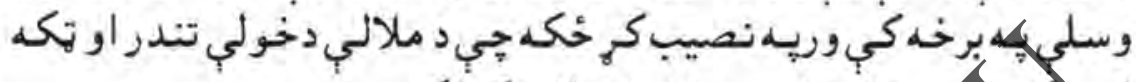

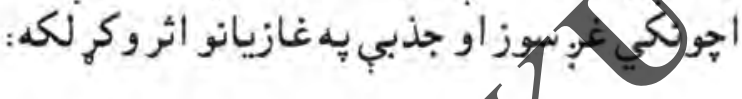

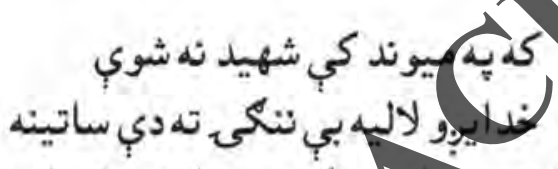

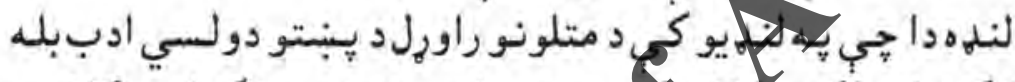

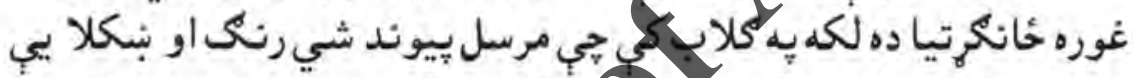

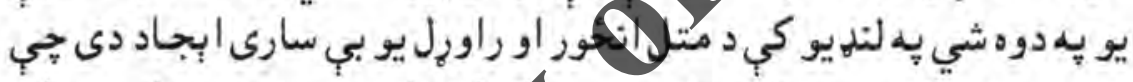

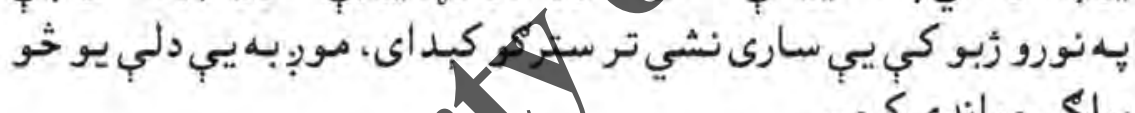

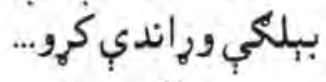

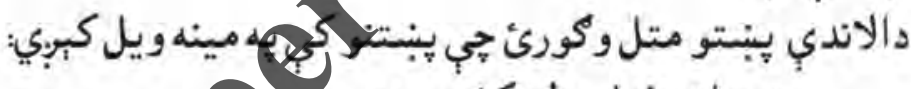

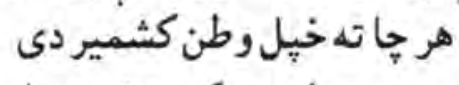

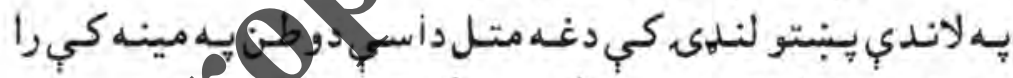

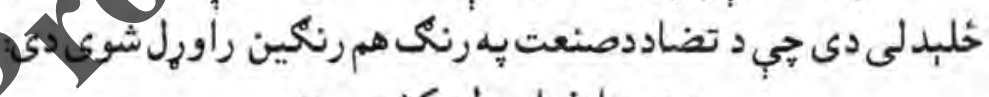

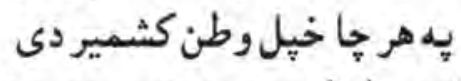

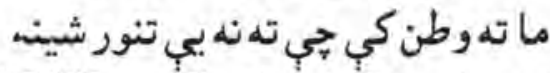

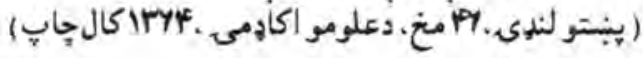

$$
\text { Jirno } \cdots 91
$$




\section{متل يه يُبْتو}

كابل مجله

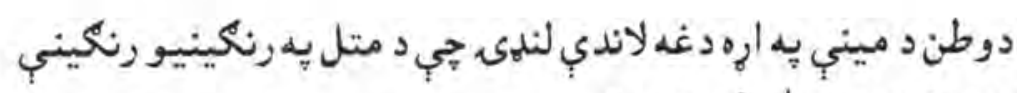

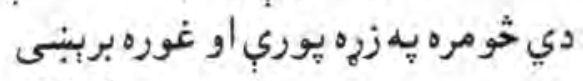

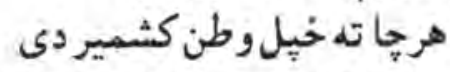

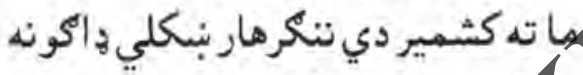

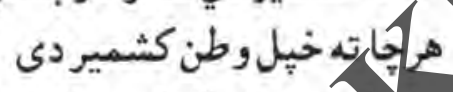

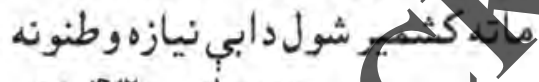

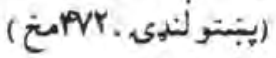

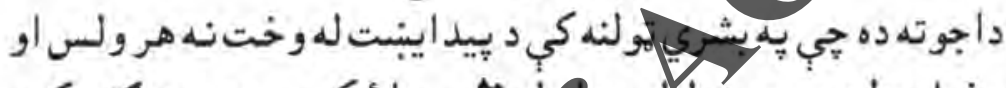

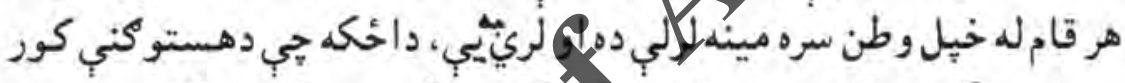

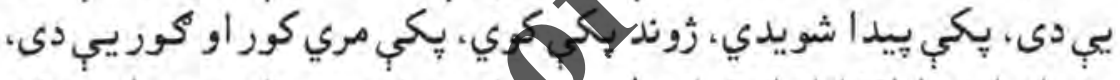

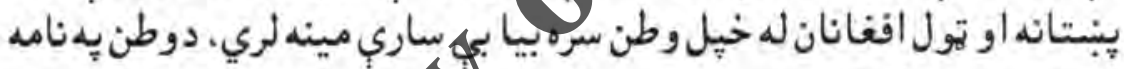

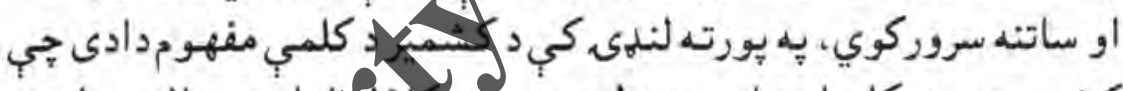

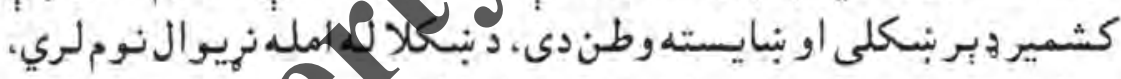

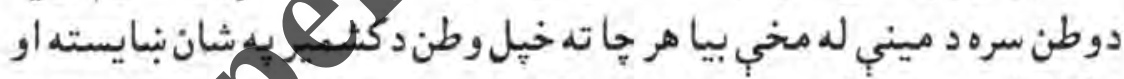

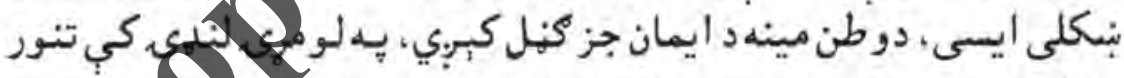

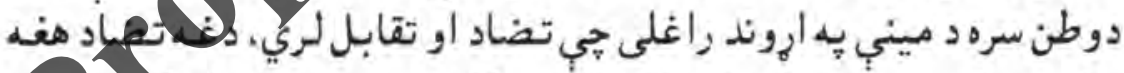

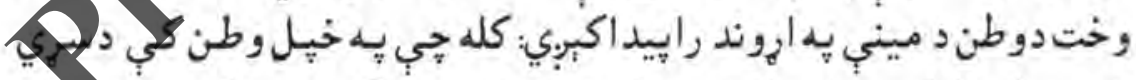

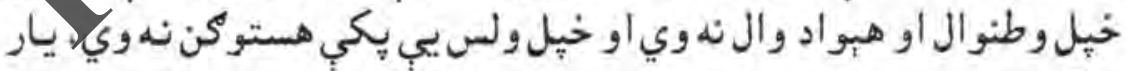

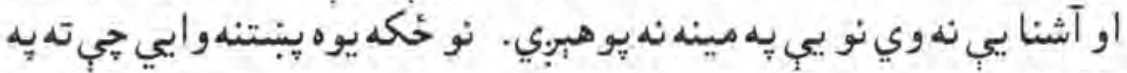

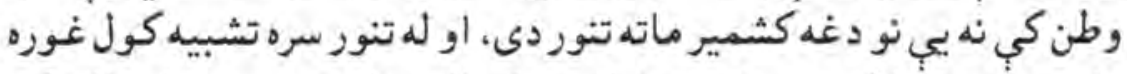

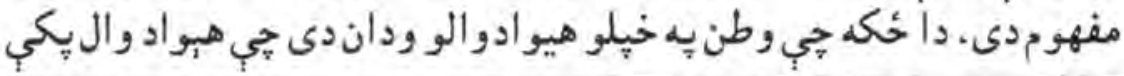

$$
\text { jlsiras } \cdots 99
$$


متل يَه ينبتو كابل مجلد

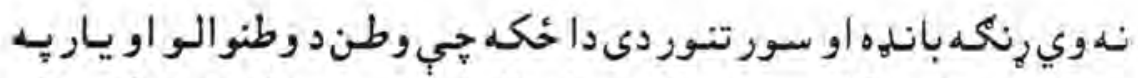

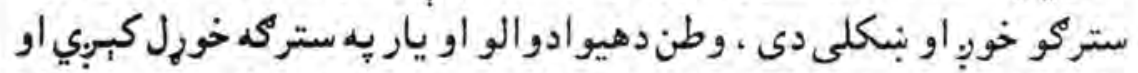

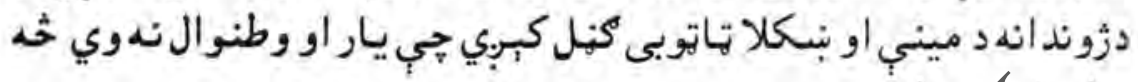

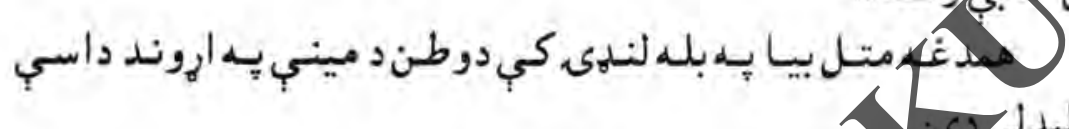
وطن خبليورطنه...

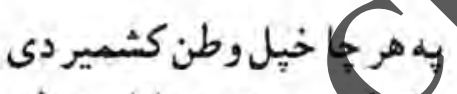

$$
\begin{aligned}
& \text { ماتهكثمير ي د جانان دوطن غرونه }
\end{aligned}
$$

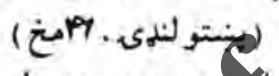

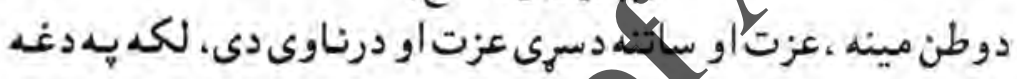

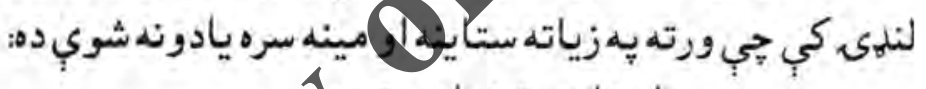

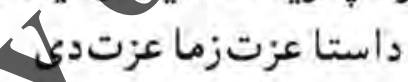

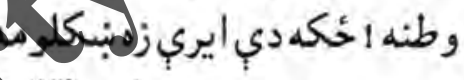

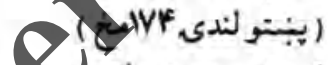

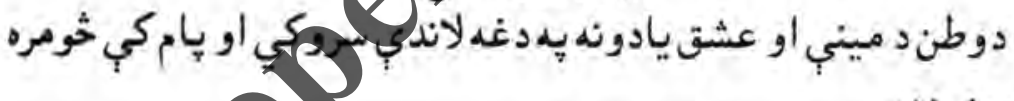

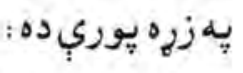

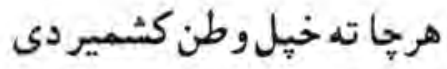

$$
\begin{aligned}
& \text { ما يردي وطن ته هبري وري } \\
& \text { زرهم مي شو زري ورئ } \\
& \text { لاس رأكه جانانه } \\
& \text { (د مجنونمنكل له خولي) }
\end{aligned}
$$

$$
1 \cdot 3 \cdot 1 \cdot 9
$$




$$
\begin{aligned}
& \text { دا يبنتو متل جبي يبنتانهيبي وايي: } \\
& \text { (( يه اصل خوك نه سرى كبربي ) ) }
\end{aligned}
$$

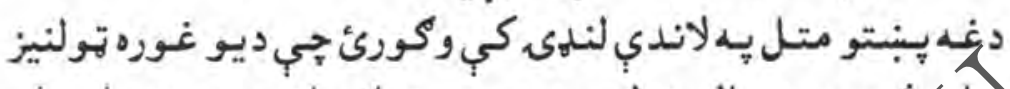

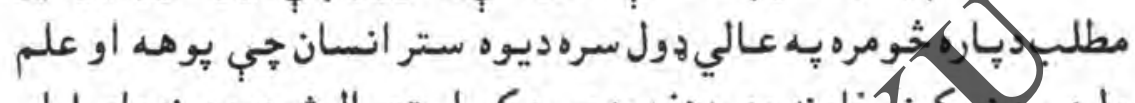

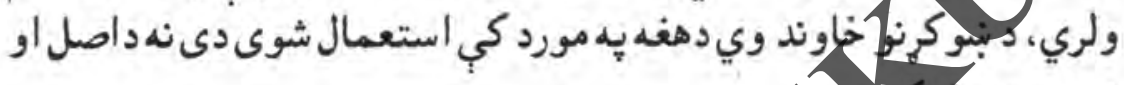

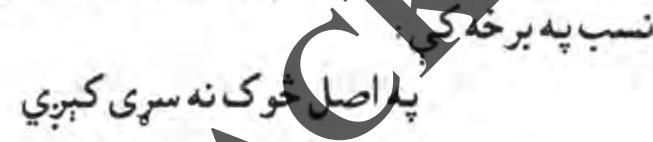

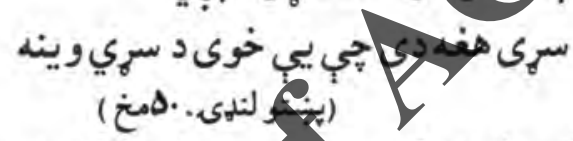

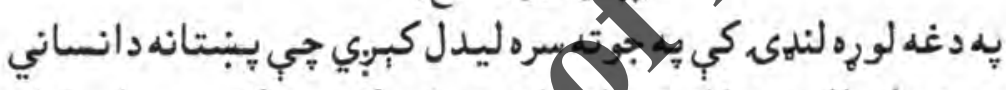

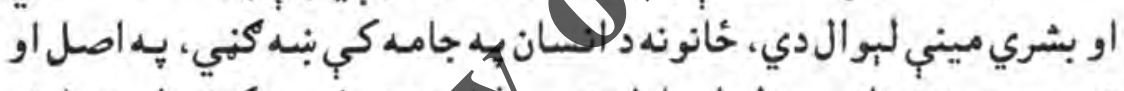

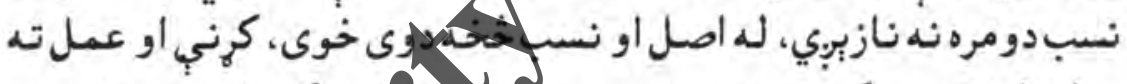

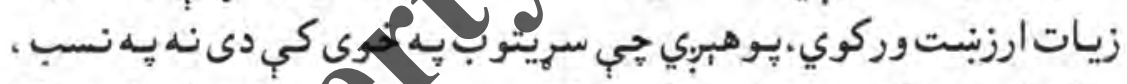

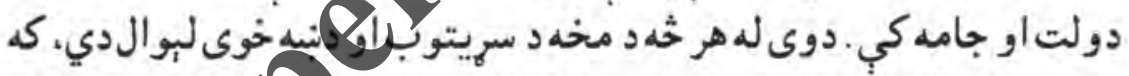

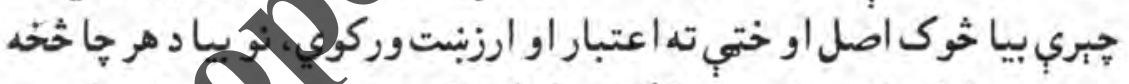

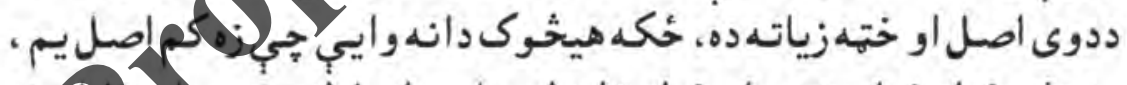

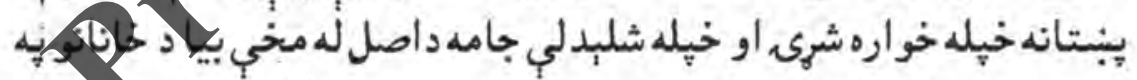

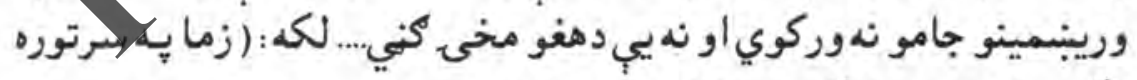

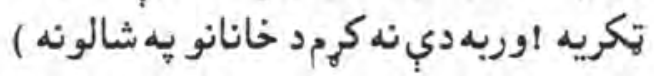

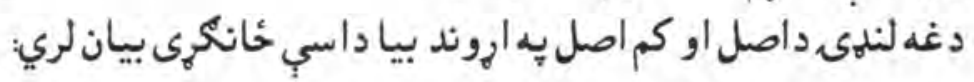

$$
\text { J }
$$




\section{متل پِيه يبنتو ...}

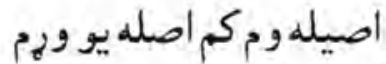

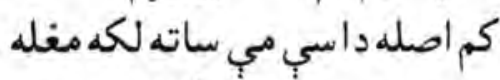

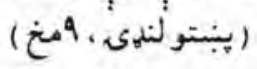

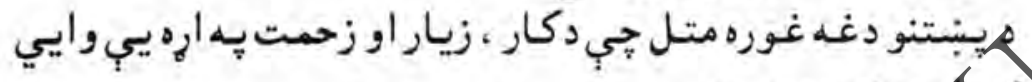

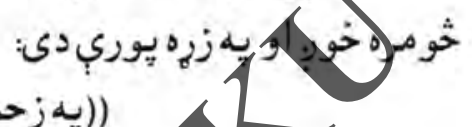

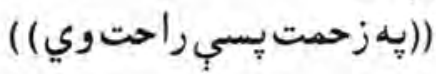

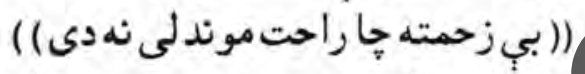

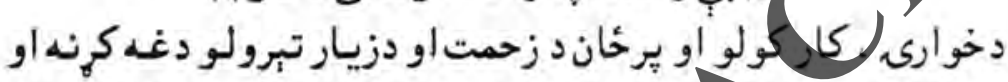

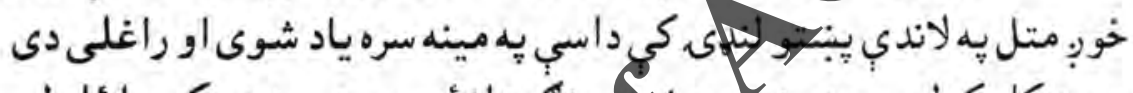

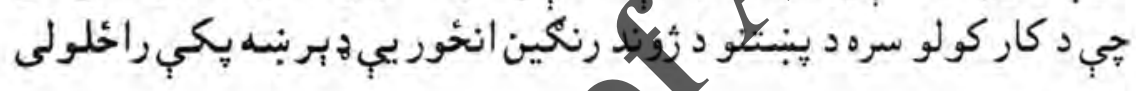
2ی

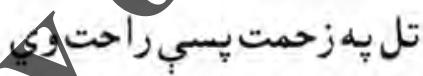

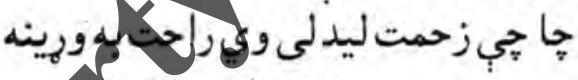

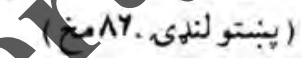

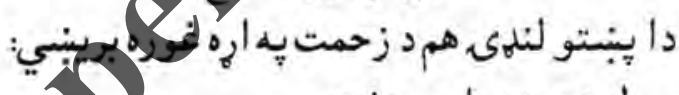

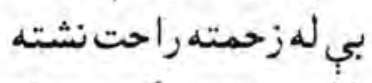

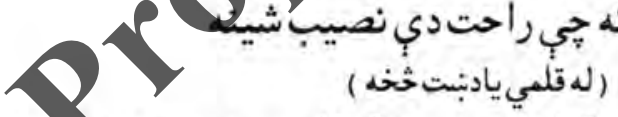

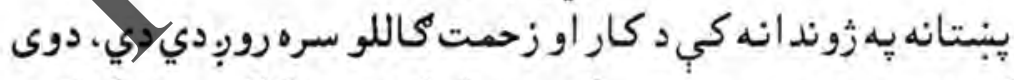

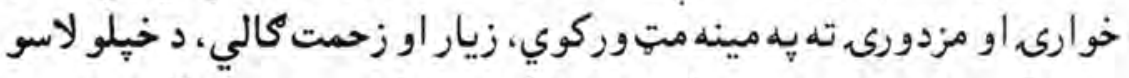

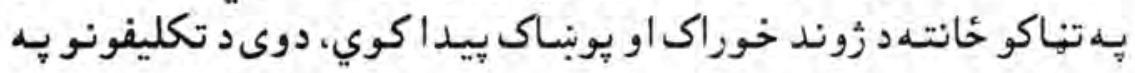

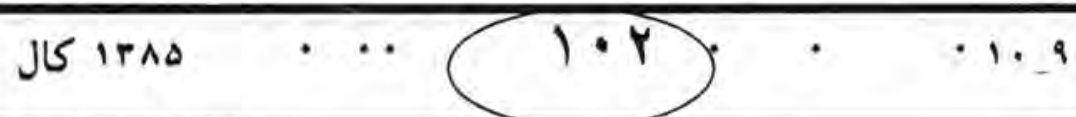




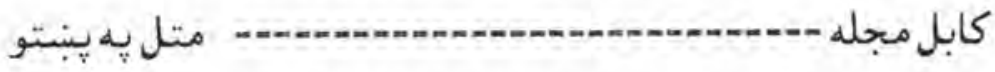

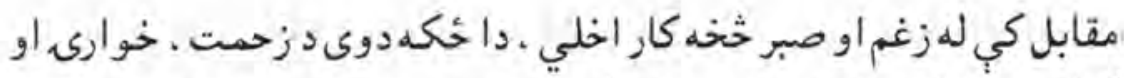

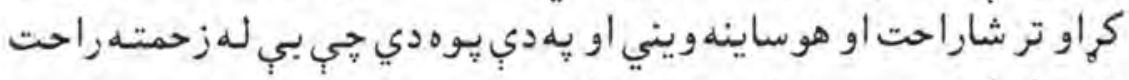

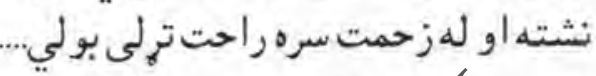

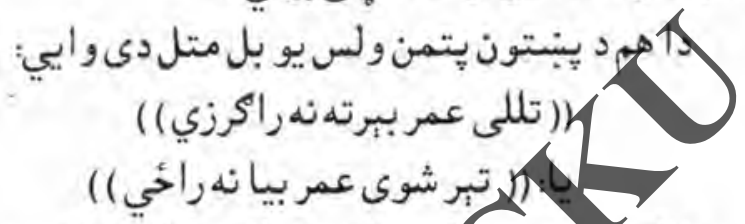

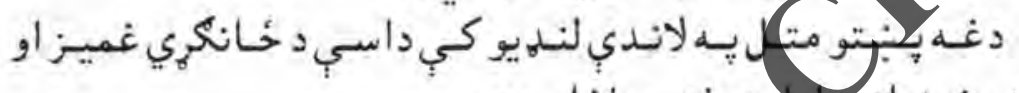

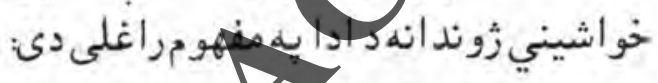
تبر شوىئلمر به برنهة شي

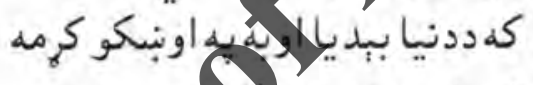

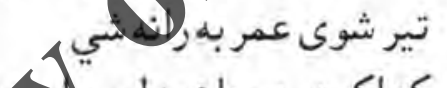

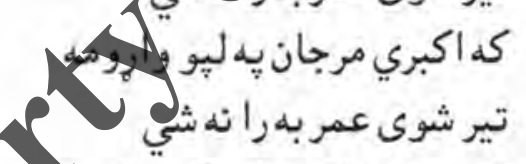

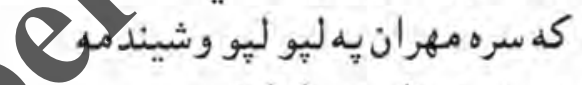
تبرشوى واربه بيا رانشي

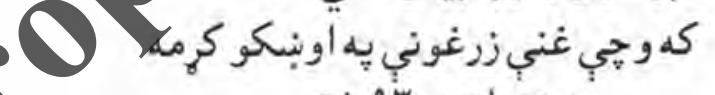

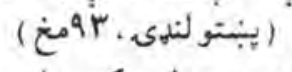

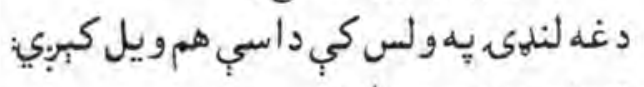
تبرشوى عمر بهرانشي

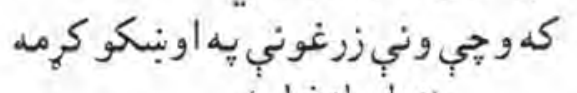

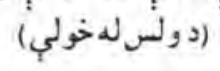

J 1 1rıo ... 


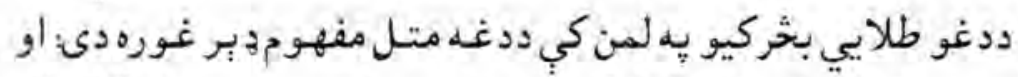

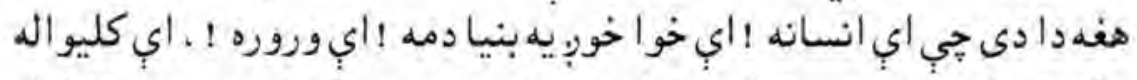

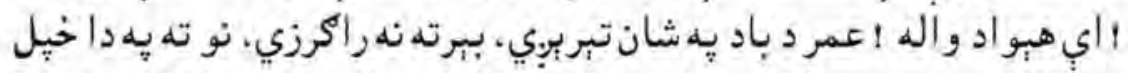

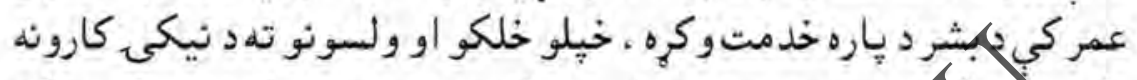

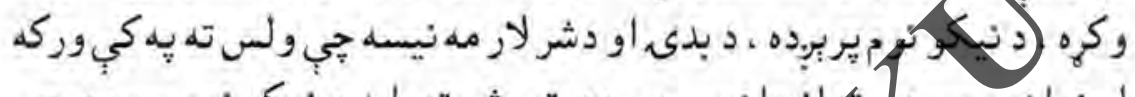

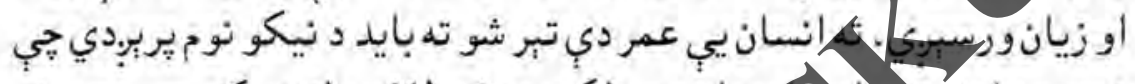

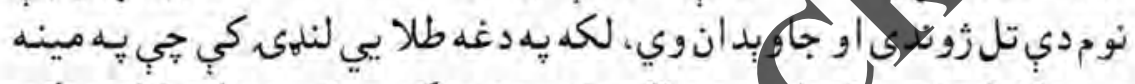

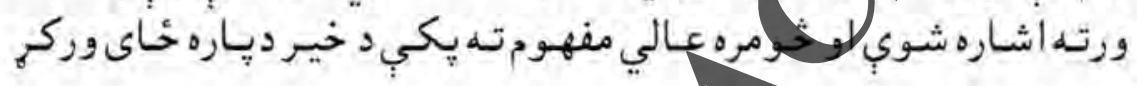

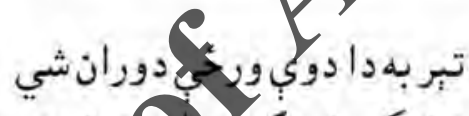

شوى ونى:

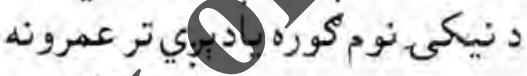

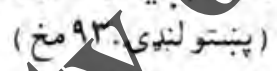

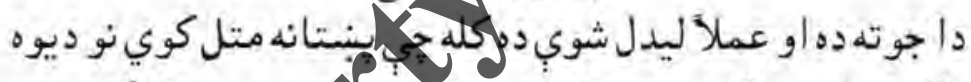

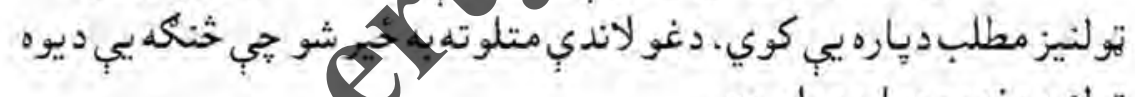
تو لنيز مفهو مديارهويلي دئي:

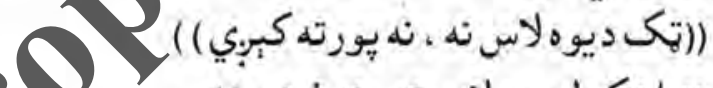

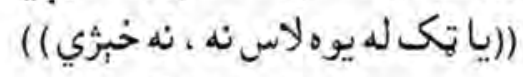

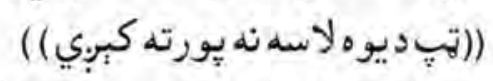

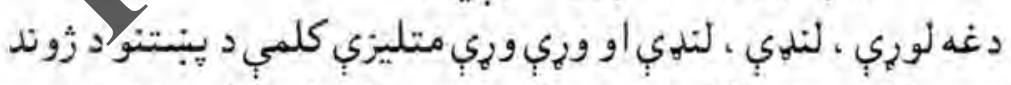

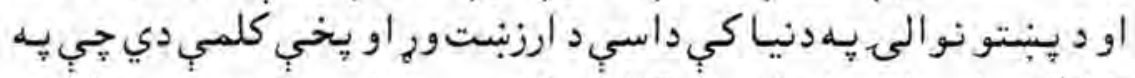

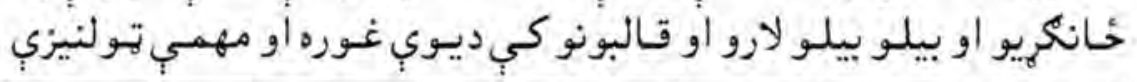

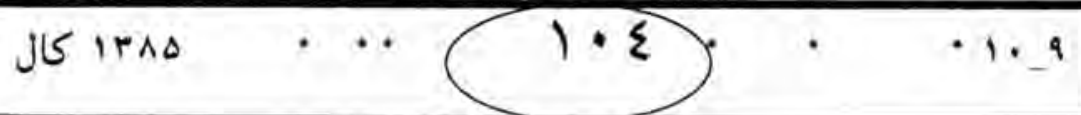




\section{متل يه يبنتو}

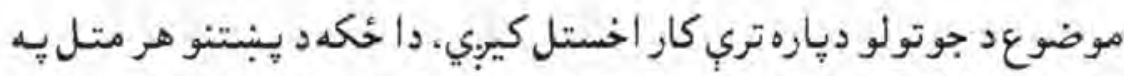

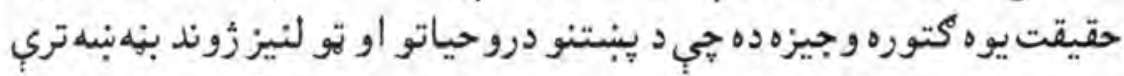

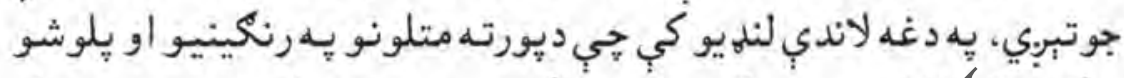

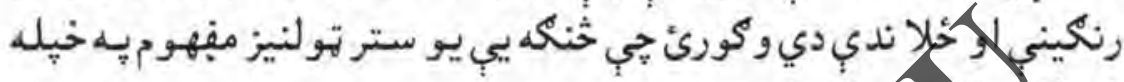

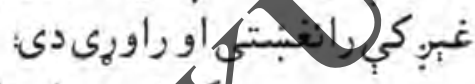

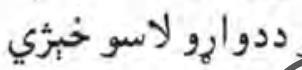

$$
\begin{aligned}
& \text { الشنا يبيم له دوارو خوا مزنكوينه } \\
& \text { تي تو هيه }
\end{aligned}
$$

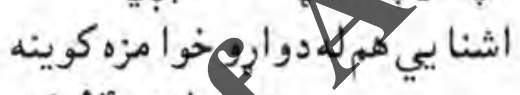

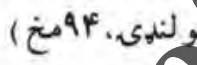

$$
\begin{aligned}
& \text { تيك خود دوارو لإولمبجي }
\end{aligned}
$$

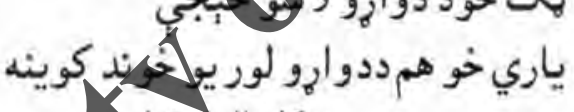

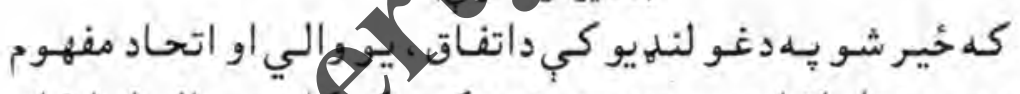

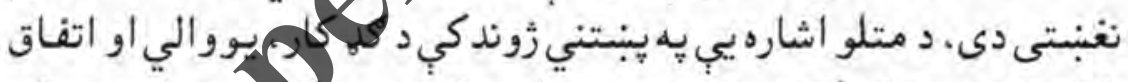

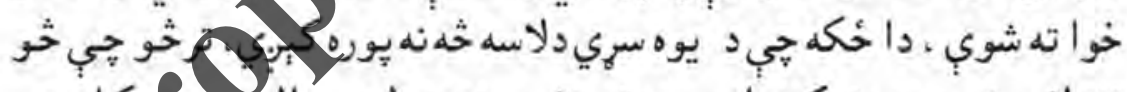

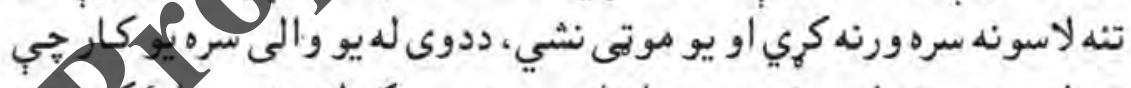

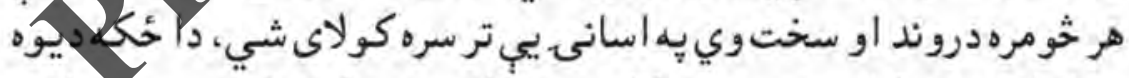

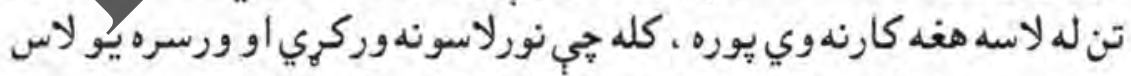

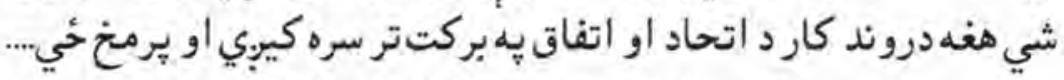

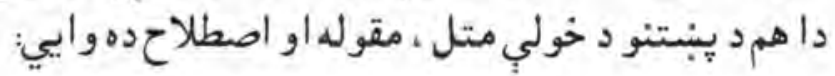

$1 \cdot 0$ 


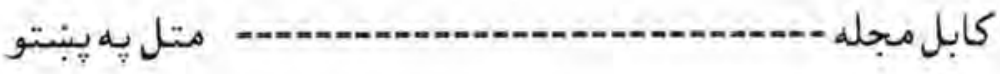

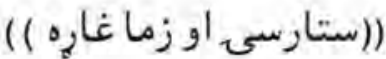 \\ يا: (( ستا خيرِه رسى أو زما يسته مسته غارهاره ) )}

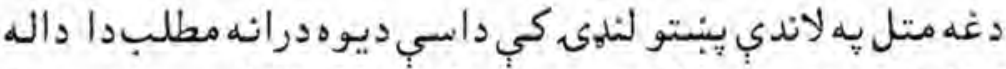

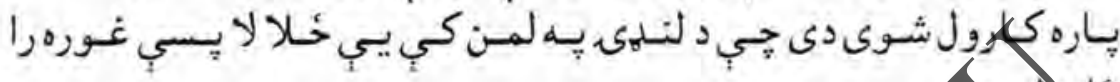

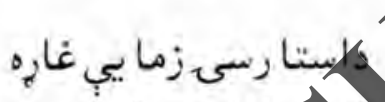

$$
\begin{aligned}
& \text { كذيهِ لزار مب خرخوي }
\end{aligned}
$$

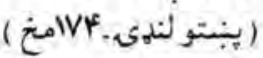

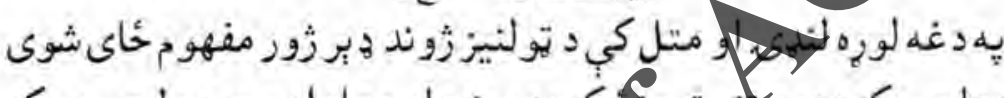

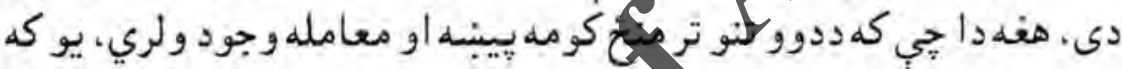

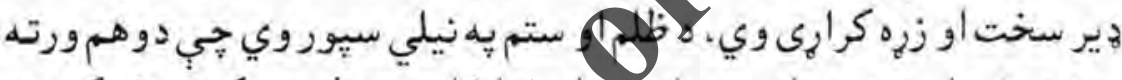

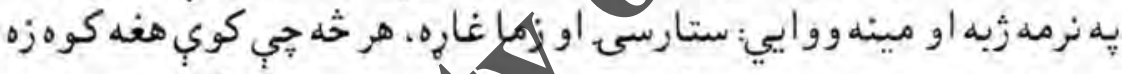

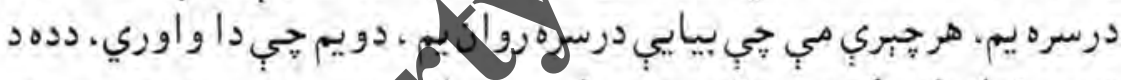

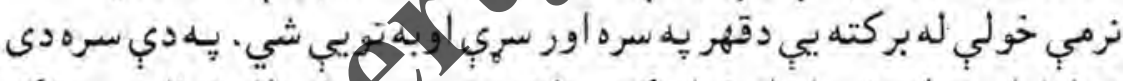

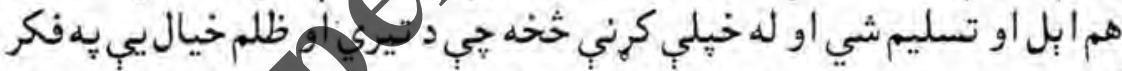

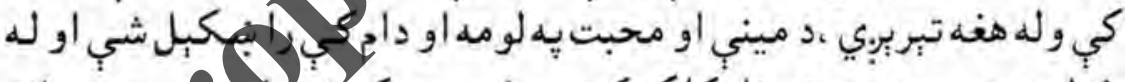

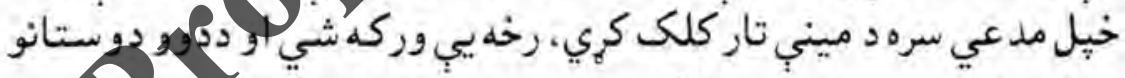

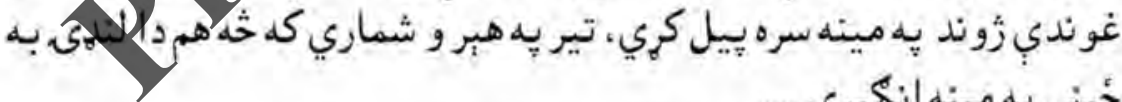

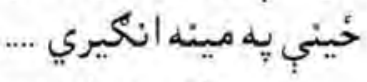

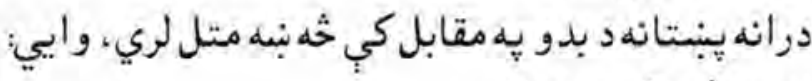

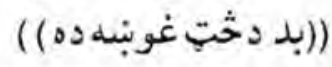




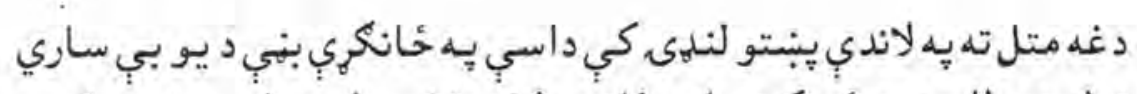

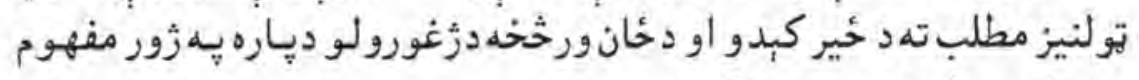

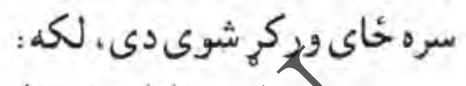

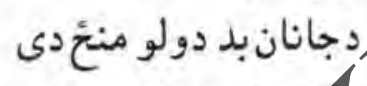

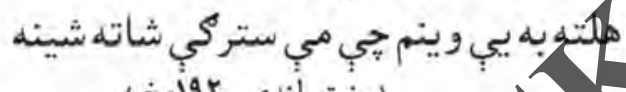

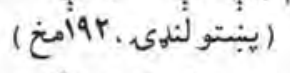

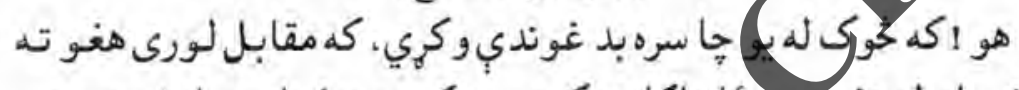

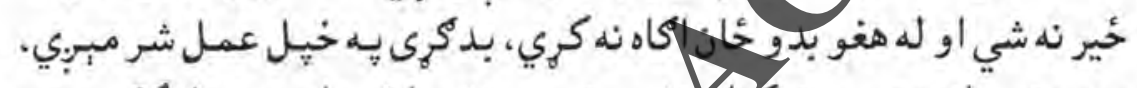

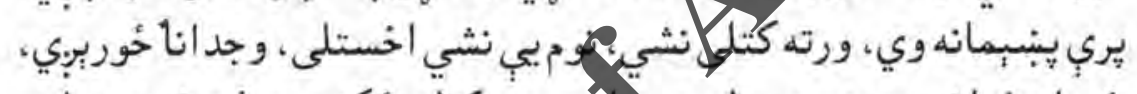

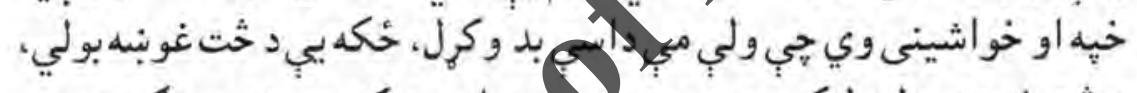

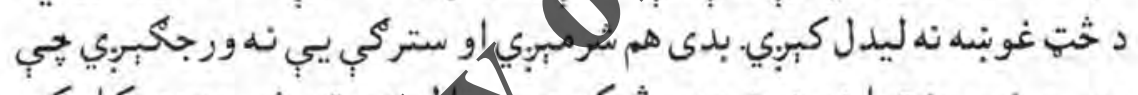

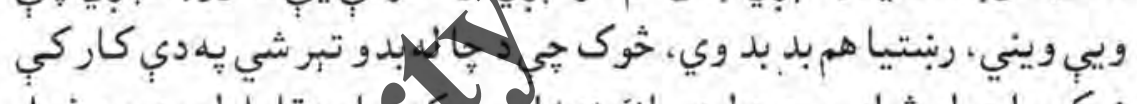

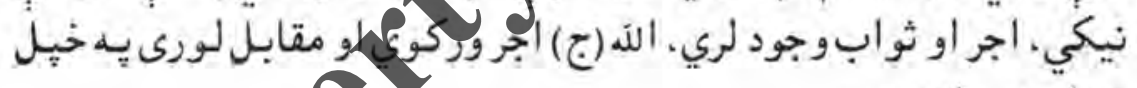
Q

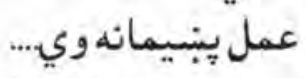

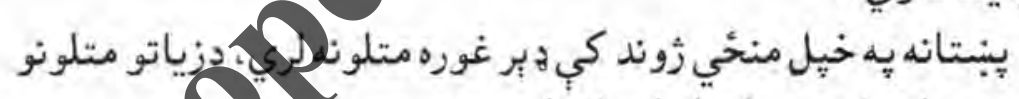

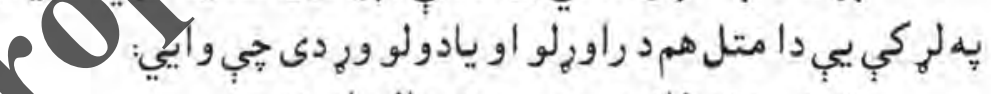

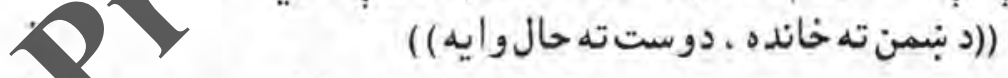

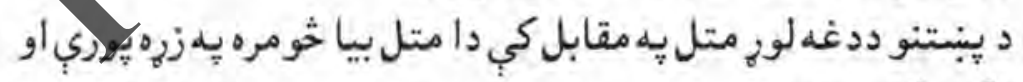
د يند نه جرك مالو مببري:

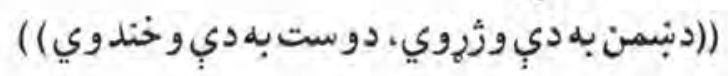
IrAs
$1 \cdot \sqrt{0}$
1. 9 


\section{متل يه يِبنتو}

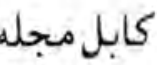

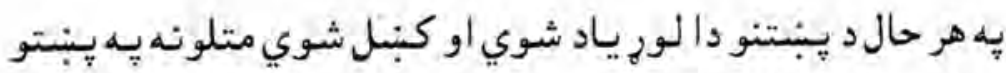

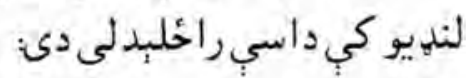

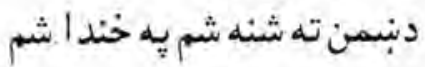

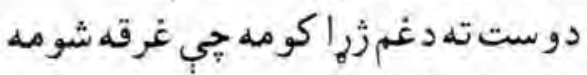

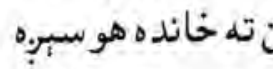

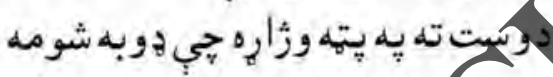

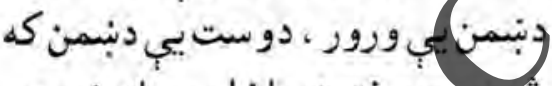

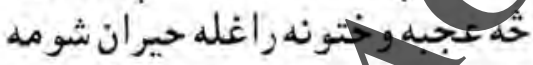

(2)

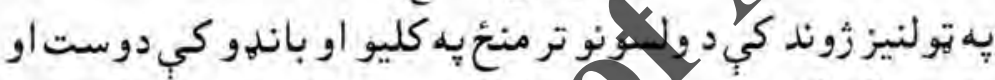

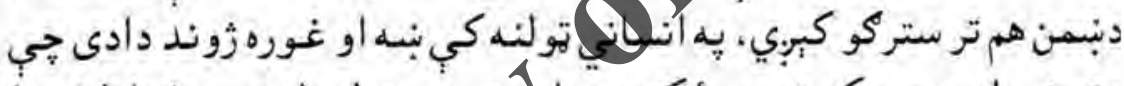

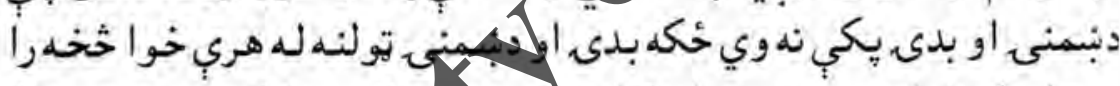

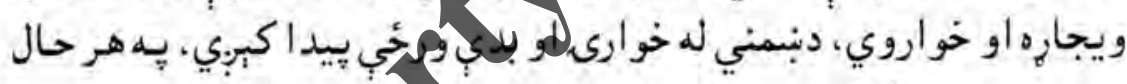

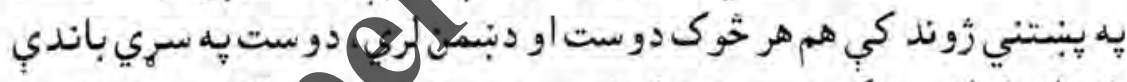

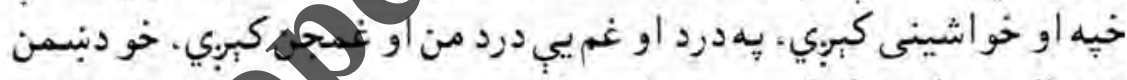

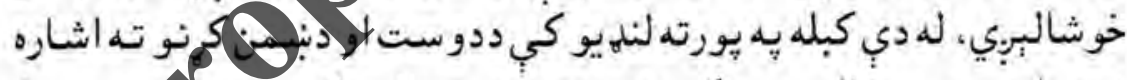

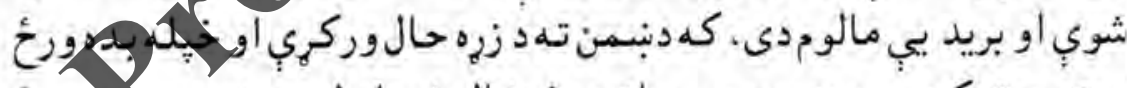

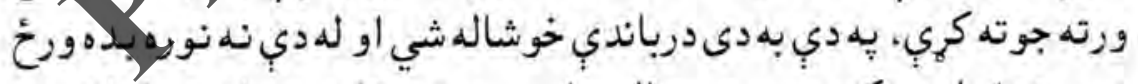

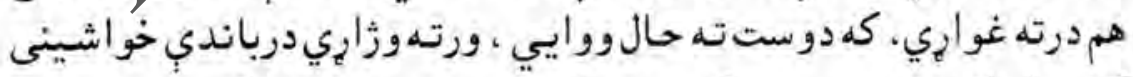

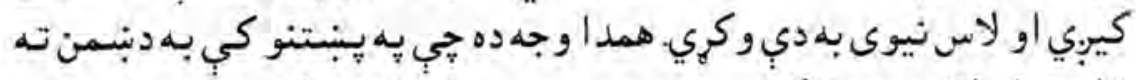

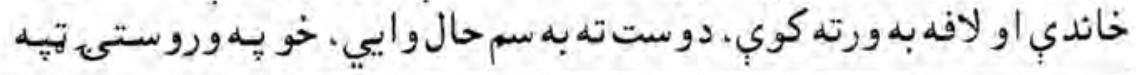

. $\cdot 1101.1 .9$




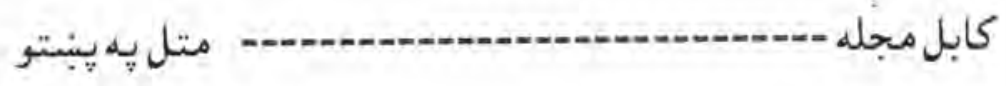

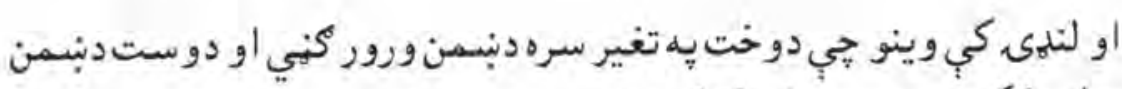

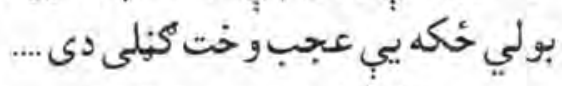

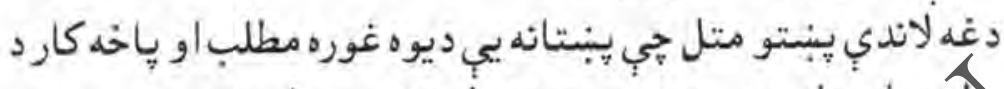

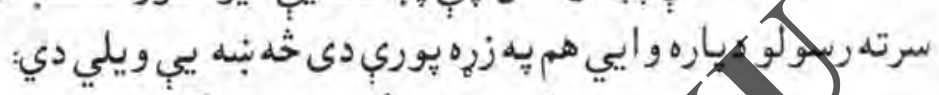

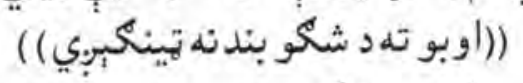

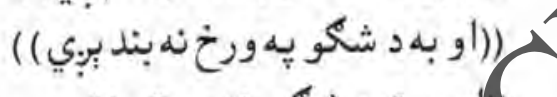

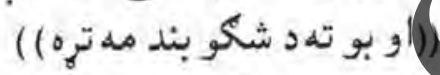

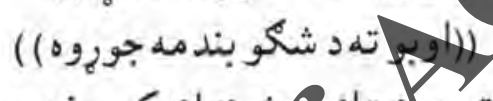

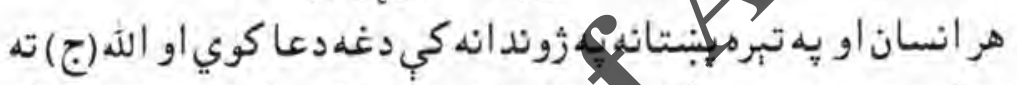

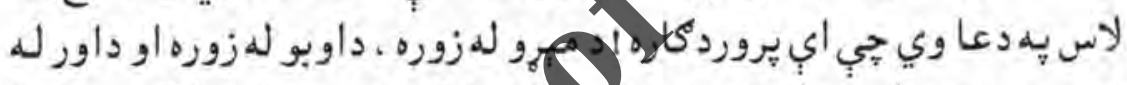

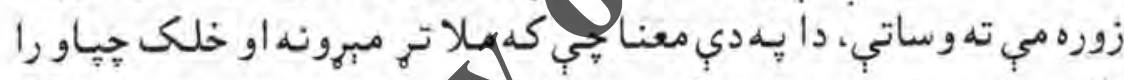

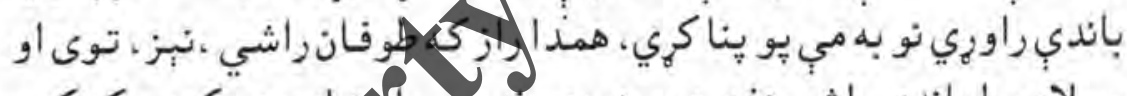

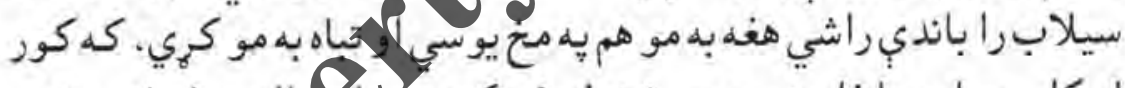

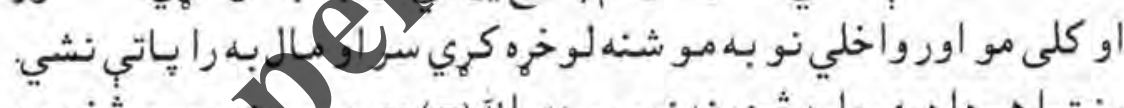

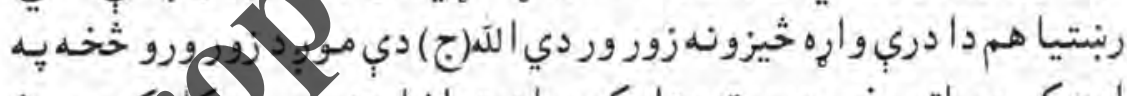

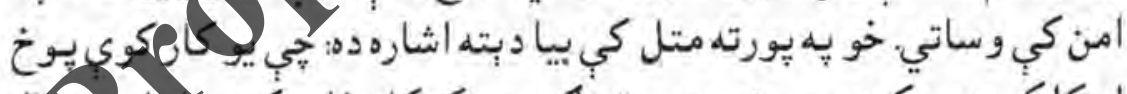

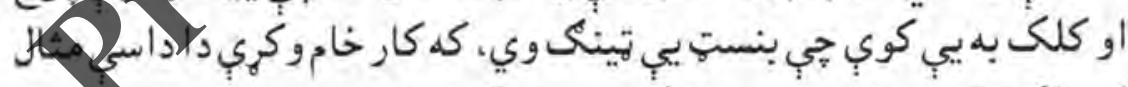

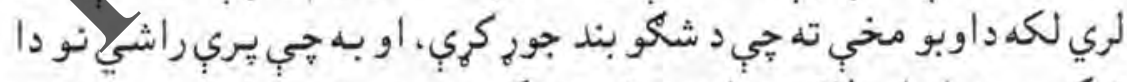

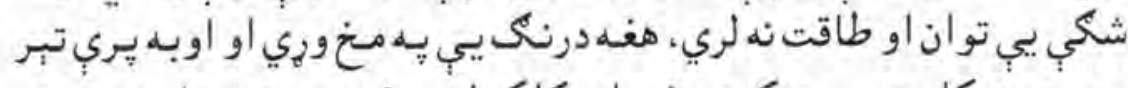

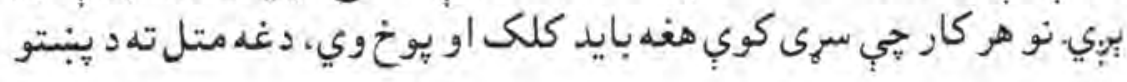

J

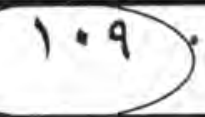

+ 1. 9 


\section{متل يَه يِبنتو}

كابل مجله

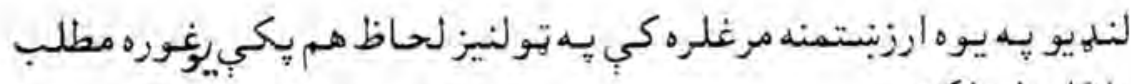

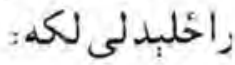

$$
\begin{aligned}
& \text { زما زئى شك شكو ورخدى }
\end{aligned}
$$

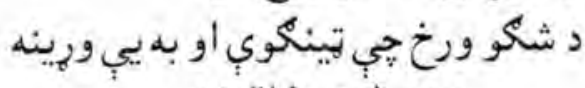

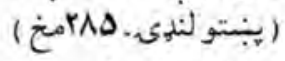

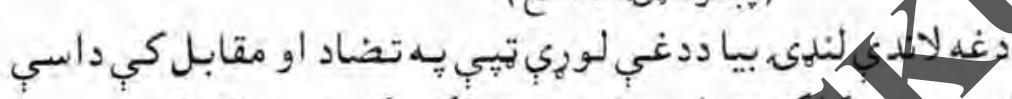

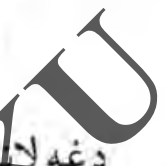

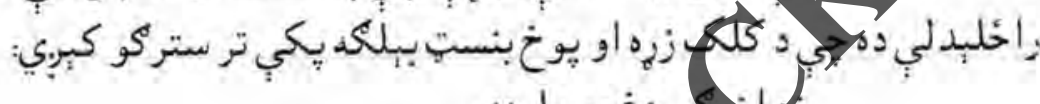

$$
\begin{aligned}
& \text { زلمانكي دغمو يل يلدى }
\end{aligned}
$$

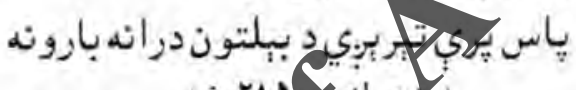

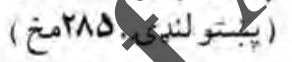

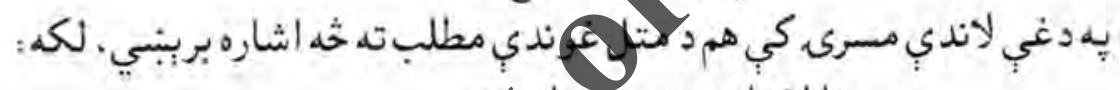

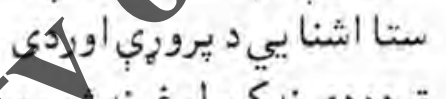

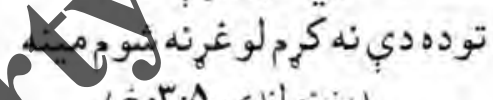

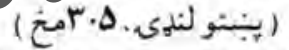

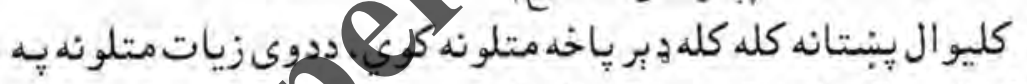

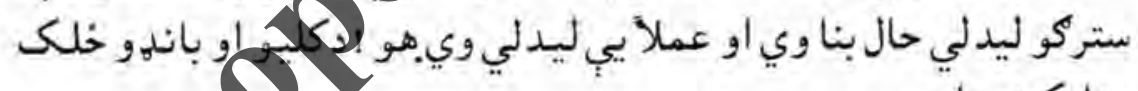

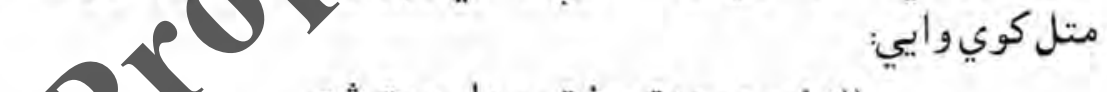

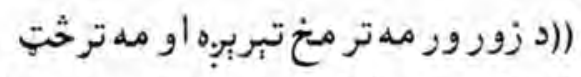

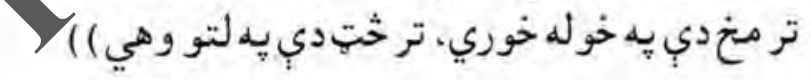

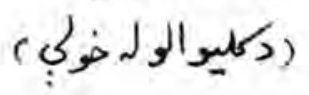

J6 irso

$11 \cdot$

- 1. 9 


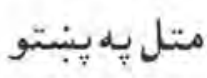
كابل مجله

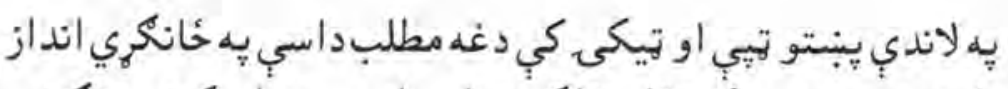

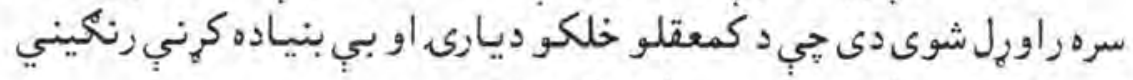

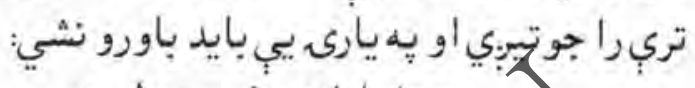

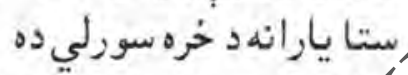

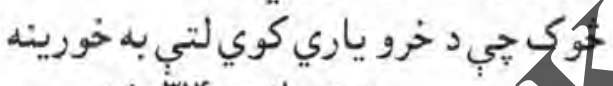

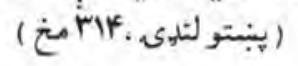

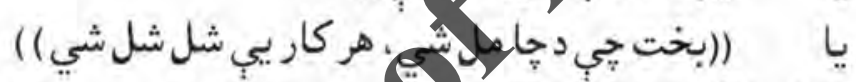

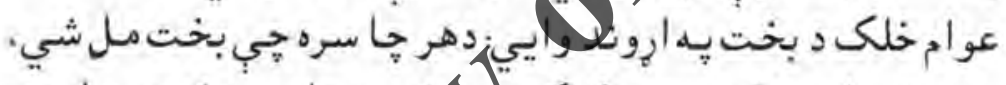

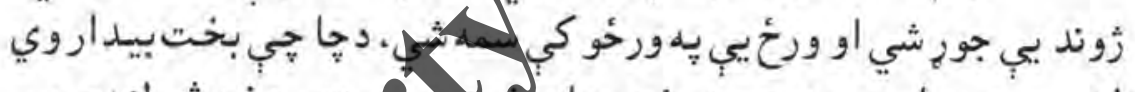

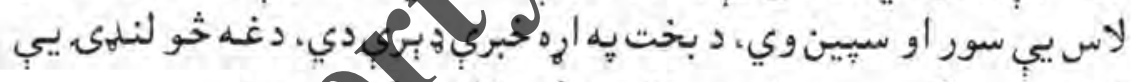

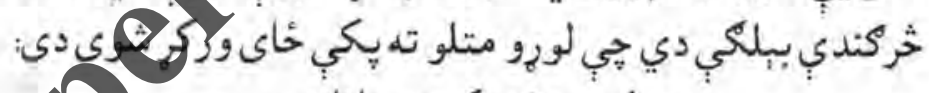

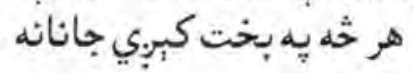

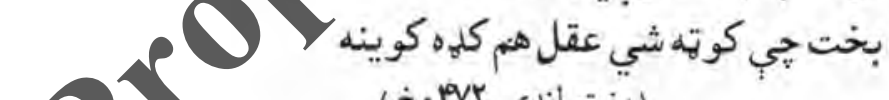

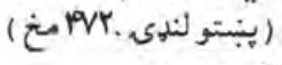

$$
\text { بخت دي دهيحا كوته نشي }
$$

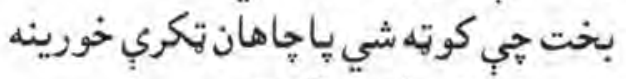

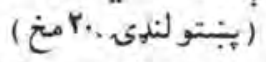

$$
\begin{aligned}
& \text { بخت خو دهيحزا كو ته مله لخي }
\end{aligned}
$$

$$
\text { juirns } \cdots(111) \cdot 9
$$




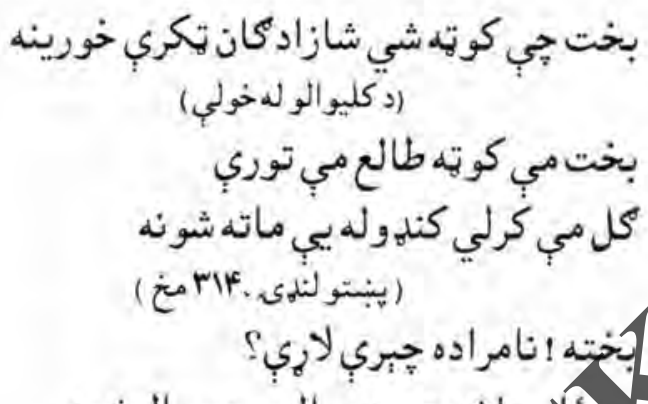

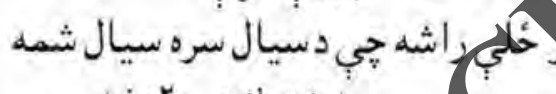

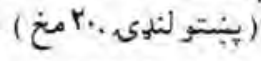

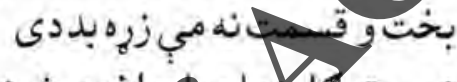

نورو ته كلرلما ديعه اغزي شينه

(2)

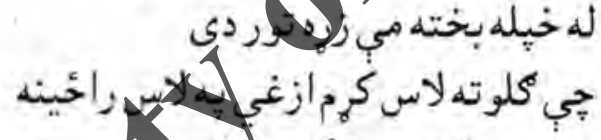

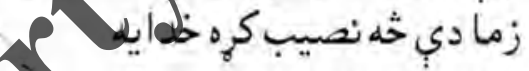

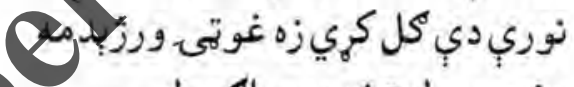
بخت مي له تخته يه هو اكى ولي

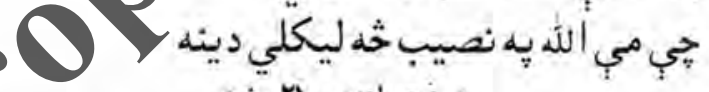

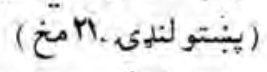

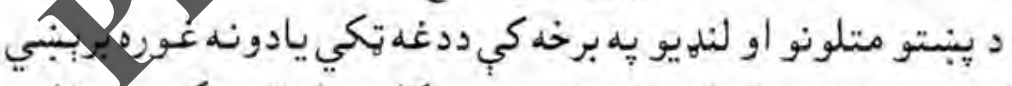

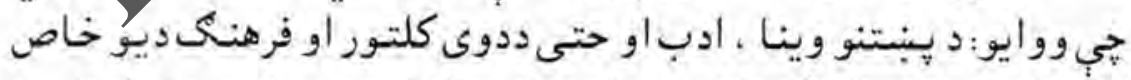

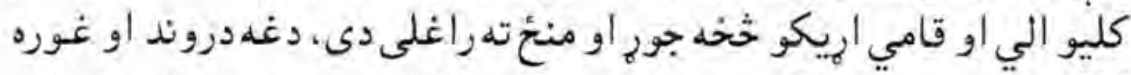

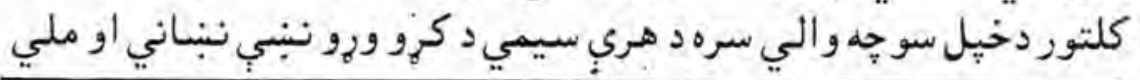

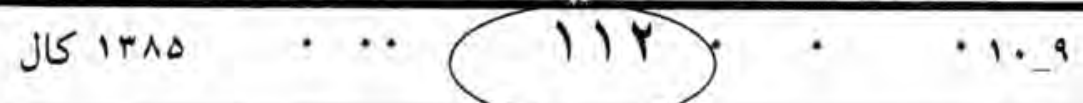




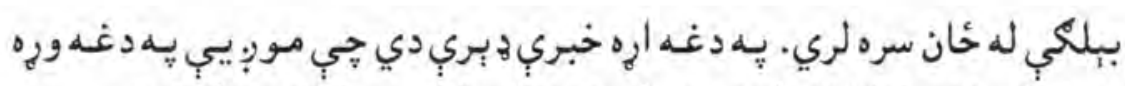

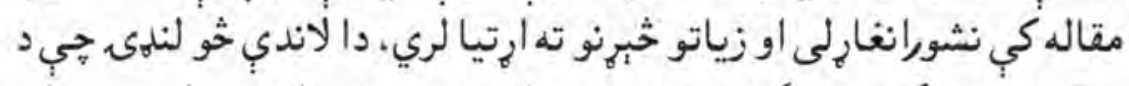

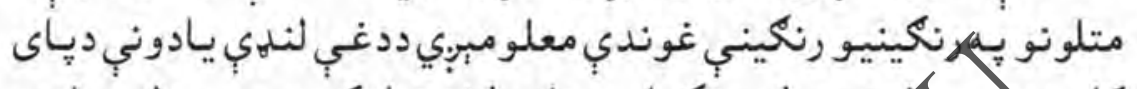

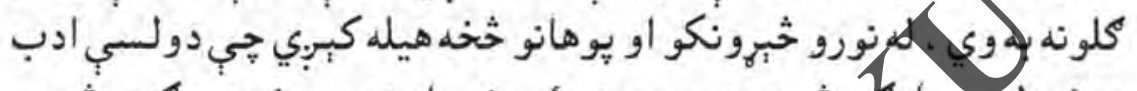

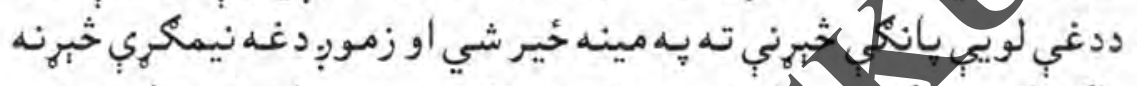

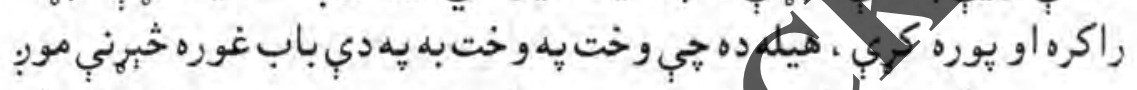

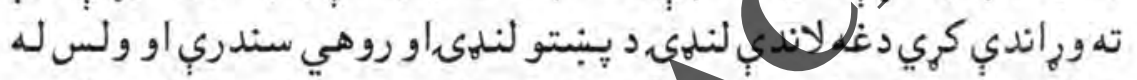

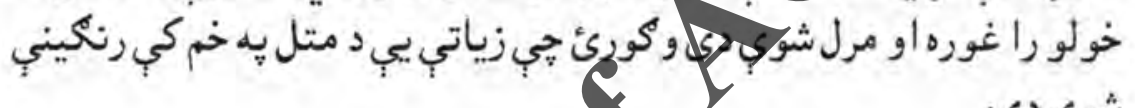

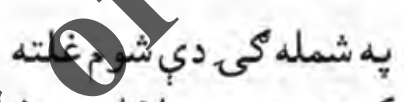
شويدي:

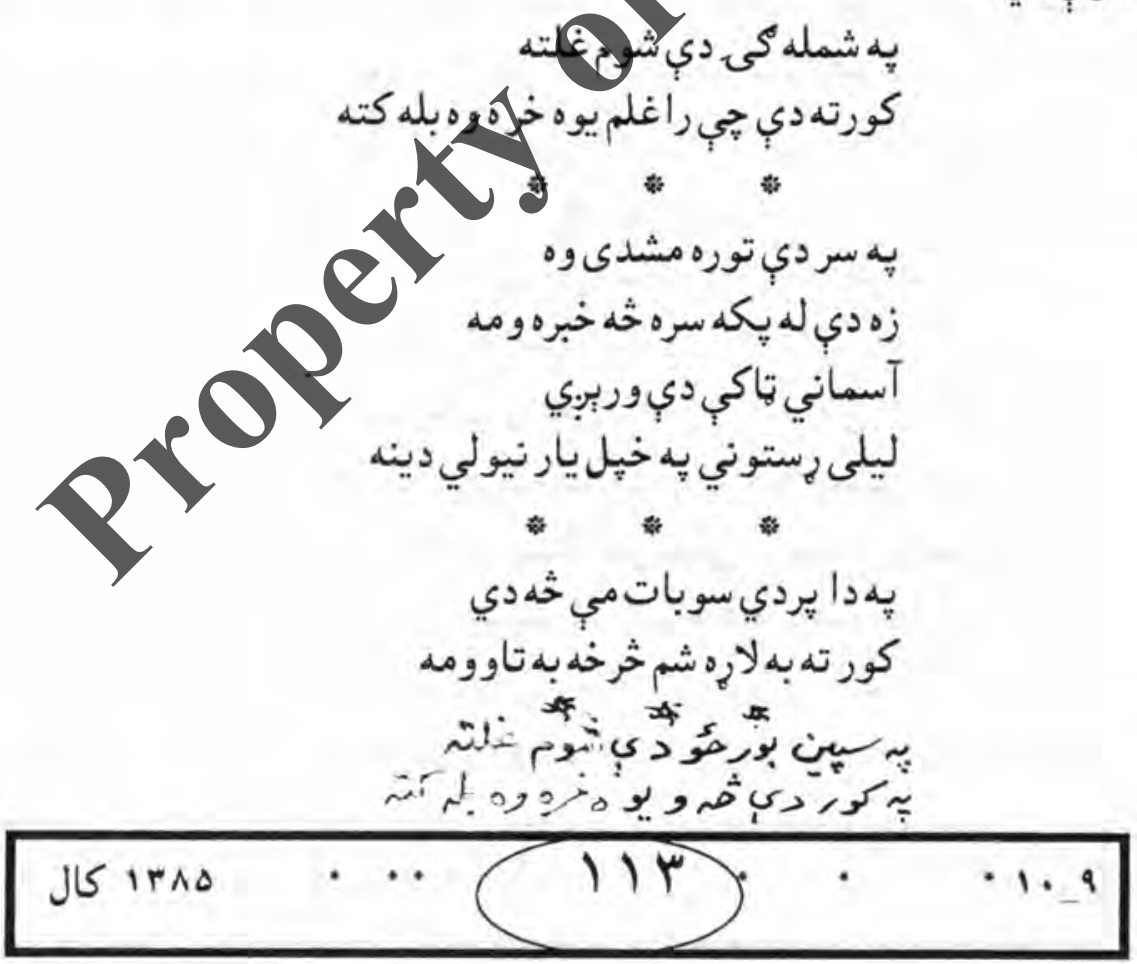




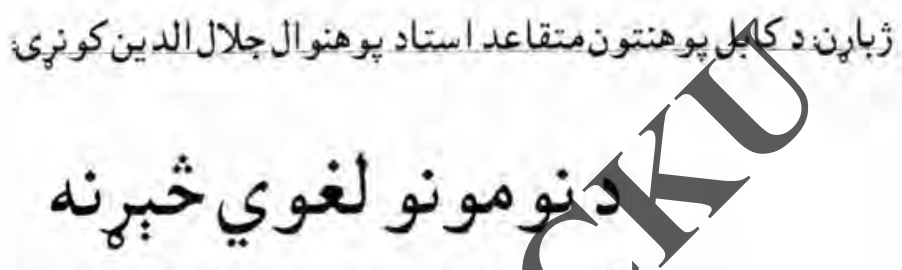

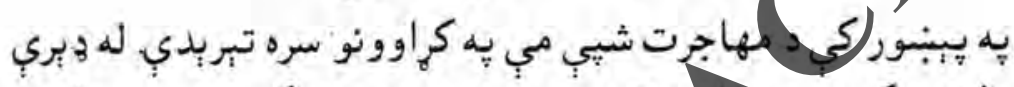

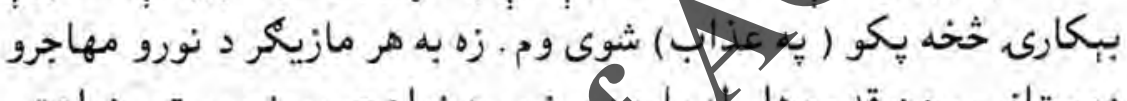

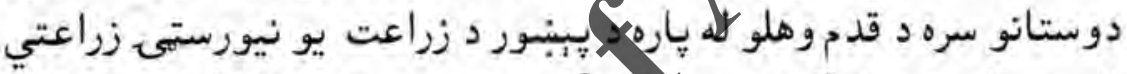

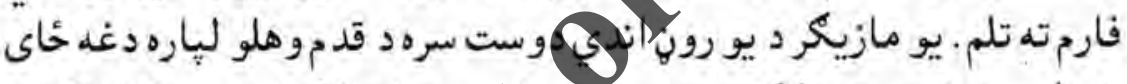

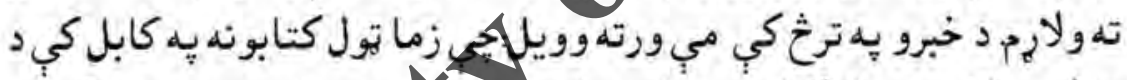

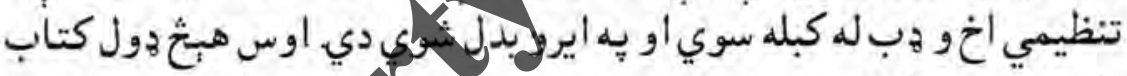

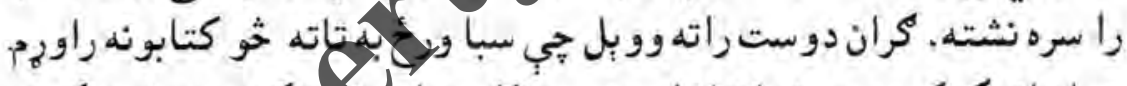

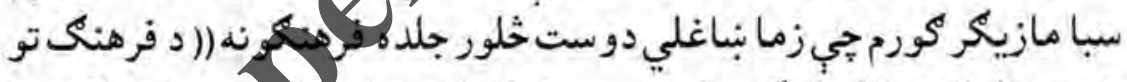

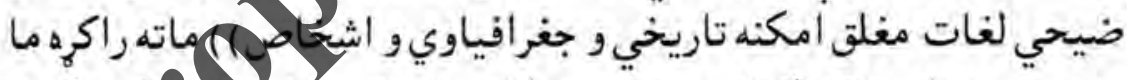

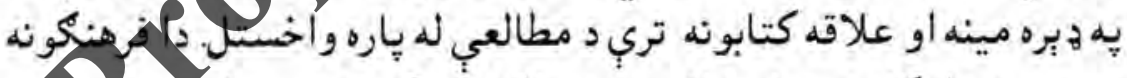

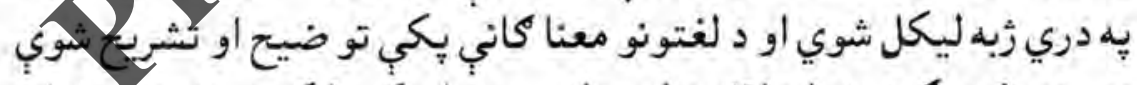

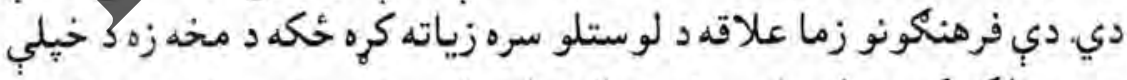

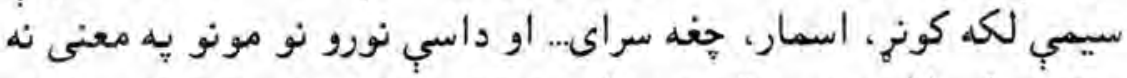

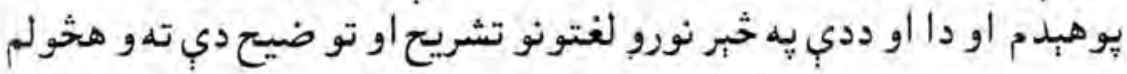

J 1 IrAs

1)ह

- 1.9 


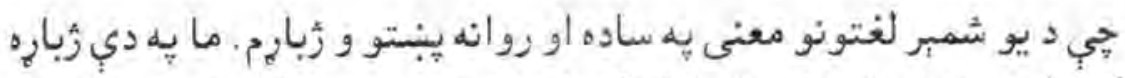

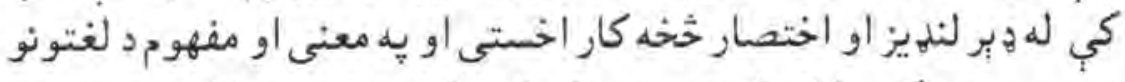

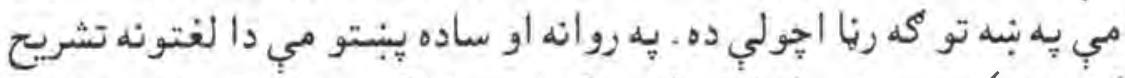

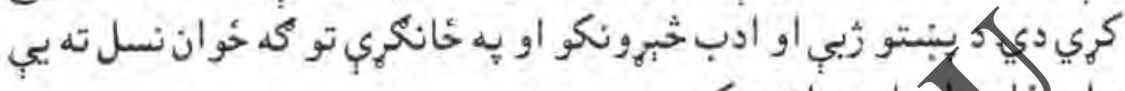

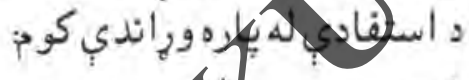

\section{معنى}

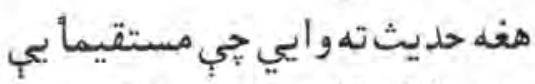

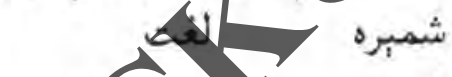

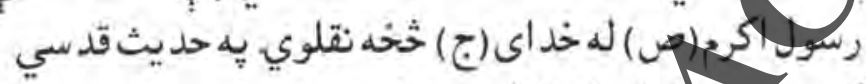

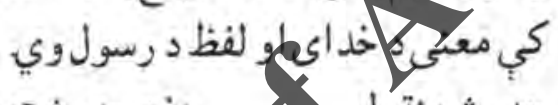

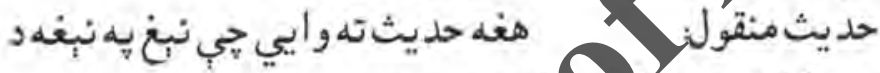

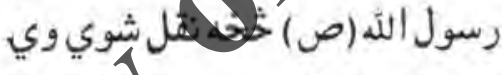

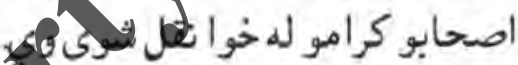

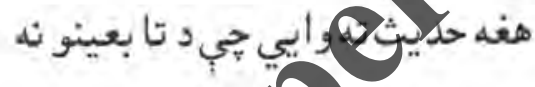

S5)

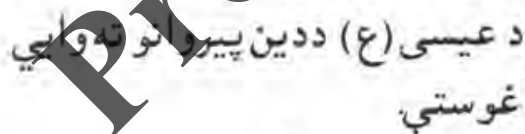

$$
\text { حِي سِيني جامي بلبي اغوستي. }
$$

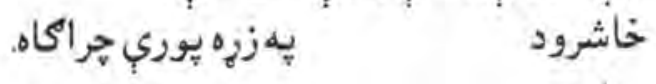$$
\text { سيوبِّمى }
$$

يما 


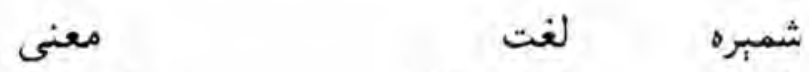

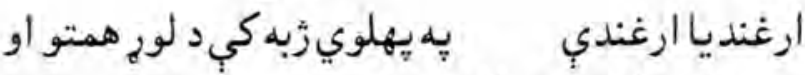

9

تورياليو د اوسبدو خائ تهو اييي

$$
\text { امبراطور }
$$

د ست ناخورده يعنب ياكه او سيبخلي

إيراطر

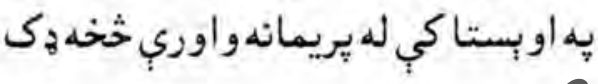

غره تهويلاكبِيجي

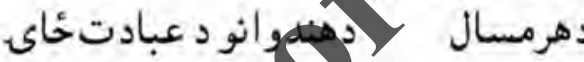

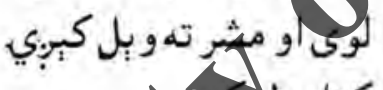

$$
\begin{aligned}
& \text { رلجه: } \\
& \text { كتابلزيكن }
\end{aligned}
$$

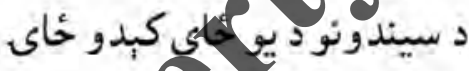

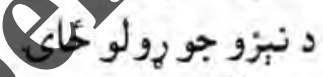

زرنج

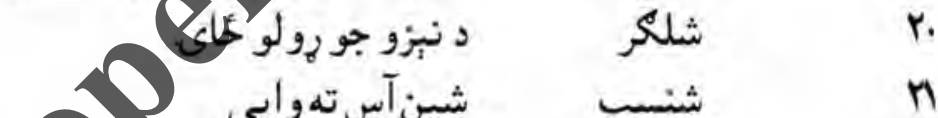

Iy

IV

in

19

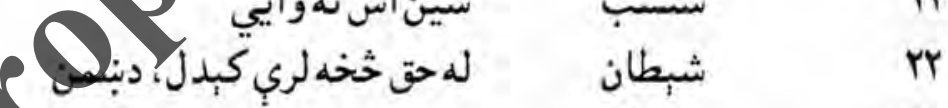

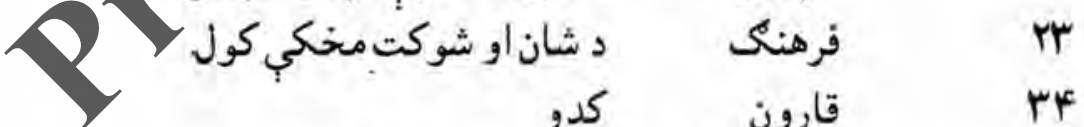

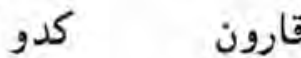

$$
\begin{aligned}
& \text { قريحه استعدادو وتركيب }
\end{aligned}
$$

$$
\text { JL iras } \cdots(117 \text {. }
$$




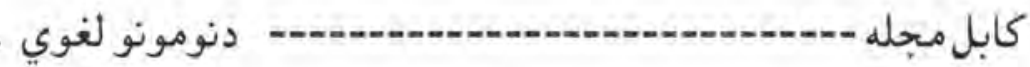

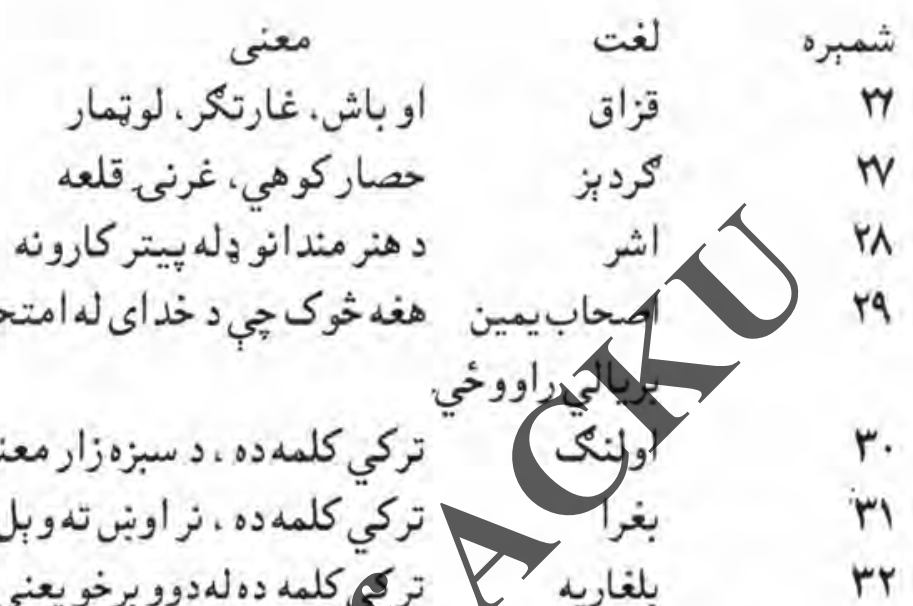

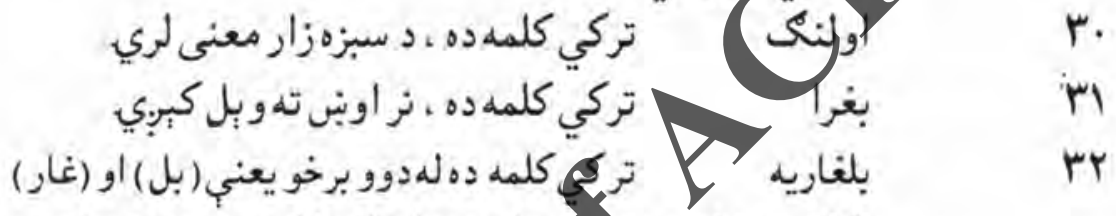

T9 $r$.

ir

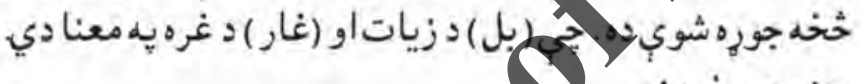

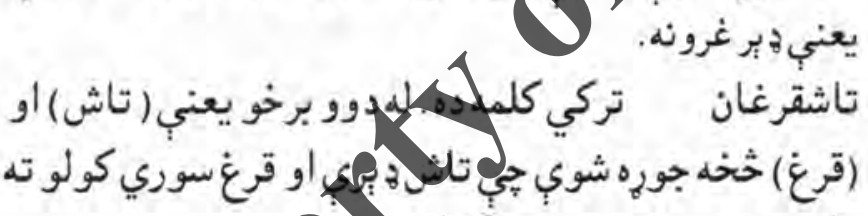

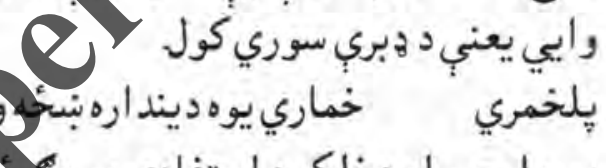

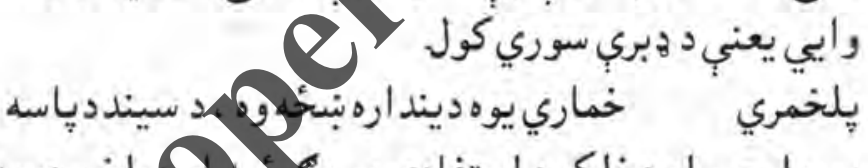
rr

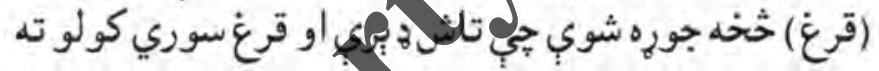

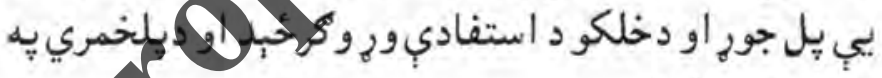

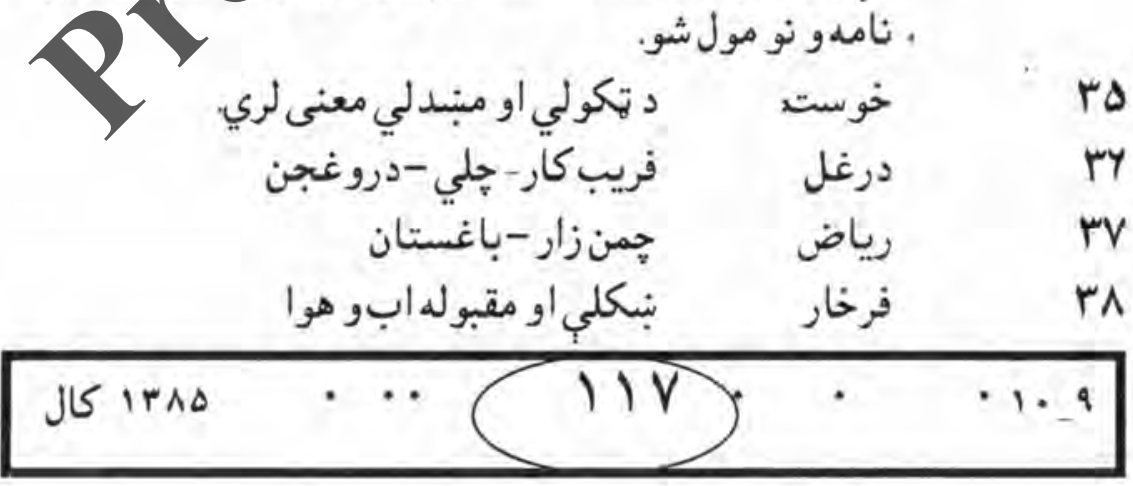




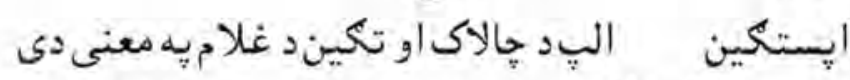

$$
\text { معنى }
$$

لغت شمبرن

يعنب جالاكى غلام

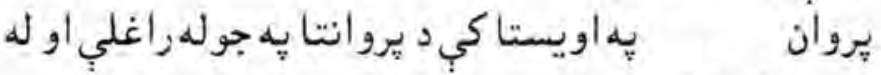

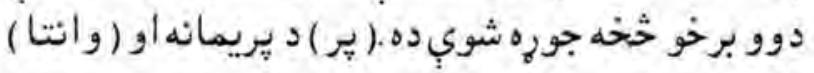

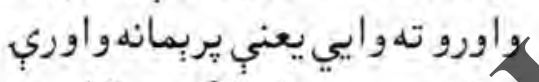

اصلا عبري كلمه ده جي ابراهام يه بنبه وه.

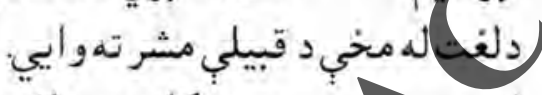

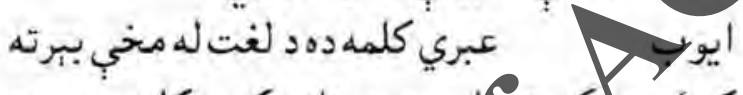

(i) pr

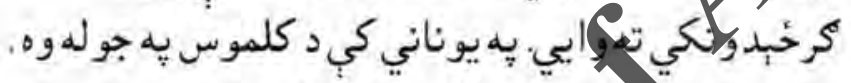

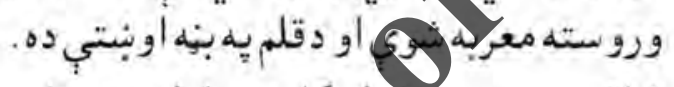

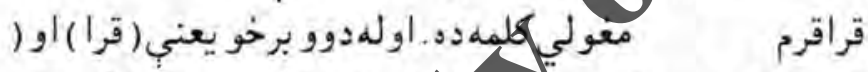
$\mathrm{Fr}$

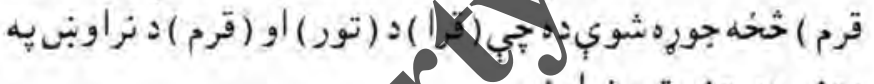

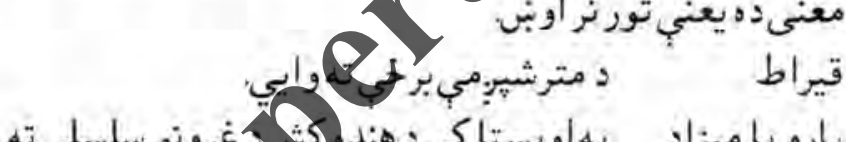
pre

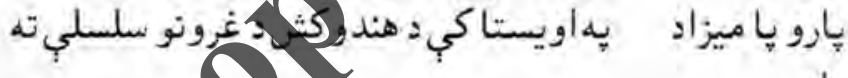
is

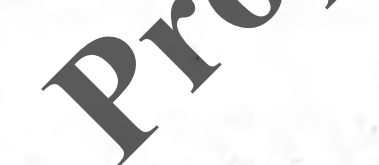

$$
\text { هلات }
$$

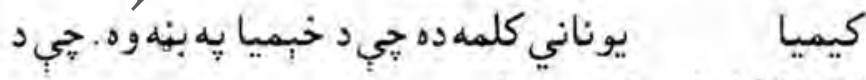
FV

$$
\text { اختلاط او امتزاجمعنى لري }
$$

$$
\text { J151rAo } \cdots(111
$$




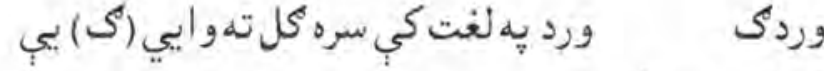

$$
\text { تصغيري حرفدى. }
$$

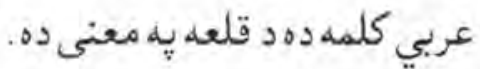

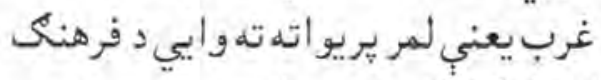

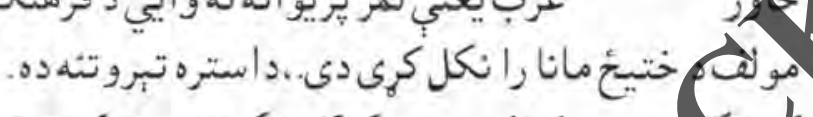

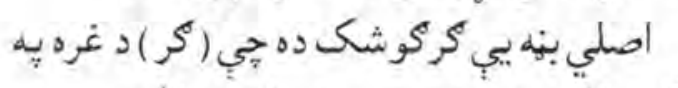

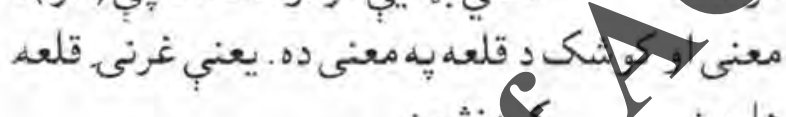

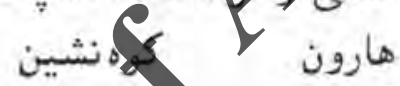

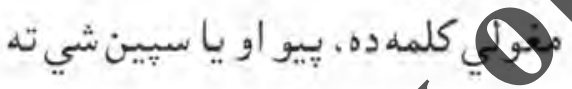

آقحهن

$\Delta r$

$\Delta f$

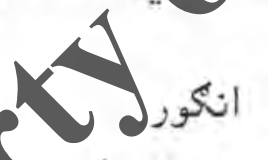

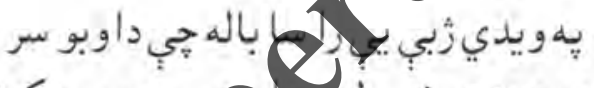

واليي.

$\Delta$.

d)

$\Delta r$

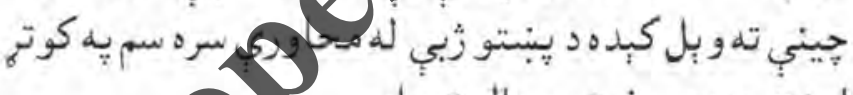

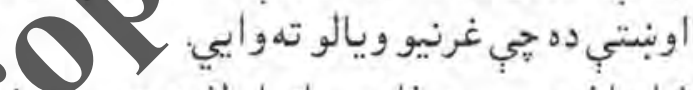

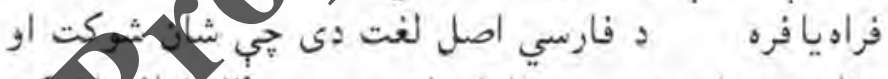

استالفي

$\Delta \Delta$

كونه

$\Delta y$

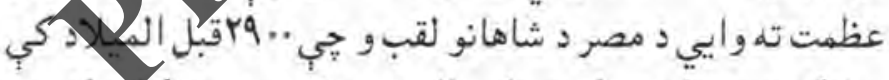

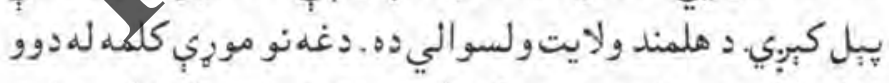

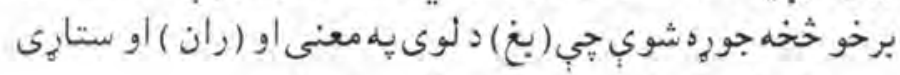

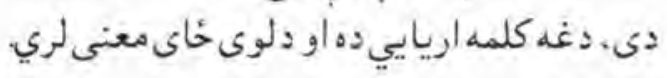




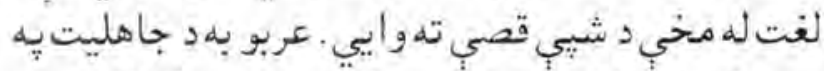

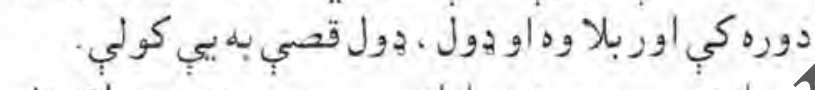

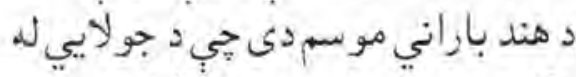
$\Delta \wedge$

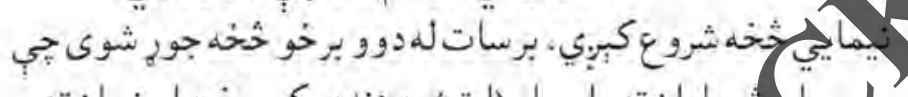

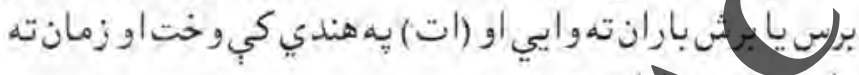

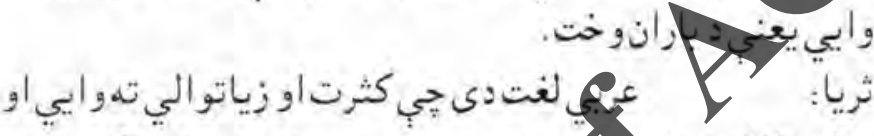

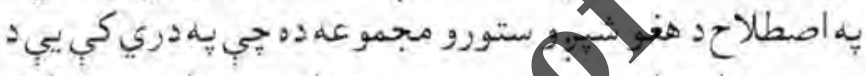

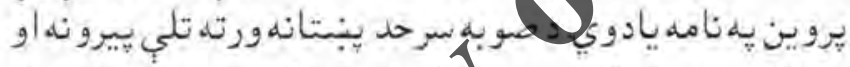

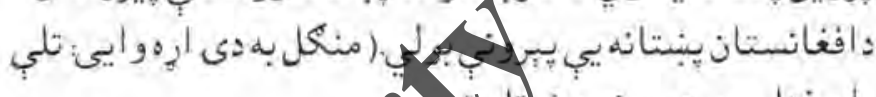

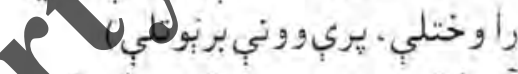

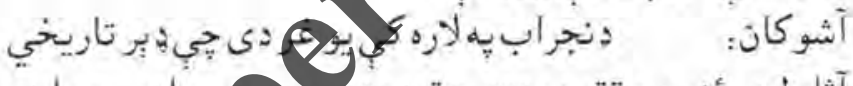
71

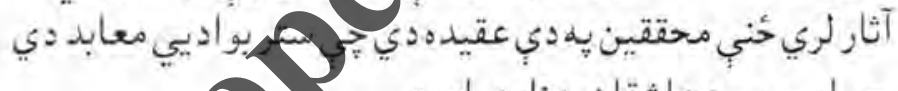

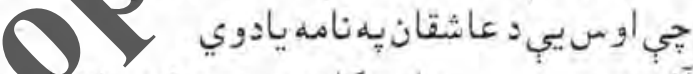

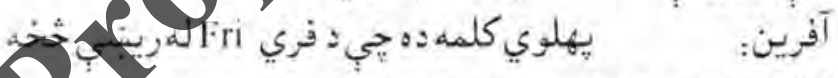

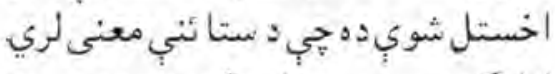

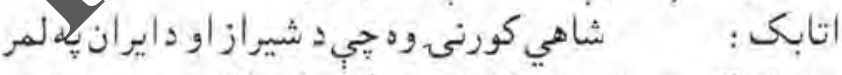
4

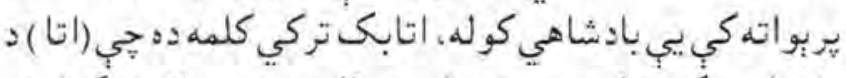

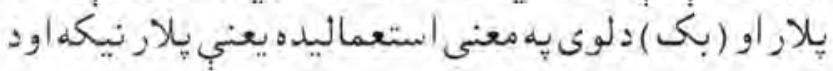

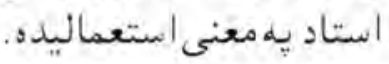




\section{معنى}

لغت

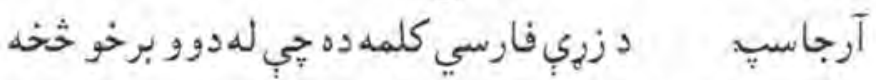

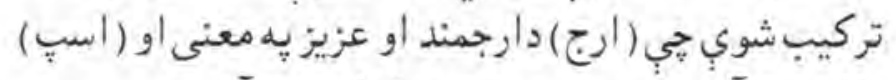

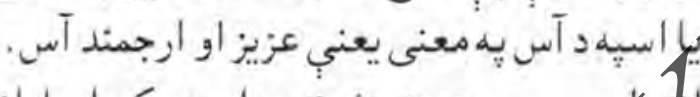

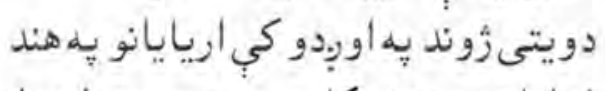

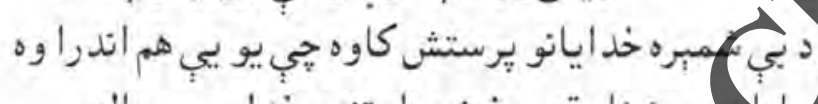

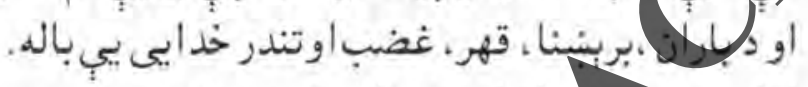

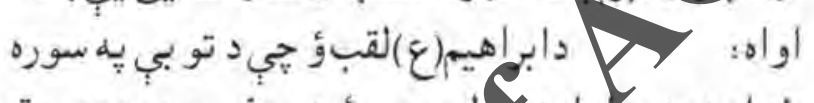

yk

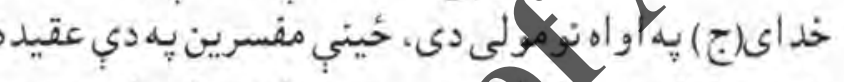

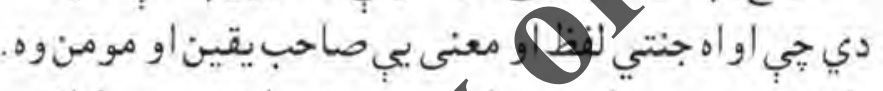
باختر:

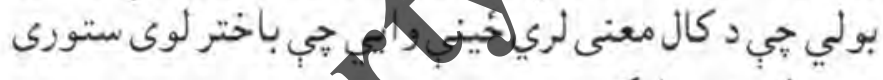

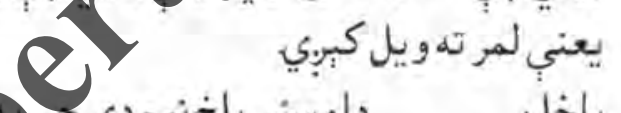

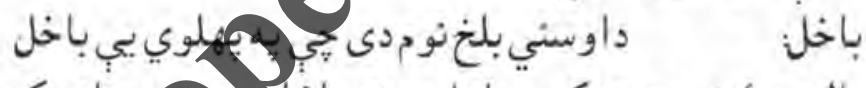

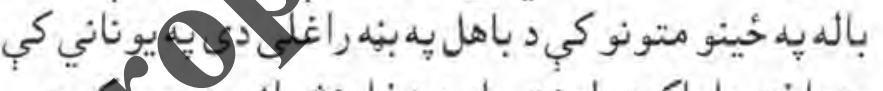

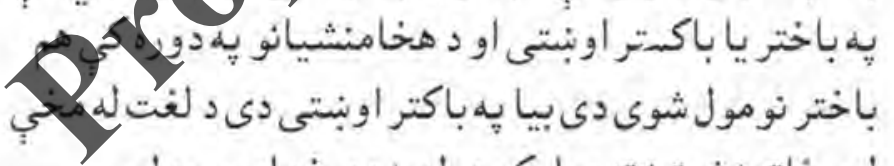

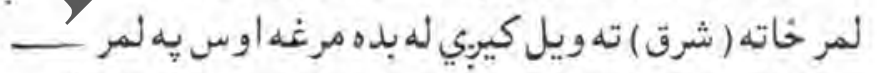

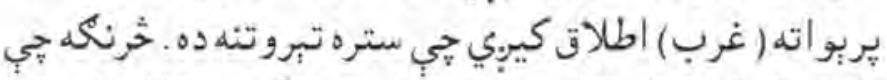

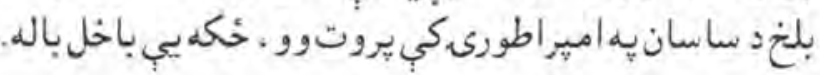

J 1 irso

$\mid 410 \cdot 1 \cdot 9$ 


\section{ses}

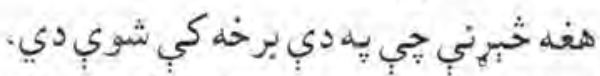

لغت شمبره

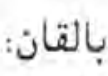

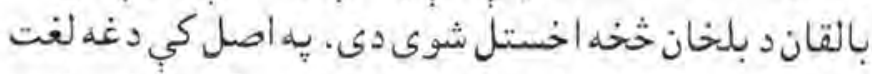

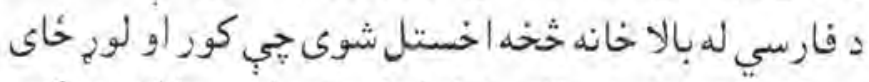

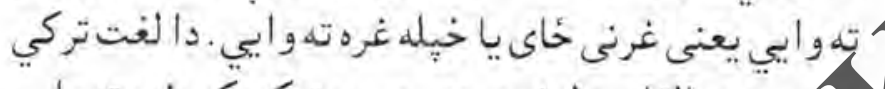

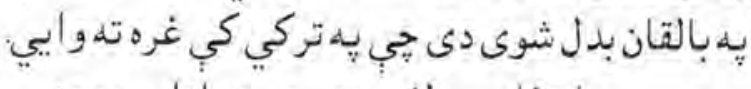

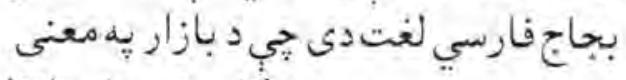

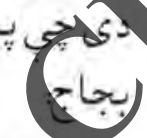

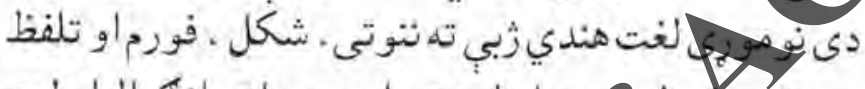

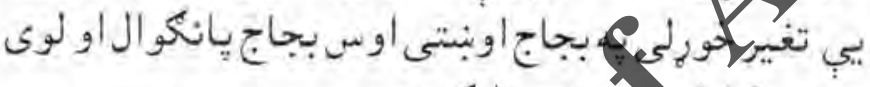
صنعت كاراها

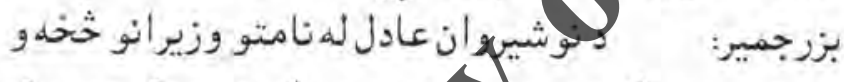
VI

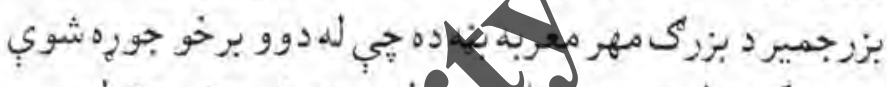

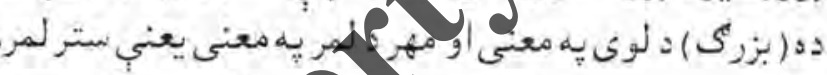

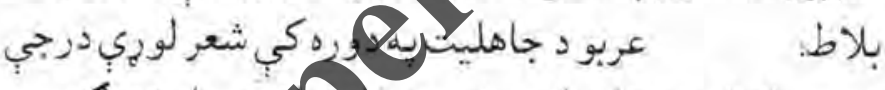
VT

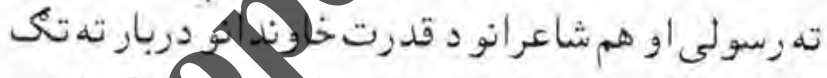

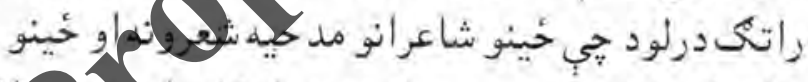

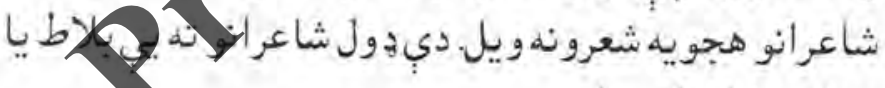

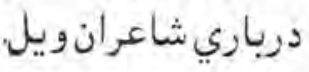

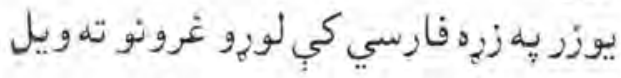
يوزر: Vr كبدل 


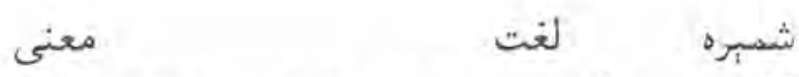

ب بF

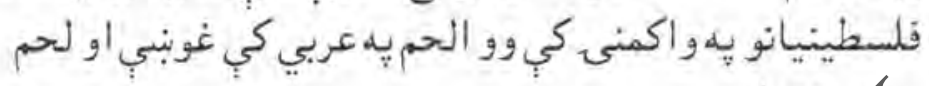

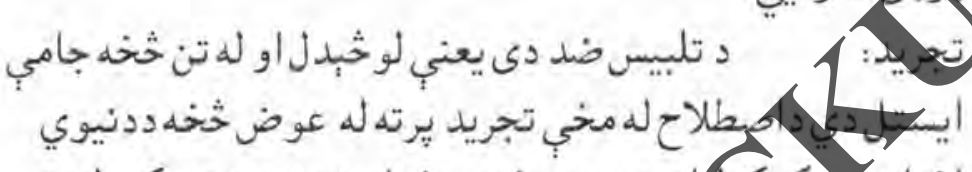

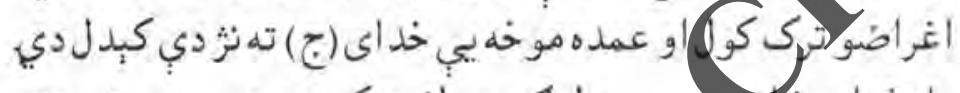

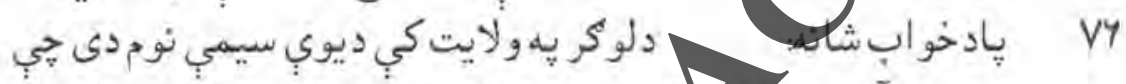

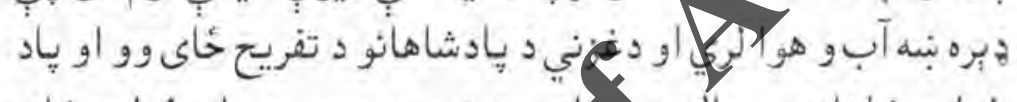

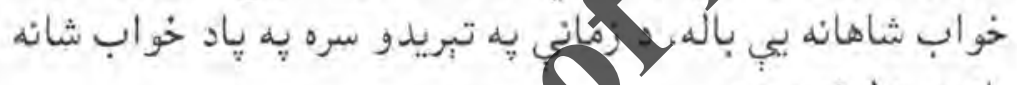

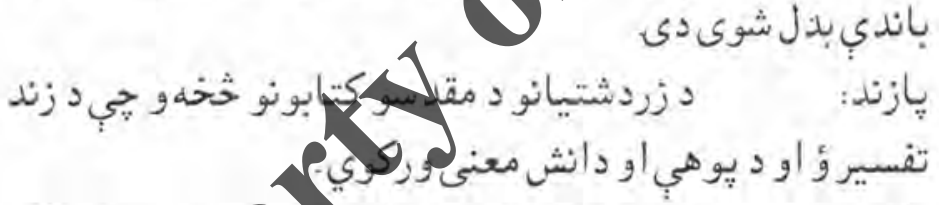
vo

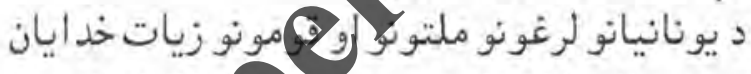
Vيان VA

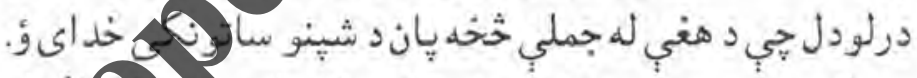

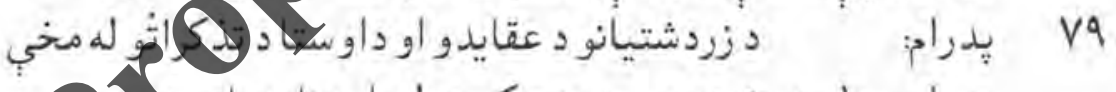

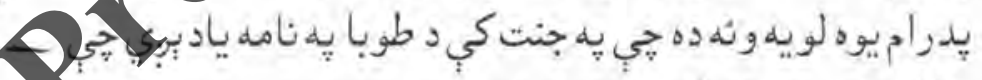

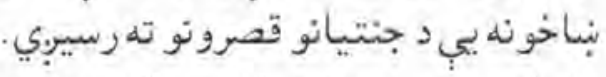

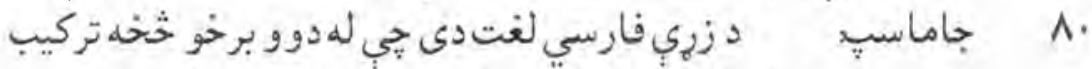

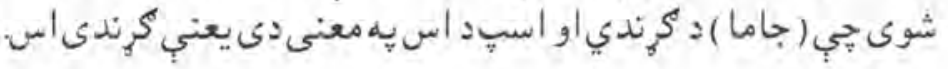


دنومونو لفوي

كابل مجلد

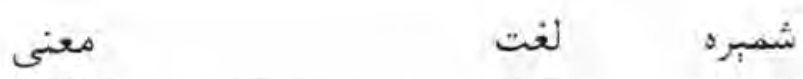

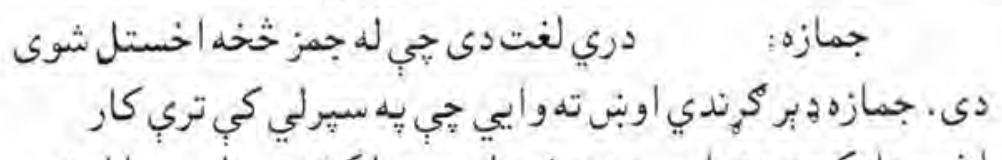

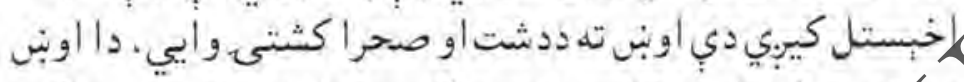

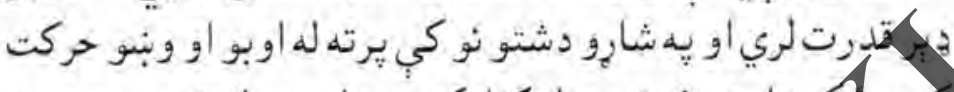

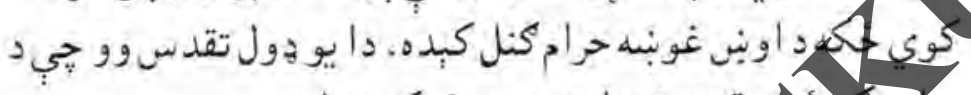

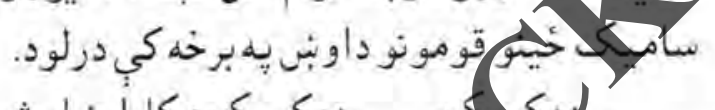

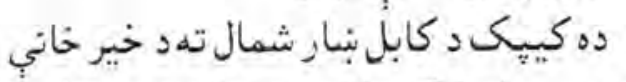

NI

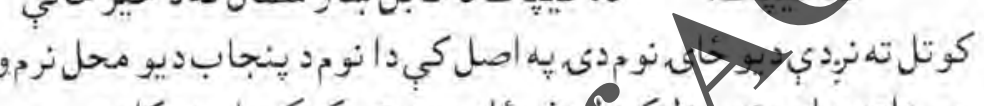

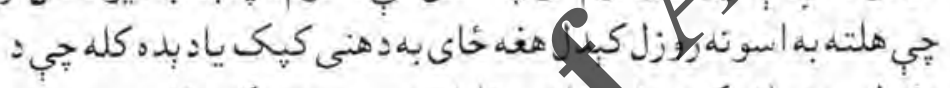

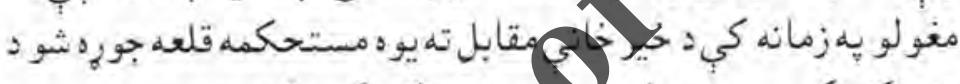

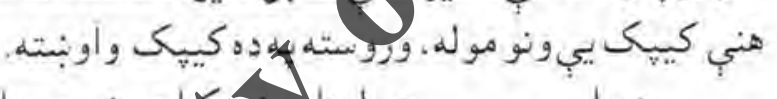

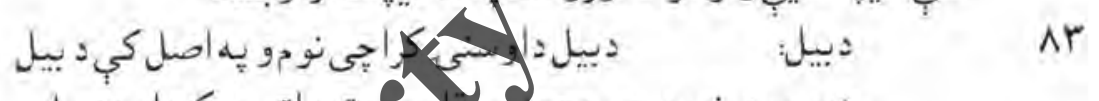

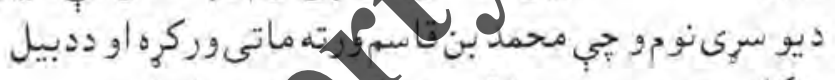

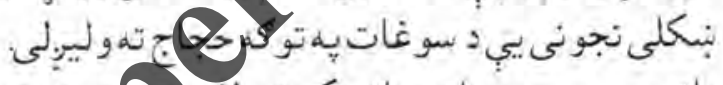

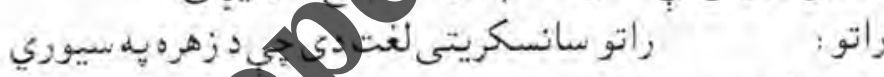
$\lambda r$

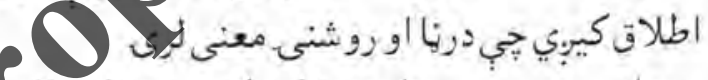

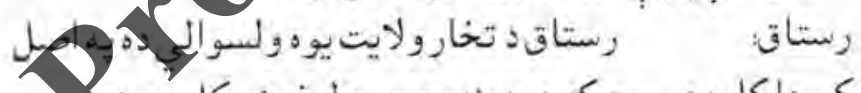

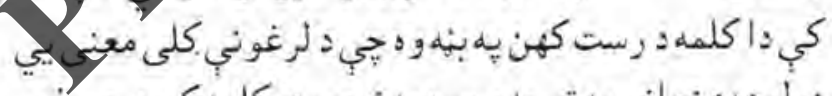

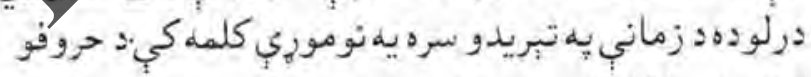
اختصار راغلى او د رستاق بئهيبي غورنهرهن. 


$$
\text { شمبره }
$$

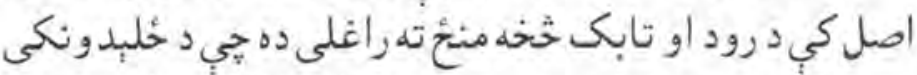

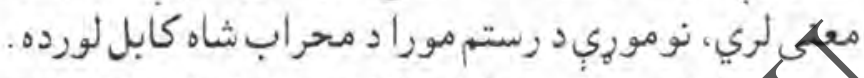

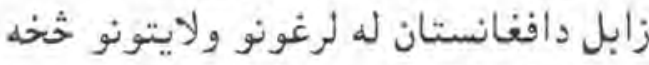

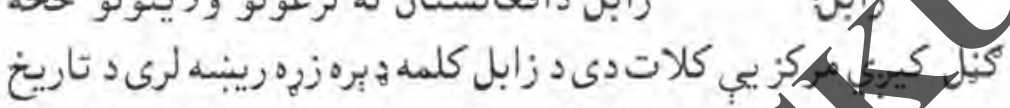

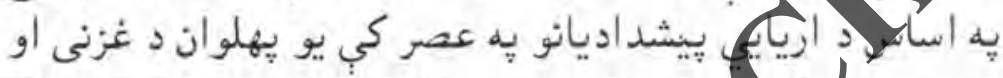

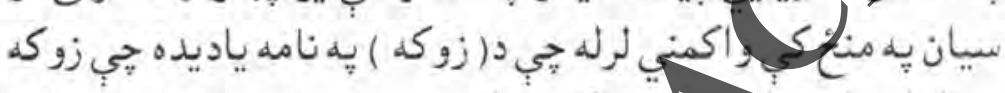

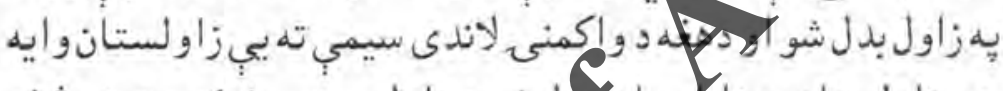

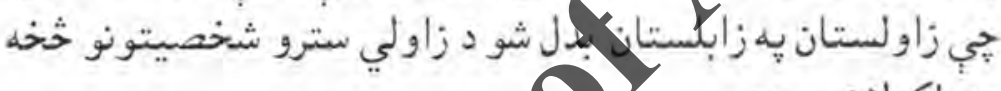
NA

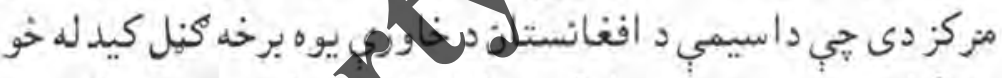

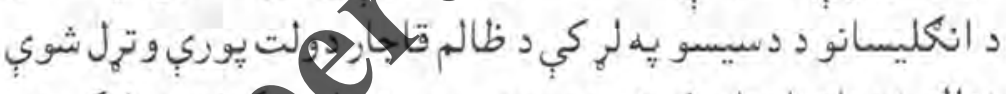

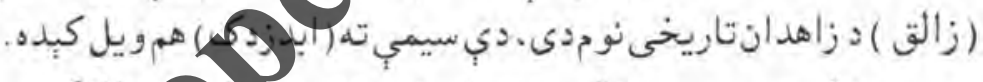

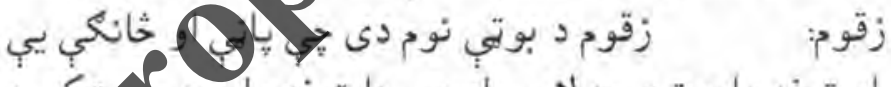

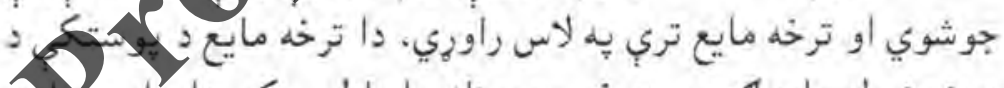

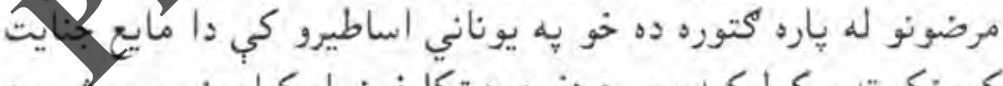

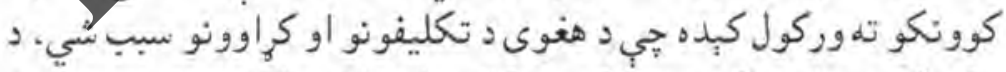

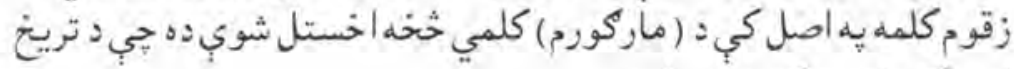

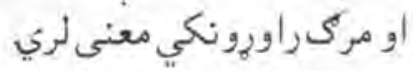

J IrAs

$$
\text { iro }
$$


دنومونو لغوي كابل مجلد -

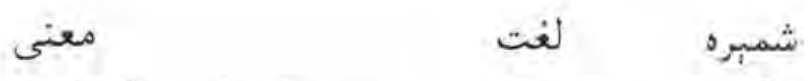

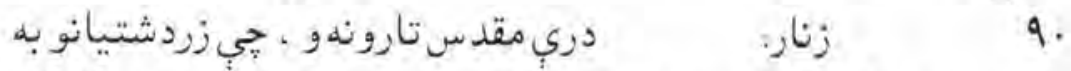

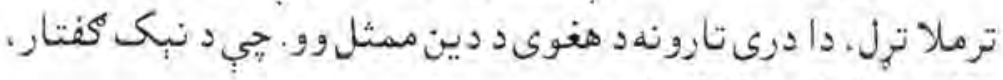

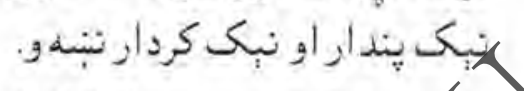

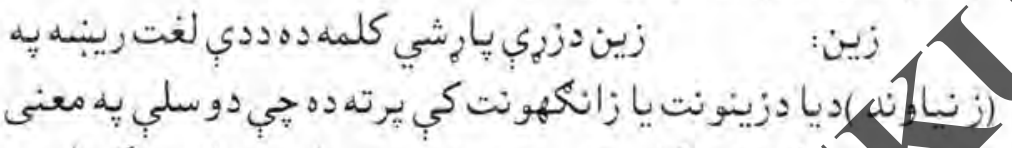

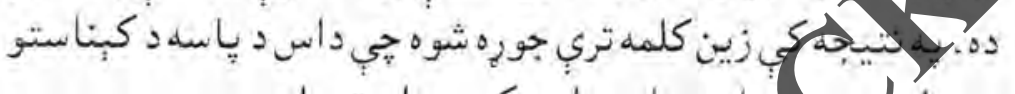

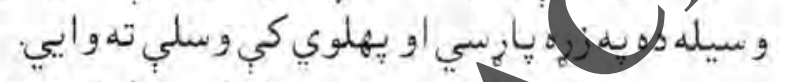

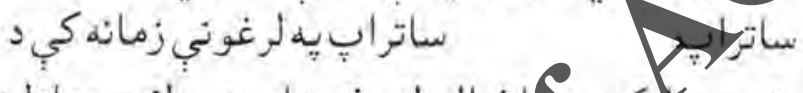

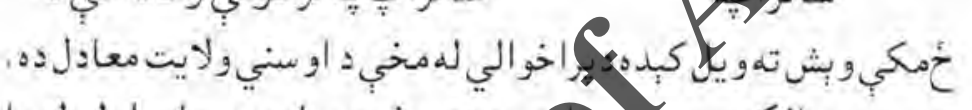

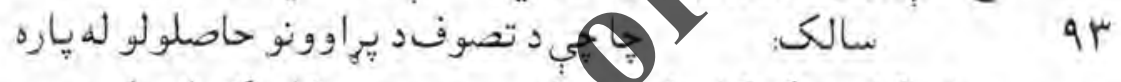

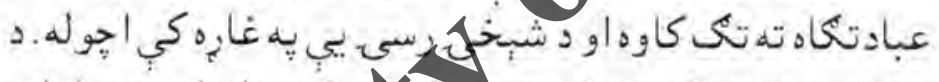

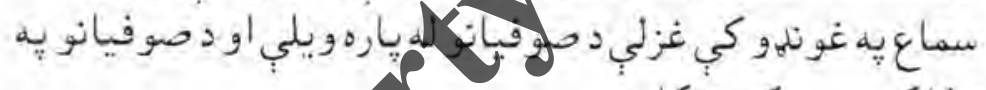

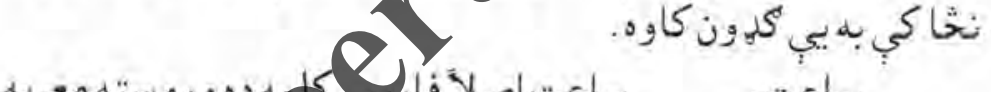

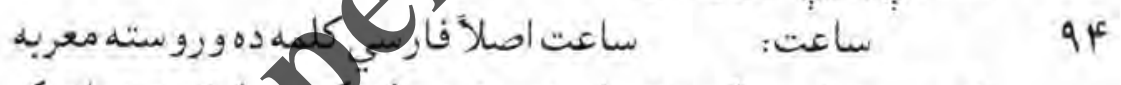

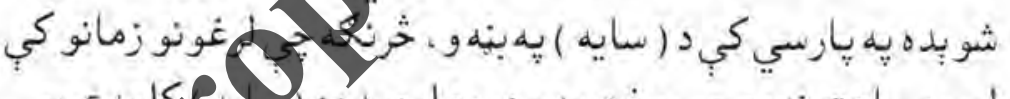

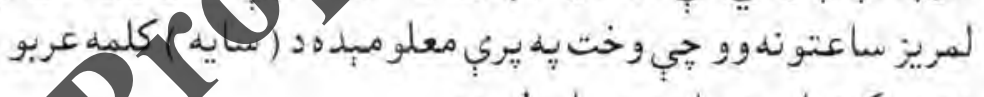

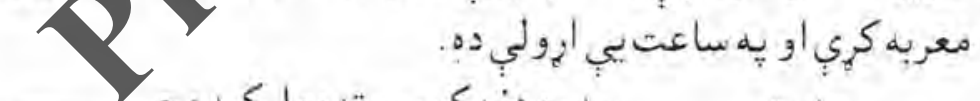

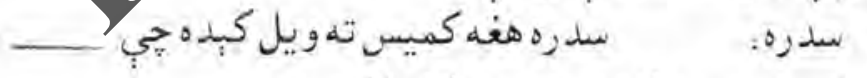
$9 r$ زردشتيانو وروسته له معين عمر خخه اغوسته.
IrAs
Iry
- 1. 9 
دنومونو لغوي كابل م-جله

معنى

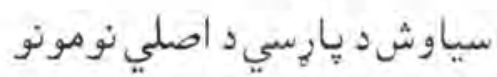

لغتياش شمبره

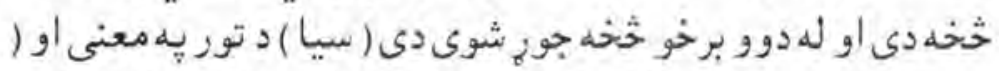

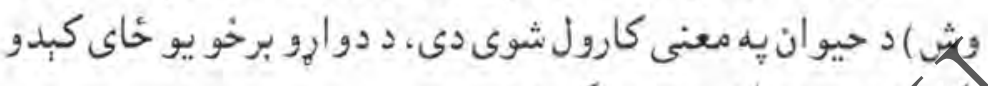

فونا لا تيني لغت ديى د معنى له يلوه تولو لو

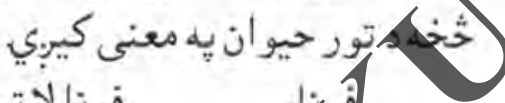

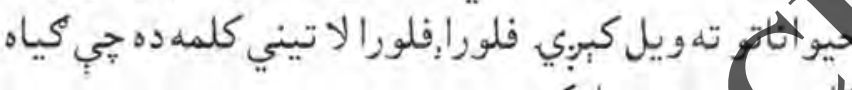

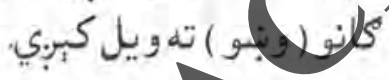

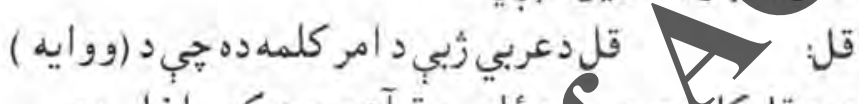
فे

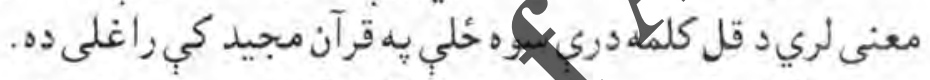

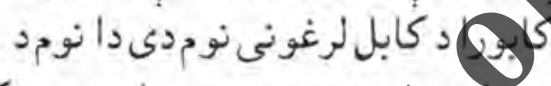
كابورا:

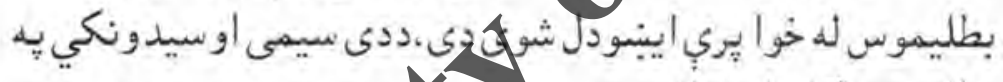

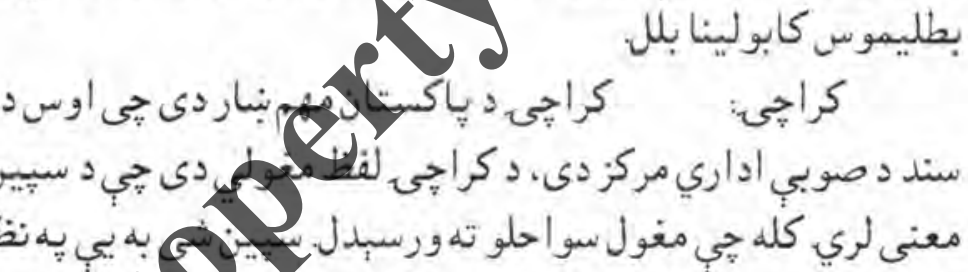

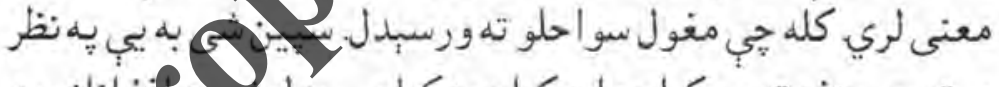

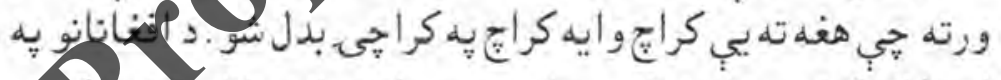

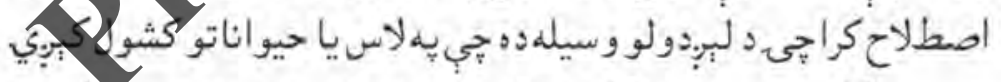

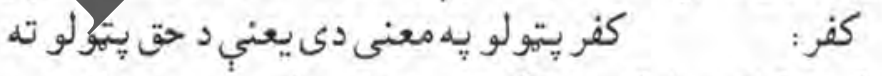

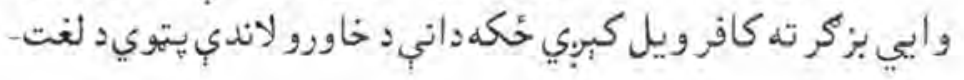




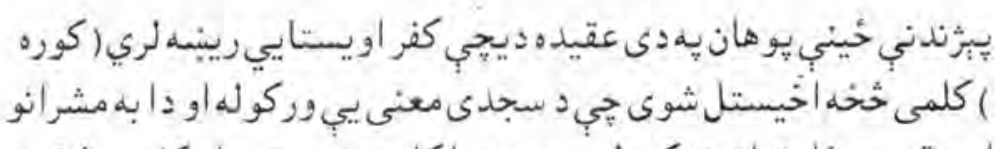

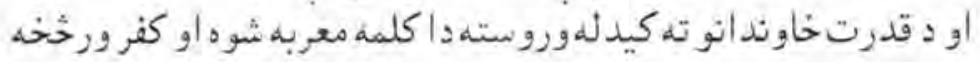

كليسا يوهيوناني كلمدوه جي د ( الكيزيا ) جورئشى

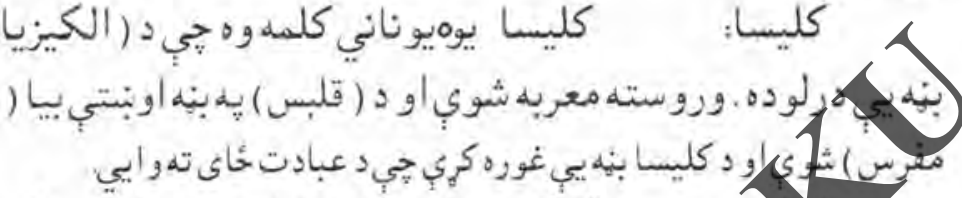

كنك دز 2 اوسنى بيخارا

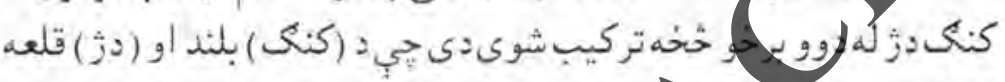

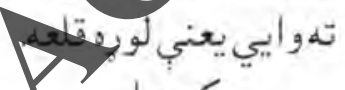

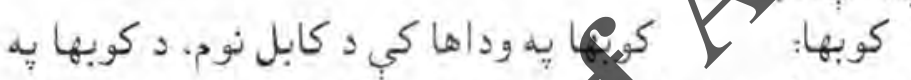

$1 \cdot 4$

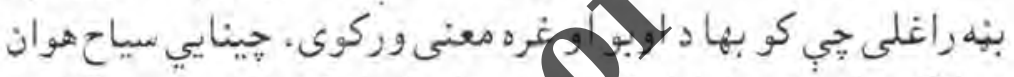

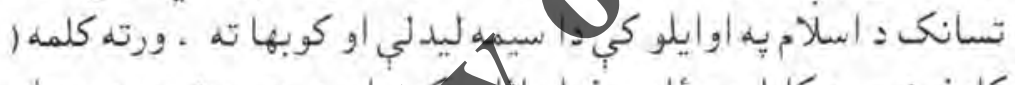

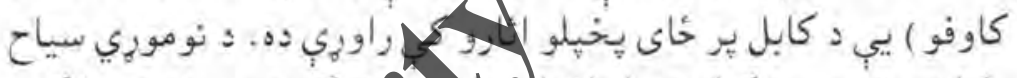

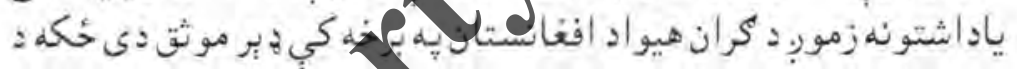

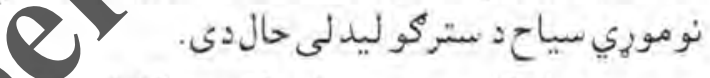

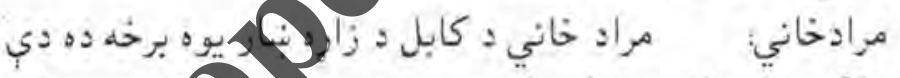

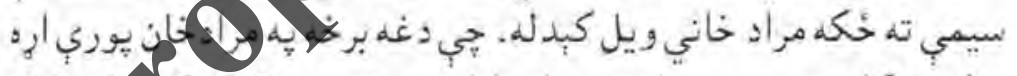

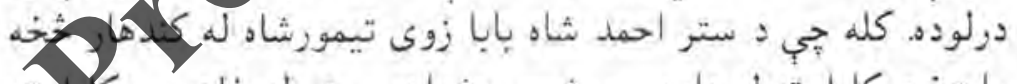

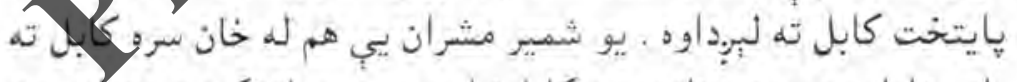

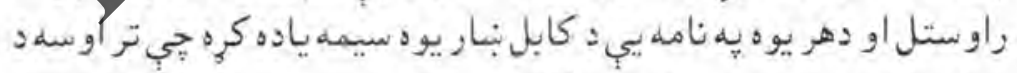

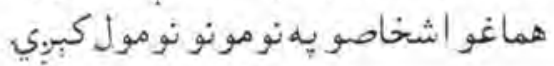

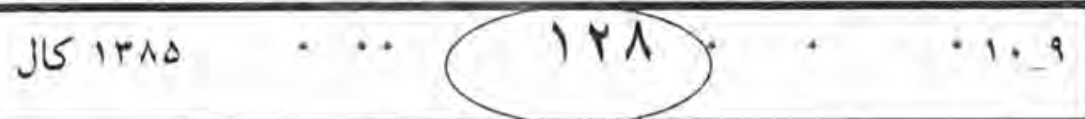


شمبره

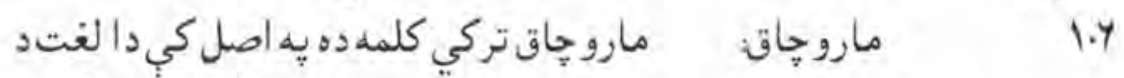

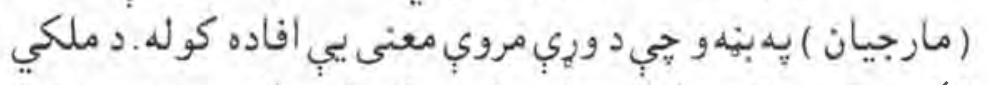

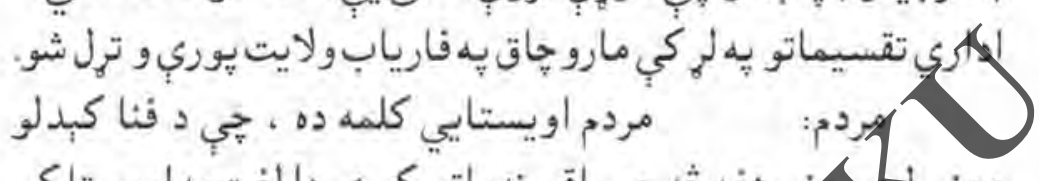

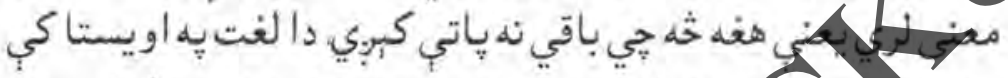

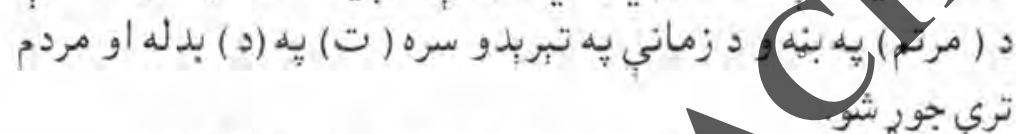

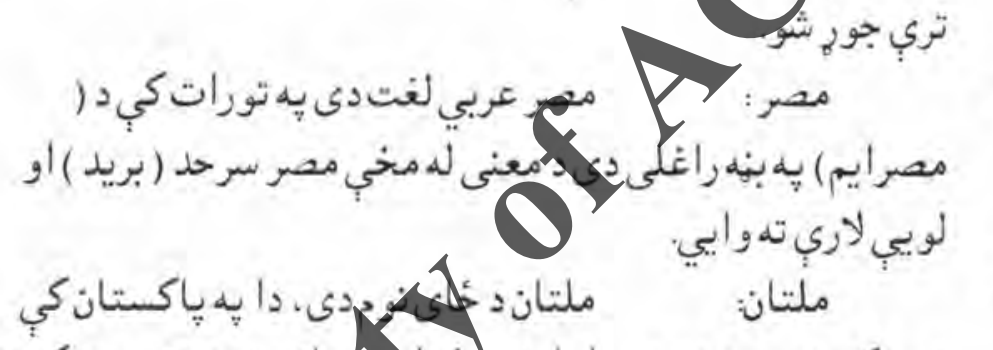

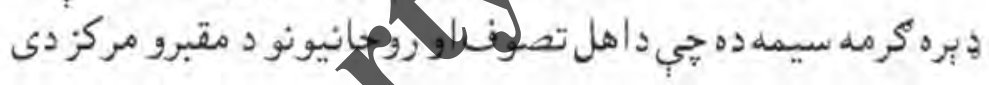

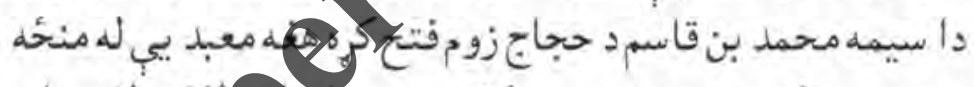

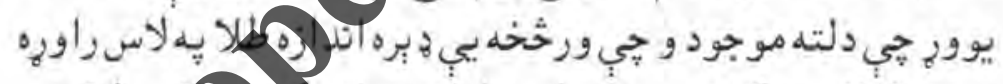

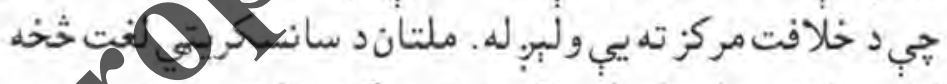

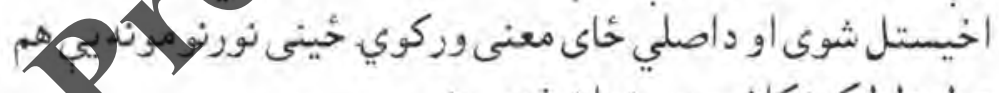

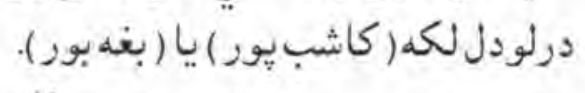

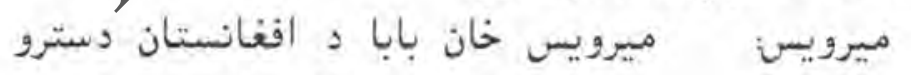
1.1 1.9

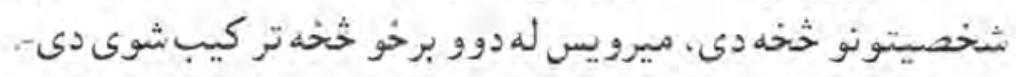
$351 \times 10 \cdot \cdots(1 \times 9$ 


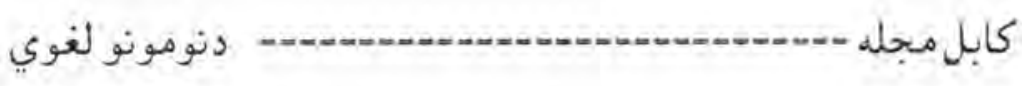

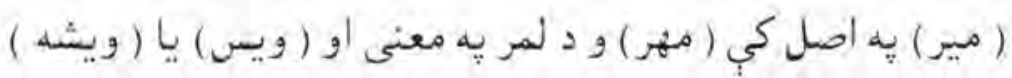

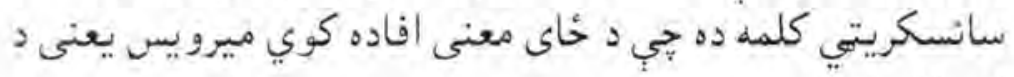

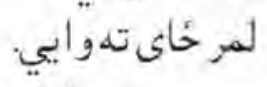

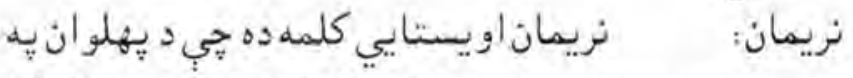
III

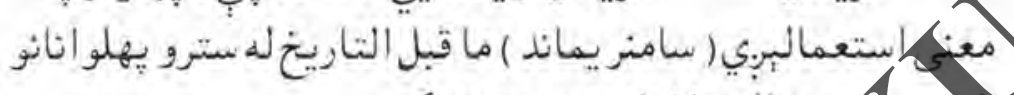

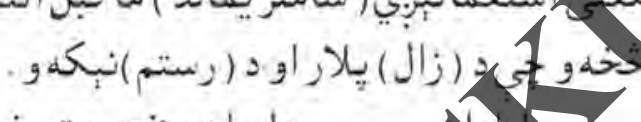

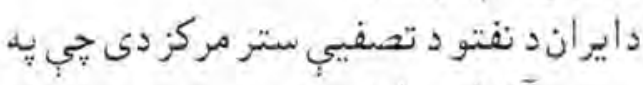

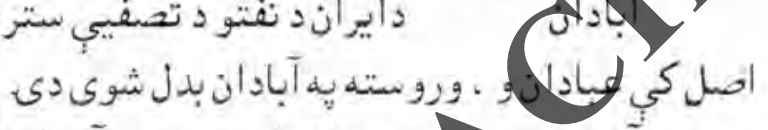

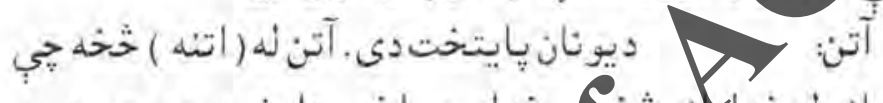

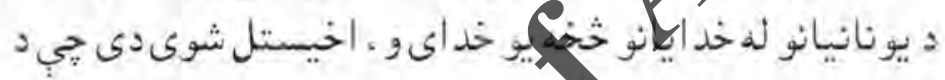

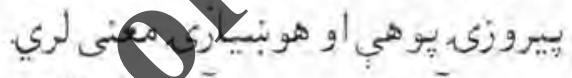

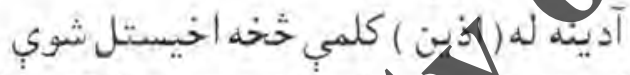
آدينه:

III

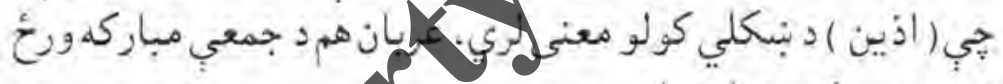

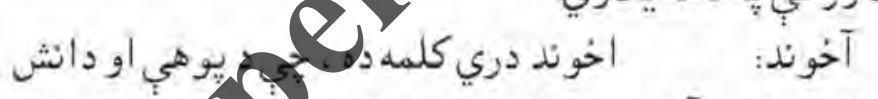

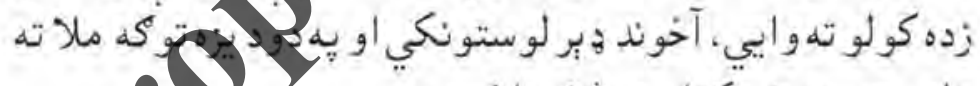

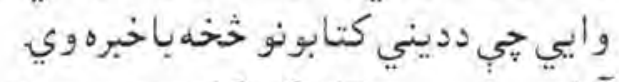

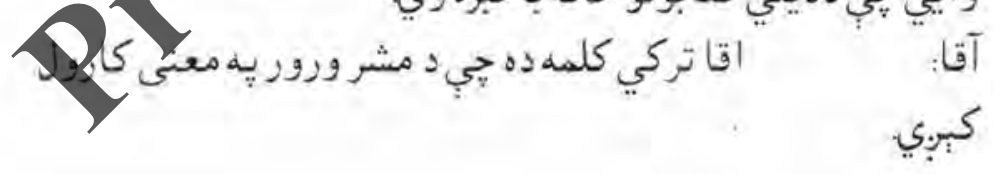

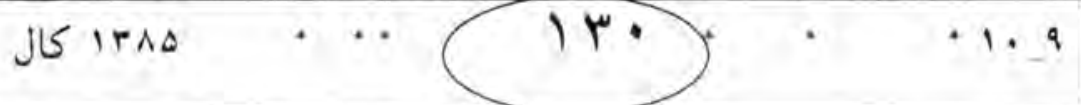




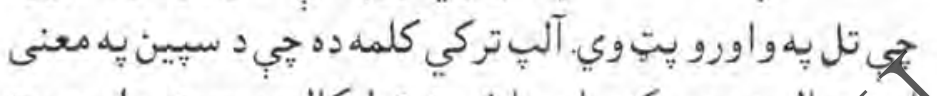

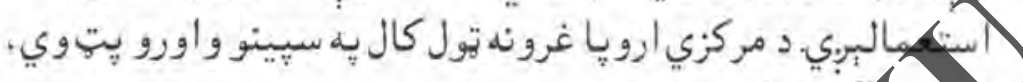

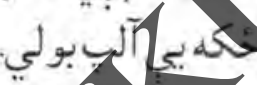

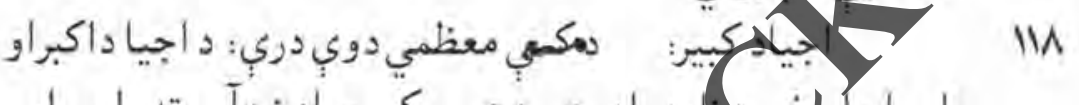

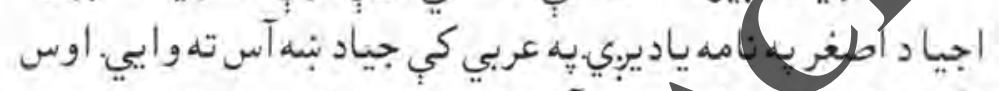

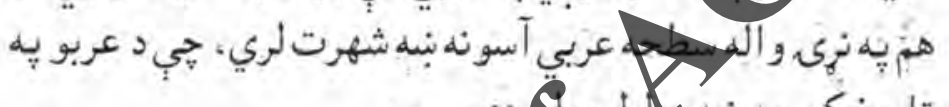

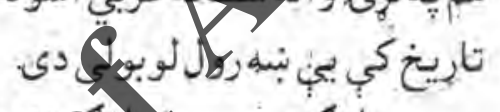

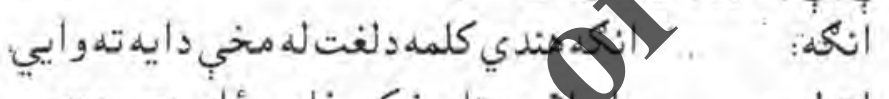

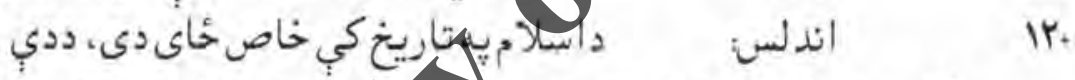

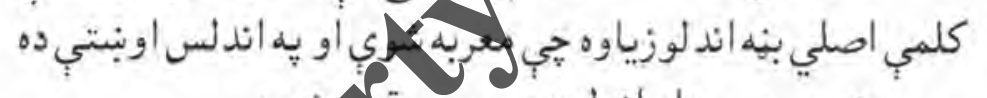

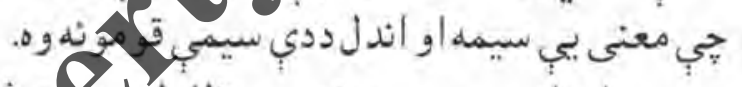

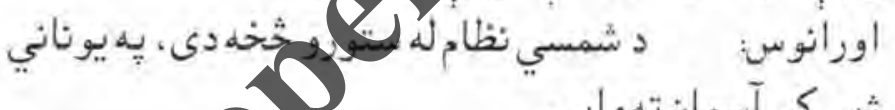

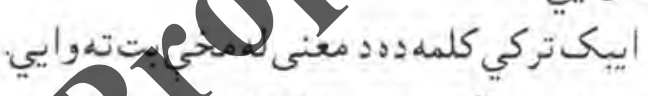
ثربي كبي آسمان تهو ابي.

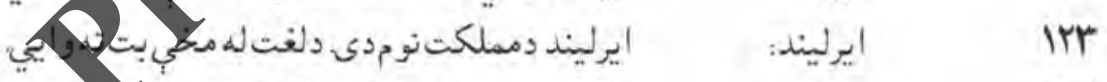

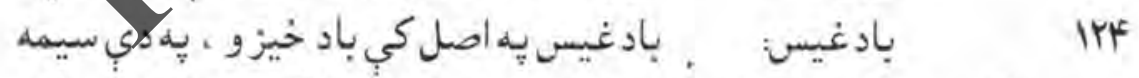

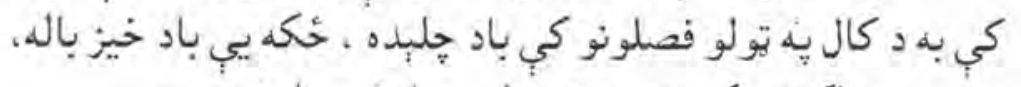

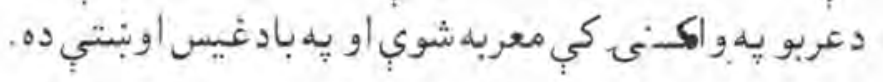




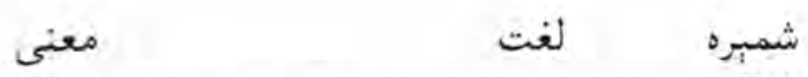

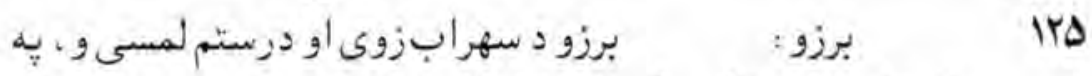

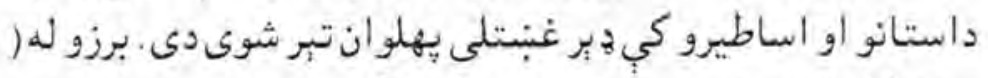

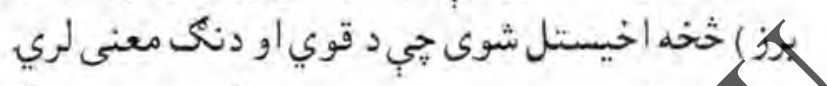

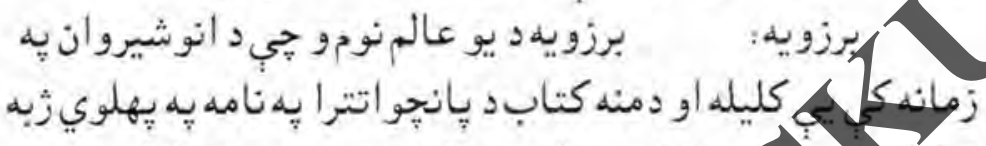

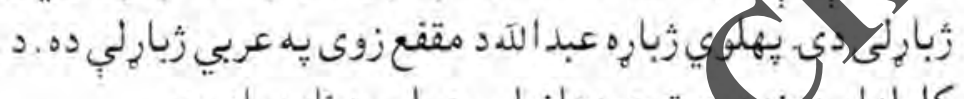

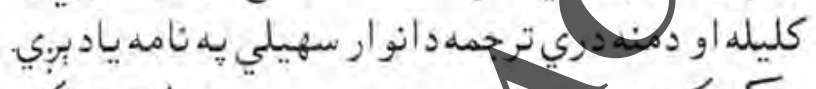

114

ك. ك > > IIr 年

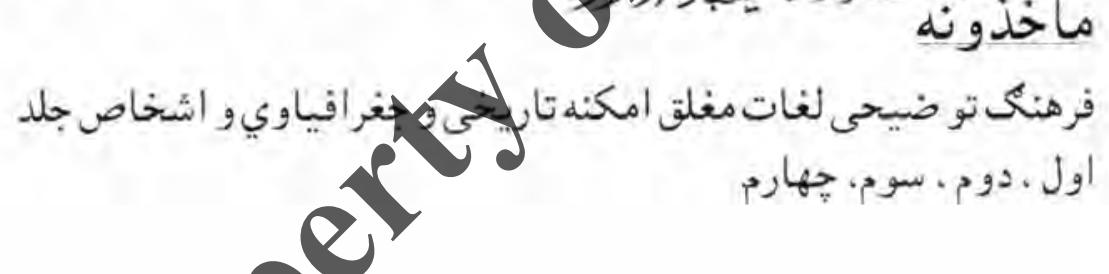

$$
\text { ماخذونئ }
$$

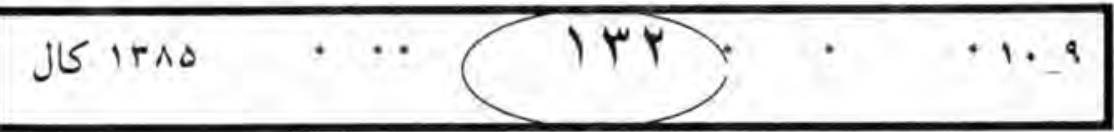



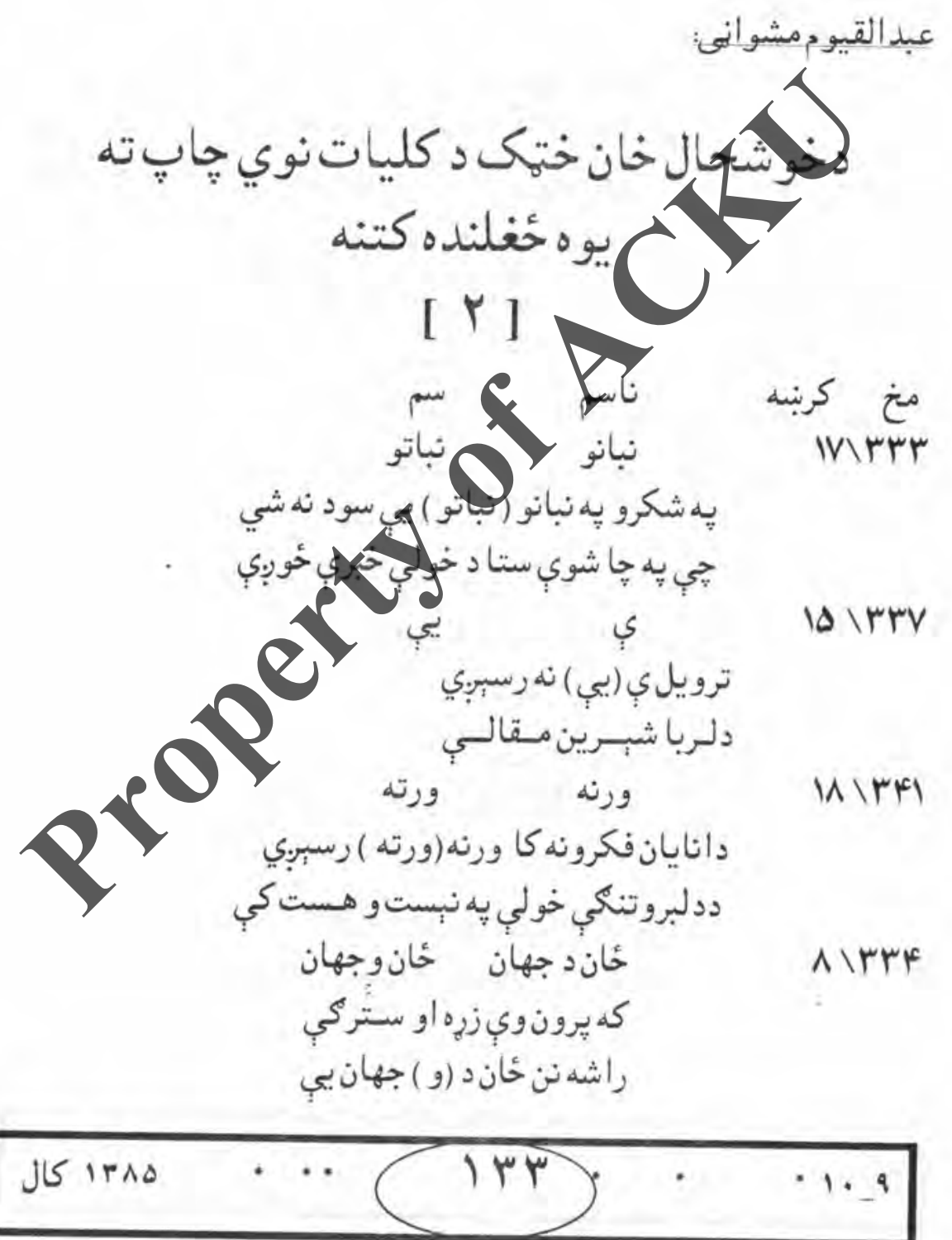
نوخوشحال خان

كابل مجله

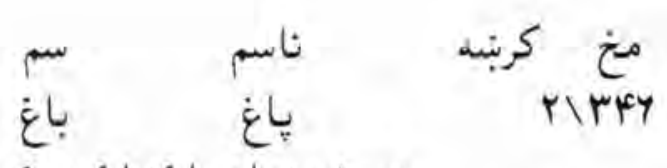

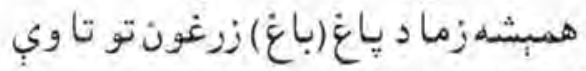

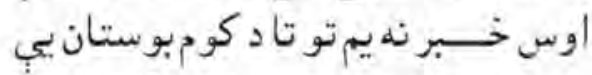

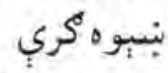

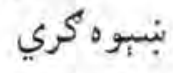

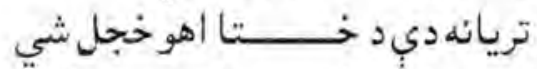

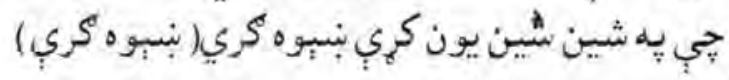

را-تر

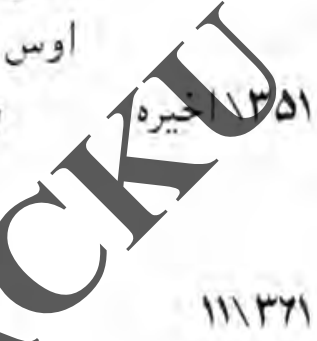

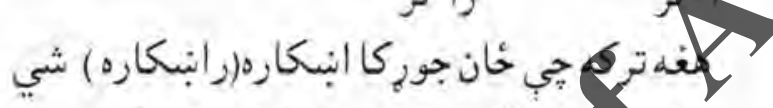

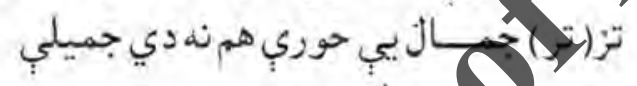

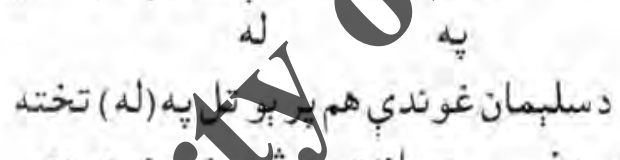

IryT

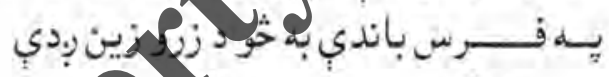

ملكئرئي

ملكىى

Irirya

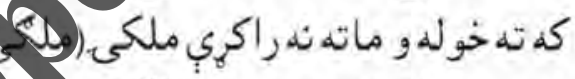

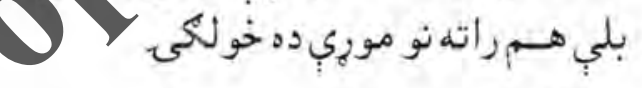

\section{بي بي بـ}

IF $\backslash$ TVF

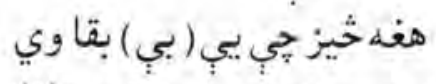

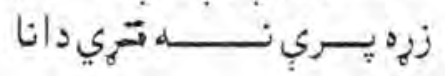

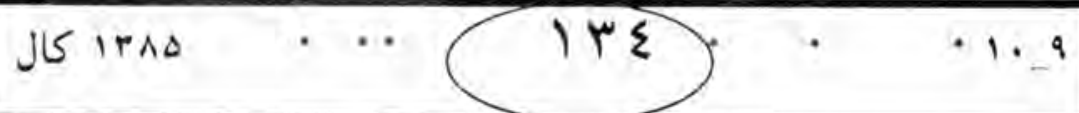


دخوشحال خان

كابل مجله

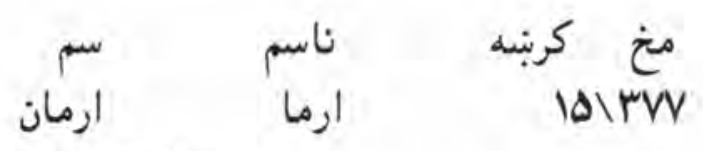

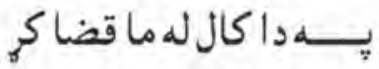

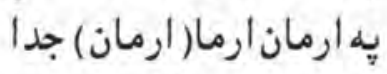

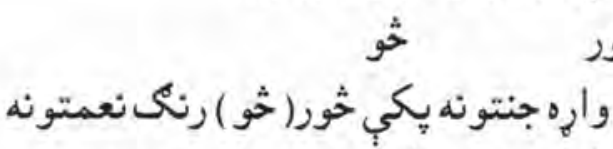

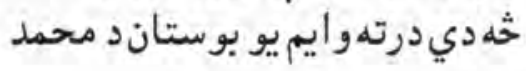

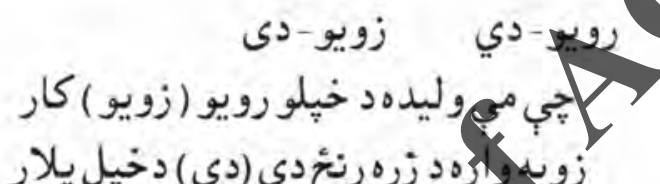

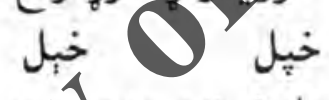

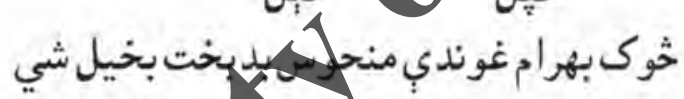

rirAF

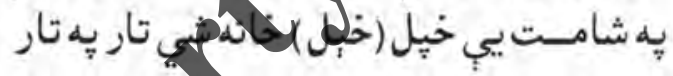

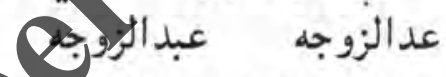

VTrAF

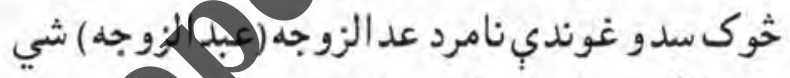

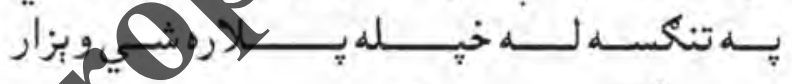

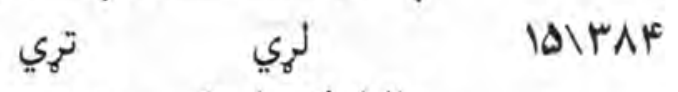

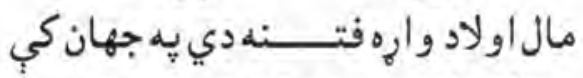

يه دا دواره بهزهره نه لهي (تري )هونينيار

دي

$\Delta r \wedge \Delta$

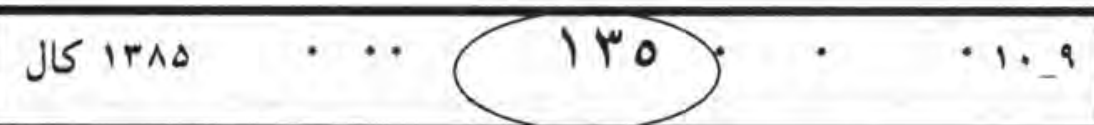


دخوشحال خان

د محنتو (د )مشقت ص صبر نهدي(دى)

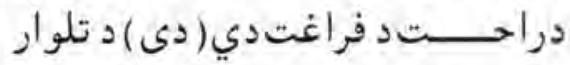

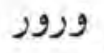

ورو

YrAs

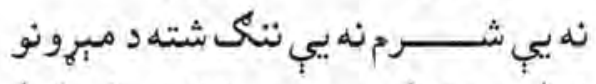
زما زويهد بل وروو( ورور ) نهدي غمخوار

درب

وركرهم هم يَّتوره هم يه عدل

دي

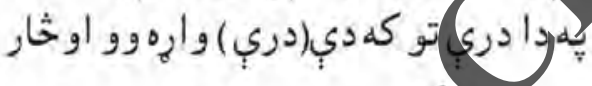

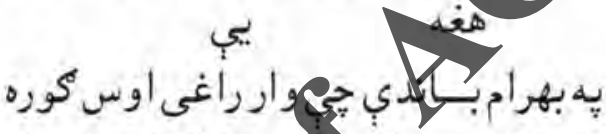

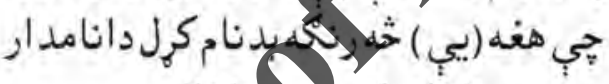

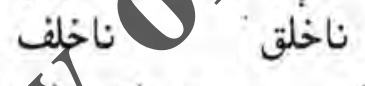

IrTrA

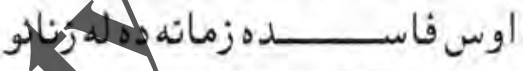

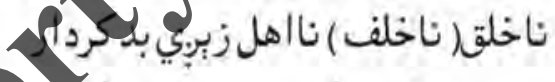

ضميران

DSIMAY

$I I I r \wedge \Delta$

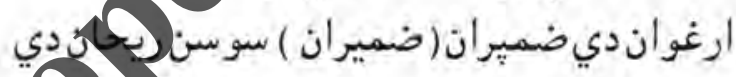

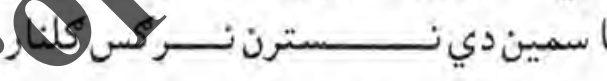

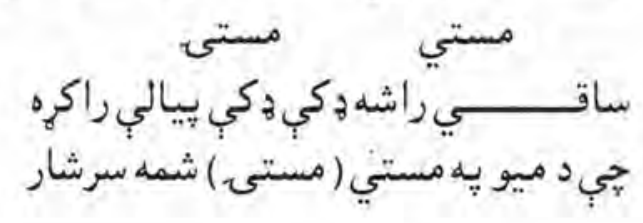

19\rNY

J IrNo

149

$\cdot 1 \cdot 9$ 
دخوشحال خان

كابل مجله

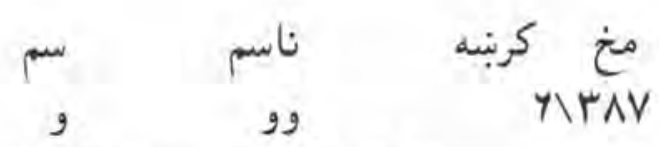

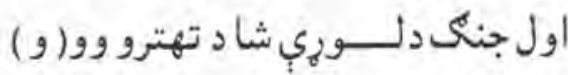

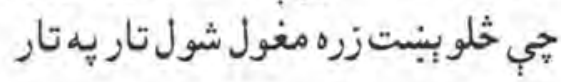

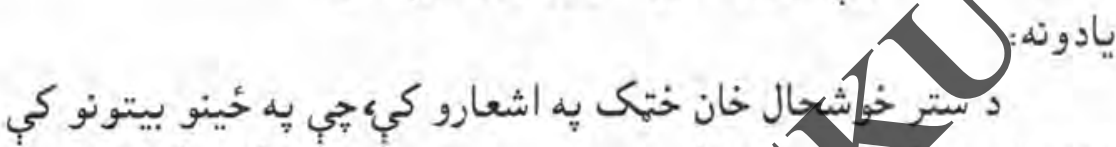

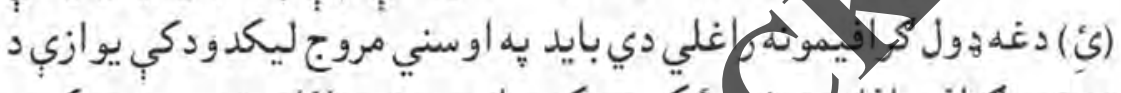

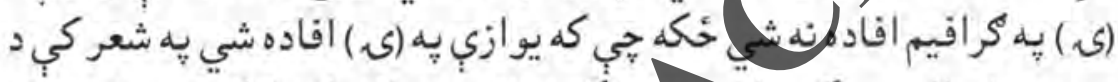

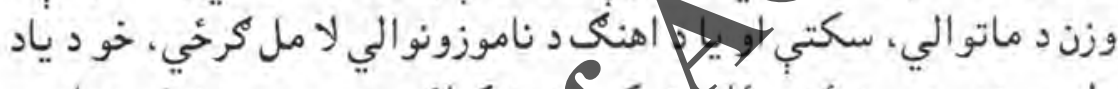

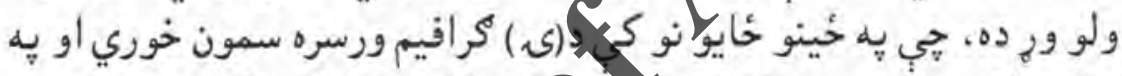

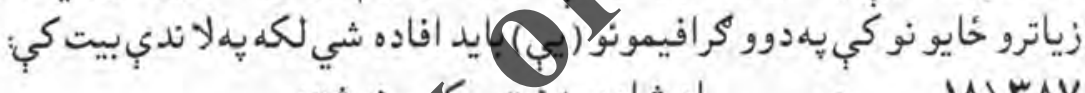

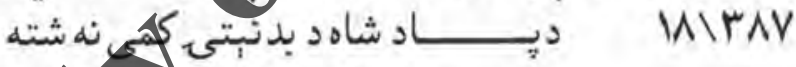

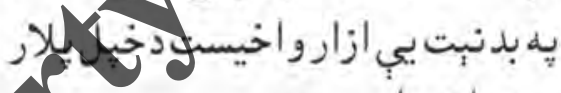

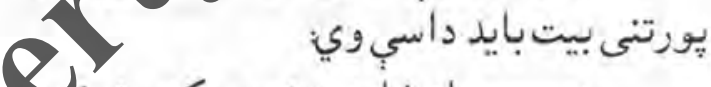

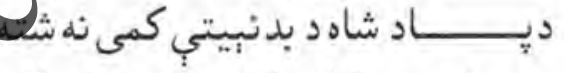

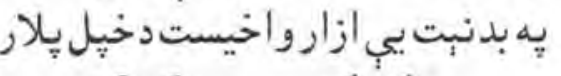

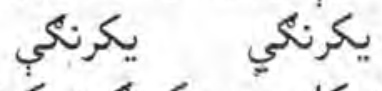
MTHN

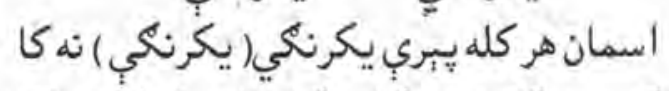

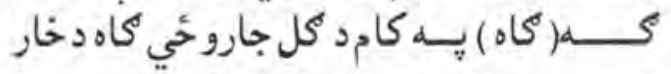
إيردي-موند إِيديدي-مو مند 


$$
\begin{aligned}
& \text { إِردي(إِريدي) موند(مومند ) شينو اريكوره خدكا }
\end{aligned}
$$

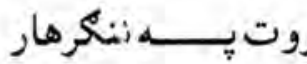

FirAN

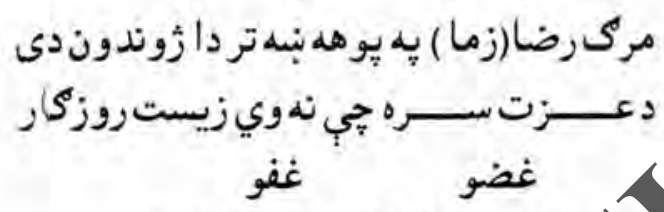

$$
\text { هدريجي خور اول كالدعضو (عفو )و }
$$

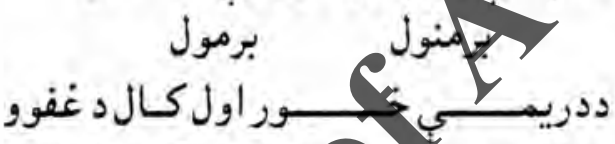

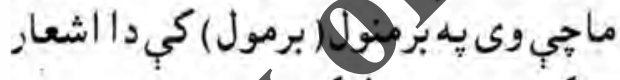

$$
\text { حوى }
$$

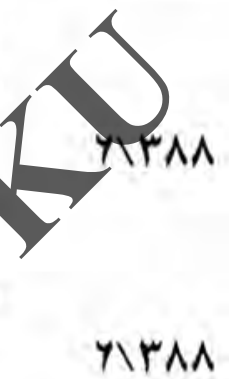

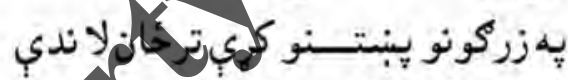

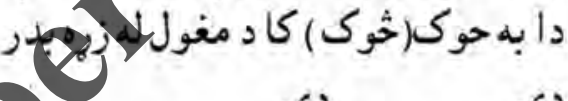

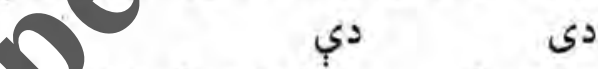

rMIMA

MIMA

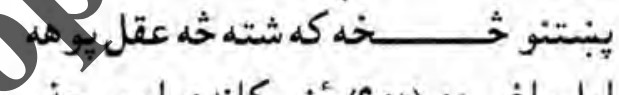

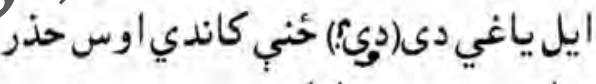

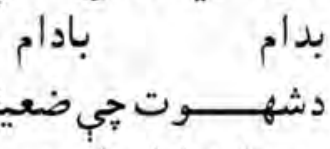

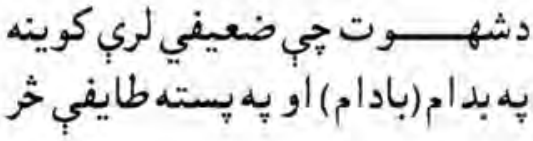

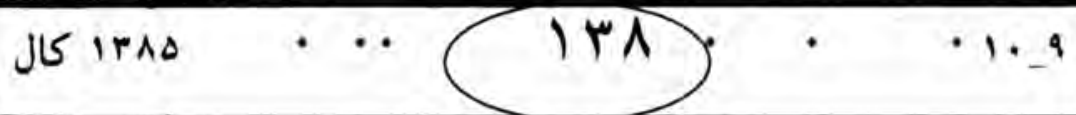




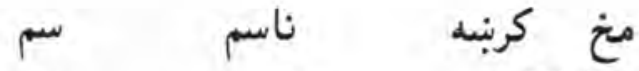

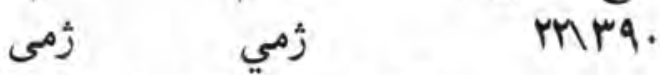

$$
\begin{aligned}
& \text { كهبي مو مي اورى رمي(رٔمى) كبينه خوره }
\end{aligned}
$$

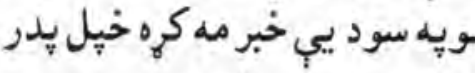

$$
\begin{aligned}
& \text { غوري } \\
& \text { غوري }
\end{aligned}
$$

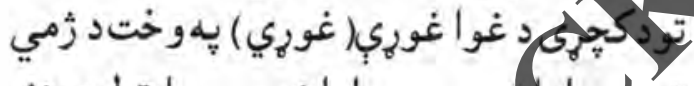

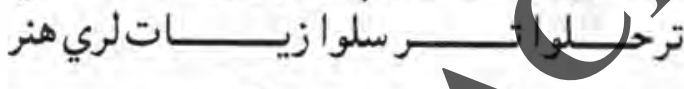

$$
\begin{aligned}
& \text { سود } \\
& \text { دباغي ويلني/لمود ومجهوراك( سوددخوراك) ) ذبردى }
\end{aligned}
$$

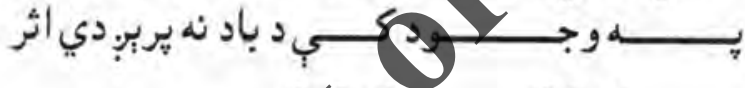

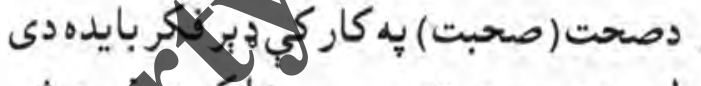

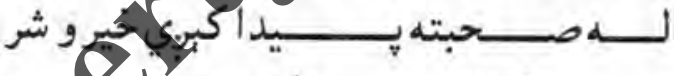

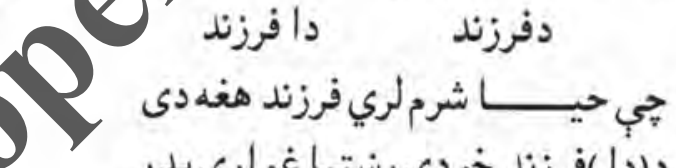

$$
\begin{aligned}
& \Delta M a r
\end{aligned}
$$

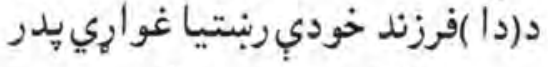

$$
\begin{aligned}
& \text { خينبي }
\end{aligned}
$$

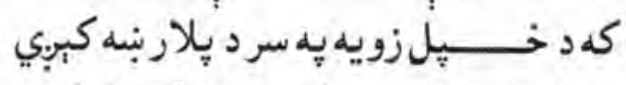

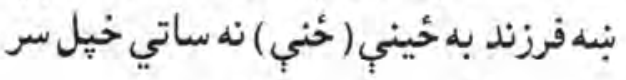

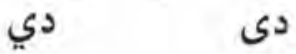

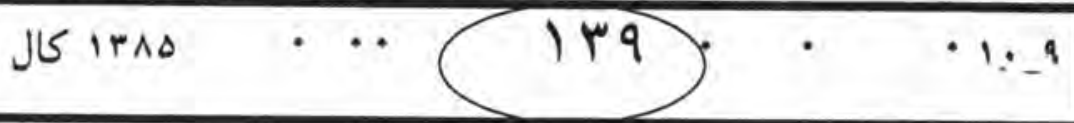


دخوشحال خان كابل مجله

اوس دديزمانب زويهزويهنهدى(دي)

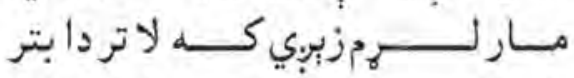
نا نا ناهل

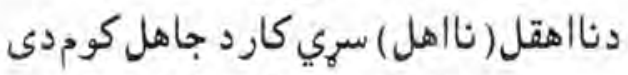

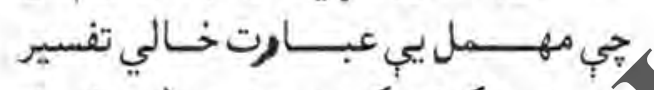

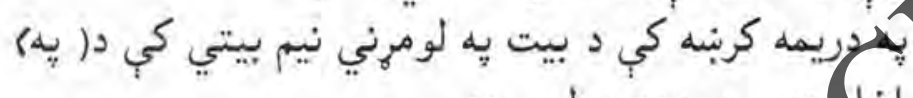

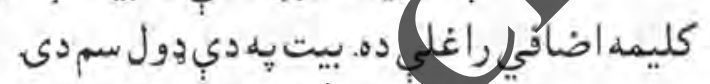

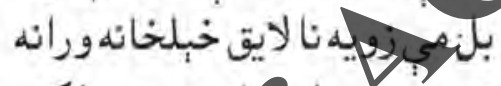

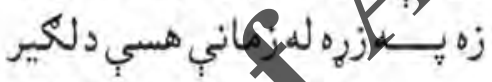

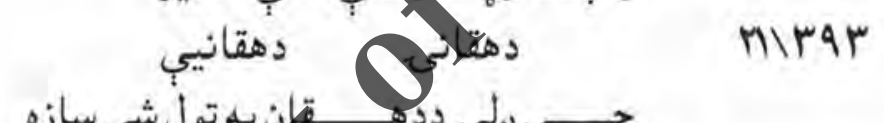

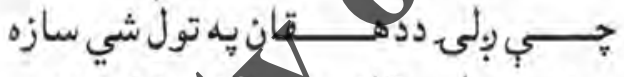

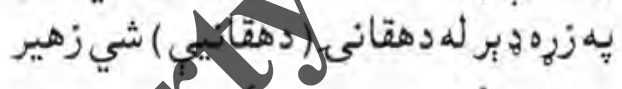
دودلت د نساوي مهر ككرى ديرة

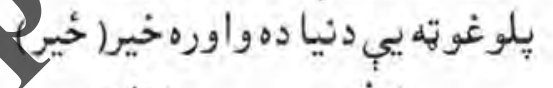

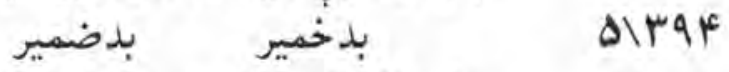

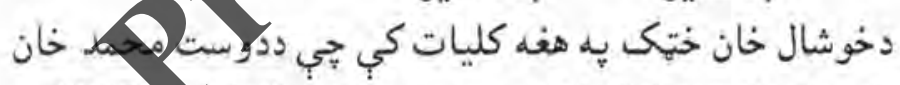

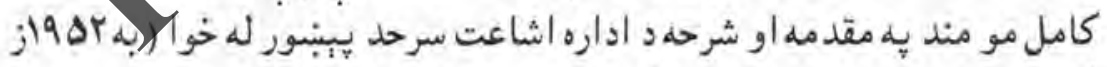

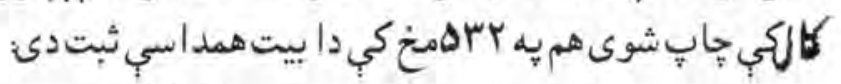

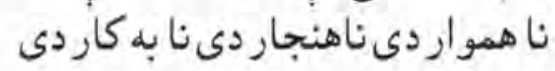

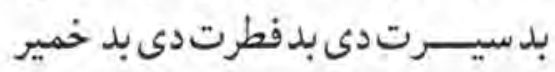
J 
دخوشحال خان

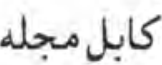

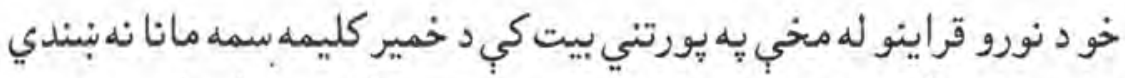

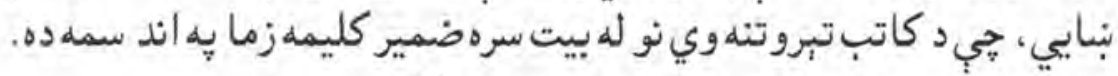

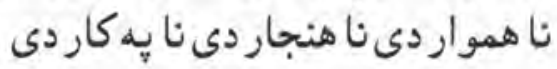

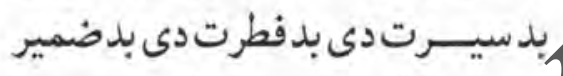

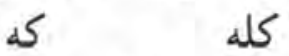

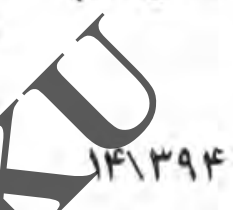

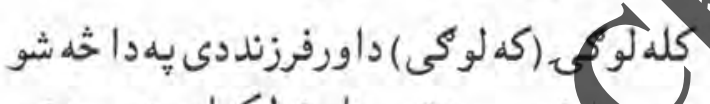

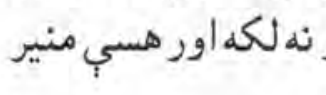

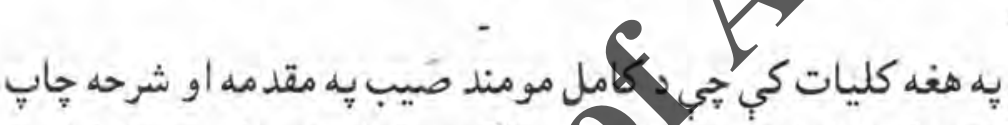
يادونه: - تي

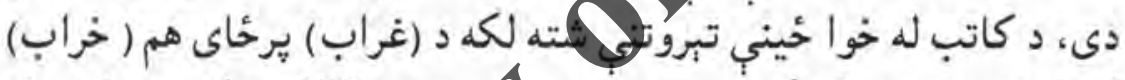

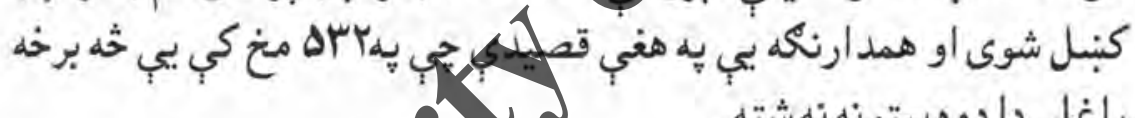
راغلي دا دوه بيتونه نه شته.

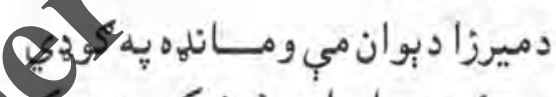

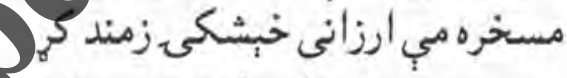

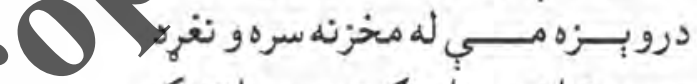

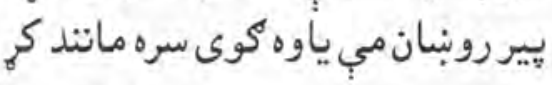

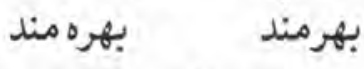
$101 \times 90$

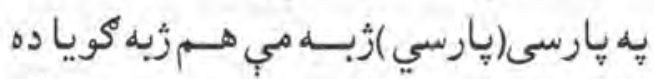

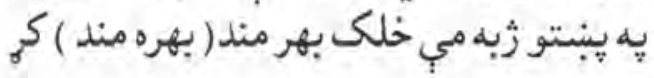
J
$1 \varepsilon$
$=1.8$ 


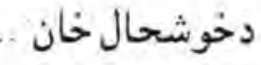

كابل مجله

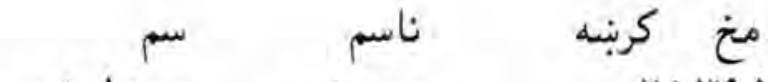

$$
\begin{aligned}
& \text { سود شعر سود له شعر } \\
& \text { كه نور سود (له) شعرنه لرمد دا بسدى }
\end{aligned}
$$

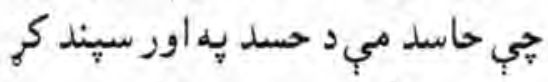

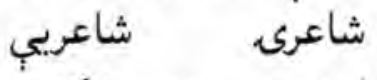$$
\text { r. Iras }
$$

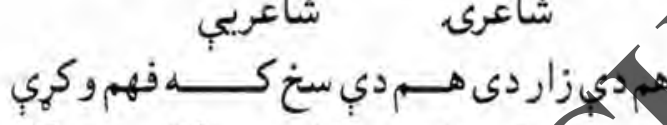

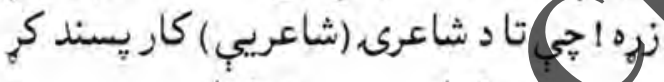

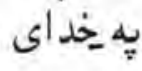$$
1+
$$

YHIMQS

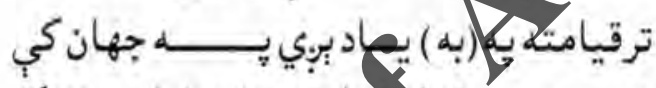

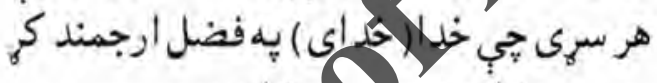
شاعرى

A. viray

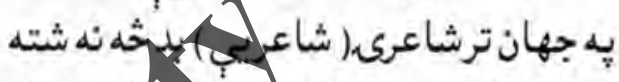

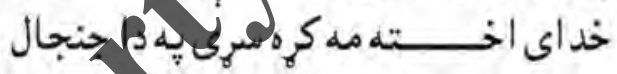

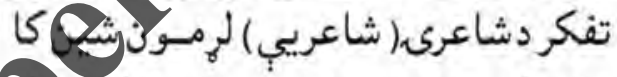

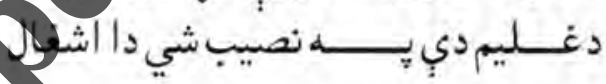

\section{يبيسب جاسوي}

III ray

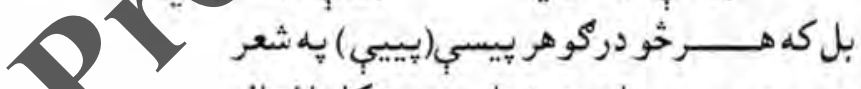
عيب جويي يب جاسوي( جاسوسي) كا دافعال

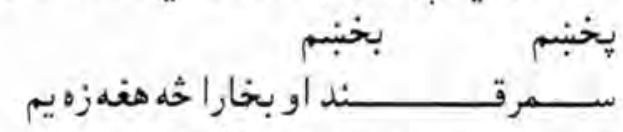

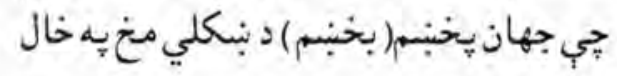


دخوشحال خان ...

كابل مجله

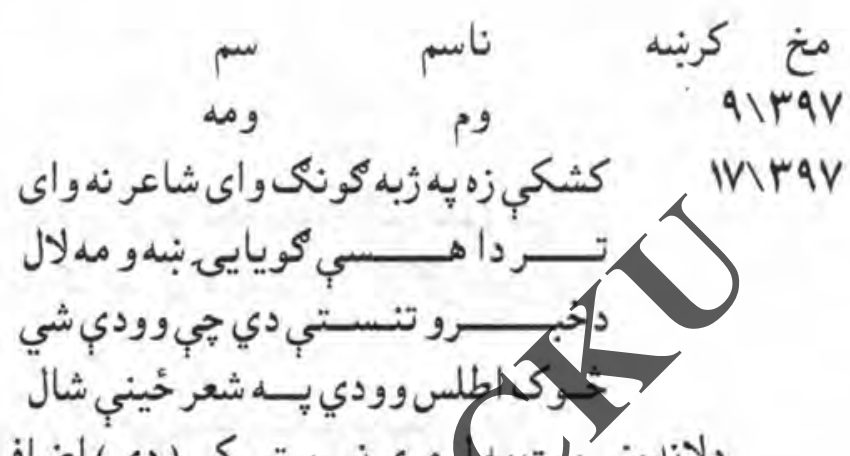

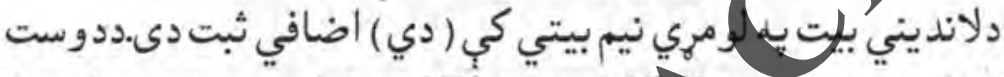

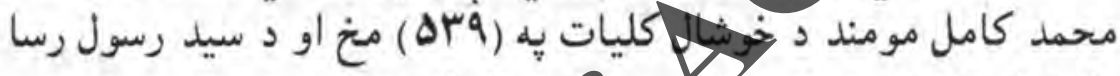

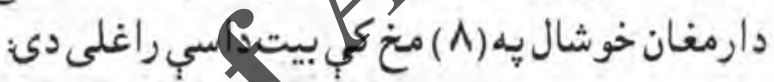
دخدانس

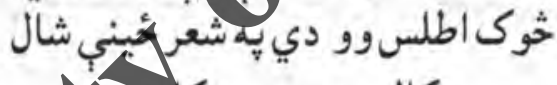
كال reITIV

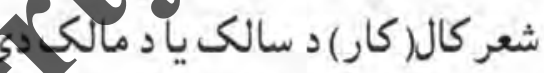

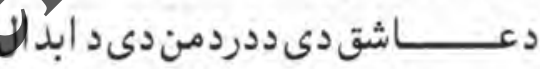

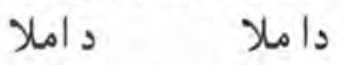
PraA

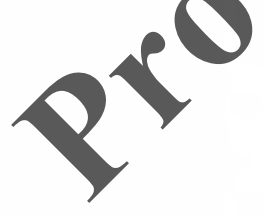

طبيعت مب عطابي نهد تحصيل ملدى كه خبريم داملا(د املا ) يه اشتغال تهال

$$
\text { طال }
$$

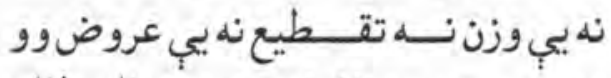

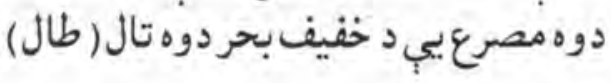

J IrAO
$1 \varepsilon \mu$
+1. 9 


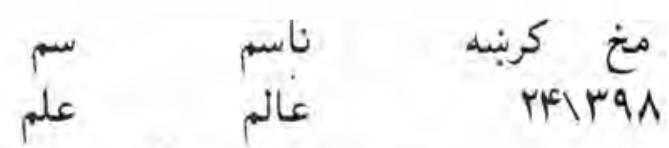

$$
\begin{aligned}
& \text { دوست دبوان مي لكهباغندعالم (علم) كنج دى }
\end{aligned}
$$

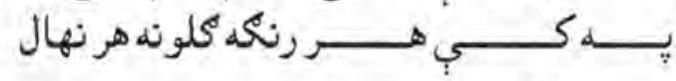

$$
\begin{aligned}
& \text { קيه }
\end{aligned}
$$

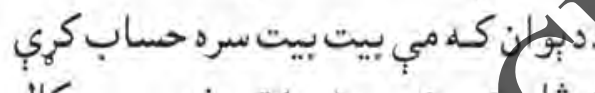

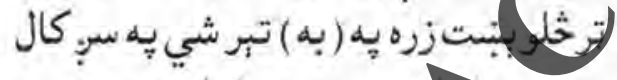

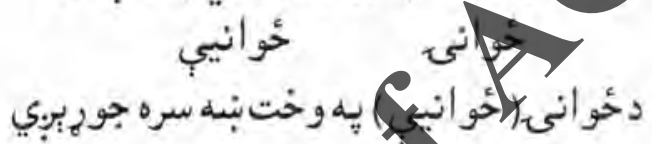

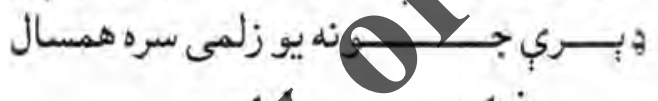

$$
\begin{aligned}
& \text { ئو } \quad \text { نو }
\end{aligned}
$$

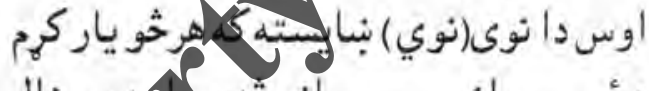

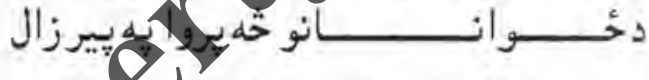

$$
\begin{aligned}
& \text { 1.11999 } \\
& \text { و } \quad 1.1199 \\
& \Delta 1 r 9 q \\
& \text { istan }
\end{aligned}
$$

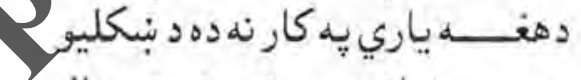

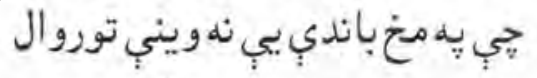

$$
\begin{aligned}
& \text { تيزيز } \\
& 101499
\end{aligned}
$$

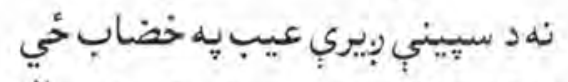

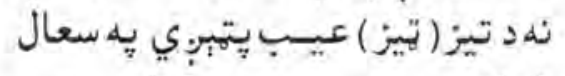

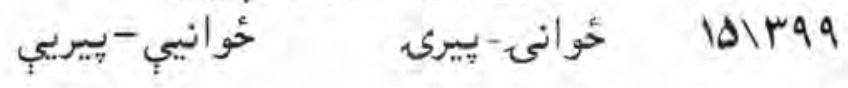

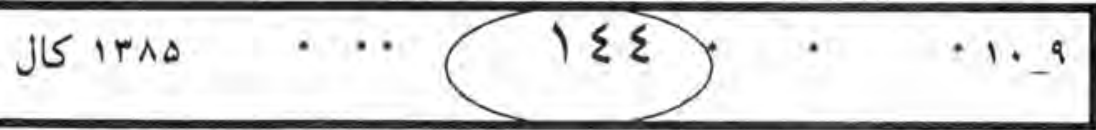


دخوشحال خان كابل مجله

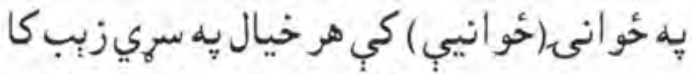

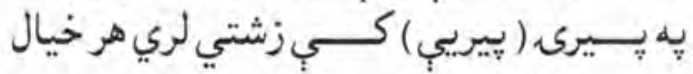

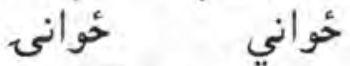

$$
\begin{aligned}
& \text { دخو اني(خوانيل ) وخته كه بيا راتلى يه ببرته } \\
& \text { مهر } \\
& \text { نه }
\end{aligned}
$$

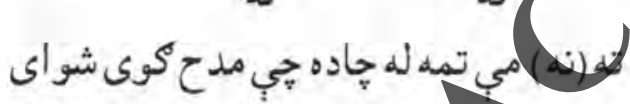

$$
\text { ب M M M M... }
$$

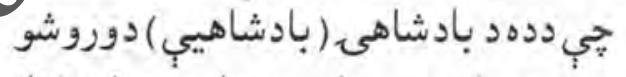

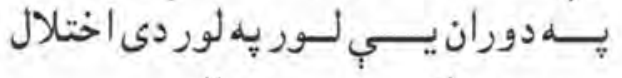

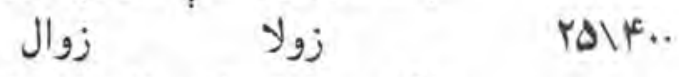

$$
\begin{aligned}
& \text { لكه دى زما زولا (زوال) و تهناظردى زولى }
\end{aligned}
$$

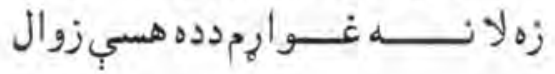

$$
\text { J }
$$


دخوشحال خان

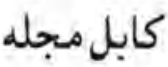

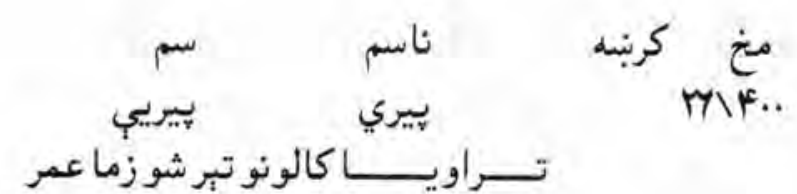

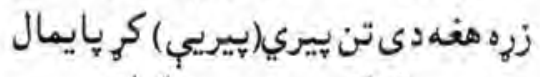

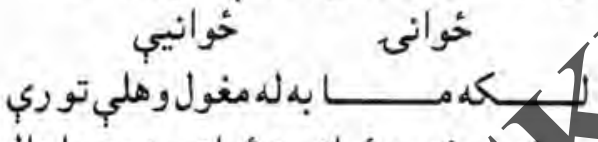

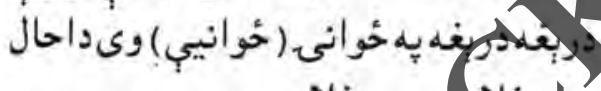

ديل-خلاصي

$|M| c . \mid$

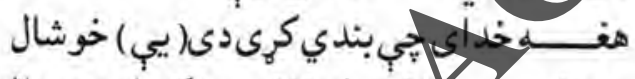

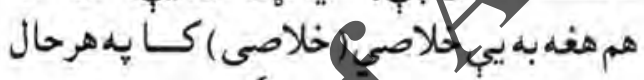

مال

MFiF..

كه خوشال ختّك واربيمونديه جهانكي

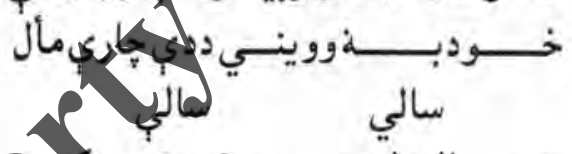

HET

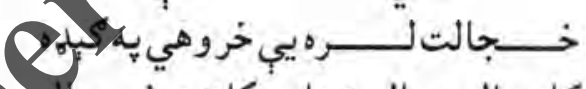

كله سالي) سالب) جاري كاندي غيروسير سار

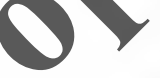

$$
\text { او }
$$

9

$\Delta \backslash r$

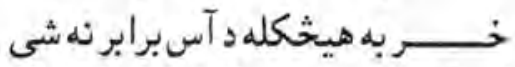

كهدآس غوندي يبيد اكا سمو (او ) يال

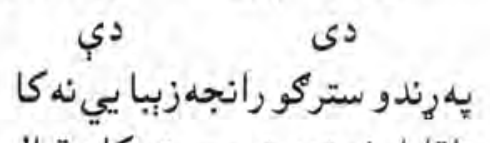

(نوربيا)

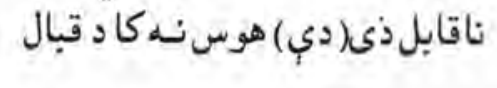

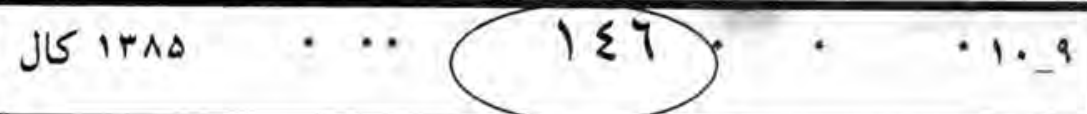




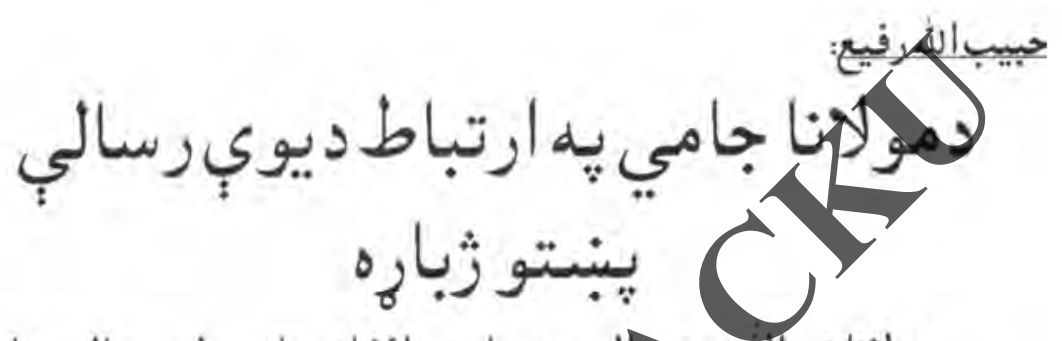

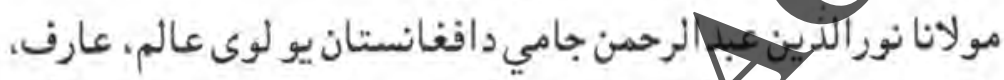

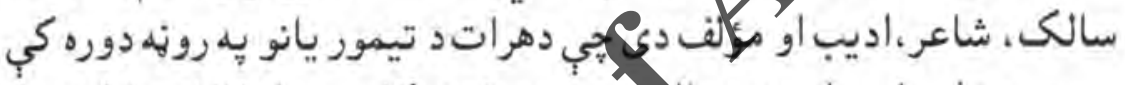

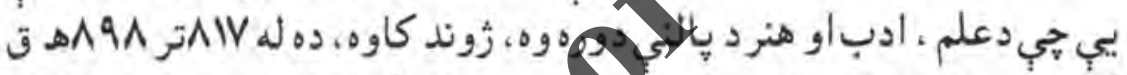

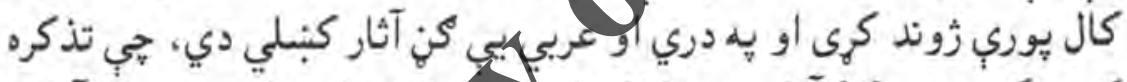

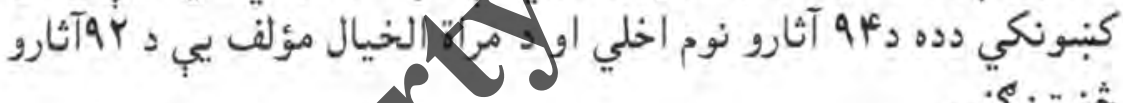
خنبتن كني.

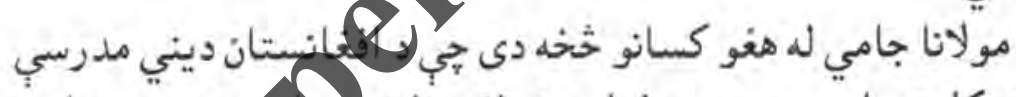

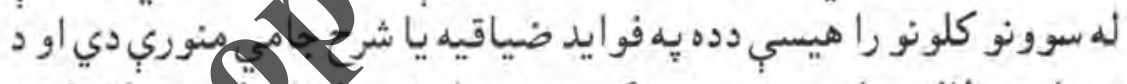

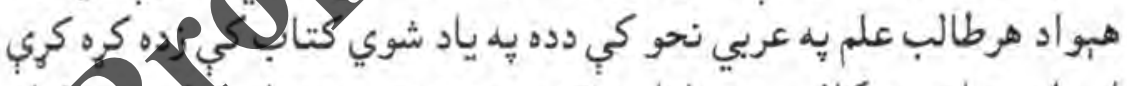

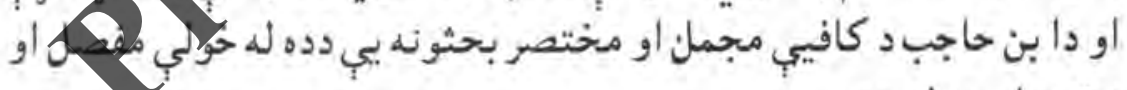
مشرح اوربدلي مدي ماجي كافي

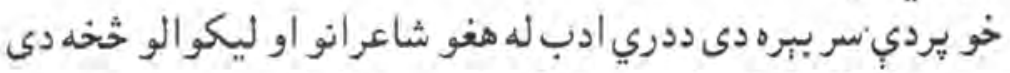

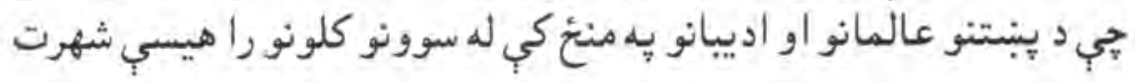


دمو لاناجامي يه.

كابل مجلة

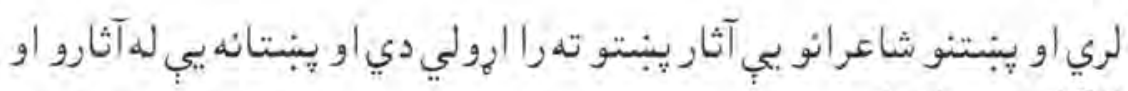

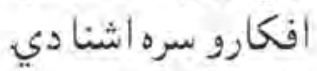

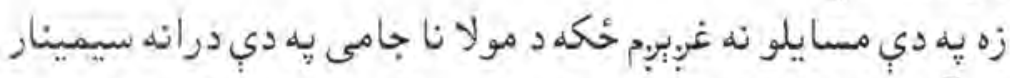

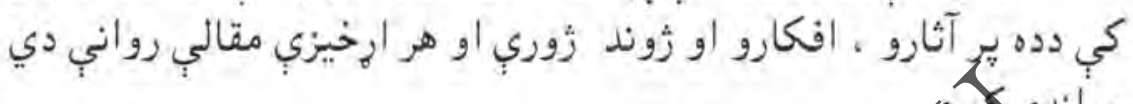

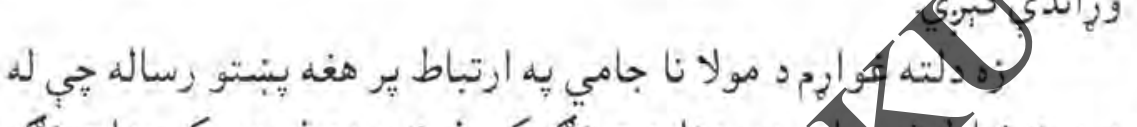

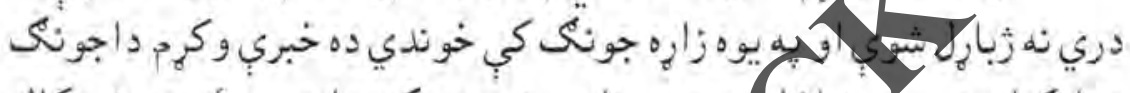

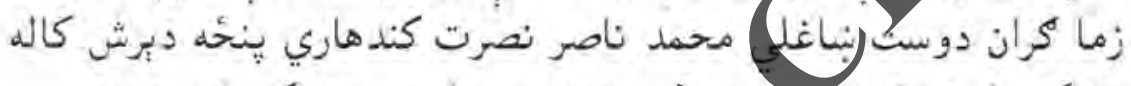

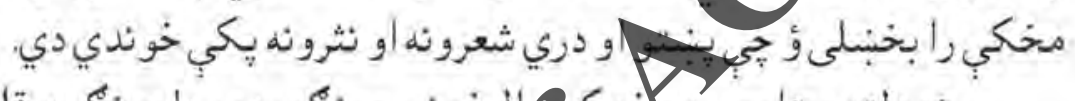

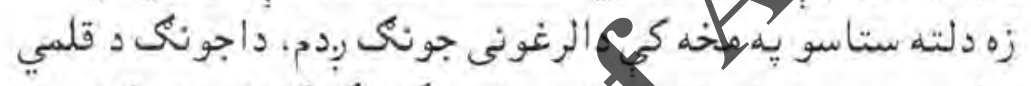

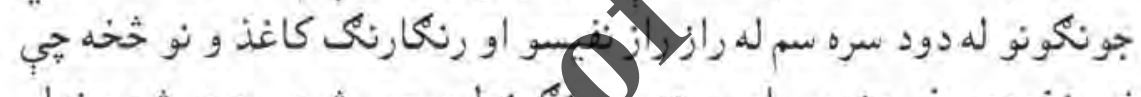

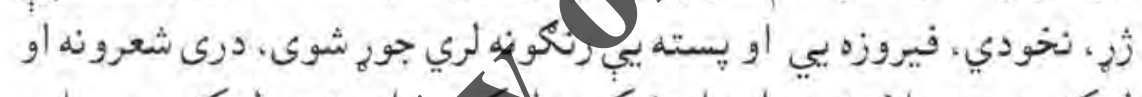

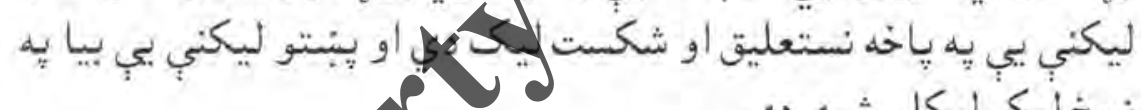

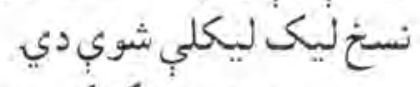

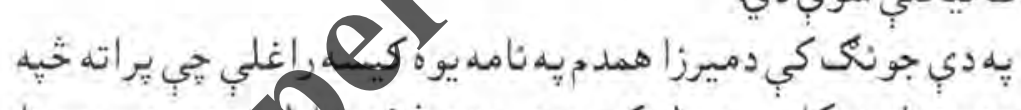

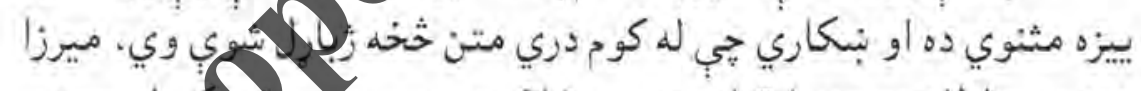

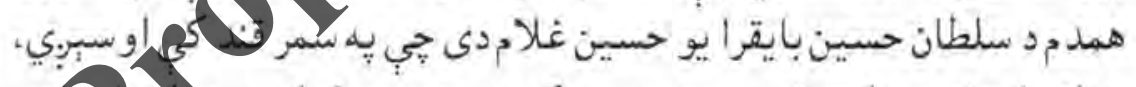

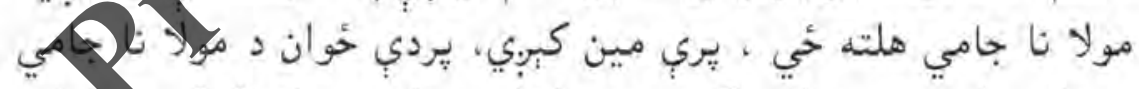

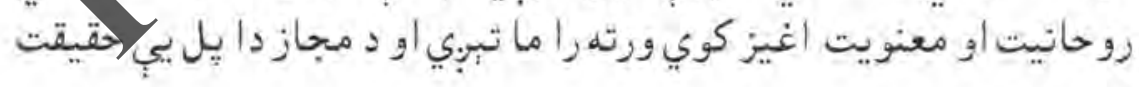
تله رسوي.
J IrAs
$1 \leqslant 1$
$+1.9$ 
بيا يـه اسمد الله كرم

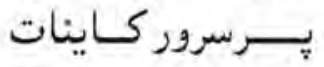

حمدثنا به كر مدخد ايى

يه يرده كي يتّينهان

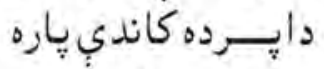

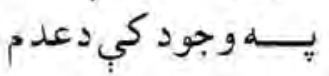

د كيسيد يِيل بيتونه دادي:

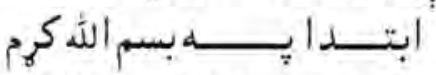

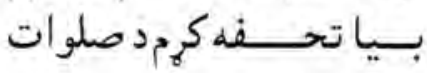

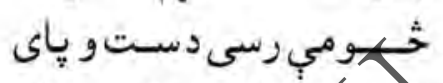

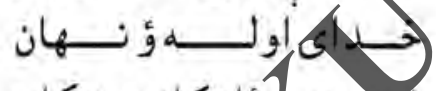

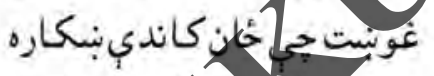

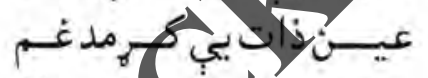

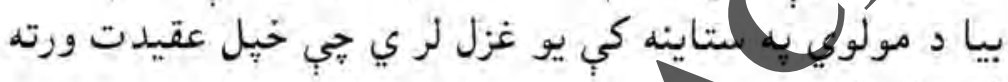

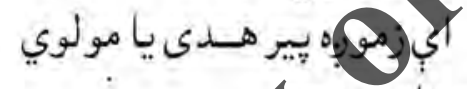

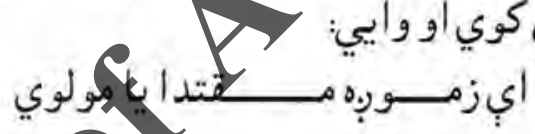
را اخيستى مي قلم دى ستا يه مد حمر

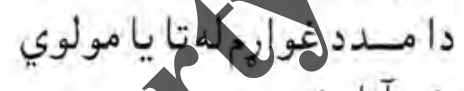

جي جاستاد كوخي خاوربشي آزادشي

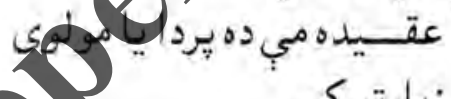

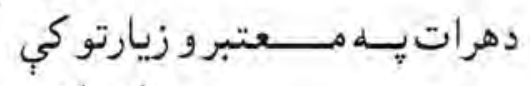

داستا نومدى هويدا يا موليويل

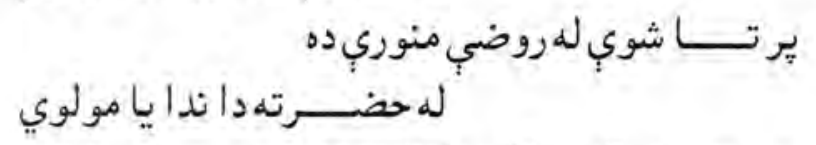

فخرزيات خهدى

$$
\text { جب حضرت جامي بلبل زماد امتدى له }
$$

Siro

$1 \leqslant 9$ 
دمولاتاجامي يه.

كابل مجله

\section{هم داستا ٍِ شان بلبل به خوش لسانه}

بل يو جبرته شي ييدا يا مولوي

كهدا ستا وصال به سر او مال مونده شي يلي

زه بــهنوكرمدا سودا يا مولوي

$$
\begin{aligned}
& \text { استعد اد مي ددي كم عقل دغهو }
\end{aligned}
$$

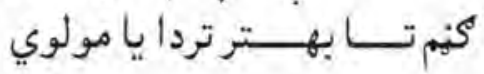

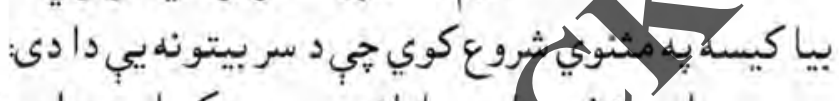

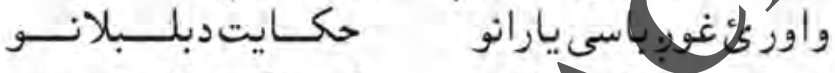

كفــــكوى كاندي عياند

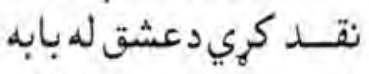

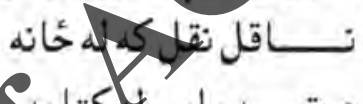

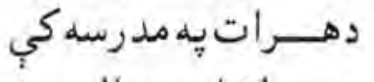

1مـــــولا نا عـبد الرحمن

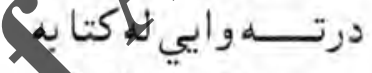

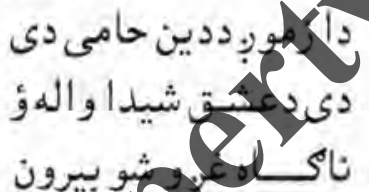

جـ

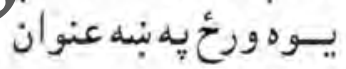

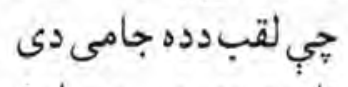

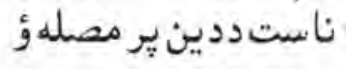

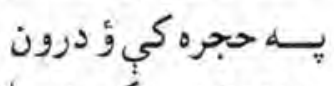

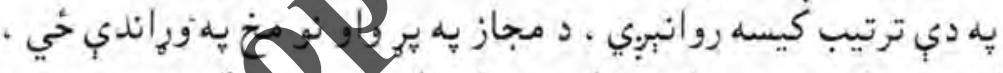

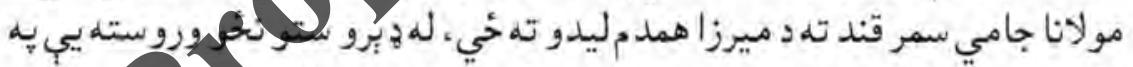

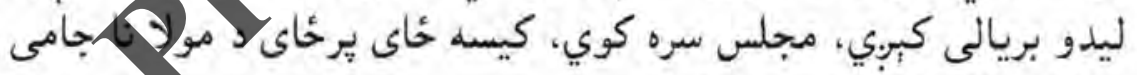

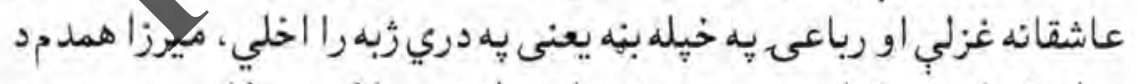

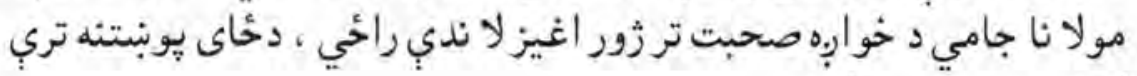
كوي جي متن بي جودا دئ
J IrAD
10.
. 1. 9 
همد موركــرله يوبنتهنه

اوس احوالر اتهتقديركره

دكومخاى، يه اراده يبي

ولى ســـــا دور غلاميم

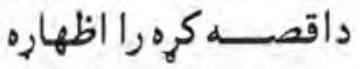

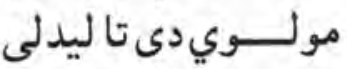

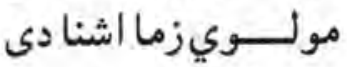

ييد اشــوي يو له موري

هم يــــو دواره هم نسب

دى راكرى زموبِ خداى

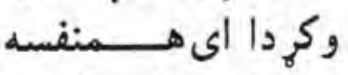

عداجــامـي له غز لياته

كثلـاده كره خيل لبان

نوأوليجا شعر آغاز كر
جي دوى خلاص شونلمخوروند

جـ جب لجِ

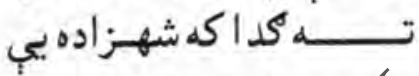

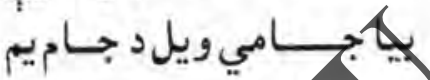

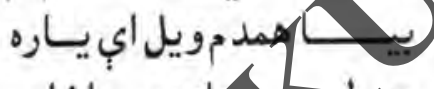

جيا

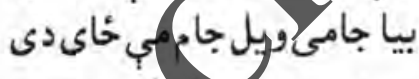

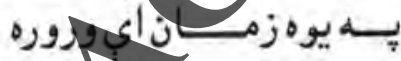

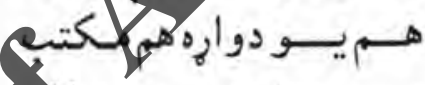

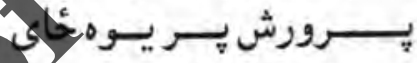

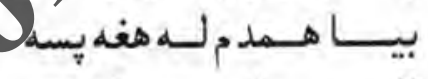
ماس و مسـولانا ته

إمامي تو تي زبان

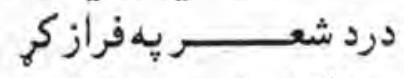

التـ

تي دادئ

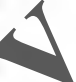

.

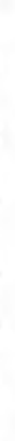

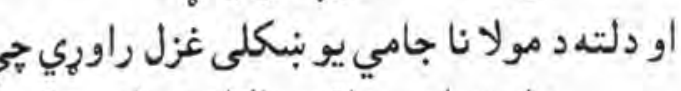

عارض استياقمر يالاله حمرا ست اين ين

يا شعاع شمس يـا آينه دلهاست الين الين

$$
\text { قامت استاينيا الفيا سرويا نخل مراد }
$$

يامكر كـلـلدستهباغجهان آراستاين

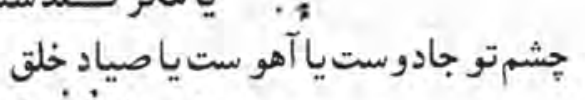

يادو بادأمُ سياهيا نركس شهلاستاين 


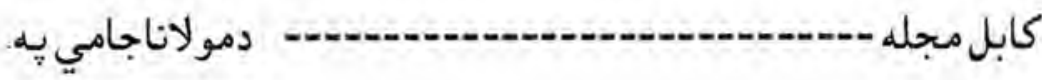

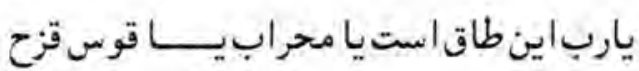

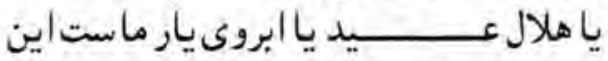

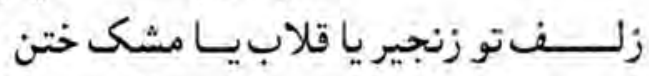

سنبل تريا سمــنـيا عنبر صحراست اين

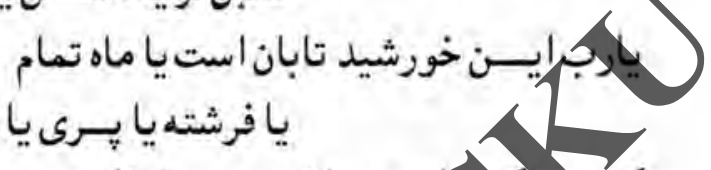

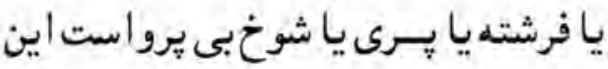

كويتوكبهم كت ،يا فردوس، يا خلد برين

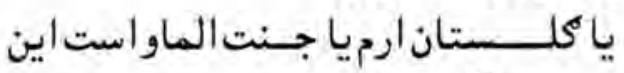

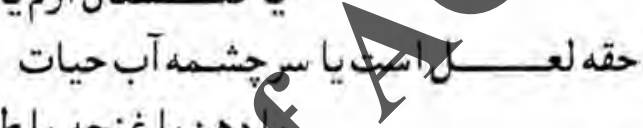

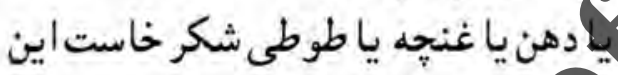

$$
\begin{aligned}
& \text { طوطى شـــروبهيا قمرى باغ جنان }
\end{aligned}
$$

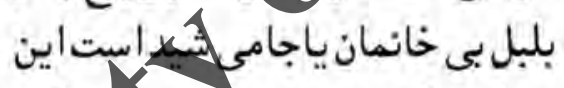

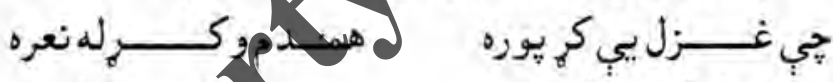

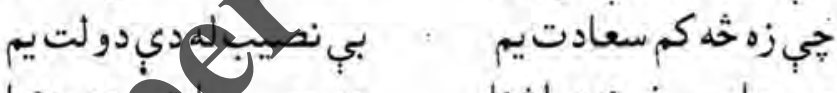

جي جامي غوندي اشنا

كويا زهيم يهزحمتكي

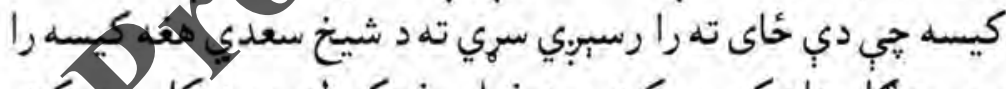

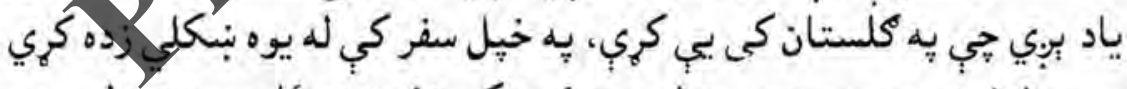

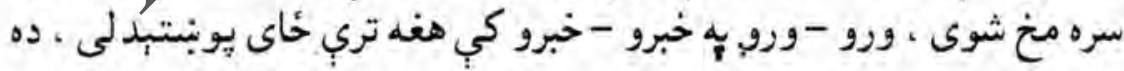

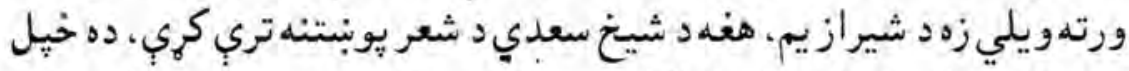

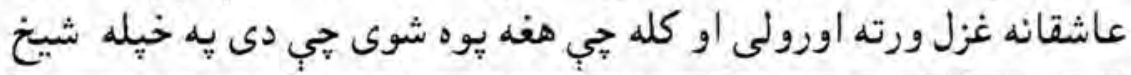

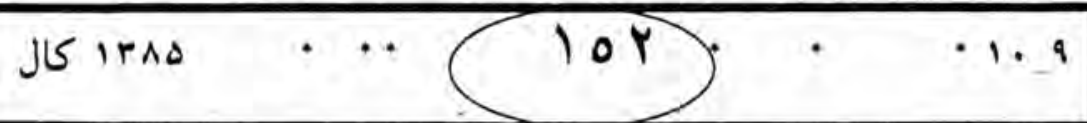




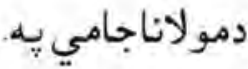
كابل مجله

سعلي دى نو بيا بي د پِا تب كيدو ورته ويلي خو شيخ خيل سفر ته دوام

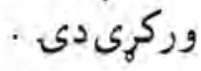

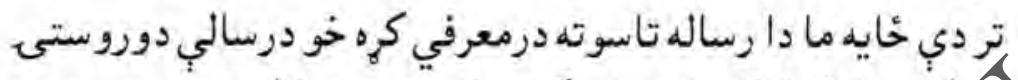

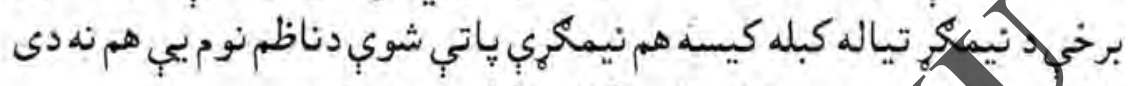

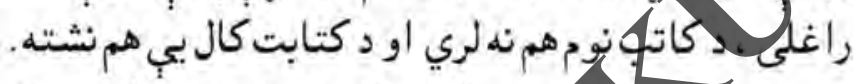

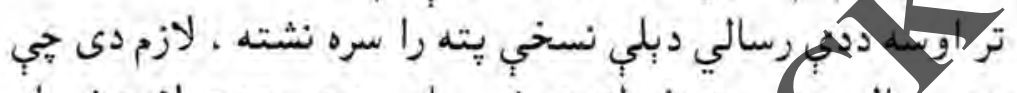

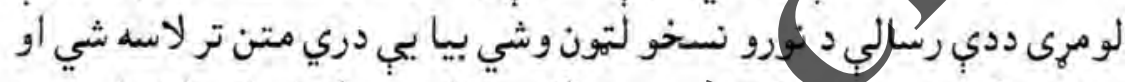

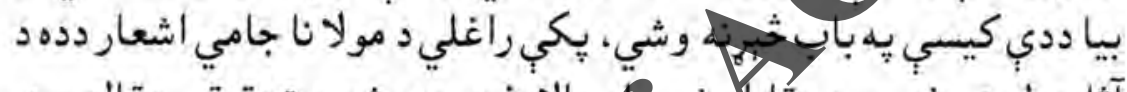

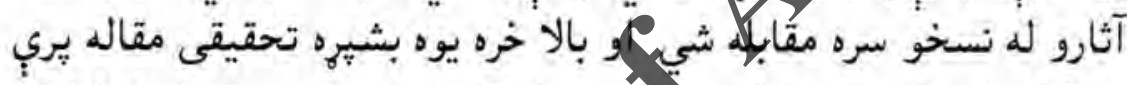

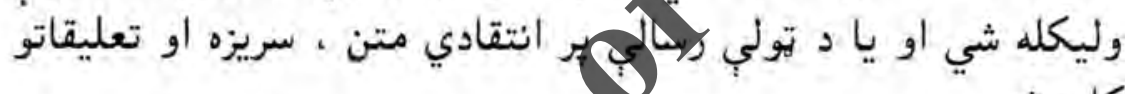

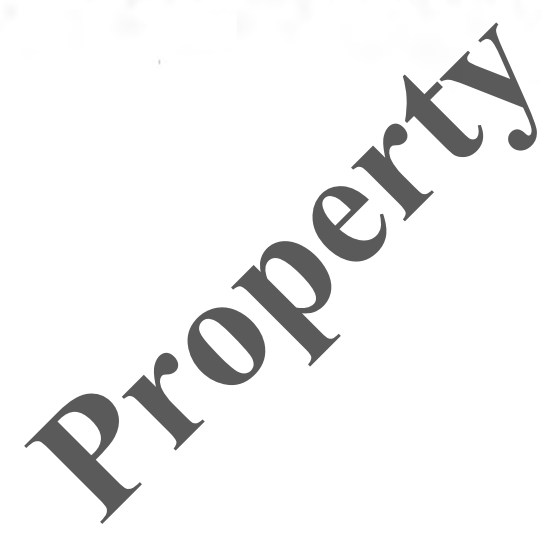
كاروشي.

Irad

104

. 1. 9 


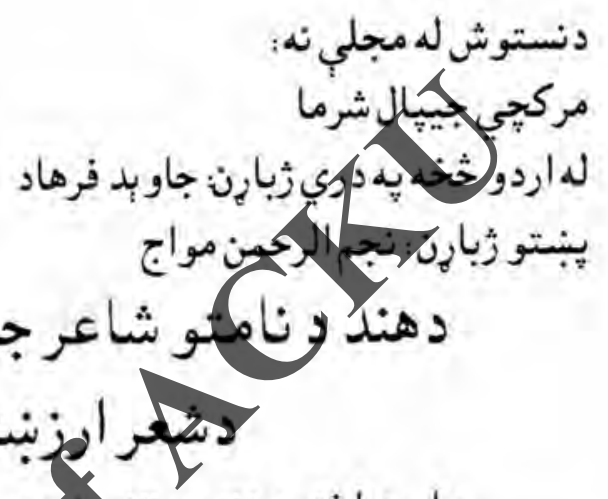

دهند ونامثو شاعر جاوبد اختر له نظره

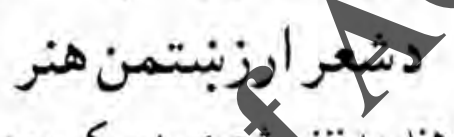

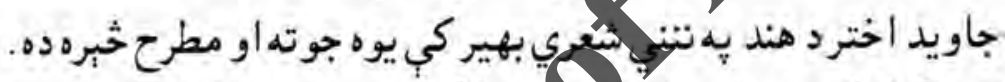

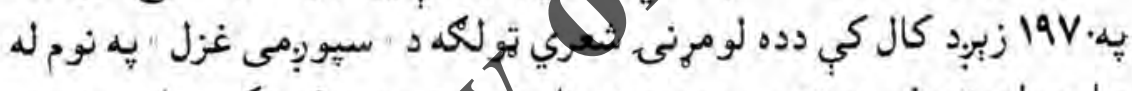

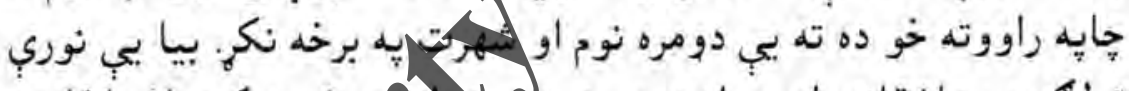

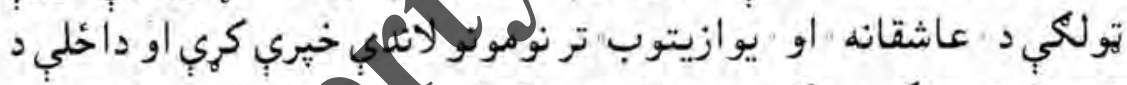

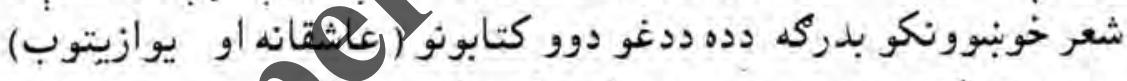

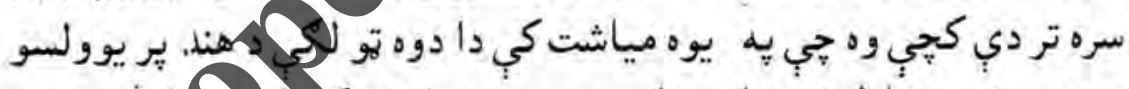

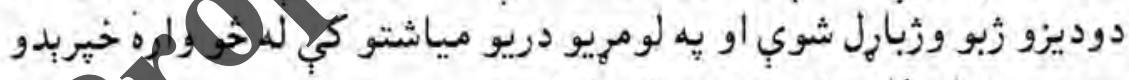

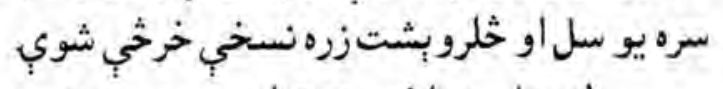

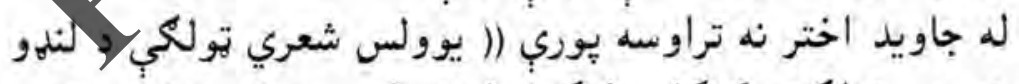

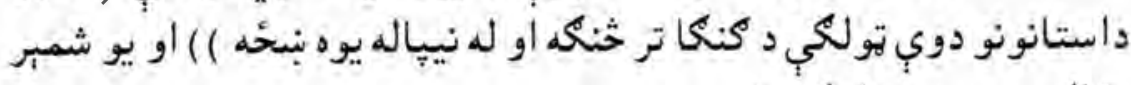

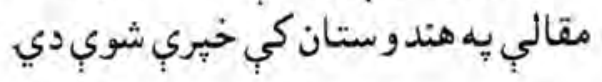

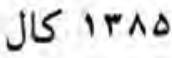
$10 \varepsilon$
1. 9 
يرته له شاعرى هغه سينمايي ارزبتتناكو كارونو سره هم لبوالتيا

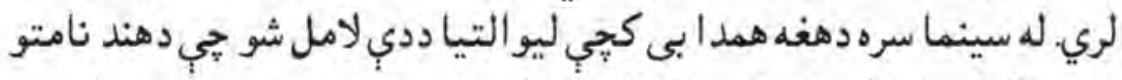

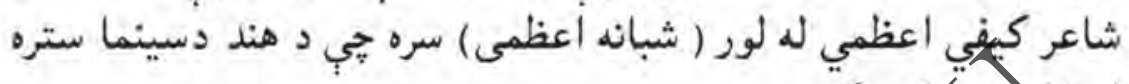

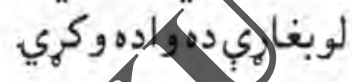

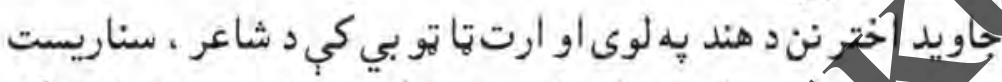

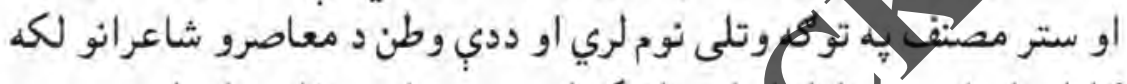

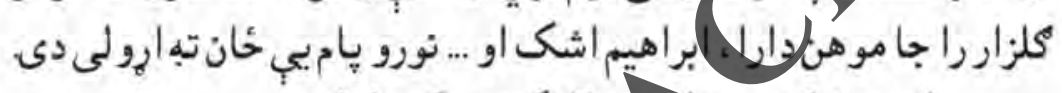

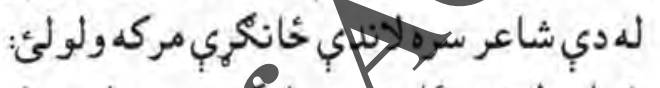

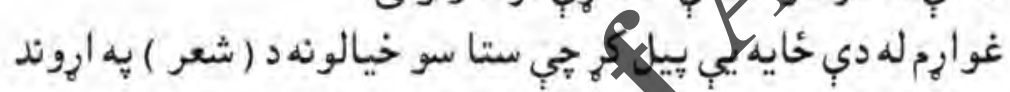

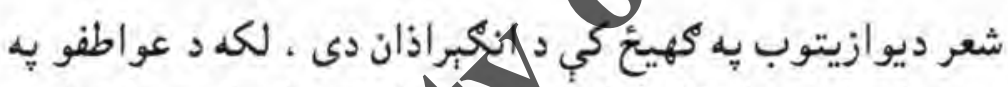

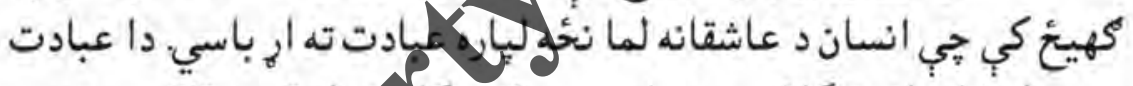

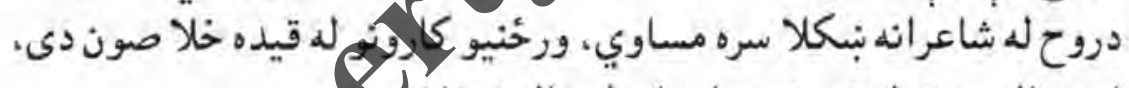

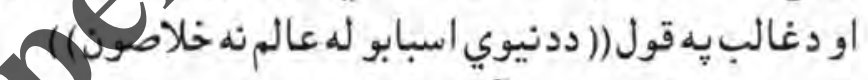

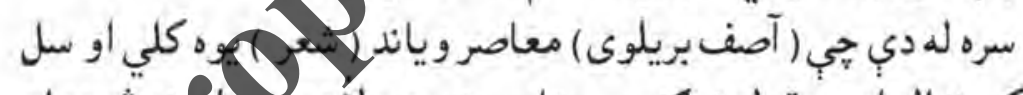

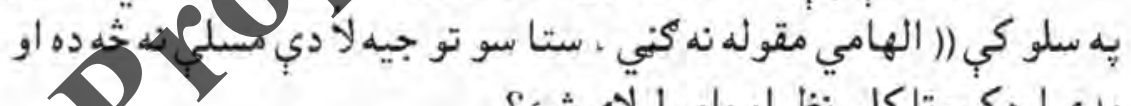

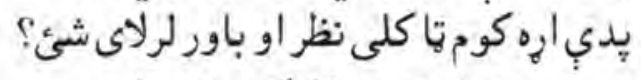

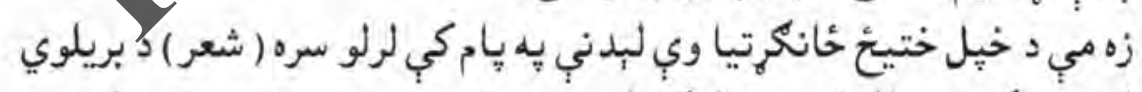

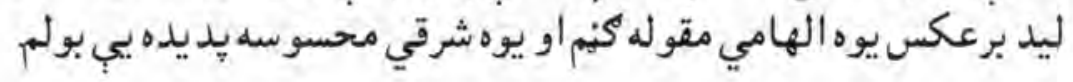

J I I INA 100 $\cdot 1.9$ 


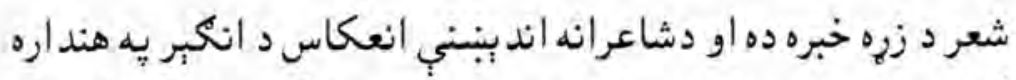

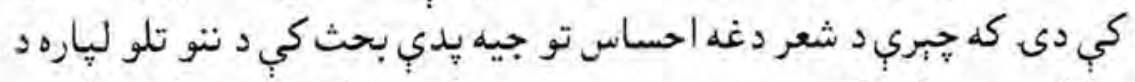

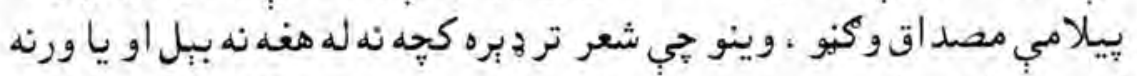

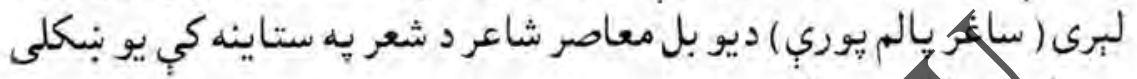

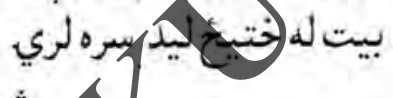

$$
\begin{aligned}
& \text { شعر بلندى هاى احساس است آه }
\end{aligned}
$$

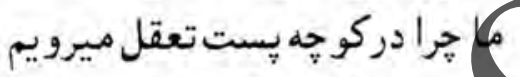

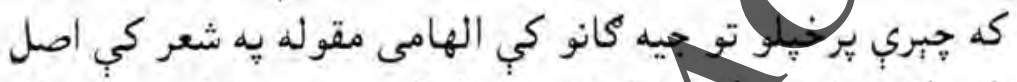

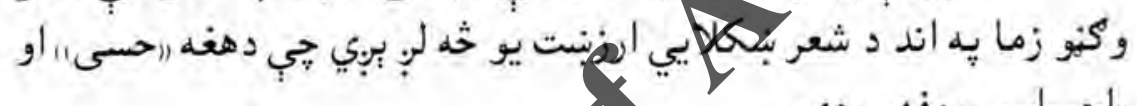

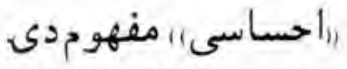

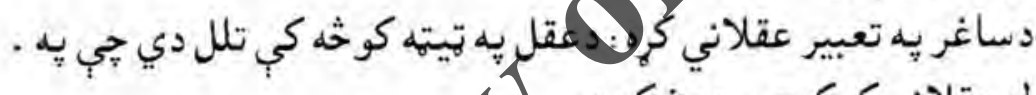

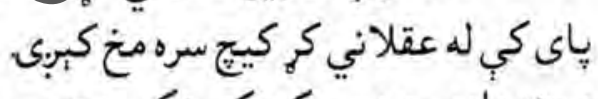

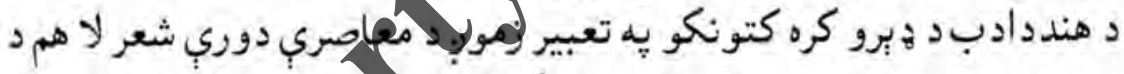

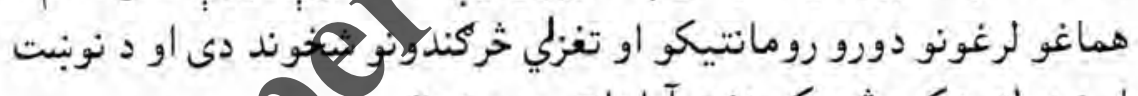

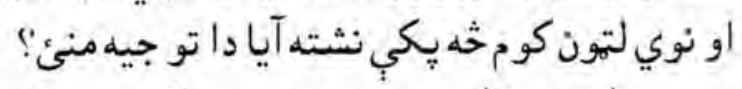

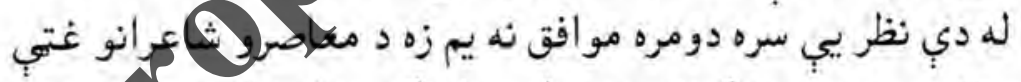

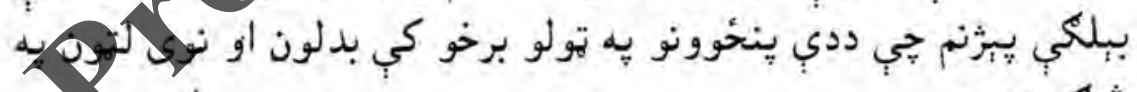

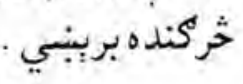

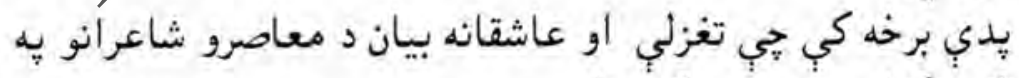
شعرونو كي تكرارببريز زدوبي كتيني لنرم

J 1 irio

109

- 1. 9 
دهند دثامتوشاعر

كابل مدجله

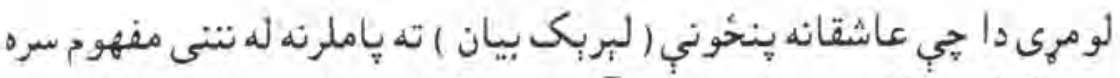

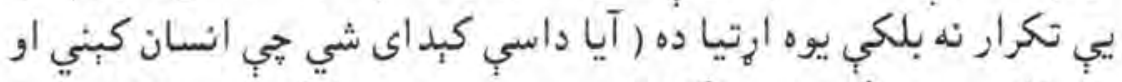

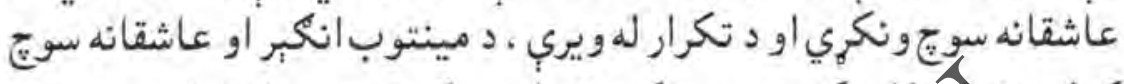

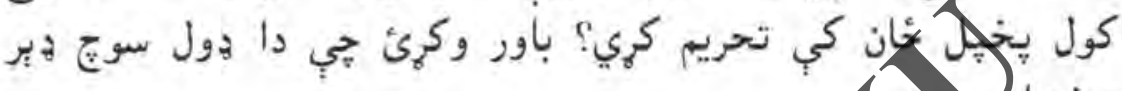

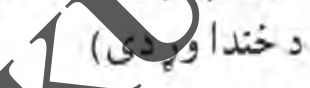

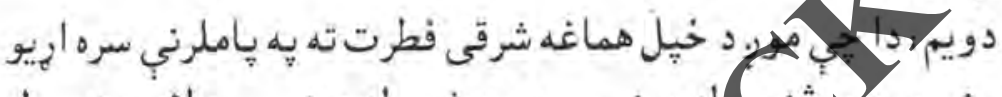

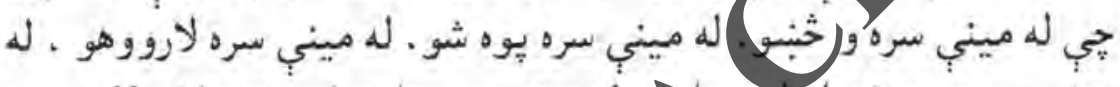

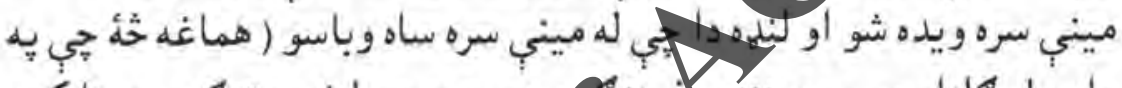

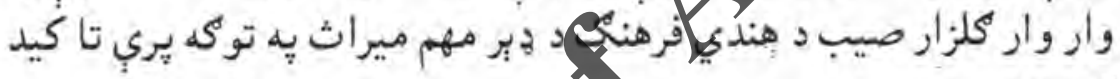

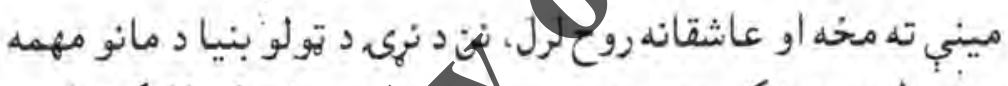

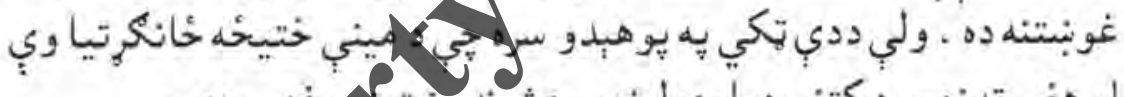

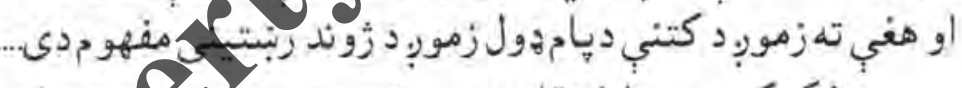

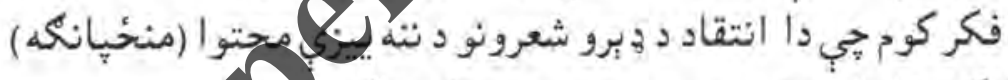

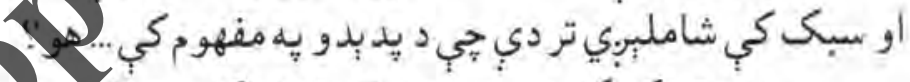

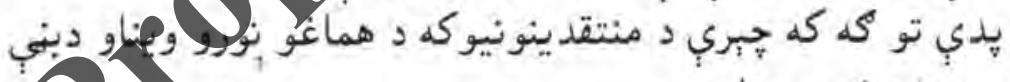

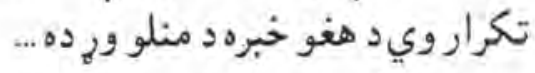

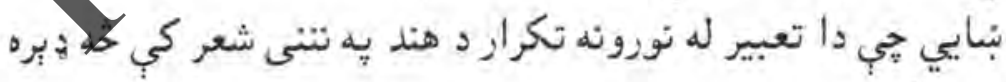
ببخايهنهوي؛

J IrAs

$10 \mathrm{~V}$

$-1.8$ 


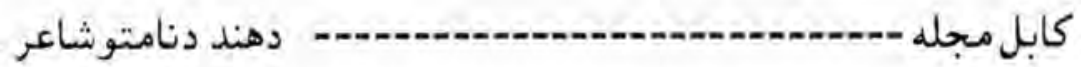

ما زب تكرار او يو ازب د كلاسيكو شاعرانو له شعرونو نه تقليد يـ

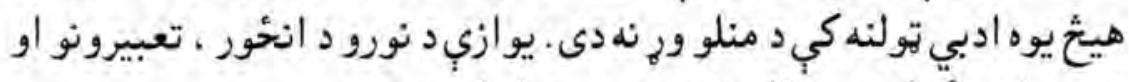

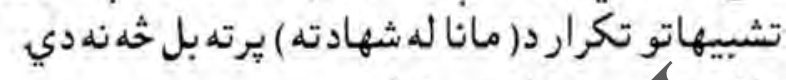

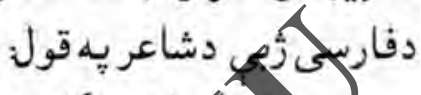

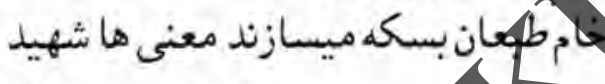

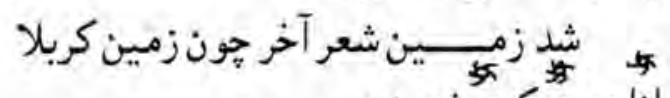

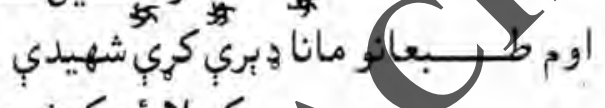

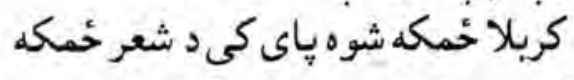

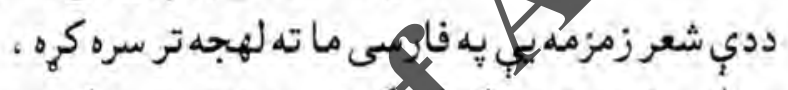

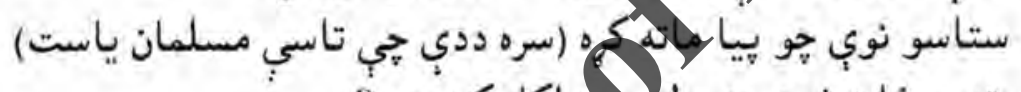

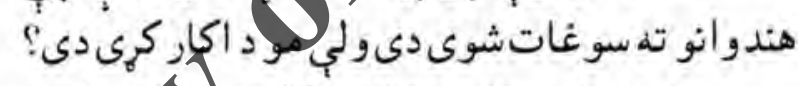

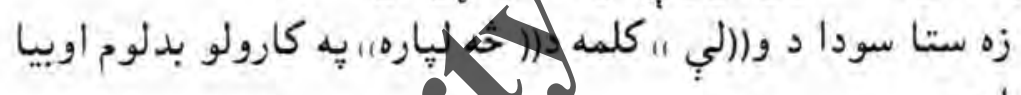

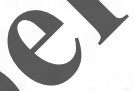

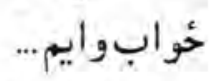

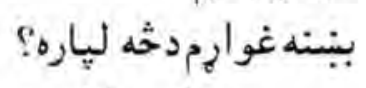

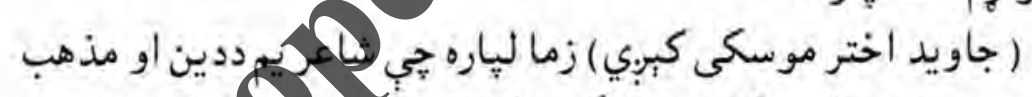

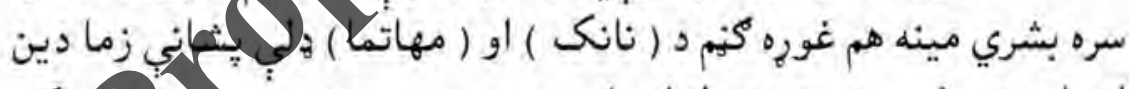

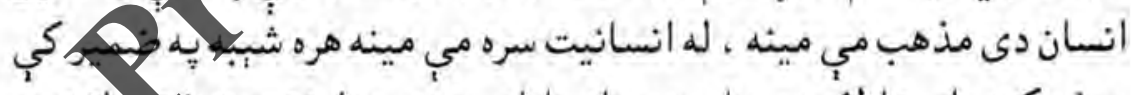

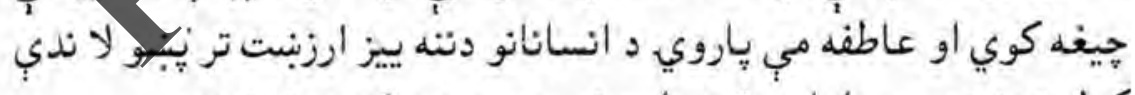

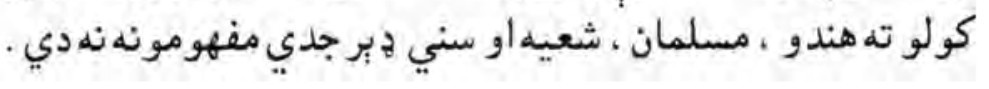

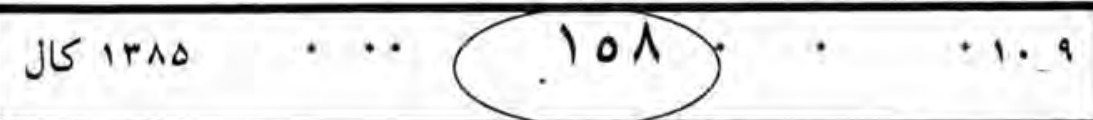




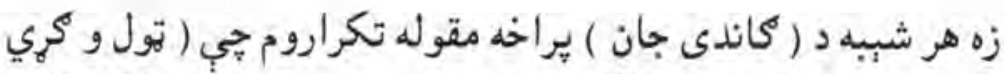

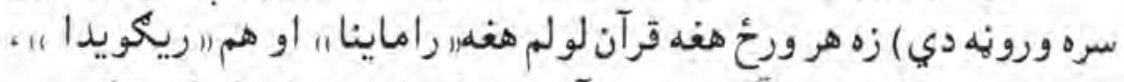

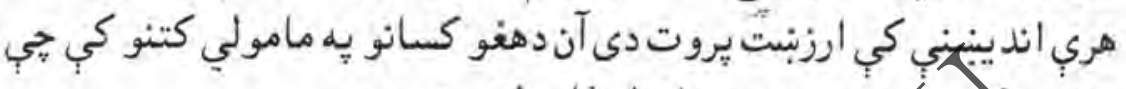

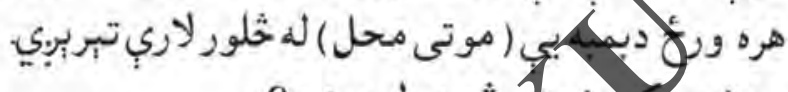

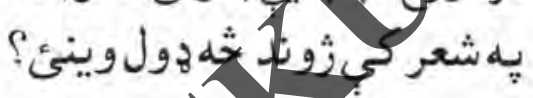

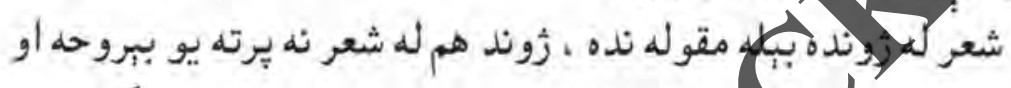

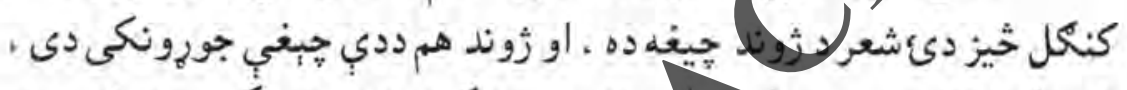

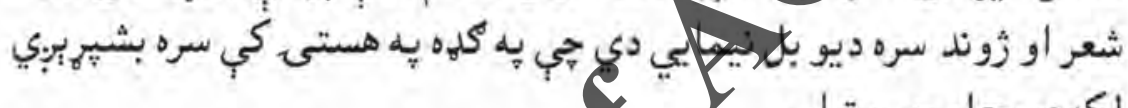
لكهدورح او جسم تراو.

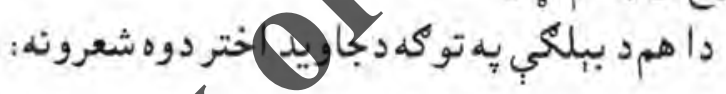

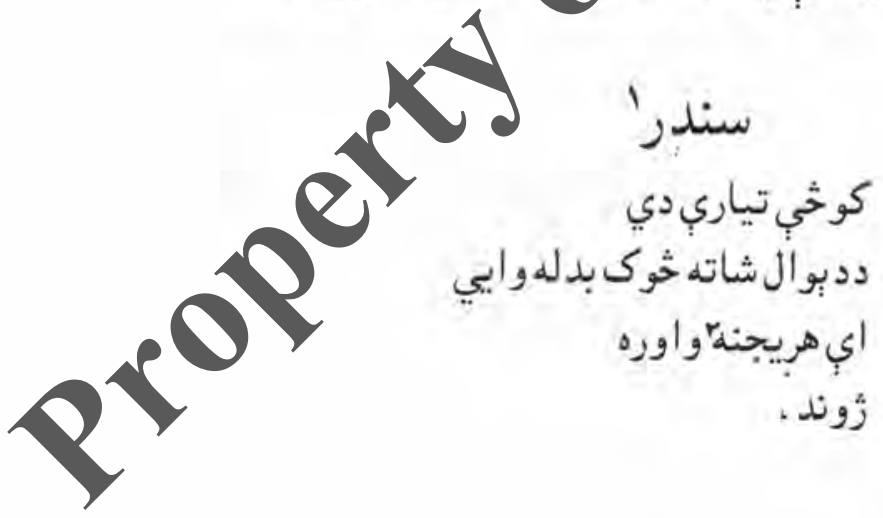

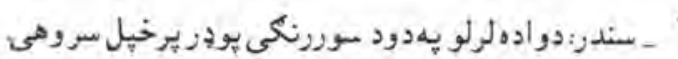

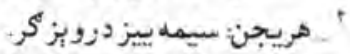

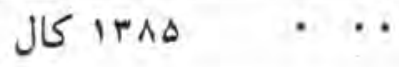

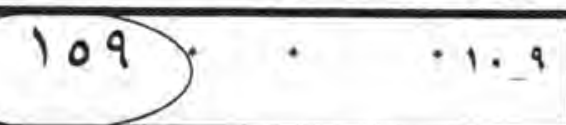


دهند دنامتوشاعر. كابل مدجله

دخداى مفهو ميشانى ندى يو رنك

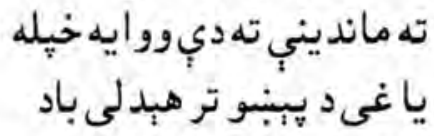
دلاس سندر دي غلا كوي يوه شيه هندارو كملماري يرمخ مه وهله وبره توبد هنداريو كسه

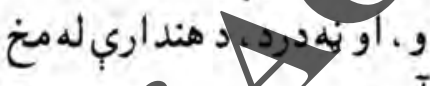
C آ آ... لهز كممه خو مرمرونه 1 كه خوك. كه يوخ.

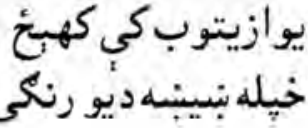
2

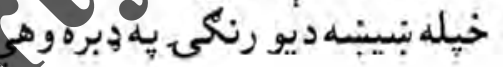
J 


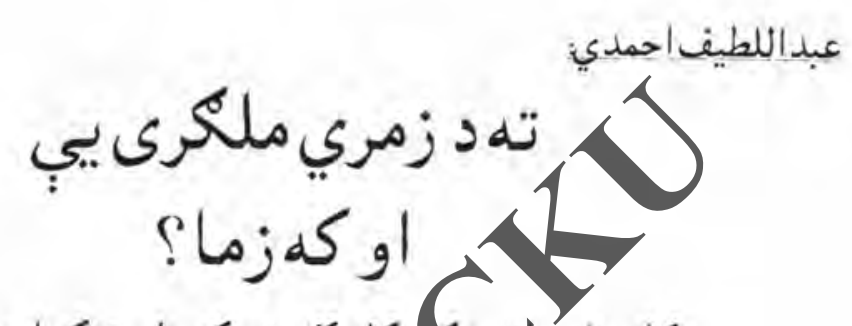

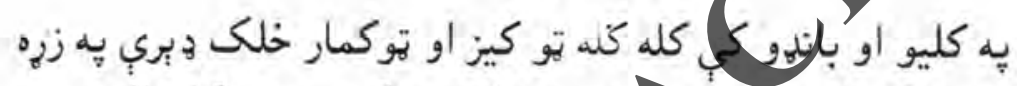

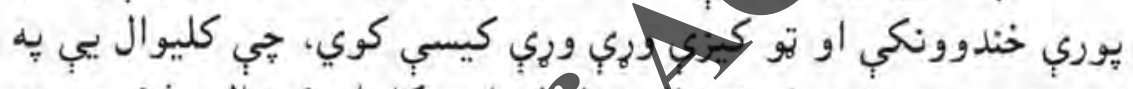

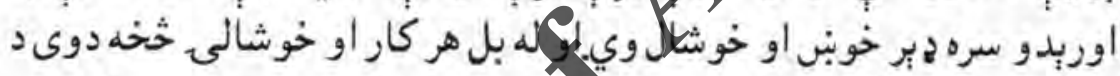

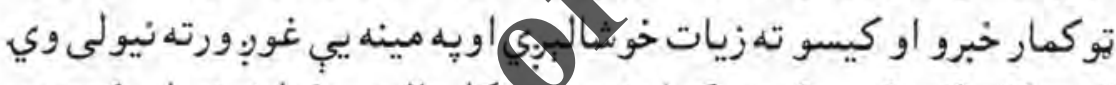

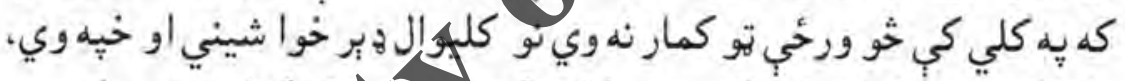

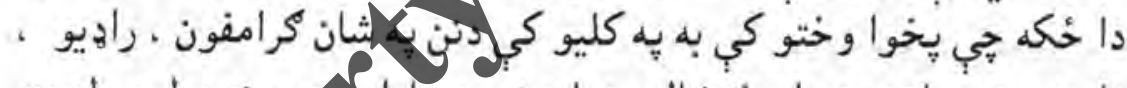

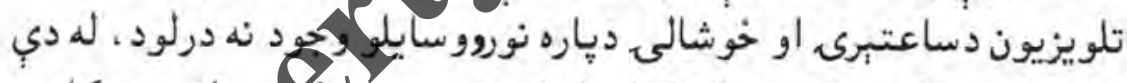

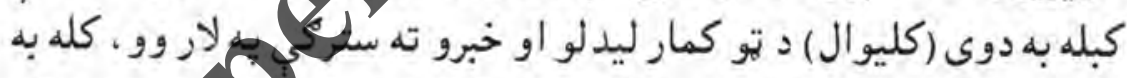

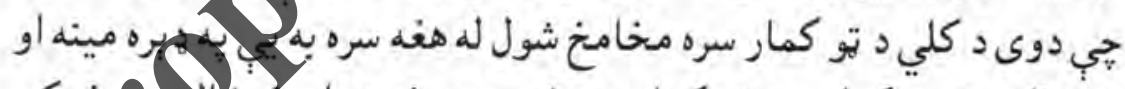

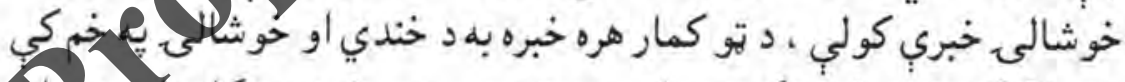

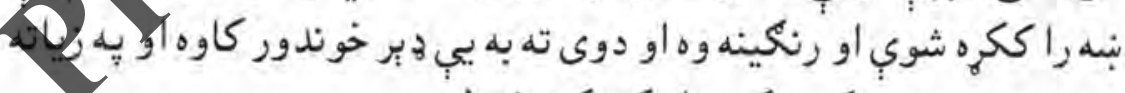

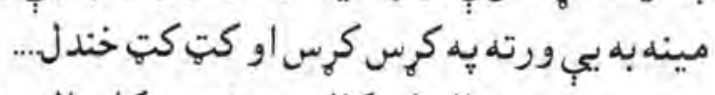

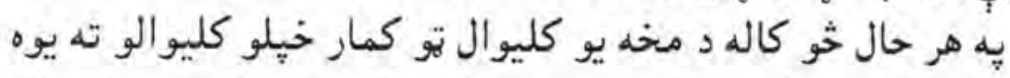

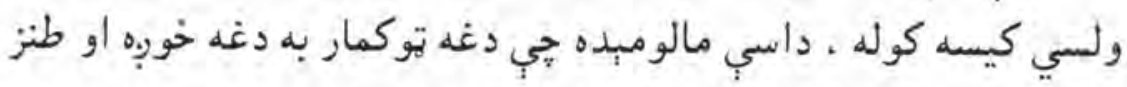

J IrAd $\cdot \cdots$

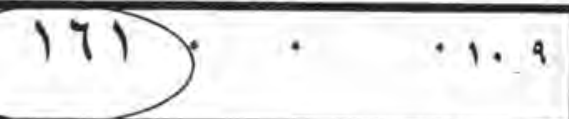




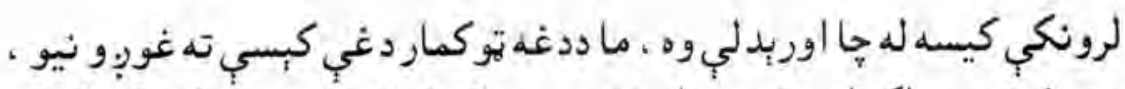

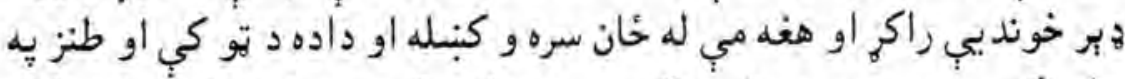

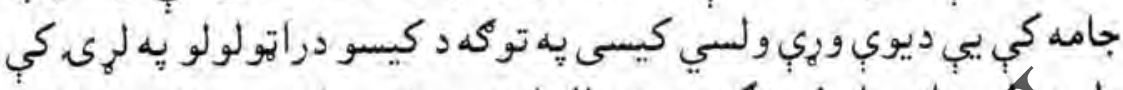

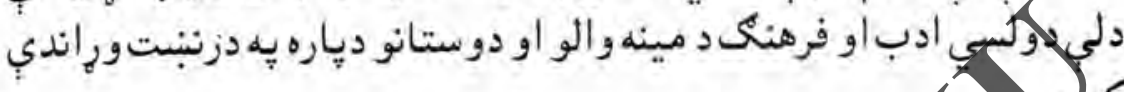

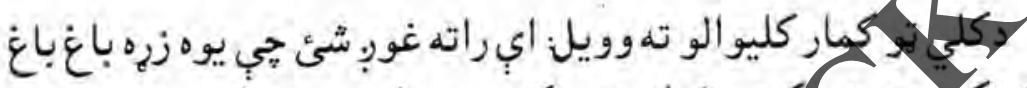

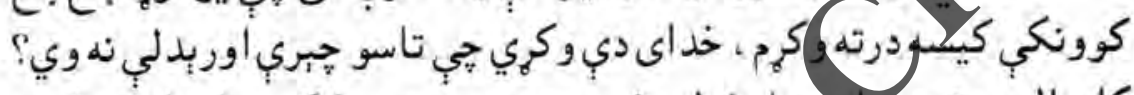

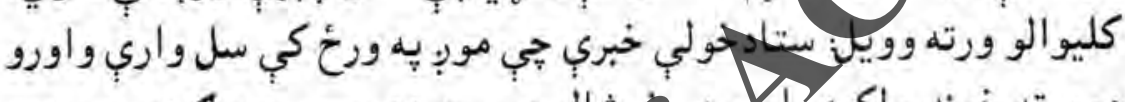

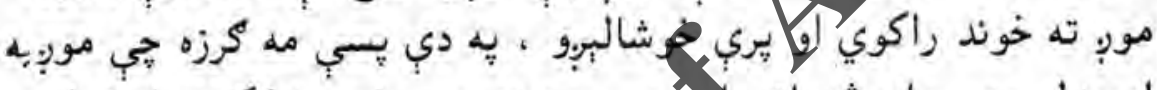

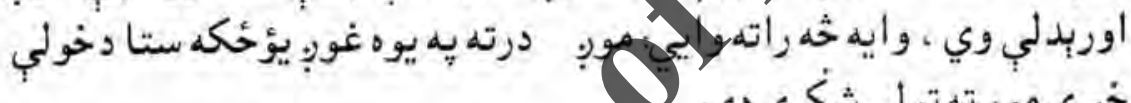

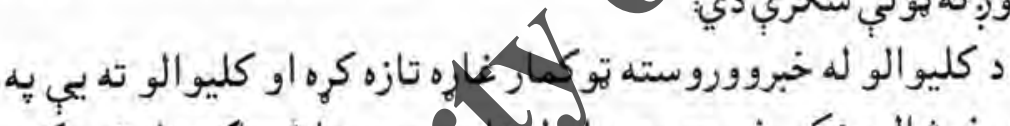

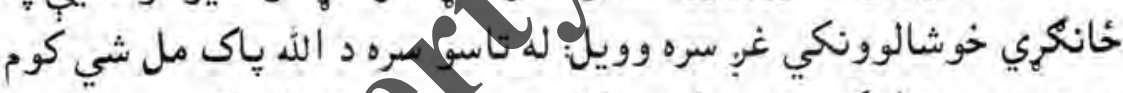

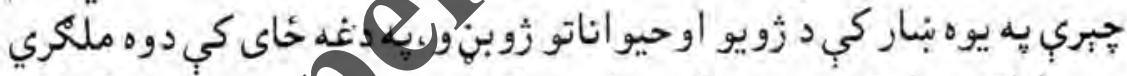

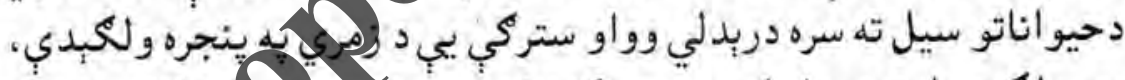

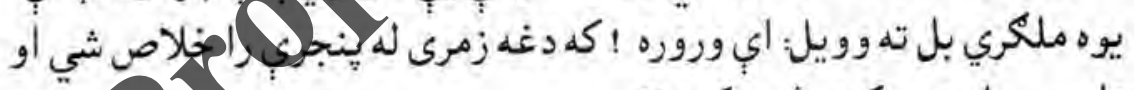

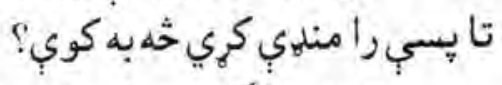

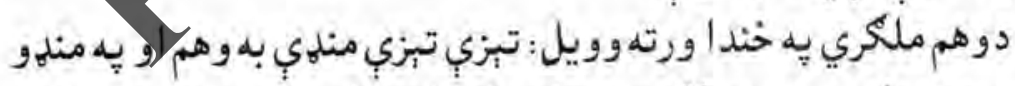

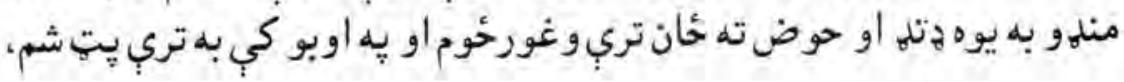

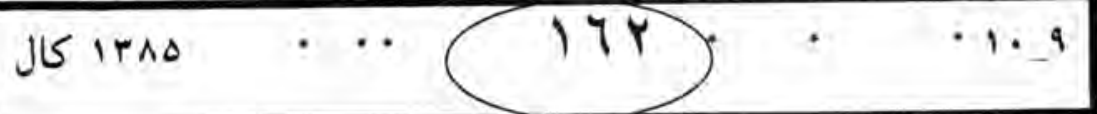




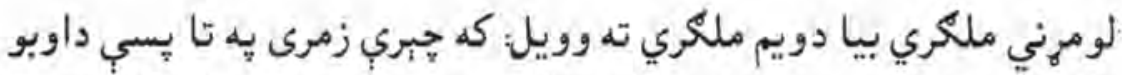

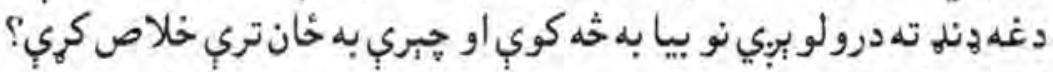

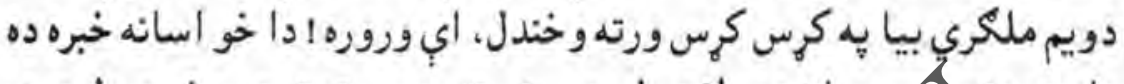

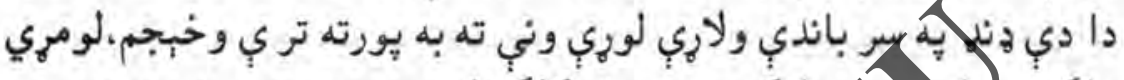

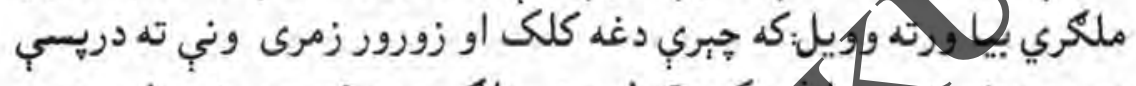

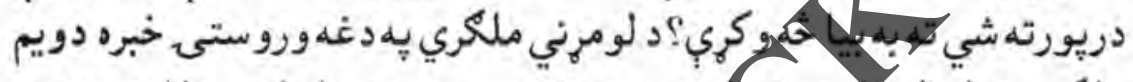

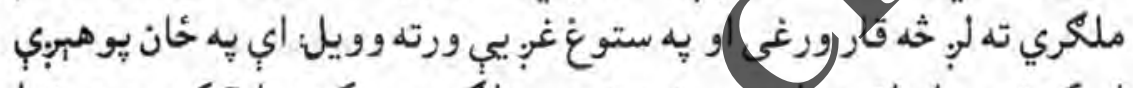

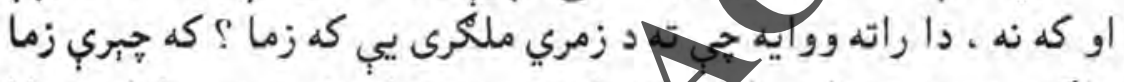

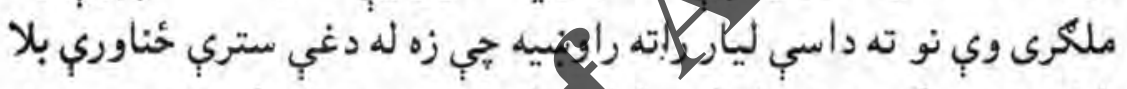

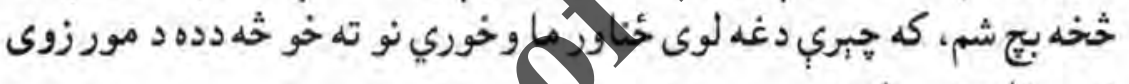
نهيب تابه هم وخوري...

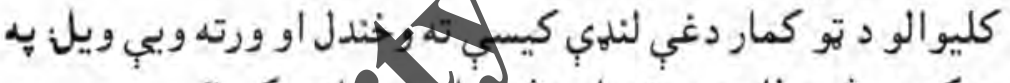

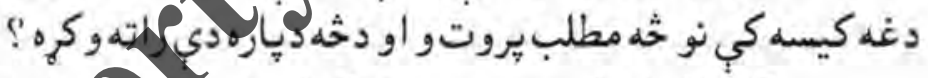

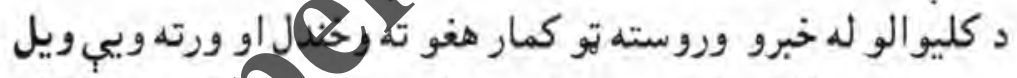

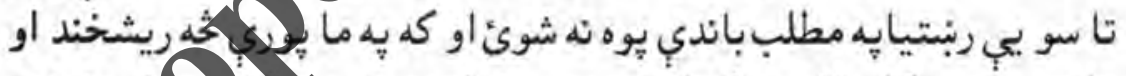

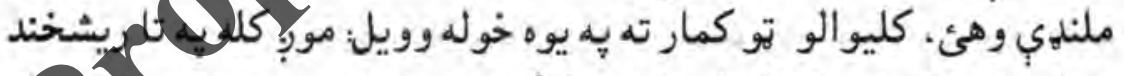

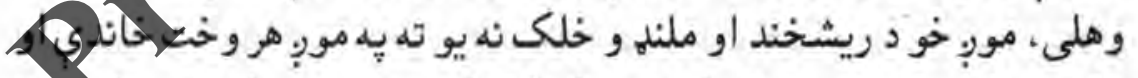

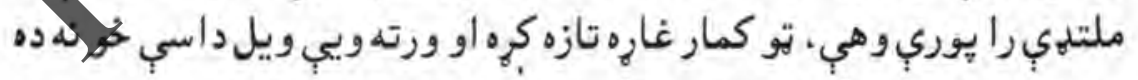

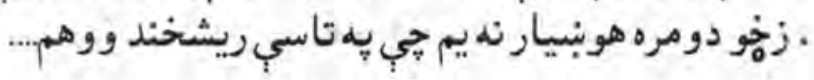

J IrAo

$17 \%$

- 1. 9 


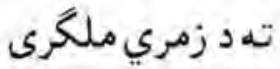

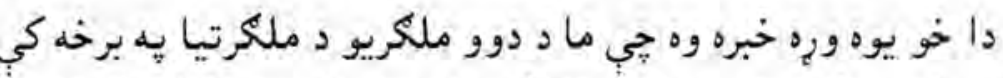

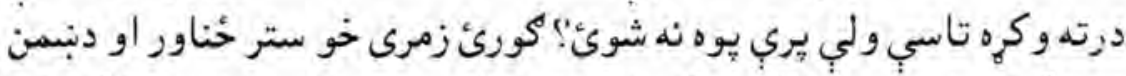

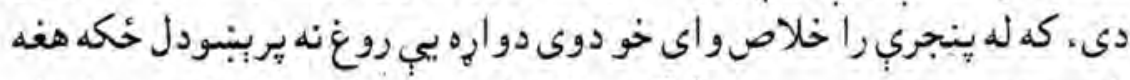

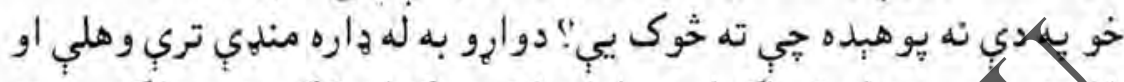

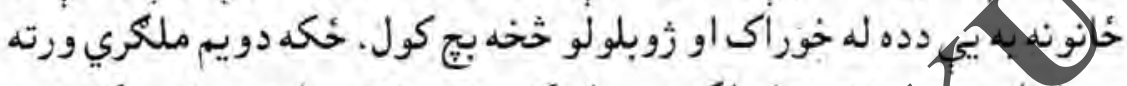

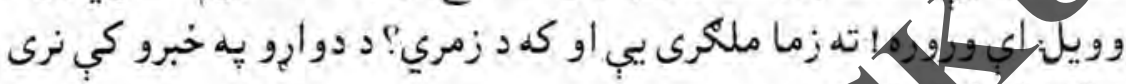

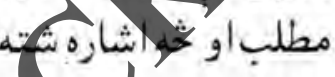

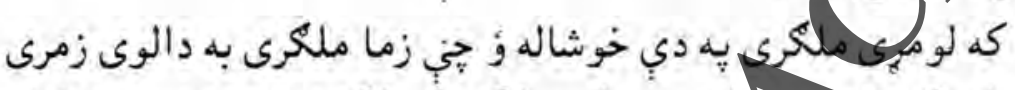

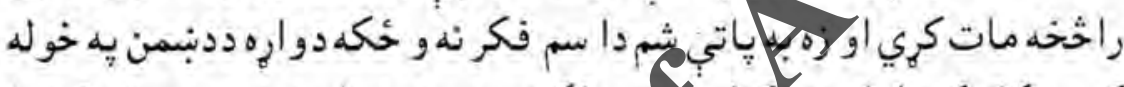

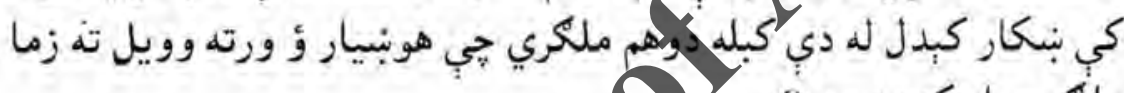

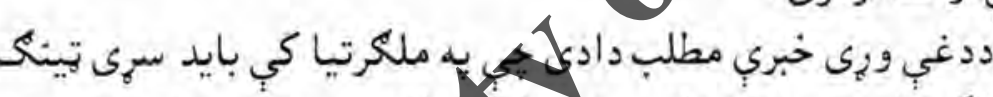

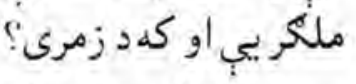

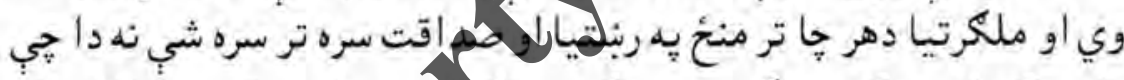

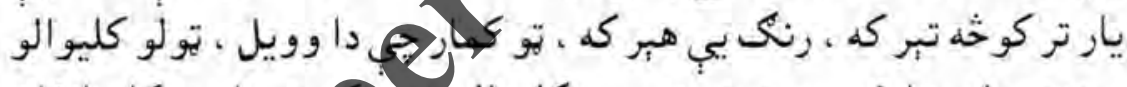

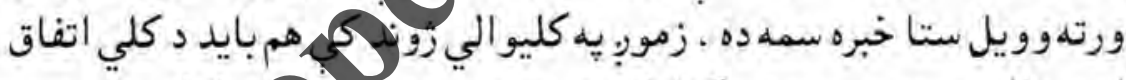

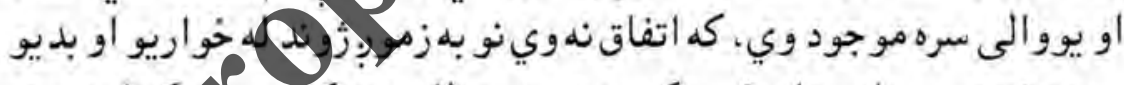

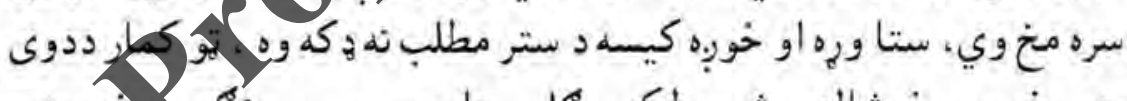

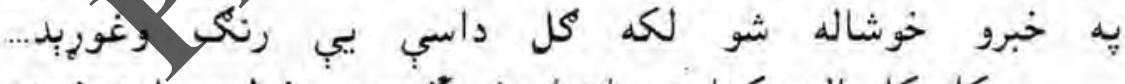

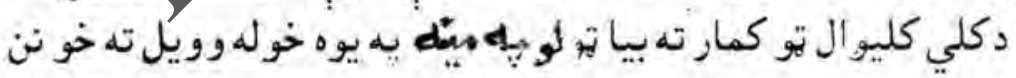

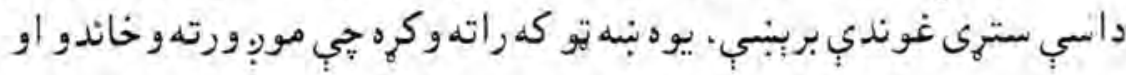

J STAO

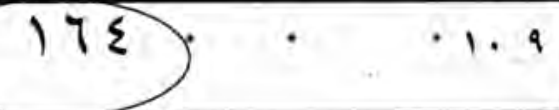


تهد زمري ملكرى

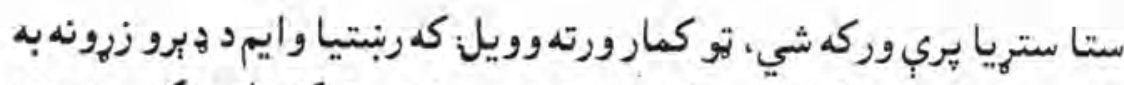

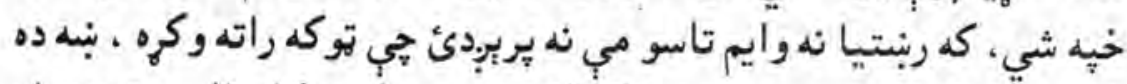

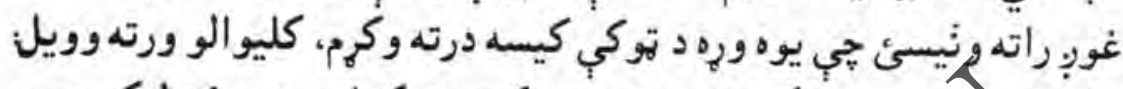

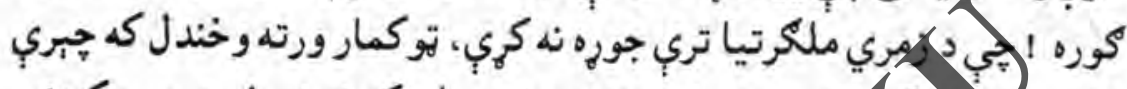

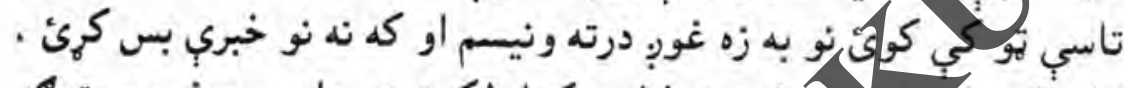

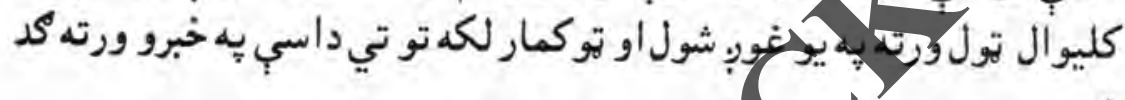

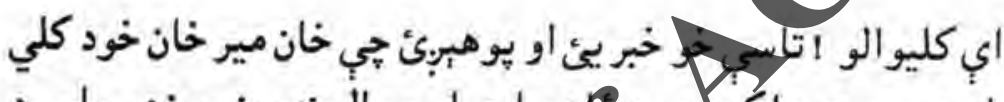

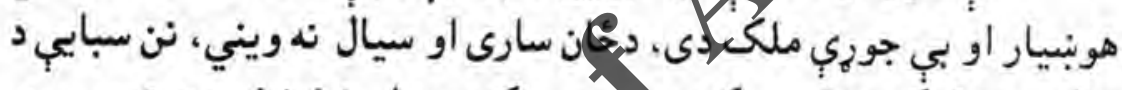

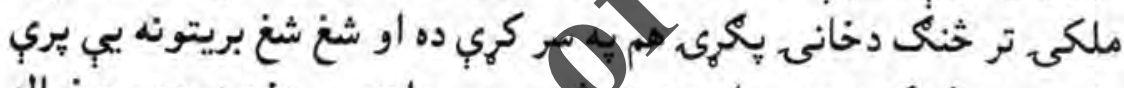

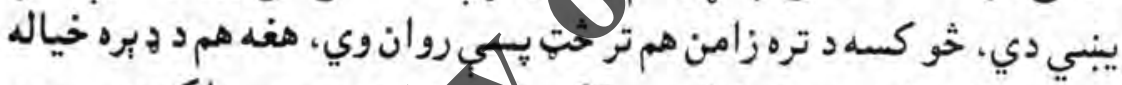

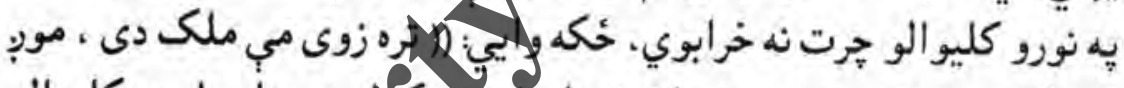

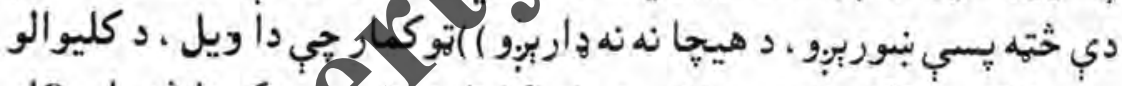

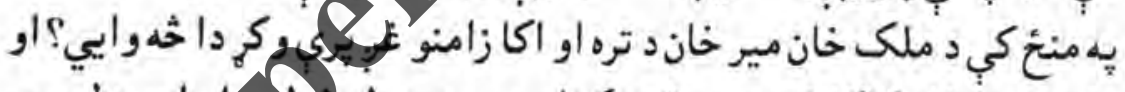

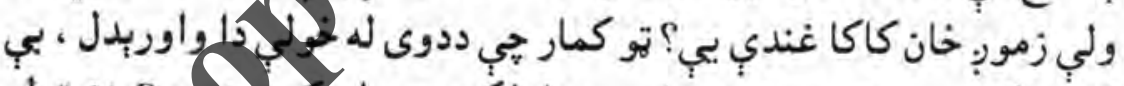

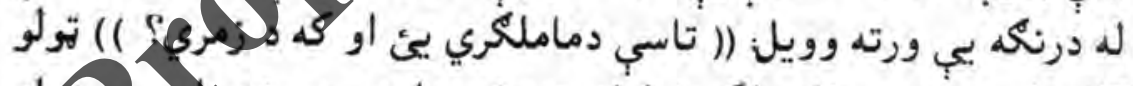

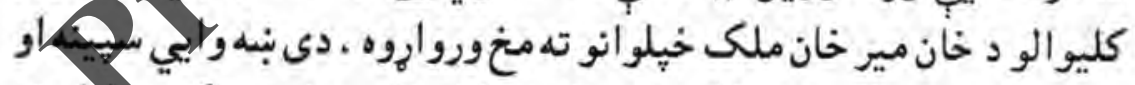

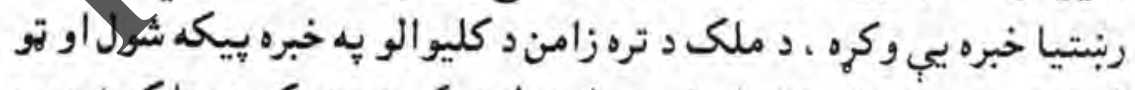

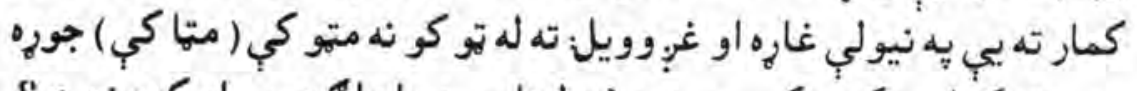

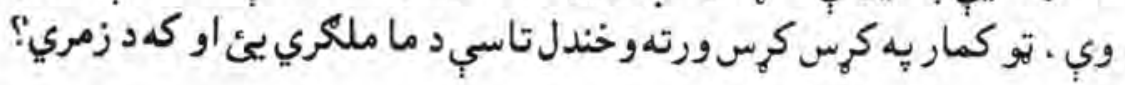

J S IRAs

170

.1 .8 


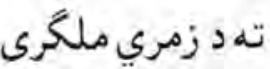

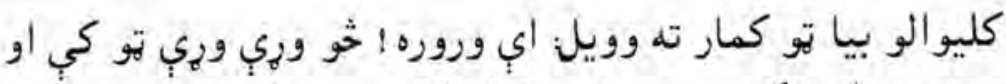

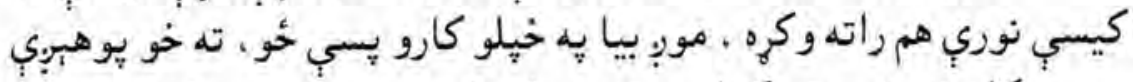

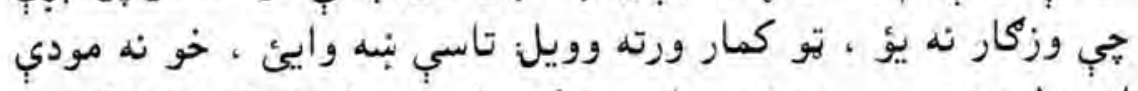

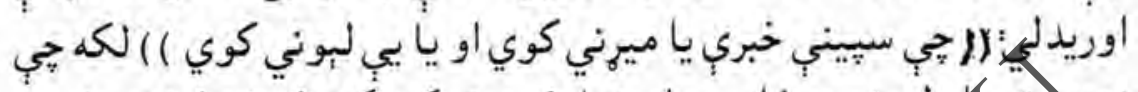

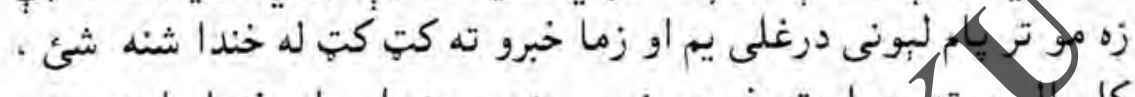

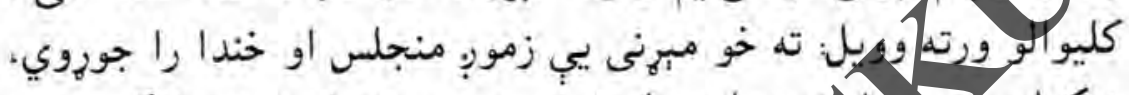

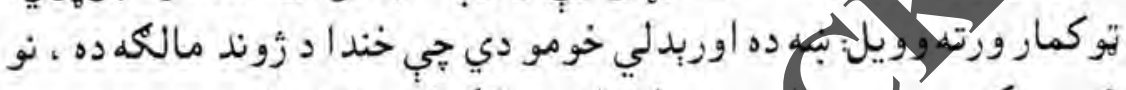

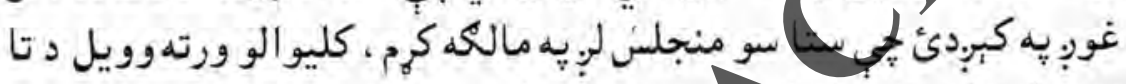

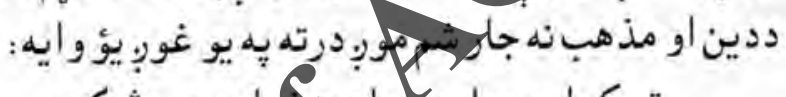

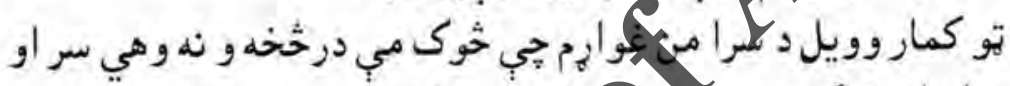

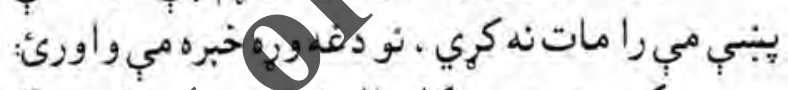

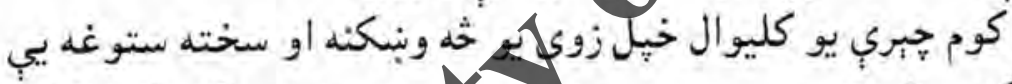

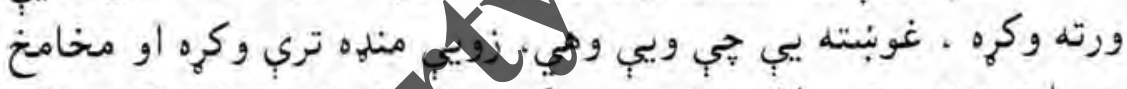

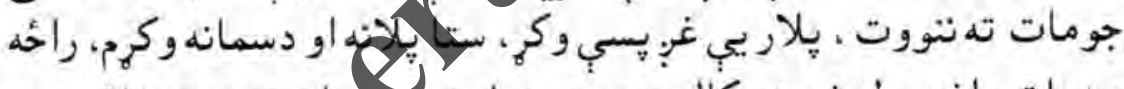

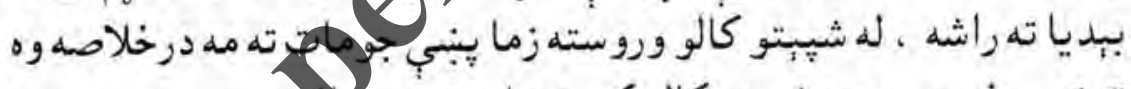

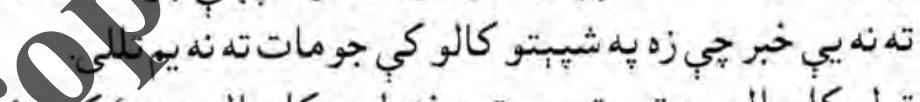

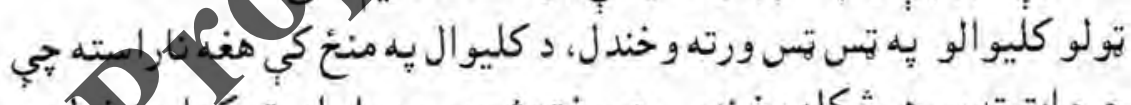

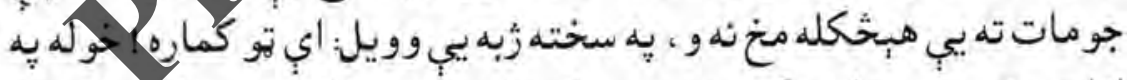

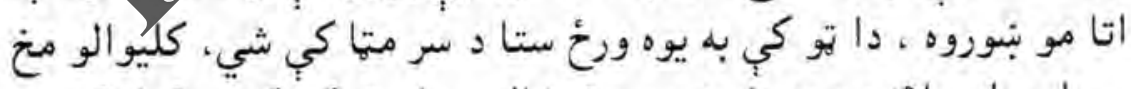

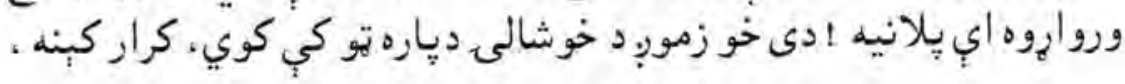

J IrAs

179 


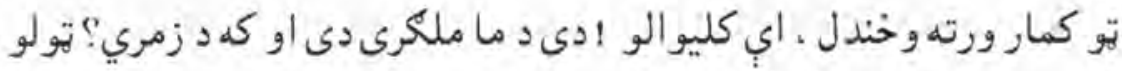

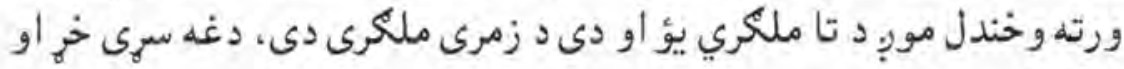

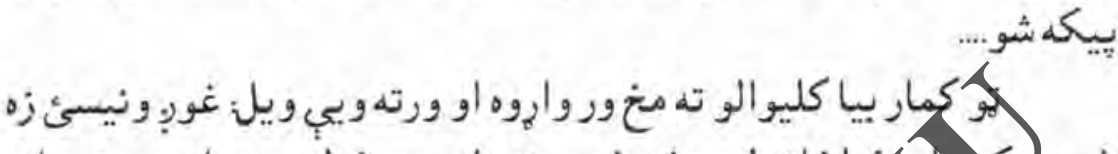

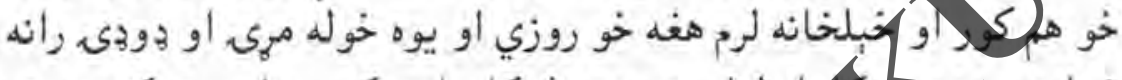

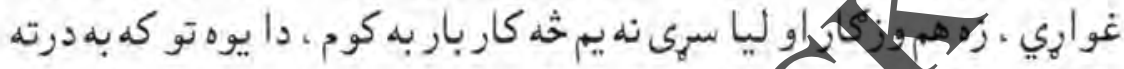

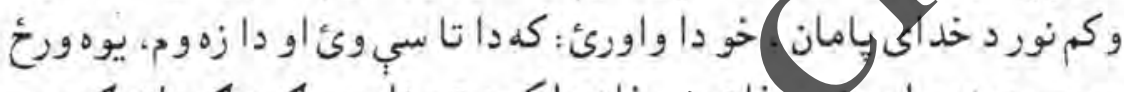

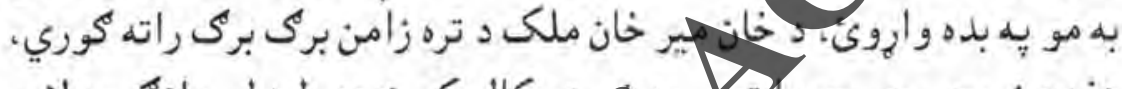

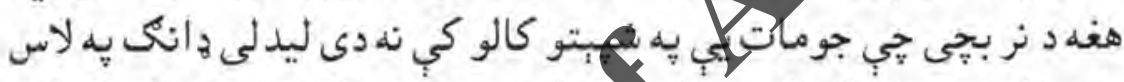

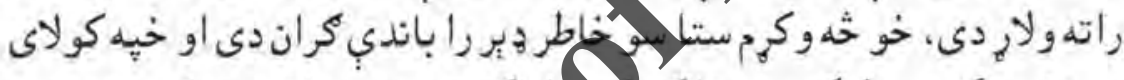

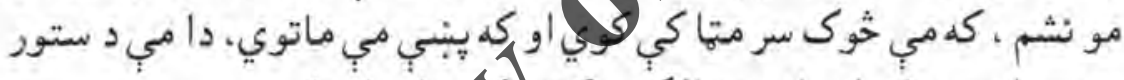

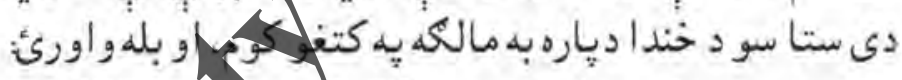

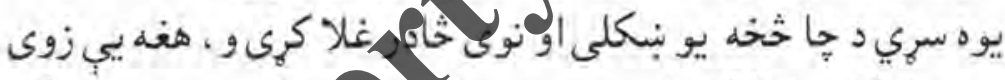

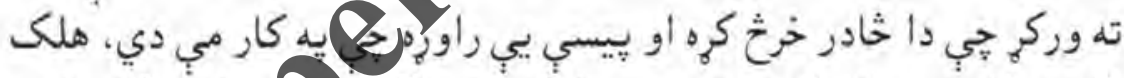

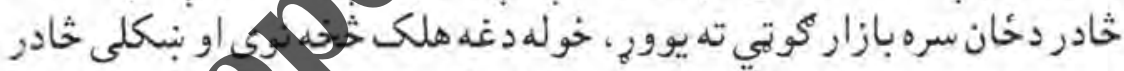

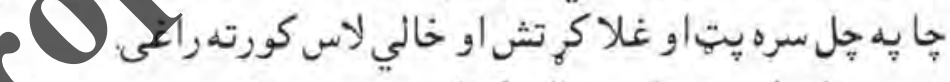

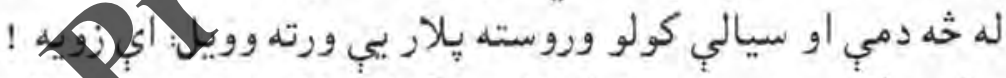

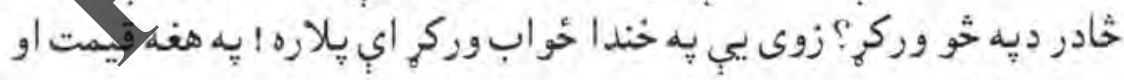

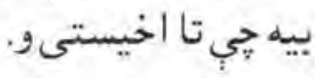


د توكمار دغبي ويزب كيسي او تو كي ته تولو كليو الو وخندل. خويو

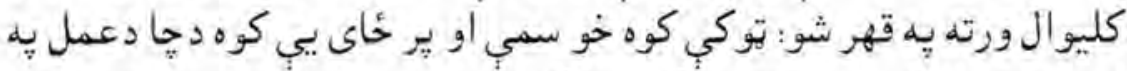

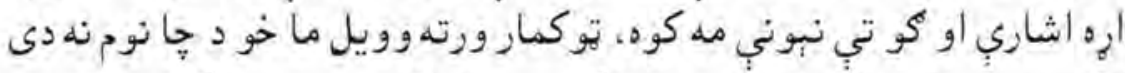

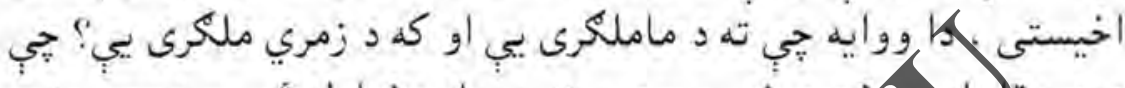

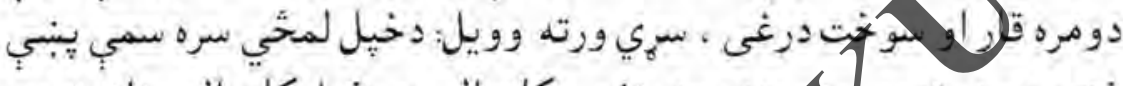

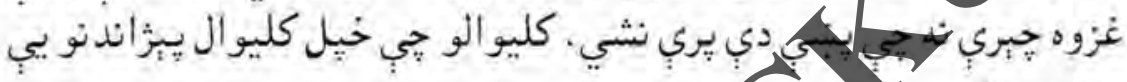

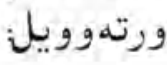

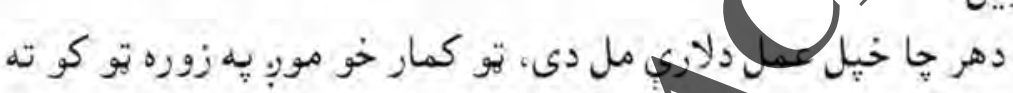

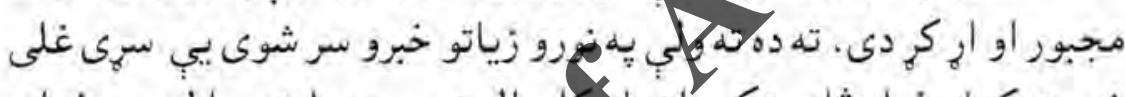

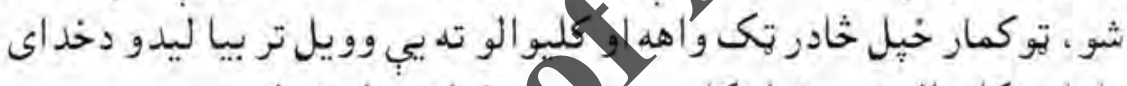

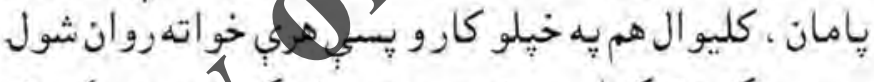

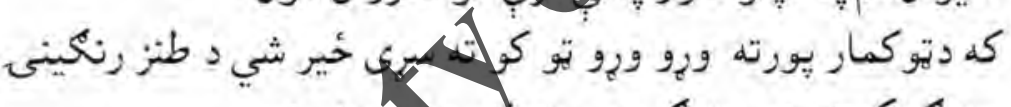

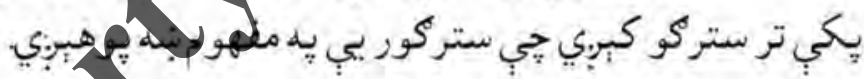
8

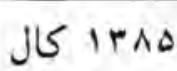




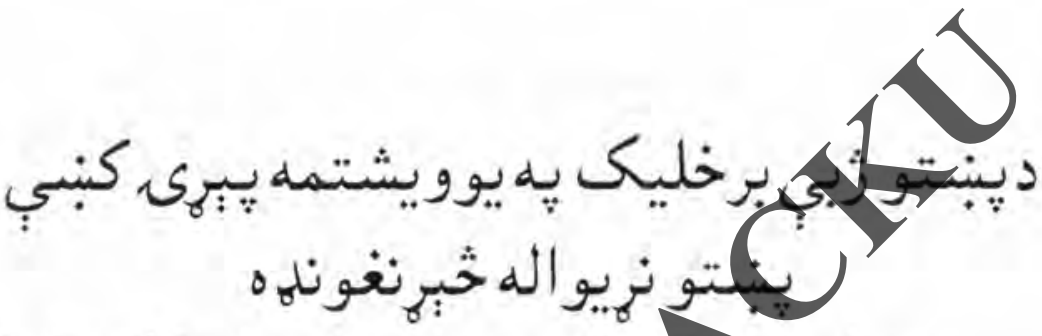

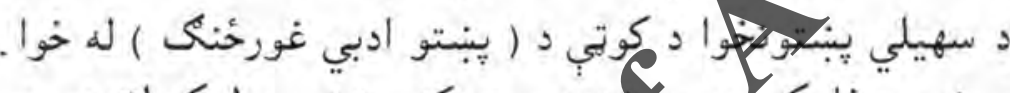

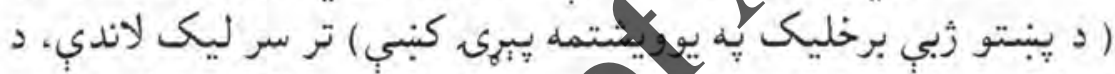

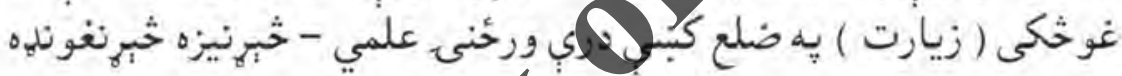
1

جويره شوي وه.

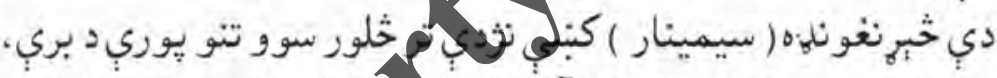

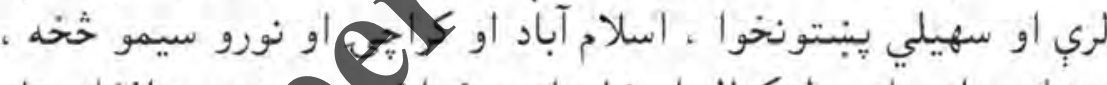

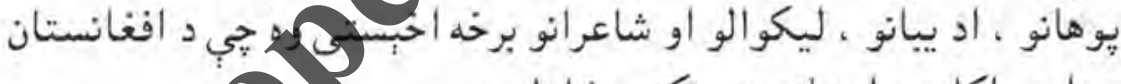

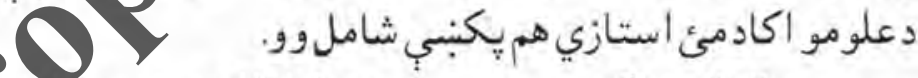

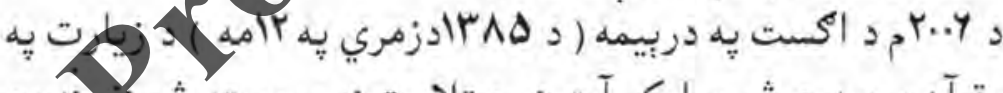

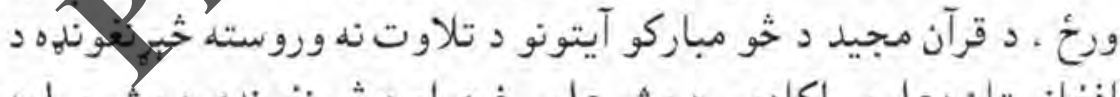

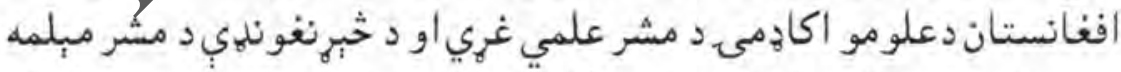

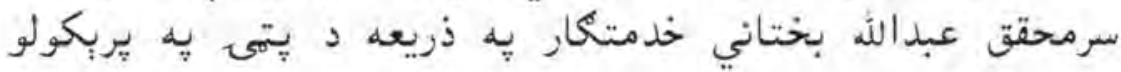
يرانيستل شوه.

IrAs

179

$\cdot 1 \cdot 9$ 


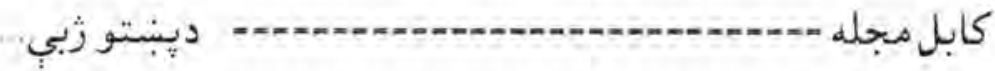

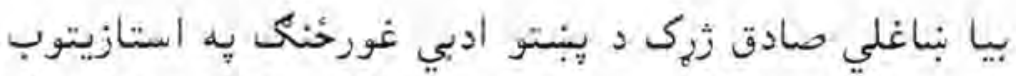

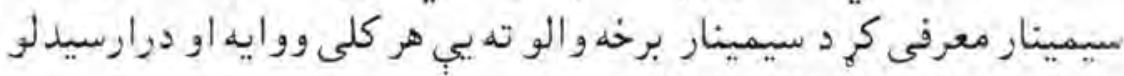

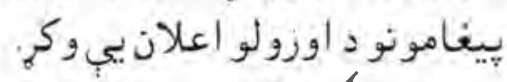

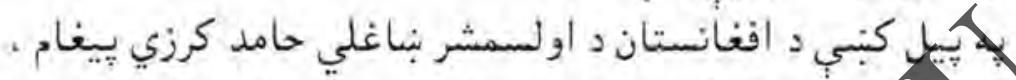

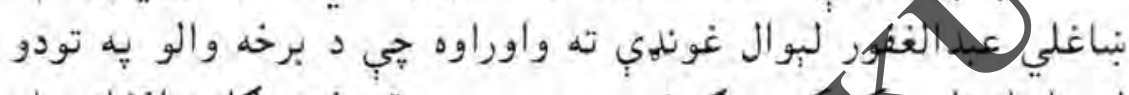

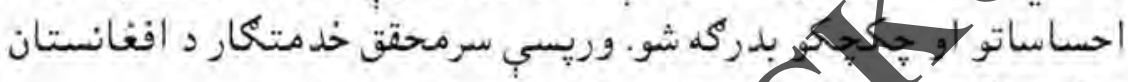

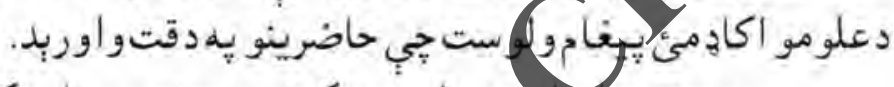

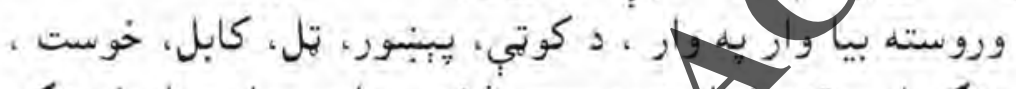

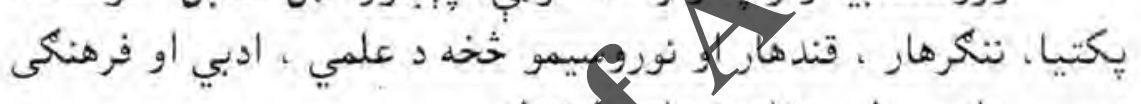

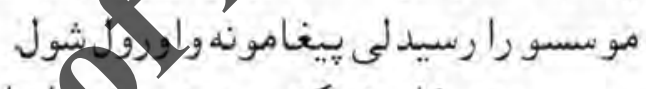

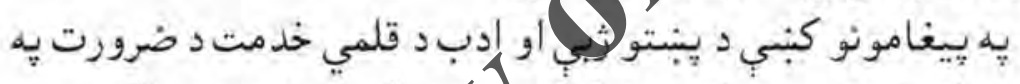

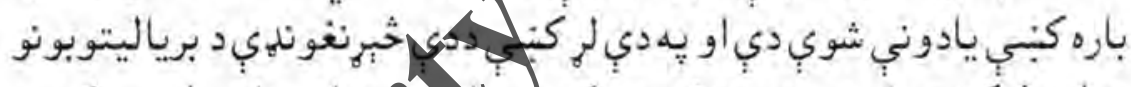

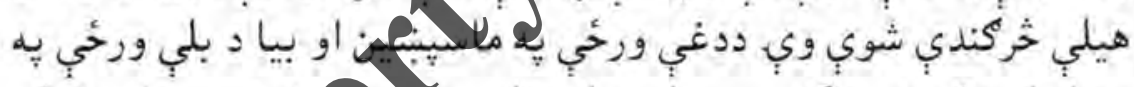

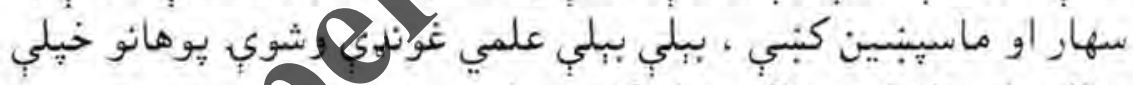

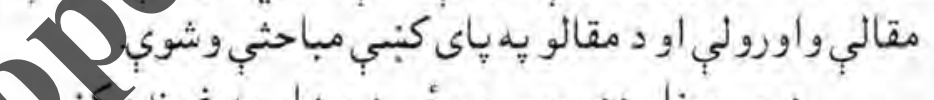

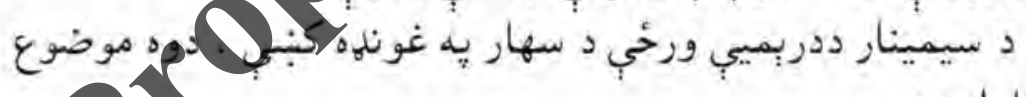

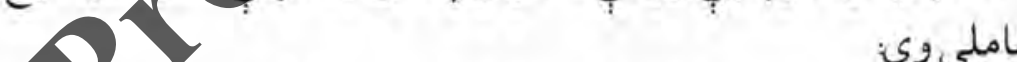

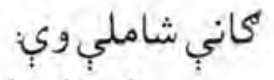

1_ إيوارجونو ( جايزو ) او سوغاتونو ويشل:

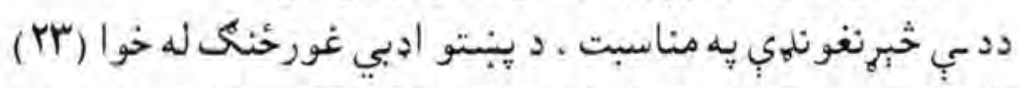

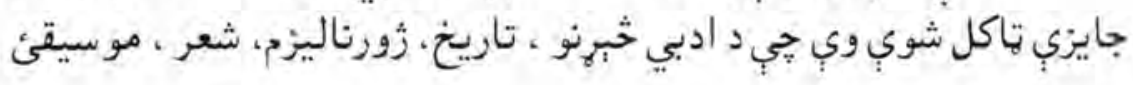

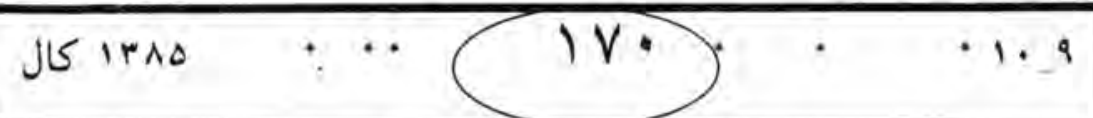




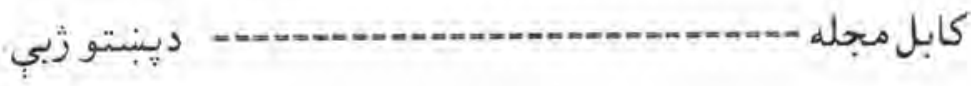

او نو رو ادبي او فُرهنكي وتلو شخصيتونو لِياره منل شوي وب او پِد دغهورَح وويشل شوي.

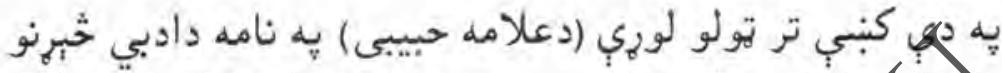

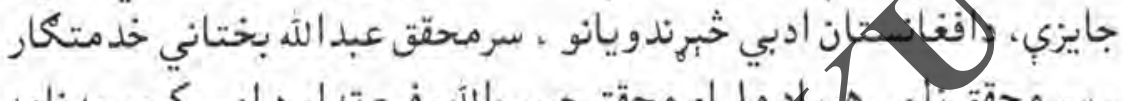

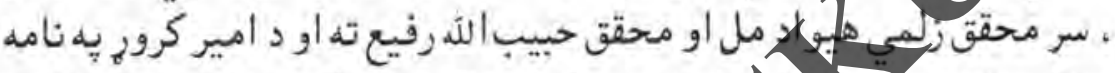

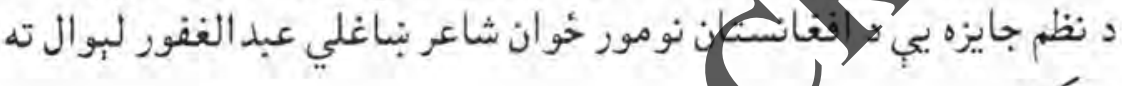
وركره.

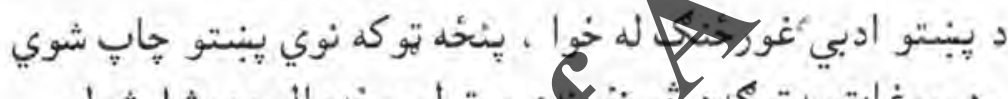

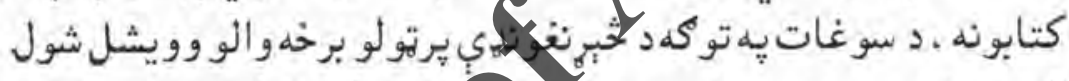

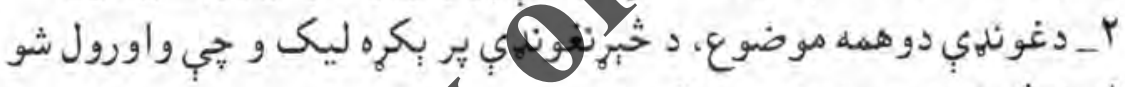

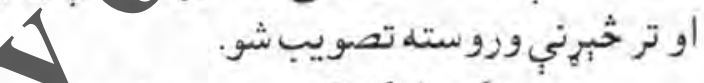

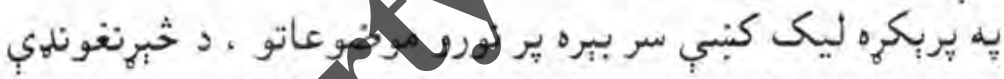

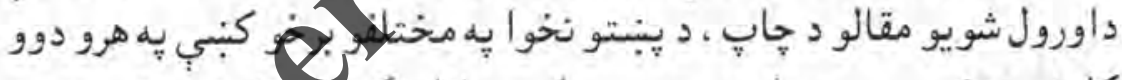

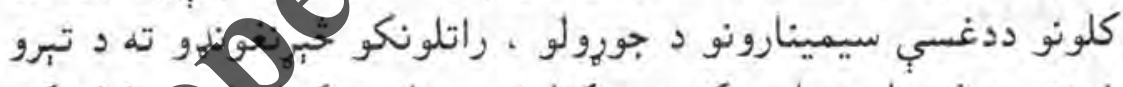

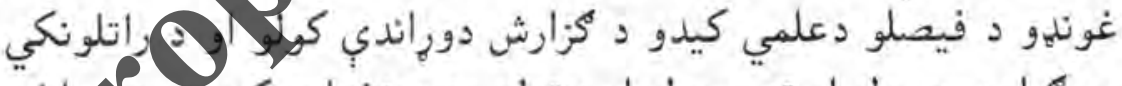

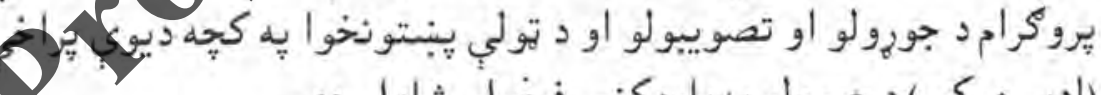

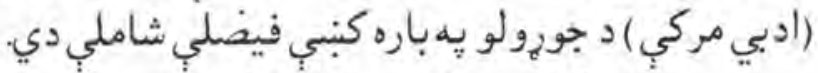

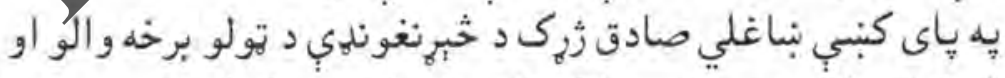

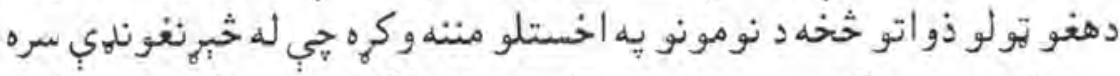

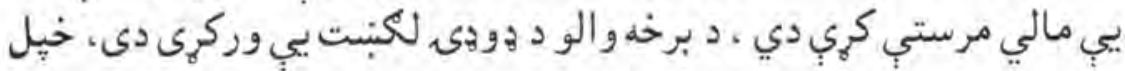




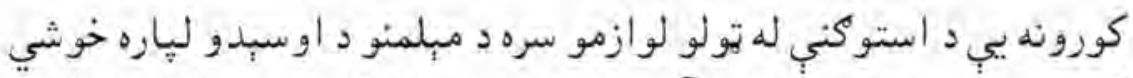

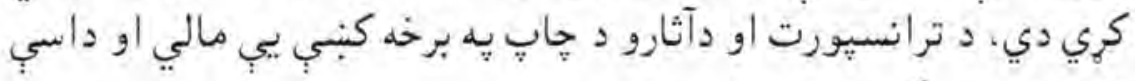

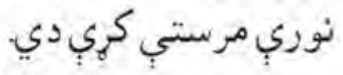

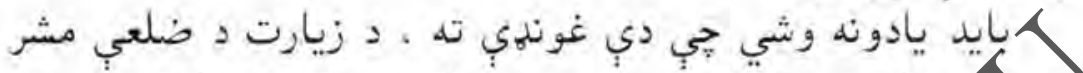

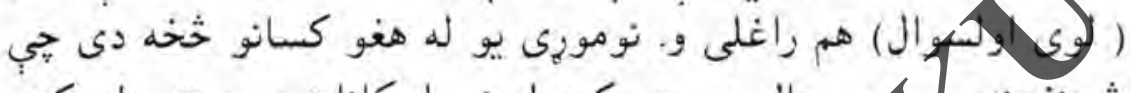

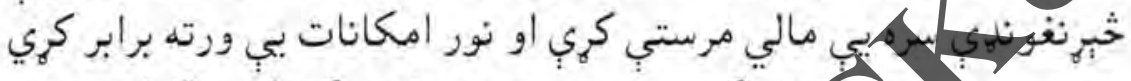

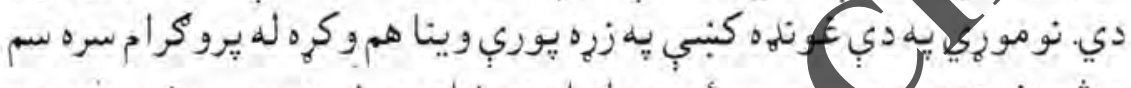

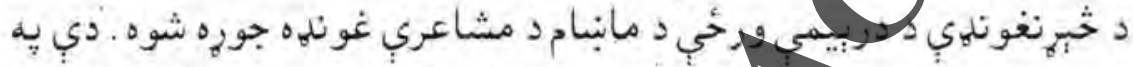

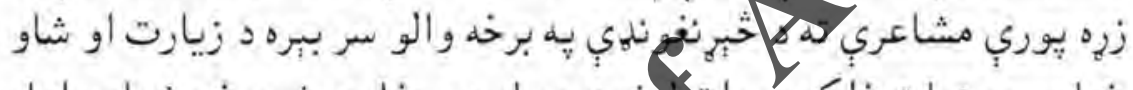

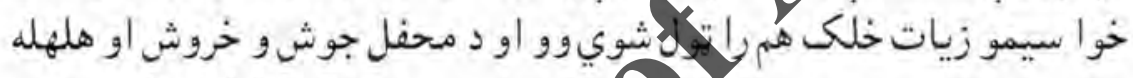

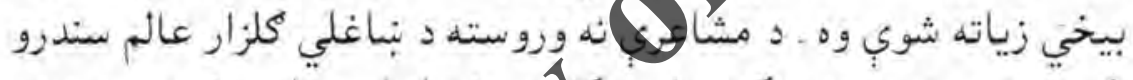

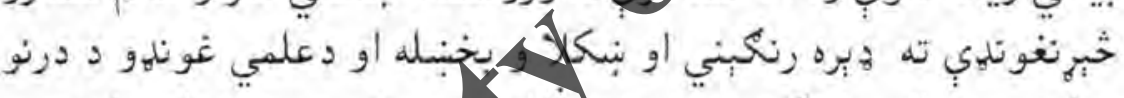

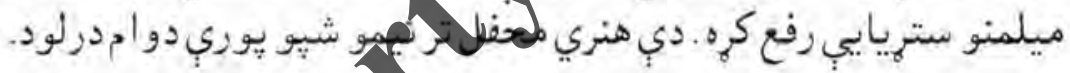

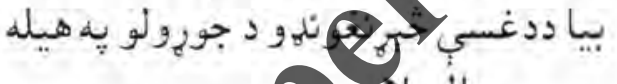

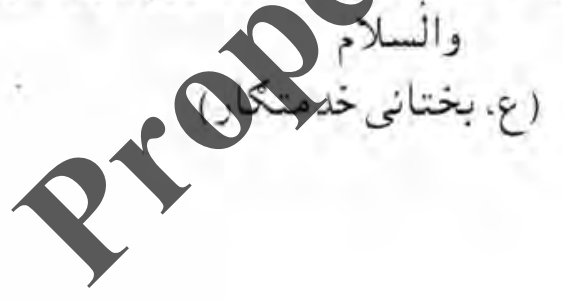

(rido

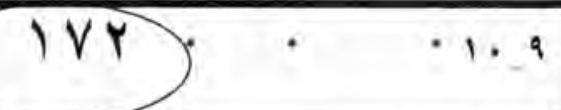


اسيتاد حمزهبابا:

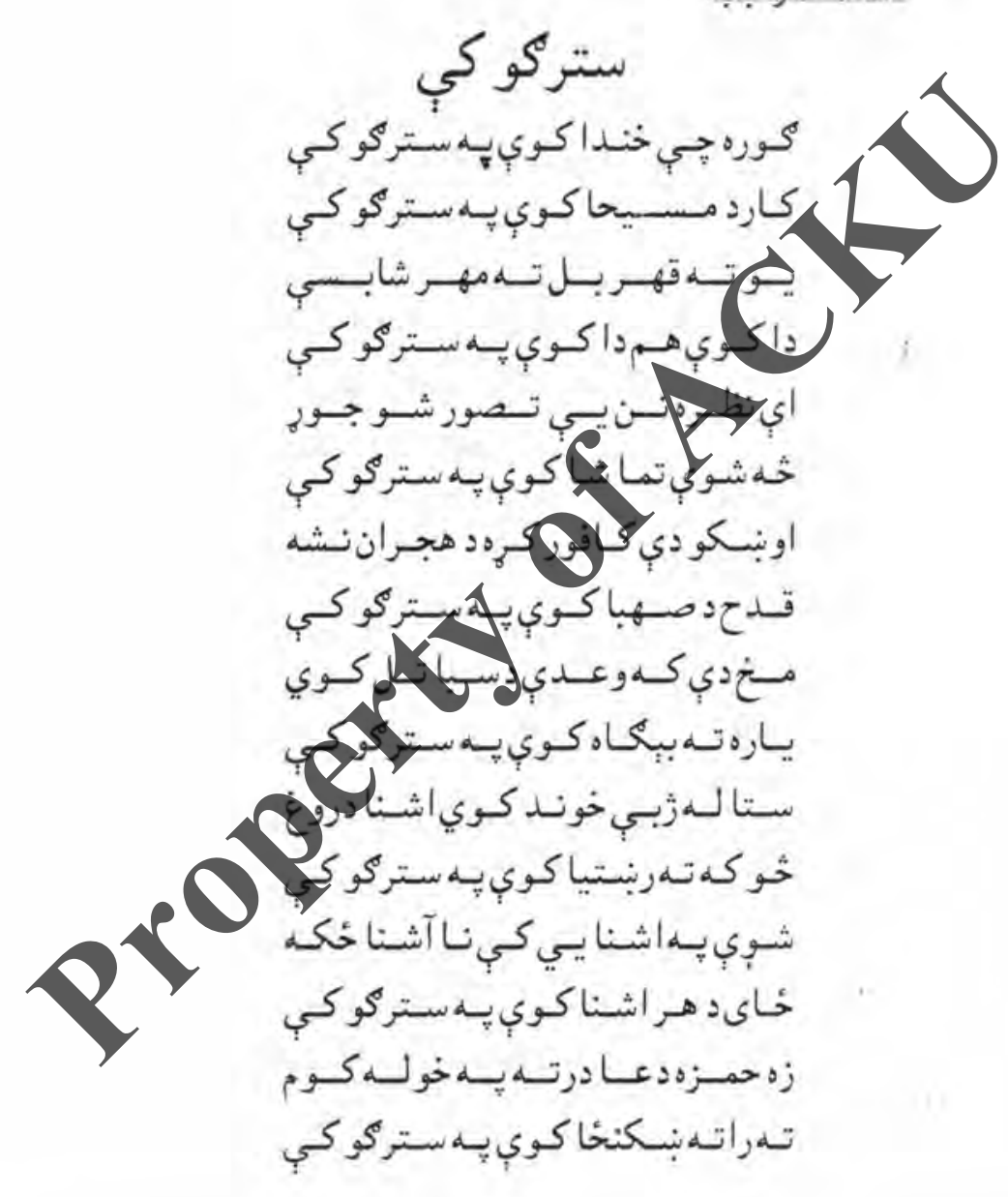

J 


$$
\text { دشعر برخه }
$$

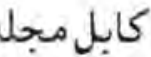

عزيز تحريك

$$
\text { دخاورو يهلمن كي }
$$

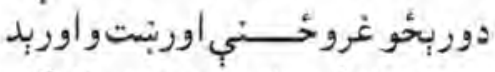

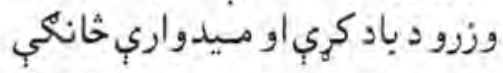

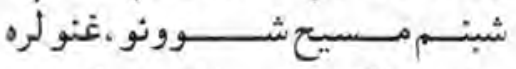
روتي جلكي شوي بيا زوندى له سرد

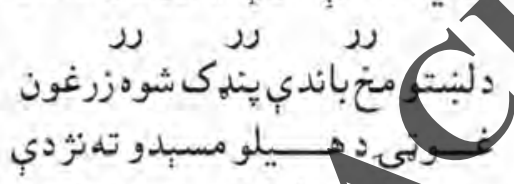

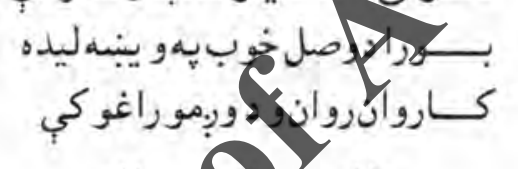
رد 20

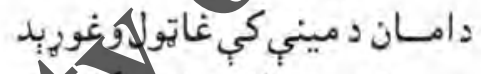

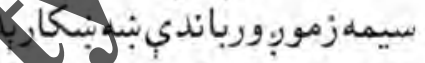

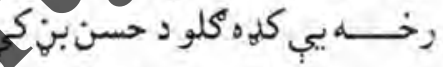

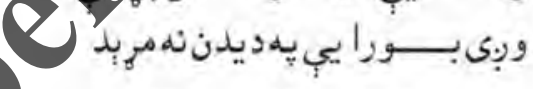

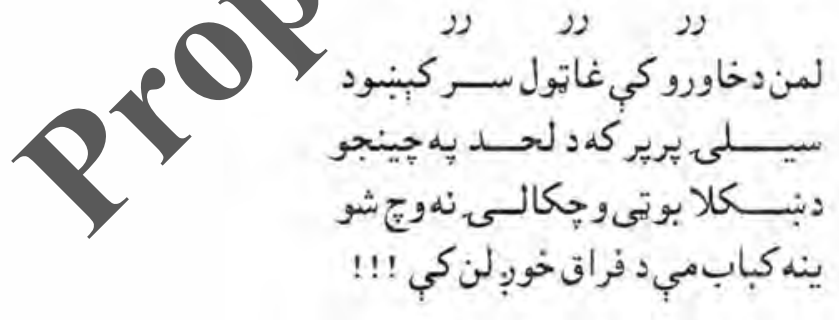




$$
\text { دشعر برخه }
$$

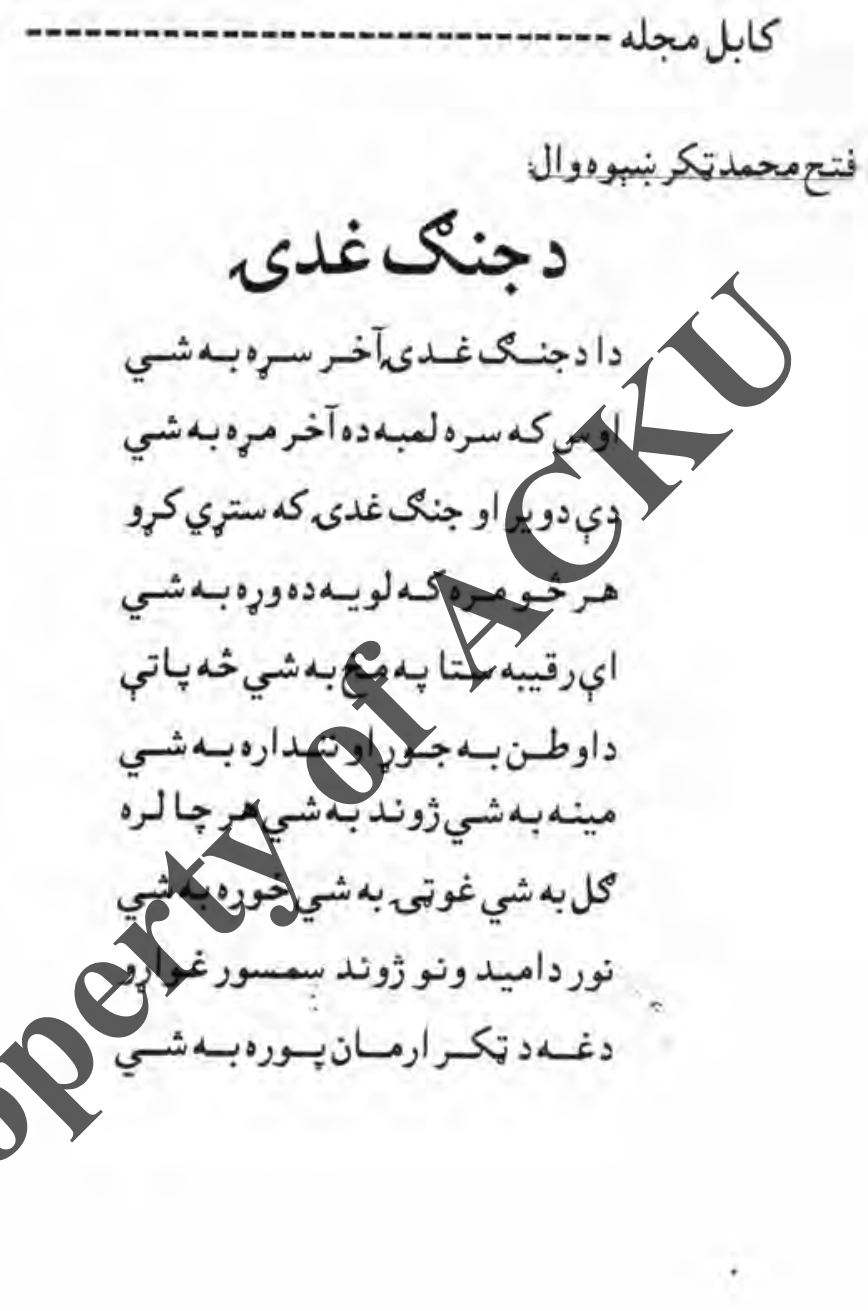

إIno

$180\} \cdot 1+9$ 


$$
\text { دشعر برخه }
$$

$$
\text { سوريل خزان: - س س }
$$

\section{دصحرا زوند}
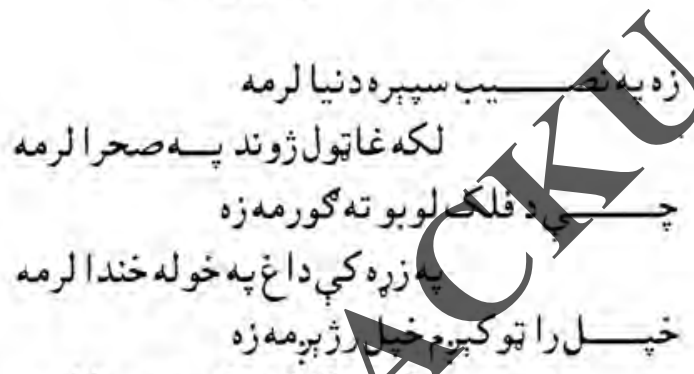

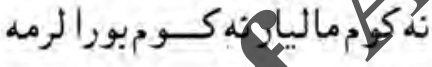

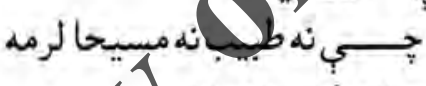

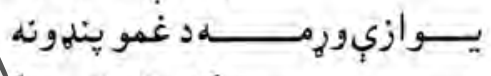

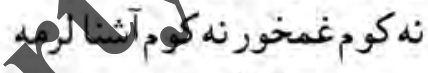

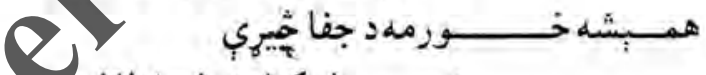

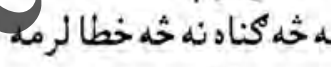

ERTJ

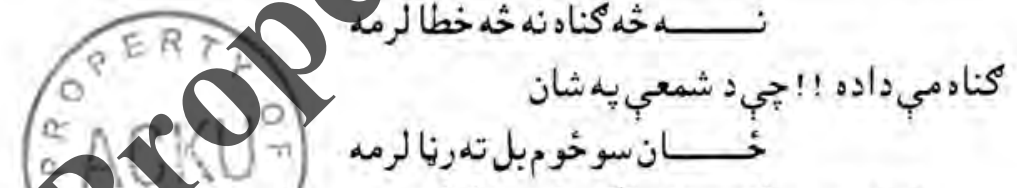

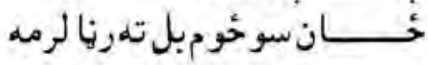

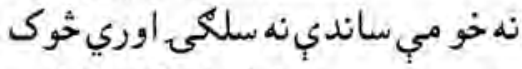

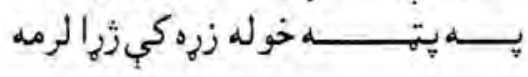

J



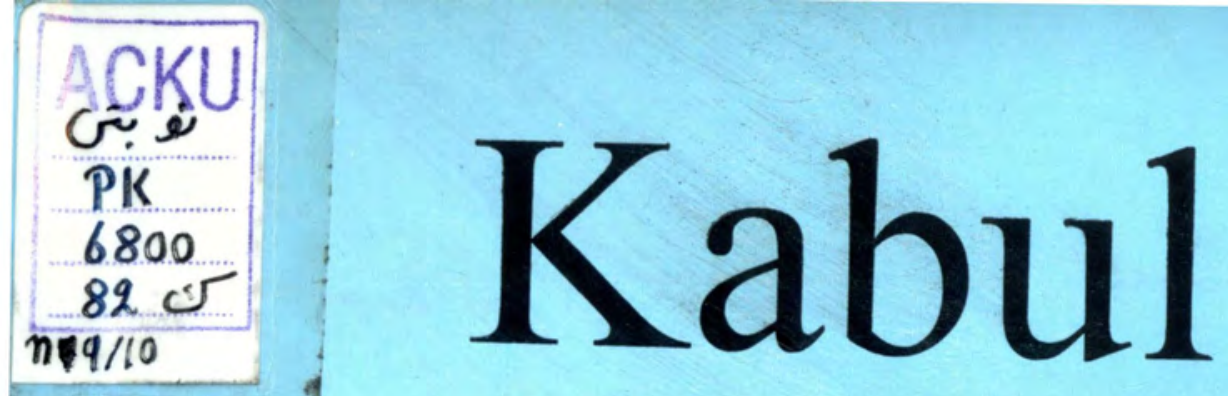

Monthly Journak of the Afghanistan!

Academy of Sciences Center of tanguage \& titerature

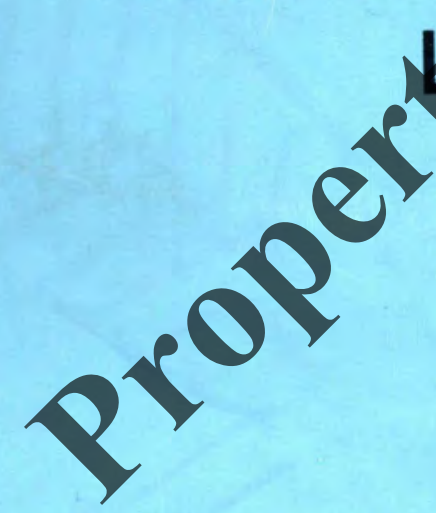

Editor: Ali Mohammad Mangal

Co-Editor: Abdul Latif Ahamadi

Composed \& Designed by: Abdul Latif Ahamadi

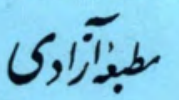

